UCID--21920

DE91 001059

\title{
Remedial Investigation of the High-Explosives (HE) Process Area, Lawrence Livermore National Laboratory Site 300
}

\author{
Neil B. Crow \\ Albert L. Lamarre \\ Technical Contributors: \\ David W. Carpenter \\ Patricia L. Cederwall \\ Linda H. Hall \\ Stephen P. Vonder Haar*
}

*Weiss Associates, Emeryville, California

\section{August 1990}

Environmental Restoration Division 


\section{Table of Contents}

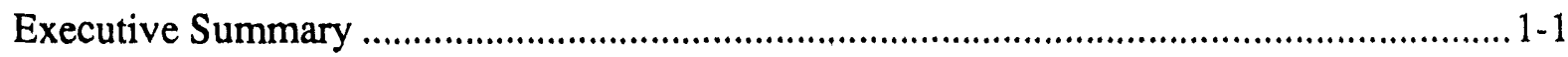

\section{Chapter 1}

Site Background Information

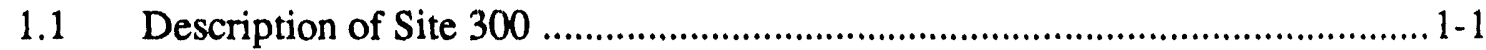

1.2 Description of the HE Process Area .......................................................1-1

1.3 Summary of Waste Disposal History, HE Process Area ................................... 1-4

1.4 Previous Investigations ............................................................................... 1-4

1.4.1 Extent of HE Compounds in Soil and Rock ....................................1-4

1.4.2 Extent of HE Compounds in Ground Water ..................................... 1-4

1.4.3 Extent of VOCs in Soil and Rock and in Ground Water ...................1-7

\section{Chapter 2}

Environmental Setting

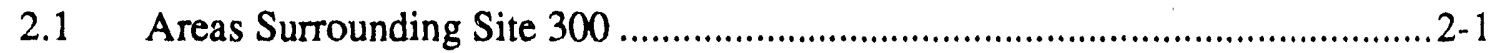

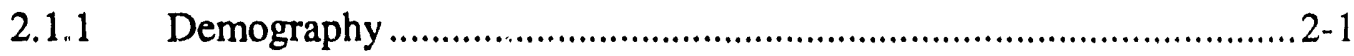

2.1.2 Land Use

2.1.2.1 Present Uses ...............................................................

2.1.2.2 Historic Uses ...........................................................

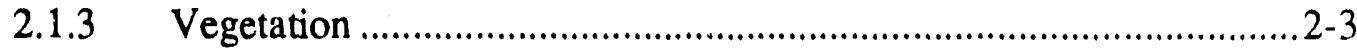

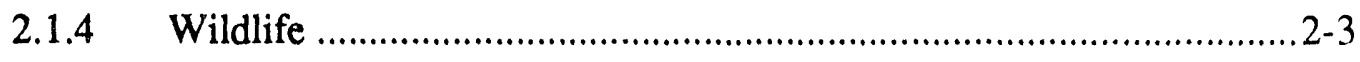

2.1.5 Surface and Ground Water Use ...................................................... 2-3

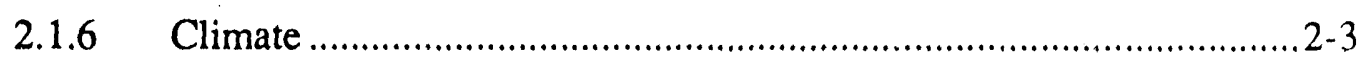

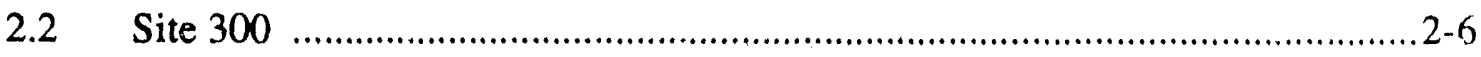

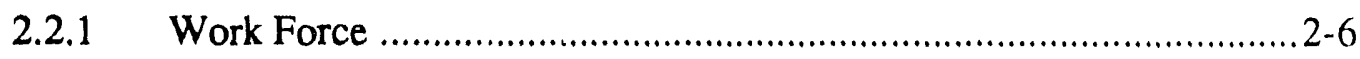

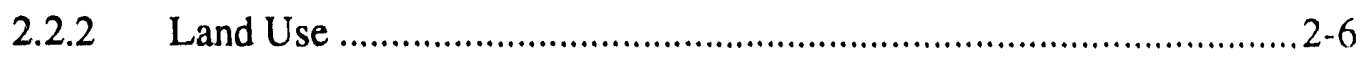

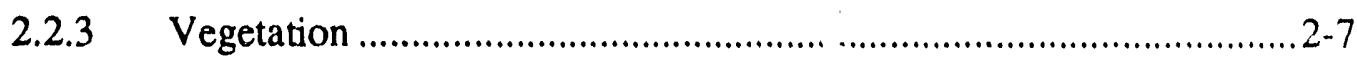

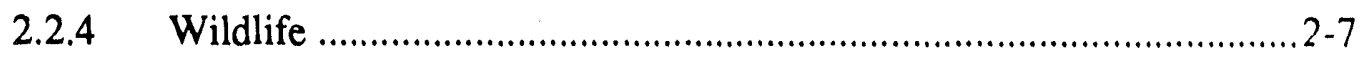

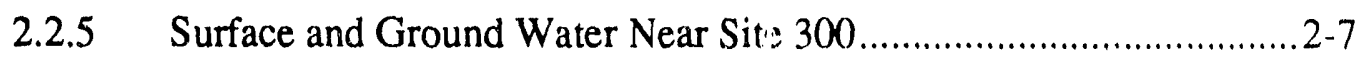

2.2.5.1 Surface Water ................................................................ $2-7$

2.2.5.2 Ground Water.............................................................

2.2.6 Climatology and Air Quality at Site $300 \ldots \ldots \ldots \ldots \ldots \ldots \ldots \ldots \ldots \ldots \ldots \ldots \ldots \ldots \ldots \ldots . . .12-12$ 


\section{Chapter 3}

Overview of the Remedial Investigation

3.1 Summary of Remedial Investigation.......................................................... 3-1

3.1.1 Early History: Investigations of Soil and Rock ……......................... 3-1

3.1.2 Decommissioning of Lagoons .....................................................

3.1.3 Closure Plan Investigations of the Decommissioned Lagoons .......... 3-1

3.1.4 Dry Well Investigations ...................................................................

3.1.5 Additional Investigations of Soil and Rock ....................................... 3-2

3.1.6 Investigations of Ground Water ................................................... 3-2

3.2 Nature and Extent of the VOCs and HE Compounds .................................... 3-2

3.3 Assessment of the Situation and Corrective Actions to Date ........................... 3-3

3.3.1 HE Compounds, Metals, and TCE in Soil and Rock ......................... 3-3

3.3.2 RDX and VOCs in Ground Water ................................................3-3

\section{Chapter 4}

Methods of Investigation

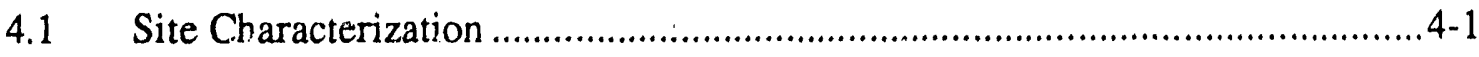

4.1.1 Geologic Mapping.........................................................................

4.1.2 Drilling Exploratory Boreholes and Monitor Wells ...........................4-1

4.1.2.1 General Drilling Protocol ................................................4-2

4.1.2.2 Exploratory Boreholes: Drilling and Sampling Methods ............................................................4-2

4.1.2.3 Monitor Wells: Drilling and Sampling Methods ............4-3

4.1.3 Arialysis of Soil Samples and Ground Water......................................4-4

4.1.3.1 Samples from Monitor Wells Adjacent to HE Surface Impoundments ................................................4-4

4.1.3.2 Samples from Boreholes and Monitor Wells Collected During LLNL's Investigations ..........................4-4

4.2 Investigations Monitoring Program ...........................................................4-4

4.2.1 Well Purging and Sampling Procedures ...........................................4-4

4.2.2 Chemical Analysis of Ground Water ............................................... 4-4

4.2.2.1 Wells of the HE Surface Impoundments Monitoring Network ...................................................... 4-4

4.2.2.2 Wells of HE Process Area Remedial Investigations ........4-5

4.2.3 Disposal of Pumped Water ....................................................... 4-5

4.2.4 Water Level Data ................................................................... 4-5

4.2.5 Dncumentation of Samples .......................................................... 4-5 


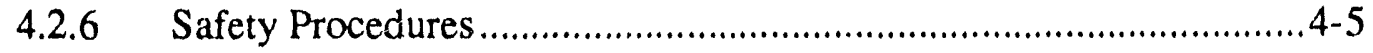

4.2.7 Data Management .....................................................................4-5

\section{Chapter 5}

Geology

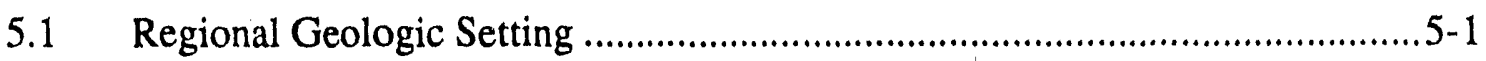

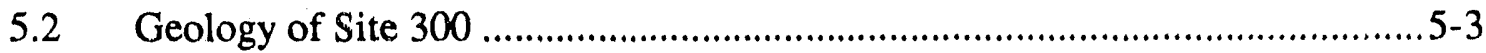

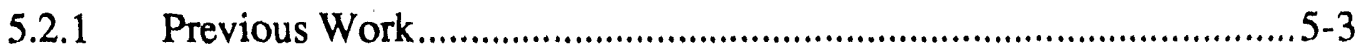

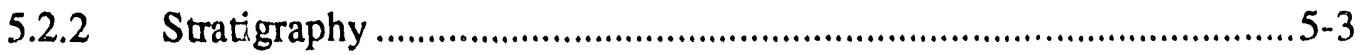

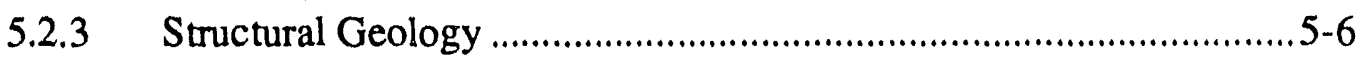

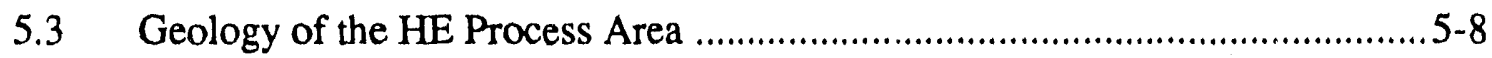

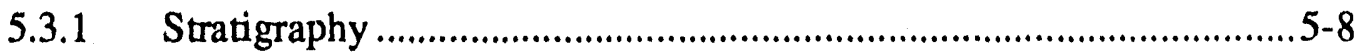

5.3.2 Structural Geology ........................................................................5-9

5.3.3 Neroly Formation: Deep Lithologic Units-Stratigraphic vs. Structural Origin .........................................................................5-10

\section{Chapter 6}

Hydrogeology

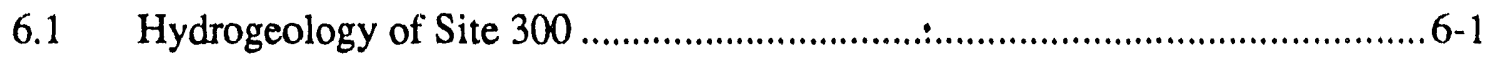

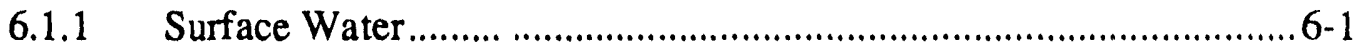

6.1.2 Ground Water Aquifers and Aquitards ............................................. 6-1

6.1.2.1 Perched Aquifers ...........................................................6-3

6.1.2.2 Regional Aquifers and Interbedded Aquitards................. 6-5

6.2 Hydrogeology of the HE Process Area ........................................................ 6-7

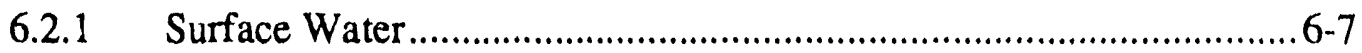

6.2.2 Ground Water Aquifers and Aquitards ...........................................6-7

6.2.2.1 Perched Aquifers of the HE Process Area ....................... 6-8

6.2.2.2 Water Table Aquifer ..................................................... 6-8

6.2.2.3 Confined Aquifers .......................................................6-11

6.2.2.4 Hydrogeology of Deeper Parts of the Neroly Formation ........................................................... 6-11

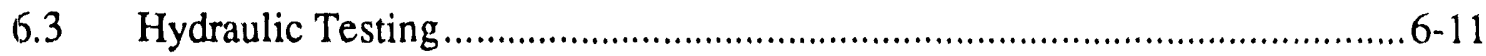

\section{Chapter 7}

Characteristics of Waste in the HE Process Area

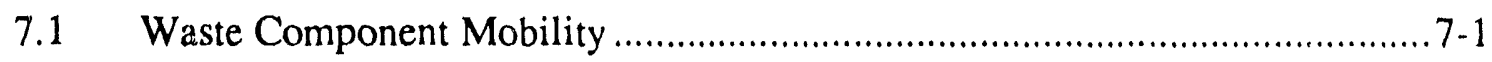

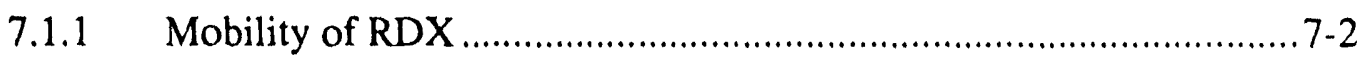

7.1.2 Mobility of HMX

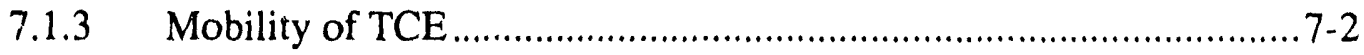




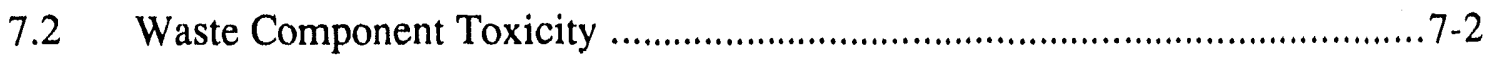

7.2.1 Toxicity of RDX .......................................................................

7.2.1.1 RDX: Chemical Characterization and

Toxicity Data................................................................

7.2.1.2 Summary of RDX Toxicity Studies .................................7-4 .

7.2.1.3 Suggested RDX Drinking-Water Criterion ........................7-5

7.2.1.4 Discussion ...................................................................

7.2.2 Toxicity of HMX ……...............................................................

7.2.2.1 HMX: Chemical Characterization and

Toxicity Data..................................................................

7.2.2.2 Summary of HMX Toxicity Studies ................................ 7-6

7.2.2.3 No-Observed-Effects-Level (NOEL) Dose .....................7-7

7.2.2.4 Drinking Water Criterion ............................................. 7-7

7.2.3 Comparison of Toxicity: $\mathrm{LD}_{50}$ Dose, RDX and HMX .....................7-7

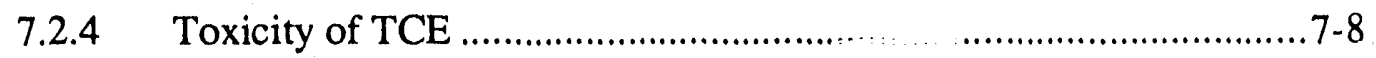

\section{Chapter 8}

Horizontal and Vertical Extent of Contamination

8.1 HE Compounds, Metals, and VOCs in Soil and Rock..................................... 8-1

8.1.1 HE Compounds, Metals, and VCCs in Soil and Rock:

Re c ulatory Standards and Des:gnated Levels......................................8-1

8.1.2 H : Compounds in Soil and Rock .................................................. $8-6$

8.1.2.1 Release Sites of HE Compounds
Beneath the Closed Lagoons.............................................. $8-6$

8.1.2.2 Release Sites of HE Compounds at
Abandoned Dry Wells and Monitor Wells ......................... 8-7

8.1.3 Metals in Soil and Rock ............................................................... $8-8$

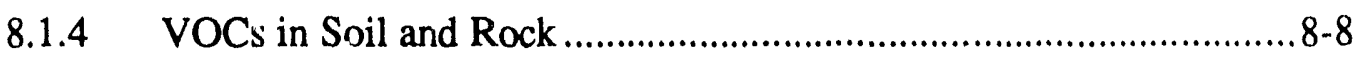

8.2 HE Compounds and VOCs in Ground Water .............................................. $8-8$

8.2.1 HE Compounds in Ground Water ................................................... 8-9

8.2.1.1 Perched Aquifer of Building 814:

HE Compounds ............................................................. 8-9

8.2.1.2 Water Table Aquifer: HE Compounds............................8-9

8.2.1.3 Confined Aquifer Beneath the HE Process Area ........... 8-12

8.2.2 VOCs in Ground Water............................................................ 8-12

8.2.2.1 Perched Aquifer of Building 814: VOCs ..................... 8-12

8.2.2.2 Perched Aquifer of Building 815: VOCs ...................... 8-12

8.2.2.3 Water Table Aquifer: VOCs …………………............. 8-12

8.2.2.4 Confined Aquifer Beneath the HE Process Area ............ 8-12 
8.3 Distribution of HE Compounds, Metals, and VOCs in Surface Water.

8.4 Possible Release Sites for HE Compounds and VOCs in the HE Process Area

8.4.1 Possible Release Sites for RDX .............................................. 8-14

8.4.2 Possible Release Sites for VOCs near Building 814 ....................8-15

8.4.3 Possible Release Sites for VOCs near Building 815 ....................8-15

\section{Chapter 9}

Effects on Air and Biota

9.1 Effects of HE Compounds (RDX and HMX) on the Air and Biota

9.1.1 Effects of HE Compounds on Air Quality ......................................9-1

9.1.2 Effects of HE Compounds in Soil and Rock.................................9-1

9.1.3 Effects of HE Compounds in Ground Water ..................................9-1

9.2 Effects of TCE on the Air and Biota ............................................................

9.2.1 Effects of TCE in Soil and Rock .................................................9-2

9.2.2 Effects of TCE in Ground Water ................................................9-2

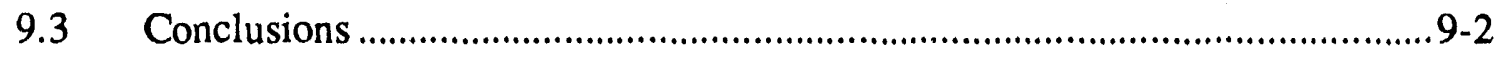

Acknowledgments

References

Appendices

Appendix A

Soils data: HE compounds, metals (nitric acid and WET), and VOCs

Appendix B

Ground water data: HE compounds, VOCs, metals, general minerals, etc.

Appendix $\mathrm{C}$

Well logs

Appendix D

Meteorological data: Site 300

Appendix E

Water levels in monitor wells: Site 300

Appendix $F$

Well construction data: HE Process Area, Site 300

Appendix G

Analytical and sample handling procedures-Laboratory QA/QC

Appendix $\mathrm{H}$

RDX and HMX Toxicology 


\section{Figures}

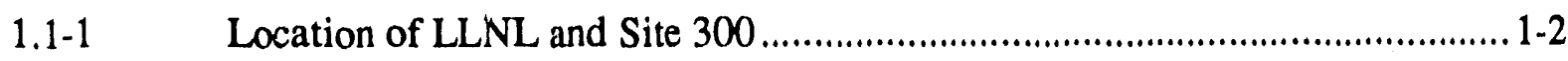

1.1-2 Location of HE Process Area and other areas of interest at Site 300 ...............1-3

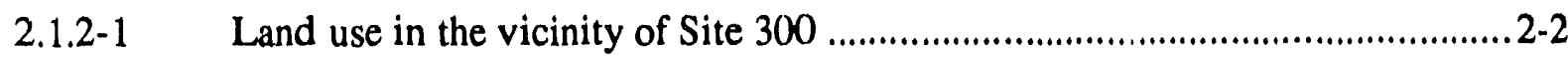

2.1.5-1 Intermittent water courses, HE Process Area ............................................. 2-4

2.1.5-2 Planimetric map of Site 300 showing locations of water supply wells and springs ..................................................................... $2-5$

2.2.6-1 Wind rose showing average annual wind direction and speed at Site 300 during 1987

5.1-1 Generalized geologic map of the San Francisco

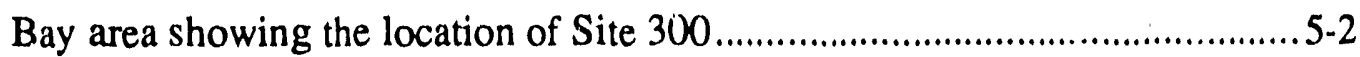

5.2.2-1 Stratigraphic correlations, LLNL Site 300 ..................................................... 5-4

5.2.2-2 Outcrop of Neroly Formation near Building 826 (foreground) .......................5-7

5.3.3-1 Conceptual sketches (not to scale) showing hypothetical stratigraphic cross-sections. .........................................................................

6.1.1-1 Intermittent water courses, HE Process Area..................................................... 6-2

6.1.2-1 Limits of perched aquifers, HE Process Area ................................................6-4

6.1.2-2 Ground water elevations in the Neroly upper blue sandstone aquifer, Site 300, March 1990 ..................................................6-6

6.2.2-1 Map of HE Process Area showing locations of cross

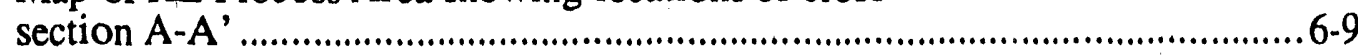

6.2.2-2 Cross section A-A' through the HE Process Area ..................................... 6-10

8.1 RDX concentrations in the perched aquifer, HE Process

Area, first quarter 1990

8.2 RDX concentrations in the Neroly upper blue sandstone aquifer, HE Process Area, first quarter 1990

8.3 TCE concentrations in the perched aquifer, Building 815

Area, first quarter 1990

8.4 TCE concentrations in the Neroly upper blue sandstone aquifer, HE Process Area, first quarter 1990

8.2.2-1 Ground water elevations in Neroly Lower Blue

Sandstone aquifer, southeastern part Site 300, March 1990

\section{Tables}

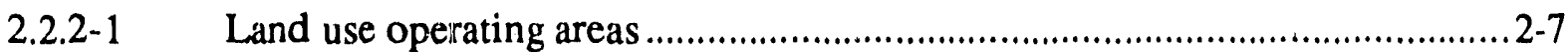

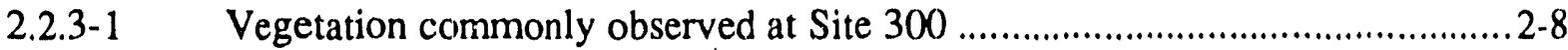

2.2.4-1 Wildlife species observed or expected at Site 300 ........................................ 2-9

7.2.3-1 RDX and HMIX acute toxicity $\left(\mathrm{LD}_{50}\right)$ dose data .......................................... 7.8 
8.1.1-1 Soluble Threshold Limit Concentrations, Maximum Contaminant Levels, Department of Health Services recommended State

Action Levels, and Designated Levels for VOCs in soil and ground water ..... 8-6

8.1.1-2 Soluble Threshold Limit Concentrations, Total Threshold Limit

Concentrations, Maximum Contaminant Levels, and Designated Levels

for metals concentrations in soil and ground water

8.2-1 Concentrations of RDX and VOCs in aquifers in the

HE Process Area

\section{Plates}

Plate 1 Topographic Map of Site 300 (in pocket folder at the end of this report)

Plate 2 Geologic Map of Site 300 (in pocket folder at the end of this report)

Plate 3 HE Process Area showing facilities (Chapter 1, Page 1-5)

Plate 4 HE Process Area. Map showing facilities, decommissioned lagoons, HE surface impoundments, monitor wells and exploratory boreholes (Chapter 1, Page 1-6)

Plate 5 Piezometric Surface, Confined Aquifer, Site 300 (End of Chapter 2) 


\section{Executive Summary}

This report presents the results of a Remedial Investigation (RI) to define the extent of high explosives (HE) compounds and volatile organic compounds (VOCs) found in the soil, rocks, and ground water of the HE Process Area of Lawrence Livermore National Laboratory's (LLNL) Site 300 Facility. The report evaluates potential public health and environmental risks associated with these compounds. Hydrogeologic information available before February 15, 1990, is included; however, chemical analyses and watzr-level data are reported through March 1990.

This report is intended to assist the California Regional Water Quality Control Board (RWQCB)-Central Valley Region and the U.S. Environmental Protection Agency (EPA) in evaluating the extent of en ironmental contarnination of the LLNL HE Process Area and ultimately in designing remedial actions.

Many of the discussions presented in this report are based on published reports, modified with new information. These reports are:

- Raber and Carpenter, 1983;

- Raber, 1983;

- Steenhoven and Crow, 1986;

- Crow et al., 1986;

- Carpenter et al., 1988;

- Quarterly issues of LLNL's Site 300 Environmental Investigations Quarterly; and

- The Draft California Environmental Impact Report (Draft EIR) prepared for the University of California Board of Regents to support LLNL's contract renewal in 1987 (University of California, 1986).

As background information, this report provides details on the environment, geology, and hydrogeology of parts of Site 300 to facilitate a more thorough understanding of the distribution of contaminants in the HE Process Area. Although our knowledge of the geology and hydrogeology of the HE Process Area is relatively complete, some relationships that affect contaminant distribution remain uncertain. Therefore, investigations will continue and supplementary reports will follow.

Prior to 1985, rinsewater containing low zoncentrations of HE compounds was discharged from various $\mathrm{HE}$ processing facilities into evaporation lagoons. Some of the water infiltrated the soil and rock beneath the lagoons, leaving environmental concentrations of RDX and HMX. The concentrations of RDX and HMX are generally less than $1 \mathrm{mg} / \mathrm{kg}$ (ppm). Subsequent environmental investigations conducted between 1986 and 1988 resulted in closure of the lagoons in accordance with a closure plan approved by the RWQCB. This closure was completed in October 1989.

In 1985, low concentrations of RDX were detected in ground water near Building $\$ 17$ in the HE Process Area. The maximum detected concentration of R.DX in ground water is 3.5() $\mu \mathrm{g} / \mathrm{L}(\mathrm{ppb})$. Since then, investigaliun: have determined RDX to be present in small areas of iwo aquifers beneath Buildings 815 and 817 . One of the aquifers is a perched aquifer; the other is the water table aquifer in the region. To date, no HE compounds have been detected in the decper regional confined aquifer at Site 300. Despite intensive irvestigations, the location of the release site of the RDX remains uncertain. 
During our evaluation of the environmental significance of the occurrence, we found that no regulatory drinking water standard for RDX exists. The U.S. Army has sponsored research that resulted in a suggested drinking water criterion (Etnier, 1989) of $105 \mu \mathrm{g} / \mathrm{L}(\mathrm{ppb}) \mathrm{RDX}$. This criterion was used as a basis for issuancr, of a National Pollution Discharge Elimination System (NPDES) permit at the Army Ammunition Plant in Grand Island, Nebraska. Comparison of the concentrations of RDX encountered in ground water samples in the HE Process Area with this criterion indicates that RDX concentrations in perched aquifer ground water are somewhat higher than the $105 \mu \mathrm{g} / \mathrm{L}$ criterion. Concentrations in ground water from the water table aquifer are slightly above to well below the suggested criterion. In recent months, the higher values for RDX detected in sets of duplicate samples have been near or slightly above the suggested drinking water criterion, but the mean is less than the $105 \mu \mathrm{g} / \mathrm{L}$ criterion.

Around the Building 815 Area, trichloroethylene (TCE) has also been detected in ground water from the perched aquifer and the first water table aquifer of the HE Process Area. The area where TCE has been detected overlaps the area containing RDX, but the two areas do not exactly coincide. The release site of the TCE is probably at Building 815 , where TCE was used to clean a steam boiler and was stored on a haidstand near the building. In this area, TCE in ground water from the two aquifers exceeds the Federal and California Maximum Contaminant Level (MCL) of $5 \mathrm{ug} / \mathrm{L}(\mathrm{ppb})$. The maximum detected TCE concentration is $280 \mu \mathrm{g} / \mathrm{L}(\mathrm{ppb}$ ) in water from a well installed immediately adjacent to Building 815. No TCE has ever been found in the regional confined aquifer beneath the HE Process Area.

In a forthcoming Feasibility Study (FS), alternative methods of remediation will be considered for ground water containing HE compounds and/or TCE. 


\section{Chapter 1. Site Background Information}

\subsection{Description of Site 300}

LLNL, operated hy the University of California for the U.S. Department of Energy (DOE), began operations in 1952 to design and test nuclear weapons and research magnetic fusion. Since 1952 , LLNL has added other major programs including:

- Applied laser fusion research,

- Laser isotope separation,

- Biomedical and environmental studies, and

- Applied energy technologies.

In. 1955, LLNL established Site 300 as an HE test arsa. Site 300 is located in the southeastern Altamont Hills, which are part of the Coast Range Physiographic Province. The site lies about 15 miles southeast of Livermore and 8.5 miles southwest of Tracy, California. Figure 1.1-1 shows its location relative to LLNL and regional points of reference. Site 300 covers about 11 square miles (6,888 acres) and is primarily located in San Joaquin County (Fig. 1.1-2). About one-sixth of the property, along the western edge, lies in Alameda County. The climate is semia. id, and the topography (Plate 1, see note below) is characterized by moderate to steep hills and deep canyons. Because of these features, cultivation was never practical, and the only prior land use was for sheep and cattle grazing. Plate 2 (see note below) shows the generalized geology of Site 300 .

Site 300 operations include four programmatic activities:

- Hydrodynamic diagnostic testing;

- Charged particle-beam research (currently not in operation)

- Physical, environmental, and dynamic testing; and

- HE formulation and fabrication.

Access to Site 300 is restricted.

T: General Services Area (GSA) supplies centralized administrative, technical, and crafts support to all operational areas. The location of each area is shown on Figure 1,1-2.

\subsection{Description of the HE Process Area}

The HE Process Area is in the south-central part of Site 300. Chemical operations include formulation of $\mathrm{HE}$ compounds for experiments. Mechanical operations include pressing and machining parts containing HE compounds. The HE Process Area occupies about 285 acres (B. Jahn, LLNL, personal communication, 1989). Plate 3 shows the topography of the area and the locations of active facilities. The steep hills and ravines provide naturally protective sites for the construction of the facilities and explosives storage magazines. These facilities are also designed for maximum personnel safety.

Buildings 812,814 , and 819 , located just east of the HE Process Area, serve functions related to it and are included in the discussions in this report. The Building 829 Complex (the HE Burn Pit), located in the northwest part of ihe HE Process Area, is used for burning HE scrap and waste. Refer to Webster-Scholten and Crow (1989) for the results of an RI of the Burn Pit, not discussed in this report.

Note: Plates 1 and 2 are in pocket folders at the end of this document. 


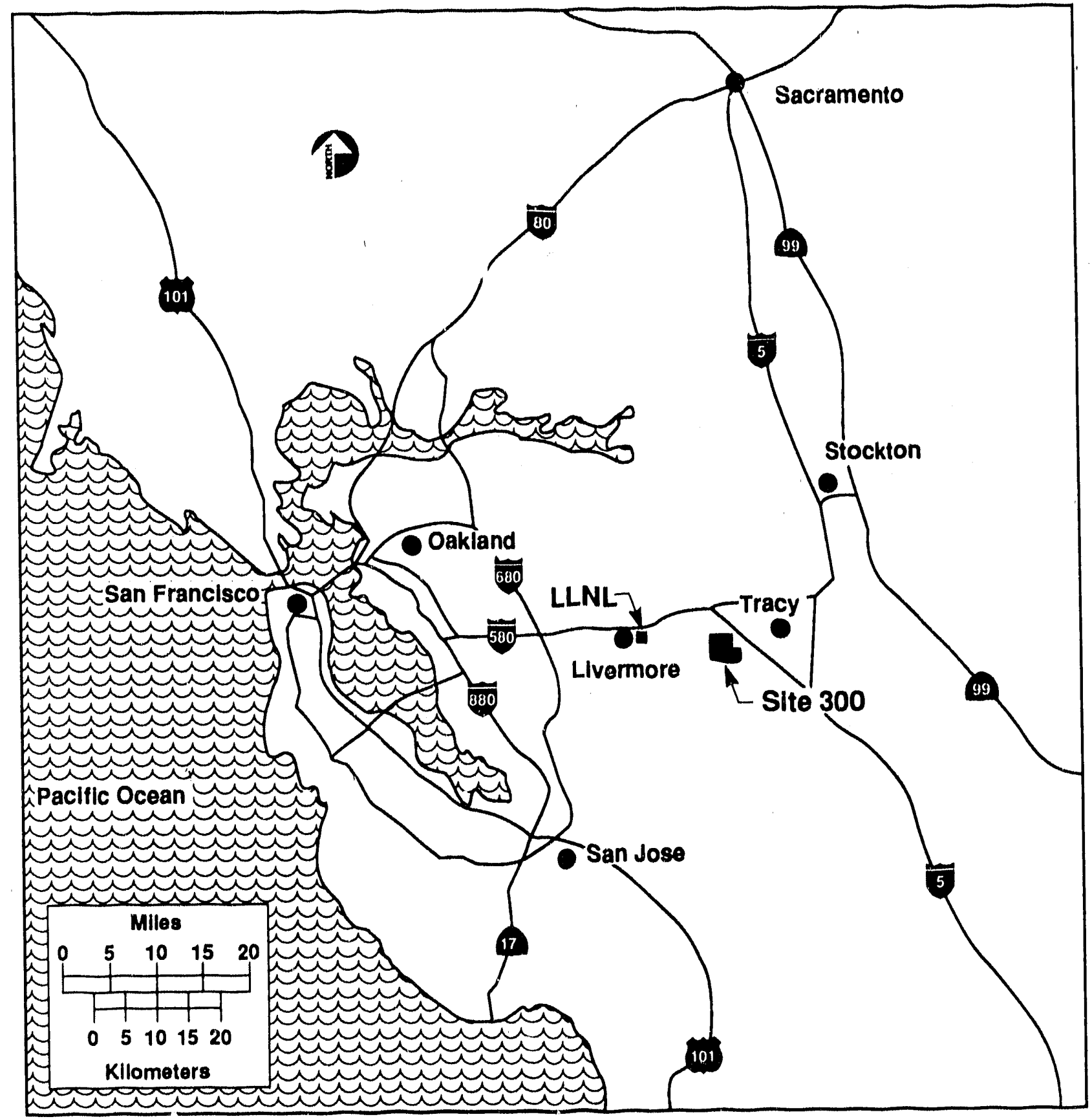

Figure 1.1-1. Location of LLNL and Site 300. 


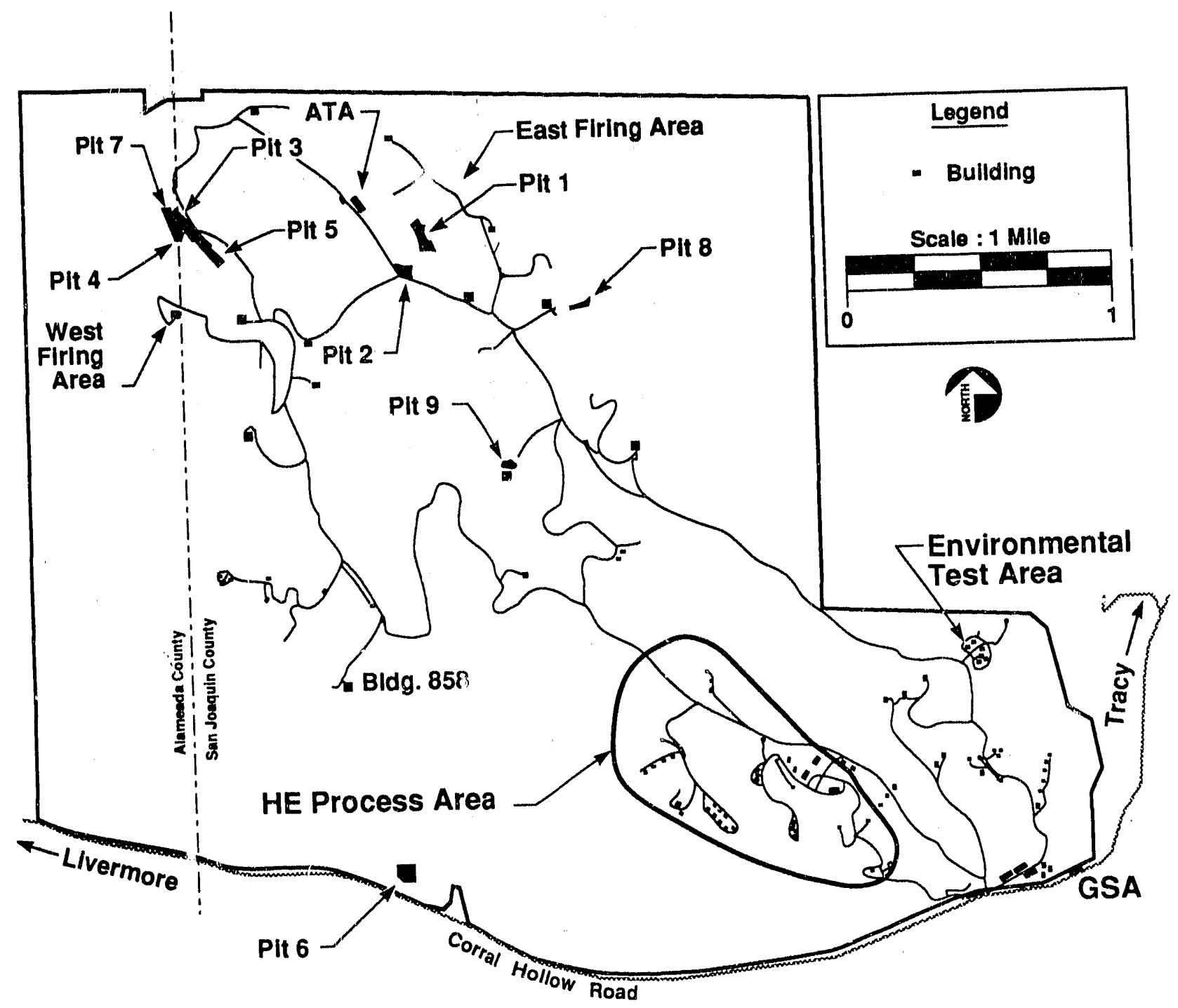

Figure 1.1-2. Location of HE Process Area and other areas of Interest at Site 300. 


\subsection{Summary of Waste Disposal History, HE Process Area}

Operations in the HE Process Area use process tap water to fabricate experimental devices containing HE compounds. Water is also used to formulate explosives and to cool and lubricate machining operations.

Until 1985, process rinsewater, containing low concentrations of the HE compounds cyclo-1,3,5trimethylene-2,4,6-trinitramine (RDX) and cyclo-tetramethylene-tetranitramine (HMX), was discharged into nine shallow lagoons where the rinsewater evaporated and infiltrated the rocks and soil beneath the lagoons. RDX and HMX were developed in the United Kingdom during World War II. RDX is an acronym for Research Department Explosive, and HMX signifies High Melting Point Explosive.

The nine lagoons were decommissioned in late 1985, and the $\mathrm{HZ}$ rinsewater that formerly drained to the lagoons is now diverted to two surface ponds (the HE Surface Impoundments), with double impermeable liners, located south of Building 817 (Plate 3). See Section 3.1.2 for details.

\subsection{Previous Investigations}

\subsubsection{Extent of HE Compounds in Soil and Rock}

In 1981, investigations of potential chemical releases within the HE Process Area began with the Hazardous Waste Assessment Project (HWAP). This included a study of the hydrology, geology, and ground water chemistry associated with the lagoons in the HE Process Area (Raber, 1983). The studies included a reconnaissance to determine the scope of potential environmental problems and limited hydrogeological studies of infiltration at several of the HE Process Area rinsewater lagoons (Raber, 1983). The installation of the HE Surface Impoundments in 1984 was accompanied by the drilling of a network of monitoring wells. These monitor wells are the nucleus of the extended network of monitor wells established during later investigations.

Between 1986 and 1988, LLNL investigated the extent of HE compounds in soil and rock beneath the decommissioned lagoons. LLNL drilled 42 exploratory boreholes during this period (see Chapter 8). Analytical data from soil and rock samples are in Appendix A. Chemical analyses of ground water samples are presented in Appendix B. Drillers' logs of the boreholes and monitor wells drilled since July 1, 1988, are in Appendix C. Earlier logs are in Toney and Crow (1989).

In 1988, when these investigations were completed, LLNL proposed a closure plan for the decommissioned lagoons (Carpenter et al., 1988). The report concluded that the decommissioned lagoons did not constitute a significant threat to human health, safety, or the environment, and that they could be closed successfully by backfilling the lagoons and installing impermeable clay caps with additional safeguards such as drainage diversion ditches. The closure plan was accepted by the RWQCB-Central Valley Region with a few modifications. Closure of the decommissioned lagoons was completed in October 1989.

\subsubsection{Extent of HE Compounds in Ground Water}

In April 1985, the HE compound RDX was first discovered at $37 \mu \mathrm{g} / \mathrm{L}$ (ppb) in ground water collected from monitor well W-817-01, located near Building 817 (Plates 3 and 4). Due to this, LLNL drilled 17 monitor wells in and near the HE Process Area to gather information (see Chapter 8 for detailed results). In October and November 1989, HMX was detected for the first time in monitor well W-817-01 in low concentrations (a mean cf $38 \mu \mathrm{g} / \mathrm{L}$ HMX) in ground water from the $\mathrm{HE}$ Process Area. More recent samples, collected form this monitor well in the winter and spring of 1990, do not contain HMX. Therefore we are, uncertain if HMX is present in this ground water. The concentrations of $\mathrm{HE}$ compounds detected in water from these wells is presented in Appendix $\mathrm{B}$; a summary of the RDX concentrations is in Table 8.2-1. 


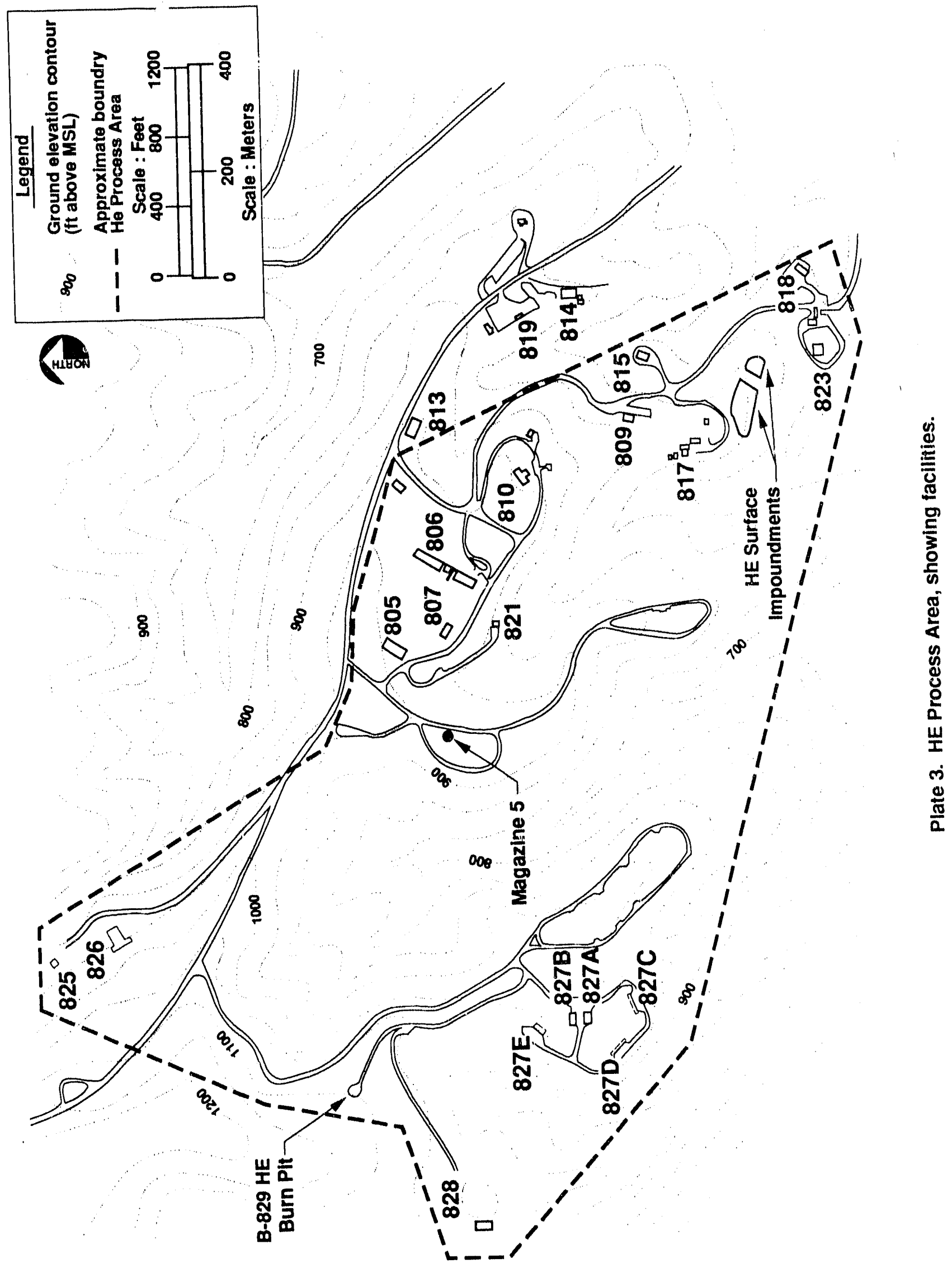




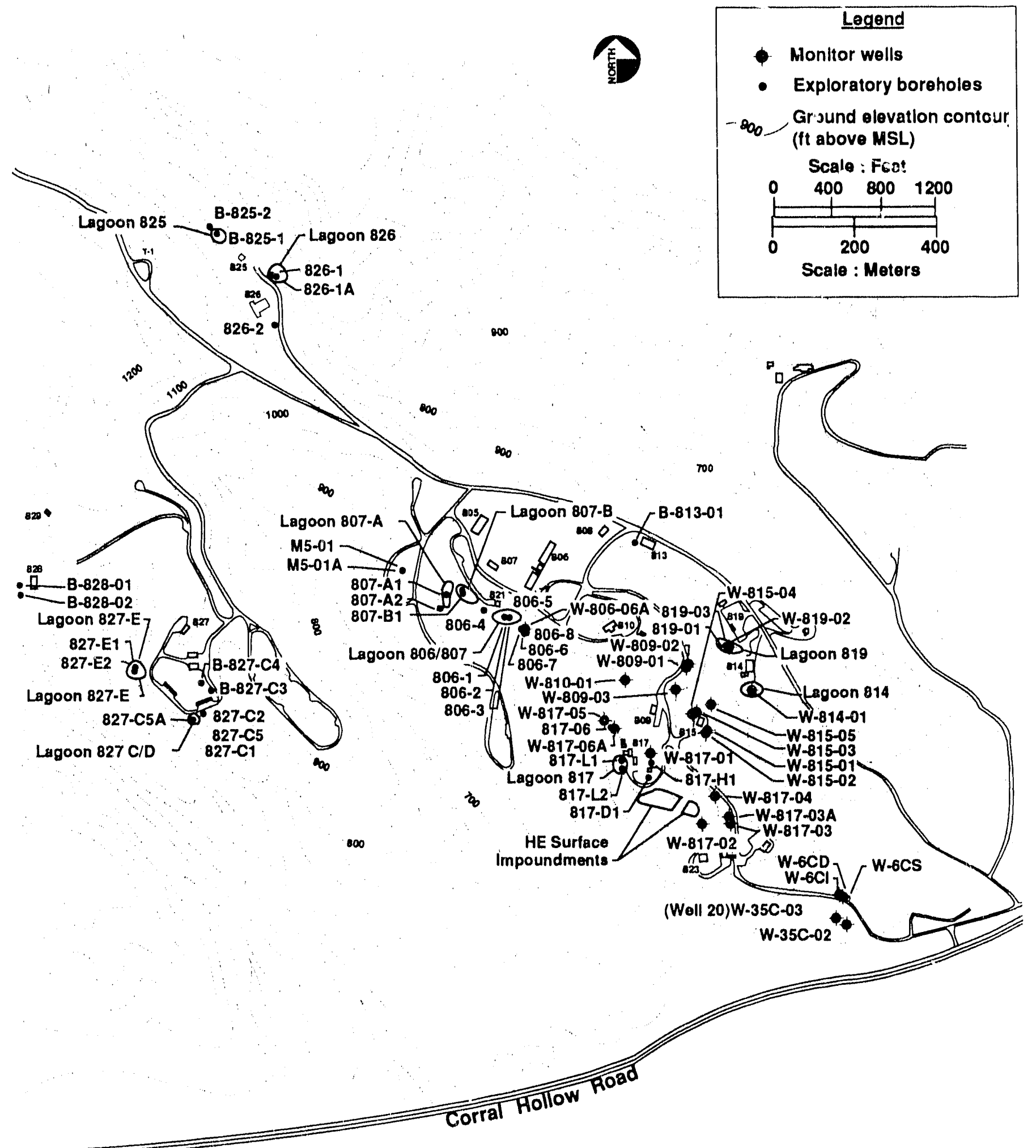

Plate 4. HE Process Area. Map showing facilities, decommissloned lagoons, HE surface impoundments, monitor wells and exploratory boreholes. 


\subsubsection{Extent of VOCs in Soil and Rock and in Ground Water}

Lcw concentrations of VOCs are present in a limited area neas, and south of, Building 815 . The VOC detected most often is TCE. TCE was first detected in ground water samples collected during April 1987 (280 ug/L [ppb]). Sirice then, monitor wells have been drilled that place partial bounds on the area containing TCE. We are continuing our work to establish a bound on the eastern side of the area.

Traces of several other VOCs have also been reported in water samples scattered over several samplings from several monitor wells in the HE Process Area (at concentrations less than federal MCLs). See Chapter 8 for details. 


\section{Chapter 2. Environmental Setting}

\subsection{Areas Surrounding Site 300}

\subsubsection{Demography}

One reason Site 300 was selected as the location for LLNL's high-explosives (HE) testing experiments is because of the sparsely populated surrounding area. Most of the neighboring land owners do not live on their properties. On the basis of residential population, the average density is less than one person per square mile around the perimeter of Site 300.

\subsubsection{Land Use}

2.1.2.1. Present Uses. Figure 2.1.2-1 shows the land use distribution in the vicinity of Site 300. Major users to the south and east include:

1. Carnegie State Vehicle Recreation Area (SVRA), an outdoor recreational facility for private and commercial offroad motorcycle riding, testing, and racing.

2. SRI International, which operates an explosives test site in the hills south of Carnegie SVRA.

3. The Gallo and the Connolly Ranches, used primarily for cattle grazing.

4. Physics International, a private firm that operates another explosives test facility adjacent to the northeast side of Site 300.

5. California Department of Fish and Game open land, which currently has no public access.

The California Department of Forestry operates the Castle Rock Fire Station, located on the Connolly property on Corral Hollow Road near the southeast corner of the site. Immediately north of Site 300 lies rangeland owned by the Mulqueeny, Yroz, and Vieira families. To the east are other smaller parcels of rangeland. Several private residences are located along Corral Hollow Road, west of Site 300 and the Carnegie SVRA. Surrounding Site 300 on the west, north, and east are farms and ranches used primarily for cattle grazing. These latter properties are generally characterized by absentee ownership.

Permanent residents live on the Connolly Ranch and at the ranger headquarters for the Carnegie SVRA. The Connolly family lives in a house on the ranch property, and the ranger and his family occupy a mobile home located on state property north of Corral Hollow Road.

The Castle Rock Fire Station has no permanent residents. The station, used as a staging area for brush and grass fire fighting in the Altamont Hills and the Diablo Range, is fully-manned with 8 fire-fighters only during the fire season (May-October). At times during the winter, two persons are assigned to the station. The Carnegie SVRA is open to the public for off-road motorcycling. It is the most heavily used area near Site 300; on peak weekends, 500 to 1000 visitors use the SVRA almost entirely on a day-use basis.

2.1.2.2. Historic Uses. The modern history of the Corral Hollow area began during the Mexican period (1800 to 1846), when it served as a major trade route between the Central Valley and San Jose. Throughout most of the 19 th century, it was sparsely populated, and economic activities were limited to raising livestock, timber cutting, and coal mining; the latter was only 


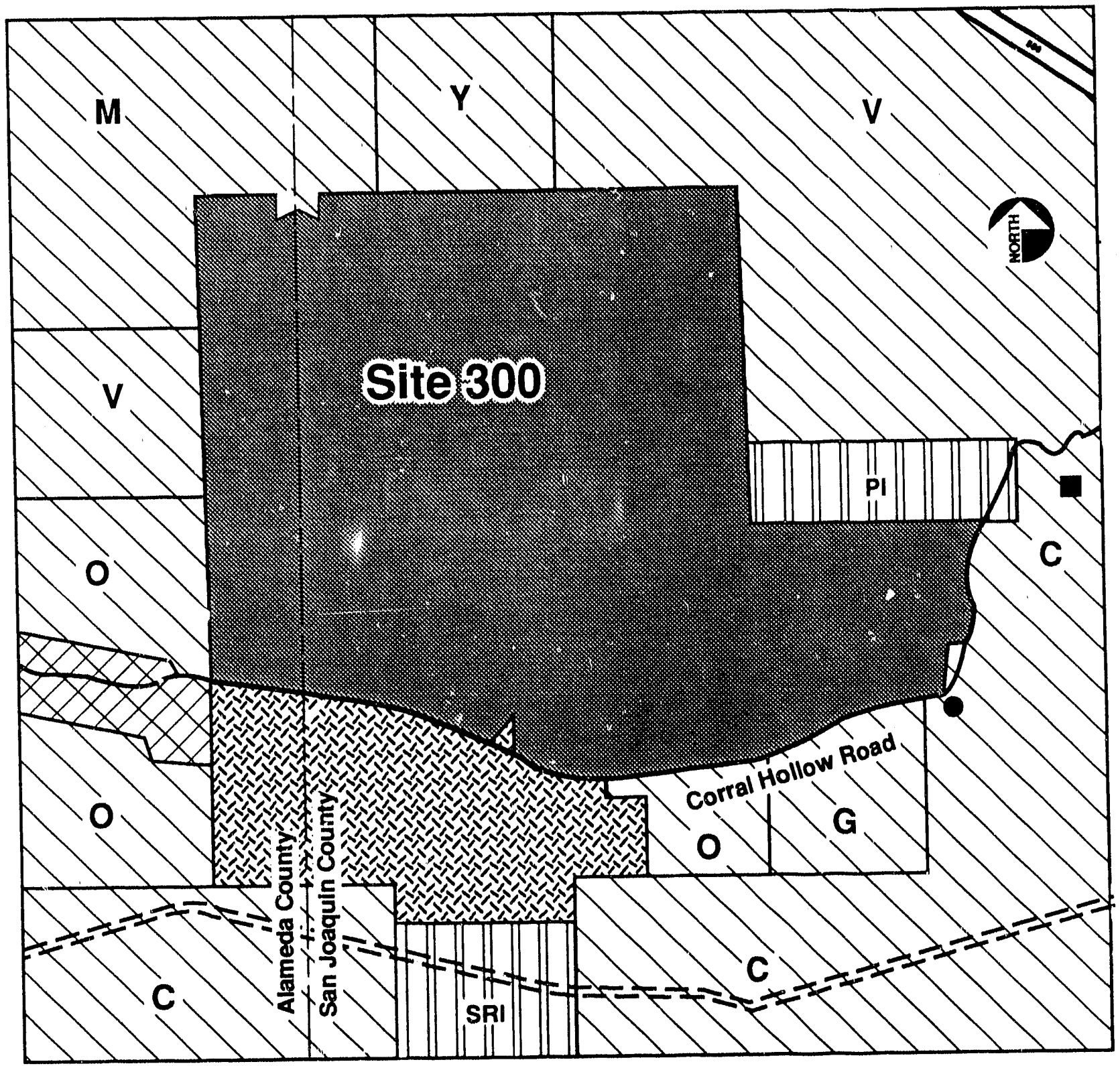

\section{Legend}

Federal Materlals Testing \& Research

[III Private Materials Testing \& Research

Private Range Land

XX Residentlal Land

EXYy Carnegie State Vehicle Recreation Area

$G=$ Gallo Ranch
$C=$ Connolly Ranch
$M=$ Mulqueeriey Ranch
$Y=$ Yroz Ranch Land
$Y=$ Vleira Ranch Land
$O=$ Other Ranch Land
$P I=$ Phyalcs International
SRI= SRI International

- Castle Rock FIre Station

$=$ Hetch Hetchy Aqueduct Interstate 580

Droadcasting tower

$\frac{\text { Scale:Feot }}{0}$

Figure 2.1.2-1. Land use in the vicinity of Site 300 . 
marginally productive. However, before the turn of the century, coal and clay mining in the Corral Hollow area were profitable. Several settlements were established in the vicinity of what is now Site 300. Carnegie, the largest of the towns, was located east of Pit 6 (Fig. 1.1-2). Although abandoned in 1912, during its peak period Carnegie had churches, schools, company stores, a hotel, saloons, boarding houses, and company-supplied family housing. An archaeological survey in 1981 (Busby et al., 1981) revealed four aboriginal sites and 21 historical sites within the boundaries of Site 300. Many of the historical sites were associated with the Carnegie development.

\subsubsection{Vegetation}

The area surrounding and including Site 300 is primarily grassland, although an oak woodland community exists in the hills to the south. Annual grasses cover both Site 300 and the adjacent hills. Isolated scrub oak trees grow on north-facing hills. With the exception of sagebrush, less vegetation is present on hills with southern exposures. Deciduous trees grow along the corral Hollow creek bed, but vegetation elsewhere is generally limited to seasonal grasses $8 . n d$ localized areas of brush. (Table 2.2.3-1 lists the species of vegetation in the vicinity of Site ?00.)

\subsubsection{Wildlife}

Many species of mammals, reptiles, insects, and birds live in the grassland and oak woodland community around Site 300. Mammals consist of rodents, such as mice, gophers, and squirrels, which feed on the plants and grasses. Larger mammals include deer, badger, coyote, fox, and bobcat. Reptiles include several varieties of snakes and lizards. There is a large variety of birds, although their population is limited due to the lack of trees to serve as a shelter from predators. Although some species of birds roost and nest elsewhere, many depend on the Site 300 region for its abundant supply of seeds and insects. (Table 2.2.4-1 lists mammals in the Site 300 area.)

\subsubsection{Surface and Ground Water Use}

Site 300 lies within the San Joaquin River drainage basin. Except following the largest storms, no water reaches the San Joaquin River from Corral Hollow Creek. Normally, there is little to no surface water at or near Site 300. During very heavy winter storms, rainfall runs off in otherwise dry watercourses (Fig 2.1.5-1). Corral Hollow Creek, the major ephemeral stream of the region, flowed most recently during and after the historically wet winter and spring of 1983. Any streamflow tends to quickly infiltrate the streambed. Ultimately, Corral Hollow and the Elk Ravine drain to the San Joaquin River Basin. The only surface water used in the area surrounding Site 300 is seasonal drinking water for wildlife and cattle.

Local ground water from wells supplies essentially all domestic (except drinking) and livestock water requirements in the vicinity of Site 300 . Bottled water is the source of drinking water. Springs, both onsite and offsite, do not represent significant water sources for year-round use. Figure 2.1.5-2 is a map of water-supply wells and seeps in the vicinity of Site 3()).

\subsubsection{Climate}

The climate of the area surrounding Site 300 is generally characterized by mild, rainy winters and hot, dry summers. Sunshine is abundant throughout the year.

During winter, cyclonic storms of the westerlies affect the region and are accompanied by southerly or southwesterly winds and short rainy periods. As barometric lows pass, light snow sometimes falls over the higher elevations. Following passage of the low-pressure front, skies 


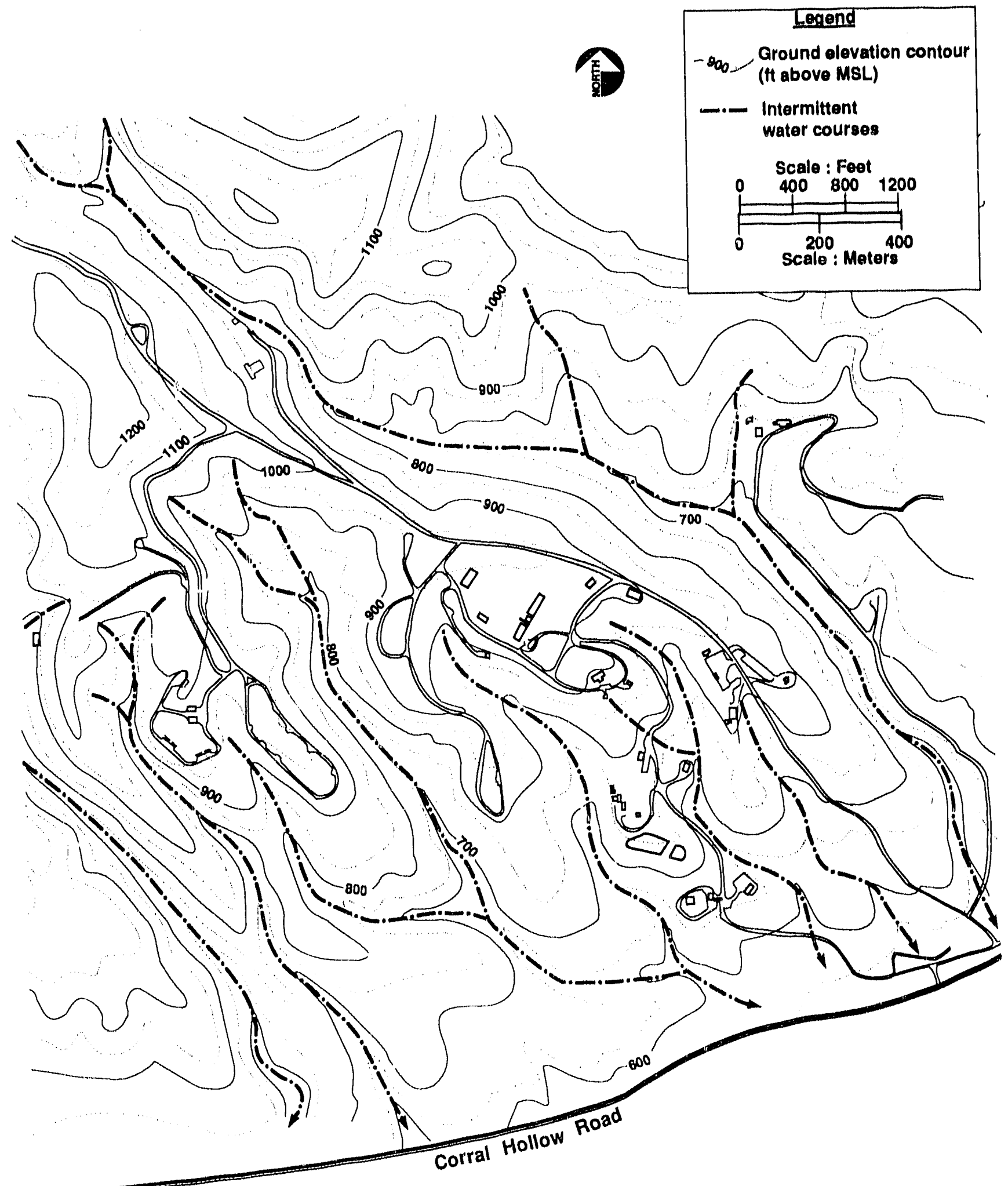

Figure 2.1.5-1. Intermittent water courses, HE Process Area. 


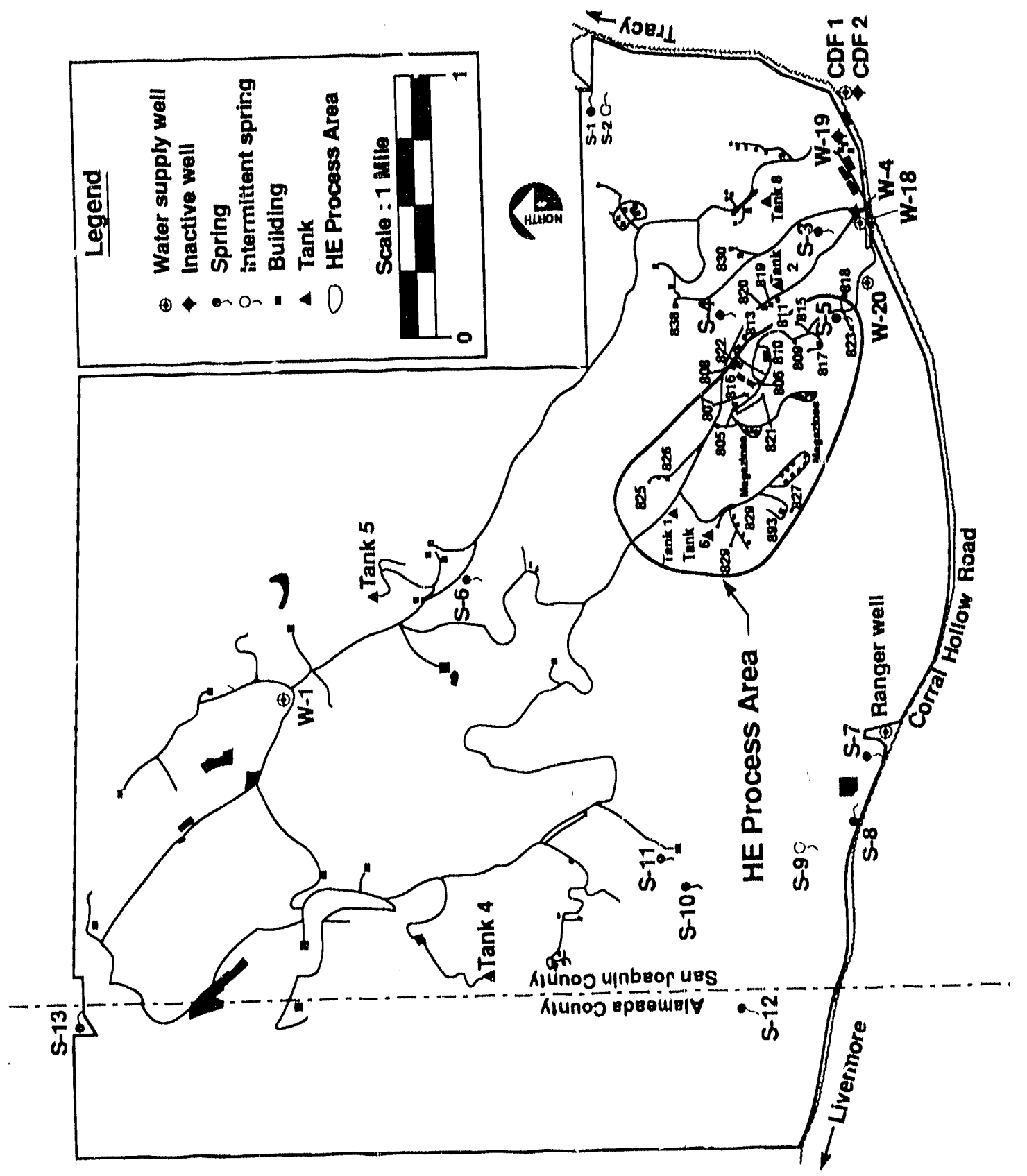

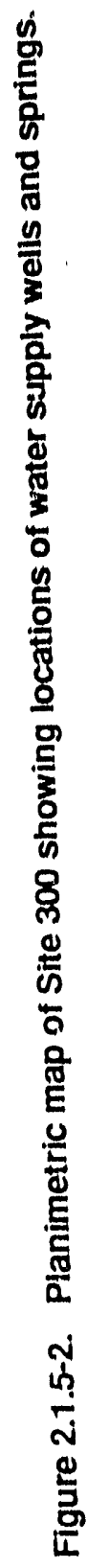


typically clear as the Eastern Pacific High builds inland. Infrequently, strong northerly surface winds with gusts in excess of 6() $\mathrm{m}$ ph are experienced for 1 to 2 days. During nonrainy perlods, fog, which frequently forms in the San Joaquin Valley, may move over the area, particularly during December and January.

Summers are consistently hot and dry, although moist subtropical air occusionally spreads over central California and thunderstorms occur. A sea breeze often develops during the afternoon when modified marine air moves through the passes to the west and is funnelled through Corral Hollow. The velocity of the sea brceze occasionally exceeds $40 \mathrm{mph}$, but is usually in the range of 10 to $30 \mathrm{mph}$. A strong breeze can reduce maximum temperatures by $40^{\circ} \mathrm{F}$. The breeze persists into the evening and sometimes throughout the night, resulting in significantly cooler mornings. If the marine alr layer is sufficiently deep, stratus clouds are advected to within several miles of the western boundary of Site 300).

In contrast, daily temperature, wind speed, and wind direction vary during spring and fall.

\subsection{Site 300}

\subsubsection{Work Force}

From 1978 to 1987 , the work force at Site 300 averaged 293 people. The work force for 1989 through the beginning of 1990 has been about 270 full-time employees and 30 supplemental employees. Over half of these personnel work in the GSA and are associated with site management, administrativc, or support activities. With the exception of the charged particle-beam research program, most of the buildings in the operating areas are staffed by fewer than 10 people.

\subsubsection{Land Use}

Figures 2.1.2-1 and 2.1.5-2 show the active programmatic and support areas at Site 300.

Programmatic areas include:

- Hydrodynamic test facilities, located in two areas, the East and West Firing Areas.

- Charged particle-beam research, located northwest of the East Firing Area. This operation was not funded for 1990.

- The Environmental Test Facility for tests of physical, environmental, and dynamic properties of nonnuclear explosives assemblies. The major portion of the ETA is located in the southeast corner of the site. Building 854 , in the west-central part of the site, is also used for such tests.

- The HE Process Area, the subject of this report. As part of its explosives testing, LLNL performs both chemical and mechanical processes on experimental components containing HE compounds, and assembles nonnuclear explosive test devices in the HE Process Area.

Site 300 explosives test facilities, including explosives mixing, pressing, machining operations and facilities, magazines, and test firing sites, were located so that the rugged topography of the site minimizes explosives test overpressure (shock waves) and maximizes test personnel safety. Personnel safety is a primary concern; therefore, LLNL has developed and continues to operate a very comprehensive safety program to prevent accidents. Remote control of explosives tests and fabrication operations, plus very strict control of access to facilities and the areas immediately surrounding them when high explosives are present, have been 
instrumental in setting an excellent safety record. No individual has been injured by exploslons since Site 300 began operations in 1955 (J. E. Lane, L.LNL, personal comrnunication, 1989).

Support areas include:

- The GSA in the southeastern part of the site, adjacent to Corral Hollow Creek.

- A peripheral buffer zone.

Table 2.2.2-1 lists these activitles and their locations.

Table 2.2.2-1. Land use operating areas.

\begin{tabular}{ll}
\multicolumn{1}{c}{ Activity } & \multicolumn{1}{c}{ Locatioin } \\
\hline Hydrodynamic testing & East and West Firing Area \\
Charged particle beam research (pret, ntly inactive) & East Firing Area \\
Physical, environmental, and dyramic testing & Southeast area of the site \\
& West Firing Area \\
High-explosive formulation & Southeast area of the site \\
Fabrication & Southeast area of the site \\
\hline \hline
\end{tabular}

\subsubsection{Vegetation}

Site 300 is generally a grassland community, with some isolated brush and shallow-rooted trees. It is considered the only natural location for a rare species of wild flower, Amsinckia grandiflora. This plant, which grows to a height of about 10 in., was first discovered in the $1880 \mathrm{~s}$. It was later thought to be extinct until a small population was discovered at Site 30() in 1938 near the present site of Building 858 (Plate 4) in western Site 300. An additional population was discovered in 1988 near the site's western boundary. The plant meets the criteria for placement on the endangered species list, according to the Endangered Species Act of 1973.

Table 2.2.3-1 lists the plants commonly found within Site 300. Some are native to the area and occur th the surrounding ares as well; others were planted as part of the landscaping.

\subsubsection{Wildlife}

Table 2.2.4-1 lists the wildlife species that reside part or most of the year within Site 3()(). Because hunting and activities associated with stock raising are prohibited at Site $3(0)$, the wildlife population has increased since 1955. No threatened or endangered species of wildlife is known to use this habitat.

A variety of snakes and lizards inhabit Site 300). Bird species include crows, lurkey vultures, hawks, eagles, and smaller species. Many insect species also populate the area.

\subsubsection{Surface and Ground Water}

2.2.5.1. Surface Water. Except during unusually heavy winter storms, there is no permanent surface water at Site 300. The discussion in Section 2.1.5 applies to Site 3()() as well as its near vicinity. 
Table 2.2.3-1. Vegetation commonly observed at Slte 300 (Taylor and Davilla, 1986),

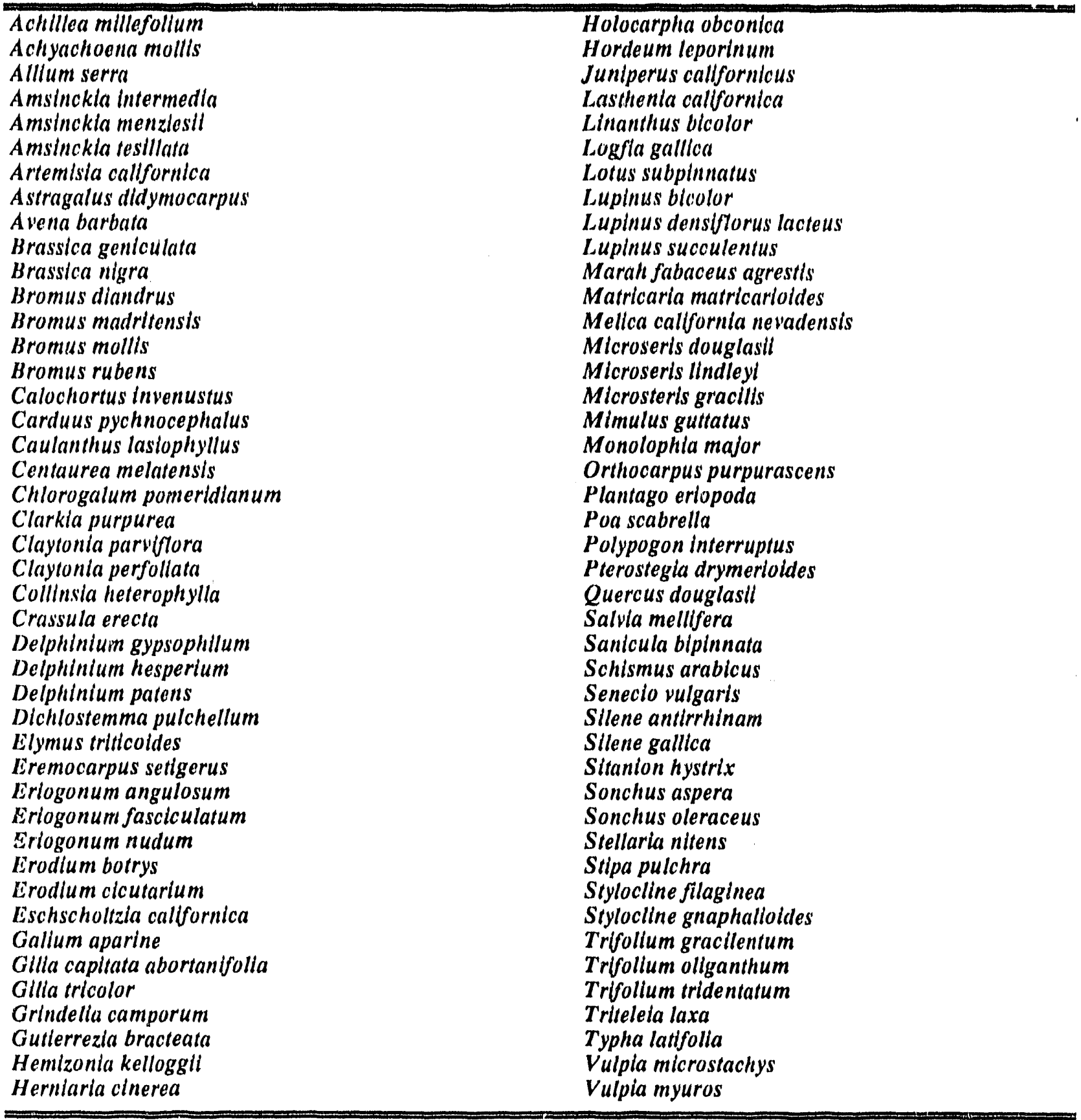


Tabld 2.2.4-1. Wildlife species observed or expected at Site 300 (Orloff, 1986).

\section{Class: Amphibia}

Tiger salumander (A mbystoma tigrinum callformiense)

Callfornia slender salamander (Batrachoseps attenuatus)

Western spadefoot (Scaphlopus hammondi)

Western toad (Bufo boreas)

Pacific treefrog (Hyla regilla)

Red-legged frog (Rana aurora draytoni)

$\mathrm{X}$

$\mathbf{X}$
$\mathbf{X}$
$\mathrm{X}$

$\mathrm{X}$

$\mathrm{X}$

$\mathbf{X}$

\section{Class: Reptilia}

Long-nosed leopard lizard (Gambella wislizenil)

Desert spiny lizard (Sceloporus magister)

Western fence lizard (Sceloporus occldentalis)

Sagebrush lizard (Sceloporus graciosus)

Side-blotched lizard (Uta stansburiana)

Coast horned lizard (Phrynosoma coronatum)

Western skink (Eumeces skiltonianus)

Gilbert's skink (Eumeces gilberti)

W'stern whiptail (Cnemidophorus tigris)

Northern alligator lizard (Gerrhonotus coeruleus)

Ringneck snake (Diadophis punctatus)

Racer (Coluber constrictor)

Couchwhip (Masticophls flagellum)

Alameda striped racer (Masticophis lateralis euryxanthus)

Glossy snake (Arizona elegans')

Gopher snake (Pltuophis melanoleucus)

Common kingsnake (Lampropeltis getulus)

Common garter snake (Thamnophis sirtalis)

Western black-headed snake (Tantilla planiceps)

Western rattlesnake (Crotalus virldis)

Long-nosed snake (Rhinochellus lecontel)

\section{Class: Aves}

Mallard (Anas platyrhynchos)

Turkey vulture (Cathartes aura)

Black-shouldered kite (Elanus caeruleus)

Northern harrier (Circus cyaneus')

Red-tailed hawk (Buteo jamaicensis)

Ferruginous hawk (Buteo regalis)

Rough-legged hawk (Buteo lagopus)

Golden eagle (Aquila chrysatoss)

American kestrel (Falco sparverius)

Merlin (Falco columbarius)

Prairte falcon (Falco mexicanus)

California quall (Callipepla californica)

Killdeer (Charadrius vociferus)

Rock dove (Columba livia)

Band-talled pigeon (Columba fasciuta)

Mourning dove (Zenaida macroura)

Common barn owl (Tyto alba)

Western screech owl (Otus kennicottii)

Great horned owl (Bubo virginianus)

Burrowing owl (Athene cunicularia)
$\mathbf{X}$

X

$\mathrm{X}$

$\mathbf{X}$

$\mathrm{X}$

$\mathrm{X}$

$\mathrm{x}$

$\mathrm{X}$

$\mathrm{X}$

$\mathrm{x}$

$\mathrm{X}$ 
Table 2.2.4-1. (Continued.)

\begin{tabular}{|c|c|c|}
\hline & Observed & Expected \\
\hline Short-eared owl (Asio flammeus) & $\mathbf{X}$ & \\
\hline Common nighthawk (Chordeiles minor) & $\mathbf{x}$ & \\
\hline White-throated swift (Aeronautes saxatalis) & $\mathbf{X}$ & \\
\hline Anna's hummingbird (Calypte anna) & $\mathbf{X}$ & \\
\hline Costa's hummingbird (Calypte costae) & & $\mathbf{X}$ \\
\hline Calliope hummingbird (Stellula calliope) & & $\mathbf{X}$ \\
\hline Rufous hummingbird (Selasphorus rufus) & $\mathbf{X}$ & \\
\hline Allen's hummingbird (Selasphorus sasin) & $\mathbf{X}$ & \\
\hline Lewis's woodpecker (Melanerpes lewis) & & $\mathbf{X}$ \\
\hline Acorn woodpecker (Melanerpes formicivorous) & & $\mathbf{X}$ \\
\hline Nuttall's woodpecker (Picoides nuttallii) & & $\mathbf{X}$ \\
\hline Northern flicker (Colaptes auratus) & $\mathbf{X}$ & \\
\hline Western wood-pewee (Contopus sordidulus) & $\mathbf{X}$ & \\
\hline Western flycatcher (Empidonax difficilis) & $\mathbf{X}$ & \\
\hline Black phoebe (Scyornis nigricans) & $\mathbf{x}$ & \\
\hline Say's phoebe (Sayornis saya) & $\mathbf{X}$ & \\
\hline Western kingbird (Tyrannus verticalis) & $\mathbf{x}$ & \\
\hline Horned lark (Eremophila alpestris) & $\mathbf{X}$ & \\
\hline Cliff swallow (Hirundo pyrrhonota) & $\mathbf{X}$ & \\
\hline Barn swallow (Hirundo rustica) & $\mathbf{X}$ & \\
\hline Scrub jay (Aphelocoma coerulescens) & $\mathbf{X}$ & \\
\hline Yellow-billed magpie (Pica nuttalli) & & $\mathbf{X}$ \\
\hline American crow (Corvus brachyrhynchos) & & $\mathbf{X}$ \\
\hline Common raven (Corvus corax) & $\mathbf{X}$ & \\
\hline Plain titmouse (Parus inornatus) & & $\mathbf{X}$ \\
\hline Bushtit (Psaltriparus minimus) & & $\mathbf{X}$ \\
\hline White-breasted nuthatch (Sitta carolinensis) & & $\mathbf{X}$ \\
\hline Rock wren (Salpinctes obsoletus) & $\mathbf{X}$ & \\
\hline Bewick's wren (Thryomanes bewickii) & & $\mathbf{X}$ \\
\hline House wren (Troglodytes aedon) & & $\mathbf{X}$ \\
\hline Blue-gray gnatcatcher (Polioptila caerulea) & & $\mathbf{X}$ \\
\hline Western bluebird (Sialia mexicana) & & $\mathbf{X}$ \\
\hline American robin (Turdus migratorius) & & $\mathbf{X}$ \\
\hline Northern mockingbird (Mimus polyglottos) & $\mathbf{X}$ & \\
\hline California thrasher (Toxostoma redivivum) & & $\mathbf{X}$ \\
\hline Water pipit (Anthus spinoletta) & $\mathbf{X}$ & \\
\hline Loggerhead shrike (Lanius ludovicianus) & $\mathbf{X}$ & \\
\hline European starling (Sturnus vulgaris) & $\mathbf{x}$ & \\
\hline Orange-crowned warbler (Vermivora celata) & & $\mathbf{X}$ \\
\hline Yellow-rumped warbler (Dendroica coronata) & & $\mathbf{X}$ \\
\hline MacGillivray's warbler (Oporornis tolmiei) & $\mathbf{X}$ & \\
\hline Western tanager (Piranga ludoviciana) & & $\mathbf{X}$ \\
\hline Lazuli bunting (Passerina amoena) & $\mathbf{X}$ & \\
\hline Rufous-sided towhee (Pipilo erythrophthalmus) & & $\mathbf{X}$ \\
\hline Brown towhee (Pipilo fuscus) & $\mathbf{x}$ & \\
\hline Rufous-crowned sparrow (Aimophila ruficeps) & $\mathbf{X}$ & \\
\hline Vesper sparrow (Pooecetes gramineus) & $\mathbf{X}$ & \\
\hline Lark sparrow (Chondestes grammacus) & $\mathbf{x}$ & \\
\hline Savannah sparrow (Passerculus sandwichensis) & $\mathbf{X}$ & \\
\hline Fox sparrow (Passerella iliaca) & $\mathbf{x}$ & \\
\hline Song sparrow (Melospiza melodia) & & $\mathbf{X}$ \\
\hline Golden-crowned sparrow (Zonotrichia atricapilla) & & $\mathbf{X}$ \\
\hline White-crowned sparrow (Zonotrichia leucophrys) & & $\mathbf{X}$ \\
\hline Red-winged blackbird (Agelaius phoeniceus) & $\mathbf{X}$ & \\
\hline Tricolored blackbird (Agelaius tricolor) & $\mathbf{x}$ & \\
\hline Western meadowlark (Sturnella neglecta) & $\mathbf{X}$ & \\
\hline Brewer's blackbird (Euphagus cyanocephalus) & $\mathbf{X}$ & \\
\hline Brown-headed cowbird (Molothrus ater) & & $\mathbf{X}$ \\
\hline
\end{tabular}


Northern oriole (Icterus galbiula)

Purple finch (Carpodacus purpureus)

House finch (Carpodacus mexicanus)

Lesser goldfinch (Carduelis psaltria)

Lawrence's goldfinch (Carduelis lawrencei)

American goldfinch (Carduelis tristis)

House sparrow (Passer domesticus)

$\mathbf{X}$

$\mathbf{X}$

$\mathbf{X}$

\begin{tabular}{ll} 
& $\mathbf{X}$ \\
$\mathbf{x}$ & $\mathbf{X}$ \\
$\mathbf{X}$ & \\
\hline
\end{tabular}

Class: Mammalia

Virginia opossum (Didelphis virginiana)

Pallid bat (Antrozous pallidus)

Brazilian free-tailed bat (Tadarida brasiliensis)

Desert cottontail (Sylvilagus audubonii)

Black-tailed hare (Lepus californicus)

California ground squirrel (Spermophilus beecheyi)

Botta's pocket gopher (Thomomys bottae)

San Joaquin pocket mouse (Perognathus inornatus inornatus)

California pocket mouse (Perognathus californicus)

Heermann's kangaroo rat (Dipodomys heermanni)

Western harvest mouse (Reithrodontu mys megalotis)

Deer mouse (Peromyscus maniculatus)

Brush mouse (Peromyscus boylii)

Desert woodrat (Neotoma lepida)

San Joaquin woodrat (Neotoma fuscipes riparia)

California vole (Microtus californicus)

House mouse (Mus muscuius)

Coyote (Canis latrans)

Red fox (Vulpes vulpes)

San Joaquin kit fox (Vulpes macrotis mutica)

Gray fox (Urocyon cinerceoargenteus)

Raccoon (Procyon lotor)

Long-tailed weasel (Mustela frenata)

Badger (Taxidea t $\sim x u s$ )

Western spotted skunk (Spilogale gracilis)

Striped skunk (Mephitis mephitis)

Mountain lion (Felis concolor)

Bobcat (Lynx rufus)

Mule deer (Odocoileus hemionus) $\mathbf{x}$

$\mathbf{X}$

$\mathbf{X}$

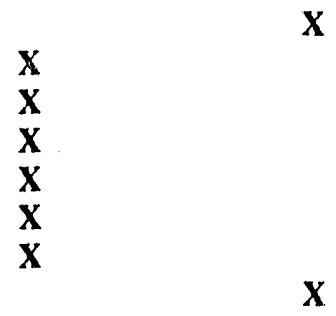

$\mathbf{X}$

$\mathbf{X}$

$\mathbf{X}$

$\mathbf{X}$

$\mathbf{X}$

$\mathbf{X}$

$\mathbf{X}$

$\mathbf{X}$

$\mathbf{X}$

$\mathbf{X}$

$\mathbf{X}$

$\mathbf{X}$

$\mathbf{X}$

$\mathbf{X}$

$\mathbf{X}$

Blowdown water from cooling towers at various facilities periodically drains down natural water courses. For example, cooling tower blowdown water from the Advanced 'lest Accelerator Facility flows down Elk Ravine (Fig. 2.1.5-1). However, this small artificial source of water is totally dependent upon whether the cooling tower is operating.

2.2.5.2. Ground Water. Several shallow water table and confined aquifers are present beneath the site. The better producers among these shallow aquifers contain water of moderately good quality and could be used for domestic or stock water supply. The smaller aquifers have no known use because of generally poor water quality and low production. Plate 5 (see note below) shows the water-level surface of the regional aquifer.

A number of small perched aquifers aie present in various parts of Site 300. Water quality in these aquifers is usually poor. There are no known uses for the water in these perched aquifers, because the sustainable yield of these aquifers to wells is less than $1 \mathrm{gpm}$ (Weiss Associates, 1988).

Note: Plate 5 is located at the end of this chapter. 
Site 300 operates two wells that produce water for process use and drinking from a thick, moderately permeable sandstone sequence encountered between 300 and $500 \mathrm{ft}$ beneath the land surface at the GSA. A system of pipelines, booster pumps, and intermediate storage reservoirs provides water to sturage tanks near operating facilities, which are serves by gravity feed pipes.

Since 1955, 20 wells have been drilled for water supply at Site 300, but only two wells. (18 and 20) are currently in use (Plate 4). Well 20 w'as added to the Site 300 water-supply system during December 1989. Well 1, in the East Firing Area, is maintained on standby as a source for emergency fire-fighting water in the remote northern part of the site that would be available if the pipeline system were to be damaged.

The peak site water-supply requirement, used in design of the water system, is $300 \mathrm{gpm}$ (K. C. Oltrogge, LLNL, personal communication, 1989). The peak requirement comes during the summer when temperatures, water use, and water evaporation are high; during the rest of the year, less water is used.

In addition to these wells, small springs, supplied by local small-capacity ground water aquifers, are found at the site (Fig. 2.1.5-2). Except to the north of the site, where springs are used for watering some livestock, springs are not used as drinking-or process-water sources.

Technically detailed discussions of the hydrogeology of the aquifers at Site 300 are included in Chapter 6.

2.2.6. Climatology and Air Quality at Site 300. Data collected at the Site 300 weather station between 1965 and 1975 indicate that the average annual rainfall during that period was 11.39 in. Between 1973 and 1985, the annual rainfall was 10.87 in.; the maximum was 21.16 in. during the heavy rainfall year of 1983; and the minimum was $5.81 \mathrm{in}$. during the drought year of 1976. All meteorological data are in Appendix D and include climatological summaries of temperature and rainfall for 1976 through 1985. Wind velocity and direction for the year 1987 ar shown in Figure 2.2.6-1. In addition, automated equipment at the meteorological sta in records barometric pressure. These data are maintained in digitized form, available on request.

LLNL has an environmental monitoring program dating from 1955. Air quality parameters measured at Site 300 include concentrations in air of:

- Beryllium;

- Gross alpha and beta radioactivity;

- Radioactivity of the radioisotopes potassium-40, cobalt-60, antimony-125, and cesium-137; and

- The radionuclides uranium and plutonium (Holland and Brekke, 1988).

Since DOE Order 5484.10 was issued in 1979, annual reports including these data (such as Holland and Brekke, 1988) are available to the public. 


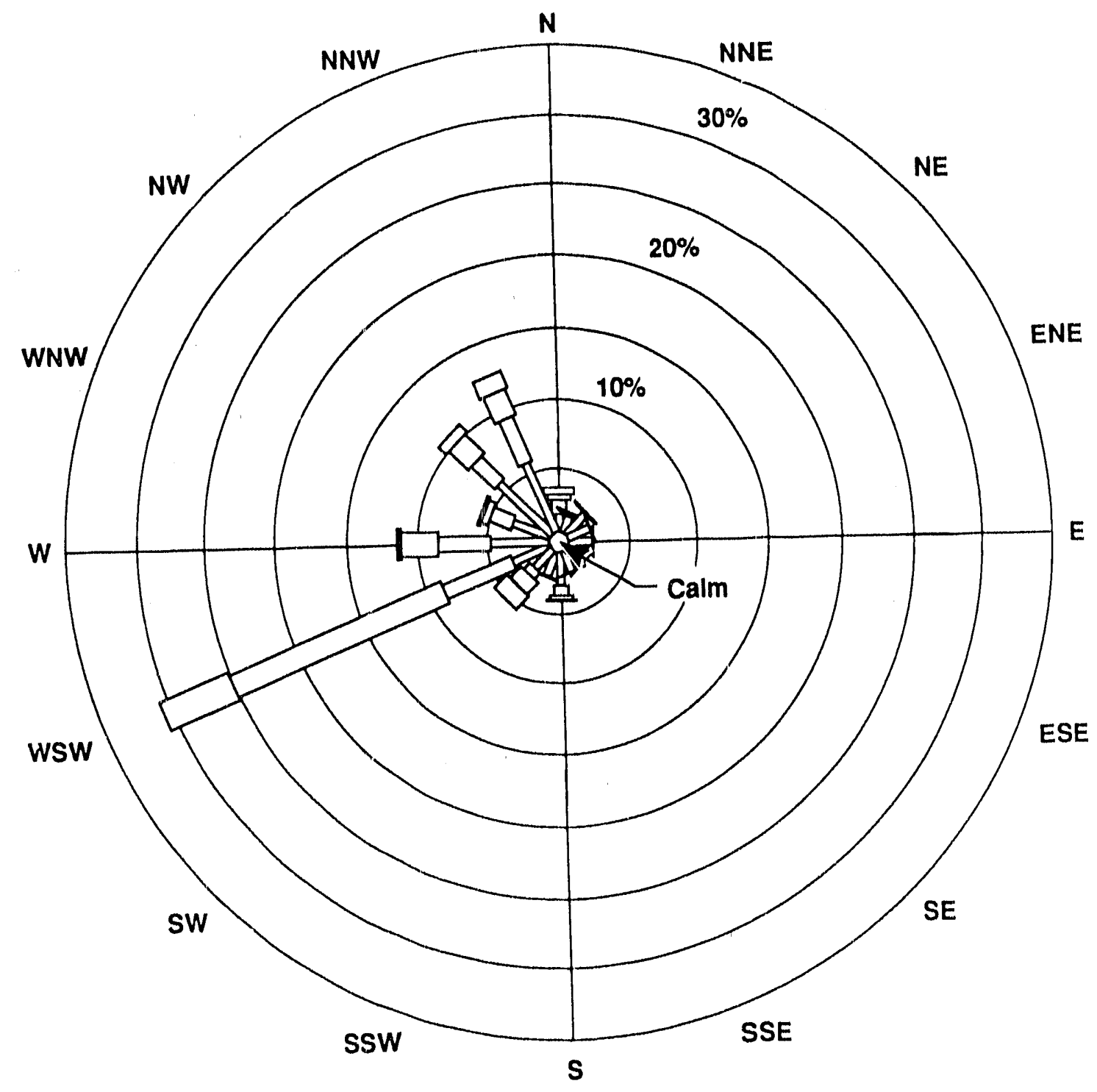

\$300 1989

Wind speed $(\mathrm{m} / \mathrm{s})$

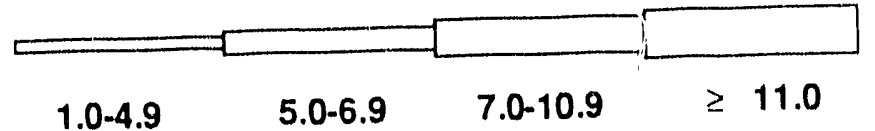

Calms: $0.0-0.9 \mathrm{~m} / \mathrm{s} 9.0 \%$

Figure 2.2.6-1. Wind rose showing the average annual wind speed frequency of occurrence and direction at Site 300 for 1989. 



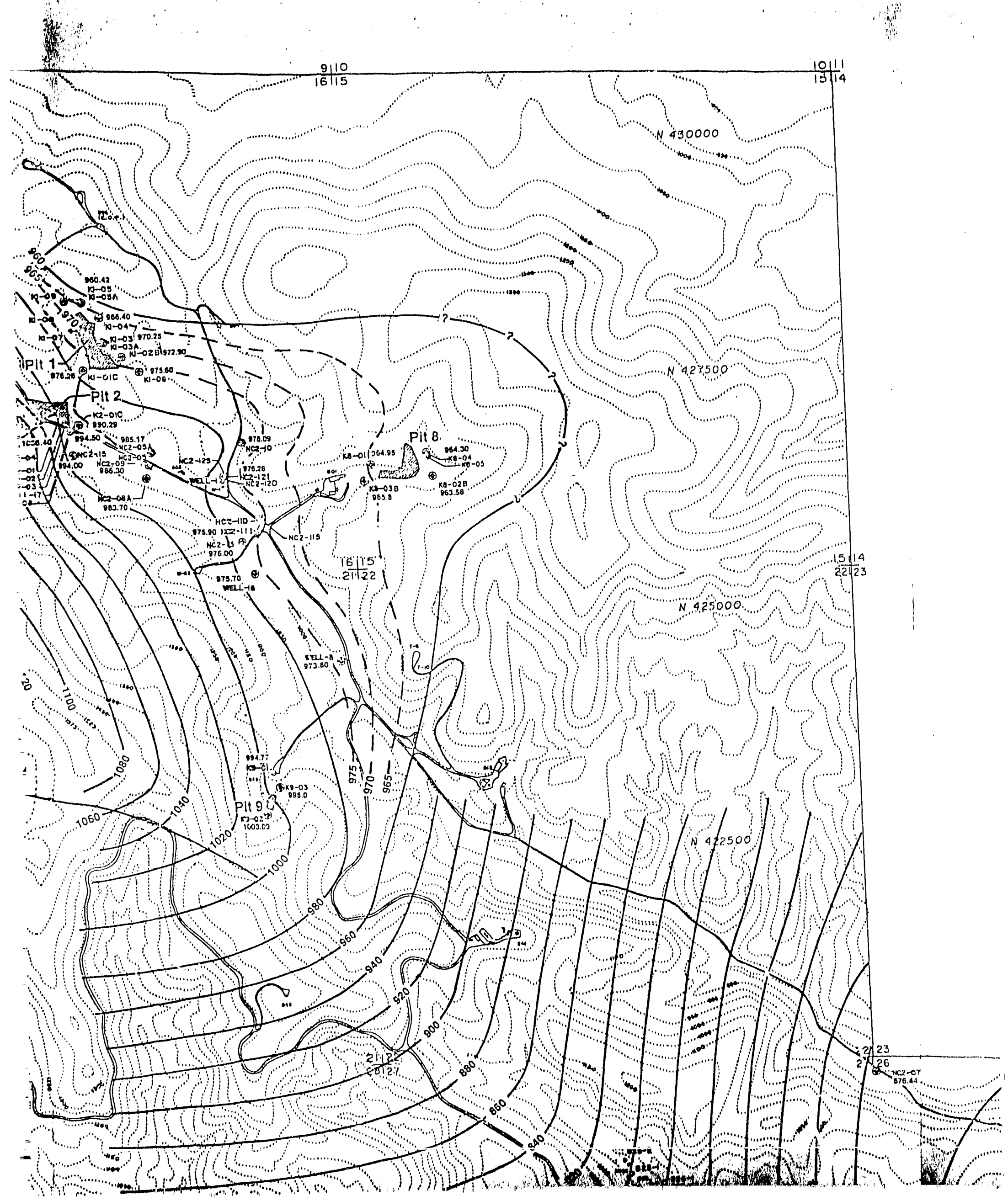




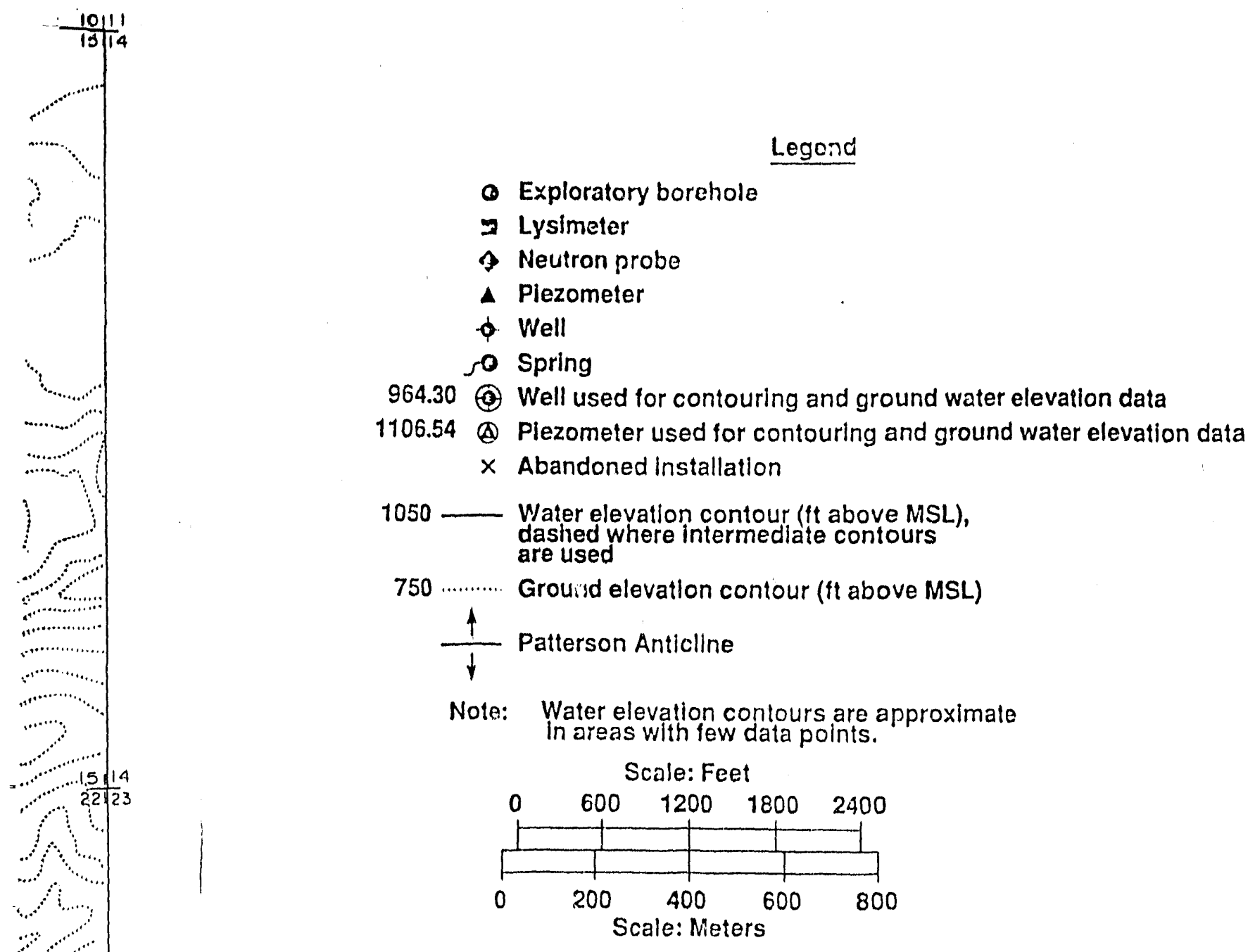




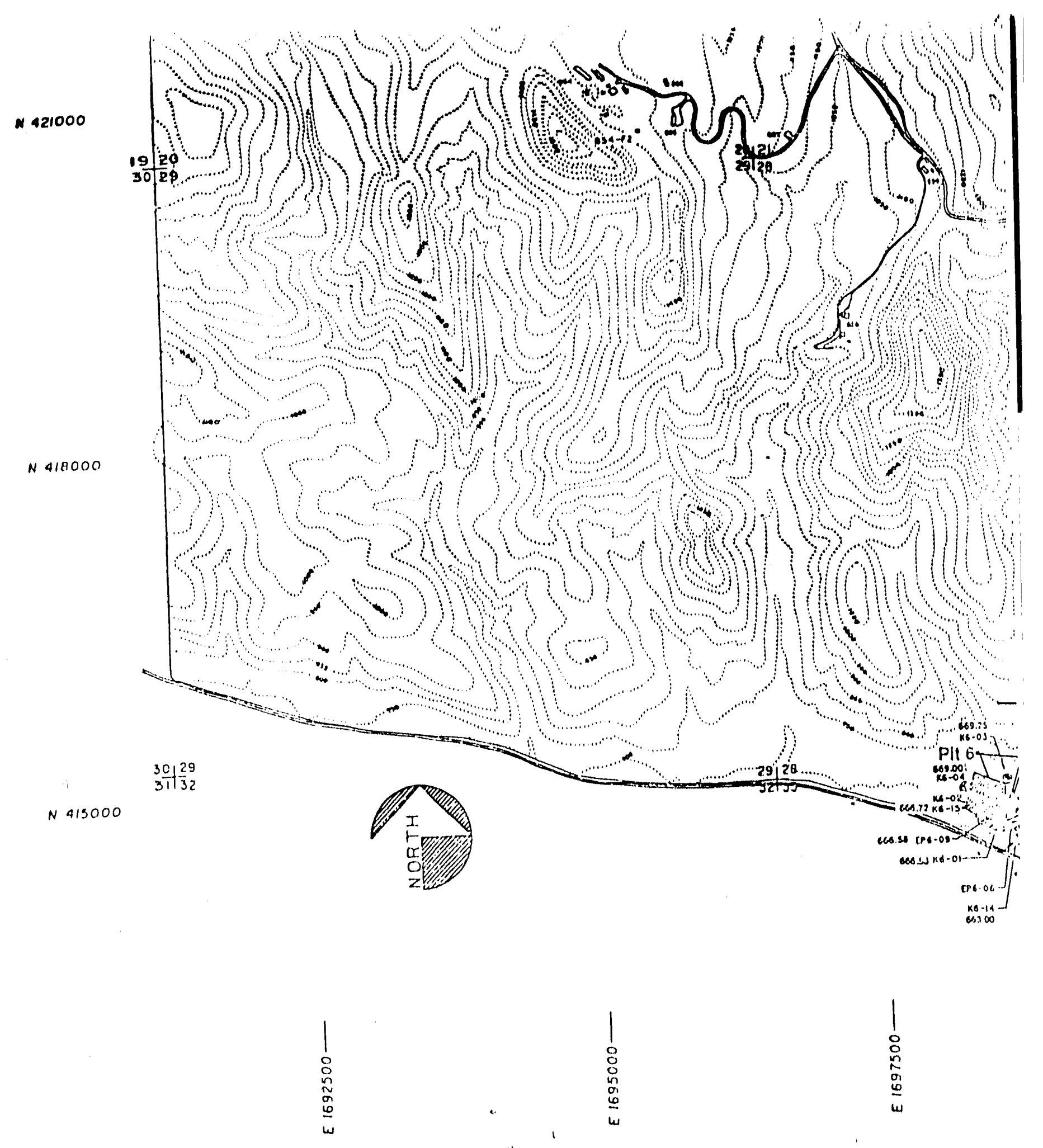





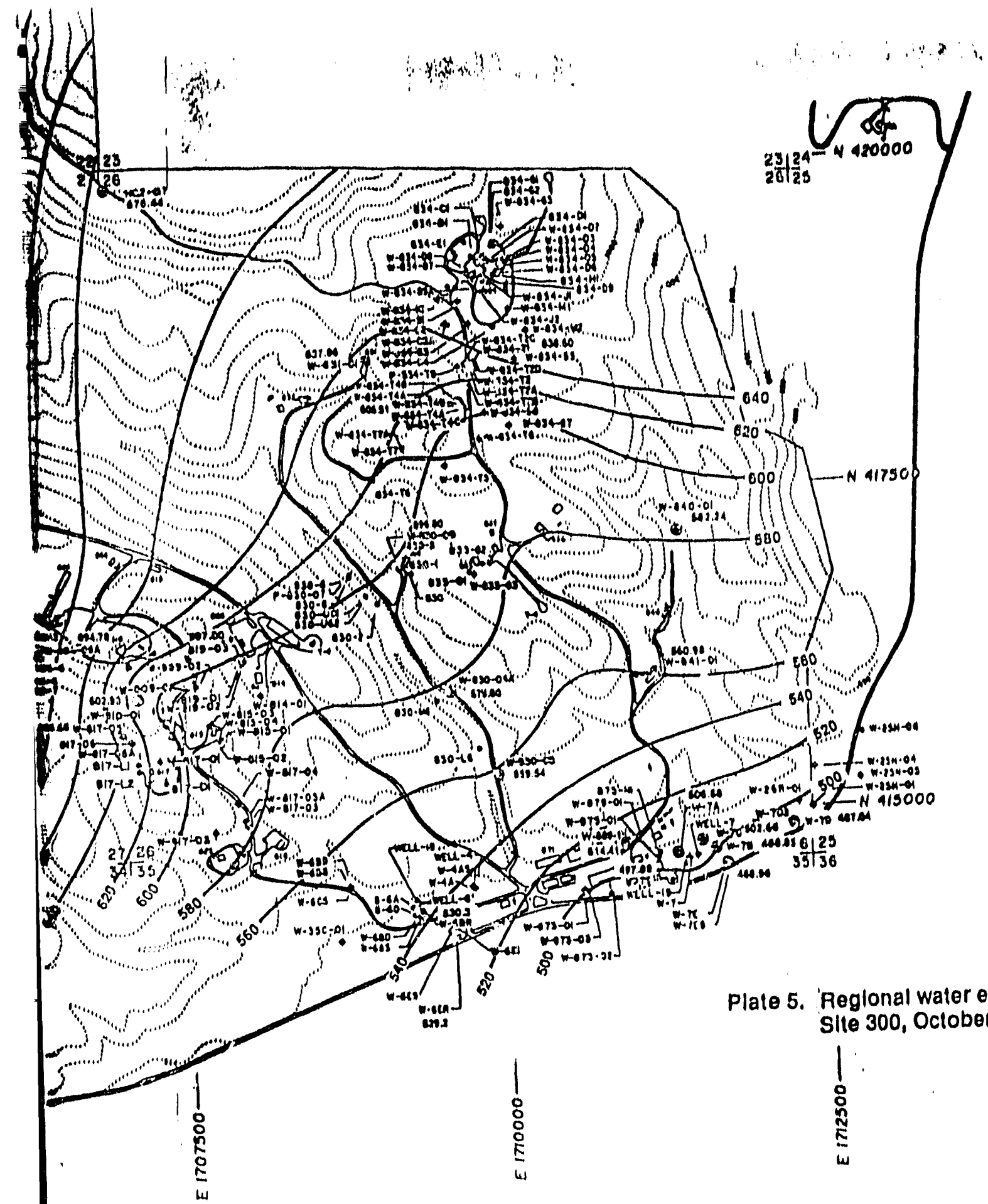

site 300, October-December, 1988.

!

Hong

Mnand $\therefore$ 


\section{Chapter 3. Overview of the Remedial Investigation}

\subsection{Summary of Remedial Investigation}

LLNL has conducted several environmental Investigations in the HE Process Aren, which collectively constitute a remedial investigation.

\subsubsection{Farly History: Investigations of Soll and Rock}

Between 1955 and 1985, nine small lagoons adjacent 10 proess fiacillties in the He Process Area lecelved discharges of rinsewater from formulation, pressing, machining, and assembly of HE compounds (Plate 4). The rinsewater contained low concentratlons of the HE compounds RDX and HMX.

Investigations of the presence of HE compounds in soll and rock near the rinsewater lagoons began in 1981. The results of this work are reported in Raber (1983).

\subsubsection{Decommissioning of Lagoons}

With the approval of the RWQCB, LLNL decommissioned the lagoons in 1985 and replaced them with the HE Surfuce Impoundments (Steenhoven and Crow, 1986). 'The impoundments are evaporation ponds doubly-lined with polyethylene sheets and impermeable compacted clay liners. Flve monitor wells (W-817-()1, W-817-()2, W-817-()3, W-817-()3A, and W-817-.(1)4) and vacuum lysimeters were installed when the ponds were constructed to detect any HE compounds that might leak from them. Depending on the location of the HE facility, rinsewater is eilher piped directly to the ponds or kept in holding lanks and then transported by a dediculed lanker ruck to the HE Surface Impoundments for disposal.

A proposed closure plan for the decommissioned lagoons (Steenhoven and Crow, 1986) was submitted to the RWQCB in 1986. The plan commilted LLNL to an investigation of the horizontal and vertical extent of HE compounds, metals, and VOCs in soil and rock in and mein the decommissioned lagoons. This work was done in 1986 and 1987.

\subsubsection{Closure Plan Investigations of the Decommissioned Lagoons}

'The geology of the area beneath the decommissioned lngoons is described in Chapler' 5 . 'The Closure Plan for the Decommissioned High Explosives Rinse-Water Lagoons al Lawrence Livermore National Laboratory Site 300 (Carpenter et al., 1988) is the primary source of information about the study, which includes details of each lagoon's investigation.

The nine decommissioned lagoons were investigated by drilling exploratory borcholes (Plate 4) to collect soil samples in and near the lagoons. Soil samples were also collected from llic pilon boreholes for monitor wells. The samples were analyzed for HE compounds, $V() C$ s, and melals. Soil analyses are in Appendix A.

The data led to the conclusion that the HE compounds, VOCs, and metals in the soil and rock of the lagoon sites would not migrate if the lagoon sites were made impermeable to direct infiltration of rain water. 
Based on the conclusions of the investigation, LLNL developed a closure plan and presented it to the RWQCB. Subsequent to some deliberation, the plan was approved by the RWQCB and used to design the final closure of the lagoons.

\subsubsection{Dry Well Investigations}

In 1987, dry wells were evaluated near Bulldings 814 and 819, adjacent to the HE Process' Area. Soil samples were collected from the pilot borehole for monitor well W-814-01, drilled near a dry well east of Bullding 814. LLNL investigated a dry well southeast of Building 819 with three boreholes drilled adjacent to one ariother (boreholes 819-(01 and 819-()3 and the pllot borehole for W-819-(12).

In 1989, LLNL conducted an additional investigation of seven abandoned dry wells in the HE Process Area, reported in Lamarre et al. (1989b) and a supplementary letter report (Hoffman, 199()). LLNL drilled sample holes (Plate 4) at Building 807, the Building 810 Complex, and the Bullding 827 Complex. Soll samples were collected from these boreholes and analyzed for HE compounds, metals, and VOCs.

\subsubsection{Additional Investigations of Soil and Rock}

In 1988 and 1989, additional soll samples were collected from the pilot boreholes for monitor wells W-809-(01, W-809.02, W-809-03, W-815-01, W-815-02, W-815-(03, W-815-(04, and W-815-05 (Plate 4). The samples were analyzed for HE compounds, metals, and VOCs. Samples were also collected from a borehole (813-01) drilled at Building 813 (Plate 4) to evaluate a recently discovered abandoned dry well. These samples were analyzed for $\mathrm{HE}$ compounds, metals, and VOCs.

\subsubsection{Investigations of Ground Water}

In April 1985, the HE compound RDX was detected at $37 \mathrm{ug} / \mathrm{L}$, (ppb) in ground water collected from monitor well W-817-01 (Plates 3 and 4). Additional monitor wells have been drilled in the HE Process Area to identify and to bound the horizontal and vertical extent of this compound in the aquifer. These investigations continue (details are in Chapter 8).

In late 1989, HMX was detected in low concentrations (averaging $38 \mathrm{ug} / \mathrm{L}$ [ppb]) in ground water from monitor well W-817-01. Samples collected from the monitoring network in early 1990 indicated that no HMX was present above detection limits in well W-817-(01 or any other well. Thus, we are uncertain about the presence of HMX, and will continue monitoring.

VOCs have been detected in ground water beneath the HE Process Area, centering near Building 815 (Plates 3 and 4). VOCs were first detected in 1987 at $28 \mu \mathrm{g} / \mathrm{L}$ (ppb). Subsequent investigations have defined nearly the full extent of VOC's in ground water. The chief VOC detected is TCE, although trace amounts of other VOCs have been found in some wells. The investigations continue (details are in Chapter 8).

\subsection{Nature and Extent of VOCs and HE Compounds}

This study demonstrated that RDX and HMX were present in soil samples collected near the decommissioned lagoons at concentrations mostly less than 1 part per million (ppm), but locally higher in concentration.

Investigations of $\mathrm{HE}$ compounds in ground water have determined that RDX is present in low to moderate concentrations (up to $350 \mathrm{ug} / \mathrm{L}[\mathrm{ppb}]$ ) in ground water from two shallow aquifers beneath a limited area near Duildings 815 and 817 (Plate 3). Monitor wells drilled as 
part of our investigation bound the area underlain by RDX in the ground water on the north, west, and south, In 199(), monitor wells will be drilled to bound the occurrence on the enst. In November 1989, HMX was detected for the first time in monitor well W-817-()1. HMX has not been detected in other monitor wells.

In 1987, VOCs were first detected in gro stid water in well W-815-01, near Building 81.5 . Since then, monitor wells constructed to determine the horizontal and vertical extent of the occurrence have determined that VOCs are present in two shallow aquifers in a small area near and south of Bullding 815. RDX is present in the perched aquifer near Bulldings 815 and 817. The area underlain by VOCs extends from W-809-1 on the north to shallow well W-817-()3A on the south (F/g. 8,2). The water table aquifer contains TCE only immediately beneath Building 815 (Fig. 8.4),

During 1987, VOCs were also detected in a perched aquifer beneath Bullding 814 (Plate 3), The aquifer is stratigraphically higher and hydrologically isolated from the perched aquifer beneath Building 815 .

\subsection{Assessment of the Situation and Corrective Actions to Date}

\subsubsection{HE Compounds, Metals, and TCE in Soil and Rock}

Exploratory boreholes drilled near the decommissioned lagoons were sampled for HE compounds; metals (Waste Extraction Test [WET] method), described in the California Administrative Code, Title 22 (1985); and VOCs. The investigation (Carpenter et al., 1988) indicated that metals and VOCs in the samples were present only at very low concentrations. Most of the exploratory boreholes contained low to moderate concentrations of RDX and HMX (generally less than $1 \mathrm{mg} / \mathrm{kg}[\mathrm{ppm}]$ ) at shallow depths. These boreholes were drilled deep enough that the bottom samples did not indicate the presence of RDX or HMX, allowing development of a profile of HE compounds in the soll and rock. Moreover, with the exception of one shallow sample, all soil concentrations of $\mathrm{HE}$ compounds were below the Designated Level (DL) of $10.5 \mathrm{mg} / \mathrm{kg}$ (ppm) RDX for the site (see Appendix H, Section H.2.3), which indicates no impact to the ground water could be demonstrated. LLNL (Carpenter et al., 1988) also concluded that the HE compounds present in the soil and rock were unlikely to be mobilized unless additional surface water infiltrated the areas near the decommissioned lagoons.

From this information, Carpenter et al. (1988) concluded that the low concentrations of HE compounds, metals and VOCs found in the soil and rock beneath the decommissioned lagoons did not constitute a hazard to public health, safety, or the environment. In addition, if rain water were not allowed to infiltrate, the RDX and HMX would be unlikely to migrate downward toward aquifers.

We recommended that the lagoons be closed by filling them with local soil, free of HE compounds, and capping them with impermeable clay caps. We also recommended peripheral drains to divert rain water around the caps. The plan was approved, with modifications, by the RWQCB, and the lagoons were closed in October 1989.

\subsubsection{RDX and VOCs in Ground Water}

Our investigations have defined the horizontal and vertical extent of RDX in ground water, except for an area east of Building 81.5 which will be investigated late in 1990. RDX is found in a small area beneath Buildings 815 and 817 (Plate 3) in a perched aquifer of limited extent, and in the first water table aquifer beneath the perched aquifer in an area even smaller (Figs. 8.1 and 8.3). The release site(s) have not been conclusively identified. 
In the HE Process Area, VOCs are found in a small area beneath and south of Building 815 (Plate 3 ) in the perched aquifer and the first water table aquifer beneath the perched aquifer (Figs. 8.2 and 8.4). TCE is the only VOC present at concentrations above MCLs. We think the release site is related to the use of TCE as a boiler cleaner in the steam plant that formerly operated at Building 815. No VOCs are found in the confined aquifer, located in the Neroly lower blue sandstone, or in deeper aquifers (Fig. 8.2.2-1). The potential source of TCE a! Bullding 815 has been removed. 


\section{Chapter 4. Methods of Investigation}

The technical methods employed during our geologic studies include:

- Geologic mapping,

- Subsurface soil and rock sampling from exploratory boreholes,

- Installation of ground water monitor wells,

- Ground water sampling and analysis,

- Routine monitoring of ground water levels, and

- Hydrologic testing.

Investigations continue and will be reported in other reports.

LLNL has prepared written Standard Operating Procedures (SOPs) for drilling boreholes and monitor wells, making water level measurements, collecting soil and water samples, and analyzing samples (Rice et al., 1990). The discussions in this chapter and in Appendix G summarize these SOPs.

\subsection{Site Characterization}

The zeology of part of Site 300 and of the HE Process Area are mapped and shown on Plate 2. Subsurface investigations include drilling exploratory boreholes and construction of monitor wells, which began in 1984. By November 1989, 42 exploratory boreholes and 17 monitor wells had been drilled in and near the HE Process Area, shown in Plate 4

\subsubsection{Geologic Mapping}

Geologic mapping and subsurface information provide detailed knowledge of geologic structure in and near the HE Process Area and an understanding of the complex stratigraphy of the Neroly Formation, which contains the major water-bearing units in the HE Process Area. Dibblee (1980a) did a reconnaissance study of the geology of the Midway quadrangle, including Site 300. During LLNL's initial hydrogeologic assessment in 1982 (Raber, 1983), the HE Process Area was mapped geologically. At present, more detailed geologic mapping in and near the HE Process Area is in progress. Although early results are available, the final interpretation will be included in later reports.

\subsubsection{Drilling Exploratory Boreholes and Monitor Wells}

In all exploratory boreholes and monitor wells, the lithology of the rocks penetrated is described from auger and drill cuttings or from core samples. Geologic logging is done by either a California Registered Geologist or by a well-site geologist working under the supervision of a California Registered Geologist.

Several appendices of this document contain supportive data:

- Appendix A-the results of chemical analyses of borehole and well soil and rock samples.

- Appendix B-similar anaiyses of ground wâté samples. 
- Appendix C-geologic and geophysical logs of all boreholes and monitor wells drilled in the HE Process Area since July 1988; earlier logs are available in a previously published compendium of Site 300 borehole and monitor well logs (Toney and Crow, 1989), and in a Remedial Investigation report on LLNL dry wells (Lamarre et al., 1989).

- Appendix E-monitor well water levels.

- Appendix F-monitor well construction data.

- Appendix G-analytical and sample handling procedures including QA/QC.

4.1.2.1. General Drilling Protocol. LLNL's general drilling protocol is designed to avoid inadvertent introduction of contaminants into the borehole or well. For example, all downhole drilling equipment-the drill rods, drive samplers, wireline coring equipment, auger flights, and drill bits-are steam cleaned after drilling each borehole or well. No petroleum-based lubricants are used on drilling equipment. The drillers may use minimum necessary amounts of a water-based, antiseize lubricant that contains dispersed copper to prevent destructive galling or seizing of drill-rod and core-barrel screw joints. Chemical analyses of the lubricant used are available, so that trace amounts can be recognized if found in collected samples.

The drill rigs are regularly steam cleaned and are inspected frequently for fluid leaks, such as gasoline, diesel fuel, cooling water, or lubricating oil, and are repaired immediately. All equipment is allowed to air dry before reuse.

4.1.2.2. Exploratory Boreholes: Drilling and Sampling Methods. Between 1984 and 1989, several series of exploratory boreholes were drilled to obtain soil and rock samples as well as information about the subsurface geology.

Exploratory boreholes that are less than $50 \mathrm{ft}$ in depth are usually drilled by a hollow-stem auger. At approximate 5-ft intervals, soil or rock samples are collected from the boreholes, using a standard California split-spoon drive sampler (1.4-in. sample diameter) driven by a 140-1b weight falling 30 in. Samples are collected in steam cleaned or washed stainless-steel, or brass sampling tubes enclosed in the California drive sampler. The split-spoon sampler is cleaned after every drive sample.

After recovery, the tubes are sealed. Samples for analysis for VOCs or metals are sealed in the tubes in two ways: by capping with aluminum foil and sealing with inert duct tape; or by sealing with Teflon tape, plastic end caps, and inert plastic tape. The sealed samples are immediately placed on ice in a portable cooler and later kept under refrigeration until transferred to the analyst. Samples for analysis for HE compounds are collected in the same manner as the samples for VOCs and metals. Because HE compounds are not volatile and thus are not sensitive to storage temperatures, it is not necessary to keep the samples refrigerated while awaiting analysis. If the samples for $\mathrm{HE}$ compounds collected from the sampling tubes are less than about $500 \mathrm{~g}$ (the optimum sample size), two or more samples are composited and stored in a clean wide-mouth glass jar, using chemically inert duct tape to seal the top.

The augering equipment cannot operate efficiently at depths greater than about $50 \mathrm{ft}$, given Site 300 drilling conditions. The part of exploratory boreholes deeper than $50 \mathrm{ft}$ is continuously cored, using rotary drilling equipment and a wireline split-tube core barrel (Christensen HQ system). The cores are recovered in stainless steel or brass sleeves (2.375-in. i.d.) inserted in the core barrel. For deeper boreholes and pilot boreholes for monitoring wells, a larger drill is used that cannot deploy an auger. With this drill, coring is continuous from the surface using the wire-line split-tube core barrel. This technique is identical to the one used for deeper parts of augered boreholes, described above. 
After recovery, the cores to be submitted for VOC and metals analyses are removed from the core barrel, sealed, and cooled on ice or in the refrigerator. These are processed in the same way as drive samples (see preceding paragraph). In a few dry wells, soil samples have been analyzed for HE compounds. Cores to be retained for future reference study are removed from the core barrel, logged geologically, and stored in core boxes.

While coring, an air-water mist from a compressor is used to keep the core barrel from sticking in the hole and to help lift cuttings. The water used in the mist comes from the Site 300 drinking water supply, which is free of organic contaminants.

After completion, exploratory boreholes are filled and sealed to the land surface with grout.

4.1.2.3. Monitor Wells: Drilling and Sampling Methods. The first monitor wells in the HE Process Area were drilled in late 1984 as part of the monitoring network installed near the HE Surface Impoundments south of Building 817. Subsequently, monitor wells have been drilled to investigate the extent of HE compounds and VOCs in ground water and to obtain stratigraphic information.

The technique of drilling monitor wells is similar to drilling exploratory boreholes, except that monitor wells require extra operations, such as reaming the pilot hole to receive the well casing, installing sand packs and well seals, and well development. In most cases, the first $50 \mathrm{ft}$ is augered; drive samples of soil and rock are collected at approximately 5-ft intervais. These samples are collected to be analyzed for VOCs, HE compounds, and metals. At depths greater than $50 \mathrm{ft}$, continuous wire-line coring using rotary drilling techniques is used. Air-water mist is employed to keep the bit from sticking and to assist in lifting well cuttings to the surface.

4.1.2.3.1. Monitor Well Completion. Each monitor well is drilled for a specific puipose. In most cases, this is to determine the presence, or to define more precisely the extent, of HE compounds or VOCs in the ground water. To complete the pilot borehole as a well, the completion interval depth of well screen (perforated interval) and length of sandpack are chosen first, based on the hydrogeologic observations made in the pilot hole. The completion is designed to allow maximum possible flow from the aquifer into the well.

Borehole geophysical logs are run in monitor wells of special geologic significance. The standard suite of logs includes specific potential/resistivity, natural gamma radiation, and a caliper log. Additional logs, such as borehole camera logs and sonic logs, have been run in a few cases.

In some cases-for example, if a borehole or well is dril'ed immediately adjacent to another hole that previously had been cored-the new hole is drilled using standard rotary drilling bits because it is not necessary to obtain core samples. A geolugist prepares a geologic log of the drill cuttings.

Unless there are special circumstances, the pilot borehole is reamed to approximately 9 in. in diameter. This provides sufficient annular space to allow installation of 4.5 -in. i.d. potable grade PVC casing with sandpack, bentonite seal, and grout seal outside the casing. Some of the early monitor wells were completed with smaller-diameter casing. The sandpack is normally \#3 Monterey sand (0.093 to 0.039 in. grain size), i.e., approximately $8 \times 16$ mesh (Driscoll, 1987; p. 951, Appendix 12.B). A bentonite seal is placed on top of the sandpack, and the well annulus is filled to the surface with grout. Details of each completion are shown on the appropriate well log (Appendix C; Toney and Crow, 1989; and Lamarre et al., 1989b).

4.1.2.3.2. Well Development. Following completion of a monitor well, the well is developed to improve productive capacity by removing drilling fluid, drill cuttings, and other debris from the hole and mud cake from the formation face. First, well water is bailed until it becomes clear. If this is not effective in clearing up the water produced, an air-lift is used, i.e., the well is blown dry and allowed to refill, thus enhancing flow. If these techniques are not 
effective, a surge block is used. In a few wells, jetting has been used, i.e., water flow is directed through jets onto the screened interval to clean mud and other debris from the casing screen and formation, thus improving flow. Water levels in monitor wells are in Appendix E.

\subsubsection{Analysis of Soil Samples and Ground Water}

Soil and ground water samples are analyzed in accordance with EPA and California procedures (see Appendix G). The results of soil and rock sample analyses are in Appendix A, and results of ground water analyses are in Appendix B. The data are discussed in Chapter 7.

4.1.3.1. Samples from Monitor Wells Adjacent to HE Surface Impoundments. Monitor wells W-817-01, W-817-02, W-817-03, W-817-04, and piezometer W-817-03A were constructed in late 1984 to monitor the HE Surface Impoundments (Plate 3). Ground water has been sampled from these wells quarterly, according to requirements established in 1985 by the RWQCB in their Waste Discharge Order 85-188 (1985). Analytical data are presented in Appendix B. Details of the analytical techniques used are given in Appendix G.

4.1.3.2. Sar.ples frum Boreholes and Monitor Wells Collected During LLNL's Investigations. In the course of LLNL's investigation in the HE Process Area, boreholes and monitor wells have been drilled. The boreholes were drilled to collect soil samples, and soil samples were collected for analysis during the drilling of monitor wells. Samples have been analyzed for VOCs, HE compounds, and metals. The results are given in Appendix A.

Ground water from the monitor wells is sampled quarterly; all samples are analyzed for VOCs and HE compounds. At least one water sarnple from each monitor well has been analyzed for metals and general minerals. Tables of analytical data are in Appendix B, and analytical techniques are described in Appendix G.

\subsection{Investigations Monitoring Program}

\subsubsection{Well Purging and Sampling Procedures}

Before sampling ground water from monitor wells, the wells are purged according to LLNL SOPs (Rice et al., 1990). All monitor wells with sufficient capacity to produce enough water are pumped to remove three casing volumes to clear the well of stagnant water and to provide a water sample representative of the water in the aquifer adjacent to the well.

A number of wells in the HE Process Area are small producers. In sampling these wells, LLNL follows the Resource Conservation Recovery Act (RCRA) sampling protocol, which states that after being pumped dry, a well that will not yield a full casing volume of water within 2 hours may be sampled after pumping it dry once.

As water flows into the well, it is sampled first for $\mathrm{pH}$, temperature, and conductivity, then for VOCs, and finally samples are collected for other analyses.

\subsubsection{Chemical Analysis of Ground Water}

4.2.2.1. Wells of the HE Surface Impoundments Monitoring Network. Monitor wells for the HE Surface Impoundments include wells W-817-01, W-817-02, W-817-03, W-817-3, and W-817-04. Piezometer W-817-03A was drilled to a depth of $10 \mathrm{ft}$; it was installed to monitor a small spring on the southern flank of the hill below the Surface Impoundments. Water from these wells is analyzed according to requirements set forth in Waste Discharge Order 
85-188 (RWQCB, 1985). The standards are in Division 4, Chapter 15, Title 22, California Administrative Code. Ground water samples are collected quarterly and analyzed for metals, nitrate, total organic carbon (TOC), total organic halides (TOX), EPA 601, conductivity, pH, and general minerals. Additionally, the samples are analyzed for $\mathrm{HE}$ compounds and tritium.

4.2.2.2. Wells of HE Process Area Remedial Investigations. Other monitor wells included in quarterly monitoring for our study, located in and near the HE Process Area, are W-806-06A, W-809-01, W-809-02, W-809-03, W-810-01, W-815-01, W-815-02, W-815-(03, W-815-04, W-817-05, and W-817-06A. Immediately adjacent to the HE Process Area, wells W814-01 and W-819-02 are monitored on the same schedule and for the same substances as those in the HE Process Area proper. Water from these wells is analyzed for VOCs (EPA 601) and HE compounds on a quarterly basis. There is at least one metals analysis and general minerals analysis available for each well.

\subsubsection{Disposal of Pumped Water}

During ground water sample collection, a specified amount of water is removed from each well to assure that water collected is from the aquifer. In wells known to be contaminated, it is necessary to contain this water. Because all the monitor wells in the HE Process Area that contain water with either RDX or TCE are small producers, the water is collected in 55-gal drums and allowed to evaporate. The total amount of water collected from wells known to contain HE compounds is small. When it becomes necessary to remove this water from the barrels, tests are run to determine if any VOCs are present. If VOCs are detected in the water, air is bubbled through the water in the barrels for 48 hours, which is the standard procedure at Site 300 to remove VOCs from pumped water. When analysis indicates that the water contains HE compounds but no VOCs, it is contained in drums and allowed to evaporate.

Wells that have consistently produced water free of any contaminant are discharged to the ground surface. If possible, discharge is to an asphalted area to allow naximum evaporation before reaching bare ground.

\subsubsection{Water Level Data}

All water levels from wells in the HE Process Area are measured quarterly and are reportsd in Appendix E.

\subsubsection{Documentation of Samples}

Chain-of-custody documents are prepared for all samples. A sample of the form used is included in Appendix G.

\subsubsection{Safety Procedures}

This investigation has been performed under guidelines outlined in the Environmental Protection Department's Site Safety Plan for Site 300 Environmental Restoration (1989), the Site. 300 Safety and Operational Manual (1988), and the LLNL Health and Safety Manual (1989).

\subsubsection{Data Management}

A database is maintained to store the data generated. There are two sources of analytical data: (1) the monitor wells for the HE Surface Impoundments are sampled under the requirements of RWQCB Waste Discharge Order 85-188; (2) the remainder of the wells in the HE Process Area are not under a regulatory order, but are collected for the purposes of our investigation. Both soil and rock sample analyses and ground water analyses are in the database. 
Analytical data from our primary analytical laboratory, Brown and Caldwell Laboratories, are entered into the database electronically via modem and are maintained on the VAX computer system. Other data, such as those from other contract laboratories for VOCs and metals and those from the LLNL laboratory that analyzes samples for HE compounds, are entered manually. The data are verified electronically to identify transmission, transceiving, and input errors. After verification, the data are tabulated and checked to determine if their values are reasonable.

The analytical laboratories provide printed reports of all data. These paper copies are used in verification and are also checked against our chain-of-custody forms for accuracy and completeness. A database containing aquifer test data has recently been added to the Environmental Investigations Quarterly.

All water level data are manually entered and verified.

Extensive graphic and statistical capabilities are available using additional PC programs such as SURFER by Golden Graphics, MINITAB, and SYSTAT. 


\section{Chapter 5. Geology}

\subsection{Regional Geologic Setting}

Site 300 is located on the eastern side of the Altamont Hills (a part of the Coast Range Physiographic Province) between the Livermore-Amador and the San Joaquin Valleys (Fig. 5.1-1). The Coast Range Physiographic Province consists of a system of north-northwest trending, fault-bounded, antiformal mountain ranges and synformal valleys. The bedrock consists of igneous, metamorphic, and sedimentary rocks that range in age from Late Jurassic to Pleistocene. The mountain ranges are composed of rocks of Late Jurassic to Tertiary age. Locally, they exceed elevations of 4000 feet. The valleys are filled with late Tertiary to Holocene sediments, mainly derived from the surrounding mountains.

The present physiography and geology of the Coast Ranges are the result of deformation and depositional processes along the tectonic boundary between the North American Plate and the Pacific Plate and that of its predecessors: the Juan de Fuca, the Farallon, and the Kula Plates (Page, 1982).

Rocks exposed in the region surrounding Site 300 may be classified into three general groups:

- Late Tertiary-Quaternary (0 to 5 million years ago [mya]): Alluvium and partly lithified sediments of chiefly continental origin;

- Early to late T'ertiary (5 to 65 mya): Neroly, Cierbo, and Tesla Formations; shallow marine and continental sedimentary and volcaniclastic rocks; and

- Late Jurassic-Cretaceous (65 to 150 mya): The basement complex. It is composed of the coeval Great Valley Sequence of marine sedimentary rocks and the Franciscan Assemblage of strongly deformed, sheared, and metamorphosed sedimentary and igneous rocks. The Coast Range Ophiolite Complex, composed chiefly of basalt that is altered regionally to serpentinite, is thought to represent the ocean floor under which the Franciscan Assemblage was subducted. The Ophiolite Complex is in depositional contact with the base of the Great Valley Sequence in various localities in northern California (e.g., Crow, 1979).

The geographic locations of these units are shown in Figure 5.1-1.

The youngest stratigraphic units in the region are predominantly nonmarine sediments that vary from Pliocene to Holocene in age (Dibblee and Darrow, 1981). Older portions of this sequence may be partly lithified; the younger strata are largely unconsolidated. As a result of stress fields associated with active Bay Area faults, even very recent Holocene sediments are folded or ruptured by seismic activity.

Tertiary marine, nonmarine, and volcaniclastic rocks underlie the immediate vicinity of Site 300. These Tertiary rocks are mainly sandstones and mudstones with some conglomerates and tuff beds. The major source of the volcanic component is in the Sierra Nevada (Lerbekmo, 1956; D. W. Carpenter, LLNL, personal communication, 1988) as well as more local centers in the Berkeley Hills and farther south in the Coast Range (Dickenson and Snyder, 1979).

The basement rocks of the region, the Franciscan Assemblage and the coeval Coast Range Ophiolite and Great Valley Sequence, are geologically related and are best understood in the context of plate tectonic theory. 


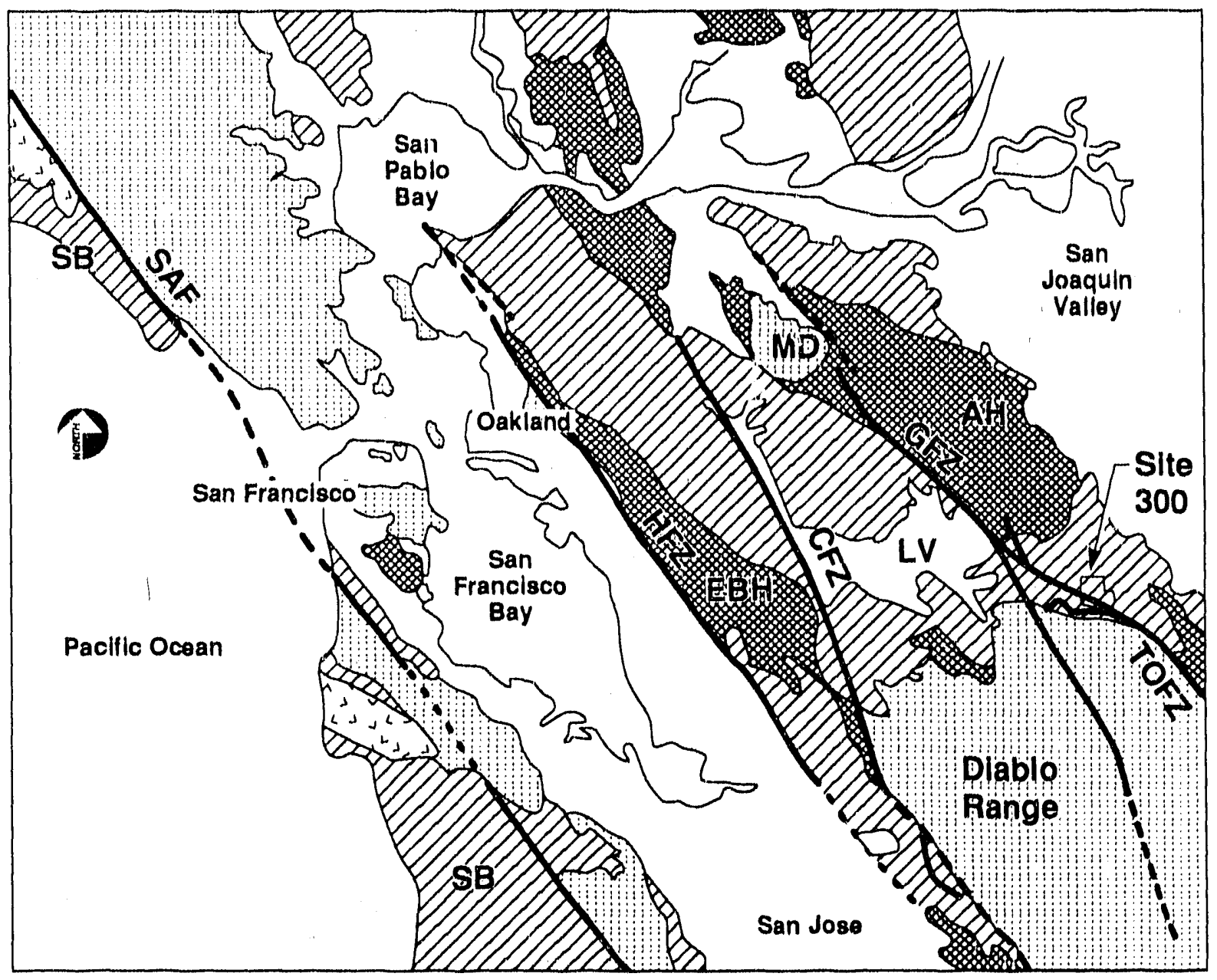

Late Tertlary-Quaternary

Alluvium and continental sediments

\section{Tertlary}

DTD sediments and volcanics (locally non. marine) including Pllo-Plolstocene

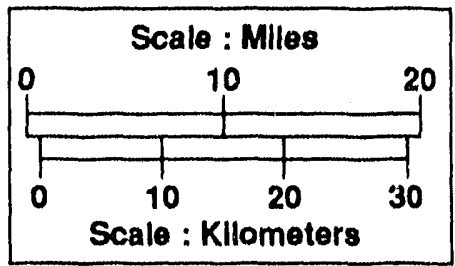

\section{Jurassic-Crotacoous}

Great Valley Soquence

Franclacan Complex

\section{Pesozolc Granite}

Figure 5.1-1. Generalized geologlc map of the San Francisco Bay area showing the location of Site 300. Key to symbors: SB, Salinlan Block; SAF, San Andreas fault; HFZ, Hayward fault zone; EBH, East Bay Hills, CFZ, Calaveras fault zone; MD, Mount Dlablo; GFZ Greenville fault zone; AH, Altamont Hills; TOFZ, Tesla-Ortigallta fault zone ; LV, LivermoreAmador Valley (Adapted from Raber and Carpenter, 1983). 
The Franciscan Assemblage was deposited on the Pacific Plate and contains several slightly different rock units (terranes) of different geologic age associated with separate subduction events. The Assemblage as a whole has been subducted beneath the North American Plate. It is very strongly deformed, largely by sheuring during subduction. It consists of generally coherent blocks of sheared metagraywacke or greenstone (metabasalt) with lesser amounts of chert and limestone, all emplaced chaotically in a matrix of metamorphosed and intensely sheared mudstone and shale (Hsu, 1971). The blocks vary from sand-size frigments to pleces severul kilometers in length.

The Franciscan Assemblage is in tectonic contact with the Coast Range Ophiolite and the Great Valley Sequence. Frequently, the zone in which the contact occurs is along the Coast Range Thrust Fault, a prominent feature in the Coast Range.

The Coast Range Ophiolite Complex is interpreted to be the altered ocean floor, located on the upper plate, beneath which the Franciscan rocks were thrust. The Coast Range Ophiolite was originally basalt of various types. Now, it is considered mostly hydrothermally altered at high temperature and pressure to serpentinite. The serpentinite was remobillzed during Tertlary time, and has been tectonically intruded into fault zones, shear zones, and the Franciscan Assemblage (McLaughlin, 1978).

The Great Valley Sequence (Kgv) depositionally overlles the Coast Range Ophiolite Complex. It is a very thick deposit of interbedded sandstone and shale (often turbidites), that is strongly folded and slightly deformed. South and east of Site 300 is the Moreno Shale and Panoche Formation, also part of the Great Valley Sequence.

\subsection{Geology of Site 300}

This section contains a brief summary of the geology of Site 300. A more detailed discussion of the geology specific to this report, is in Section 5.3.

\subsubsection{Previous Work}

Knowledge of the geology of Site 300 is based on regional geologic mapping by Huey (1948), Raymond (1969), and Dibblee (1980a, b, and c). This geologic information was incorporated in the Draft California EIR prepared for the University of California Board of Regents to support LLNL's contract renewal in 1987 (University of Californit, 1986). The following summary of Site 300 geology is developed from this information, as modified and supplemented by geologic observations made during hydrogeologic studies conducted by LLNL in recent years (i e., Raber and Carpenter, 1983; Raber, 1983; Crow et al., 1986; Carpenter et al., 1986, 1988; and several issues of the Site 300 Environmental Investigations Quarterly Reports).

\subsubsection{Stratigraphy}

The stratigraphy at Site 300 is shown in Figure 5.2.2-1. Plate 2 is a generalized geologic map of Site 300 .

Along the southern boundary of Site 300, the channel of Corral Hollow Creek is filled with recent channel gravels. Cobbles up to $12 \mathrm{in}$. in diameter have been deposited in a matrix of sand and subordinate silt and clay.

The upland part of Site 300 is underlain by Quaternary to Recent unconsolidalted colluvium and alluvium, including ravine fills, cobbly terrace alluvium (Qii), and landslide deposits (Qls). These deposits blanket the hills in the southern part of the area; usually they range between 5 and 


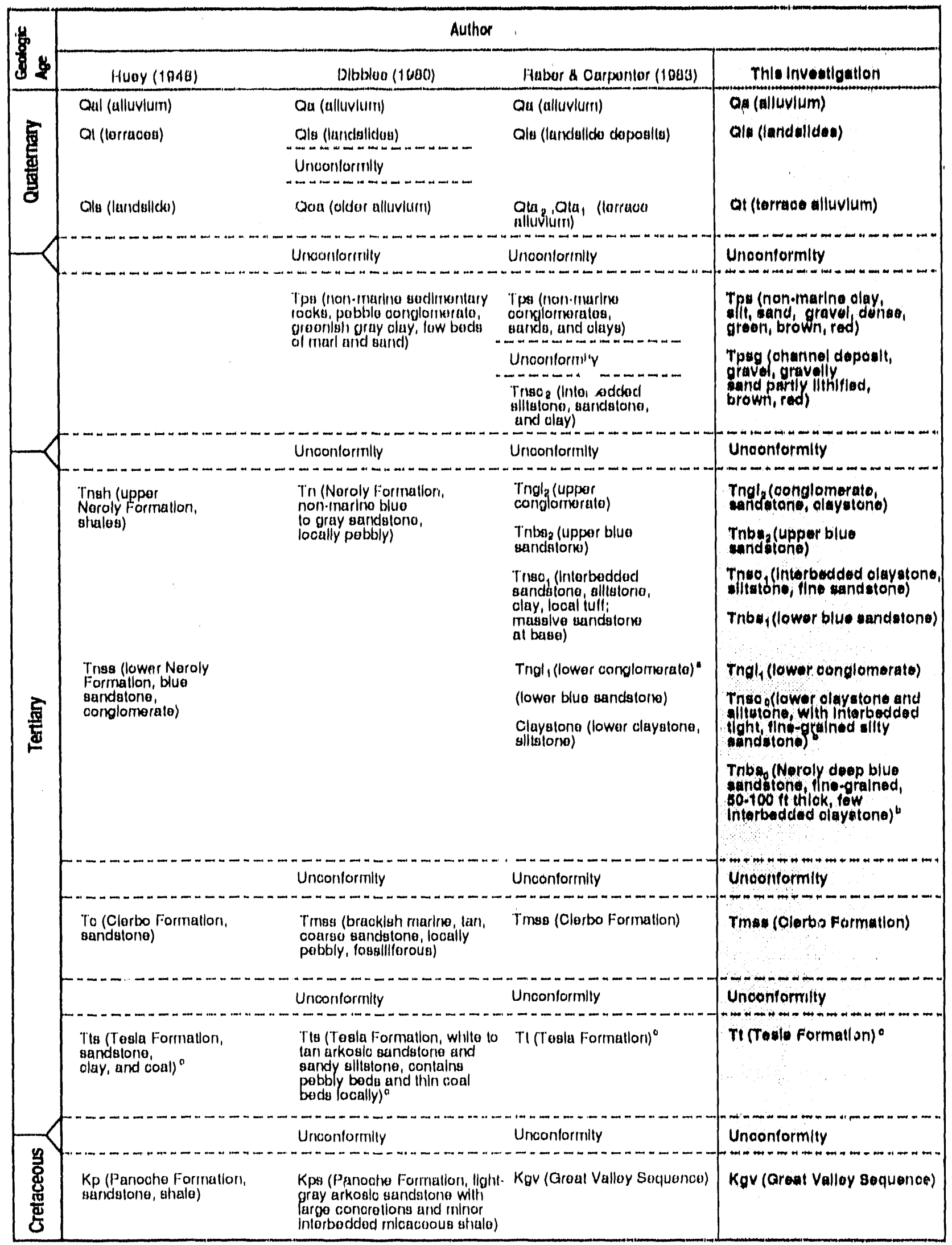

Figure 5.2.2-1 Stratigraphlc correlations, LLNL Site 300 (modifled from Carpenter of al, 1988). For detalls of stratigraphy, see text. $a=$ not present in HE Process Area; $b=$ Tnsc 0 and Tribs o possibly repeated by faulting; ${ }^{\circ}=$ exposed southwest cif slte 300 , may underlle portions of slte. 


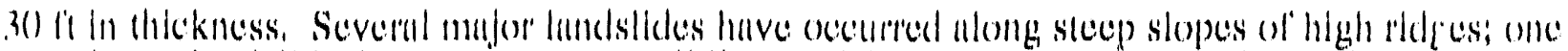

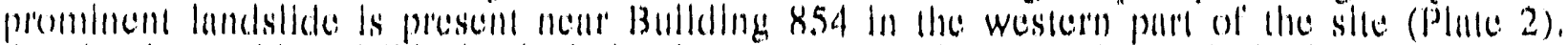

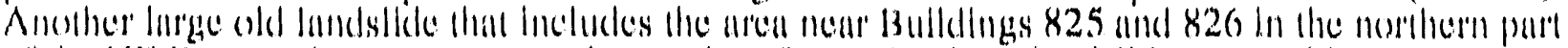

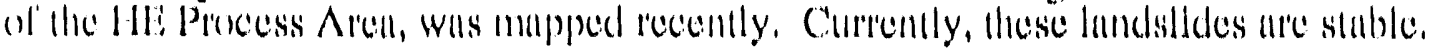

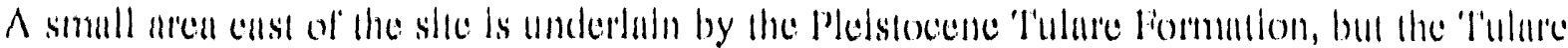
is mol present ill Sile 3()() .

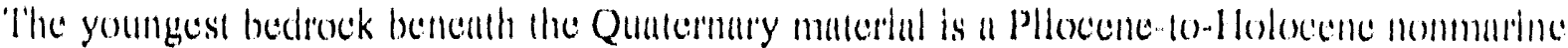

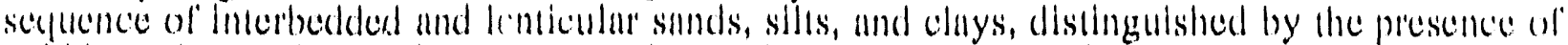

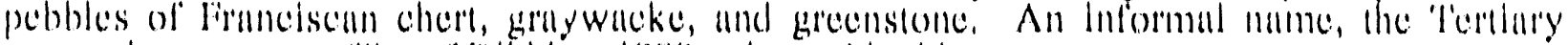

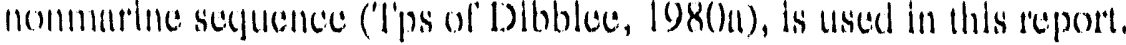

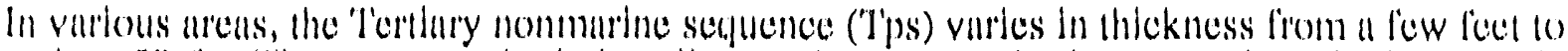
more than 5() fl. The seguence Includes silly to clayey gravels that were deposiled in entulle channels; the channel fills are encinsed in finer-grained, low permeability clays and sills. Some of these channel fill gravels contain perched ground water.

Underlying the l'ertiary nommarine secpuence ds the Late Mlocene Neroly Formation. 'Ithe Neroly formation is churacterized by interbedded sandstones, siltstones, and cluystones, containing large announts of voleanice ash; in some areas, voleanic tuff is found, the volcunle ash gives the sandstones a distinctive blac-gray eolor when dry. The major souree of these pyroclastics was in the western Sierra Nevada, where Miocene lava flows are found Interbedeled with ash-rich sandstones. 'Ihese sandstones are very similar in appearance to, and correlative with, the Neroly Formation of Site 30) (Lerbekmo, 19.56; D. W. Carpenter, LLNL, persomal communication, 1988). Other possible sources are volcante centers in the Coust Ranges, especially in the Berkeley Hills (Dickenson and Snyder, 1979).

Where exposed in outcrop, the thichuess of the Neroly Formation is approximately 4.50 ft. Although the rocks are lenticular, Neroly Formation lithologic units often extend for several miles. Several informal lithologic units can be traced within the site. The upper part of the Neroly is persistent in the norther'n part of the site, but appears to be irregularly distributed in the southern part. In the south, it consists of silty sandstone and conglomerate interbedded with silt and clay, Exposures in the vicinity of the He Process Area suggest that an erosion surface formed on top of this seguence prior to deposition of the overlying Pliocene nommarine seguence ('l'ps).

I'he Neroly upper blue sundstone ('T'nbs:2) often forms prominent ledges on the hillsides and cian be seen at outcrops (e.g., Fig. 5.2.2-2) in much of the site. It is the most identifiable marker bed in the Tertiary section at Site 3()(). The sandstone is relatively clean, massive, and heavily fractured, with the blussh-gray color characteristic of Neroly sandstones, Locally, this unit contains claystone and siltstone interbeds; claystone rip-up clasts are often found near the base of Inbsiz.

The Neroly lower siltstone and claystone unit ('Inse ) underlies the upper blue sandstone; this unit is a regionally-extensive acyutard at Site $3(x)$. Lenticular, predominantly fine-graincel silty sindstone beds occur within unit 'Tnsc l; locally, these beds yjeld small amounts of witer' to monitor walls.

Beneath the lower siltstone and elaystone unit lies the Neroly lower blue sandstone (Thbs!) (Iig. 5,2,2-2). 'This unit is characterized by interbedded sandstones and silty claystones. 'I'he sandstones, which together contain a confined acjuifer, yield water to monitor wells in most of Site 3()(). 
In the southern part of slte 300, additlonal aquitards and aquifers were penetrated by deep wells W-3.5C-(02 and W-35C-(1)3 (completed as well 20), These rocks do not appear in outcrops It Site 3(0). 'Their strulggrtuphy und structure are discussed in detull in Section 5,3.3.

The Miocene Clerbo Formation ('Tmss) unclerlles the Neroly Formation unconformably, In generil, the Clerbo Formalon is composed of micaceous, quartz-rich sandstones and curbonaceous shales. The wells and boreholes at Plt 6 near the southern boundary of Slte 300) have encountered Clerbo rocks south of the Carnegle Fault, where they dip near-vertically as a result of fault of fset and concurrent foldlng. These sandstones are light gray and clean with little cement; they can also be seen at the outcrop near the Ranger Statlon to the east of Plt 6 . In the northwestern part of the site, Clerbo rocks hive been encountered in several boreholes and wells. 'The rocks are carbonaceous shales and tight sandstones. Extensive clays present in the pore spaces of these Clerbo sandstones may explain the low permeabllity.

The Eocene Tesla Formution crops out south of the Curnegle Fault near Plt 6, adjacent to the southern boundary of Sito 3(0). It is not clear from subsurface information that Tesla rocks extend very far northeastward, becalse they have not been identified in deep monitor wells or exploratory boreholes drilled within the part of Slte 300 north of the Carnegle Fault.

Plezometer NC7.50, located in the northwestern part of Site 300, is completed in a fault zone that cuts turbidites of the Cretaceous Panoche Formation, a part of the Great Valley Sequence. Punoche Formation sandstones and s. "es are exposed on a hill northeast of the piezometer location (Plate 2). South of the Carnegie Fault, a major tectonic feature, vertlcally dipping shales and turbldites of the Great Valley Sequence crop out and are in tectonic contact with the Franciscan Assemblage.

\subsubsection{Structural Geology}

As shown in Plate 2, bedrock structure at Site 300 is dominated by the Patterson Anticline, which trends west-northwest by east-southeast as it traverses the central part of the site. South of the crest of this anticline, the bedrock sequence dips not theasterly into the trough of a subsidiary syncline with paralle1 strike.

Two faults are part of the regional structure at Site 300:

- The Carnegle Fault, a major structural discontinuity whose southeasterly strike parallels the upper reach of Corral Hollow Creek; and

- The Elk Ravine Fault, also striking southeast subparallel to the axis of the Patterson Anticline (Plate 2).

The Carnegie Fault has a strong effect on the local structure of the Tertiary rocks at Site 300 . South of the Carnegle Fault (Plate 2), steeply dipping to overturned Tertiary sandstones and claystones of the Neroly, Clerbo, and Tesla Formations, overlie strongly folded shales and turbidites of the Cretaceous Great Valley Sequence. These Great Valley Sequence sedimentary rocks are in tectonic contact with metamorphic rocks of the Franciscan Assemblage farther south.

North of the Carnegie Fault, the Tertiary rocks appear to dip generally southward towards the fault. However, a zone north of the Carnegie Fault exhibits moderate faulting, probably caused by compression of the Patterson Anticline against the Carnegie Fault. Recent geologic mapping shows that this zone is wider than previously thought, and thrust faulting has been identified at the Building 827 Complex in the western part of the HE Process Area. Although not yet shown on our geologic map (Plate 2), several thrust faults with WNW-ESE strike were located approximately $3 \mathrm{mi}$ north of the Carneigie Fault, approximately due north of Pit 6 . As previously noted, these thrust faults may extend southeasterly to the southeastern part of the HE Process 

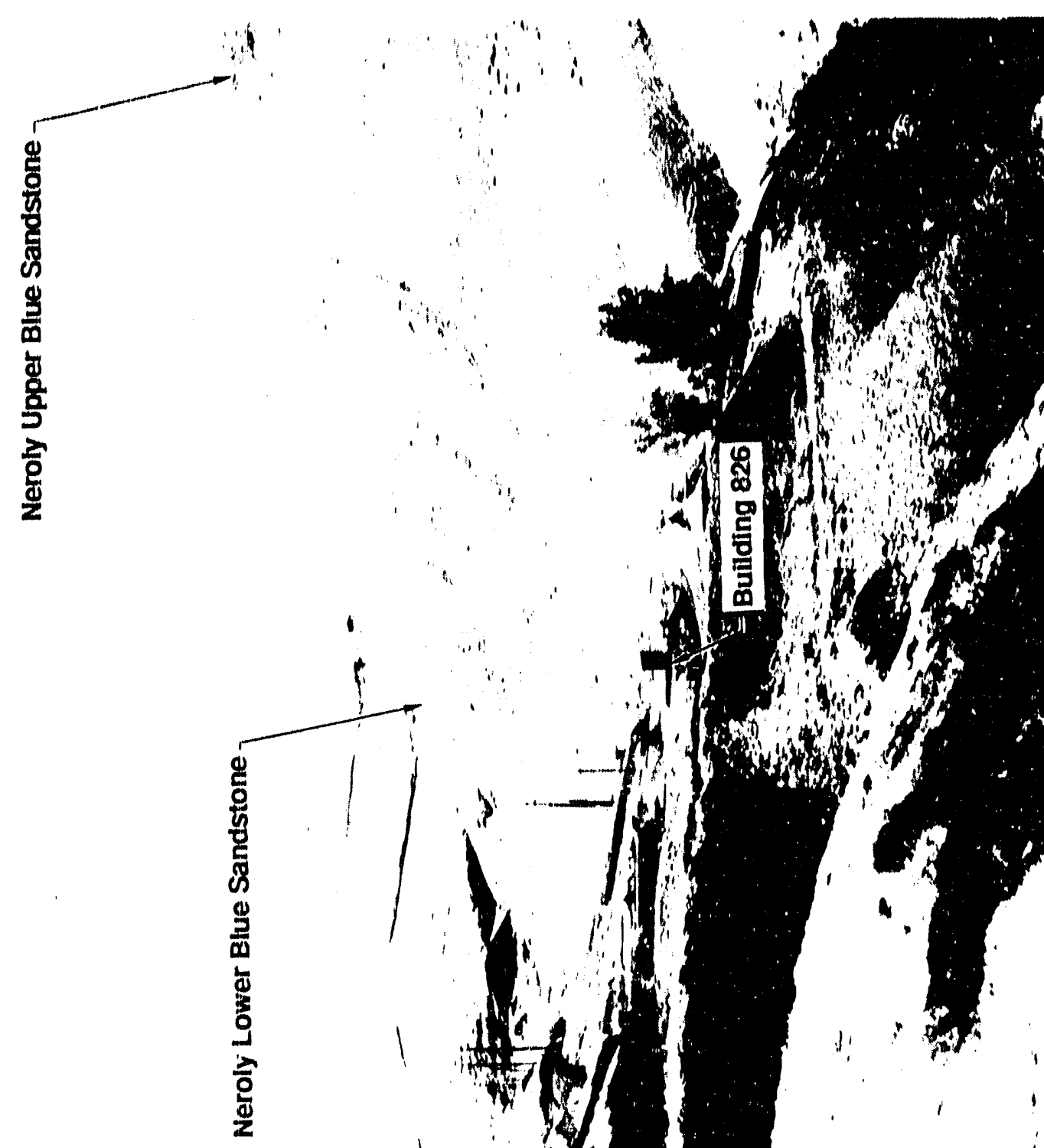
Area, and may have some effect on the hydrogeology of aquifers in that area. We are currently mapping the geology of the southern part of Site $3(X)$, and will determine where such faults are present.

The Elk Ravine Fault strikes southesistward in the northern part of the site, in the area between the axis of the Patterson Anticline and the subsidiary syncline to the north. The fault has two or more strands in some localities. The southwestern branch of the Elk Ravine Fault. passes beneath Pit 2; the northeastern branch passes beneath Pit 1 (Plate 2). Several north- to east-trending faults that appear to be local in extent have recently been identified in the eastern and southern part of Site 30() .

The Elk Ravine fault shows no evidence of Holocene displacement (Raber and Carpenter, 1983; Hoffman, 1988). Geologlc mapping in progress adjacent to pit 6 shows evidence of Holocene faulting on a branch of the Carnegle fault.

\subsection{Geology of the HE Process Area}

Parts of this discussion are excerpted from Carpenter et al. (1988), with modifications based on more recent information.

Geologic investigations in the HE Process Area have been limited to the late Tertiary nonmarine sediments (Tps of Dibblee, 1980a) and to the Miocene Neroly Formation. No older rocks are known to crop out in the area, nor have any been encountered in the exploratory boreholes or monitor wells drilled. This includes the 550-ft deep monitor well W-35C-(02 immediately to the south of the HE Process Area.

\section{b.3.1. Stratigraphy}

Figure 5.2.2-1 shows the stratigraphic relationships in the HE Process Area. Much of the HE Process Area is blanketed by colluvial and ravine fill soils, which consist of gray-brown, silty, and locally gravelly clay (Plate 2). These surficial solls are discontinuously underlain by terrace remnants (unit $\mathrm{Qt}$ ), which consist chiefly of coarse, cobble-bearing silty gravel. This gravel is derived from the Franciscan Assemblage outcrops in the core of the Diablo Range south of Site 300 .

These gravels are lithologically similar to the gravels in the Corral Hollow Creek flood plain deposits south of Site 300 (Section 5.2.1). They appear to represent deposits of ancestral Corral Hollow drainage systems. The terrace remnants primarily underlie more level portions of the HE Process Area. They vary from about 3 to $10 \mathrm{ft}$ thick, but may be as thick as $40 \mathrm{ft}$, e.g., north of Building 821 (Plates 2 and 4). A pebble conglomerate thought to be part of this unit was encountered beneath colluvium in exploratory boreholes Mag 5 and Mag- $5 \mathrm{~A}$. These boreholes were drilled rear Magazine 5 (Plate 4) on a flat ridgetop west of Building 805.

Beneath these surficial deposits, the HE Piocess Area is underlain by a folded and faulted sequence of late Tertiary continental and marine strata. Outcrops of these rocks are found in cut slopes at a few localities in the main portion of the HE Process Area, located on the northeast wall of the ravine, northeast of Buildings 825 and 826 . Outcrops are also found in the steep canyons west and south of Buildings 827 and 828 (Plates 2 and 4).

The uppermost unit within the Tertiary sequence consists of dense, partially lithified clays, clayey silts, and fine silty sands with lenticular interbeds of coarser silty to clean sands, gravelly sands, and gravels, presumably deposited as channel fills. These strata (Fig. 5.2.2-1) appear to be chiefly of continental origin. 'They were originally correlated with the upper part of the Neroly Formation (Raber, 1983; Raber and Carpenter, 1983); nevertheless, subsequent investigations indicate that these strata are better correlated with the sequence of Pliocene 
nonmarine rocks (map unit Tps) (Fig. 5.2.2-1) (Carpenter et al., 1988). Their distribution in the subsurface may be more extensive than shown on Plate 2.

Remnants of a sequence of interbedded fine pebble conglomerates, sandstones, and claystones ( $\mathrm{Tngl}_{2}$ ) that overlie the Neroly upper blue sandstone are locally present, but appear to have been largely eroded beneath most of the HE Process Area before deposition of the Pliocene continentai sediments.

As shown in Figure 5.2.2-1, the Neroly Formation has been divided into several informal lithologic units (Raber, 1983; Raber and Carpenter, 1983; Carpenter et al., 1988). The upper three units are:

- The Neroly upper blue sandstone (Tnbs2);

- The Neroly lower siltstone and claystone unit ('Tnsc 1 ), composed of siltstones and claystones with several fine silty to clayey sandstone interbeds; and

- The Neroly lower blue sandstone unit (Tnbs 1$)$, an interbedded sequence of sandstone, siltstone, and claystone with minor tuff.

The Neroly upper blue sandstone and the Neroly siltstone and claystone unit are exposed in the northwest part of the HE Process Area near Buildings 825 and 826 (Fig. 5.2.2-2). They are also exposed in deep canyons east and west of Buildings 827 and 828 (Plate 2). The third unit, the Neroly lower blue sandstone, is exposed only in the lower portion of the deep ravine northwest of Building 828 and on the hillside north of Buildings 825 and 826 (Fig. 5.2.2-2). These units have also been encountered in boreholes of monitor wells in the HE Process Area.

Two newly named informal lithologic units are discussed for the first time in this report. These units, encountered only in the subsurface, are the Neroly deep siltstone and claystone unit $\left(\operatorname{Tnsc}_{0}\right)$ and an underlying thick sandstone unit (Tnbs 0$)$.

In the deeper wells W-810-01 and W-819-02 in the HE Process Area, siltstones and claystones were encountered below the Neroly lower blue sandstone. Similar siltstones and claystones were also encountered in wells W-35C-02 and W-35C-03 (completed as water-supply well 20), immediately south of the HE Process Area (Plates 3 and 4). As these wells were drilled deeper, an additional thickness was encountered of very similar siltstone and claystone with thin interbedded sandstones. This overall sequence of rocks forms a discrete lithologic unit which we informally name the Neroly deep siltstone and claystone unit $\left(\operatorname{Tnsc}_{0}\right)$. Beneath these claystones and siltstones, well W-35C-02 and well 20 encountered a thick unit of bluish-gray sandstone, the Neroly deep blue sandstone $\left(\mathrm{Tnbs}_{0}\right)$. Although the data are inconclusive, the thick sandstone of well 20 is thought to correlate with that of well 18.

An alternative hypothesis about the origin of these Neroly deep units is discussed in Section 5.3.3.

Rocks of the Cierbo Formation are found in the northern part of the site, but Cierbo rocks have not been encountered in the deep wells in and near the HE Process Area.

\subsubsection{Structural Geology}

The HE Process Area is located on the southern limb of the Patterson Anticline, and beds beneath the area dip about 5 to 10 degrees to the south-southwest. The bedrock sequence is offset by several northeast- to east-trending faults of local extent.

As shown in Plate 2, a short, unnamed fault projects into the northeastern portion of the HE Process Area. Vertical slin has occurred along this fault in beds of the Neroly Formation. The 
fault has no geomorphic expression and is buried by Plio-Pleistocene alluvium, indicating that it has been inactive since late Tertiary time.

Recent geologic mapping, discussed previously in Section 5.2.3, indicates that thrust faults are present northwest of the HE Process Area. If this faulting extends to the southeasterly part of the HE Process Area, it may affect the hydrogeology of the aquifers. The significance of these structural features to the hydrogeology and to the behavior of substances in ground water in the HE Process Area has not been fully determined. A more intensive discussion follows in Section 5.3.3.

Recent geologic mapping has also revealed that HE Process Area Buildings 825 and 826 (Plate 4) are located in the lower part of a large, stabilized landslide, similar to those previously identified in the western part of Site 300.

\subsubsection{Neroly Formation: Deep Lithologic Units-Stratigraphic vs. Structural Origin}

Recently discovered thrust faulting in the southwest part of Site 300 extends as far east as the Building 827 Complex of the HE Process Area. This faulting gives rise to potentially significant hydrogeologic effects which are discussed further in Section 6.2.2.4 on page 6-11. Although the faulting may affect the entire Neroly section, the basal part, encountered only in two deep wells in the south part of the process area, seems most likely to be affected.

Wells W-810-01 and W-819-01, located in the eastern part of the HE Process Area (Plate 3), encountered thin interbeds of tight, silty sandstones and clayey siltstones beneath the Neroly lower blue sandstone unit. A similar sequence was encountered in deep monitor well W-35C-02 and in monitor well W-35C-03 (completed as water-supply well 20), at locations shown in Plate 3. These beds comprise a coherent lithologic unit, which we have named the Neroly deep siltstone and claystone unit (Tnsco). Beneath this unit, both wells penetrated a clean sandstone, $100 \mathrm{ft}$ thick, with the typical Neroly bluish-gray color, the Neroly deep blue sandstone (Tnbs0).

We have interpreted the stratigraphy of the deep Neroly rocks and aquifers in the southern HE Process Area and the adjacent western GSA to be the result of transgressive overlap as sedimentation progressed locally northward over time. Younger beds are thought to have overlapped the older zones that contain the Neroly deep sandstones, siltstones, and claystones; such overlaps are quite common in the stratigraphy of younger sedimentary rocks in California and elsewhere.

The recent discovery of thrust faulting to the northwest suggests a possible alternative explanation. If the thrust fault zones extend eastward to this region, the possibility of repetition of the lithologic units that might result from thrust faults must be considered. If the faults were large enough, these structural effects might account for the added lithologic section.

The concepts of transgressive overlap and of repetition as a result of thrust faulting are difficult to explain; therefore, conceptual sketches of these concepts (Fig. 5.3.3-1) are included to illustrate them. 


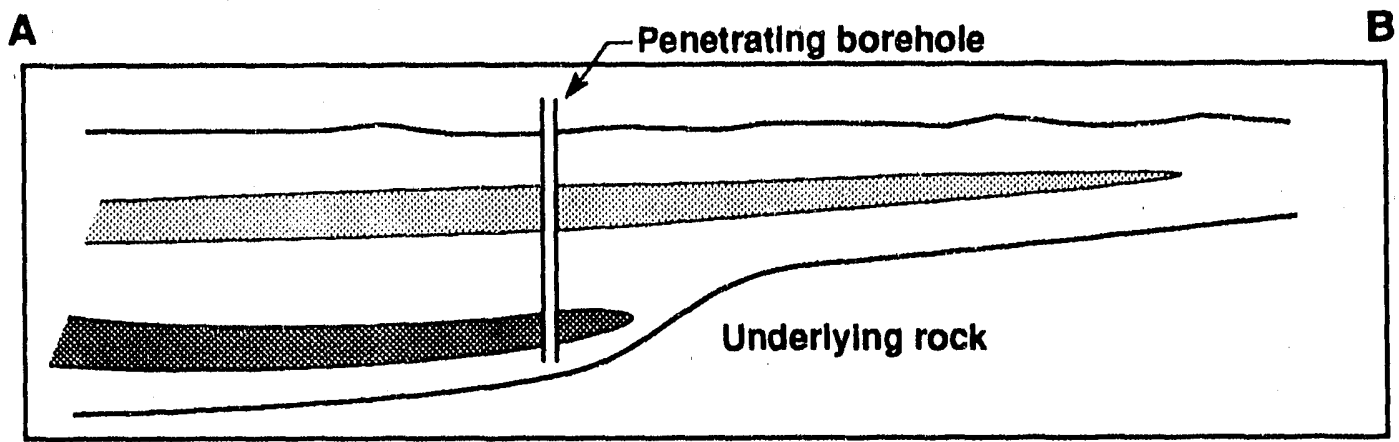

B

a) Transgressive overlap

A

B

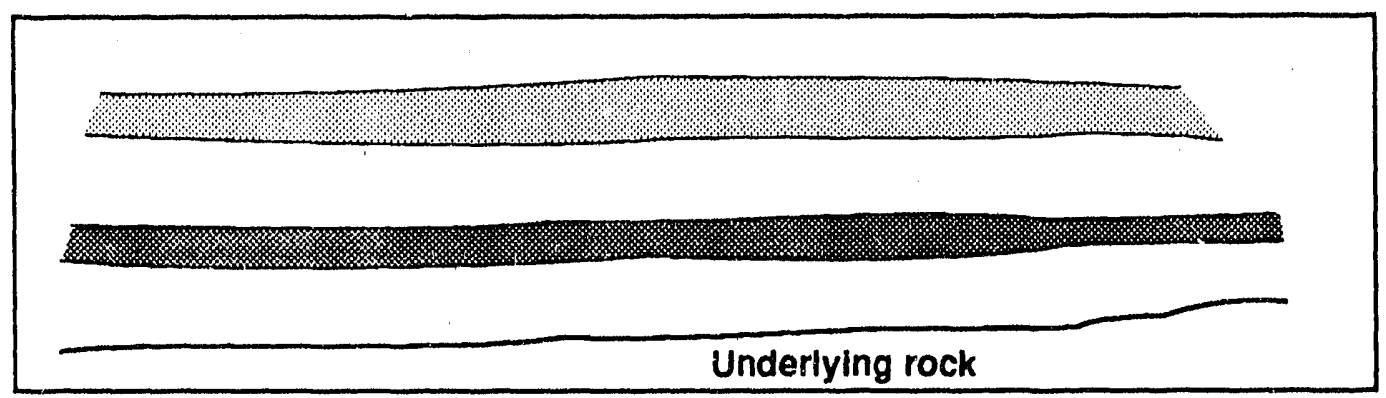

b) Section pre-overthrust

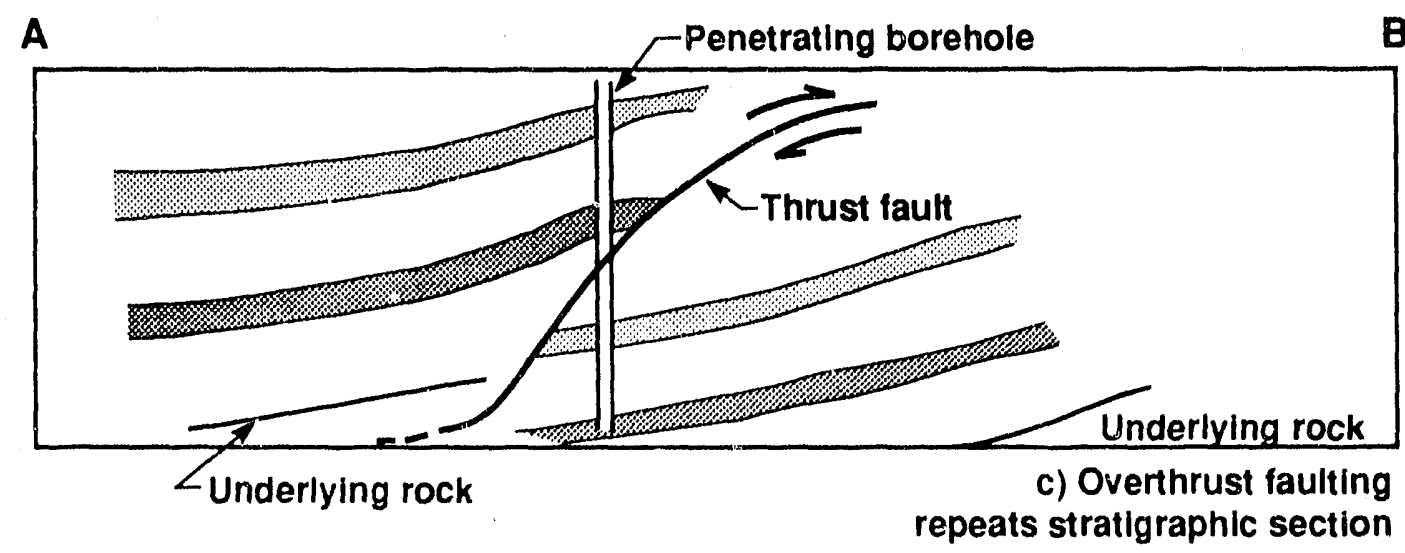

Figure 5.3.3-1. Conceptual sketches (not to scale) showing hypothetical stratlgraphic cross-sections. See text, Section 5.2.2. Sketches illustrate a) transgressive overlap, b) stratigraphic section before overthrusting, and c) stratigraphic section after overthrusting, demonstrating repetition of beds. The sketches do not represent actual conditions ai Siie उôv, âinu are soteliy to demonstrate alternate explanat!ons of stratigraphy. 


\section{Chapter 6. Hydrogeology}

This chapter discusses the hydrogeology of the HE Process Area. In general, knowledge of the hydrogeology is necessary to understand the distribution, transport, and fate of HE compounds

and VOCs in the ground water of this area. Some aspects of the hydrogeology are not fully understood; therefore, further investigations will follow, to be discussed in the forthcoming FS report.

\subsection{Hydrogeology of Site 300}

Based on a reconnaissance study done in 1981 and 1982, Raber and Carpenter (1983) presented a preliminary analysis of the hydrogeology of Site 300. More recent investigations of occurrences of VOCs, tritium, and HE compounds are discussed in several additional reports, namely Raber (1983); Carpenter et al. (1983, 1988); Buddemeier et al. (1985, 1987); Crow et al. (1986); Weiss Associates (1988); Toney and Crow (1989); Taffet et al. (1989); and several issues of the Site 300 Environmental Investigations Quarterly. Data from these reports were extracted to develop a synthesis of the hydrogeology of Site 300 .

\subsubsection{Surface Water}

The following discussion of surface water hydrology is modified from Taffet et al. (1989). There are no perennial surface water bodies at Site 300. Flow in the dry stream channels is intermittent, occurring almost exclusively during heavy rains. During intense storms, there is temporary flow in otherwise dry watercourses. Sheet flow of water across the land surface also may occur. Corral Hollow Creek, the main surface water drainage of the region, flows intermittently; the last occurrence of observable flow in the creek in the vicinity of Site 30) was during and after the wet winter of 1982 and 1983. Cooling tower blowdown from several Site 3()) facilities drains down natural watercourses. These small man-made flows may last for several months or years, and they are totally dependent upon operation of the cooling towers.

The specific surface water conditions in the HE Process Area are discussed in Section 6.2.1 of this report. A map of the surface drainage in the vicinity of the HE Process Area is shown in Figure 6.1.1-1.

\subsubsection{Ground Water Aquifers and Aquitards}

The hydrogeology of Site 300 is summarized in the following paragraphs. The discussion is arranged by the age of the rocks which contain the aquifers and aquitards. A more detailed treatment of the hydrogeology of the HE Process Area is in Section 6.2.2.

The creek gravels of Corral Hollow Creek contain ground water. In the upland part of Site 300 , the alluvial cover and the underlying Tertiary nonmarine sequence contain perched aquifers. The layered Tertiary rocks beneath them contain a series of aquifers, separated by very slightly permeable aquitards.

With the exception of the perched aquifers, the depth to water at Site 300 is relatively large. In the southern part of the site, the depth to the first regional aquifer ranges from about 80 ft to more than $300 \mathrm{ft}$. Depending upon the locality, the unsaturated zone above the regional aquifer is located in the Tertiary nonmarine sequence and in the upper part of the Neroly Formation. 


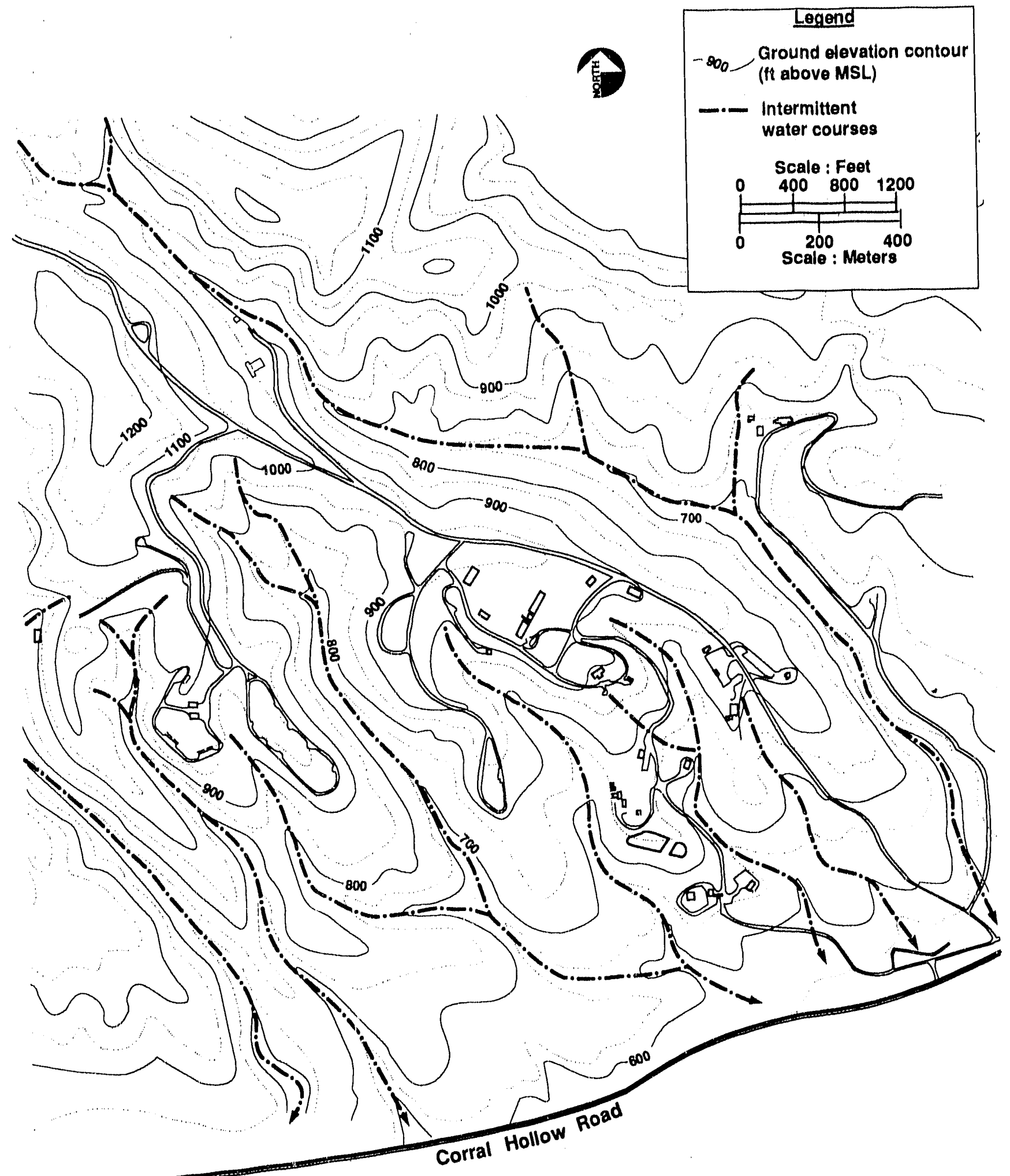

Figure 6.1.1-1. Intermittent water courses, HE Process Area. 
The rocks in these formations are generally silty claystones and clayey siltstones, interbedded with clean to silty sandstones. There is interstitial water in these rocks, but it is bound to the sediment grains by capillary attraction and cannot move downward until the rock becomes fully saturated.

6.1.2.1. Perched Aquifers. The Glossary of Geology (American Geological Institute, 1980) defines perched water as unconfined ground water separated from an underlying main body of ground water by an unsaturated zone. Implicit in this definition is the presence of a perching aquitard, which prevents or retards downward motion of ground water in the perched aquifer to the saturated zone.

There are three kinds of perched aquifers at Site 300:

1. Aquifers found in alluvial sediments above bedrock and in the upper few feet of the underlying bedrock,

2. Aquifers found in channel fills of silty and clayey gravel encased in less permeable claystone and siltstone in the Tertiary nonmarine sequence, and

3. A perched aquifer found in fractured claystone of the Neroly lower siltstone and claystone unit $\left(\operatorname{Tnsc}_{1}\right)$ at the Building 829 Complex.

Examples of Number 1 are found at Pit 6, in the southwestern part of the site, and at the Pit 7 complex. The Pit 6 perched aquifer is in the alluvial cover above bedrock and in the top of the bedrock itself; the perching horizon is impermeable bedrock. At Pit 7, a perched aquifer is found beneath the stream channel at the axis of the valley. Here, the water level was high in 1983, after several historically wet winters. Since that time, the water level has declined and parts of the aquifer are no longer saturated.

The extent of these perched aquifers is relatively small, and the aquifers are seldom more than 5 $\mathrm{ft}$ thick. The alluvial aquifer at Pit 7 is unusual because the alluvium extends from Pit 7 through Doall Ravine to the east for a distance of approximately $2500 \mathrm{ft}$.

Examples of Number 2 are found in irregularly scattered channel fills located in the Tertiary nonmarine sequence (Tps). These channels are often filled with poorly sorted silty, clayey gravels. Some of these channel fills are saturated. The perching horizon generally is the underlying, less permeable claystone and siltstone beds of the nonmarine sequence. The overall extent of these aquifers is small, permeability is low, and water productivity is generally very low. Typically, flow rates are less than $1 \mathrm{gpm}$ (Weiss Associates, 1988).

A perched aquifer of this kind is found at the Building 834 Complex. It is relatively narrow and extends southerly from the buildings for about $1000 \mathrm{ft}$. The saturated zone is seldom more than $5 \mathrm{ft}$ thick (Bryn et al., 1990).

Two perched aquifers of the same kind have been found in the HE Process Area. The geographic extent of these perched aquifers is shown in Figure 6.1.2-1. Their hydrogeology is discussed in detail in Section 6.2.2. The aquifers are the perched aquifer of Building 814 , stratigraphically higher and distinct from the larger perched aquifer of Building 815 . In both aquifers, the saturated thickness is about $5 \mathrm{ft}$, the permeability is low, and water production is small.

A borehole and two monitor wells at the Building 829 Complex (the HE Burn Pit) encountered perched water in fractured claystone in unit Tnsc 1 about $40 \mathrm{ft}$ below the Neroly upper blue sandstone (Webster-Scholten and Crow, 1989). The saturated thickness is less than $3 \mathrm{ft}$, the permeability is low, and water production is small. 


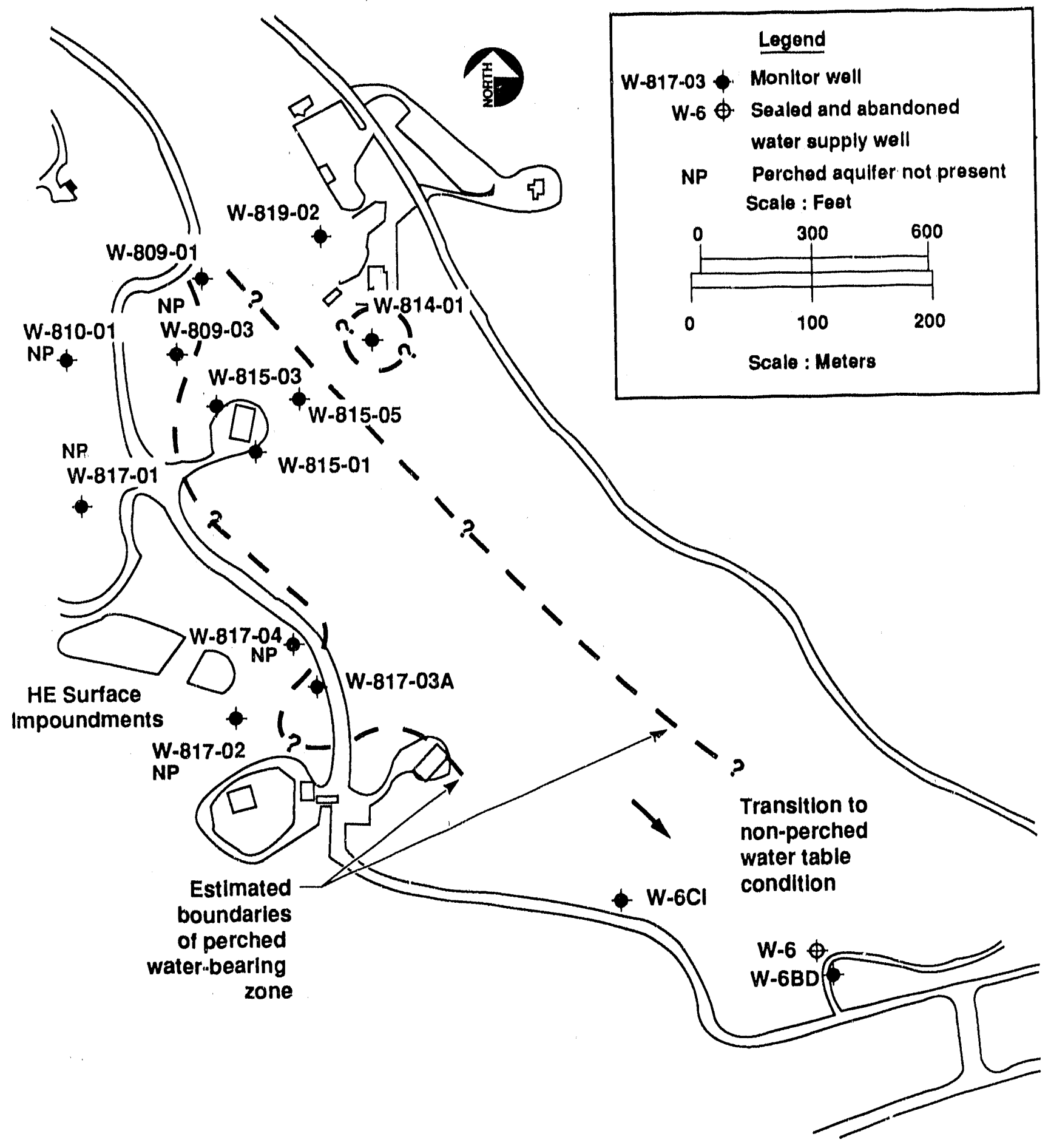

Figure 6.1.2-1. Limits of perched aquifers, HE Process Area. 
6.1.2.2. Regional Aquifers and Interbedded Aquitards. The alluvium of Corral Hollow is a mappable unit. This coarse gravel beneath the Corral Hollow flood plain contans ground water in an unconfined aquifer. Flow is interstitial in the coarse sediment. Recharge is by infiltration from, water moving downward from the surface after stoms. The water is present primarily in areas where the gravels are relatively thick. The gravel containing the ayuifer extends from the head of Corral Hollow Creek, several miles west of Site 300, to a point northeast of the site. The gravel is usually about $20 \mathrm{ft}$ thick, with a probable maximum of $30 \mathrm{ft}$; usually part of the gravel is above the water table. Boreholes and monitor wells drilled in and near the gravel of Corral Hollow indicate that the thickness of the gravels varies near the edge of the deposit.

The hydrologic relationship of the gravel of Corral Hollow to the underlying bedrock is not completely clear because of insufficient information, but in most localities the saturation is confined to the gravel zone. In areas where the gravel is very clean, well yields can be relatively large, as much as $40 \mathrm{gpm}$.

The bedrock regional aquifers at Site 300 are all located in the Neroly Formation. At the southern edge of the site, in the western GSA, most aquifers are under confined conditions, i.e.. they have artesian head and the water level in monitor wells rises above the top of the aculfer containing the water. Farther to the north, beneath the upland part of the site, the shallowest regional aquifer is usually unconfined, i.e., it is a water-table aquifer. Deeper aquifers are confined. In the following paragraphs, the Neroly sandstone aquifers and the aquitards that separate them are discussed.

The Neroly sandstones are poorly sorted; silt, clay, and volcanic ash reduce interstitial permeability. These sedimentary rocks are more consolidated than the overlying alluvial deposits, although interstitial cement is rare. However, the Neroly rocks are sufficiently britlle, so thill fractures will both form and remain open. Hydraulic testing and examination of cores, collected in the Neroly sandstones that contain the aquifers, suggest that much of the water produced from these aquifers moves through fractures; nevertheless, interstitial porous flow may occur in cleance sandstone beds.

6.1.2.2.1. Neroly Upper Blue Sandstone (Tnbs2). Although it is present beneath much of Site 300, the Neroly upper biue sandstone unit is saturated only under the southeastern part of the HE Process Area and the western GSA immediately to the south (Fig. 6,1.2-2). The sandstone averages 20 to $30 \mathrm{ft}$ in thickness, but not all of the sandstone body is salturated in the $11 \mathrm{l}$ : Process Area. The saturated thickness is approximately 10 to $15 \mathrm{ft}$. Water yields are gencrally small, averaging approximately $1 \mathrm{gpm}$ where the rock is not heavily fractured and approximatcly 5 $\mathrm{gpm}$ where fractures are pervasive.

6.1.2.2.2. Neroly Lower Siltstone and Claystone Unit (Tnsc 1). Underlying the Neroly upper blue sandstone aquifer is an aquitard composed of silty claystone and clayey sillstonc interbedded with tight silty sandstones. At the outcrop, northeast of Building 826 (Fig. 5.2.2.2), this unit is approximately $100 \mathrm{ft}$ thick. Subsurface information indicates that bencath the southeastern part of the IIE Process Area, thin interbedded sandstones in the lower hall of the unit may produce small amounts of water. A fairly persistent, well-lithified claystone bed in the middle of the unit forms ledges at some small outcrops in the south-central part of the site (e.g., lig. 5.2.2-2).

6.1.2.2.3. Neroly Lower Blue Sandstone Unit (Tnbs 1). The Neroly lower bluc sandstone is saturated beneath much of the site. Normally, water in the aquifer is confined, exceph near the upgradient edge of the aquifer (e.g., in wells W-8()6-6A and W-817-()5). Plate 5 is is piezometric surface map of this aquifer. The aquifer occupies one or more relatively thin $(<10$ lit) sandstones intcrbedded with thin claystones; the sandstones act as one alyuifer, 


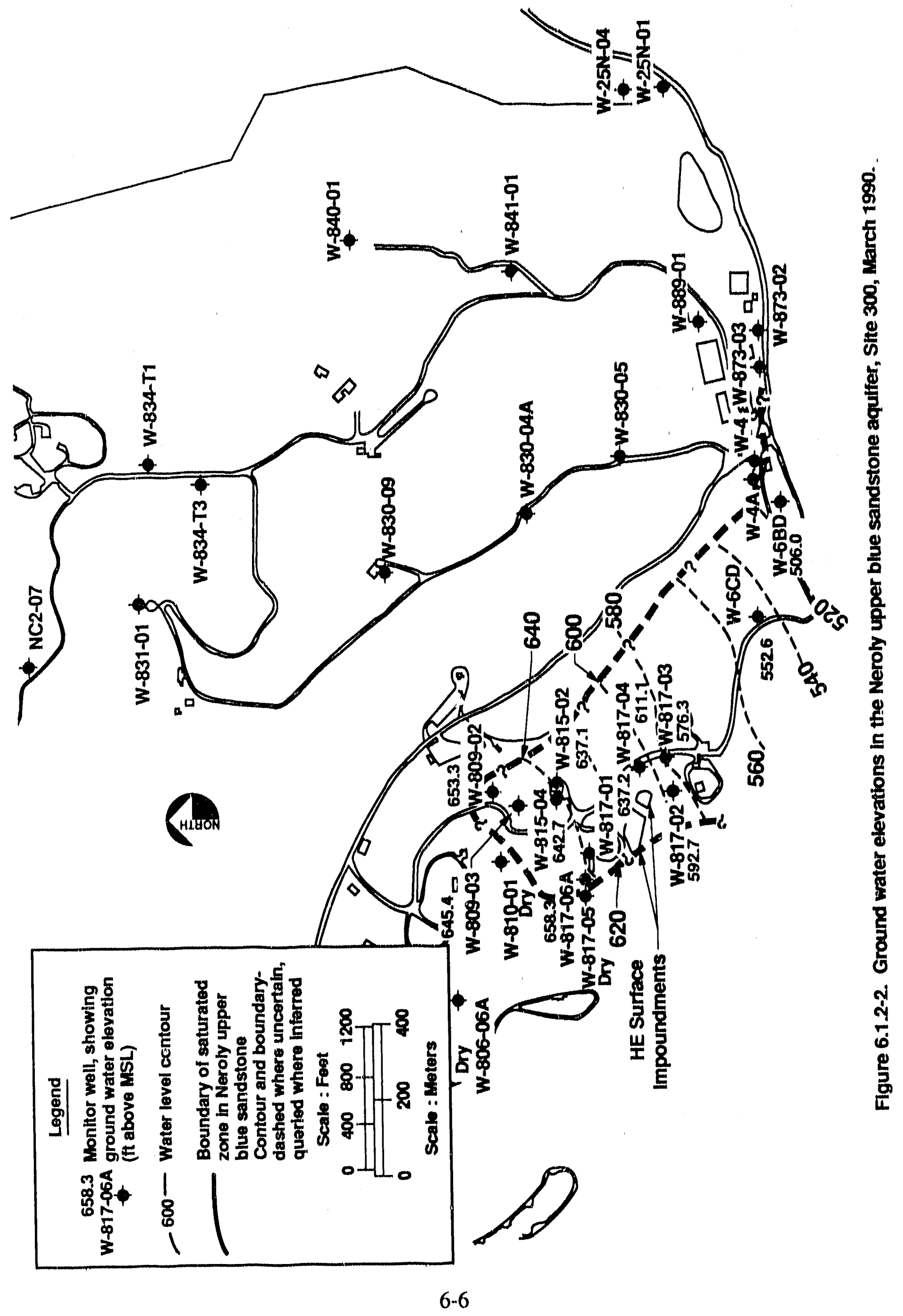


because the thin, Interbedded claystones are hydrologleally discontinuous. The capacily of the wells depends upon the presence of fractures; when these are plentiful, witer production is relatively large. When fractures are absent, water productlon may be small. Hydraulle tests conducted by Weiss Associates (1988) in several Site 3(X) monitor wells indicate that in wells where the Tnbs 1 sandstone is thought to be poorly fractured, yields are in the range of 1 to 3 gpm. In some wells, probably with well-developed fructures in the actuifer, ylelds are higher, l,e., \& to $15 \mathrm{gpm}$.

6.1.2.2.4. Neroly Deep Siltstone and Claystone Unit ('Tnsoo): The Deep Aquitard. A thick (about 1(0)-ft) aquitard (Tnsc()), composed primarily of poorly permeable silty sandstone, clayey siltstone, and claystone underlles the Neroly lower blue sandstone unlt, The unit is known chiefly from deep test wells W-35C-(12 and W-35C-()3, drilled just south of the HIE Process Area. This aquiturd is discussed in more detail in Section 6.2.

6.1.2.2.5. Neroly Deep Blue Sandstone (Tnbso). A thick (5)- to 1()()-ft) sindstone, apparently near the base of the Neroly Formation ('T'nbs()), which produces large amounts of water, was encountered during 1989 while drilling deep test wells W-35C-(1) and W-35C-()3. 'This aquifer is also thought in produce water in well 18, a major water-supply well at Site 3()). Thic sandstone cannot be identified in outcrops at Site 30). Also, it is not present in the northern part of the site, where beds correlated with aquitard unit 'Insc) rest directly on rocks of the Clerbo Formation. The horizontal extent is not known with certainty, but must be moderately large to have supplied Site 300's water needs for years. Details of the hydrology of this acuifer are discussed in Section 6.2.

6.1.2.2.6. Cierbo Formation. Clerbo rocks that crop out along Corral Hollow Creck neur Pit 6, along the southern boundary in the western part of the site, are porous and permeable; however, no well at Site 3()) has encountered water in the unit. In the northern part of the site, where the Cierbo Formation has been encountered, the rocks are largely impermeable sands and mudstones, although a few local water-bearing zones have been found by detalled hydrogeologic analysis (Tuffet et al., 1989).

\subsection{Hydrogeology of the HE Process Area}

\subsubsection{Surface Water}

The HE Process Area is situated on a rugged hillslope deeply dissected by several dry watercourses (Fig, 6.1.1-1). Surface water is apparent only after infrequen, heavy rains.

A small perennial spring is present near a road southeast of the HE Surface Impoundments (Fig, 6.1.2-1). Piezometer $W-817-3 \mathrm{~A}$ is completed at a depth of $5 \mathrm{ft}$ in the ayuifer supplying the spring with water. The piezometer is sampled regularly and monitors the source of the spring. Results of the analyses are in Section 6,2.1.1. 'This section also discusses the perched ayufifer of Building 815. Other small springs have been found south of the He Process Areat their localtions may be controlled by faulting.

\subsubsection{Ground Water Aquifers and Aquitards}

As stated in Chapter 5, the rocks at Site 3(0), including the HE Process Area, can be correlated sufficiently to identify aquifers extending for a few miles. Figure 5.3.3-1 shows a good example of an outerop of the upper part of the Neroly formation adjacent in the northern part of the lll: Process Area. Farther to the south, the sandstones are saluraled. Figures $6,1,2.1$ and $6,1,2-2$, 
and Plate 5, show the extent of several aquifers in the HE Procoss Area. A cross section in the Bullding 817 Area (Figs, 6.2.2.1 and 6.2.2.2) shows the subsurface relationships of three of these aquifers.

6.2.2.1. Perched Aquifers of the HE Process Area. Two perched acpulfers ure found In the HE Process Area and are located in the Tertary nommarine sequence (T'ps). Filgure 6.1.2"1 shows the extent of these aquifers.

6.2.2.1.1. Perched Aquifer near Building 814. During the drilling of well W-814.()1, aperched aquifer was encountered to the northeast of the HE Process Area, southeast of Bullding 814 (Fig, 6.1,2-1). This aquifer is in a silty sand, stratigraphically younger and considerably higher in the section than the more extensive perched aquifer near Bulding 815 , located several hundred feet southwest.

The zone has not been found in other monitor wells and is appurently limited to the aren surrounding the well. Ground water production is small. Water from the achulfer contains truce concentrations of several VOCs. No HE compounds have ever been detected. Perlodic monitoring continues.

6.2.2.1.2. Perohed Aquifer near Building 815. The second perched aquifer was first Identified beneath Bullding 815 (Fig, 6.1.2-1). It underlies a larger area than the perched aculfer of Building 814. The perched aquifer of Building 815 (Fig. 6.1.2-1) is in a silty sand near the base of the Tertiary nonmarine sequence. In some wells, it contacts the unsuturated top of the Neroly upper blue sandstone (Tnbs2), as shown in a cross section in Figure 6.2.2-2.

The distribution of the aquifer is irregular. It is present in well W-809-01, but is absent to the south in W-809-03 (Fig. 6.1.2-1). It is present surrounding Building 815 in well W-815.05 and in wells W-815-(01 and W-815-(3). Plezometer W-817-03A, on the road east of the HE Surface Impoundments, monitors a small spring that discharges water from a zone correlative with the perched aquifer. The spring is thought to be a ground water outcrop of this aqulfer. This perched aquifer is also thought to be present further south, in monitor well W-6CI.

The horizontal and vertical extent of RDX and VOCs in this aquifer and their potential release sites are discussed in Chapter 8.

6.2.2.2. Water Table Aquifer. The Neroly upper blue sundstone (T'nbs2) is water-saturated beneath the southeastern part of the HE Process Area and the area immediately to the south. Figure 6.1.2-2 shows the extent of this saturated zone and its water table elevations. Although the Neroly upper blue saridstone unit is present under much of Site 3()(), it is saturated with water only in this area. The Neroly upper blue sandstone crops out on the west wall of the major ravine northeast of the HE Process Area, thought to be one of the recharge areas for the aquifer. In ravines west of the HE Process Area, the Neroly upper blue sandstone also crops out; scattered springs mapped in this ravine may represent discharge areas for this aquifer.

The hydrogeology of the Neroly upper blue sandstone aquifer (Fig. 6,1.2-2) is relatively complex. In the upgradient feather edge of the saturated zone, some of the behavior of the aquifer suggests perched conditions, but evidence is not sufficient for a determinution. Under most of the HE Process Area, the aquifer acts as an unconfined water table aquifer. To the south, beneath the western GSA, the saturated zone has an artesian head and therefore, is a corfined aquifer. 


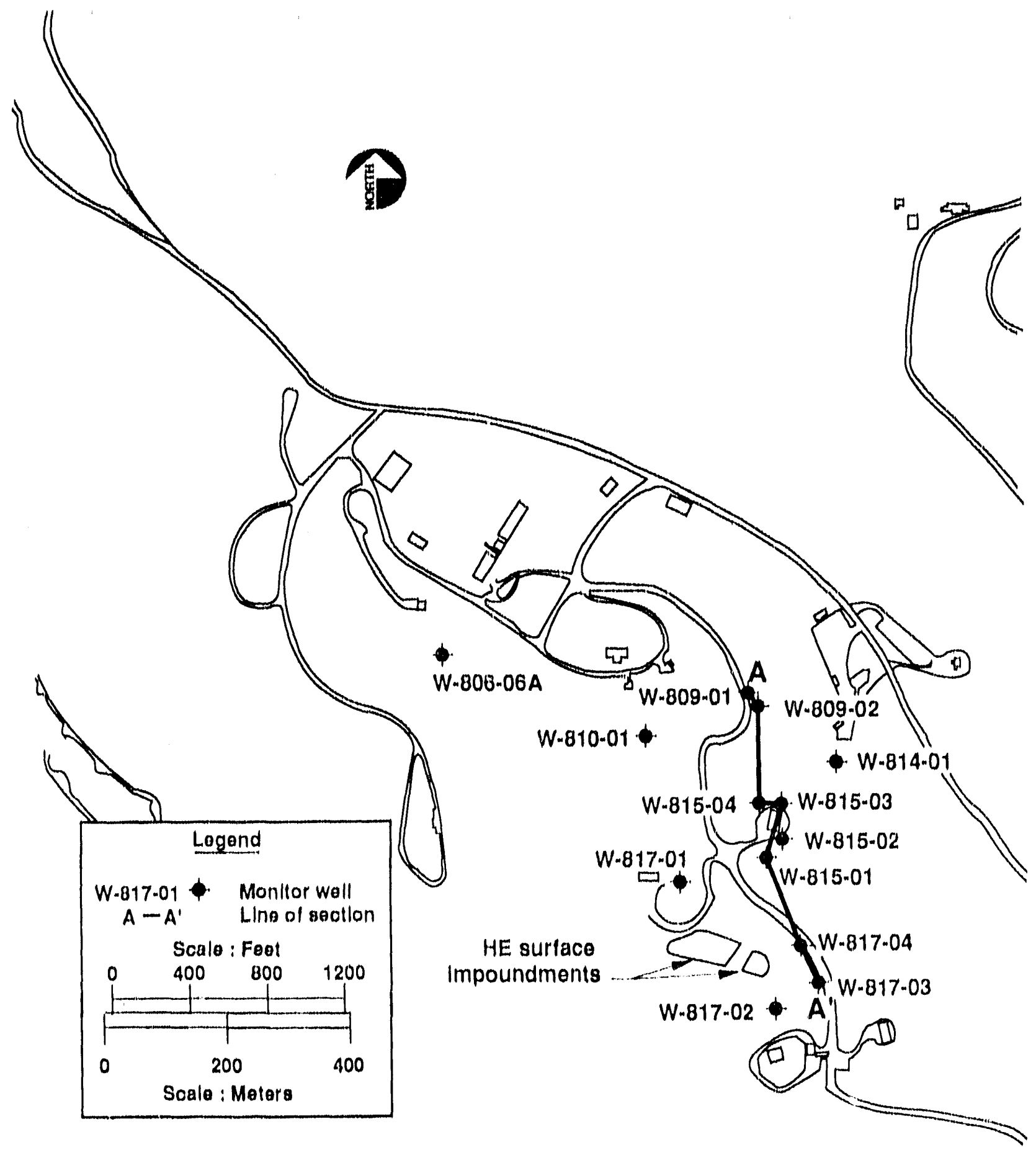

Figure 6.2.2.1. Map of HE Process Area showing locatlons of cross sectlon A.A', 

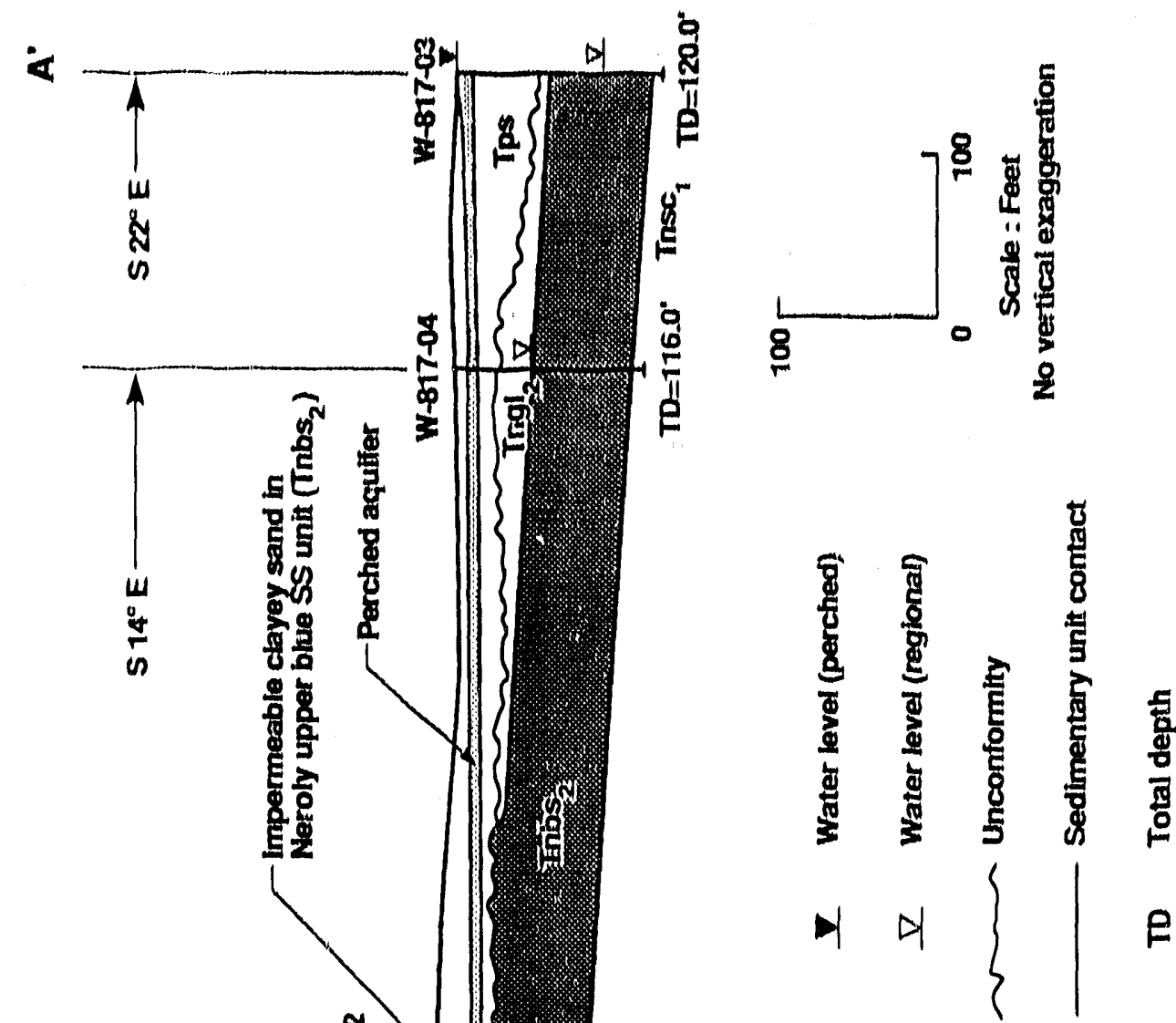

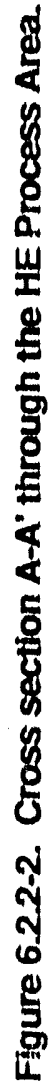

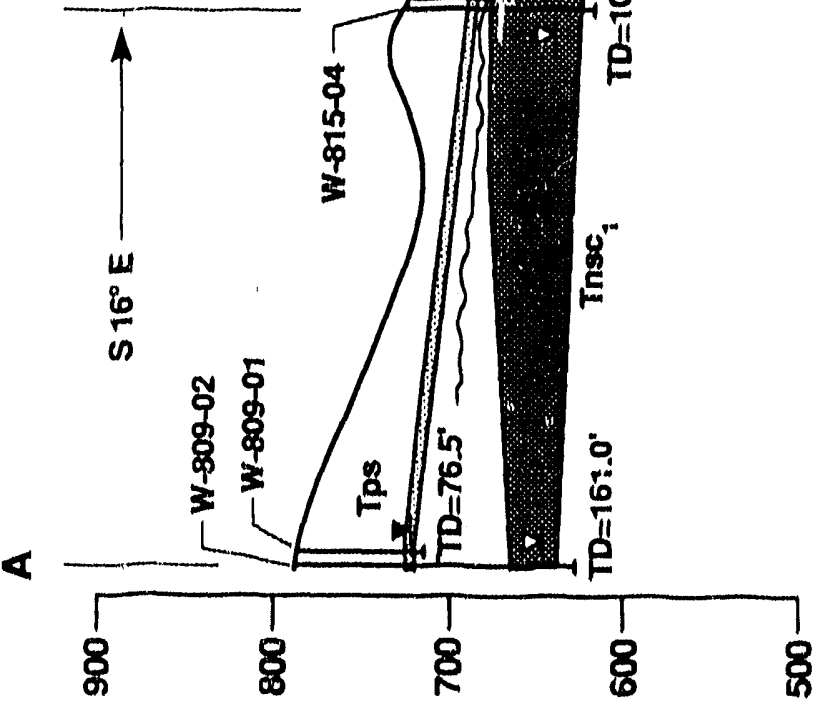

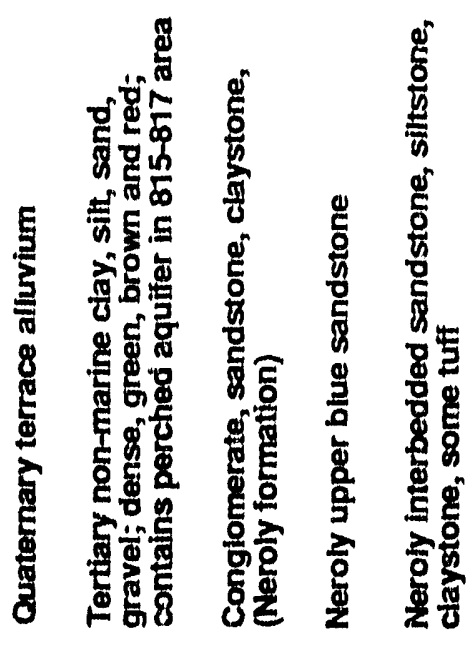

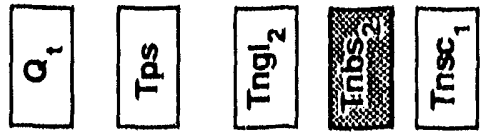

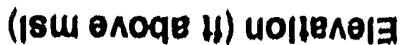


6.2.2.3. Confined Aquifers. Beneath the HE Process Area, there are confined aquifers in several sandstones of the Neroly lower blue sandstone unit (T'nbs 1 ) that consist of relatively thin Interbedded sandstones separated by siltstone and claystone. The T'nbs unit contains water under confining pressure, that appear's to tnorease the downgradient to the southenst. Plate 5 is a piezometric surface map of this aguffer. No RDX or VOCs have ever been found in ground water from the Neroly lower blue sundstone anquifers.

Sundstones in the Neroly lower blue sundstone ('Tnbs 1) are saturated bententh much of the site, Including most of the HE Process Area. However, in the deep canyons west of Building 827 and 828 (Plate 4), interbedded sandstones crop out in the approximate stratigraphic position of the Neroly lower blue sandstone unit. They are dry at the outcrop, and tho springs have been observed. Northeast of Buildings 825 and 826 (F/g, 5.2.2-2), simllar dry sandstones also crops out. In both areas, the Neroly lower blue sundstone unit may be unsaturated in the subsurface,

These outcropping sandstones are thought to be part of the Neroly lower blue sandstone unit, encountered in deep wells (W-810-()1 and W-819-(2) in the HE Process Area. The relationships of the sandstones in the outerops and in the monitor wells are unclear. Using existing data, we will investigate the strattgraphic relatlonships of these sandstones in the subsurfice to conflirm our interpretution in the HE Process Area.

6.2.2.4. Hydrogeology of Deeper Parts of the Neroly Formation. Four wells, two in the enstern part of the HE Process Area (W-810-(01 and W-819-()2) and two just south of the process area (W-35C-(22 and W-35C-03-Well 20), penetruted a siltstone and claystone unlt ('Tnse()) and a thick, clean sandstone approximately $1(0)$ ft thick, with the typical Neroly bluishgray color (Tnbs()). In well 2(), this sandstone produces large amounts of water, pump testing is discussed in Section 6.3.

As discussed in Section 5.3.3, the possible existence of thrust faults may have cut the Neroly section and caused repetition of the lithologic section. The effects of such faulting on hydrogeology would depend on whether the thrust faults cut acjulfers, and if the faults had sufficient throw to displace the aquifers to produce hydrologic discontinuities. Any such discontiruities could affect the movement of water and transport of contaminants in the acjuifers, either by increasing or decreasing the permeability and flow rates.

In future studies, we will continue to investigate the extent of these funlts and their control on hydrogeology.

\subsection{Hydraulic Testing}

Two hydraulic tests, conducted in and near the LIE Process Areal, provided some datia necessary to fully understand the ground water system in the HE Process Area. Additional testing is planned.

In the summer of 1987, a short pilot pump test was conducted to evaluate the logistics of a fullscale chemical time-series test. The proposed full-scale te:it was intended to gain hydrologic: information about the distribution of RDX in the ground water of well W-17-()1. Before the fullscale test could be run, a series of monitor wells drilled near Building 815, to the enst of well W817-(01, encountered RDX in ground water. Therefore, the proposed full-scille pump test was superfluous.

A 1-hour test was conducted in well W-817-()1. The drawdown curve was difficult (o) interpret, because a stable pumping rate could not be estatilished; therefore, it was hard to estimate the pumping rate. A rate of $1 \mathrm{gpm}$ wass used for the calculation. Well recovery was uninterrupted, and the recovery curve was classified to be of gond quality. 
Well W-817-01 is a small producer, much like a number of wells completed elsewhere at Site 300 in the Neroly upper and lower blue sandstones where few fractures are present in the aquifer sandstones (Weiss Associates, 1988). The aquifer thickness is $9 \mathrm{ft}$, the calculated transmissivity is $86 \mathrm{gpd} / \mathrm{ft}$, and the nydraulic conductivity is $9.5 \mathrm{gpd} / \mathrm{ft}^{2}(4.5 \mathrm{E}-4 \mathrm{~cm} / \mathrm{sec})$.

Immediately south of the HE Process Area (Fig. 6.1.2-2), three hydraulic tests of Well 20 were conducted in April 1989 (R. Ferry, in Lamarre, 1989a, Table C-1). They were completed in the deep Neroly sandstone aquifer. An aquifer thickness of $108 \mathrm{ft}$ was used in the hydraulic calculations. The tests showed that the transmissivity of this well averages $4250 \mathrm{gpd} / \mathrm{ft}$, and the hydraulic conductivity averages approximately $42.3 \mathrm{gpd} / \mathrm{ft}^{2}(2.3 \mathrm{E}-3 \mathrm{~cm} / \mathrm{sec})$. As a result of the tests, Ferry (Weiss Associates, personal communication, 1989) stated this well should be capable of producing more than $300 \mathrm{gpm}$, indefinitely.

In 1987, Weiss Associates (1988) conducted a series of hydraulic tests in the Environmental Test Area (ETA), east of the HE Process Area. 'These tests were performed in strata of the Pliocene nonmarine sequence (Tps) and in rocks correlated with the Neroly lower blue sandstone unit (Tnbs). Results of these tests could be applicable to correlative strata in the HE Process Area. Their use will be investigated in future hydrologic analyses, to be reported in the FS. 


\section{Chapter 7. Characteristics of Waste in the HE Process Area}

In the HE Process Area, investigations have determined that the HE compounds RDX and HMX and the VOC TCE are the primary waste components.

Other VOCs, fuel compounds and metals have been detected in a few samples from soil and rock, and from ground water. Metals are not present at levels above threshold limit concentrations. With the exception of one analysis for lead and five analyses for barium, no metals have been detected in soils at concentrations higher than DLs (Table 8.1.1-2). Lead was detected at $6.9 \mathrm{mg} / \mathrm{L}(\mathrm{DL}=0.5 \mathrm{mg} / \mathrm{L})$ in one soil sample at Lagoon 825 , and barium was detected in concentrations up to $35 \mathrm{mg} / \mathrm{L}(\mathrm{DL}=10 \mathrm{mg} / \mathrm{L})$ in one sample collected from each of Lagoons 806, 807, 817, 825 and 835. These VOCs, fuel compounds, and metals are not found in ground water at concentrations higher than California State Action Levels. Because they are not a threat to public health and safety, we have not discussed them in this chapter.

\subsection{Waste Component Mobility}

\subsubsection{Mobility of RDX}

Rosenblatt (1986) presented data about the mobility of RDX. These were based on experimental results at the Louisiana Army Ammunition Plant (LAAP). At this location, the subsurface sediment is porous and permeable Gulf Coast sand, with small amounts of silt and clay. His data indicate that a concentration of $10.1 \mathrm{mg} / \mathrm{kg}(\mathrm{ppm})$ in soil will result in a concentration of $0.035 \mathrm{mg} / \mathrm{L}[35 \mu \mathrm{g} / \mathrm{L}(\mathrm{ppb})]$ in ground water less than approximately $25 \mathrm{ft}$ below the surface (Rosenblatt, 1986, his Table 6, p. 13).

Rosenblatt stated that the concentration of RDX is lcwer in the ground water than in the soil and rock, which indicates that sorption and dispersion have affected the amount of RDX that passes through the soil. Marshack (1989) termed this phenomenon the attenuation factor. It can be defined as:

$$
A=\frac{C_{\mathrm{S}}}{C_{\mathrm{W}}}
$$

where:

$$
\begin{aligned}
& A=\text { attenuation factor, } \\
& C_{\mathrm{S}}=\text { concentration in soil, and } \\
& C_{\mathrm{W}}=\text { concentration in water. }
\end{aligned}
$$

Using this relationship and Rosenblatt's data for the retardation of RDX at the LAAP, we calculate an attenuation factor of approximately 300 for RDX at the LAAP. At that location, the water table is shallow (less than $100 \mathrm{ft}$ ), and the sandy soil and rock are relatively clean and permeable.

The hydrogeology at Site 300 is very different. The soil and rock at Site 300 contain sand mixed with large amounts of clay and silt and have relatively low permeability. These rocks have very different physical and chemical properties than the relatively clean sands of the Louisiana coastal plain. The silt and clay contained in the sediment at Site 300 ) recutute 
permeability and porosity. This results in increased sorption and dispersion, two physical processes that reduce the mobility of such organic compounds as RDX and therefore increase the site's attenuation factor. In addition, the saturated zone at Site 300 lies much deeper than that in many localities.

Even though the natural geologic conditions at Site 300 would be expected to produce an attenuation factor greater than at the LAAP, we have decided to be conservative in our calculations and have chosen an attenuation factor of 100 rather than 300 . According to Marshack (1987), 100 is an attenuation factor for an average site. See Appendix $H$ for a further discussion of the attenuation factor.

\subsubsection{Mobility of HMX}

No data about the mobility of HMX were found in the technical literature. Our data (Appendix A) show that HMX concentrations are higher than RDX in the soil and rock near and beneath the closed rinsewater lagoons. The solubility of HMX is 2.4 to $5.0 \mathrm{mg} / \mathrm{L}$, almost 20 times less than that of RDX $(42.2 \mathrm{mg} / \mathrm{L})$; see sections 7.2.1.1 and 7.2.2.1. Because of the retention of HMX in soil and rock and its low solubility in water, we think that it is substantially less mobile than RDX.

\subsubsection{Mobility of TCE}

Studies of the velocity of migration of TCE indicate that it is fairly mobile in natural ground water (Schwille, 1988; Mackay and Vogel, 1985; Thorpe et al., 1990). TCE has a solubility of $1070 \mathrm{mg} / \mathrm{L}$ at $20^{\circ} \mathrm{C}$ (Verscheuren, 1983). The studies have determined the relationship between the rate of flow of ground water and that of TCE.

Retardation can be expressed as a ratio between the mobility of a substance and that of water, as follows:

$$
R=\frac{V}{V_{\mathrm{c}}}
$$

where:

$$
\begin{aligned}
& R=\text { retardation, } \\
& V=\text { average velocity of ground water, and } \\
& V_{\mathrm{c}}=\text { the contaminant velocity in ground water. }
\end{aligned}
$$

Literature values for TCE retardation range from 1.04 in porous and fractured media model experiments (Schwille, 1988) to 10.3 in three Norwegian soils (Seip et al., 1986). Retardation factors for TCE calculated from sorption studies conducted at LLNL's Livermore site ranged from 3.7 to 6.4 (Bishop et al., 1989). VOC migration modeling performed for LLNL's Livermore Site Remedial Investigation used a retardation factor of 1.5 . This value represented an average literature retardation value for all VOCs detected at the Livermore Site, including TCE (Thorpe et al., 1990). These studies suggest TCE transport in the subsurface is slightly slower than the velocity of water (1.0).

\subsection{Waste Component Toxicity}

Because toxicity studies of RDX and HMX are few, the data is reviewed here in detail. A summary is presented in this chapter, and details are presented in Appendix $H$. The toxicity of TCE is well known; thus, it has been briefly summarized here. 
Many of the toxicological studies discussed in this section and in Appendix $H$ make use of the term $\mathrm{mg} / \mathrm{kg}$ in a different sense than that used in the other parts of this report. In the toxicology studies, $\mathrm{mg} / \mathrm{kg}$ means weight of substance being tested (in mg units) divided by body weight (in $\mathrm{kg}$ units). It is used to normalize doses given to individual laboratory animals so that experimental results can be compared. In other parts of this report, the term $\mathrm{mg} / \mathrm{kg}$ is used to define the concentration of a solid substance in soil or rock. Here, the term $\mathrm{mg} / \mathrm{L}$ is used to define concentration of a solvent in a solute; for example, in defining the concentration of liquid doses when the weight of the test animal is not considered. This usage is essentially identical to the use of the term elsewhere in this report.

\subsubsection{Toxicity of RDX}

Etnier (1989) conducted a study to determine a proposed water quality criterion for RDX. As part of her study, she reviewed the toxicological literature and presented a summary in her paper. For this report, her review has been expanded with data obtained from Layton et al. (1987).

7.2.1.1. RDX: Chemical Characterization and Toxicity Data. RDX is formulated widely for use as an HE compound. The synthesis is described in Meyer (1981). Military-grade RDX contains 8 to $12 \mathrm{wt} \%$ of HMX as a byproduct of the synthesis. RDX is formulated and used at Site 300 .

\section{Substance. RDX:}

- Chemical name: cyclo-1,3,5-trimethylene-2,4,6-trinitramine (Meyer, 1981).

- Other names: Cyclonite, hexahydro-1,3,5-trinitro-1,3,5-triazine (Etnier, 1989).

- Solubility: $42.2 \mathrm{mg} / \mathrm{L}$ (Sikka et al., 1980).

- Vapor Pressure: 0.00054 millibar at $110^{\circ} \mathrm{C}$ (Meyer, 1981).

- Regulations and Advisories for Drinking Water:

None for RDX in drinking water (see Section 8.2.2.1).

Proposed drinking water criterion (U.S. Army): $105 \mu \mathrm{g} / \mathrm{L}$ RDX (Etnier, 1989), accepted by the EPA as the basis for the NPDES permit for discharge of RDX 10 at surface stream in Grand Island, Nebraska (Etnier, 1989), issued by the EPA.

- Other standards:

The threshold limit value (TLV) for RDX recommended in 1980 by the American Conference of Governmental Industrial Hygienists (ACGIH) is $1.5 \mathrm{mg} / \mathrm{m}^{3}$. The listing of this value is followed by the notation "skin," which suggests the possibility of absorption through the skin.

However, Rosenblatt (1986) stated that because RDX is not particularly lipid-soluble, dermal absorption is an unlikely route of exposure. Furthermore, Etnier (1989) noted that a review of the literature provided no evidence that RDX can be dermally absorbed.

The short-term exposure limit (STEL) for RDX is $3 \mathrm{mg} / \mathrm{m}^{3}$ in air (ACGIH, 198()). 
The California Occupational Safety and Health Act (CAL OSHA) has adopted the ACGIH TLV limit of $1.5 \mathrm{mg} / \mathrm{m}^{3}$ in air. The USSR has a maximum acceptable concentration (MAC) of $1 \mathrm{mg} / \mathrm{m}^{3}$ in air for RDX (Etnier, 1989).

- DLs: The Site $300 \mathrm{DL}$ in soil and rock for RDX is $10.5 \mathrm{mg} / \mathrm{kg} \mathrm{RDX}$ (value derived in Appendix H, Section H.2.3).

7.2.1.2. Summary of RDX Toxicity Studies. There are no controlled studies of RDX toxicity in humans, although adverse health effects have been documented following instances of accidental inhalation or ingestion. RDX exerts its primary toxic effect on the human central nervous system (CNS); these effects appear to be completely reversible (Etnier, 1989).

In laboratory rats and mice, RDX is metabolized primarily in the liver. RDX does not accumulate in any tissue and is excreted in urine or exhaled as carbon dioxide (Etnier, 1989).

CNS excitation is the most prominent acute effect of RDX in most animals. Other toxic effects include gasping and labored breathing (Etnier, 1989).

Brown (1975), Hart (1976), Levine et al. (1983), and Lish et al. (1984) studied the effects of subchronic exposure of laboratory rats and mice to RDX. Their results are summarized here; details are in Appendix H.

Brown (1975) studied rats exposed for 12 weeks to RDX. Except at the lowest dose $(0.3$ $\mathrm{mg} / \mathrm{kg}-\mathrm{d}$ ), the treatment was found to induce time- and dose-related biphasic changes in brain monoamine oxidase, cholinesterase, and oxygen uptake.

Hart (1976) conducted a two-year study of the effects of dietary intake of RDX in rats. Tests of hematology, blood chemistry, urinalysis, gross necropsies, organ weight, and histopathological examination resulted in no significant evidence of RDX toxicity; doses were less than $10 \mathrm{mg} / \mathrm{kg}$-d.

Levine et al. (1983) conducted a two-year study to evaluate the toxicity of chronic doses of RDX in the diet of Fischer 344 rats. Rats given RDX at $1.5 \mathrm{mg} / \mathrm{kg}-\mathrm{d}$ and above exhibited anemia, hepatotoxicity, possible CNS involvement, and urogenital lesions. However, the next lowest dose of RDX, $0.3 \mathrm{mg} / \mathrm{kg}-\mathrm{d}$, did not elicit any adverse effects. Levine et al. (1983) concluded that under the conditions of this study, $0.3 \mathrm{mg} / \mathrm{kg}-\mathrm{d}$ represented the NoObserved-Effects-Level (NOEL) for RDX.

Lish et al. (1984) studied groups of male and femaie mice fed RDX over a two-year period. Toxic effects included hepatotoxicity, possible CNS involvement, and testicular degeneration in the males. A possible treatment-related increase in serum triglyceride levels was observed in female mice given RDX at $35 \mathrm{mg} / \mathrm{kg}$-d, and elevated serum cholesterol levels were observed in female mice at $35 \mathrm{mg} / \mathrm{kg}$-d, and possibly at $7 \mathrm{mg} / \mathrm{kg}$-d. These effects were not seen in animals that received RDX at $1.5 \mathrm{mg} / \mathrm{kg}$-d.

Toxicity values for the same species may differ among laboratories, depending on the physical form of the RDX, and on the vehicle used to suspend or dissolve it (Schneider $e t$ al., 1977).

In laboratory animals, there is no evidence of genotoxicity or developmental/reproductive toxicity.

Three investigations (Hart, 1976; Levine et al., 1983; and Lish et al., 1984) were designed to determine if RDX is carcinogenic. Etnier (1989) reviewed these studies, and her comments appear in the following sections. Hart (1976) and Levine et al. (1983) found no evidence of carcinogenicity in rats fed RDX in the diet. Lish et al. (1984) srudied groups of 
male and female B6C3F1 mice fed RDX at doses of 1.5 to $100 \mathrm{mg} / \mathrm{kg}-\mathrm{d}$. Initially, the highdose group received RDX at $175 \mathrm{mg} / \mathrm{kg}$-d, but excessive mortality necessitated a reduction in dose to $100 \mathrm{mg} / \mathrm{kg}$-d. Lish et al. (1984) reported that there was a dose-related increase in hepatocellular carcinomas in female mice, but not in males. The increase was not statistically significant. However, the combined incidence of hepatocellular carcinomas and hepatocellular adenomas in female mice in the 7.0 and $35.0 \mathrm{mg} / \mathrm{kg}-\mathrm{d}$ treatment groups was statistically significant $(p<0.05)$. See Appendix $H$ for details.

Although these data indicate that high doses of RDX may be carcinogenic to mice, they have not been corroborated by other investigators. All other indications are that RDX is not carcinogenic. Short-term tests of genotoxicity have given consistently negative results, and Hart (1976) and Levine et al. (1983) found no evidence of carcinogenicity.

Etnier (1989) also concluded that there are insufficient data to determine whether or not RDX is carcinogenic, and that, consequently, drinking water criteria should be based on data from long-term chronic toxicity studies reported by Levine et al. (1983).

7.2.1.3. Suggested RDX Drinking-Water Criterion. To date, the EPA has not established a water-quality criterion for RDX, nor is it regulated under the Safe Drinking Water Act by a maximum contaminant level (MCL) or maximum contaminant level goal (MCLG).

In the absence of guidance for water-quality goals for RDX, the U.S. Army Medical Bioengineering Research and Development Laboratory (USABRDL), Ft. Detrick, Maryland, has sponsored studies to determine a drinking-water criterion for RDX (e.g., Rosenblatt, 1986; Etnier, 1989). Rosenblatt (1986, his Table 1, p. 5) suggested a drinking-water criterion for RDX of $35 \mu \mathrm{g} / \mathrm{L}$.

A study of RDX toxicity in rats by Levine et al. (1986), summarized above, concluded that $0.3 \mathrm{mg} / \mathrm{kg}$-d represented a NOEL dose. Other studies, by Brown (1975) and Hart (1976), indicated that this NOEL was conservative. Using the value $0.3 \mathrm{mg} / \mathrm{kg}-\mathrm{d} \mathrm{RDX}$ as a NOEL, Etnier (1989) calculated a drinking-water criterion for RDX of $105 \mu \mathrm{g} / \mathrm{L}$ (Appendix $\mathrm{H}$ ).

Etnier's suggested criterion is well supported because of the rigorous analysis of toxicity data and the use of EPA methodology and is therefore applicable for the Site 300 HE Proces's Area.

Etnier's drinking-water criterion was used to evaluate contamination by RDX at the Cornhusker Army Ammunition Plant (Cornhusker AAP), Nebraska. It was also the basis for an application by the U.S. Army for an NPDES permit to discharge ground water containing small concentrations of RDX to surface water. We quote Etnier (1989) on the outcome of this application:

The criterion for RDX $(105 \mu \mathrm{g} / \mathrm{L})$ was used to set discharge limits for NPDES permits allowing discharge of RDX-contaminated ground water into a creck near the Cornhusker AAP in Grand Island, Nebraska. Based on the water quality criterion calculated for USABRDL, Nebraska and EPA officials stated that the permit discharge levels should pose no threalt to humans.

7.2.1.4. Discussion. A maximum RDX concentration of $350 \mu \mathrm{g} / \mathrm{L}$ (monitor well W-815-01, March 1988) was detected in grcund water in the perched aquifer of Building 815 in the HE Process Area. The mean concentration of RDX measured since 1987 in wells W-815-01 and W-815-03 is $215 \mu \mathrm{g} / \mathrm{L}$ (Fig. 8.1 and Appendix A).

The water-quality criterion (Etnier, 1989) is quite conservative. To assess the potential effects of higher concentrations of RDX in ground water, the amount of water was calculated 
from monitor wells $\mathrm{W}-815-01$ and $\mathrm{W}-815-03$ that would have to be ingested to receive the NOEL dose of RDX.

Etnier (1989) selected a NOEL for RDX in rats of $0.3 \mathrm{mg} / \mathrm{kg}$-day. For a $70-\mathrm{kg}$ human, this is equivalent to $21 \mathrm{mg} /$ day. To receive this quantity of RDX by ingesting water from wells W-815-01 and W-815-03, it would be necessary for an individual to drink $60 \mathrm{~L}$ of water per day from the wells for seven days a week, a very unlikely amount. We conclude that at the concentrations of RDX in these two wells, the risk of RDX toxicity from drinking the water is low.

Moreover, these monitor wells are located in a part of the HE Process Area with stringent access control. The wells are in locked enclosures. LLNL monitoring personnel are aware of the concentration of RDX in the water and have instructions not to drink the water from wells containing RDX.

\subsubsection{Toxicity of HMX}

In the following paragraphs, we present a summary of the toxic effects of HMX. This information is discussed in greater detail in Appendix $\mathrm{H}$.

Wilson (1985) is a primary source of information about the toxicity of HMX. He presents data from acute toxicity, 14-day, and 13-week studies of HMX toxicity in laboratory animals.

7.2.2.1. HMX: Chemical Characterization and Toxicity Data. HMX is a byproduct of RDX synthesis and is present in technical (military) grade RDX at 8 to 12 weight percent. It can be prepared as the sole product by a different method of synthesis (Meyer, 1981) and is used in pure form as an HE compound. HMX is formulated and used at Site 300 .

The chemical characteristics and toxic hazard criteria for HMX are summarized in the following paragraphs.

\section{Substance. HMX:}

- Chemical name: cyclo-tetramethylene-tetranitramine.

- Other names: octahydro-tetranitro-tetrazocine (Etnier, 1989); Homocyclonite; Octagen.

- Aqueous Solubility:

$2.6 \mathrm{mg} / \mathrm{L}$ (Spanggord et al., 1982).

$5.0 \mathrm{mg} / \mathrm{L}$ (Glover and Hoffsommer, 1973).

- Vapor Pressure: $9 \times 10^{-16}$ torr (Layton et al., 1987). Calculated from vapor pressure-temperature equation.

- Regulations and Advisories for Drinking Water: None for HMX in drinking water.

- Other Standards or Criteria: None.

7.2.2.2. Summary of HMX Toxicity Studies. No studies of HMX toxicity in humans were found.

The literature contains very few studies of HMX toxicity in animals. Most of the information available is from two studies, McNamara et al. (1974) and Wilson (1985). 
Layton et al. (1990, in press) reviewed the literature on HMX; excerpts are cited here. 'T'he original of Wilson (1985) was used in preparing this review.

Once in an animal's body, HMX is widely distributed. It has been detected in the heart, CNS, liver, and kidneys of mice and rats (McNamara et al., 1974; Wilson, 1985). Wilson (1985) noted that following oral $(500 \mathrm{mg} / \mathrm{kg})$ or intravenous $(2.0 \mathrm{mg} / \mathrm{kg})$ administration of HMX to rats, the highest concentrations were found in the liver and kidneys, and the lowest concentrations were found in the brain.

The major toxic effects of HMX administered for 14 days in the diet of rats and mice are to the liver and kidneys. "Significant" effects to livers (enlarged centrilobular cells) were observed in males at dose rates of $150 \mathrm{mg} / \mathrm{kg}$-d HMX and above. Kidney effects (focal atrophy and dilation) were observed in females at dose rates of $270 \mathrm{mg} / \mathrm{kg}-\mathrm{d}$ HMX or more. Toxic effects were also observed in the CNS and the cardiovascular system (Wilson, 1985).

In a 13-week study, male mice were dosed with HMX at 0 to $200 \mathrm{mg} / \mathrm{kg}$-d, and the females at 0 to $750 \mathrm{mg} / \mathrm{kg}-\mathrm{d}$ HMX (Wilson, 1985). Laboratory studies of the mice did not reveal any major differences between the treated animals and the control groups. At the highest dose rate $(200 \mathrm{mg} / \mathrm{kg}$ for males, 250 or $700 \mathrm{mg} / \mathrm{kg}$-d for females) mortality was high (13/20 males, 20/20 females).

Simmon et al. (1977) investigated the mutagenicity of HMX in the Ames assay with Salmonella typhimurium. HMX did not significantly increase the frequency of reverse mutations in any of the tests.

There are no data on the teratogenicity or carcinogenicity of HMX.

7.2.2.3. No-Observed-Effects-Level (NOEL) Dose. Although Wilson's (1985) data from a 13-week study provides some evidence that HMX may be toxic to mice only at doses greater than $10 \mathrm{mg} / \mathrm{kg}-\mathrm{d}$, the lack of statistical analyses of the results precluded selection of this value as a NOEL for HMX.

7.2.2.4. Drinking Water Criterion. Because Wilson's (1985) data do not clearly define a NOEL for HMX, they cannot be used to estimate a drinking water criterion.

\subsubsection{Comparison of Toxicity: $\mathrm{LD}_{50}$ Dose, $\mathrm{RDX}$ and $\mathrm{HMX}$}

Data from acute toxicity tests reported by Etnier (1989) and Wilson (1985) define LD 50 doses for RDX and HMX, respectively.

Etnier (1989) reported that Cholakis et al. (1980) administered oral doses of RDX in aqueous methyl cellulose-polysorbate to male and female rats and identified a $L_{50}$ of 118 $\mathrm{mg} / \mathrm{kg}$. Cholakis et al. (1980) also reported a $\mathrm{LD}_{50}$ of $80 \mathrm{mg} / \mathrm{kg}$ in male and female mice dosed orally with RDX in the same vehicle.

Wilson (1985) administered HMX orally in $0.15 \%$ aqueous carboxymethylcellulose to Fischer 344 rats. The LD 50 for HMX was $7.36(6.89-7.83) \mathrm{g} / \mathrm{kg}$. For mice dosed in the same manner, the LD 50 for HMX was $2.71(2.48-2.94) \mathrm{g} / \mathrm{kg}$. Wilson stated that HMX may be considered practically nontoxic to rats, and slightly toxic to mice.

Because the experimental conditions used by Cholakis et al. (1980) to evaluate RDX are qualitatively similar to those used by Wilson (1985) to evaluate HMX, their results were compared (Table 7.2.3-1). The data indicate that HMX has a higher $\mathrm{LD}_{50}$ ) than RDX for both rats and mice. These data indicate that HMX is much less toxic than RDX. 
Table 7.2.3-1. RDX and HMX acute toxiclty $\left(L D_{50}\right)$ dose data.

\begin{tabular}{|c|c|c|c|c|}
\hline Species & Route & $\begin{array}{c}\operatorname{RDX} L_{1} D_{50} \\
(\mathrm{mg} / \mathrm{kg})^{a}\end{array}$ & $\begin{array}{c}\underset{(m g / k g)}{H} / D_{60} \\
\end{array}$ & Reference \\
\hline Rat (male/female) & Oral & 118 & - & Cholakis et al. (1980) \\
\hline Rat (male/female) & Oral & - & $7960^{\prime \prime}$ & Wilson (1985) \\
\hline Mouse (male/female) & Oral & 80 & - & Cholakis et al. (1980) \\
\hline Mouse & Oral & - & $2710^{-7}$ & Willyon $(1985)^{b}$ \\
\hline
\end{tabular}

These resulte are reporter as $\mathrm{mg} / \mathrm{kg}$. This does not desoribe a conoentration in the solld state, lie. parts per million. It describes the dose per kellogram of body woight in teet groups of laboratury animals.

${ }^{b}$ Wilson (1885) roported resalt as as $\mathrm{g} / \mathrm{kg}$. Data have been converted to mg/kg for purposes of oomparlscon.

\subsubsection{Toxicity of TCE (adapted from Taffet et al., 1989)}

\section{Substance: TCE:}

- Clear, colorless liquid with a characteristic odor.

- Solubility: $1070 \mathrm{mg} / \mathrm{L}$ (Verscheuren, 1983).

- Regulations and Advisories for Drinking Water:

Safe Drinking Water Act MCLG, $0.0 \mu \mathrm{g} / \mathrm{L}$.

Reference concentration for potential carcinogens, $2.8 \mu \mathrm{g} / \mathrm{L} \mathrm{per} 70 \mathrm{~kg}$.

Aquatic organisms and drinking water, $0(2.7 \mu \mathrm{g} / \mathrm{L})$. EPA takes the position that there is no zero risk for a carcinogen, so zero is specified. The concentration in parentheses refers to the $1 \times 10^{-6}$ risk from drinking $2.5 \mathrm{~L}$ per day for one year of water containing this concentration, i.e., $2.7 \mu \mathrm{g} / \mathrm{L}$ (Superfund Public Health Assessment Manual).

Adjusted for drinking water only, $0(2.8 \mu \mathrm{g} / \mathrm{L})$.

EPA, California DHS MCL, $5 \mu \mathrm{g} / \mathrm{L}$.

- DL: The Site $300 \mathrm{DL}$ for TCE in soil is $500 \mu \mathrm{g} / \mathrm{kg}$ (Table 8.1.1-1).

- Exposure to TCE:

Vapors may irritate the eyes, nose, and throat.

Prolonged inhalation of moderate concentrations of vapor may cause headaches and drowsiness.

Inhalation of high concentrations may cause narcosis and anesthesia.

Severe acute exposure may cause cardiac failure.

Significant chronic exposure may damage the liver and other organs.

Prolonged repeated skin contact with the liquid may cause irritation and dermatitis. 
The Permissible Exposure Limit (PEL) for a Time Weighted Average (TWA) for an 8-h period is $25 \mathrm{ppm}$ in alr, acoording to the Callfornta Administrative Code, 'Tlite 8 , Section 5155.

- Mammalian Inhalatlon Toxicity:

Mouse: LC $50: \quad 49,(0) 0$ ppm for 30 minutes

$8450 \mathrm{ppm}$ for 4 hours

$5500 \mathrm{ppm}$ for in hours

No effect at 1600 ppm for 4 hours

Rat: LC50: $\quad 8000$ ppm for 4 hours

No effect at $100 \mathrm{ppm}$ for 8 hours or $730 \mathrm{ppm}$ for 8 hours/day, 6 weeks

Rabbit: No effect at $1200 \mathrm{ppm}$ for 473 hours or 730 ppm for 8 hours/day, 6 weeks

Guinea pig, ape: No effect at $730 \mathrm{ppm}$ for 8 hours/day, 6 weeks

- Mammalian Oral Toxicity:

Rat: 3 to $5 \mathrm{~mL} / \mathrm{kg}$

- Toxicity:

Eye irritation at $160 \mathrm{ppm}$; supportable during 30 minutes: 379 to $372 \mathrm{ppm}$

Full narcosis: 2500 to $6000 \mathrm{ppm}$

Severe toxic effects: $2000 \mathrm{ppm}=10,940 \mathrm{mg} / \mathrm{m}^{3}, 60$ minutes

Symptoms of illness: $800 \mathrm{ppm}=4376 \mathrm{mg} / \mathrm{m}^{3}$

Unsatisfactory: $>400 \mathrm{ppm}=2188 \mathrm{mg} / \mathrm{m}^{3}$

- Carcinogenicity:

As a potential carcinogen, TCE appears in EPA category group B2:

- sufficient evidence of carcinogenicity in animals;

-. Inadequate evidence of carcinogenicity in humans.

As a noncarcinogen, TCE has an EPA Rating Value (RVe) of 5 for oral intake--... reversible cellular changes:

- cloudy swelling, hydropic change, or fatty changes.

- An RVe of 4 for inhalation: hyperplasia, hypertrophy, or atrophy with changes in organ weights. 


\section{Chapter 8. Horizontal and Vertical Extent of Contamination}

In the HE Process Area, low to moderate concentrations of the HE compounds RDX and HMX are found in soll and rock near decommissioned HE rinsew'ller lagoons (Plate 4) where rinsewater was formerly dischurged. HE compounds are also found in ground water benenth Bulldings 815 and 817 (Figs. 8.1, 8.2, and 8.3).

VOCs have been identified in ground water beneath the area neur Bullding 815. 'I'CE (above regulatory stundards) and very low concentrations of 1,1-DCA and chloroform (below regulatory standards) have been Identified (Figs, 8.2, 8.3, and 8.4)

This chapter presents the information currently available about the extent of contamination and discusses our present understanding of the sltuation. The release site(s) of the HE compounds have not been identified; therctore, investigations continue.

\subsection{HE Compounds, Metals, and VOCs in Soil and Rock}

\subsubsection{HE Compounds, Metals, and VOCs in Soil and Rock: Regulatory Standards and Designated Levels}

A regulatory drinking water standard for RDX does not exist; however, the U.S. Army sponsored research (Etnier, 1989), to develop a suggested drinking water criterion ( $1(0.5 \mu \mathrm{g} / \mathrm{l}$. RDX), which we have used in our evaluation of HE compounds in water. The long-term toxicity data available for HMX were not subjected to statistical analysis and, thus, are not defined rigorously enough to support determination of a proposed drinking water criterion. However, the $L_{50}$ dose of RDX and HMX were compared, which indicated that HMX is an order of magnitude less toxic than RDX (Table 7.2.3-1).

DLs are concentrations of waste constituents in soll and rock that provide a site-specific indication of a waste's potential to impair ground water quality. If measured concentrations of contaminants in soll and rock exceed the DLs, the soil or rock is assumed to pose a waler-quality threat at the site in question. The DLs for VOCs and metals in soll and rock are shown in Tables $8.1,1-1$ and $8.1 .1-2$.

Using the suggested drinking water criterion $(105 \mu \mathrm{g} / \mathrm{L})$ and the $\mathrm{DL}$ methodology of Marshack (1989), the DL in soil and rock for RDX was calculated to be $10.5 \mathrm{mg} / \mathrm{kg}$ (ppm) (Appendix H), Only one soil sample in the HE Process Area had a concentration of RDX that exceeded the DL $(11 \mathrm{mg} / \mathrm{kg} / \mathrm{ppm} /$ from $8.0-8.4 \mathrm{ft}$ in B-806-05). Because there is no drinking water criterion for HMX, a DL cannot be determined for it. However, because the toxicity of HMX is much lower than that of RDX, if a drinking water criterion and DL could be determined, they would be much higher than the criterion and DL for R.DX.

Soluble Threshold Limit Concentrations (STLCS) are concentrations of metals analyzed using the Waste Extraction Test (WET) and are listed in the California Code of Regulations, Chapter 22. At metals concentrations above these levels, a waste or soil is classificed as a hazardous waste for purposes of specifying treatment and disposal reculirements. 'lotal Threshold Limit Concentrations (T"TLCs) are concentrations of metals analyzed using the nitric acid digestion technique and are also listed in the California Code of Regulations, 


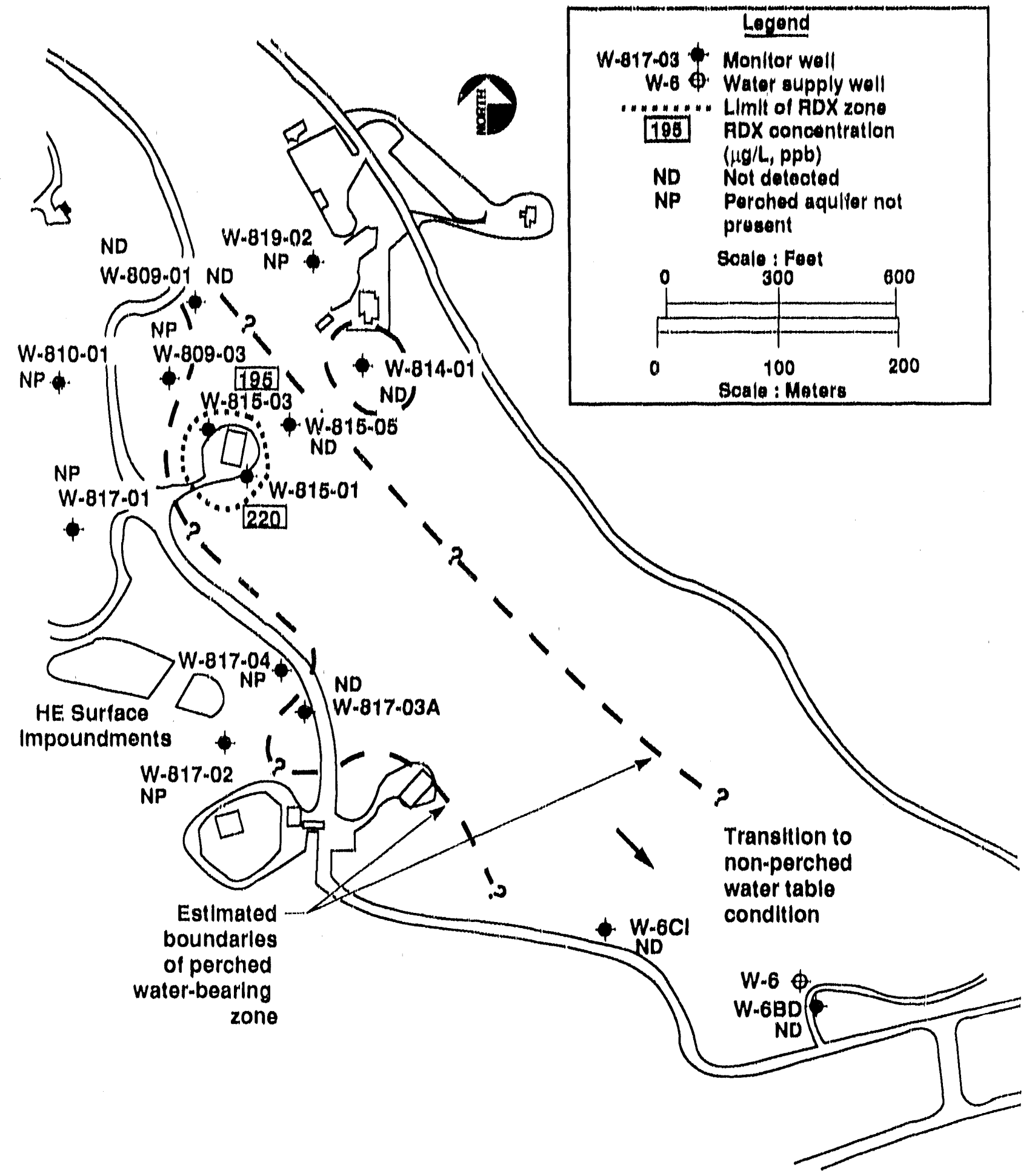

Figure 8.1. RDX concentrations In the perched aquiler, HE Process Area, flrst quarter 1990. 


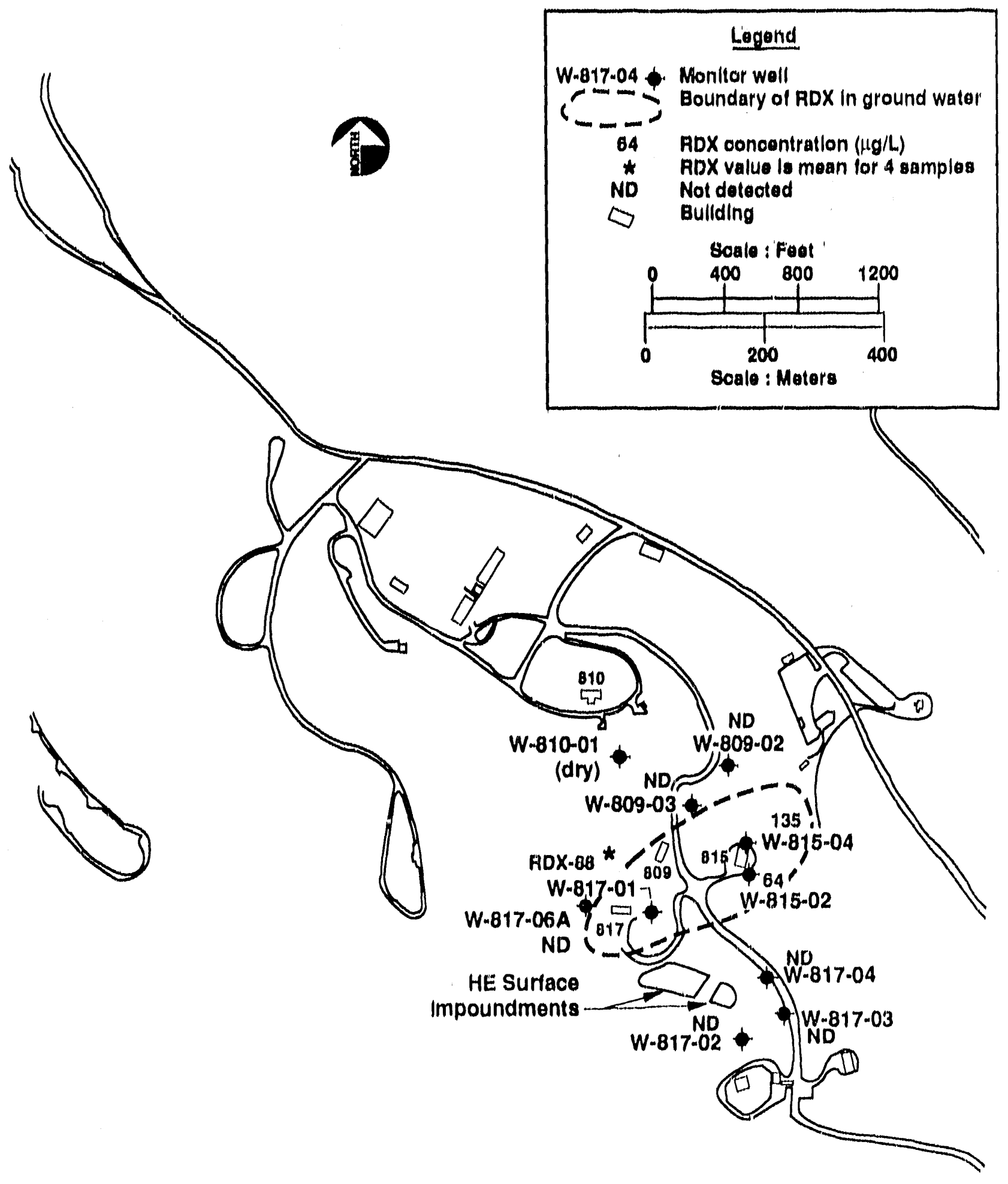

Figure 8.2. ADX concentrations In the Neroly upper blue sandstone aqulfer, HE Process Area, flrst quarter 1990. 


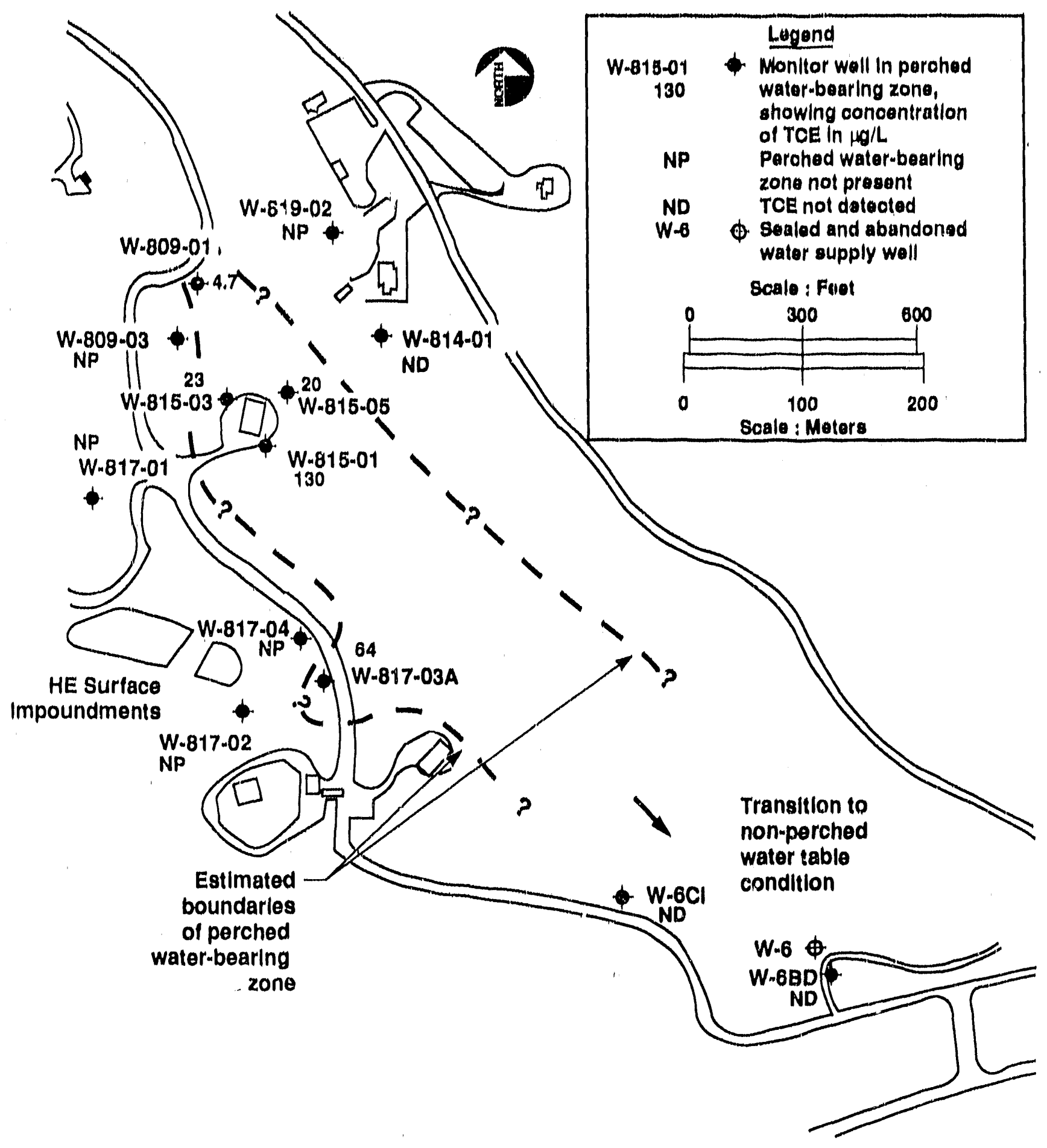

Flgure 8.3. TCE concentrations in the perched aquifer, Bullaling 815 Area, first quarter 1990. 


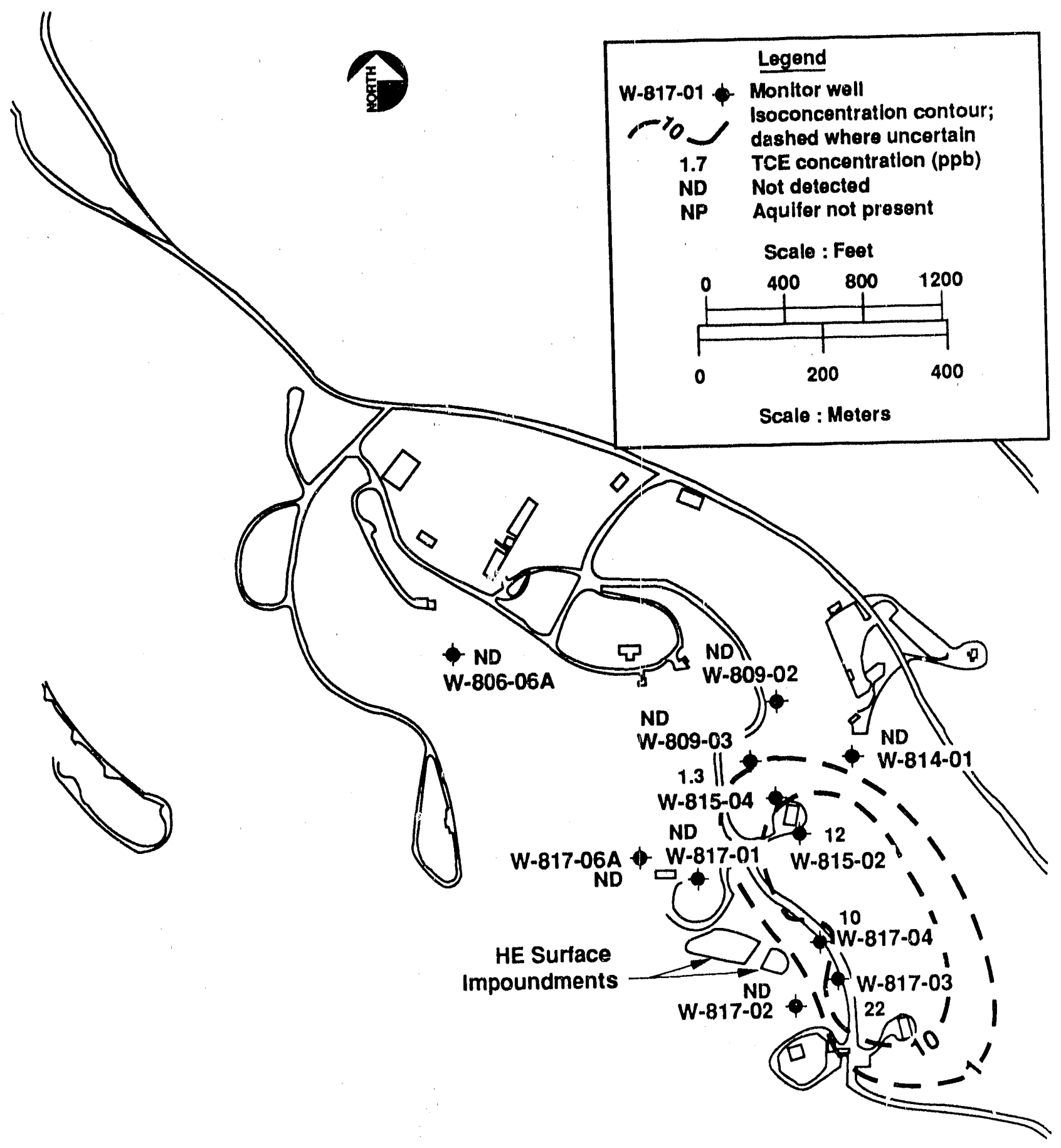

F!gure R.4. TCE concentrations in the Neroly upper blue sandstone aquifer, HE Process Area, first quarter 1990. 
Title 22. At metals concentrations above these levels, a waste or soil is classified as a hazardous waste. Table 8.1.1-1 includes the following regulatory standards for VOCs: STLC (for TCE only), Maximum Contaminant Levels (MCLs) or California State Action Levels (SALs), and DLs. Table 8.1.1-2 includes the following regulatory standards for metals: STLCs, TTLCs, MCLs, and DLs.

Table 8.1.1-1. Soluble Threshold Limit Concentrations (STLCs), Maximum Contaminant Levels (MCLs), Department of Health Services recommended State Action Levels (SALs), and Designated Levels (DLs) for VOCs in soil and ground water.

\begin{tabular}{lcrr}
\hline Parameter & $\begin{array}{c}\text { STLC } \\
(\mathrm{mg} / \mathrm{L})\end{array}$ & $\begin{array}{c}\text { MCL/SAL } \\
(\mu \mathrm{g} / \mathrm{L})\end{array}$ & $\begin{array}{r}\mathrm{DLc} \\
(\mu \mathrm{g} / \mathrm{kg})\end{array}$ \\
\hline Trichloroethylene & 204 & 5 & 500 \\
Chloroform & - & 100 & 10,000 \\
1,1-Dichloroethane & - & 5 & 500 \\
\hline \hline
\end{tabular}

a Only those VOCs that were detected in soil samples are listed.

b Callfornia Administrative Code, Title 22 (Californla Department of Health Services, 1989).

${ }^{c}$ Calculated from MCL or SAL by assuming an attenuation factor of 100 (Marshack, 1987).

Note: “ " indicates no standard has been establlshed.

A Maximum Contaminant Level (MCL) of $5 \mu \mathrm{g} / \mathrm{L}(\mathrm{ppb})$ has been established for 'TCE in ground water. From this, a Site $300 \mathrm{DL}$ waş determined for TCE in soil of $500 \mu \mathrm{g} / \mathrm{kg}(\mathrm{ppb})$ (Table 8.1.1-1).

\subsubsection{HE Compounds in Soil and Rock}

The distribution of HE compounds has been examined in soil and rock at Site 300 (Carpenter et al., 1988; Appendix A). HE compounds are present at low concentrations in some soil and rock samples collected from beneath the closed rinsewater lagoons, at several of the dry wells, and near facilities where $\mathrm{HE}$ compounds have been handled. In areas distant from the immediate vicinity of processing facilities, the soil was found to be free of $\mathrm{HE}$ compounds. For example, the borrow pits used to provide fill for the closure of the decommissioned lagoons were free of HE compounds (J. Clarkson, LLNL, personal communication, 1989). The area underlain by HE compounds in soil is small (less than 2 acres total) relative to the size of the HE Process Area (285 acres). Only one soil sample from beneath one lagoon (Lagoon 806) contained RDX at a concentration $(11 \mathrm{mg} / \mathrm{kg}[\mathrm{ppm}])$ slightly above the calculated DL of $10.5 \mathrm{mg} / \mathrm{kg}$ (ppm). Therefore, these occurrences of RDX and HMX present no threat to the public safety or health, or to the environment.

8.1.2.1. Release Sites of HE Compounds Beneath the Closed Lagoons. Until 1985, HE compounds contained in rinsewater from processing facilities were discharged to rinsewater lagoons. There, part of the water infiltrated the soil and rock beneath the lagoons. Thus, the lagoons were release sites for the HE compounds to the environment. The driving force that moved the $\mathrm{HE}$ compounds downward from the lagoons was the infiltration of rinsewater. Because discharge of rinsewater ceased when the lagoons were decommissioned in 1985, only infitirating rain water remained to further move the HE compounds. The impermeable caps installed during formal closure of the lagoons in 1989 exclude rain water from the lagoons, thereby preventing further movement of the HE compounds. 
Table 8.1.1-2. Soluble Threshold Limit Concentrations (STLCs), Total Threshold Limit Concentration (TTLCs), Maximum Contaminant Levels (MCLs), and Designated Levels (DLs) for metals concentrations in soil and ground water.

\begin{tabular}{|c|c|c|c|c|}
\hline Parameter & $\begin{array}{l}\text { STLCa } \\
(\mathrm{mg} / \mathrm{L})\end{array}$ & $\begin{array}{c}\text { TTLCa } \\
(\mathrm{mg} / \mathrm{kg})\end{array}$ & $\begin{array}{l}\mathrm{MCL}^{\mathrm{b}} \\
(\mathrm{mg} / \mathrm{L})\end{array}$ & $\begin{array}{c}D L^{c} \\
(\mathrm{mg} / \mathrm{kg})\end{array}$ \\
\hline Alurninum & - & - & 1 & 10 \\
\hline Antimony & 15 & 500 & - & - \\
\hline Arsenic & 5 & 500 & 0.05 & 0.5 \\
\hline Barium & 100 & 10,000 & 1 & 10 \\
\hline Beryllium & 0.75 & 75 & - & - \\
\hline Cadmium & 1 & 100 & 0.010 & 0.1 \\
\hline Chromium (VI) compounds & 5 & 500 & 0.05 & 0.5 \\
\hline $\begin{array}{l}\text { Chromium and/or chromium } \\
\text { (III) compounds }\end{array}$ & 560 & 2,500 & 0.05 & 0.5 \\
\hline Cobalt & 80 & 8,000 & - & - \\
\hline Copper & 25 & 2,500 & - & - \\
\hline Lead & 5 & 1,000 & 0.05 & 0.5 \\
\hline Mercury & 0.2 & 20 & 0.002 & 0.02 \\
\hline Molybdenum & 350 & 3,500 & - & - \\
\hline Nickel & 20 & 2,000 & - & - \\
\hline Selenium & 1 & 100 & 0.01 & 0.1 \\
\hline Silver & 5 & 500 & 0.05 & 0.5 \\
\hline Thallium & 7 & 700 & - & - \\
\hline Vanadium & 24 & 2,400 & - & - \\
\hline Zinc & 250 & 5,000 & - & - \\
\hline
\end{tabular}

a,b California Administrative Code, Title 22 (California Department of Health Services, 1989).

c Calculated from MCL by assuming an attenuation factor of 100 and dividing by 10 , as described by Marshack (1987).

Note: "-" indicates no standard has been established.

8.1.2.2. Release Sites of HE Compounds at Abandoned Dry Wells and Monitor Wells. In the past, HE compounds released during cleaning operations at several facilities in the HE Process Area were released in waste water to dry wells. Some of the waste water infiltrated the soil beneath the dry wells, leaving HE compounds in the soil and rock. Thus, some of the dry wells were the release sites of $\mathrm{HE}$ compounds.

Concentrations of $\mathrm{HE}$ compounds detected in soil samples from the sample holes in the vicinity of the dry wells did not exceed the DL of $10.5 \mathrm{mg} / \mathrm{kg} \mathrm{RDX}$ in soil (Carpenter et al., 1988). HE compounds were not detected at depths greater than $12 \mathrm{ft}$ in the sample holes, which indicates a downward limit to vertical infiltration. 
Soil samples from most of the pilot boreholes of monitor wells contain little RDX or HMX, Samples from a few monitor wells, namely W-815-01, W-815-02, and W-819-02, detected low concentrations. A sample from well W-810-01 contained $\mathrm{HE}$ compounds at $85 \mathrm{ft}$. The distribution of $\mathrm{HE}$ compounds is too irregular to assist in determining a release site.

\subsubsection{Metals in Soil and Rock}

We examined the distribution of metals (Appendix A) in the soil samples collected from the boreholes in the HE Process Area. Metals analyses conducted on soil samples collected from test boreholes and monitor wells drilled in support of the lagoon closure plan (Carpenter et al., 1989) were done using both the nitric acid extraction and citric acid (WE'T) method. Excluding the surface sample S-825-L1, all samples (Appendix A) contained lower concentrations of metals than the applicable threshold limit: TTLCs for the samples extracted by nitric acid digestion and STLCs for the sample leached by WET method extraction. The concentration of lead in surface sample S-825-L1 is $6.5 \mathrm{mg} / \mathrm{L}$, and the STLC is $5.0 \mathrm{mg} / \mathrm{L}$. The $6.5 \mathrm{mg} / \mathrm{L}$ value also exceeds the DL for lead of $0.5 \mathrm{mg} / \mathrm{kg}$. Other samples (S-825-L2, S-825-L3, and S-825-LB) collected adjacent to S-825-L1, detected lead at concentrations less than the STLC. We do not think the slightly elevated concentration in surface sample S-825-L1 is environmentally significant.

Barium was detected in concentrations up to $35 \mathrm{mg} / \mathrm{L}$ in one sample collected from adjacent to each of the following lagoons: $806,807,817$, and 827 ; the DL for barium is $10 \mathrm{mg} / \mathrm{L}$. We do not think these single sample analytical results are environmentally significant.

Soil samples collected from the abandoned dry wells and monitor wells contained metals at concentrations less than the STLCs and DLs (Table 8.1.1-2).

\subsubsection{VOCs in Soil and Rock}

The distribution of VOCs has been examined in soil samples from boreholes in the HE Process Area. Although VOCs were present sporadically in soil samples from the boreholes, the concentrations did not exceed the Site 300 DLs (Table 8.1.1-1).

\subsection{HE Compounds and VOCs in Ground Water}

The following discussion of the distribution of $\mathrm{HE}$ compounds in ground water was developed using reports by D. W. Carpenter and the senior author incorporated in several Site 300 Environmental Investigations Quarterlies subsequent to 1987.

The hydrogeology of the aquifers in this area is discussed in detail in Section 6.2. Four of these aquifers are of interest:

- Two separate perched aquifers of limited extent in the late Tertiary nonmarine sequence (Tps).

- The water table aquifer in the Neroly upper blue sandstone (Tnbs2).

- The confined aquifer in the Neroly lower blue sandstone (Tnbs 1 ).

One of the perched aquifers is near Building 814 ; the other is beneath Building 815 . The two deeper aquifers underlie large areas of Site 300.

RDX was first detected in ground water from monitor well W-817-01, completed in the water table aquifer in April 1985. Since then, RDX has been detected in water from two aquifers: the perched aquifer of Building 815; and the first water table aquifer, located in part of the Neroly 
upper blue sandstone beneath Buildings 815 and 817. Maximum, minimum and mean concentrations of RDX in ground water are shown on Table 8.2-1.

VOCs were first detected in a ground water sample collected during April 1987 from well W-815-01. Since that time, VOCs have been detected near and south of Building 815 (Figs. 8.3 and 8.4). The primary VOC detected in the ground water is TCE. Water sampled from wells W-814-01 and W-815-03 has consistently contained very low levels of chloroform. 1,1-DCA has been detected in some samples of ground water from well W-815-03. Maximum, minimum and mean concentrations of VOCs are shown on Table 8.2-1.

\subsubsection{HE Compounds in Ground Water}

8.2.1.1. Perched Aquifer of Building 815: HE Compounds. RDX is found in a small portion of the perched aquifer in the immediate vicinity of Building 815 . The RDX concentrations, shown in Figure 8.1 and Appendix B, exceed the suggested drinking water criterion of $105 \mu \mathrm{g} / \mathrm{L}$ (Etnier, 1989). RDX has not been detected in water from other parts of the perched aquifer. This aquifer is either dry or absent in wells surrounding the area containing RDX (Fig. 8.1). Its distribution is somewhat irregular; for example, the perched aquifer is not present in well W-809-03, located between wells W-809-01 and W-815-(03.

8.2.1.2. Water Table Aquifer: HE Compounds. The regional water table aquifer is in the Neroly upper blue sandstone aquifer (Section 6.2.2.2). Although the upper blue sandstone is present beneath a wide area of Site 300, it contains a saturated zone only in the southern part of the HE Process Area and the adjacent GSA to the south (Fig. 6.1.2-2).

8.2.1.2.1. $R D X$. RDX has been detected in ground water collected from wells W-815-()2, W-815-04, and W-817-01 (Fig. 8.2). Table 8.2-1 shows the maximum, minimum, and mean RDX concentrations in samples from each well.

The RDX concentrations detected in ground water (Table 8.2-1) from well W-815-()4 exceed the suggested drinking water criterion of $105 \mu \mathrm{g} / \mathrm{L}$ (Etnier, 1989) (Fig. 8.2; Appendix B). In well W-817-01, the maximum concentrations of RDX in ground water sampled in the fall of 1989 exceeded the RDX criterion; however, the mean concentrations of RDX of all the samples taken at that time did not exceed the criterion (Table 8.2-1). Previous samples from this well were below the criterion (Appendix B). Samples collected from well W-817-()1 in early 199() were also considerably less than the criterion. We think that the samples collected in the fall of 1989 were anomalous. The concentration of RDX in well W-815-(02 has never exceeded the criterion.

The region occupied by RDX is small, lying beneath wells W-815-(02, W-815-04, and W-817-01 (Fig. 8.2). To date, the area has been bounded on three sides:

- To the west, W-817-06A produces ground water in which RDX is not detected.

- To the north, the aquifer is dry in W-810-()1, and RDX is not detected in ground water sampled from W-809-(03.

- To the south, RDX has not been detected in W-817-()2, W-817-(03, and W-817-()4.

During 1990, the limits of RDX will be determined in ground water east of Building 815 by drilling a monitor well(s).

8.2.1.2.2. $\boldsymbol{H M X}$. In the fall of $1989, \mathrm{HMX}$ was reported in four ground water samples from well W-817-01 (mean concentration, $38 \mu \mathrm{g} / \mathrm{L}$ ). Ground water samples collected in early 1990 showed no detectable HMX, so HMX may or may not be present in ground water from well W-817-01. To determine if a trend exists, evaluation of the data from quarterly moniloring samples will continue. 


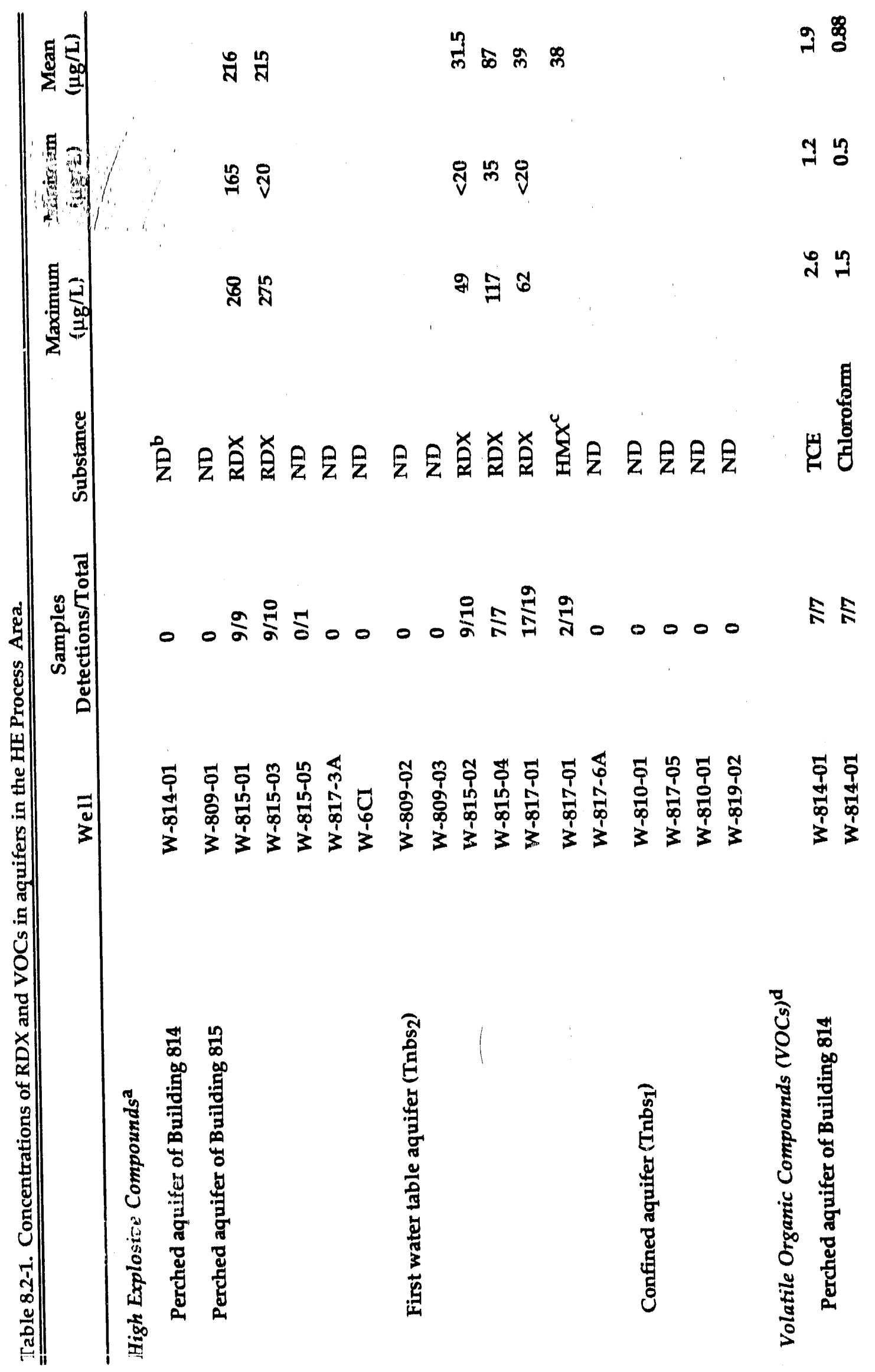




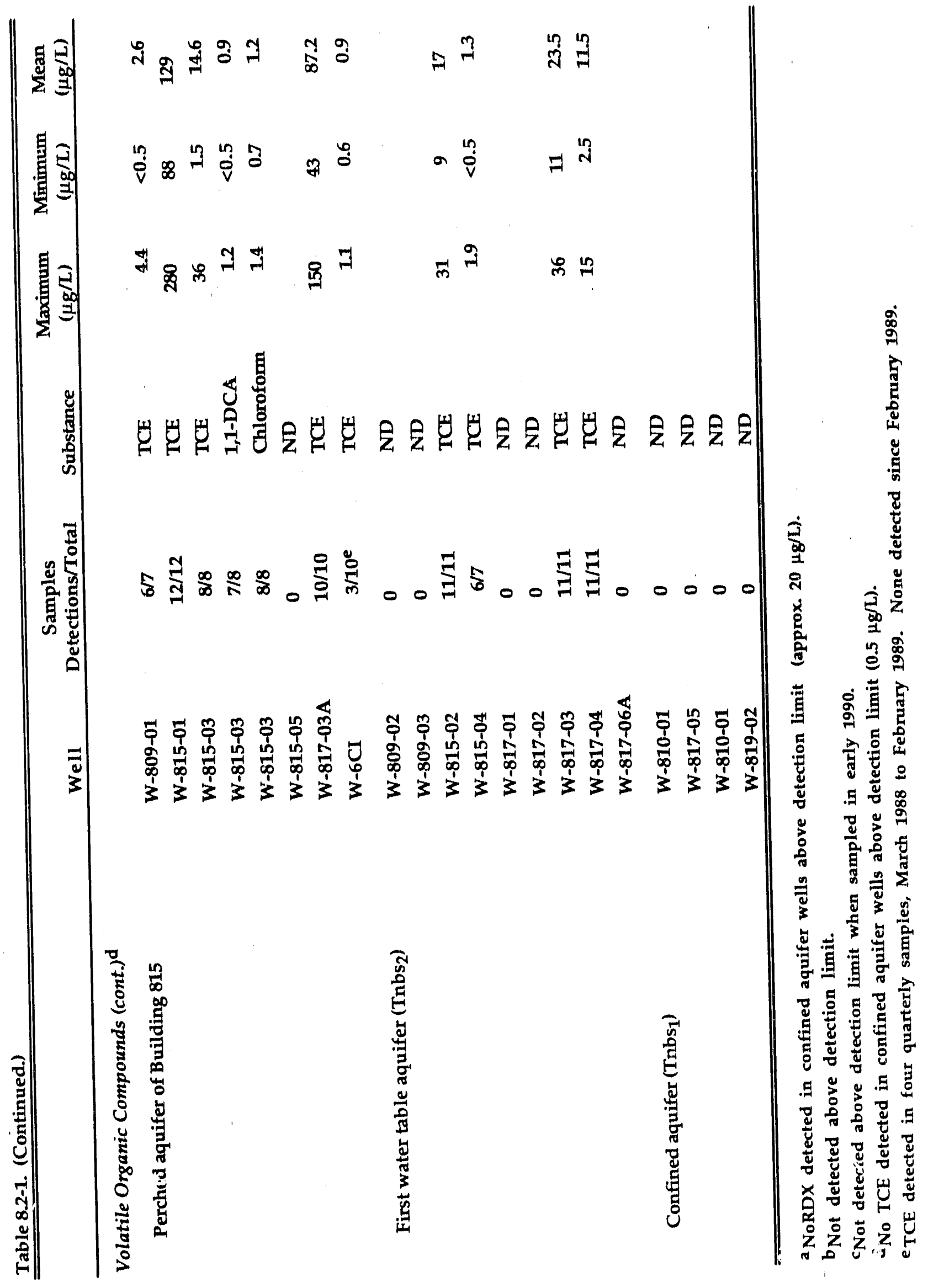


8.2.1.3. Confined Aquifer Beneath the HE Process Area. HE compounds have never been detected in the confined aquifer.

\subsubsection{VOCs in Ground Water}

8.2.2.1. Perched Aquifer of Building 814: VOCs. Low concentrations of TCE and chloroform (Table 8.2-1) at less than the MCLs have been detected in ground water from well W-814-01 in the localized perched aquifer near Building 814 (Fig, 6.1.2-1). Neither of these was detected during the first quarter of 1990 (Fig. 8.3).

Both the aquifer and its ground water production appear to be small (Fig. 8.3). We will continue to monitor the well to determine if a trend exists in the behavior of the VOCs found in it.

8.2.2.2. Perched Aquifer of Building 815: VOCs. Means, maximums, and minimums of TCE concentrations in key wells (Fig. 8.3) are summarized in Table 8.2-1; details are given in Appendix B. In ground water from wells W-815-01 and W-815-03, TCE concentrations exceed the MCL for drinking water $(5 \mu \mathrm{g} / \mathrm{L})$. The concentrations of chloroform and 1,1-DCA, present in the ground water beneath the area, are less than the applicable MCL or California State Action Level.

8.2.2.3. Water Table Aquifer: VOCs. Figure 8.4 shows the distribution of VOCs in ground water from wells completed in the water table aquifer. TCE concentrations exceed the MCL in water from wells W-815-02, W-817-03, and W-817-04. Water from well W-815-04 contains TCE at concentrations less than the MCL.

No VOCs have ever been detected in other wells completed in this aquifer.

8.2.2.4. Confined Aquifer Beneath the HE Process Area. The confined aquifer beneath the HE Process Area is in the Neroly lower blue sandstone. Water saturation is widespread in the lower blue sandstone aquifer. The piezometric surface of water in this aquifer is shown in Figure 8.2.2-1.

Neither HE compounds nor VOCs have ever been detected in ground water from this aquifer beneath the HE Process Area.

\subsection{Distribution of HE Compounds, Metals, and VOCs in Surface Water}

Because of the aridity at Site 300 , there are no perennial streams. A few small springs feeding seeps and very small heavily vegetated areas are the only perennial surface water at Site 300 .

TCE is discharged by a small spring, monitored by well W-817-03A, on the east side of the HE Surface Impoundments. The discharge is small, and the TCE evaporates from the spring discharge quickly, probably at concentrations much less than the Permitted Exposure Level $\left(25 \mathrm{mg} / \mathrm{m}^{3}\right)$.

No other contaminant compounds are found in surface water in the HE Process Area. 


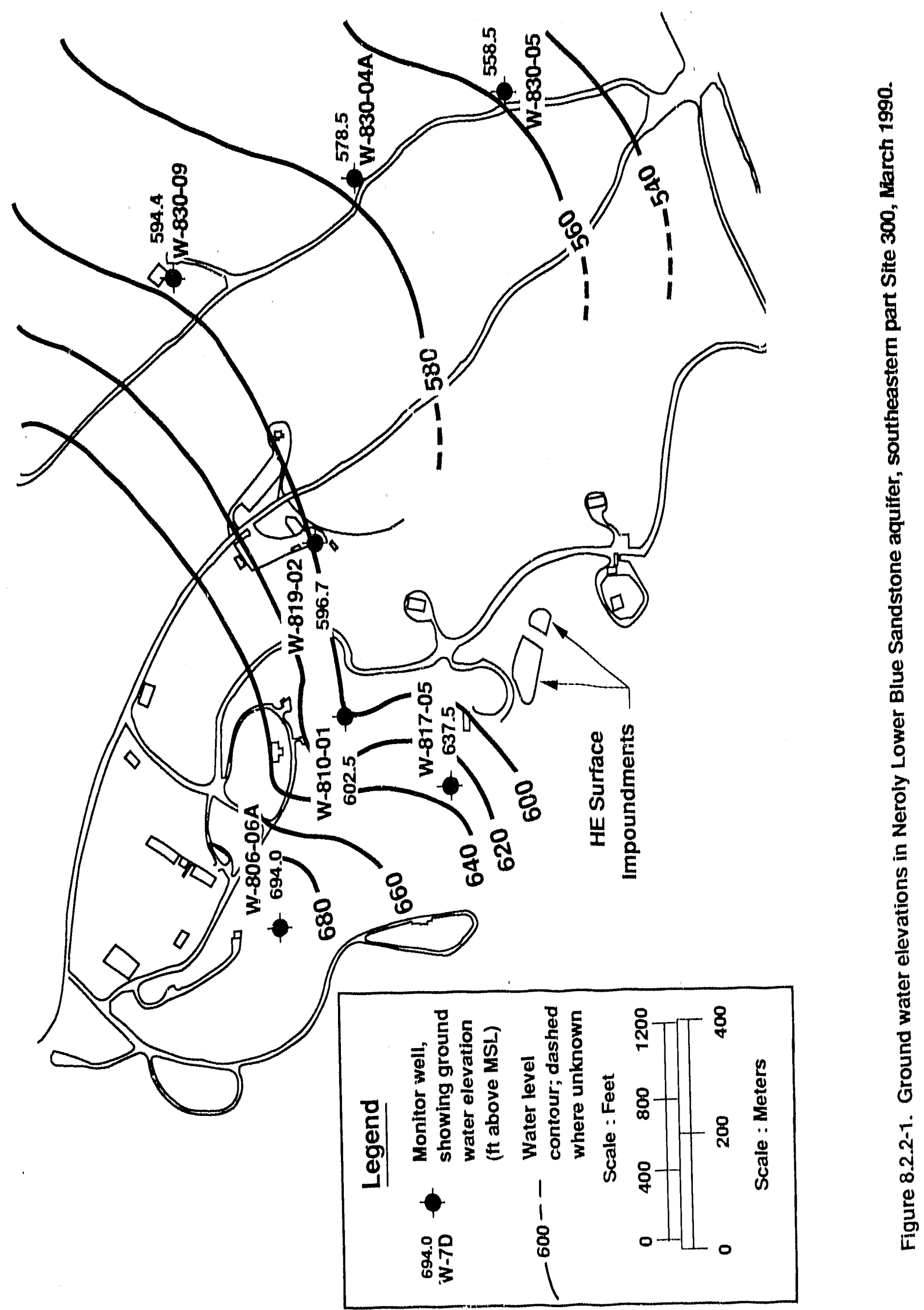




\subsection{Possible Release Sites for HE Compounds and VOCs in the HE Process Area}

\subsubsection{Possible Release Sites for RDX}

A credible site(s) has not yet been Identified for the release of RDX to the saturated water bodies berneath the Bullding 815-817 area. In the perched aquifer of Building 815, RDX is present in both W-815-(01 and W-815-03. The perched aquifer is not present in well W-817-(01 (Fïg. 8.1).

RDX has also been detected in water from wells W-815-()2, W-815-()4, and in W-817-()1, completed in the water-table aquifer (Fig. 8,2),

Building 817 has long been used for pressing components fabricated from HE compounds. Well W-817-01, which is slightly cross-gradient from Building 817 (Fig. 8.2), has shown a consistently low concentration of RDX since April 1985. Exploratory boreholes (Plate 4) drilled near the decommissioned lagoon near Building 817 (817-D1, 817-H1, 817-L1, and 817-L2) show relatively low concentrations of $\mathrm{HE}$ compounds in soil and rock; each was drilled into clean soil below. The use of the building for pressing $\mathrm{HE}$ compounds, and the presence of $\mathrm{HE}$ compounds in the ground water beneath it, suggest that Building 817 might be a release site. Yet, the highest concentration of RDX is beneath Building 815, and well W-817-01 is hydrologically upgradient from Building 815 (Fig. 8.2). These facts are puzzling because reliable information about the uses of the buildings in the HE Process Area indicates that HE compounds have never been handled in Building 815. This building was purportedly used only as a steam plant to serve the HE Process Area.

Other possible release sites have been considered. Building 809 lies northwest of the occurrences of RDX (Fig. 8.2). Recently we learned that Building 809 has been used for HE fabrication. We will investigate to learn if it is a release site for $\mathrm{HE}$ compounds.

Building 810 is used to assemble experimental devices using HE compounds. Well W-810-01 (Fig. 8. 2 ) was drilled to test the possibility of a release site at or near Building 810. Low concentrations of RDX and HMX were found in the soil near Building 810 (Fig. 8.2). During the drilling of well W-810-01, soil sampled from a zone at a depth of $85 \mathrm{ft}$ apparently contained RDX, though samples for a considerable distance above this zone did not. A recent borehole, D-810C-01, drilled about $50 \mathrm{ft}$ south of Building $81($ ), encountered a zone containing oxidized organic matter at a depth of $18 \mathrm{ft}$. In this borehole (D-810C-01), RDX and HMX were present in samples collected at depths less than $12 \mathrm{ft}$. Perched ground water from well W-81001 , approximately $300 \mathrm{ft}$ south of the Building 810 Complex, has never contained HE compounds. We plan to conduct additional investigations in 1990 to determine whether these data have any significance.

During July 1989, in an investigation designed to identify a possible release site north of Building 815, two monitor wells (W-809-03 and W-815-05) were drilled (Fig. 8.1). At this time, a small, but deep gully that heads southeast from Building 810 towards Building 815 (Plates 1 and 3) and a larger, and equally deep gully that heads southeast from the northern part of the HE Process Area were found. Hypothetically, their presence suggests a release site northwest of Building 815 might have released RDX to water, which migrates southeastward in the shallow colluvium above the bedrock. This water might infiltrate preferentially to the perched aquifer and to the water-table aquifer near and beneath Building 815.

Samples of water from these two new wells (W-809-(03 and W-815-()5) contain no IHE compounds in either the perched or water-table aquifers (Figs. 8.1 and 8.2), which makes this hypothesis seem unlikely. 
Despite these efforts, we cannot ddentlfy with any cortainty a releuse site(s) for the RDX detected in the ground water of the HE Process Area. We plan to investigate LLLNL records further and to conduct idditional investigations almed at locating a crediblo sources(s), II necessury, these investigations will include exploratory boreholes and new monitor wells. Results will be reported in subsequent reports.

\subsubsection{Possible Release Sites for VOCs near Building 814}

The concentrations of TCE and chloroform detected in the perched aquifer of Bullding 814 (Table 8.2-1) are lower than the MCLs for elther compound. We do not know the precise locution of the release site of these substances; presumably, it is near Bullding 814. The small size and probable low productive capacity of well W-814-(0) in this aquifer indicate it will not be a source of drinking water, and therefore, is not environmentally significant. Nevertheless, we will continue to monitor this well.

\subsubsection{Possible Release Sites for VOCs near Building 815}

In the perched aquifer of Bullding 815 , VOCs are concentrated in the region immediately beneath Building 815 . They also occur in plezometer W-817-03A, which provides a monitoring point east of the HE Surface Impoundments (Fig. 8.3). The data are summarized in Table 8.2-1.

In addition, TCE occurs in lower concentrations in the water table aquifer beneath Building 815 and to the south in monitor wells W-817-03 and W-817-04 (Fig. 8.4).

As stated earlier, investigations indicate that Building 815 was used as a steam plant. Apparently, the steam boiler at Bullding 815 was cleaned periodically to remove soot, using TCE as a solvent. The TCE was stored in drums on a concrete hardstand south of the building; minor stains were visible on the hardstand. During the investigation, monitor wells W-815-01 and W815-02 were drilled immediately adjacent to the hardstand. TCE was found in the soil and rock and in the ground water. The highest concentrations of TCE in the HE Process Area are found in water from well W-815-01. TCE was also detected in soil samples collected during drilling of these wells (Appendix A).

Data indicate that TCE found in the ground water benenth Building 815 was released to the environment either during use in cleaning the boiler at Building 815 or during storage at the hardstand south of the building.

Ground water from monitor well W-815-03, also completed in the perched aquifer of Building 815, contains very small concentrations of 1,1-DCA and chloroform. These substances are present in well W-815-(03 at concentrations substantially less than the SAL and MCL, respectively, for these substances. 


\section{Chapter 9. Effects on Air and Biota}

In this chapter, the effects on the air and blota of HE compounds and TCE in soll, rock, and ground water at the HE Process Area are considered. Although a specific study of the effects of HE compounds and TCE on animals and plants has not been done, no apparent effects on either have been found. In addition, an analysis is presented of the amounts of these substances detected in ground water that are avallable to the surface enviromment, and the probable effect of these concentrations on the air and blota.

\subsection{Effects of HE Compounds (RDX and HMX) on the Air and Biota}

In summary:

- RDX and HMX are low in volatility (Chapter 8),

- RDX is moderately to highly toxic (Etnier, 1989).

- The suggested drinking-water criterion is $105 \mu \mathrm{g} / \mathrm{L}$ RDX.

- HMX is virtually non-toxic (Chapter 8).

\subsubsection{Iffects of HE Compounds on Air Quality}

Until 1985, virtually none of the small quantities of RDX and HMX that were discharged to the environment in rinsewater entered the air. This was due to the low volatility of RDX and HMX. Thus, these substances had no significant effect on the air.

RI)X and HMX are formulated, pressed, and machined indoors at various buildings in the HE Process Area. As a result of these operations, small particles of HE compounds may erter the indoor air. Because the particles settle to the floor where they are periodically washed down, they are not a significant hazard to environmental air quality or the biota.

\subsubsection{Effects of HE Compounds in Soil and Rock}

Between 1955 and 1985, rinsewater containing low concentrations of the HE compounds RDX and HMX was discharged to shallow lagoons near various buildings in the HE Process Area. The lagoons were decommissioned in 1985, and the HE Surface Impoundments were opened; rinsewater was then discharged to the impoundments and was no longer discharged to the open environment. In 1986 and 1987, the lagoons were evaluated by drilling boreholes and taking samples to determine the horizontal and vertical extent of HE compounds.

In October 1989, the lagoons were formally closed. As a result, the HE compounds dispersed in the soil beneath and adjacent to the closed lagoons are no longer exposed to the air or available to the biota. Thus, they have no effect or. the environment.

\subsubsection{Effects of HE Compounds in Ground Water}

The HE compound RDX is found in ground water beneath a small area which centers on Building 815 and extends westward to Building 817. The area is limited in size, and the depth to water varies between 50 and $12.5 \mathrm{ft}$. The spring east of the HE Surface Impoundments is the only natural discharge of water in the area, and does not contain RDX. 'Thus, the ground water 
containing HE compounds does not reach the ground surfuce and ts not avaluble to the air or biota. The shallowest ground water containing RDX is approximately $50 \mathrm{ft}$ below the land surface and is totally inaceessible to plants or animals.

Therefore, the RDX present in the ground water is not a threat to the biota in the area.

\subsection{Effects of TCE on the Air and Biota}

\subsubsection{Effects of TCE in Soll and Rock}

Except in monitor well W.815-(01, TCE is detected in soll of the HE Process Area in errutle trace concentrations near the detection limit. 'ICIZ was used for boller cleaning at Bullding 815 and stored in 55-gal drums on a concrete hardstand south of the bullding. Presumably, TCE entered the environment through inadvertent spillage elther at Bulding 815 or at the hardstand prior to 1985. In well W-815-01 (adjacent to one of the presumed release sites, the hurdstand), concentrations of a few $10 \mathrm{ppb}$ occur in some soil and rock samples at depths below $5 \mathrm{ft}$. None of these occurrences are near the land surface.

It is likely that soon after release, much of the TCE, which is very volatile, evaporates quickly from the soil surfuce and immediately underlying soil, and is therefore dispersed in the air at low concentrations. In the HE Process Area, we think TCE in soil and rock does not constitute a hazard to the air or biota.

\subsubsection{Effects of TCE in Ground Water}

TCE occurs in ground water in several wells in the HE Process Area near Bulldings 815 and 817. Except at the spring east of the HE Surface Impoundments, none of this water is accessible at the surface. Moderate amounts of TCE have been detected in a plezometer, W-817-3A, which is located adjacent to the spring. The spring discharges small amounts of water into a small, heavily vegetated area. The TCE evaporates from the spring water into the air quickly after discharge from the ground, probably at concentrations less than the Permitted Exposure Level (PEL) of $25 \mathrm{mg} / \mathrm{m}^{3}$. The other occurrences of TCE are in monitor wells in which the water level is deeper than $50 \mathrm{ft}$ below the ground surface. The water from the wells is not accessible to animals or plants.

Therefore, the concentration of TCE in ground water is so small and evaporation so rapid near the land surface that the TCE presents no threat to the biota.

\subsection{Conclusions}

We conclude that the amounts of HE compounds and TCE available to the air, the biota from the closed lagoons, and the ground water are too small and too limited in extent to have a significant effect on the air or biota. 


\section{Acknowledgments}

A great many Individuals have particlpated in the investigation over the years, and the authors wish to thank them all for their efforts. We have altempted to lnclude all their names and regret any omissions.

F. Hoffman of LLNL Environmental Restoration Division provided overall guldance, direction and support.

W. MoConachle of LLNL Environmental Restoration Division technically reviowed the report:

D. Harms of LLNL provided secretuilal support.

J. Tweed typed several drafts of the manuscript.

B. Sellick, R. Rulz, J. Coker, and J, Grecl (in chronological order) have provided fleld coordination sind technical support to Site 300 operations.

J. Cunningham and E. Mortensen of LLNL, and M. Lima and others of KMI assisted with field technical operations.

B. Nations and S. Gregory coordinated the sampling done as part of the investigation;

T. Carlsen, M. Brown, and R. Herrman were in charge of the sampling by the Environmental Monitoring Group of the Environmental Protection Department.

W. Barr, F. Hudson, R. Festich and S, Pereira, of LLNL Site 300) staff, provided Plant Engineering coordination.

E. Draney and M. Gonzalez of LLNL, formerly of Site $3(X)$ management, logether with M. Grissom and J. Lane of Site 300 management, have been very supportive of our investigations.

J. Mize, R. McCabe, and B. Cummins of Site 3(0) HE Process Area supervision, have coordinated our operations.

P. Webster-Scholten, K. Lee, and R. Elwood of LLNL, and W. Dugan, L. Glick, R. Mateik, J. Pavletich, M. Wade, and R. Devany of Weiss Associates provided field geology support to the project, by sampling and logging boreholes and monitor wells and doing geologic mapping.

K. Toney of Brown and Caldwell Engineers prepared the well logs of the wells drilled during this investigation.

D. Carpenter and M. Taffet of LLNL participated in hydraulic testing of W-817-()1;

R. Ferry of Weiss Associates interpreted the test.

D. Carpenter of LLNL was responsible for the investigation of soil and rock in the III: Process Area, and for the closure of the HE lagoons; he consulted in the formulation of strategy for the investigation of ground water. Mr. Carpenter also provided critical reviews of two drafts of the manuscript.

L. Hall of LLNL provided a rigorous critical review of the discussion of the toxicology of HE compounds.

S. Vonder Haar reviewed earlier discussions of HE compounds and VOCs in soil and rock.

P. Cederwall managed the dita collected for this report, and prepared many of the tables. 
J. Clarkson and J. Cupps of LLNL analyzed samples of soil and ground water for HE compounds.

R. Nations and S. Gregory of LLNL coordinated periodic sampling of water from monitor wells drilled during our investigation. Personnel of Brown and Caldwell Laboratories including J. Swardenski, J. Laplante, R. Larson, and J. Ruef, have collected periodic samples of ground water.

R. Hermann of Environmental Monitoring Group (EMG), and T. Carlsen and M. Brown, formerly of EMG, coordinated saimpling to meet RWQCB Waste Discharge Order 85-188 requirements for monitor wells W-817-01, W-817-02, W-817-03, W-817-03A, and W-817-04.

D. Erickson (KMI) edited the final text of this report. H. Sherman (LLNL) edited earlier drafts, and J. Witherell (KMI) edited part of Appendix A.

K. Heyward (LLNL) and C. Johnson and M. Meamber (both KMI) prepared the illustrations.

R. Ambrosini of LLNL drilled many of the early boreholes and wells. D. Wagster, G. Hickmon, and S. Fleming of PC Exploration drilled more recent boreholes and wells. 


\section{References}

American Conference of Governmental Industrial Hygienists (ACGIH) (1980), Documentation of the Threshold Limit Values, 4th ed., p 115, Cincinnati, Ohio.

American Geological Institute (1980), Glossary of Geology, Washington, D.C.

American Public Health Association (1987), Standard Methods for the Examination of Water and Wastewater.

Bates, R. L., and J. Jackson (Eds.) (1980), Glossary of Geology, 2nd ed., American Geological Institute, Falls Church, Virginia.

Bentley, R. E., J. W. Dean, S. J. Ells, T. A. Hollister, G. A. LeBlanc, S. Sauter, and B. H. Sleight (1977), Laboratory Evaluation of the Toxicity of RDX to Aquatic Organisms, Final Report, EG\&G Bionomics, Wareham, MA (DAMD17-74-C-4101).

Bishop, D. J., J. P. Knezovich, and D. W. Rice, Jr. (1989), Sorption Studies of VOCs Related to Soil/Ground Water Contamination at LLNL, Lawrence Livermore National Laboratory, Livermore, Calif. (UCDD-21651).

Brown, D. (1975), The Acute and Chronic Biochemical and Behavioral Effects of Cyclotrimethylenetriamine, Maryland University School of Pharmacy, Baltimore, MD (AD-A024415/2).

Bryn, S. M., R. K. Landgraf, and S. E. Booth (1990, in press), Remedial Investigation and Feasibility Study for the Lawrence Livermore National Laboratory Site 300 Building 834 Complex, Lawrence Livermore National Laboratory, Livermore, Calif. (UCRL-ID-103963).

Buddemeier, R. W., M. R. Ruggieri, D. W. Carpenter, and D. T. Young (1985), Investigation of Tritium in Groundwater at Site 300, Lawrence Livermore National Laboratory, Livermore, Calif. (UCD-20600).

Buddemeier, R. W., M. R. Ruggieri, and J. A. Oberdorfer (1987), Tritium in Ground Water at Site 300, Lawrence Livermore National Laboratory, Livermore, Calif. (UCID-21031).

Busby, C. I., D. M. Garaventa, L. S. Kobori, P. E. Endzweig, D. J. Fee, R. M Harmon, A. C. Oetting, and F. M. Oglesby (1981), A Cultural Resource Inveniory of Lawrence Livermore National Laboratory's Site 300, Alameda and San Joaquin Counties, California, Basin Research Associates, Inc., Hayward, Calif. (UCRL-15364).

California Administrative Code (1985), Title 22, Environmental Heulth, Sec. 66700.

California Administrative Code (1989), Titles 8 and 22.

California Department of Health Services (DHS) (1989), Title 22 ralifornia Code of Regulations, Division 4, Environmental Health, as amended.

California Regional Water Quality Control Board-Central Valley Region (1985), Waste Discharge Order 85-188.

Carpenter, D. W. (1988), Lawrence Livermore National Laboratory, Livermore, Calif., personal communication. 
Carpenter, D. W., A. L. Lamarre, N. B. Crow, and P. M. Swearengen (1988), Closure Plan for the Decommissioned High Explosives Rinse-Water Lagoons at Lawrence Livermore Nationai Laboratory Site 300, Lawrence Livermore National Laboratory, Livermore, Calif. (UCID-21369).

Carpenter, D. W., R. Elwood, L. G. Gross (1986), Assessment of the Extent of Trichloroethylene in Soil and Water at Lawrence Livermore National Laboratory, Site 300; Lawrence Livermore National Laboratory, Livermore, Calif. (UCID-20774).

Carpenter, D. W., and D. W. Peifer, Eds. (1983), Supplementary Data Report, Site 300, Chemical and Hydrogeological Assessment, Lawrence Livermore National Laboratory, Livermore, Calif. (UCID-19801).

Cholakis, J. M., L. C. K. Wong, D. L. Van Goethem, J. Minor, R. Short, H. Sprinz, and H. V. Eliis (1980), Mammalian Toxicological Evaluation of RDX, Final Report, Midwest Research Institute, Kansas City, MO (Contract DAMD17-78-C-8027).

Clarkson, J., Lawrence Livermore National Laboratory, Livermore, Calif., personal communications (1988 and 1989).

Code of Federal Regulations, Title 40, Protection of Environment, Farts 100 to 149 (sec. 141.61), July 1, 1987.

Cortruvo, J. A., V. F. Simmon, and R. J. Spanggord (1977), "Investigation of mutagenic effects of products of ozonation reactions in water," Ann. N.Y. Acad. Sci. 298, 124-140.

Crow, N., R. Elwood, and P. Weoster-Scholten (1986), Distribution of High Explosives Compounds in Soil and Water at the 806/807 Lagoons, HE Process Area, LLNL Site 300, Lawrence Livermcre National Laboratory, Livermore, Calif. (UCAR-10169).

Crow, N. B. (1979), An Environmental Overview of Geothermal Development: The GeysersCalistoga KGRA, Vriume 4. Environmental Geology, Lawrence Livermore National Laboratory, Livermore, Calif. (UCRL-52496, Vol. 4, Rev. 1).

Dibbiee, T. W., Jr. (1980a), A Preliminary Map of the Midway Quadrangle, Alameda and San Joaquin Counties, California, U.S. Geological Survey (USGS Open File Report 80-535).

Dibblee, T. W., Jr. (1980b), A Preliminary Map of the Cedar Mountain Quadrangle, Alameda and San Joaquin Counties, California, U.S. Geological Survey (USGS Open File Report 80-850).

Dibblee, T. W., Jr. (1980c), Preliminary Geologic Map of the Lone Tree Creek Quadrangle, San Joaquin County, California, U.S. Geological Survey (USGS Open File Report 80566).

Dibblee, T. W., Jr., and R. L. Darrow (1981), "Geology of the Northeriı Diablo Range and Livermore Valley Area," Geology of Central and Northern Diablo Range, California, V. Frizzell, Ed. (Pacific Section of SEPM, Los Angeles, Calif., pp. 77-112).

Dickinson, W. R., and W. S. Snyder (1979), "Geometry of Triple Junctions Related to San Andreas Transform," J. Geophys. Res. 84, 561-572.

Driscoll, F. G. (1987), Groundwater and Wells, 2d ed. (Johnson Division, St. Paul, Minn.).

Etnier, E. L. (1989), "Water Quality Criteria for Hexahydro-1,3,5-trinitro-1,3,5-triazine (RDX)," Regulatory Toxicology and Phamacology 9, 147-157. 
Ferry, R. (1989), "Table C-1" In: Lamarre, A. L., W. A. McIlvride, M. J. Taffet, and N. B. Crow (1989a), LLNL Site 300 Environmental Investigations Quarterly, April-June 1989, Lawrence Livermore National Laboratory, Livermore, Calif. (UCAR-10194-89-2).

Garrison, J., S. MacLean, R. Bocanegra, M. R. Ruggieri, and R. W. Buddemeier (1985), Radiochemical Methods of the Site Environmental Monitoring Program, Lawrence Livermore National Laboratory, Livermore, Calif. (M-122, Rev. 1).

Glover, D. J. and J. C. Hoffsamer (1973), "Thin-layer Chromatographic Analysis of HMX in Water," Bull. Environ. Contam. Toxicol. 10, 302-304.

Hart, E. R. (1976), Two-year Feeding Study in Rats, Final Report, AD 040161, Litton Bionetics, Inc., Kensington, Md. (N00014-73--C-0162, NR202-043).

Hathaway, J. A., and C. R. Buck (1977), "Absence of Health Hazards Associated with RDX Manufacture and Use," Occup. Med. 19, p. 269.

Higgins, M. L. (1988), WRC Engineer, California Regional Water Quality Control BoardCentral Valley Region, letter to R. C. Ragaini, Department Head, Environmental Protection Department, Larence Livermore National Laboratory, Livermore, Calif., regarding High Explosives Lagoon Closure Plan, August 24, 1988.

Hoffman, F. (1988), Fault Investigation at Pit 1, LLNL Site 300, personal communication to Michael L. Higgins, Regional Water Quality Control Board-Central Valley Region, December 15, 1988.

Hoffman, F. (1990), Temedial Investigation of Dry Wells, Lawrence Livermore National Laboratory Site 300, personal communication to Michael J. Higgins, Regional Water Quality Control Board-Central Valley Regien, January 29, 1990.

Holland, R. C., and D. Brekke (1988), Environmental Monitoring at the Lawrence Livermore National Laboratory, 1987 Annual Report, Lawrence Livermore National Laboratory, Livermore, Calif. (UCRL-50027-87).

Hsü, K. J. (1971), "Franciscan Melanges as a Model for Eugeosynclinal Sedimentation and Underthrusting Tectonics," J. Geophys. Res. 76(5):1162-1170.

Huey, A. S. (1948), Geology of the Tesla Quadrangle, California, California Division of Mines (Bull. 140, 75 pp.).

Isbister, J. D., G. L. Anspach, J. F. Kitchens, and R. C. Doyle (1984), "Composting for Decontamination of Soils Containing Explosives," Microbiologica (Bologna) 7, 47-73.

Jahn, B. (1989), personal communication, Lawrence Livermore National Laboratory.

Lamarre, A. L., W. A. McIlvride, M. J. Taffet, and N. B. Crow (1989a), LLNL Site 300 Environmental Investigations Quarterly, April-June 1989, Lawrence Livermore National Laboratory, Livermore, Calif. (UCAR-10194-89-2),

Lamarre, A. L., T. L. Phillips, and N. B. Crow (1989b), Remedial Investigalion of Dry Wells, Lawrence Livermore National Laboratory Site 300, Lawrence Livermore National Laboratory, Livermore, Calif. (UCID-21774).

Lawrence Livermore National Laboratory (1988), Lawrence Livermore Laboratory Site 300 Safety and Operational Manual, Lawrence Livermore National Laboratory, Livermore, Calif. (M-091). 
Lawrence Livermore National Laboratory (1989), Site Safety Plan for Site 300 Environmental Restoration, Lawrence Livermore National Laboratory, Livermore, Calif. (UCRL-21172).

Layton, D., B. Mallon, W. Mitchell, L. Hall, R. Fish, L. Perry, G. Snyder, K. Bogen, W. Malloch, C. Ham, and P. Dowd (1987), Conventional Weapons Demilitarization: A Health and Environmental Effects Data-Base Assessment; Explosives and Their Co-Contaminants, Final Report, Phase II, Lawrence Livermore National Laboratory; Livermore, Calif. (UCRL-21109).

Lerbekmo, J. F. (1956), The Character and Origin of Late Tertiary Blue Sandstones in Central California, Ph.D. dissertation, University of California, Berkeley, Calif.

Levine, B. S., E. H. Furedi, V. S. Rac, D. E. Gordon, and P. M. Lish (1983), Determination of the Chronic Mammalian Toxicological Effects of RDX. Twenty-four Month Chronic Toxicity/Carcinogenicity Study of Hexahydro-1,3,5-trinitro-1,3,5-triazine (RDX) in the Fischer 344 Rat, Final Report, Contract No. DAMD7-79-C-9161, IITRI Project No. L6121, Study No. 6, U.S. Army Medical Research and Development Command, Ft. Detrick, MD.

Lish, P. M., B. S. Levine, E. M. Fuerdi, J. W. Sagartz, and V. S. Rac (1984), Determination of the Chronic Mammalian Toxicological Effects of RDX. Twenty-four Month Chronic Toxicity/Carcinogenicity Study of Hexahydro-1,3,5-trinitro-1,3,5-triazine (RDX) in the B6C3F1 Hybrid Mouse, Phase VI, Final Report, Phase VI, Volume 1, U.S. Army Medical Research and Development Command, Ft. Detrick, MD.

Mackay, D. M., and T. M. Vogel (1985), Ground Water Contamination by Organic Chemicals: Uncertainties in Assessing Impact, Banff, Alberta, Canada, B. Hitchon and M. R. Trudell (Eds.), National Water Well Association, Dublin, Ohio, pp. 50-59.

MacPhail, R. C. (1985), Neurot xicity of Cyclotrimethylcnetrinitramine (RDX), Progress Report to U.S. Army Medi al Bioengineering Research and Development Laboratory, Project Order No, 2813, February 1.

MacPhail, R. C. (1984), Neurotoxicity of Cyclotrimethylenetrinitramine (RDX), Progress Report to U.S. Army Medical Bioengineering Research and Development Laboratory, Project Order No. 2813, October 16.

Marshack, J. B. (1987), The Designated Level Methodology for Waste Classification and Cleanup Level Determination: A Summary of the Staff Report of the California Regional Water Quality Control Board, Central Valley Region, California Regional Water Quality Control Board, Central Valley Region, Sacramento, Calif.

Marshack, J. B. (1989), The Designated Level Methodology for Waste Classification and Cleanup Level Determination: Staff Report, California Regional Water Quality Control Board, Central Valley Region, Sacramento, Calif.

McLaughlin, R. J. (1978), Preliminary Geologic Map and Structural Sections of the Central Mayacmas Mountains Plus the Geysers Steam Field, Sonoma, Lake, and Mendocino Counties, U.S. Geological Survey Open File Report 78-389, 2 sheets, 1 map $(1: 24,000)$, explanation and cross-sections.

McNamara, B. P., H. P. Averill, E. J. Owens, J. F. Callahan, D. G. Fairchild, H. P. Ciuchta, R. H. Rengstorff, and D. K. Biskup (1974), The Toxicology of Cyclotrimethylene Trinitramine (RDX) and Cyclotetramethylene Tetranitramine (HMX) Solutions in Dimethylsulfoxide (DMSO), Cyclohexanone, and Acetone, Edgewood Arsenal, Aberdeen Proving Ground, MD (EB-TR-73040). 
Meyer, R. (1981), Explosives, 2nd ed., Verlag Chemie, Weinheim, West Germany.

Page, B. M. (1982), Sequential Geologic Indicators of Plate Interactions, Central California, E.O.S. Trans. Am. Geophys. Union, G3(45).911.

Raber, E., Ed. (1983), Chemical Characterization and Hydrogeological Considerations Concerning Wastewater Discharge into Surface Impoundments at LLNL Site 300, Lawrence Livermore National Laboratory, Livermore, Calif. (UCID-19753).

Raber, E., and D. W. Carpenter, Eds. (1983), An Evaluation of the Hydrogeology and Ground Water Chemistry Associated with Landfills at LLNL's Site 300, Lawrence Livermore National Laboratory, Livermore, Calif. (UCRL-53416).

Raber, E., D. Helm, D. Carpenter, D. Peifer, and J. Sweeney (1982), Site 300 Hazardous Waste Assessment Project, Interim Report: November 1981, Preliminary Site Reconnaissance and Project Work Plan, Lawrence Livermore National Laboratory, Livermore, Calif. (UCID-19315).

Raymond, L. A. (1969), The Stratigraphy and Structural Geology of the Northern Lone Tree Creek and Southern Tracy Quadrangles, California, M.S. thesis, San Jose State College, San Jose, Calif., 143 pp.

Rice, D., P. Daley, and T. Carlsen (Eds.) (1990), Environmental Restoration Program Standard Operating Procedures (SOPS), Lawrence Livermore National Laboratory, Livermore, Calif. (M-245 Draft, Rev. 1.3).

Rosenblatt, D. (1986), Contaminated Soil Cleanup Objectives for Cornhusker Army Ammunition Plant, U.S. Army Medical Bioengineering Research and Development Laboratory, Ft. Detrick, Maryland, Technical Report 8603.

Schneider, N. R., S. L. Bradley, and M. E. Anderson (1977), Toxicology of Cyclotrimethylene Trinitramine: Distribution and Metabolism in the Rat and the Miniature Swine, Toxicol. Appl. Pharmacol., 39(3), pp 531-541.

Schwille, F. (1988) Dense Chlorinated Solvents in Porous and Fractured Media Model Experiments (Lewis Publishers, Chelsea, Mich.).

Seip, H. M., J. Alstad, G. E. Carlberg, K. Martinsen, and R. Skaane (1986), "Measurement of Mobili y of Organic Compounds in Soils," The Science of the Total Environment, 50, 87-101.

Sikka, H. C., S. Banerjee, E. J. Pack, and H. T. Appleton (1980), Environmental Fate of $R D X$ and TNT, Syracuse Research Corporation, Syracuse, New York (no report number); sponsored by U.S. Army Medical Research and Development Laboratory, Ft. Detrick, Maryland.

Simmon, V. F., R. J. Spanggord, S. L. Eckford, and V. McClung (1977), Mutagenicity of Some Munitions Wastewater Chemicals and Chlorine Test Kit Reagents, SRI International, Menlo Park, CA, Final Report (AD-A(057680/1).

Sklanskaya, R. M. and F. I. Pozhariskii (1945), "Toxicity of Hexogen," Farmakol. Toksikol. (USSR), vol. 7, pp. 43-47 (1944). Abstract in Chem. Abstracts, vol. 39, p. 3()73 (1945).

Spanggord, R. J., W. R. Mabey, T. W. Chou, D. L. Haynes, P. L. Alferness, D. S. Tse, and T. Mill (1982), Environmental Fate Studies of HMX: Screening Studies, Final Report, Phase I, SRI International, Menlo Park, CA (LSU-4412). 
Steenhoven, J. C., and N. B. Crow (1986), Closure Plan for Site 300 High Explosives Lagoons, Administrative Report, Lawrence Livermore National Laboratory, Livermore, Calif., May 28, 1986.

Stilwell, J. M., M. A. Fisher, W. L. Margard, W. L. Matthews, and T. B. Stanford (1977), Toxicological Investigations of Pilot Treatment Wastewaters at Holton Army Ammunition Plant, Final Report, AD A042601, Battelle Columbus Laboratories, Columbus, Ohio (DAMD17-74-C-4123).

Sunderman, F. W. (1944), Hazards to the Health of Individuals Working With RDX(B), National Defense Research Committee of the Office of Scientific Research and Development.

Taffet, M. J., A. L. Lamarre, and W. A. McIlvride (1989), LLNL Site 300 Environmental Investigations Quarterly, January-March 1989, Lawrence Livermore National Laboratory, Livermore, Calif. (UCAR-10194-1-89).

Thorpe, R. K., W. F. Isherwood, M. D. Dresen and C. P. Webster-Scholten, Eds. (1990), CERCLA Remedial Investigations Report for the LLNL Livermore Site, Lawrence Livermore National Laboratory, Livermore, Calif. (UCAR-10299).

Toney, K. C., and N. B. Crow (1989), Logs of Wells and Boreholes Drilled During Hydrogeologic Studies at Lawrence Livermore National Laboratory Site 300, June I, 1982-June 30, 1988, Lawrence Livermore National Laboratory, Livermore, Calif. (UCID21536).

University of California (1986), Draft Environmental Impact Report for the University of California Contract with the Department of Energy for Operation and Maragement of Lawrence Livermore National Laboratory, University of California, Berkeley, Calif. (SCH-851 12611).

U.S. Department of Energy (1981), "DOE Order 5484.1, Environmental Protection, Safety, and Health Protection Information Reporting Requirements," Washington, D.C.

U.S. Environmental Protection Agency (EPA) (1987), Integrated Risk Information System, Supportive Documentation, Vol. 1, Office of Health and Environmental Assessment, U.S. Environmental Protection Agency, EPA/600/8-86/032a.

U.S. Environmental Protection Agency (EPA) (1986), EPA Superfund Public Health Evaluation Manual, Office of Emergency and Remedial Response, Washington, D.C., OSWER Directive 9285.4-1, October 1986, 157 p.

U.S. Environmental Protection Agency (EPA) (1980), "Guidelines and Methodology Used in the Preparation of Health Effects Assessment Chapters of the Consent Decree Water Quality Criteria," Fed. Regist. 45, 79347-79357.

Verscheuren, K. (1983), Handbook of Environmental Data on Organic Cherricals, Van Nostrand Reinhold, 1310 pp.

Webster-Scholten, C. P., and N. B. Crow (1989), Remedial Investigation of the High Explosives Burn Pit Facility, Building 829 Complex, Lawrence Livermore National Laboratory Site 300, Lawrence Livermore National Laboratory, Livermore, Calif. (UCID-21692).

Weiss Associates (1988), Well Development and Hydraulic Testing at LLNL Site 300 Building 830, 834, 840 and GSA Areas, Lawrence Livermore National Laboratory Contractor Report, Weiss Associates, Oakland, Calif. (UCRL-21010). 
Wilson, A. B. (1985), HMX: Determination of the Acute and Subchronic Mammalian Toxicity, Draft Final Summary Report, Contract DAMD-17-80-C-0053, U.S. Army Medical Bioengineering Research and Development Laboratory, Ft. Detrick, MD; Inverest Research International, Ltd., Musselborough, Scotland, IRI Projects 415669 and 416877, IRI Report No. 3465. 
Appendix A

Soils Data:

HE Compounds, Metals, and VOCs 
Table A-1. HE compounds in soll samples from sample holes at the "06/807 Lagoon.

\begin{tabular}{|c|c|c|c|c|c|}
\hline \multirow[b]{2}{*}{ Borehole } & \multirow[b]{2}{*}{ Sample No. } & \multirow[b]{2}{*}{ Depth $(f t)$} & \multicolumn{3}{|c|}{ HE compounds $[\mu \mathrm{g} / \mathrm{g}(\mathrm{ppm})]$} \\
\hline & & & HMX & RDX & TNT \\
\hline \multirow[t]{6}{*}{ B-806-01 } & B-806-01-1A & $4.0-4.4$ & 3.1 & 0.17 & ND \\
\hline & B-806-01-2A & $9.3-9.7$ & 0.97 & 1.5 & ND \\
\hline & B-806-01-3A & $14.5-14.9$ & 0.11 & 0.001 & ND \\
\hline & B-806-01-4A & $19.5-20$ & 0.008 & $<0.0006$ & ND \\
\hline & B-806-01-5A & $24.5-24.8$ & 0.020 & $<0.0006$ & ND \\
\hline & B-806-01-6A & $29.5-30$ & 0.016 & $<0.0006$ & ND \\
\hline \multirow[t]{7}{*}{$B-806-02$} & $B-806-02-1 A$ & $3.0-3.3$ & 2.0 & 0.06 & ND \\
\hline & B-806-02-2A & $5.0-5.5$ & 0.85 & 0.13 & ND \\
\hline & B-806-02-3A & $10.0-10.3$ & 2.1 & 1.1 & 0.13 \\
\hline & $B-806-02-4 A$ & $15.0-15.5$ & 0.043 & 0.0008 & ND \\
\hline & B-806-02-5A & $20.0-20.5$ & $<0.0003$ & 0.0005 & ND \\
\hline & B-806-02-6A & $25.0-25.5$ & $<0.0003$ & $<0.0005$ & ND \\
\hline & B-806-02-7A & $30.0-30.5$ & $<0.0009$ & $<0.0009$ & ND \\
\hline \multirow[t]{7}{*}{ B-806-03 } & B-806-03-1A & $2.2-2.5$ & 0.016 & $<0.0006$ & ND \\
\hline & B-806-03-2A & $4.7-5.0$ & 0.022 & $<0,0006$ & ND \\
\hline & B-806-03-3A & $9.7-10.1$ & $<0.0003$ & $<0.0006$ & ND \\
\hline & B-806-03-4A & $14.8-15.2$ & 0.020 & $<0.0006$ & ND \\
\hline & B-806-03-5A & $15.9-20.3$ & $<0.0003$ & $<0.000$ & ND \\
\hline & B-806-03-6A & $24.7-2 \leq 5.2$ & 0.003 & 0.26 & ND \\
\hline & B-806-03-7A & $30.1-30.3$ & $<0.0005$ & $<0.0006$ & ND \\
\hline \multirow[t]{8}{*}{ B-806-04 } & B-806-04-1A & $1.0-1.3$ & 0.14 & 1.4 & ND \\
\hline & B-806-04-2A & $5.0-5.3$ & $<0.0009$ & $<0.001$ & ND \\
\hline & B-806-04-3A & $10.0-10.5$ & 0.14 & 0.082 & ND \\
\hline & B-806-04-4A & $15.0-15.5$ & 0.0013 & 0.073 & ND \\
\hline & B-806-04-5A & $20.0-20.5$ & 0.039 & 0.25 & ND \\
\hline & B-806-04-6A & $25.5-26.0$ & 0.004 & $<0.0008$ & ND \\
\hline & B-806-04-6B & $26.0-26.5$ & $<0.0003$ & $<0.0006$ & ND \\
\hline & B-806-04-7A & $30.0-30.5$ & $<0.0004$ & $<0.0007$ & ND \\
\hline \multirow[t]{8}{*}{ B-806-05 } & B-806-05-1A & $8.0-8.4$ & 18 & 11 & ND \\
\hline & B-806-05-2A & $13.2-13.7$ & $<0.0004$ & $<0.0007$ & ND \\
\hline & B-806-05-3A & $18.3-18.8$ & $<0.0003$ & $<0.0006$ & ND \\
\hline & B-806-05-4A & $23.5-24.0$ & $<0.0003$ & $<0.0007$ & ND \\
\hline & B-806-05-5A & $28.5-29.0$ & $<0.0003$ & $<0.0006$ & ND \\
\hline & B-806-05-6A & $33.6-34: 1$ & $<0.0003$ & $<0.0006$ & ND \\
\hline & B-806-05-7A & $43.0-43.3$ & $<0.0005$ & $<0.0010$ & ND \\
\hline & B-806-05-8A & 46.0 & 1.5 & $<0.0015$ & ND \\
\hline \multirow[t]{6}{*}{ B-806-06 } & B-806-06-1A & 40.5 & 1.4 & $<0.0009$ & ND \\
\hline & B-806-06-2A & 45.0 & 0.10 & $<0.0007$ & ND \\
\hline & B-806-06-3A & 50.0 & 2.2 & $<0.0017$ & ND \\
\hline & B-806-06-4A & 55.0 & 0.51 & $<0.0009$ & ND \\
\hline & B-806-06-5A & 60.0 & 0.019 & $<0.0009$ & ND \\
\hline & B-806-06-6A & 64.0 & 0.0068 & $<0.0005$ & ND \\
\hline
\end{tabular}


Table A-1. (Continued)

\begin{tabular}{|c|c|c|c|c|c|c|}
\hline \multirow[b]{2}{*}{ Borehole } & \multirow[b]{2}{*}{ Sample number } & \multirow[b]{2}{*}{ Depth $(f t)$} & & \multicolumn{3}{|c|}{ HE compounds $[\mu \mathrm{g} / \mathrm{g}(\mathrm{ppm})]$} \\
\hline & & & & HMX & RDX & TNT \\
\hline \multirow[t]{5}{*}{ B-806-06 } & B-806-06 & 72.0 & & $<0.0003$ & $<0.0005$ & ND \\
\hline & B-806-06 & 76.0 & & $<0.0003$ & $<0.0005$ & ND \\
\hline & B-806.06 & 81.0 & . & $<0.0003$ & $<0.0005$ & ND \\
\hline & B-806-06 & 86.0 & & $<0.0003$ & $<0.0005$ & ND \\
\hline & B-806-06 & 90.0 & & $<0.0003$ & $<0.0005$ & ND \\
\hline \multirow[t]{4}{*}{ B-806-6A } & B-806-6A-1 & $141.6-141.8$ & & $<0.005$ & $<0.006$ & ND \\
\hline & B-806-6A-2 & $147.4-147.6$ & & $<0.005$ & $<0.006$ & ND \\
\hline & E.806-6A-3 & $151.6-151.8$ & & $<0.005$ & $<0.006$ & ND \\
\hline & B-806-6A-4 & $156.5-156.7$ & & $<0.005$ & $<0.006$ & ND \\
\hline
\end{tabular}

ND $=$ Not detected. 
Table A-2. HE compounds in soil and rock samples at Lagoon $807 \mathrm{~A}$.

\begin{tabular}{llllll}
\hline & & & \multicolumn{2}{c}{ HE compounds $[\mu \mathrm{g} / \mathrm{g}(\mathrm{ppm})]$} \\
\cline { 5 - 6 } Borehole & Sample No. & Depth (ft) & HMX & RDX & TNT \\
\hline B-807-A1 & B-807-A1-1A & $1.0-1.4$ & $<0.11$ & $<0.0008$ & ND \\
& B-807-A1-2A & $5.0-5.4$ & $<0.0005$ & $<0.0009$ & ND \\
& B-807-A1-3A & $10.5-10.7$ & $<0.0014$ & $<0.0027$ & ND \\
& B-807-A1-4A & $15.0-15.5$ & $<0.0003$ & $<0.0007$ & ND \\
& B-807-A1-5A & $20.0-20.3$ & 0.0018 & 0.0036 & ND \\
& B-807-A1-6A & $25.0-25.5$ & $<0.0004$ & $<0.0008$ & ND \\
& B-807-A1-7A & $30.0-30.5$ & $<0.0004$ & $<0.0008$ & ND \\
& & & & & \\
B-807-A2 & B-807-A2-1A & $1.0-1.3$ & $<0.0004$ & 0.24 & ND \\
& B-807-A2-2A & $5.5-5.7$ & $<0.0004$ & 1.2 & ND \\
& B-807-A2-3A & $10.5-10.7$ & $<0.0004$ & 0.48 & ND \\
& B-807-A2-4A & $15.5-15.7$ & $<0.0004$ & 0.20 & ND \\
& B-807-A2-5A & $20.0-20.4$ & $<0.0004$ & 0.14 & ND \\
& B-807-A2-6A & $25.0-25.5$ & $<0.0004$ & $<0.0005$ & ND \\
& B-807-A2-7A & $30.0-30.5$ & $<0.0004$ & $<0.0005$ & ND \\
\hline
\end{tabular}

ND $=$ Not detected. 
Table A-3 HE compounds in soil and rock sarnples, sample hole B-807-B1, 807B Lagoon.

\begin{tabular}{llcccc}
\hline & & & \multicolumn{2}{c}{ HE compounds [ $\mu \mathrm{g} / \mathrm{g}$ (ppm)] } \\
\cline { 5 - 6 } Borehole & Sample No. & Depth (ft) & HMX & RDX & TNT \\
\hline B-807-B1 & B-807-B1-1A & $1.0-1.2$ & 2.3 & 0.75 & ND \\
& B-807-B1-2A & $4.5-5.0$ & 0.0009 & 0.055 & ND \\
& B-807-B1-3A & $9.5-9.8$ & 0.035 & 0.012 & ND \\
& B-807-B1-4A & $14.5-14.8$ & $<0.0007$ & $<0.0067$ & ND \\
& B-807-B1-5A & $19.5-19.8$ & 0.21 & 0.43 & ND \\
& B-807-B1-6A & $24.5-24.7$ & 0.0022 & $<0.0014$ & ND \\
& B-807-B1-7A & $29.5-30.0$ & $<0.0004$ & $<0.0007$ & ND \\
\hline
\end{tabular}

$\mathrm{ND}=$ Not detected. 
Table A-4. HE compounds in soil and rock samples from sample holes, Building 817 Area.

\begin{tabular}{|c|c|c|c|c|}
\hline \multirow[b]{2}{*}{ Sample IDa } & \multirow[b]{2}{*}{ Sample depth (ft) } & \multicolumn{3}{|c|}{ HE compounds in micrograms/gram $(\mu \mathrm{g} / \mathrm{g})$ of soil ${ }^{b}$} \\
\hline & & HMX & RDX & TNT \\
\hline B-817-D1-1A & $1.0-1.3$ & 0.0047 & $<0.0007$ & $<0.001$ \\
\hline B-817-D1-2A & $5.0-5.7$ & 0.077 & 0.021 & $<0.001$ \\
\hline B-817-D1-3B & $10.7-11.5$ & $<0.0005$ & 0.041 & $<0.001$ \\
\hline B-817-D1-4B & $15.7-16.5$ & $<0.0004$ & $<0.0005$ & $<0.001$ \\
\hline B-817-D1-5B & $22.7-23.0$ & $<0.0004$ & $<0.0006$ & $<0.001$ \\
\hline B-817-D1-6B & $25.8-26.5$ & 0.10 & $<0.0006$ & $<0.001$ \\
\hline B-317-D1-7B & $30.0-30.7$ & $<0.0007$ & $<0.0010$ & $<0.001$ \\
\hline B-817-D1-8A & $35.0-35.7$ & $<0.0003$ & $<0.0005$ & $<0.001$ \\
\hline B-817-H1-1B & 4.2-4.4 & $-c$ & $-c$ & $-c$ \\
\hline B-817-H1-2B & $9.2-9.4$ & $-c$ & $-_{-c}^{c}$ & $-c$ \\
\hline B-817-H1-3B & $14.5-14.7$ & $-c$ & $-^{c}$ & -c $^{c}$ \\
\hline B-817-H1-4B & $20.0-20.2$ & $-^{c}$ & $-^{c}$ & $-_{c}^{c}$ \\
\hline B-817-H1-5B & $25.0-25.3$ & $-^{c}$ & $-c$ & $-c$ \\
\hline B-817-H1-6A & $29.5-29.8$ & $-c$ & -c & $-c$ \\
\hline B-817-H1-7B & $35.0-35.2$ & -c & -c $^{c}$ & -c $^{c}$ \\
\hline B-817-H1-8B & $39.5-40.0$ & $-^{c}$ & - $^{c}$ & $-c$ \\
\hline B-817-H1-9B & $44.9-45.1$ & $-c$ & $-^{c}$ & $-c$ \\
\hline B-817-H1-10A & $49.5-49.8$ & $-c$ & -c & $ـ_{c}^{c}$ \\
\hline B-817-H1-11A & $55.3-55.6$ & $-c$ & $-c$ & $\ldots c$ \\
\hline B-817-H1-12A & $60.5-60.7$ & $-c$ & $-c$ & $-c$ \\
\hline B-817-H1-13A & $66.5-66.7$ & $-c$ & $-c$ & $-c$ \\
\hline B-817-H1-14A & $70.5-70.7$ & _c & _c & -c \\
\hline B-817-H1-15A & $74.7-74.9$ & $-c$ & $-c$ & $-c$ \\
\hline B-817-H1-16A & $81.3-81.6$ & $-c$ & -c $^{c}$ & -c \\
\hline B-817-H1-17A & $86.4-86.6$ & $-c$ & $-_{c}^{c}$ & -c $^{c}$ \\
\hline B-817-H1-18A & $92.0-92.2$ & $-c$ & $-c$ & -c $^{c}$ \\
\hline B-817-H1-19A & $97.2-97.4$ & $-c$ & $-c$ & $-c$ \\
\hline B-817-H1-20A & $102.4-102.7$ & $-c$ & $-_{c}^{c}$ & $-c$ \\
\hline B-817-L1-1A & $5.2-5.4$ & 0.0054 & $<0.0015$ & $<0.0008$ \\
\hline B-817-L1-2A & $10.2-10.7$ & $<0.0004$ & $<0.0007$ & $<0.0008$ \\
\hline B-817-L1-3A & $15.2-15.5$ & $<0.0005$ & $<0.0010$ & $<0.0008$ \\
\hline B-817-L1-4B & $20.7-21.0$ & 0.0042 & $<0.0006$ & $<0.0008$ \\
\hline B-817-L1-5A & $25.2-25.5$ & 0.015 & $<0.0014$ & $<0.0608$ \\
\hline B-817-L1-6A & $30.2-30.4$ & $<0.0007$ & $<0.0014$ & $<0.0008$ \\
\hline B-817-L1-7A & $35.6-36.1$ & $<0.0005$ & $<0.0009$ & $<0.0008$ \\
\hline B-817-L2-1A & $1.0-1.3$ & $<0.0005$ & $<0.0009$ & $<0.0008$ \\
\hline B-817-L2-2B & $4.7-4.9$ & $<0.0007$ & $<0.0014$ & $<0.0008$ \\
\hline B-817-L2-3B & $9.6-9.8$ & $<0.0008$ & $<0.0016$ & $<0.0008$ \\
\hline B-817-L2-4B & $14.8-15.0$ & $<0.0018$ & $<0.0034$ & $<0.0008$ \\
\hline B-817-L.2-5B & $19.8-20.0$ & $<0.0013$ & $<0.0025$ & $<0.0008$ \\
\hline B-817-L2-6A & $24.3-24.7$ & 0.023 & $<0.0010$ & $<0.0008$ \\
\hline B-817-L2-7A & $29.3-29.6$ & $<0.0003$ & $<0.0006$ & $<0.0008$ \\
\hline
\end{tabular}

All samples were collected with a 1-1/2-in.-i.d. split-spoon sampler advanced by a 140-lb hammer falling 30 in. Samples were encased in stainless steel sleeves, ends covered with aluminum foil, and sealed with inert tape.

b Analyses by normal HPLC procedure.

c No HE compounds detected. Detection limits are approximately

$\begin{array}{ll}\text { HMX } & =<0.0008 \mu \mathrm{g} / \mathrm{g} \text { of soil, } \\ \text { RDX } & =<0.0008 \mu \mathrm{g} / \mathrm{g} \text { of soil, } \\ \text { TNT } & =<0.0008 \mu \mathrm{g} / \mathrm{g} \text { of soil. }\end{array}$


Table A-5. HE compounds i.1 825 Lagoon and background samples, Building 825/826 Area.

\begin{tabular}{lcccc}
\hline & & \multicolumn{3}{c}{ : IE compounds $[\mu \mathrm{g} / \mathrm{g}$ (ppm)]" } \\
\cline { 4 - 5 } Sample & Depth (ft) & HMX & RDX & TNT \\
\hline 825 Lagoon' & & & & \\
B-825-01/1A $_{\text {B-825-01/1B }}$ & $1.0-1.5$ & 0.09 & ND & ND \\
B-825-01/2a & $1.0-1.5$ & 0.01 & ND & ND \\
B-825-01/3b & $5.1-5.3$ & ND & ND & ND \\
B-825-01/4B & $10.4-10.6$ & ND & ND & ND \\
Background & $15.5-15.7$ & ND & ND & ND \\
B-825-02/1A & & & & \\
B-825-02/2A & $1.0-1.2$ & 0.37 & ND & ND \\
B-825-02/3B & 4.0 & 0.18 & ND & ND \\
B-825-02/4A & $5.3-5.5$ & 0.02 & ND & ND \\
B-825-02/5b & $10.0-10.2$ & ND & ND & ND \\
\hline
\end{tabular}

a HLC analysis performed by LLNL Analytical Chemistry Laboratory.

bue to accessibility problems with drill rig, B-825-1 Lagoon sampling borehole was actually drilled immediately to the northeast of the lagoon edge. The background sample was taken $\sim 50 \mathrm{ft}$ north west of the lagoon sample.

ND $=$ Not detected. Detection limits: HMX $=0.01 \mu \mathrm{g} / \mathrm{g}$ soil,

RDX $=0.01 \mu \mathrm{g} / \mathrm{g}$ soil,

TNT $=0.01 \mu \mathrm{g} / \mathrm{g}$ soil. 
Table A-6. HE compounds in soil and rock samples from sample holes, Building 826 Area.

\begin{tabular}{|c|c|c|c|c|}
\hline \multirow[b]{2}{*}{ Sample ID } & \multirow[b]{2}{*}{ Sample depth (ft) } & \multicolumn{3}{|c|}{ Concentration $\mu \mathrm{g} / \mathrm{g}$ of soil $\mathrm{b}$} \\
\hline & & HMX & RDX & TNT \\
\hline$B-826-1-1 A$ & $2.7-3.1$ & 2.2 & $<0.0014$ & $<0.0008$ \\
\hline$B-826-1-2 A$ & $6.5-6.7$ & 3.2 & 0.19 & $<0.00 C 8$ \\
\hline B-826-1-3A & $10.0-10.4$ & 2.3 & 0.11 & $<0.0008$ \\
\hline B-826-1-4A & $15.0-15.1$ & 0.23 & $<0.0011$ & $<0.0008$ \\
\hline B-826-1-5A & $20.0-20.2$ & 0.13 & $<0.0011$ & $<0.0008$ \\
\hline$B-826-1-6 A$ & $25.0-25.2$ & 0.27 & $<0.0013$ & $<0.0008$ \\
\hline$B-826-1-7 B$ & $30.4-30.6$ & 0.32 & $<0.0016$ & $<0.0008$ \\
\hline B-826-1A-1A & $30.0-30.3$ & 0.081 & $<0.0008$ & $<0.001$ \\
\hline B-826-1A-2A & $35.0-35.4$ & 0.0017 & $<0.0005$ & $<0.001$ \\
\hline B-826-1A-3A & $40.0-40.3$ & 0.15 & $<0.0007$ & $<0.001$ \\
\hline$B-826-1 A-4 A$ & $45.0-45.4$ & 0.12 & $<0.0004$ & $<0.001$ \\
\hline$B-826-1 A-5 A$ & $50.0-50.3$ & $<0.0004$ & $<0.0005$ & $<0.001$ \\
\hline$B-826-2-1 A$ & $2.5-3.0$ & $<0.0004$ & $<0.0007$ & $<0.0008$ \\
\hline B-826-2-2A & $7.5-7.7$ & $<0.0006$ & $<0.0011$ & $<0.0008$ \\
\hline B-826-2-3B & $12.9-13.1$ & $<0.0007$ & $<0.0014$ & $<0.0008$ \\
\hline B-826-2-4B & $18.0-18.2$ & $<0.0008$ & $<0.0014$ & $<0.0008$ \\
\hline B-826-2-5B & $22.9-23.1$ & $<0.0008$ & $<0.0015$ & $<0.0008$ \\
\hline B-826-2-6B & $28.0-28.2$ & $<0.0008$ & $<0.0015$ & $<0.0008$ \\
\hline B-826-2-7B & $33.0-33.2$ & $<0.0008$ & $<0.0014$ & $<0.0008$ \\
\hline
\end{tabular}

all samples were taken with a 1-1/2-in.-i.d. split-spoon sampler advanced by a 140-lb hammer falling 30 in. Samples were encased in stainless steel sleeves, ends covered with aluminum foil, and sealed with inert tape.

b Analyses by normal HPLC procedure. 
Table A-7. HE compounds in soil and rock samples from sample holes, Building 827 Area.

\begin{tabular}{|c|c|c|c|c|}
\hline \multirow[b]{2}{*}{ Sample IDa } & \multirow[b]{2}{*}{ Depth (ft) } & \multicolumn{3}{|c|}{ HE compounds $\mu g / g$ of soilb } \\
\hline & & HMX & RDX & TNT \\
\hline B-827-C1-1A & $4.5-5.0$ & $<0.0004$ & $<0.0008$ & $<0.001$ \\
\hline B-827-C1-2A & $9.5-9.8$ & $<0.0004$ & $<0.0007$ & $<0.001$ \\
\hline B-827-C1-3A & $14.5-15.0$ & $<0.0003$ & $<0.0006$ & $<0.001$ \\
\hline B-827-C1-4A & $20.0-20.5$ & $<0.0003$ & $<0.0006$ & $<0.001$ \\
\hline B-827-C1-5A & $24.8-25.3$ & $<0.0004$ & $<0.0007$ & $<0.001$ \\
\hline B-827-C.1-6A & $29.5-29.8$ & $<0.0005$ & $<0.0010$ & $<0.001$ \\
\hline B-827-C1-7A & $34.5-35.0$ & $<0.0004$ & $<0.0007$ & $<0.001$ \\
\hline B-827-C2-1A & $1.5-1.6$ & $<0.0010$ & $<0.0018$ & $<0.001$ \\
\hline$B-827-C 2-2 A$ & $5.0-5.5$ & $<0.0004$ & $<0.0007$ & $<0.001$ \\
\hline$B-827-C 2-3 B$ & $10.2-10.7$ & $<0.0006$ & $<0.0011$ & $<0.001$ \\
\hline B-827-C2-4A & $15.1-15.6$ & $<0.0004$ & $<0.0007$ & $<0.001$ \\
\hline B-827-C2-5A & $20.5-21.0$ & $<0.0004$ & $<0.0007$ & $<0.001$ \\
\hline B-827-C2-6B & $25.6-25.7$ & $<0.0020$ & $<0.0037$ & $<0.001$ \\
\hline B-827-C2-7A & $30.0-30.3$ & $<0.0020$ & $<0.0009$ & $<0.001$ \\
\hline B-827-C3-1B & $1.5-2.0^{c}$ & $<0.0007$ & $<0.0013$ & $<0.001$ \\
\hline B-827-C3-2A & $5.0-5.8$ & $<0.0009$ & $<0.0016$ & $<0.001$ \\
\hline B-827-C $3-3 B$ & $10.8-11.5$ & 0.16 & $<0.0027$ & $<0.001$ \\
\hline B-827-C $3-4 A$ & $16.3-16.5$ & $<0.0010$ & $<0.0018$ & $<0.001$ \\
\hline B-827-C3-6B & $20.5-20.8$ & $<0.0007$ & 0.044 & $<0.001$ \\
\hline B-827-C3-7B & $25.3-25.4$ & $<0.0006$ & $<0.0011$ & $<0.001$ \\
\hline B-827-C3-8B & $30.3-30.4$ & $<0.0009$ & $<0.0016$ & $<0.001$ \\
\hline B-827-C4 & 7.5 & 0.0011 & $<0.0008$ & $<0.0008$ \\
\hline B-827-C4 & 12.5 & $<0.0008$ & $<0.0008$ & $<0.0008$ \\
\hline B-827-C4 & 15.6 & 0.12 & $<0.0008$ & $<0.0008$ \\
\hline B-827-C4 & 20.8 & $<0.0008$ & $<0.0008$ & $<0.0008$ \\
\hline B-827-C4 & 25.5 & 0.027 & $<0.0008$ & $<0.0008$ \\
\hline B-827-C4 & 31.0 & $<0.0008$ & $<0.0008$ & $<0.0008$ \\
\hline B-827-C4 & 35.5 & 0.0083 & $<0.0008$ & $<0.0008$ \\
\hline B-827-C4 & 40.1 & 0.0268 & $<0.0008$ & $<0.0008$ \\
\hline B-827-C4 & 45.0 & $<0.0008$ & $<0.0008$ & $<0.0008$ \\
\hline B-827-C4 & 50.5 & 0.0043 & $<0.0008$ & $<0.0008$ \\
\hline B-827-C4 & 55.0 & $<0.0008$ & $<0.0008$ & $<0.0008$ \\
\hline B-827-C5 & 9.5 & 0.017 & $<0.0008$ & $<0.0008$ \\
\hline B-827-C5 & 15.5 & 0.0082 & $<0.0008$ & $<0.0008$ \\
\hline B-827-C5 & 20.5 & 0.0051 & $<0.0008$ & $<0.0008$ \\
\hline B-827-C5 & 25.5 & 0.0059 & $<0.0008$ & $<0.0008$ \\
\hline B-827-C5 & 28.7 & $<0.0005$ & $<0.0008$ & $<0.0008$ \\
\hline B-827-C5 & 35.0 & $<0.0005$ & $<0.0008$ & $<0.0008$ \\
\hline B-827-C5 & 40.0 & $<0.0005$ & $<0.0008$ & $<0.0008$ \\
\hline B-827-C5 & 46.2 & $<0.0005$ & $<0.0008$ & $<0.0008$ \\
\hline B-827-C5 & 52.7 & $<0.0005$ & $<0.0008$ & $<0.0008$ \\
\hline B-827-C5 & 59.5 & $<0.0005$ & $<0.0008$ & $<0.0008$ \\
\hline
\end{tabular}

all samples were collected with a 1-1/2-in.-i.d. split-spoon sampler advanced by a 140-lb hammer falling 30 in. Samples were encased in stainless steel sleeves, ends covered with aluminum foil, and sealed with inert tape.

b Analyses by normal HPLC proceedure.

Approximate depth. Sample interval was noted but not sample depth. 
Table A-8. HE compounds in soil and rock samples obtained from B-827-E1 and B-827-E2.

\begin{tabular}{lllll}
\hline & & \multicolumn{3}{c}{ HE compounds micrograms/gram $(\mu \mathrm{g} / \mathrm{g})$ of soil } \\
\cline { 2 - 4 } Sample ID & Sample depth & HIMX & RDX & TNT \\
\hline & & & & \\
B-827-E1 & $1.0^{\mathrm{b}}$ & 6.2 & 0.007 & ND \\
B-827-E1 & $3.0^{\mathrm{b}}$ & 5.2 & 0.14 & ND \\
B-827-E1 & $5.0^{\mathrm{b}}$ & 1.1 & $<0.0006$ & ND \\
B-827-E1 & $9.5^{\mathrm{b}}$ & 3.2 & $<0.0008$ & ND \\
B-827-E2 & $7.0^{-7.2^{c}}$ & 0.39 & $-d$ & ND \\
\hline
\end{tabular}

Analyses by normal HPLC procedure.

bSamples from hand auger cuttings, packed in glass jar sealed with duct tape.

c Sample was obtained in a 1-1/2 -in. -o.d. stainless-steel tube filled by hand-driving a 1-1/2 -in.-i.d. split-spoon sampler. Tube ends were covered with aluminum foll and sealed with inert tape.

${ }^{d} R D X$ concentration could not be determined because of the presence of another substance with the same retention time as RDX. The substance was determined not to be RDX based upon dissimilar UV spectra.

NOTE: ND = Not detected, detection limit for TNT approximately $0.0008 \mu \mathrm{g} / \mathrm{gram}$. 
Table A-9. Soll analyses for HE compounds (HMX, RDX, and TN'T) reported by January 1990.

\begin{tabular}{|c|c|c|c|c|c|}
\hline \multirow[b]{2}{*}{ Wel.1 } & \multirow[b]{2}{*}{ Date } & \multirow[b]{2}{*}{ Depth } & \multicolumn{3}{|c|}{ HE compounds in $\mu \mathrm{g} / \mathrm{g}$ (ppm) } \\
\hline & & & $H M X$ & RDX & TNT \\
\hline \multirow[t]{12}{*}{$806-08$} & Apri1 1987 & 25.5 & $<0,0005$ & $<0,0005$ & $<0.0008$ \\
\hline & Apr11 1987 & 27.3 & $<0,0005$ & $<0.0005$ & $<0.0008$ \\
\hline & Apr11 1987 & 28.2 & $<0,0005$ & $<0,0005$ & $<0,0008$ \\
\hline & Apri1 1987 & 32.4 & $<0,0005$ & $<0.0005$ & $<0,0008$ \\
\hline & Apri1 1987 & 37.5 & $<0,0005$ & $<0,0005$ & $<0,0008$ \\
\hline & Apri1 1987 & 41.3 & $<0,00,105$ & $<0,0005$ & $<0.0008$ \\
\hline & Apri1 1987 & 46.7 & $<0,0005$ & $<0.0005$ & $<0.0008$ \\
\hline & Apr11 1987 & 53.6 & $<0,0005$ & $<0.0005$ & $<0.0008$ \\
\hline & Apri1 1987 & 55.0 & $<0,0005$ & $<0,0005$ & $<0.0008$ \\
\hline & Apri1 1987 & 55.6 & $<0.0005$ & $<0.0005$ & $<0,0008$ \\
\hline & Apri1 1987 & 57.9 & $<0,0005$ & $<0.0005$ & $<0.0008$ \\
\hline & April 1987 & 58.9 & $<0,0005$ & $<0.0005$ & $<0.0008$ \\
\hline \multirow[t]{9}{*}{ W- $809-01$} & Apri1 1988 & 10.5 & $<0.0008$ & $<0.0008$ & $<0.0008$ \\
\hline & April 1988 & 20.5 & $<0,0008$ & $<0,0008$ & $<0.0008$ \\
\hline & Apri1 1988 & 25.5 & $<0.0008$ & $<0.0008$ & $<0,0008$ \\
\hline & Apri1 1988 & 30.5 & $<0,0008$ & $<0.0008$ & $<0.0008$ \\
\hline & April 1988 & 35.5 & $<0,0008$ & $<0.0008$ & $<0.0008$ \\
\hline & April 1988 & 40.5 & $<0.0008$ & $<0.0008$ & $<0.0008$ \\
\hline & Apr11 1988 & 45.5 & $<0,0008$ & $<0.0008$ & $<0.0008$ \\
\hline & April 1988 & 55.8 & $<0.0008$ & $<0,0008$ & $<0.0008$ \\
\hline & April 1988 & 69.3 & $<0,0008$ & $<0.0008$ & $<0.0008$ \\
\hline \multirow[t]{3}{*}{ W-809.02 } & Apri1 1988 & 91.1 & $<0,0008$ & $<0.0008$ & $<0.0008$ \\
\hline & Apri1 1988 & 101.3 & $<0.0008$ & $<0.0008$ & $<0.0008$ \\
\hline & Apri1 1988 & 106.2 & $<0.0008$ & $<0.0008$ & $<0,0008$ \\
\hline \multirow[t]{14}{*}{$W-809-03$} & June 1.989 & 0.0 & $<0.001$ & $<0.002$ & $<0.001$ \\
\hline & June 1989 & 5.3 & $<0.001$ & $<0.001$ & $<0.001$ \\
\hline & June 1989 & 10.8 & $<0,001$ & $<0.001$ & $<0.001$ \\
\hline & June 1989 & 15.5 & 0.005 & $<0.001$ & $<0.001$ \\
\hline & June 1989 & 20.5 & 0.02 & $<0,001$ & $<0.001$ \\
\hline & June 1989 & 28.1 & $\cup .005$ & $<0.001$ & $<0,001$ \\
\hline & June 1989 & 41.0 & 0.0510 & 0.013 & $<0,001$ \\
\hline & June 1989 & 50.8 & 0.003 & $<0.001$ & $<0,001$ \\
\hline & July 1989 & 59.5 & $<0.001$ & $<0.001$ & $<0,001$ \\
\hline & July 1989 & 69.5 & $<0.001$ & $<0.001$ & $<0,001$ \\
\hline & July 1989 & 81.8 & $<0,001$ & $<0.001$ & $<0,001$ \\
\hline & Ju1y 1989 & 90.2 & $<0,001$ & $<0.001$ & $<0.001$ \\
\hline & July 1989 & 99.1 & $<0.001$ & $<0.001$ & $<0.001$ \\
\hline & July 1989 & 1.08 .9 & $<0,001$ & $<0.001$ & 0.001 \\
\hline W-810-01. & March 1988 & 5.1 & 0.0023 & $<0,0008$ & $<0,0008$ \\
\hline
\end{tabular}


Table A-9. Sol1 analyses for HE compounds (HMX, RDX, and I'NT) reported by January 1990.

\begin{tabular}{|c|c|c|c|c|c|}
\hline \multirow[b]{2}{*}{ We11 } & \multirow[b]{2}{*}{ Date } & \multirow[b]{2}{*}{ Depth } & \multicolumn{3}{|c|}{ HE compounds $\ln \mu \mathrm{g} / \mathrm{g}(\mathrm{ppm})$} \\
\hline & & & HMX & RDX & TNT \\
\hline & March 1988 & 10.5 & $<0,0008$ & $<0.0008$ & $<0,0008$ \\
\hline & March 1988 & 15.5 & 0.0012 & $<0.0008$ & $<0.0008$ \\
\hline & March 1988 & 20.3 & $<0,0008$ & $<0,0009$ & $<0.0008$ \\
\hline & March 1988 & 25.5 & $<0,0008$ & $<0.0008$ & $<0.0008$ \\
\hline & March 1988 & 30.0 & $<0.0008$ & $<0,0008$ & $<0.0008$ \\
\hline & March 1.988 & 39.8 & $<0.0008$ & $<0.0008$ & $<0.0008$ \\
\hline & Marr?: 1988 & 42.9 & 0.0011 & $<0.0008$ & $<0.0008$ \\
\hline & Narch 1988 & 60.0 & $<0,0008$ & $<0.0008$ & $<0.0008$ \\
\hline & March 1988 & 70.0 & 0.0015 & $<0.0008$ & $<0,0008$ \\
\hline & March 1988 & 87.0 & 0.0037 & 0.073 & $<0.0008$ \\
\hline & March 1988 & 99.8 & $<0.0008$ & $<0.0008$ & $<0.0008$ \\
\hline & March 1988 & 109.8 & $<0.0008$ & $<0.0008$ & $<0,0008$ \\
\hline & March 1988 & 110.0 & $<0.0008$ & $<0.0008$ & $<0,0008$ \\
\hline & March 1988 & 129.8 & $<0.0008$ & $<0,0008$ & $<0,0008$ \\
\hline & March 1988 & 135.0 & $<0,0008$ & $<0.0008$ & $<0,0008$ \\
\hline & March 1988 & 155.0 & $<0,0008$ & $<0.0008$ & $<0.0008$ \\
\hline & March 1988 & 157.0 & $<0.0008$ & $<0.0008$ & $<0.0008$ \\
\hline & March 1988 & 164.8 & $<0.0008$ & $<0.0008$ & $<0.0008$ \\
\hline & March 1988 & 165.0 & $<0,0008$ & $<0.0008$ & $<0.0008$ \\
\hline & March 1988 & 172.0 & $<0.0008$ & $<0.0008$ & $<0.0008$ \\
\hline & March 1988 & 185.0 & $<0.0008$ & $<0.0008$ & $<0.0008$ \\
\hline & March 1.988 & 191.5 & $<0.0008$ & $<0.0008$ & $<0,0008$ \\
\hline & March 1988 & 199.5 & $<0.0008$ & $<0.0008$ & $<0,0008$ \\
\hline \multirow[t]{8}{*}{813.01} & July 1989 & 0.8 & $<0.001$ & $<0.001$ & $<0,001$ \\
\hline & July 1989 & 5.8 & $<0,001$ & $<0,001$ & $<0.001$ \\
\hline & July 1989 & 10.5 & 0.11 & $<0.001$ & $<0,001$ \\
\hline & July 1989 & 15.8 & 0.087 & $<0.001$ & $<0.001$ \\
\hline & July 1989 & 20.8 & 0.026 & 0.002 & $<0.001$ \\
\hline & July 1.989 & 30.8 & $<0.001$ & $<0.001$ & $<0,001$ \\
\hline & July 1989 & 40.8 & 0.004 & $<0.001$ & $<0.001$ \\
\hline & July 1989 & 50.8 & $<0.001$ & $<0.001$ & $<0.001$ \\
\hline \multirow[t]{13}{*}{ W- $814-01$} & June 1987 & 5.8 & 0.68 & 0.052 & $<0.0008$ \\
\hline & June 1987 & 11.3 & 0.33 & 0.079 & $<0.0008$ \\
\hline & June 1987 & 13.8 & 0.036 & 0.0063 & $<0.0008$ \\
\hline & June 1987 & 18.8 & 0.054 & 0.026 & $<0.0008$ \\
\hline & June 1987 & 25.0 & $<0.0005$ & $<0.0005$ & $<0.0008$ \\
\hline & June 1987 & 30.0 & $<0.0005$ & $<0.0005$ & $<0.0008$ \\
\hline & June 1987 & 35.0 & $<0.0005$ & $<0.0005$ & $<0,0008$ \\
\hline & June 1987 & 40.0 & $<0.0005$ & $<0.0005$ & $<0.0008$ \\
\hline & June 1987 & 45.5 & $<0.0005$ & $<0,0005$ & $<0,0008$ \\
\hline & June 1987 & 50.8 & $<0,0005$ & $<0.0005$ & $<0,0008$ \\
\hline & June 1987 & 59.8 & $<0.0005$ & $<0,0005$ & $<0.00018$ \\
\hline & June 1987 & 70.0 & $<0.0005$ & $<0.0005$ & $<0.0008$ \\
\hline & June 1987 & 80.0 & $<0.0005$ & $<0,0005$ & $<0.0008$ \\
\hline
\end{tabular}


Table A-9. Soll analyses for HE compounds (HMX, RDX, and TNT) reported by January 1990.

\begin{tabular}{|c|c|c|c|c|c|}
\hline \multirow[b]{2}{*}{ We 11.} & \multirow[b]{2}{*}{ Date } & \multirow[b]{2}{*}{ Depth } & \multicolumn{3}{|c|}{ HE compounds $\ln \mu \mathrm{g} / \mathrm{g}($ ppir) } \\
\hline & & & $\operatorname{HMX}$ & RDX & TNT \\
\hline & June 1987 & 100.5 & $<0,0005$ & $<0,0005$ & $<0,0008$ \\
\hline & June 1987 & 110.3 & $<0.0005$ & $<0,0005$ & $<0,0008$ \\
\hline$W-81.5-01$ & May 1987 & 0.0 & $<0,0008$ & $<0.0008$ & $<0,0008$ \\
\hline & May 1987 & 10.5 & $<0,0008$ & $<0,0008$ & $<0,0008$ \\
\hline & May 1.987 & 15.5 & $<0,0008$ & $<0,0008$ & $<0,0008$ \\
\hline & May 1987 & 20,5 & $<0.0008$ & $<0,0008$ & $<0,0008$ \\
\hline & May 1987 & 28.0 & $<0.0008$ & $<0,0008$ & $<0,0008$ \\
\hline & May $198 \%$ & 33.0 & $<0,0008$ & $<0,0008$ & $<0.0008$ \\
\hline & May 1987 & 37.5 & $<0,0008$ & $<0,0008$ & $<0.0008$ \\
\hline & May 1987 & 42.5 & $<0,0008$ & $<0,0008$ & $<0,0008$ \\
\hline & May 1987 & 47.5 & $<0.0008$ & $<0.0008$ & $<0.0008$ \\
\hline$W-815-02$ & June 1987 & 0.0 & $<0.0005$ & $<0,0005$ & $<0,0008$ \\
\hline & June 1987 & 67.0 & $<0,0005$ & $<0,0005$ & $<0.0008$ \\
\hline & June 1987 & 73.5 & $<0,0005$ & $<0,0005$ & $<0.0008$ \\
\hline & June 1987 & 84.8 & $<0,0005$ & $<0,0005$ & $<0.0008$ \\
\hline & June 1987 & 96.3 & $<0,0005$ & $<0,0005$ & $<0.0008$ \\
\hline & June 1987 & 96.3 & $<0,0005$ & $<0,0005$ & $<0,0008$ \\
\hline & June 1987 & $106 \cdot 3$ & $<0.0005$ & $<0.0005$ & $<0.0008$ \\
\hline & June 1.987 & 106.3 & $<0.0005$ & $<0.0005$ & $<0,0008$ \\
\hline W- $81.5-03$ & February 1988 & 6.0 & $<0.0016$ & $<0,0017$ & $<0.001$ \\
\hline & February 1988 & 10.5 & $<0,0022$ & $<0,0023$ & $<0.001$ \\
\hline & February 1988 & 13.0 & $<0,002$ & $<0,0021$ & $<0.001$ \\
\hline & February 1.988 & 15.5 & $<0,0008$ & $<0,0008$ & $<0.001$ \\
\hline & February 1988 & 20.5 & $<0,0008$ & $<0,0008$ & $<0.001$ \\
\hline & February 1988 & 25.5 & $<0,0008$ & $<0,0008$ & $<0.001$ \\
\hline & February 1988 & 30.5 & $<0,0008$ & $<0,0008$ & $<0.001$ \\
\hline & February 1988 & 35.5 & $<0,0008$ & $<0,0008$ & $<0.001$ \\
\hline & February 1988 & 40.5 & $<0,0008$ & 0.069 & $<0,001$ \\
\hline & February 1988 & 45.5 & $<0,0011$ & $<0,0012$ & $<0.001$ \\
\hline$W-815-04$ & March 1988 & 10.0 & 0.0042 & $<0,0008$ & $<0.0008$ \\
\hline & March 1988 & 50.5 & $<0,0008$ & $<0,001$ & $<0.0008$ \\
\hline & March 1988 & 55.0 & $<0,0008$ & 0,068 & $<0.0008$ \\
\hline & March 1988 & 56.8 & $<0,0005$ & 0.048 & $<0.0008$ \\
\hline & March 1.988 & 65.5 & $<0,0005$ & 0.061 & $<0,0008$ \\
\hline & March 1988 & 71.3 & $<0,0005$ & 0.084 & $<0.0008$ \\
\hline & March 1988 & 75.8 & $<0,0005$ & $<0,0008$ & $<0,0008$ \\
\hline & March 1988 & 80.5 & $<0,0005$ & 0.013 & $<0,0008$ \\
\hline & March 1988 & 81.3 & $<0,0005$ & 0.02 & $<0,0008$ \\
\hline
\end{tabular}


Table A-9. Soll analyses for HE compounds (HMX, RDX, and I'N'T) reported by January 1990.

\begin{tabular}{|c|c|c|c|c|c|}
\hline \multirow[b]{2}{*}{ We11 } & \multirow[b]{2}{*}{ Date } & \multirow[b]{2}{*}{ liepth } & \multicolumn{3}{|c|}{ HE compounds $\ln \mu \mathrm{g} / \mathrm{g}(p \min )$} \\
\hline & & & $H M X$ & RDX & $\mathrm{TN}^{\prime} \mathrm{T}$ \\
\hline & March 1988 & 87.0 & $<0.0005$ & 0.024 & $<0.0008$ \\
\hline & March 1988 & 90.0 & $<0.0005$ & $<0,0005$ & $<0.0008$ \\
\hline & March 1988 & 100.5 & $<0,0005$ & $<0.0005$ & $<0,0008$ \\
\hline & March 1988 & 105.5 & $<0.0005$ & $<0.0005$ & $<0,0008$ \\
\hline \multirow[t]{8}{*}{$W-8.15 .05$} & July 1989 & 1.3 & $<0,001$ & $<0.001$ & $<0,001$ \\
\hline & July 1989 & 5.5 & $<0,001$ & $<0,001$ & $<0.001$ \\
\hline & July 1989 & 10.8 & 0.02 .8 & $<0,001$ & $<0,001$ \\
\hline & July 1989 & 15.8 & 0.005 & $<0,001$ & $<0,001$ \\
\hline & Juily 1989 & 20.8 & $<0.001$ & $<0,001$ & $<0,001$ \\
\hline & July 1989 & 31.0 & $<0.001$ & $<0.001$ & $<0.001$ \\
\hline & July 1.989 & 40.2 & $<0.001$ & $<0.001$ & $<0,001$ \\
\hline & July 1989 & 47.8 & $<0,001$ & $<0,001$ & $<0,001$ \\
\hline & & & & & \\
\hline \multirow[t]{31}{*}{$w .817 .05$} & June 1988 & 5.8 & $<0.0008$ & $<0.0008$ & $<0.0008$ \\
\hline & June 1988 & 10.8 & $<0.0008$ & $<0.0008$ & $<0,0008$ \\
\hline & June 1988 & 15.8 & $<0.0008$ & $<0.0008$ & $<0,0008$ \\
\hline & June 1988 & 20.5 & $<0,0008$ & $<0.0008$ & $<0,0008$ \\
\hline & June 1988 & 25.0 & $<0,0008$ & $<0.0008$ & $<0,0008$ \\
\hline & June 1988 & 30.3 & $<0.0008$ & $<0.0008$ & $<0,0008$ \\
\hline & June 1988 & 35.3 & $<0.0008$ & $<0.0008$ & $<0.0008$ \\
\hline & May 1988 & 41.0 & $<0,0008$ & $<0,0008$ & $<0,0008$ \\
\hline & May 1988 & 45.8 & $<0.0008$ & $<0.01$ & $<0,0008$ \\
\hline & May 1988 & 50.8 & $<0.0008$ & $<0,0008$ & $<0.0008$ \\
\hline & May 1.988 & 56.3 & $<0,0008$ & $<0.006$ & $<0.0008$ \\
\hline & May 1988 & 60.8 & $<0.0008$ & $<0,0008$ & $<0,0008$ \\
\hline & May 1988 & 65.8 & $<0.0008$ & $<0.0008$ & $<0,0008$ \\
\hline & May 1988 & 70.8 & $<0.0008$ & $<0.0008$ & $<0.0008$ \\
\hline & May 1988 & 75.8 & $<0.0008$ & $<0.003$ & $<0.0008$ \\
\hline & May 1988 & 80.8 & $<0,0008$ & $<0.0008$ & $<0,0008$ \\
\hline & May 1988 & 85.8 & $<0.0008$ & $<0,015$ & $<0,0008$ \\
\hline & May 1988 & 90.5 & $<0.0008$ & $<0.0008$ & $<0,0008$ \\
\hline & May 1.988 & 95.8 & $<0.0008$ & $<0.01$ & $<0,0008$ \\
\hline & May 1988 & 100.8 & $<0,0008$ & $<0,007$ & $<0,0008$ \\
\hline & May 1988 & 105.8 & $<0.0008$ & $\therefore 0.04$ & 0.0008 \\
\hline & May 1988 & 110.8 & $<0.0008$ & 60.007 & $<0.0008$ \\
\hline & May 1988 & 115.8 & $<0,0008$ & $<0.003$ & $<0.0008$ \\
\hline & May 1988 & 120.8 & $<0.0008$ & $<0,01$ & $<0.0008$ \\
\hline & May 1988 & 125.5 & $<0.0008$ & $<0.001$ & $<0,0008$ \\
\hline & May 1988 & 130.8 & $<0,0008$ & $<0,0008$ & $<0.0008$ \\
\hline & May 1.988 & 1.35 .8 & $<0,0008$ & $<0,0008$ & 60,00083 \\
\hline & May 1988 & 140.8 & $<0,0008$ & 0.0 .02 & 40.00088 \\
\hline & May 1.988 & 145.8 & $<0.0008$ & $\therefore 0,0008$ & $<0,000183$ \\
\hline & May 1989 & 150.8 & $<0,0008$ & 60.0008 & $<0,0008$ \\
\hline & May 1988 & 157.5 & $<0.0008$ & 0.0008 & $<0,0008$ \\
\hline
\end{tabular}


Table A-9, Sol1 analyses for HE compounds (HMX, RDX, and TNT) reported by January 1990.

\begin{tabular}{|c|c|c|c|c|c|}
\hline We 11 & Date & Depth & \multicolumn{3}{|c|}{$\begin{array}{c}\mathrm{HE} \text { compnunds } \text { in } \mu \mathrm{g} / \mathrm{g}(\mathrm{ppm}) \\
\ldots\end{array}$} \\
\hline 817.06 & $\begin{array}{ll}\text { May } & 1988 \\
\text { May } & 1988 \\
\text { May } & 1988 \\
\text { May } & 1988 \\
\text { May } & 1988 \\
\text { May } & 1988 \\
\text { May } & 1988 \\
\text { May } & 1988 \\
\text { May } & 1988 \\
\text { May } & 1988 \\
\text { May } & 1988 \\
\text { May } & 1988 \\
\text { May } & 1988 \\
\text { May } & 1988 \\
\text { May } & 1988 \\
\text { May } & 1988 \\
\text { May } & 1988 \\
\text { May } & 1988 \\
\text { May } & 1988 \\
\text { May } & 1988 \\
\text { May } & 1988 \\
\text { May } & 1988 \\
\text { May } & 1988\end{array}$ & $\begin{array}{l}6.0 \\
11.0 \\
16.0 \\
21.0 \\
26.0 \\
29.5 \\
35.2 \\
40.5 \\
46.0 \\
50.8 \\
55.0 \\
60.0 \\
65.0 \\
70.5 \\
75.5 \\
80.5 \\
85.0 \\
90.5 \\
95.5 \\
100.5 \\
105.5 \\
110.5 \\
115.5\end{array}$ & $\begin{array}{l}<0.0008 \\
<0.0008 \\
<0.0008 \\
<0.0008 \\
<0.0008 \\
<0.0008 \\
<0.0008 \\
<0.0008 \\
<0.0008 \\
<0.0008 \\
<0.0008 \\
<0.0008 \\
<0.0008 \\
<0.0008 \\
<0.0008 \\
<0.0011 \\
<0.0006 \\
<0.0014 \\
<0.0019 \\
<0.0008 \\
<0.0008 \\
<0.0015 \\
<0.0008\end{array}$ & $\begin{array}{l}<0.008 \\
<0.008 \\
<0.008 \\
<0.0008 \\
<0.008 \\
<0.0008 \\
<0.008 \\
<0.008 \\
<0.0008 \\
<0.008 \\
<0.0008 \\
<0.0012 \\
<0.001 \\
<0.001 \\
<0.0008 \\
<0.002 \\
<0.001 \\
<0.0015 \\
<0.002 \\
<0.0008 \\
<0.0008 \\
<0.0017 \\
<0.0008\end{array}$ & $\begin{array}{l}<0.0008 \\
<0.0008 \\
<0.0008 \\
<0.0008 \\
<0.0008 \\
<0.0008 \\
<0.0008 \\
<0,0008 \\
<0.0008 \\
<0.0008 \\
<0.001 \\
<0.001 \\
<0.001 \\
<0.001 \\
<0.001 \\
<0.001 \\
<0.001 \\
<0.001 \\
<0.001 \\
<0.001 \\
<0.001 \\
<0.001 \\
<0.001\end{array}$ \\
\hline $819-01$ & $\begin{array}{ll}\text { November } & 1986 \\
\text { November } & 1986 \\
\text { November } & 1986 \\
\text { November } & 1986 \\
\text { November } & 1986 \\
\text { November } & 1986 \\
\text { November } & 1986\end{array}$ & $\begin{array}{l}5.8 \\
10.8 \\
13.7 \\
18.5 \\
24.0 \\
28.4 \\
33.3\end{array}$ & $\begin{array}{l}1.3128 \\
0.122 \\
0.1484 \\
0.6638 \\
0.0187 \\
3.7168 \\
0.4211 .\end{array}$ & $\begin{array}{l}<0.0008 \\
<0.0008 \\
<0.0008 \\
<0.0005 \\
0.1193 \\
0.0345 \\
0.022\end{array}$ & $\begin{array}{l}<0,001 \\
<0,001 \\
<0.001 \\
<0,001 \\
<0.001 \\
<0.001 \\
<0.001\end{array}$ \\
\hline$W-819.03$ & $\begin{array}{ll}\text { January } & 1988 \\
\text { January } & 1988 \\
\text { January } & 1988 \\
\text { January } & 1988 \\
\text { January } & 1988 \\
\text { January } & 1988 \\
\text { January } & 1988 \\
\text { January } & 1988 \\
\text { January } & 1988 \\
\text { January } & 1988 \\
\text { January } & 1988\end{array}$ & $\begin{array}{l}10.0 \\
15.5 \\
20.0 \\
26.3 \\
30.7 \\
35.3 \\
40.3 \\
45.7 \\
50.3 \\
55.3 \\
60.3\end{array}$ & $\begin{array}{l}0.201 \\
0.054 \\
0.16 \\
0.285 \\
0.103 \\
0.008 \\
0.005 \\
<0.0008 \\
<0.0008 \\
<0.0008 \\
<0.0008\end{array}$ & $\begin{array}{l}<0.0008 \\
<0.0008 \\
<0.0008 \\
0.018 \\
0.082 \\
0.023 \\
0.009 \\
<0.0008 \\
<0.0008 \\
<0.0008 \\
<0.0008\end{array}$ & $\begin{array}{l}<0,0008 \\
<0,0008 \\
<0,0008 \\
<0,0008 \\
<0,0008 \\
<0,0008 \\
<0,0008 \\
<0,0008 \\
<0,0008 \\
<0,0008 \\
<0,0008\end{array}$ \\
\hline
\end{tabular}


Table A-9. Sol1 analyses for HE compounds (HMX, RDX, and INT) reported by January 1990.

\begin{tabular}{|c|c|c|c|c|c|}
\hline \multirow[b]{2}{*}{ We11 } & \multirow[b]{2}{*}{ Date } & \multirow[b]{2}{*}{ Depth } & \multicolumn{3}{|c|}{ 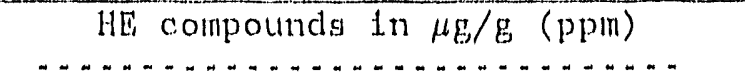 } \\
\hline & & & HMX & RDX & 'TN'T' \\
\hline \multirow[t]{10}{*}{829.01} & November 1986 & 2.5 & 3.1234 & 0,0145 & $<0.001$ \\
\hline & November 1986 & 4.8 & 1.7486 & 0.9049 & $<0.001$ \\
\hline & November $1: 986$ & 9.7 & 0.1413 & $<0,0011$ & $<0.001$ \\
\hline & November 1986 & 14.7 & 0.0232 & $<0,001$ & $<0,001$ \\
\hline & November 1986 & $19 \cdot 3$ & 0.0186 & $<0,0004$ & $<0.001$ \\
\hline & November 1986 & $\because 4.4$ & 0.3297 & $<0,0006$ & $<0,001$ \\
\hline & November 1986 & 30.0 & 1.1624 & 0.0174 & $<0.001$ \\
\hline & November 1986 & 34.3 & 0.224 & 0.0522 & $<0.001$ \\
\hline & November 1986 & 39.8 & 0.0175 & $<0,0009$ & $<0.001$ \\
\hline & November 1986 & 44.8 & 0.0587 & $<0,0008$ & $<0.001$ \\
\hline \multirow[t]{20}{*}{829.02} & December 1986 & 0.0 & 3.95 & 0.074 & $<0,0008$ \\
\hline & December 1986 & 5.1 & 0.071 & 0.045 & $<0.0008$ \\
\hline & December 1986 & 10.2 & 0.0006 & 0.017 & $<0,0008$ \\
\hline & December 1986 & 15.1 & 0.006 & 0.12 & $<0.0008$ \\
\hline & December 1986 & 20.6 & 0.026 & 0.033 & $<0.0008$ \\
\hline & December 1986 & 25.6 & 0.026 & 0.016 & $<0,0008$ \\
\hline & December 1986 & 29.1 & 0.0003 & 0.016 & $<0.0008$ \\
\hline & December 1986 & 35.6 & 0.0003 & 0.0003 & $<0.0008$ \\
\hline & December 1986 & 40.8 & $<0.0005$ & $<0.0005$ & $<0.0003$ \\
\hline & December 1986 & 45.6 & $<0.0005$ & $<0.0005$ & $<0.0003$ \\
\hline & December 1986 & 50.9 & $<0.0005$ & $<0.0005$ & $<0.0003$ \\
\hline & December 1986 & 55.6 & $<0.0005$ & $<0.0005$ & $<0.0003$ \\
\hline & December 1986 & 60.8 & $<0.0005$ & $<0.0005$ & $<0,0003$ \\
\hline & December 1986 & 69.8 & $<0.0005$ & $<0.0005$ & $<0,0003$ \\
\hline & December 1.986 & 75.7 & $<0.0005$ & $<0.0005$ & $<0.0003$ \\
\hline & December 1986 & 80.1 & $<0,0005$ & $<0.0005$ & $<0.0003$ \\
\hline & December 1986 & 85.2 & $<0.0005$ & $<0.0005$ & $<0,0003$ \\
\hline & December 1986 & 91.5 & $<0.0005$ & $<0.0005$ & $<0.0003$ \\
\hline & December 1986 & 94.7 & $<0.0005$ & $<0.0005$ & $<0,0003$ \\
\hline & December: 1986 & 100.7 & $<0.0005$ & $<0,0005$ & $<0,0003$ \\
\hline \multirow[t]{11}{*}{$829-03$} & Fobruary $198 \%$ & 0.0 & 0.98 & 0.18 & $<0.001$ \\
\hline & F'ebruary 1987 & 4.3 & 0.022 & 0.041 & $<0,001$ \\
\hline & February 1987 & 9.2 & 0.25 & 0.045 & $<0,001$ \\
\hline & February 1.987 & 1.4 .3 & 0.1 .2 & 0.027 & $<0.001$ \\
\hline & February 1987 & 19.2 & 0.58 & 0.038 & $<0.001$ \\
\hline & February 1.987 & 24,2 & $<0.0008$ & $<0,0008$ & $<0,001$ \\
\hline & February 1987 & 29.8 & $<0.0009$ & $<0,0009$ & $<0.001$ \\
\hline & February 1987 & 35.7 & $<0.0007$ & $<0.0007$ & $<0.001$ \\
\hline & February 1987 & 40.7 & $<0.0011$ & $<0.001$ & $<0.001$ \\
\hline & February 1987 & 45.5 & $<0.0005$ & $<0,0005$ & $<0,001$ \\
\hline & F'ebruary 1987 & 50.7 & $<0.0004$ & $<0.0004$ & $<0,001$ \\
\hline
\end{tabular}


Table A-9. Sol.1. analyses for HE compounds (HMX, RDX, and TNT) reported by January 1990.

\begin{tabular}{|c|c|c|c|c|c|}
\hline \multirow[b]{2}{*}{ We1.1 } & \multirow[b]{2}{*}{ Date } & \multirow[b]{2}{*}{ Depth } & \multicolumn{3}{|c|}{ HE compounds in $\mu \mathrm{g} / \mathrm{g}(\mathrm{ppm})$} \\
\hline & & & $\operatorname{HIMX}$ & $\mathrm{RDX}$ & TNT \\
\hline & February 1987 & 55.3 & 0.0012 & 0.0005 & $<0.001$ \\
\hline & February 1987 & 60.2 & $<0,0005$ & $<0,0005$ & $<0,001$ \\
\hline & February 1987 & 65.2 & $<0,0005$ & $<0.0005$ & $<0,001$ \\
\hline & February 1987 & 70.2 & 0.0066 & $<0.0005$ & $<0.001$ \\
\hline & February 1987 & 75.4 & 0.003 & $<0.0005$ & $<0.001$ \\
\hline & February 1987 & 80.3 & $<0.0005$ & $<0.0005$ & $<0.001$ \\
\hline & February 1987 & 85.3 & $<0.0005$ & $<0,0005$ & $<0.001$ \\
\hline & February 1987 & 90.4 & $<0,0005$ & $<0.0005$ & $<0.001$ \\
\hline & February 1987 & 95.2 & 0.0059 & $<0,0005$ & $<0.001$ \\
\hline & Apr11 1987 & 98.5 & 0.0056 & $<0.0005$ & $<0.0009$ \\
\hline & Apri1 1987 & 99.8 & 0.13 & 0.0097 & $<0.0009$ \\
\hline & February 1987 & 100.0 & 0.037 & 0.037 & $<0.001$ \\
\hline 829.04 & March 1987 & 5.0 & 0.74 & 0.018 & $<0.0008$ \\
\hline & March 1987 & $10 \cdot 4$ & $<0,0005$ & $<0.0005$ & $<0.0008$ \\
\hline & March 1987 & 15.5 & $<0,0005$ & $<0.0005$ & $<0.0008$ \\
\hline & March 1987 & 19.4 & $<0,0005$ & $<0.0005$ & $<0.0008$ \\
\hline & March 1987 & 26.8 & $<0.0005$ & $<0.0005$ & $<0.0008$ \\
\hline & March 1987 & 31.7 & $<0.0005$ & $<0.0005$ & $<0.0008$ \\
\hline & March 1987 & 37.9 & $<0.0005$ & $<0.0005$ & $<0.0008$ \\
\hline & March 1987 & 42.3 & $<0.0005$ & $<0.0005$ & $<0.0008$ \\
\hline & March 1987 & 48.3 & $<0.0005$ & $<0.0005$ & $<0.0008$ \\
\hline & Harch 1987 & 52.6 & $<0.0005$ & $<0.0005$ & $<0.0008$ \\
\hline & March 1987 & 57.8 & $<0,0005$ & $<0.0005$ & $<0.0008$ \\
\hline & March 1987 & 64.3 & $<0.0005$ & $<0.0005$ & $<0.0008$ \\
\hline & March 1987 & 71.5 & $<0.0005$ & $<0.0005$ & $<0.0008$ \\
\hline & March 1987 & 76.7 & $<0.0005$ & $<0.0005$ & $<0,0008$ \\
\hline & March 1987 & 81.7 & $<0,0005$ & $<0.0005$ & $<0.0008$ \\
\hline & March 1987 & 86.6 & $<0,0005$ & $<0,0005$ & $<0.0008$ \\
\hline & March 1987 & 91.7 & $<0,0005$ & $<0.0005$ & $<0.0008$ \\
\hline & March 1987 & 96.7 & $<0.0005$ & $<0.0005$ & $<0.0008$ \\
\hline & March 1987 & 101.0 & $<0.0005$ & $<0.0005$ & $<0.0008$ \\
\hline $829-05$ & January 1987 & 1.2 & 0.093 & 0.038 & $<0.0005$ \\
\hline & January 1987 & 5.2 & $<0.0005$ & $<0.0006$ & $<0.0005$ \\
\hline & January 1987 & 10.8 & $<0.0005$ & $<0.0006$ & $<0.0005$ \\
\hline & January 1987 & 15.4 & $<0.0005$ & $<0,0006$ & $<0.0005$ \\
\hline & January 1987 & 20.4 & $<0.0005$ & $<0.0006$ & $<0,0005$ \\
\hline & January 1987 & 25.4 & $<0,0005$ & $<0.0006$ & $<0.0005$ \\
\hline & January 1987 & 30.8 & $<0.0005$ & $<0.0006$ & $<0.0005$ \\
\hline & January 1987 & 35.5 & $<0.0005$ & $<0.0006$ & $<0.0005$ \\
\hline & January 1987 & 40.5 & $<0.0005$ & $<0.0006$ & $<0.0005$ \\
\hline & January 1987 & 45.5 & $<0.0005$ & $<0.0006$ & $<0.0005$ \\
\hline & January 1987 & 50.5 & $<0.0005$ & $<0,0006$ & $<0.0005$ \\
\hline & January 1987 & 54.7 & $<0.0005$ & $<0.0006$ & $<0.0005$ \\
\hline
\end{tabular}


Table A-9. Soll analyses for HE compounds (HMX, RDX, and TNT) reported by January 1990.

\begin{tabular}{|c|c|c|c|c|c|}
\hline \multirow[b]{2}{*}{ We11 } & \multirow[b]{2}{*}{ Date } & \multirow[b]{2}{*}{ Depth } & \multicolumn{3}{|c|}{ HE compounds in $\mu \mathrm{g} / \mathrm{g}(\mathrm{ppm})$} \\
\hline & & & HMX & RDX & TNT \\
\hline & January 1987 & 61.5 & $<0,0005$ & $<0,0006$ & $<0,0005$ \\
\hline & January 1987 & 66.5 & $<0.0005$ & $<0.0006$ & $<0,0005$ \\
\hline & January 1987 & 72.3 & $<0,0005$ & $<0,0006$ & $<0.0005$ \\
\hline & January 1987 & 76.9 & $<0.0005$ & $<0,0006$ & $<0.0005$ \\
\hline & January 1987 & 81.7 & $<0,0005$ & $<0,0006$ & $<0,0005$ \\
\hline & January 1987 & 87.2 & $<0.0005$ & $<0,0006$ & $<0.0005$ \\
\hline$M 5-01 A$ & October 1986 & 0.0 & $<0.0002$ & $<0.0004$ & $<0.0005$ \\
\hline & October 1986 & 10.8 & $<0,0002$ & 0.005 & $<0.0005$ \\
\hline & October 1986 & 15.5 & $<0.0002$ & 0.0108 & $<0.0005$ \\
\hline & October 1986 & 21.0 & $<0,0002$ & $<0.0004$ & $<0.000 .5$ \\
\hline & October 1986 & 25.5 & $<0,0002$ & $<0.0004$ & $<0,0005$ \\
\hline & October 1986 & 30.0 & $<0,0002$ & $<0.0004$ & $<0.0005$ \\
\hline & October 1986 & 32.2 & $<0,0002$ & $<0.0004$ & $<0,0005$ \\
\hline & October 1986 & 37.2 & $<0.0002$ & $<0,0004$ & $<0.0005$ \\
\hline & October 1986 & 42.3 & $<0,0002$ & $<0.0004$ & $<0.0005$ \\
\hline
\end{tabular}

Notes:

A11 analyses performed by HPLC Laboratory, LLNL. 
Table A-10. Soil analyses from the Dry Well. Investigation for HE compounds (HMX, RDX, and TNT) reported by January 1990.

\begin{tabular}{|c|c|c|c|c|c|}
\hline \multirow[b]{2}{*}{ We 11} & \multirow[b]{2}{*}{ Date } & \multirow[b]{2}{*}{ Depth } & \multicolumn{3}{|c|}{$\mathrm{HE}$ compounds in $\mu \mathrm{g} / \mathrm{g}$ (ppm) } \\
\hline & & & HMX & $\mathrm{RDX}$ & TNT \\
\hline \multirow[t]{5}{*}{$D-8.10 A-01$} & June 1989 & 1.0 & $<0.001$ & $<0.001$ & $<0.001$ \\
\hline & June 1989 & 5.0 & 0.026 & $<0.001$ & $<0.001$ \\
\hline & June 1989 & 10.0 & 0.024 & 0.002 & $<0.001$ \\
\hline & June 1989 & 17.0 & 0.027 & 0.002 & $<0.001$ \\
\hline & June 1989 & 20.8 & 0.039 & 0.002 & $<0.001$ \\
\hline \multirow[t]{5}{*}{$D-810 C-01$} & November 1989 & 2.3 & 21 & 0.006 & $<0.001$ \\
\hline & November 1989 & 6.0 & 2.7 & 0.028 & $<0.001$ \\
\hline & November 1989 & 12.0 & 1.2 & 0.39 & $<0.001$ \\
\hline & November 1989 & 16.2 & $<0.001$ & $<0.001$ & $<0.001$ \\
\hline & November 1989 & 19.3 & $<0.001$ & $<0.001$ & $<0.001$ \\
\hline \multirow[t]{5}{*}{ D $-827 A-01$} & June 1989 & 2.5 & 0.039 & 0.002 & $<0.001$ \\
\hline & June 1989 & 5.0 & 0.006 & 0.004 & $<0.001$ \\
\hline & June 1989 & 10.0 & $<0.0008$ & 0.035 & $<0.001$ \\
\hline & June 1989 & 16.0 & $<C .0008$ & $<0.001$ & $<0.001$ \\
\hline & June 1989 & 21.0 & $<0.0008$ & $<0.001$ & $<0.001$ \\
\hline \multirow[t]{3}{*}{ D $-827 \mathrm{~B}-01$} & June 1989 & 1.0 & $<0.0008$ & 0.05 & $<0.001$ \\
\hline & June 1989 & 5.0 & $<0.0008$ & 0.036 & $<0.001$ \\
\hline & June 1989 & 11.0 & $<0.0008$ & 0.002 & $<0.001$ \\
\hline \multirow[t]{5}{*}{ D $-827 \mathrm{C}-01$} & June 1989 & 1.0 & 1.47 & $<0.001$ & $<0.001$ \\
\hline & June 1989 & 5.0 & $<0.0008$ & $<0.001$ & $<0.001$ \\
\hline & June 1989 & 12.3 & $<0.0008$ & $<0.001$ & $<0.001$ \\
\hline & June 1989 & 15.3 & $<0.0008$ & $<0.001$ & $<0.001$ \\
\hline & June 1989 & 20.3 & $<0.0008$ & $<0.001$ & $<0.001$ \\
\hline \multirow[t]{4}{*}{$D-827 D-01$} & June 1989 & 5.3 & 0.02 & 0.002 & $<0.001$ \\
\hline & June 1989 & 10.3 & $<0.001$ & $<0.001$ & $<0.001$ \\
\hline & June 1989 & 17.1 & $<0.001$ & $<0.001$ & $<0.001$ \\
\hline & June 1989 & 20.3 & $<0.001$ & $<0.001$ & $<0.001$ \\
\hline \multirow[t]{5}{*}{ D- $827 E-01$} & June 1989 & 1.3 & $<0.001$ & $<0.001$ & $<0.001$ \\
\hline & June 1989 & 6.5 & $<0.001$ & $<0.001$ & $<0.001$ \\
\hline & June 1989 & 10.9 & 0.009 & 0.008 & $<0.001$ \\
\hline & June 1989 & 15.0 & $<0.001$ & $<0.001$ & $<0.001$ \\
\hline & June 1989 & 21.0 & $<0.001$ & $<0.001$ & $<0.001$ \\
\hline
\end{tabular}

Notes:

Ali andilyses peifuined by liRLC Laboratory, LINL. 


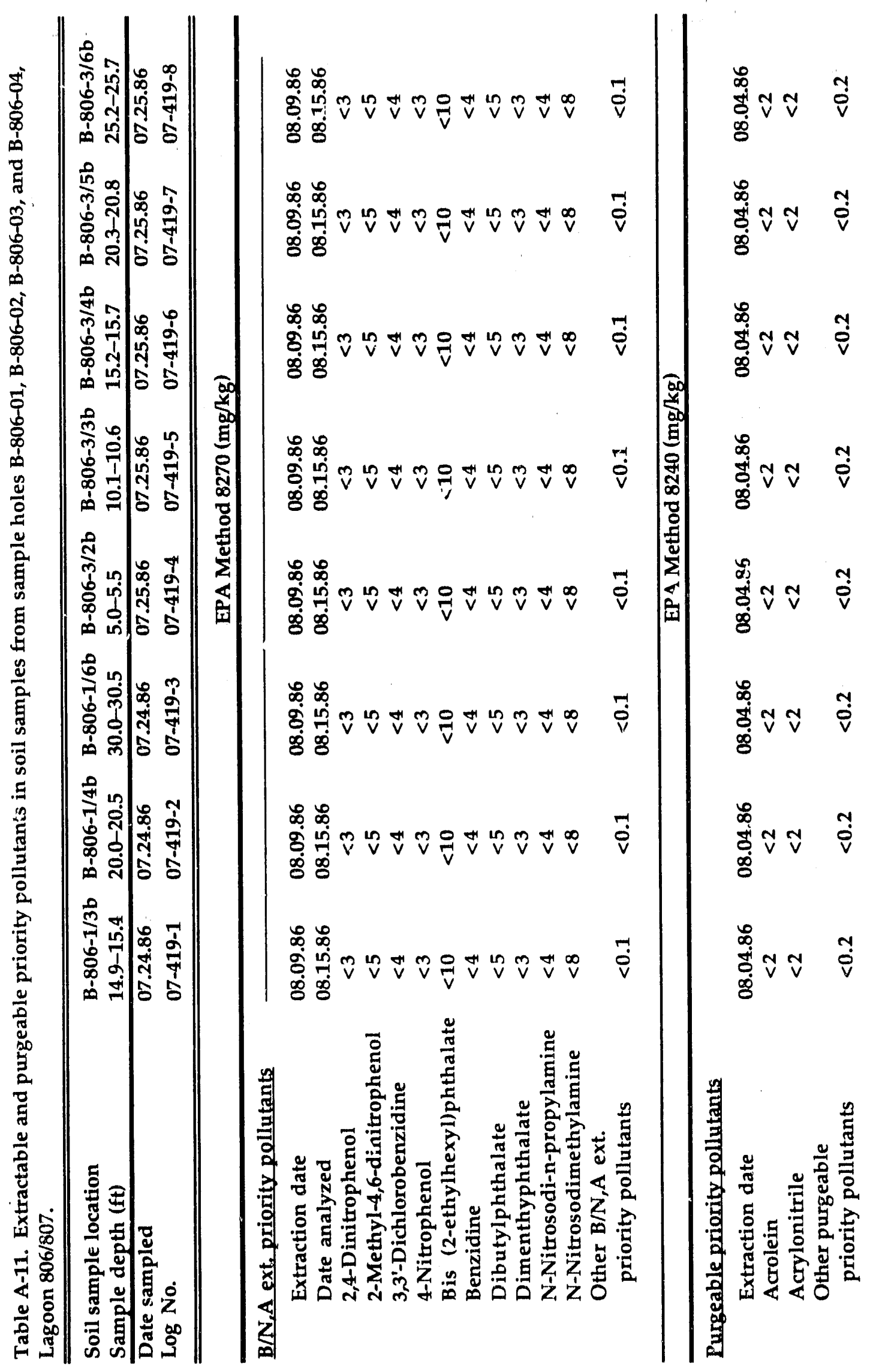




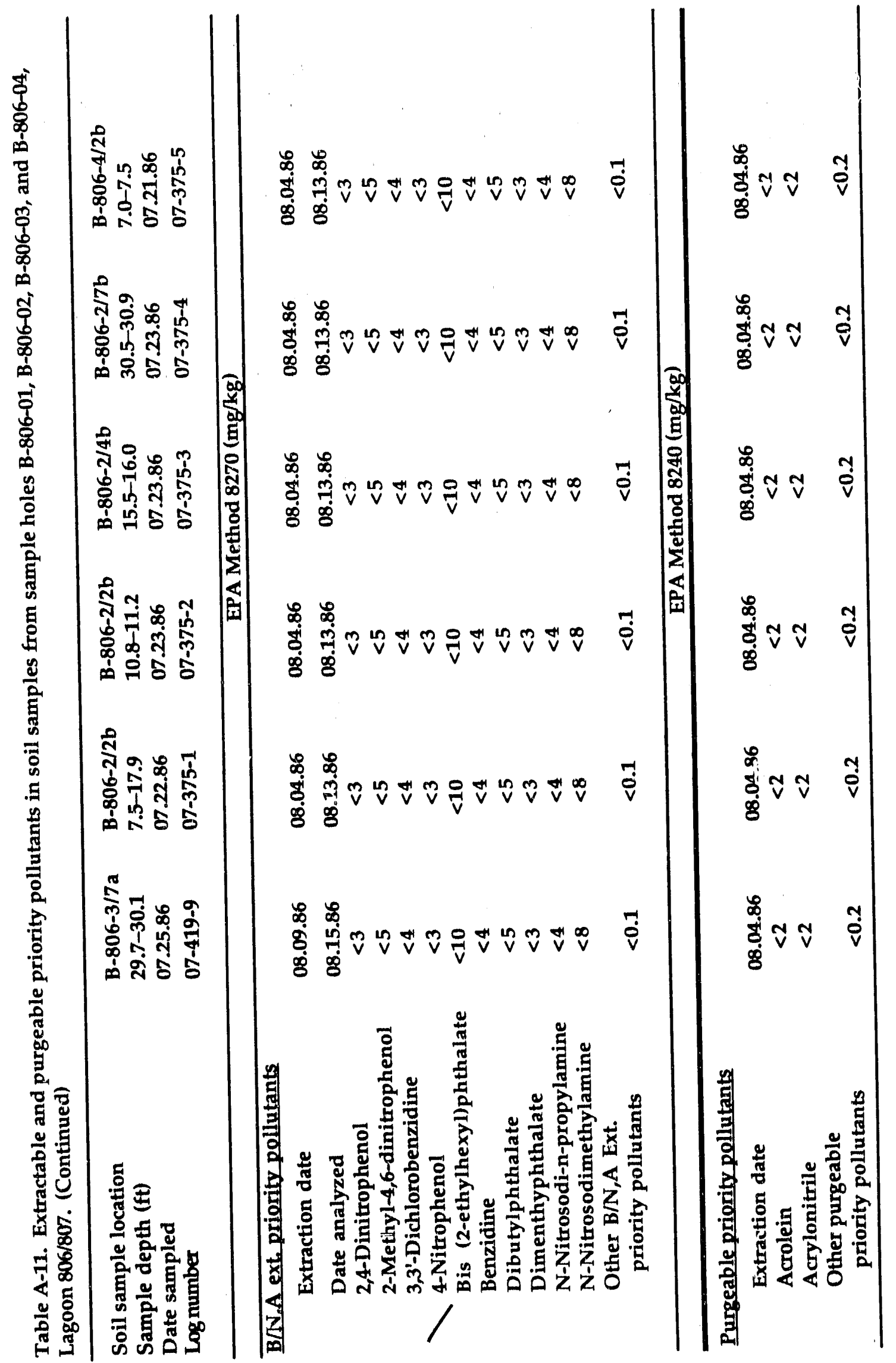




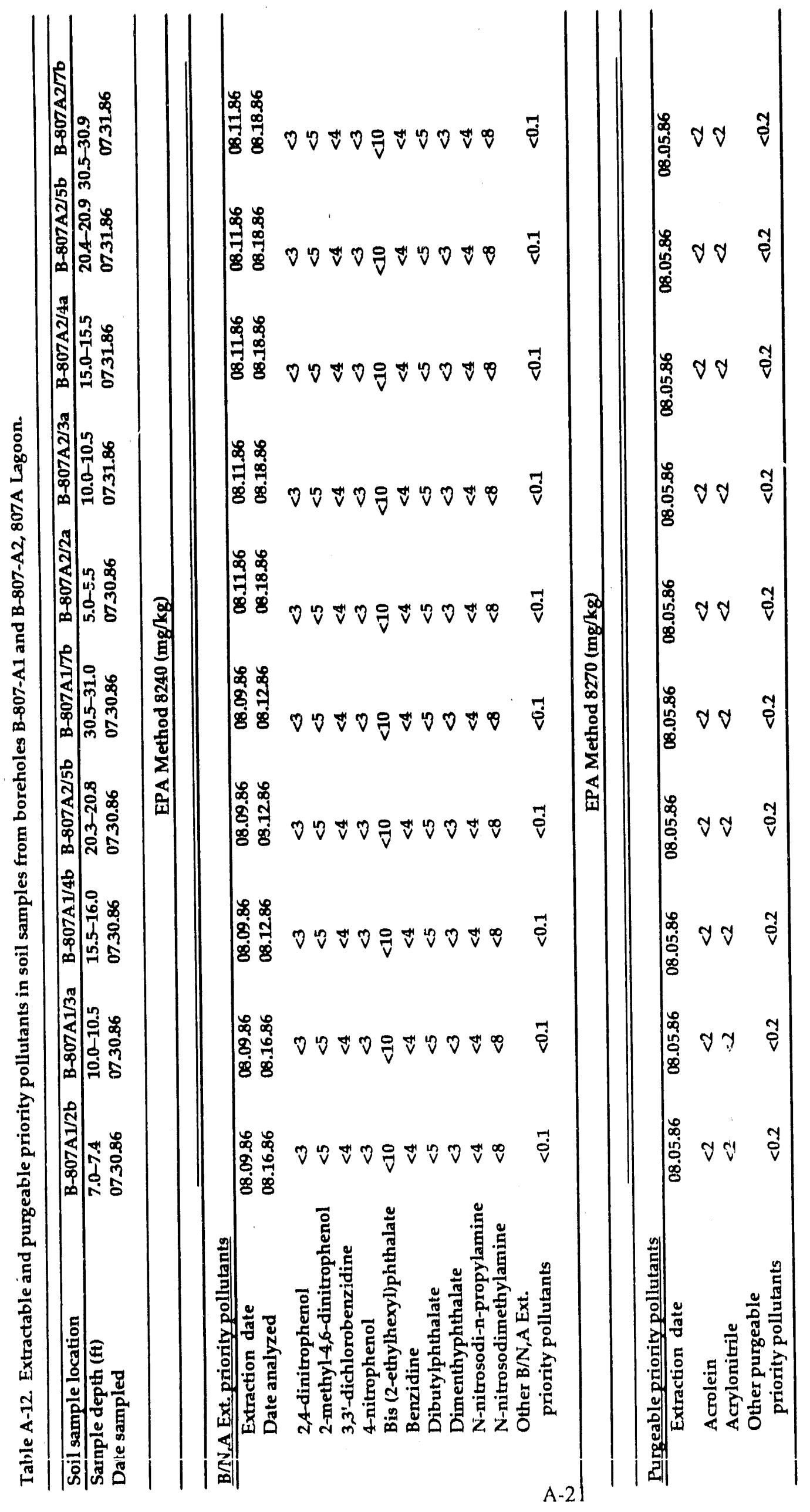


Table A-13. Extractable and purgeable priority' pollutants in soil samples, sample hole B-807-B1, 807B Lagoon.

\begin{tabular}{llllll}
\hline \hline Soil sample location & \\
Sample depth (ft) & B-807B1/2b & B-807B1/3b & B-807 $1 / 4 b$ & B-807B1/5b & B-807B1/7b \\
Date sampled & $5.0-5.5$ & $9.8-10.3$ & $14.8-15.3$ & $19.8-20.3$ & $30.0-30.5$ \\
\hline & 07.30 .86 & 07.30 .86 & 07.30 .86 & $\mathbf{0 7 . 3 0 . 8 6}$ & 07.30 .86 \\
\hline
\end{tabular}

B/N.A ext.priority pollutants

EPA Method $8270(\mathrm{mg} / \mathrm{kg})$

Extraction date

Date analyzed

2,4-dinitrophenol

2-methyl-4,6-dinitrophenol

3,3'-dichlorobenzidine

4-nitrophenol

Bis (2-ethylhexyl)ph thalate

Benzidine

Dibutylph thalate

Dimenthyph thalate

N-nitrosodi-n-propylamine

N-nitrosodimethylamine

Other B/N,A ext.

priority pollutants

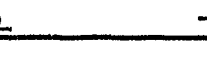

$\longrightarrow$

\begin{tabular}{lllll}
\hline 08.09 .86 & 08.09 .86 & 08.11 .86 & 08.11 .86 & 08.11 .86 \\
08.12 .86 & 08.12 .86 & 08.17 .86 & $08.1 \% .86$ & 08.17 .86
\end{tabular}

$<3 \quad<3 \quad<\quad<3<3$

$<5<<<<<<0$

$<4<4<4<4<4$

$<3<3<3<3<3$

$<10 \quad<10 \quad<10 \quad<10 \quad<10$

$<4<4<4<4<4$

$<5 \quad<5 \quad<5 \quad<5 \quad<5$

$<3<<<3<<<3$

$<4<4<4 \quad<4 \quad<4$

$\begin{array}{llll}<8 & <8 & <8 & <8\end{array}$

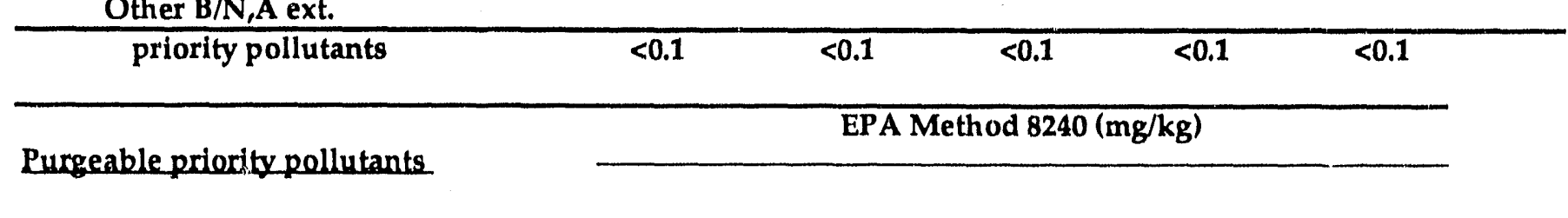

\begin{tabular}{lccccc}
\hline Extraction date & 08.05 .86 & 08.05 .86 & 08.05 .86 & 08.05 .86 & 08.05 .86 \\
Acrolein & $<2$ & $<2$ & $<2$ & $<2$ & $<2$ \\
Acrylonitrile & $<2$ & $<2$ & $<2$ & $<2$ & $<2$ \\
Other purgeable & & & & & \\
\hline priority pollutants & $<0.2$ & $<0.2$ & $<0.2$ & $<0.2$ & $<0.2$
\end{tabular}


Table A-14. Extractable and purgeable priority pollutants in soll and rock samples, sample hole B-817-01.

\begin{tabular}{|c|c|c|c|c|c|c|}
\hline $\begin{array}{l}\text { Sample locationa } \\
\text { Sample depth (ft) } \\
\text { Date sampled }\end{array}$ & $\begin{array}{l}\text { B.817-01 } \\
10.0-10.3 \\
10.22 .86\end{array}$ & $\begin{array}{l}\text { B-817-01 } \\
15.0-15.7 \\
10.22 .86\end{array}$ & $\begin{array}{l}B \sim 817 \sim 01 \\
21.5-22.3 \\
10.23 .86\end{array}$ & $\begin{array}{l}B-817-01 \\
25.0-25.8 \\
10.23 .86\end{array}$ & $\begin{array}{l}B-817-01 \\
30.7-31.5 \\
10.23 .86\end{array}$ & $\begin{array}{l}13-817-01 \\
35.7-36.5 \\
10.23 .86\end{array}$ \\
\hline B/NA ext priority pollutants & \multicolumn{6}{|c|}{ EPA method $8270(\mathrm{mg} / \mathrm{kg})$} \\
\hline $\begin{array}{l}\text { Date extracted } \\
\text { Date analyzed }\end{array}$ & $\begin{array}{l}10.30 .86 \\
11.03 .86\end{array}$ & $\begin{array}{l}10.30 .86 \\
11.03 .86\end{array}$ & $\begin{array}{l}10.30 .86 \\
11.03 .86\end{array}$ & $\begin{array}{l}10.30 .86 \\
11.04 .86\end{array}$ & $\begin{array}{l}10.30 .86 \\
11.04 .86\end{array}$ & $\begin{array}{l}10.30 .86 \\
11.04 .86\end{array}$ \\
\hline $\begin{array}{l}\text { 1,2,4-trichlorobenzene } \\
\text { 1,2-dich lorobenzene } \\
\text { 1,2-diphenylhydrazine } \\
\text { 1,3-dichlorobenzene } \\
\text { 1,4-dichlorobenzene }\end{array}$ & $\begin{array}{l}<0.1 \\
<0.1 \\
<0.1 \\
<0.1 \\
<0.1\end{array}$ & $\begin{array}{l}<0.1 \\
<0.1 \\
<0.1 \\
<0.1 \\
<0.1\end{array}$ & $\begin{array}{l}<0.1 \\
<0.1 \\
<0.1 \\
<0.1 \\
<0.1\end{array}$ & $\begin{array}{l}<0.1 \\
<0.1 \\
<0.1 \\
<0.1 \\
<0.1\end{array}$ & $\begin{array}{l}<0.1 \\
<0.1 \\
<0.1 \\
<0.1 \\
<0.1\end{array}$ & $\begin{array}{l}<0.1 \\
<0.1 \\
<0.1 \\
<0.1 \\
<0.1\end{array}$ \\
\hline $\begin{array}{l}\text { 2,4,6-trichlorophenol } \\
\text { 2,4-dichlorophenol } \\
\text { 2,4-dimethylphenol } \\
\text { 2,4-dinitrotoluene } \\
\text { 2,4-dinitrophenol }\end{array}$ & $\begin{array}{l}<0.1 \\
<0.1 \\
<0.1 \\
<0.1 \\
<3.0\end{array}$ & $\begin{array}{l}<0.1 \\
<0.1 \\
<0.1 \\
<0.1 \\
<3.0\end{array}$ & $\begin{array}{l}<0.1 \\
<0.1 \\
<0.1 \\
<0.1 \\
<3.0\end{array}$ & $\begin{array}{l}<0.1 \\
<0.1 \\
<0.1 \\
<0.1 \\
<3.0\end{array}$ & $\begin{array}{l}<0.1 \\
<0.1 \\
<0.1 \\
<0.1 \\
<3.0\end{array}$ & $\begin{array}{l}<0.1 \\
<0.1 \\
<0.1 \\
<0.1 \\
<3.0\end{array}$ \\
\hline $\begin{array}{l}\text { 2,6-dinitrotoluene } \\
\text { 2-chloronaphthalene } \\
\text { 2-nitrophenol } \\
\text { 2-chlorophenol } \\
\text { 2-methyl-4,6-dinitrophenol }\end{array}$ & $\begin{array}{l}<0.1 \\
<0.1 \\
<0.1 \\
<0.1 \\
<5.0\end{array}$ & $\begin{array}{l}<0.1 \\
<0.1 \\
<0.1 \\
<0.1 \\
<5.0\end{array}$ & $\begin{array}{l}<0.1 \\
<0.1 \\
<0.1 \\
<0.1 \\
<5.0\end{array}$ & $\begin{array}{l}<0.1 \\
<0.1 \\
<0.1 \\
<0.1 \\
<5.0\end{array}$ & $\begin{array}{l}<0.1 \\
<0.1 \\
<0.1 \\
<0.1 \\
<5.0\end{array}$ & $\begin{array}{l}<0.1 \\
<0.1 \\
<0.1 \\
<0.1 \\
<5.0\end{array}$ \\
\hline $\begin{array}{l}\text { 3,3'-dichlorobenzidine } \\
\text { 4-bromophenylphenylether } \\
\text { 4-chloro-3-methylphenol } \\
\text { 4-chlorophenylphenylether } \\
\text { 4-nitrophenol }\end{array}$ & $\begin{array}{l}<4.0 \\
<0.1 \\
<0.1 \\
<0.1 \\
<3.0\end{array}$ & $\begin{array}{l}<4.0 \\
<0.1 \\
<0.1 \\
<0.1 \\
<3.0\end{array}$ & $\begin{array}{l}<4.0 \\
<0.1 \\
<0.1 \\
<0.1 \\
<3.0\end{array}$ & $\begin{array}{l}<4.0 \\
<0.1 \\
<0.1 \\
<0.1 \\
<3.0\end{array}$ & $\begin{array}{l}<4.0 \\
<0.1 \\
<0.1 \\
<0.1 \\
<3.0\end{array}$ & $\begin{array}{l}<4.0 \\
<0.1 \\
<0.1 \\
<0.1 \\
<3.0\end{array}$ \\
\hline $\begin{array}{l}\text { Acenaphthene } \\
\text { Acenaphthylene } \\
\text { Anthracene } \\
\text { Bis(2-ethylhexyl)phthalate } \\
\text { Benzidine }\end{array}$ & $\begin{array}{l}<0.1 \\
<0.1 \\
<0.1 \\
<16.0 \\
<4.0\end{array}$ & $\begin{array}{l}<0.1 \\
<0.1 \\
<0.1 \\
<10.0 \\
<4.0\end{array}$ & $\begin{array}{r}<0.1 \\
<0.1 \\
<0.1 \\
<10.0 \\
<4.0\end{array}$ & $\begin{array}{l}<0.1 \\
<0.1 \\
<0.1 \\
<10.0 \\
<4.0\end{array}$ & $\begin{array}{r}<0.1 \\
<0.1 \\
<0.1 \\
<10.0 \\
<4.0\end{array}$ & $\begin{array}{l}<0.1 \\
<0.1 \\
<0.1 \\
<10.0 \\
<4.0\end{array}$ \\
\hline $\begin{array}{l}\text { Bis(2-chloroethyl)ether } \\
\text { Bis(2-chloroisopropyl)ether } \\
\text { Bis(2-chloroethoxy)methane } \\
\text { Benzo(a)anthracene } \\
\text { Benzo(a)pyrene }\end{array}$ & $\begin{array}{l}<0.1 \\
<0.1 \\
<0.1 \\
<0.1 \\
<0.1\end{array}$ & $\begin{array}{l}<0.1 \\
<0.1 \\
<0.1 \\
<0.1 \\
<0.1\end{array}$ & $\begin{array}{l}<0.1 \\
<0.1 \\
<0.1 \\
<0.1 \\
<0.1\end{array}$ & $\begin{array}{l}<0.1 \\
<0.1 \\
<0.1 \\
<0.1 \\
<0.1\end{array}$ & $\begin{array}{l}<0.1 \\
<0.1 \\
<0.1 \\
<0.1 \\
<0.1\end{array}$ & $\begin{array}{l}<0.1 \\
<0.1 \\
<0.1 \\
<0.1 \\
<0.1\end{array}$ \\
\hline $\begin{array}{l}\text { Benzo(b)fluoranthene } \\
\text { Benzo(g,h,i)perylene } \\
\text { Benzo(k)fluoranthene } \\
\text { Butylbenzylph thalate } \\
\text { Chrysene }\end{array}$ & $\begin{array}{l}<0.1 \\
<0.1 \\
<0.1 \\
<0.1 \\
<0.1\end{array}$ & $\begin{array}{l}<0.1 \\
<0.1 \\
<0.1 \\
<0.1 \\
<0.1\end{array}$ & $\begin{array}{l}<0.1 \\
<0.1 \\
<0.1 \\
<0.1 \\
<0.1\end{array}$ & $\begin{array}{l}<0.1 \\
<0.1 \\
<0.1 \\
<0.1 \\
<0.1\end{array}$ & $\begin{array}{l}<0.1 \\
<0.1 \\
<0.1 \\
<0.1 \\
<0.1\end{array}$ & $\begin{array}{l}<0.1 \\
<0.1 \\
<0.1 \\
<0.1 \\
<0.1\end{array}$ \\
\hline $\begin{array}{l}\text { Di-n-octylph thalate } \\
\text { Dibenzo(a,h)anthracene } \\
\text { Dibutylphthalate }\end{array}$ & $\begin{array}{l}<0.1 \\
<0.1 \\
<5.0\end{array}$ & $\begin{array}{l}<0.1 \\
<0.1 \\
<5.0\end{array}$ & $\begin{array}{l}<0.1 \\
<0.1 \\
<5.0\end{array}$ & $\begin{array}{l}<0.1 \\
<0.1 \\
<5.0\end{array}$ & $\begin{array}{l}<0.1 \\
<0.1 \\
<5.0\end{array}$ & $\begin{array}{l}<0.1 \\
<0.1 \\
<5.0\end{array}$ \\
\hline
\end{tabular}


Table A-14. (Continued)

\begin{tabular}{|c|c|c|c|c|c|c|}
\hline $\begin{array}{l}\text { Sample location" } \\
\text { Sample depth }(\mathrm{ft}) \\
\text { Date sampled }\end{array}$ & $\begin{array}{l}\text { B-817-01 } \\
10.0-10.3 \\
10.22 .86\end{array}$ & $\begin{array}{l}\text { B-817-01 } \\
15.0-15.7 \\
10.22 .86\end{array}$ & $\begin{array}{l}B-817-01 \\
21.5-22.3 \\
10.23 .86\end{array}$ & $\begin{array}{l}B-817-01 \\
25.0-25.8 \\
10.23 .86\end{array}$ & $\begin{array}{l}\text { B- } 817-01 \\
30.7-31.5 \\
10.23 .86\end{array}$ & $\begin{array}{l}\text { B-817-01 } \\
35.7-36.5 \\
10.23 .86\end{array}$ \\
\hline & \multicolumn{6}{|c|}{ EPA method $8270(\mathrm{mg} / \mathrm{kg})$} \\
\hline $\begin{array}{l}\text { Date extracted } \\
\text { Date analyzed }\end{array}$ & $\begin{array}{l}10.30 .86 \\
11.03 .86\end{array}$ & $\begin{array}{l}10.30 .86 \\
11.03 .86\end{array}$ & $\begin{array}{l}10.30 .86 \\
11.03 .86\end{array}$ & $\begin{array}{l}10.30 .86 \\
11.04 .86\end{array}$ & $\begin{array}{l}10.30 .86 \\
11.04 .86\end{array}$ & $\begin{array}{l}10.30 .86 \\
11.04 .86\end{array}$ \\
\hline $\begin{array}{l}\text { Diethylphthalate } \\
\text { Dimethylph thalate }\end{array}$ & $\begin{array}{l}<0.1 \\
<3.0\end{array}$ & $\begin{array}{l}<0.1 \\
<3.0\end{array}$ & $\begin{array}{l}<0.1 \\
<3.0\end{array}$ & $\begin{array}{l}<0.1 \\
<3.0\end{array}$ & $\begin{array}{l}<0.1 \\
<3.0\end{array}$ & $\begin{array}{l}<0.1 \\
<3.0\end{array}$ \\
\hline $\begin{array}{l}\text { Fluorene } \\
\text { Fluoranthene } \\
\text { Hexachlorobenzene } \\
\text { Hexachlorobutadiene } \\
\text { Hexachlorocyclopentadiene }\end{array}$ & $\begin{array}{l}<0.1 \\
<0.1 \\
<0.1 \\
<0.1 \\
<0.1\end{array}$ & $\begin{array}{l}<0.1 \\
<0.1 \\
<0.1 \\
<0.1 \\
<0.1\end{array}$ & $\begin{array}{l}<0.1 \\
<0.1 \\
<0.1 \\
<0.1 \\
<0.1\end{array}$ & $\begin{array}{l}<0.1 \\
<0.1 \\
<0.1 \\
<0.1 \\
<0.1\end{array}$ & $\begin{array}{l}<0.1 \\
<0.1 \\
<0.1 \\
<0.1 \\
<0.1\end{array}$ & $\begin{array}{l}<0.1 \\
<0.1 \\
<0.1 \\
<0.1 \\
<0.1\end{array}$ \\
\hline $\begin{array}{l}\text { Hexachloroethane } \\
\text { Indeno }(1,2,3-c, d) \text { pyrene } \\
\text { Isophorone } \\
\text { N-nitrosodi-n-propylamine } \\
\text { N-nitrosodimethylamine }\end{array}$ & $\begin{array}{l}<0.1 \\
<0.1 \\
<0.1 \\
<4.0 \\
<8.0\end{array}$ & $\begin{array}{l}<0.1 \\
=0.1 \\
<0.1 \\
<4.0 \\
<8.0\end{array}$ & $\begin{array}{l}<0.1 \\
<0.1 \\
<0.1 \\
<4.0 \\
<8.0\end{array}$ & $\begin{array}{l}<0.1 \\
<0.1 \\
<0.1 \\
<4.0 \\
<8.0\end{array}$ & $\begin{array}{l}<0.1 \\
<0.1 \\
<0.1 \\
<4.0 \\
<8.0\end{array}$ & $\begin{array}{l}<0.1 \\
<0.1 \\
<0.1 \\
<4.0 \\
<8.0\end{array}$ \\
\hline $\begin{array}{l}\text { N-nitrosodiphenylamine } \\
\text { Naphthalene } \\
\text { Nitrobenzene } \\
\text { Pentachlorophenol } \\
\text { Phenanthrene }\end{array}$ & $\begin{array}{l}<0.1 \\
<0.1 \\
<0.1 \\
<0.1 \\
<0.1\end{array}$ & $\begin{array}{l}<0.1 \\
<0.1 \\
<0.1 \\
<0.1 \\
<0.1\end{array}$ & $\begin{array}{l}<0.1 \\
<0.1 \\
<0.1 \\
<0.1 \\
<0.1\end{array}$ & $\begin{array}{l}<0.1 \\
<0.1 \\
<0.1 \\
<0.1 \\
<0.1\end{array}$ & $\begin{array}{l}<0.1 \\
<0.1 \\
<0.1 \\
<0.1 \\
<0.1\end{array}$ & $\begin{array}{l}<0.1 \\
<0.1 \\
<0.1 \\
<0.1 \\
<0.1\end{array}$ \\
\hline $\begin{array}{l}\text { Phenol } \\
\text { Pyrene }\end{array}$ & $\begin{array}{l}<0.1 \\
<0.1\end{array}$ & $\begin{array}{l}<0.1 \\
<0.1\end{array}$ & $\begin{array}{l}<0.1 \\
<0.1\end{array}$ & $\begin{array}{l}<0.1 \\
<0.1\end{array}$ & $\begin{array}{l}<0.1 \\
<0.1\end{array}$ & $\begin{array}{l}<0.1 \\
<0.1\end{array}$ \\
\hline
\end{tabular}

Purgeable priority pollutants

EPA Method $8240(\mathrm{mg} / \mathrm{kg})$

Date extracted
Date analyzed

1,1,1-trichloroethane

1,1,2,2-tetrachloroethane

1,1,2-trichloroethane

1,1-dichloroethane

1,1-dichloroethylene

1,2-dichloroethane

1,2-dichloropropane

1,3-dichloropropene

2-chloroethylvinylether

Acrolein

Acrylonitrile

Fit amodichloromethane

Brumomethane

\begin{tabular}{cccccc}
\hline 10.22 .86 & 10.22 .86 & 10.23 .86 & 10.23 .86 & 10.23 .86 & 10.23 .86 \\
11.07 .86 & 11.07 .86 & 11.07 .86 & 11.07 .86 & 11.07 .86 & 11.07 .86 \\
$<0.2$ & $<0.2$ & $<0.2$ & $<0.2$ & $<0.2$ & $<0.2$ \\
$<0.2$ & $<0.2$ & $<0.2$ & $<0.2$ & $<0.2$ & $<0.2$ \\
$<0.2$ & $<11.2$ & $<0.2$ & $<0.2$ & $<0.2$ & $<0.2$ \\
$<0.2$ & $<0.2$ & $<0.2$ & $<0.2$ & $<0.2$ & $<0.2$ \\
$<0.2$ & $<0.2$ & $<0.2$ & $<0.2$ & $<0.2$ & $<0.2$ \\
$<0.2$ & $<0.2$ & $<0.2$ & $<0.2$ & $<0.2$ & $<0.2$ \\
$<0.2$ & $<0.2$ & $<0.2$ & $<0.2$ & $<0.2$ & $<0.2$ \\
$<0.2$ & $<0.2$ & $<0.2$ & $<0.2$ & $<0.2$ & $<0.2$ \\
$<0.2$ & $<0.2$ & $<0.2$ & $<0.2$ & $<0.2$ & $<0.2$ \\
$<2.0$ & $<2.0$ & $<2.0$ & $<2.0$ & $<2.0$ & $<2.0$ \\
$<2.0$ & $<2.0$ & $<2.0$ & $<2.0$ & $<2.0$ & $<2.0$ \\
$<0.2$ & $<0.2$ & $<0.2$ & $<0.2$ & $<0.2$ & $<0.2$ \\
$<0.2$ & $<0.2$ & $<0.2$ & $<0.2$ & $<0.2$ & $<0.2$
\end{tabular}


Table A-14. (Continued)

\begin{tabular}{|c|c|c|c|c|c|c|}
\hline $\begin{array}{l}\text { Sample location" } \\
\text { Sample depth ( } f t) \\
\text { Date sampled }\end{array}$ & $\begin{array}{l}B-817 \times 01 \\
10.0-10.3 \\
10.22 .86\end{array}$ & $\begin{array}{l}B \cdot 817 \sim 01 \\
15.0-15.7 \\
10.22 .86\end{array}$ & $\begin{array}{l}B-8.17 \cdot 01 \\
21.5-22.3 \\
10.23 .86\end{array}$ & $\begin{array}{l}\text { B. } 817-01 \\
25.0-25.8 \\
10.23 .86\end{array}$ & $\begin{array}{l}\text { B }-817-01 \\
30.7-31.5 \\
10.23 .86\end{array}$ & $\begin{array}{l}B-817-01 \\
35.7-36.5 \\
10.23 .86\end{array}$ \\
\hline Purgeable priority pollutants & \multicolumn{6}{|c|}{ EPA Method $8240(\mathrm{mg} / \mathrm{kg})$} \\
\hline $\begin{array}{l}\text { Datc extracted } \\
\text { Date analyzed }\end{array}$ & $\begin{array}{l}10.22 .86 \\
11.07 .86\end{array}$ & $\begin{array}{l}10.22 .86 \\
11.07 .86\end{array}$ & $\begin{array}{l}10.23 .86 \\
11.07 .86\end{array}$ & $\begin{array}{l}10.23 .86 \\
11.07 .86\end{array}$ & $\begin{array}{l}10.23 .86 \\
11.07 .86\end{array}$ & $\begin{array}{l}10.23 .86 \\
11.07 .86\end{array}$ \\
\hline $\begin{array}{l}\text { Benzene } \\
\text { Chlorobenzene }\end{array}$ & $\begin{array}{l}<0.2 \\
<0.2\end{array}$ & $\begin{array}{l}<0.2 \\
<0.2\end{array}$ & $\begin{array}{l}<0.2 \\
<0.2\end{array}$ & $\begin{array}{l}<0.2 \\
<0.2\end{array}$ & $\begin{array}{l}<0.2 \\
<0.2\end{array}$ & $\begin{array}{l}<0.2 \\
<0.2\end{array}$ \\
\hline $\begin{array}{l}\text { Carbon tetrachloride } \\
\text { Chloroethane } \\
\text { Bromoform } \\
\text { Chloroform } \\
\text { Chloromethane }\end{array}$ & $\begin{array}{l}<0.2 \\
<0.2 \\
<0.2 \\
<0.2 \\
<0.2\end{array}$ & $\begin{array}{l}<0.2 \\
<0.2 \\
<0.2 \\
<0.2 \\
<0.2\end{array}$ & $\begin{array}{l}<0.2 \\
<0.2 \\
<0.2 \\
<0.2 \\
<0.2\end{array}$ & $\begin{array}{l}<0.2 \\
<0.2 \\
<0.2 \\
<0.2 \\
<0.2\end{array}$ & $\begin{array}{l}<0.2 \\
<0.2 \\
<0.2 \\
<0.2 \\
<0.2\end{array}$ & $\begin{array}{l}<0.2 \\
<0.2 \\
<0.2 \\
<0.2 \\
<0.2\end{array}$ \\
\hline $\begin{array}{l}\text { Dibromochloromethane } \\
\text { Ethylbenzene } \\
\text { Methylene chloride } \\
\text { Tetrachloroethylene } \\
\text { Trichloroethylene }\end{array}$ & $\begin{array}{l}<0.2 \\
<0.2 \\
<0.2 \\
<0.2 \\
<0.2\end{array}$ & $\begin{array}{l}<0.2 \\
<0.2 \\
<0.2 \\
<0.2 \\
<0.2\end{array}$ & $\begin{array}{l}<0.2 \\
<0.2 \\
<0.2 \\
<0.2 \\
<0.2\end{array}$ & $\begin{array}{l}<0.2 \\
<0.2 \\
<0.2 \\
<0.2 \\
<0.2\end{array}$ & $\begin{array}{l}<0.2 \\
<0.2 \\
<0.2 \\
<0.2 \\
<0.2\end{array}$ & $\begin{array}{l}<0.2 \\
<0.2 \\
<0.2 \\
<0.2 \\
<0.2\end{array}$ \\
\hline $\begin{array}{l}\text { Trichlorofluoromethane } \\
\text { Toluene } \\
\text { Vinyl chloride } \\
\text { trans-1,2-dichloroethylene } \\
\text { trans-1,3-dichloropropene }\end{array}$ & $\begin{array}{l}<0.2 \\
<0.2 \\
<0.2 \\
<0.2 \\
<0.2\end{array}$ & $\begin{array}{l}<0.2 \\
<0.2 \\
<0.2 \\
<0.2 \\
<0.2\end{array}$ & $\begin{array}{l}<0.2 \\
<0.2 \\
<0.2 \\
<0.2 \\
<0.2\end{array}$ & $\begin{array}{l}<0.2 \\
<0.2 \\
<0.2 \\
<0.2 \\
<0.2\end{array}$ & $\begin{array}{l}<0.2 \\
<0.2 \\
<0.2 \\
<0.2 \\
<0.2\end{array}$ & $\begin{array}{l}<0.2 \\
<0.2 \\
<0.2 \\
<0.2 \\
<0.2\end{array}$ \\
\hline
\end{tabular}

"All samples were collected with a 1-1/2-in.-1,d, split-spoon sampler advanced by a 140-1b hammer falling 30 in. Samples were encased in stainless stecl slecves, ends covered with aluminum foll, and sealed with inert tape. 


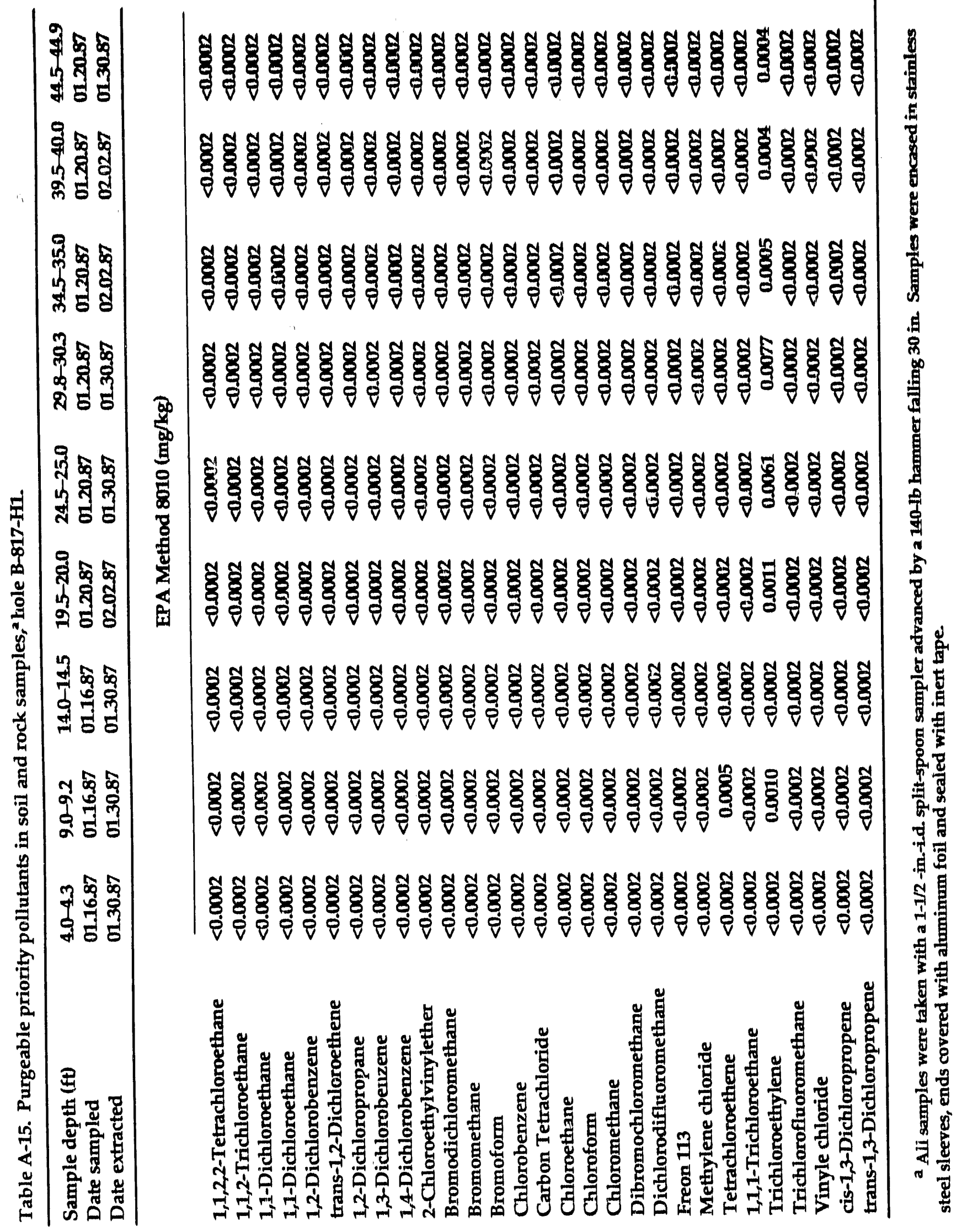




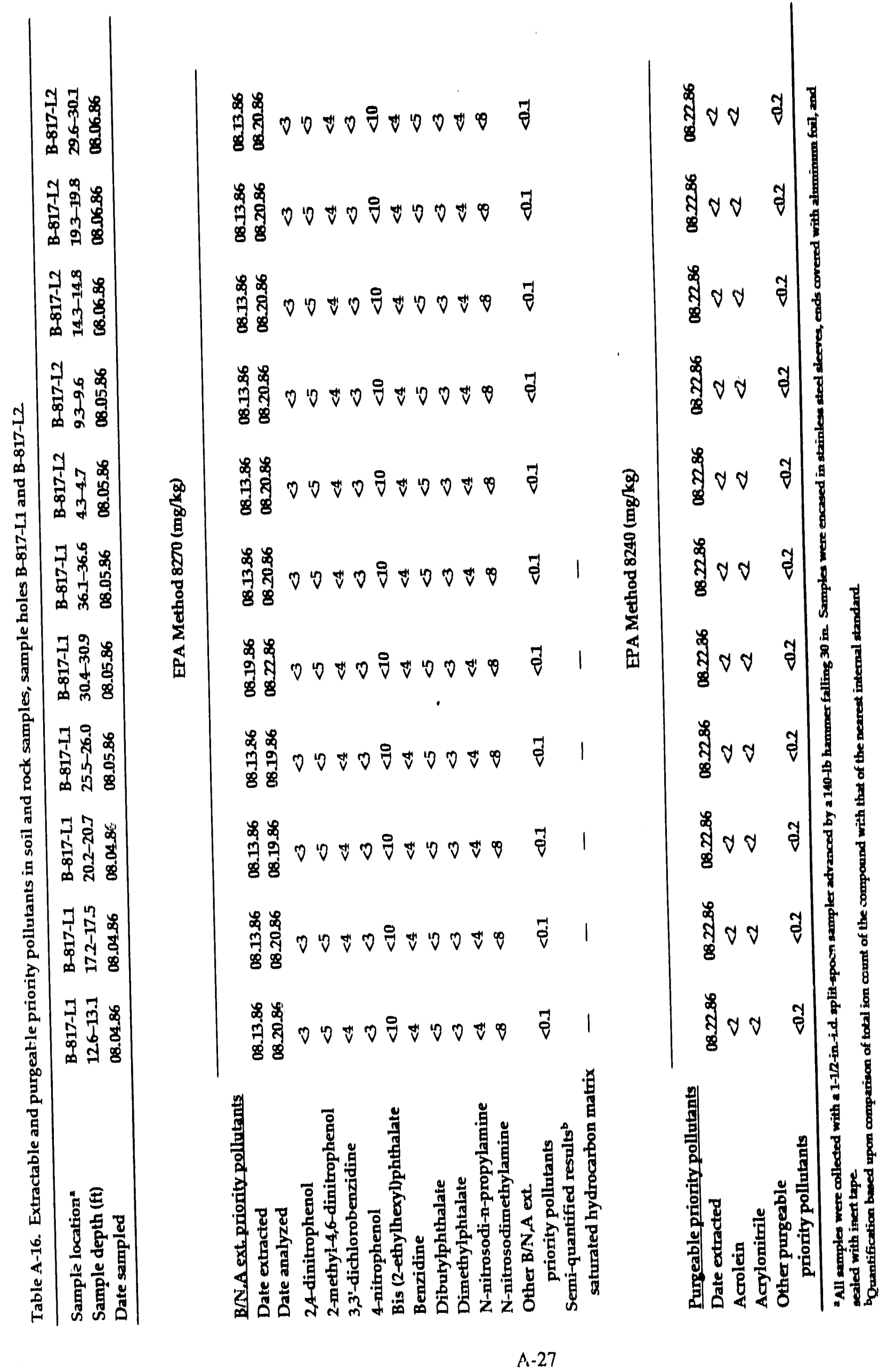


Table A-17. Purgeable halocarbons in soll samples, sample hole B-825-1, 825 Lagoon.

\begin{tabular}{lll}
\hline Sample location" & B $8825-1 / 3 a$ & B-825-1/4a \\
Sample depth (ft) & $9.9-10.4$ & $15.0-15.5$ \\
Date sampled & 03.25 .86 & 03.25 .86 \\
Date extracted & 03.31 .86 & 03.31 .86 \\
\hline
\end{tabular}

1,1,2,2-Tetrachloroethane

1,1,2-Trichloroethane

1,1-Dichloroethane

1,1 -Dichloroethane

1,2-Dichlorobenzene

1,2-Dichloroethane

trans-1,2-Dichloroethene

1,2-Dichloropropane

1,3-Dichlorobenzene

1,4-Dichlorobenzene

2-Chloroethylvinylether

Bromodichloromethane

Bromomethane

Bromoform

Chlorobenzene

Carbon tetrachlorlde

Chloroethane

Chloroform

Chloromethane

Dibromochloromethane

Dichlorodifluoromethane

Freon 113

Methylene chloride

Tetrachloroethene

1,1,1-Trichloroethane

Trichloroethylene

Trichlorofluoromethane

Vinyl chloride

cis-1,3-Dichloropropene

trans-1,3-Dichloropropene

\begin{tabular}{|c|c|}
\hline$<0.0002$ & $<0.0002$ \\
\hline$<0.0002$ & $<0.0002$ \\
\hline$<0.0002$ & $<0.0002$ \\
\hline$<0.00012$ & $<0.0002$ \\
\hline$\angle O$, BKOOZ & $<0.0002$ \\
\hline$<0.0002$ & $<0.0002$ \\
\hline$<0.0002$ & $<0,0002$ \\
\hline$<0.0 .002$ & $<0,0002$ \\
\hline$<0.0002$ & $<0.0002$ \\
\hline$<0.0002$ & $<0.0002$ \\
\hline$<0.0002$ & $<0.0002$ \\
\hline$<0.0002$ & $<0.0002$ \\
\hline$<0.0002$ & $<0.0002$ \\
\hline$<0.0002$ & $<0.0002$ \\
\hline$<0.00 \times 12$ & $<0.0002$ \\
\hline$<0.00012$ & $<0.0002$ \\
\hline$<0.0002$ & $<0.0002$ \\
\hline$<0.0002$ & $<0.0002$ \\
\hline$<0.0002$ & $<0.0002$ \\
\hline$<0.0002$ & $<0.0002$ \\
\hline$<0.0002$ & $<0.0002$ \\
\hline$<0.0002$ & $<0.0002$ \\
\hline$<0.0002$ & $<0.0002$ \\
\hline$<0.0002$ & $<0.0002$ \\
\hline$<0.0002$ & $<0.00012$ \\
\hline$<0.0002$ & $<0.0002$ \\
\hline$<0.0002$ & $<0.0002$ \\
\hline$<0.0002$ & $<0.0002$ \\
\hline$<0.0002$ & $<0.0002$ \\
\hline$<0.0002$ & $<0.0002$ \\
\hline
\end{tabular}

Samples were taken with a 1.1/2-in,-1,d. oplit-apoon ampler advanced by a 140-1b hammer falling $30 \mathrm{in}$. Samples were encased in atainless ateel sleeves, endo covered with aluminum foil, and sealed with inert tape. 
Table A-18. Extractable and purgeable priority pollutants in soll and rock samples, sample holes B-826-1 and B-826-2.

\begin{tabular}{|c|c|c|c|c|c|}
\hline $\begin{array}{l}\text { Sample location } \\
\text { Depth (ft) } \\
\text { Date sampled }\end{array}$ & $\begin{array}{c}B-826-1 b \\
12.0-12.5 \\
08.18 .86\end{array}$ & $\begin{array}{c}\text { B-826-1 } \\
15.1-15.6 \\
08.18 .86\end{array}$ & $\begin{array}{c}\text { B-826-1 } \\
20.2-20.7 \\
08.19 .86\end{array}$ & $\begin{array}{c}\text { B }-826-1 \\
25.2-25.7 \\
08.19 .86\end{array}$ & $\begin{array}{c}\text { B-826-1 } \\
30.0-30.4 \\
08.20 .86\end{array}$ \\
\hline & \multicolumn{5}{|c|}{ EPA Method $8270(\mathrm{mg} / \mathrm{kg})$} \\
\hline \multicolumn{6}{|l|}{ B/NA ext pritority pollutants } \\
\hline Extraction & 08.19 .86 & 08.19 .86 & 08.19 .86 & 08.19 .86 & 08.21 .86 \\
\hline Data analyzed & 08.27 .86 & 08.27 .86 & 08.27 .86 & 08.27 .86 & 08.27 .86 \\
\hline 2,4-dinitrophenol & $<3$ & $<3$ & $<3$ & $<3$ & $<3$ \\
\hline 2-methyl-4,6-dinitrophenol & $<5$ & $<5$ & $<5$ & $<5$ & $<5$ \\
\hline 3,3'-dichlorobenzidine & $<4$ & $<4$ & $<4$ & $<4$ & $<4$ \\
\hline 4-nitrophenol & $<3$ & $<3$ & $<3$ & $<3$ & $<3$ \\
\hline Bis(2-ethylhexyl)phthalate & $<10$ & $<10$ & $<10$ & $<10$ & $<10$ \\
\hline Benzidine & $<4$ & $<4$ & $<4$ & $<4$ & $<4$ \\
\hline Dibutylphthalate & $<5$ & $<5$ & $<5$ & $<5$ & $<5$ \\
\hline Dimethylph thalate & $<3$ & $<3$ & $<3$ & $<3$ & $<3$ \\
\hline N-nitrosodi-n-propylamine & $<4$ & $<4$ & $<4$ & $<4$ & $<4$ \\
\hline N-nitrosodimethylamine & $<8$ & $<8$ & $<8$ & $<8$ & $<8$ \\
\hline \multirow{2}{*}{$\begin{array}{l}\text { Other } B / N, A \text { ext. } \\
\text { priority pollutants }\end{array}$} & $<0.1$ & $<0,1$ & $<0.1$ & $<0.1$ & $<0.1$ \\
\hline & \multicolumn{5}{|c|}{ EPA Method $8240(\mathrm{mg} / \mathrm{kg})$} \\
\hline \multicolumn{6}{|l|}{ Purgeable priarity pollutants } \\
\hline Extraction & $08: 21.86$ & 08.21 .86 & 08.21 .86 & 08.21 .86 & 08.21 .86 \\
\hline Acrolein & $<2$ & $<2$ & $<2$ & $<2$ & $<2$ \\
\hline Acrylonitrile & $<2$ & $<2$ & $<2$ & $<2$ & $<2$ \\
\hline \multicolumn{6}{|l|}{ Other purgeable } \\
\hline priority pollutants & $<0.2$ & $<0.2$ & $<0.2$ & $<0.2$ & $<0.2$ \\
\hline
\end{tabular}


Table A-18. (Continued).

\begin{tabular}{lccccccc}
\hline Sample locatlon" & $\mathbf{B} \times 826-2$ & $\mathbf{B}-826-2$ & $\mathbf{B}-826-2$ & $\mathbf{B}-826-2$ & $\mathbf{B}-826-2$ & B-826-2 \\
Sample depth (ft) & $7.7 \times 8.1$ & $\mathbf{1 2 . 5 - 1 2 . 9}$ & $\mathbf{1 7 . 5 - 1 8 . 0}$ & $\mathbf{2 2 . 5 - 2 2 . 9}$ & $\mathbf{2 7 . 5 - 2 8 . 0}$ & $\mathbf{3 2 . 5 - 3 3 . 0}$ \\
Date sampled & $\mathbf{0 8 . 2 0 . 8 6}$ & $\mathbf{0 8 . 2 0 . 8 6}$ & 1.26 .86 & $\mathbf{0 8 . 2 6 . 8 6}$ & $\mathbf{0 8 . 2 6 . 8 6}$ & $\mathbf{0 8 . 2 6 . 8 6}$ \\
\hline
\end{tabular}

EPA Method 8270 (continued) (mg/kg)

\begin{tabular}{|c|c|c|c|c|c|c|}
\hline \multicolumn{7}{|l|}{ B/N.A ext. priority pollutants } \\
\hline \multirow{2}{*}{$\begin{array}{l}\text { Extraction } \\
\text { Data analyzed }\end{array}$} & 08.25 .86 & 08.25 .86 & 08.25 .86 & 08.25 .86 & 08.25 .86 & \multirow{2}{*}{$\begin{array}{l}08.27 .86 \\
09.03 .86\end{array}$} \\
\hline & 08.28 .86 & 08.28 .86 & 08.28 .86 & 08.28 .86 & 08.28 .86 & \\
\hline \multirow{11}{*}{$\begin{array}{l}\text { 2,4-dinitrophenol } \\
\text { 2-methyl-4,6-dinitrophenol } \\
\text { 3,3'-dichlorobenzidine } \\
\text { 4-nitrophenol } \\
\text { Bis(2-ethylhexyl)ph thalate } \\
\text { Benzidine } \\
\text { Dibutylphthalate } \\
\text { Dimethylphthalate } \\
\text { N-nitrosodi-n-propylamine } \\
\text { N-nitrosodimethylamine } \\
\text { Other B/N,A ext. } \\
\text { priority pollutants }\end{array}$} & $<3$ & $<3$ & $<3$ & $<3$ & $<3$ & \multirow{2}{*}{$\begin{array}{l}<3 \\
<5\end{array}$} \\
\hline & $<5$ & $<5$ & $<5$ & $<5$ & $<5$ & \\
\hline & $<4$ & $<4$ & $<4$ & $<4$ & $<4$ & $<4$ \\
\hline & $<3$ & $<3$ & $<3$ & $<3$ & $<3$ & \multirow{2}{*}{$\begin{array}{l}<3 \\
<10\end{array}$} \\
\hline & $<10$ & $<10$ & $<10$ & $<10$ & $<10$ & \\
\hline & $<4$ & $<4$ & $<4$ & $<4$ & $<4$ & $<4$ \\
\hline & $<5$ & $<5$ & $<5$ & $<5$ & $<5$ & $<5$ \\
\hline & $<3$ & $<3$ & $<3$ & $<3$ & $<3$ & \multirow{2}{*}{$\begin{array}{l}<3 \\
<4\end{array}$} \\
\hline & $<4$ & $<4$ & $<4$ & $<4$ & $<4$ & \\
\hline & $<8$ & $<8$ & $<8$ & $<8$ & $<8$ & $<8$ \\
\hline & $<0.1$ & $<0.1$ & $<0.1$ & $<0.1$ & $<0.1$ & \multirow[t]{2}{*}{$<0.1$} \\
\hline \multicolumn{6}{|c|}{ EPA Method $8240(\mathrm{mg} / \mathrm{kg})$} & \\
\hline \multicolumn{7}{|l|}{ Purgeable priority pollutants } \\
\hline Extraction & 08.21 .86 & 08.21 .86 & 08.21 .86 & 08.21 .86 & 08.21 .86 & 08.21 .86 \\
\hline Acrolein & $<2$ & $<2$ & $<2$ & $<2$ & $<2$ & $<2$ \\
\hline Acrylonitrile & $<2$ & $<2$ & $<2$ & $<2$ & $<2$ & $<2$ \\
\hline \multicolumn{7}{|l|}{ Other purgeable } \\
\hline priority pollutants & $<0.2$ & $<0.2$ & $<0.2$ & $<0.2$ & $<0.2$ & $<0.2$ \\
\hline
\end{tabular}

"All samples were collected with a 1-1/2-In. l.d. split-spoon sampler advanced by a 140-lb hammer falling 30 in. Samples wero encased in stainless steel sleeves, ends covered with aluminum foll, and sealed with inert tape.

bamples recovered at $<12 \mathrm{ft}$ depth were of insufficient volume and/or quality to be suitable for analysis. 
Table A-19. Extractable and purgeable priority pollutants in soil and rock samples, sample holes $B-827 \cdot C 1, B-827 \cdot C 2$, and $B \times 827 \cdot C 3$.

\begin{tabular}{lllllll}
\hline Sample location & B-827-C1 & B-827-C1 & B-827-C1 & B-827-C1 & B-827-C1 & B3-827-C1 \\
Sample depth (ft) & $5.0-5.5$ & $9.8-10.3$ & $15.0-15.5$ & $20.5-21.0$ & $29.8-30.3$ & $35.0-35.5$ \\
Date sampled & 08.27 .86 & 08.27 .86 & 08.27 .86 & 08.27 .86 & 08.27 .86 & 08.27 .36 \\
\hline
\end{tabular}

EPA Method $8270(\mathrm{mg} / \mathrm{kg})$

B/NA ext, priority pollutants

Extraction date

Data analyzed

2,4-dinitrophenol

2-methyl-4,6-dinitrophenol

3,3'-dichlorobenzidine

4-nitrophenol

Bis(2-ethylhexyl)ph thalate

Benzidine

Dibutylphthalate

Dimethylph thalate

N-Nitrosodi-n-propylamine

N-Nitrosodimethylamine

Other $B / N, A$ ext.

priority pollutants

\subsection{4 .86}

09.15 .86

09.04 .86

09.15 .86

$<3$

$<5$

$<4$

$<3$

$<10$

$<4$

$<5$

$<3$

$<4$

$<8$

$<0.1$

$<0.1$

$<3$

$<5$

$<4$

$<3$

$<10$

$<4$

$<5$

$<3$

$<4$

$<8$

09.04 .86
09.15 .86

09.04 .86

09.15 .86

09.04 .86

09.15 .86

09.04 .86

$<3$

$<5$

$<4$

$<3$

$<10$

$<4$

$<5$

$<3$

$<4$

$<8$

$<3$

$<5$

$<4$

$<3$

$<10$

$<4$

$<5$

$<3$

$<4$

$<8$

$<0.1$

$<0.1$

$<3$

$<5$

$<4$

$<3$

$<10$

$<4$

$<5$

$<3$

$<4$

$<8$

$<0.1$

$<0.1$
09.15 .86

$<3$

$<5$

$<4$

$<3$

$<10$

$<4$

$<5$

$<3$

$<4$

$<8$

EPA Method $8240(\mathrm{mg} / \mathrm{kg})$

Purgeable priority pollutants

Extraction date

Acrolein

Acrylonitrile

Other purgeable priority pollutants
09.02 .86

$<2$

$<2$

$<0.2$
09.02 .86
$<2$
$<2$

$<0.2$

09.02 .86
$<2$
$<2$

$<0.2$

09.02 .86
$<2$
$<2$

$<0.2$
09.02 .86

$<2$

$<2$

$<0.2$ 
Table A-19. (Continued)

\begin{tabular}{lcccccc}
\hline Sample location" $^{2}$ & B-827-C2 & B-827-C2 & B-827-C2 & B-827-C2 & B-827-C2 & B-827-C2 \\
Sample depth (ft) & $1.6-2.1$ & $5.5-6.0$ & $10.2-10.7$ & $15.6-16.1$ & $21.0-21.5$ & $30.3-30.8$ \\
Date sampled & 08.26 .86 & 08.26 .86 & 08.26 .86 & 08.26 .86 & 08.26 .86 & 08.26 .86 \\
\hline
\end{tabular}

EPA Method $8270(\mathrm{mg} / \mathrm{kg})$

B/N.A ext priority pollutants Extraction date

Data analyzed

$09.02 .86 \quad 09.02 .86$

$09.10 .86 \quad 09.10 .86$

09.02 .86

09.0286

09.02 .86

09.02 .86

2,4-Dinitrophenol

2-Methyl-4,6-dinitrophenol

3,3'-Dichlornbenzidine

$\begin{array}{lr}<3 & <3 \\ <5 & <5 \\ <4 & <4 \\ <3 & <3 \\ <10 & <10 \\ <4 & <4 \\ <5 & <5 \\ <3 & <3 \\ <4 & <4 \\ <8 & <8\end{array}$

$<3$

$<5$

$<4$

$<3$

4-Nitrophenol

$<3$

$<10$

Benzidine

$<4<4$

Dibutylphthalate

Dimethylph thalate

$<5 \quad<5$

$<5$
$<3$

$<3$
$<4$

$\mathrm{N}$-nitrosodimethylamine

$<4$
$<8$

09.12 .86

09.12 .86

09.12 .86

Other B/N,A ext.

priority pollutant's

$<0.1$

$<0.1$

$<8$

$<3<3$

$<5 \quad<5$

$<3$

$<5 \quad<5 \quad<5$

$<4$

$<3 \quad<3 \quad<3$

$<10<10<10$

$\begin{array}{lll}<4 & <4 & <4 \\ <5 & <5 & <5\end{array}$

$\begin{array}{lll}<5 & <5 & <5 \\ <3 & <3 & <3\end{array}$

$<4<4<4$

$<8<8 \quad<8$

$<0.1$

$<0.1$

$<0.1$

$<0.1$

EPA Method $8240(\mathrm{mg} / \mathrm{kg})$

Purgeable priority pollutants
Extraction date
Acrolein
Acrylonitrile
Other purgeable
priority pollutants
Semi-quantified results ${ }^{b}$
$C_{7} H_{16}$
Tetrahydrofuran

$\begin{array}{cccccc}09.02 .86 & 09.02 .86 & 09.02 .86 & 09.02 .86 & 09.02 .86 & 09.02 .86 \\ <2 & <2 & <2 & <2 & <2 & <2 \\ <2 & <2 & <2 & <2 & <2 & <2 \\ <0.2 & <0.2 & <0.2 & <0.2 & <0.2 & <0.2 \\ & & & & & \\ 40 & 40 & 60 & 40 & 40 & 40 \\ 1 & 1 & 1 & 0.8 & 0.9 & 0.6\end{array}$


Table A-19. (Continued)

\begin{tabular}{|c|c|c|c|c|c|c|}
\hline $\begin{array}{l}\text { Sample locationa } \\
\text { Sample depth (ft) } \\
\text { Date sampled }\end{array}$ & $\begin{array}{c}\text { B-827-C3 } \\
1.5-1.8 \\
08.26 .86\end{array}$ & $\begin{array}{c}\text { B-827-C3 } \\
5.8-6.5 \\
08.26 .86\end{array}$ & $\begin{array}{c}\text { B-827-C3 } \\
10.0-10.8 \\
08.26 .86\end{array}$ & $\begin{array}{c}\text { B-827-C3 } \\
16.5-17.0 \\
08.27 .86\end{array}$ & $\begin{array}{c}\text { B-827-C3 } \\
20.0-20.5 \\
08.27 .86\end{array}$ & $\begin{array}{c}\text { B-827-C3 } \\
30.0-30.3 \\
08.27 .86\end{array}$ \\
\hline & \multicolumn{6}{|c|}{ EPA Method $8270(\mathrm{mg} / \mathrm{kg})$} \\
\hline \multicolumn{7}{|l|}{ B/N,A ext, priority pollutants } \\
\hline Extraction date & 09.02 .86 & 09.02 .86 & 09.02 .86 & 09.04 .86 & 09.04 .86 & 09.04 .86 \\
\hline Data analyzed & 09.12 .86 & 09.12 .86 & 09.15 .86 & 09.15 .86 & 09.15 .86 & 09.15 .86 \\
\hline 2,4-Dinitrophenol & $<3$ & $<3$ & $<3$ & $<3$ & $<3$ & $<3$ \\
\hline 2-Methyl-4,6-dinitrophenol & $<5$ & $<5$ & $<5$ & $<5$ & $<5$ & $<5$ \\
\hline 3,3'-Dichlorobenzidine & $<4$ & $<4$ & $<4$ & $<4$ & $<4$ & $<4$ \\
\hline 4-Nitrophenol & $<3$ & $<3$ & $<3$ & $<3$ & $<3$ & $<3$ \\
\hline Bis(2-ethylhexyl)ph thalate & $<10$ & $<10$ & $<10$ & $<10$ & $<10$ & $<10$ \\
\hline Benzidine & $<4$ & $<4$ & $<4$ & $<4$ & $<4$ & $<4$ \\
\hline Dibutylphthalate & $<5$ & $<5$ & $<5$ & $<5$ & $<5$ & $<5$ \\
\hline Dimethylphthalate & $<3$ & $<3$ & $<3$ & $<3$ & $<3$ & $<3$ \\
\hline N-Nitrosodi-n-propylamine & $<4$ & $<4$ & $<4$ & $<4$ & $<4$ & $<4$ \\
\hline N-Nitrosodimethylamine & $<8$ & $<8$ & $<8$ & $<8$ & $<8$ & $<8$ \\
\hline \multirow[t]{2}{*}{$\begin{array}{l}\text { Other } \mathbf{B} / \mathbf{N}, \mathbf{A} \text { ext. } \\
\text { priority pollutants }\end{array}$} & $<0.1$ & $<0.1$ & $<0.1$ & $<0.1$ & $<0.1$ & $<0.1$ \\
\hline & \multicolumn{6}{|c|}{ EPA Method $8240^{\prime}(\mathrm{mg} / \mathrm{kg})$} \\
\hline \multicolumn{7}{|l|}{ Purgeable priority pollutants } \\
\hline Extraction date & 09.02 .86 & 09.02 .86 & 09.02 .86 & 09.02 .86 & 09.02 .86 & 09.02 .86 \\
\hline Acrolein & $<2$ & $<2$ & $<2$ & $<2$ & $<2$ & $<2$ \\
\hline Acrylonitrile & $<2$ & $<2$ & $<2$ & $<2$ & $<2$ & $<2$ \\
\hline \multicolumn{7}{|l|}{ Other purgeable } \\
\hline priority pollutants & $<0.2$ & $<0.2$ & $<0.2$ & $<0.2$ & $<0.2$ & $<0.2$ \\
\hline Benzene & $<0.2$ & 0.9 & 0.4 & $<0.2$ & $<0.2$ & $<0.2$ \\
\hline Chlorofiorm & $<0.2$ & $<0.2$ & 0.4 & $<0.2$ & $<0.2$ & $<0.2$ \\
\hline Trich lorofluoromethane & $<0.2$ & 0.2 & 0.4 & $<0.2$ & $<0.2$ & $<0.2$ \\
\hline \multicolumn{7}{|l|}{ Semi-quantified results } \\
\hline $\mathrm{C}_{7} \mathrm{H}_{16}$ & 40 & 40 & 30 & - & - & - \\
\hline Tetrahydrofuran & 0.8 & 0.8 & 0.8 & - & - & - \\
\hline
\end{tabular}

all samples were collected with a 1-1/2-in.-i.d. split-spoon sampler advanced by a $140-16$ hammer falling 30 in. Samples were encased in stainless steel sleeves, ends covered with aluminum foil, and sealed with inert tape.

${ }^{b} Q$ uantification based upon comparison of total ion count of the compound with that of the nearest internal standard. 


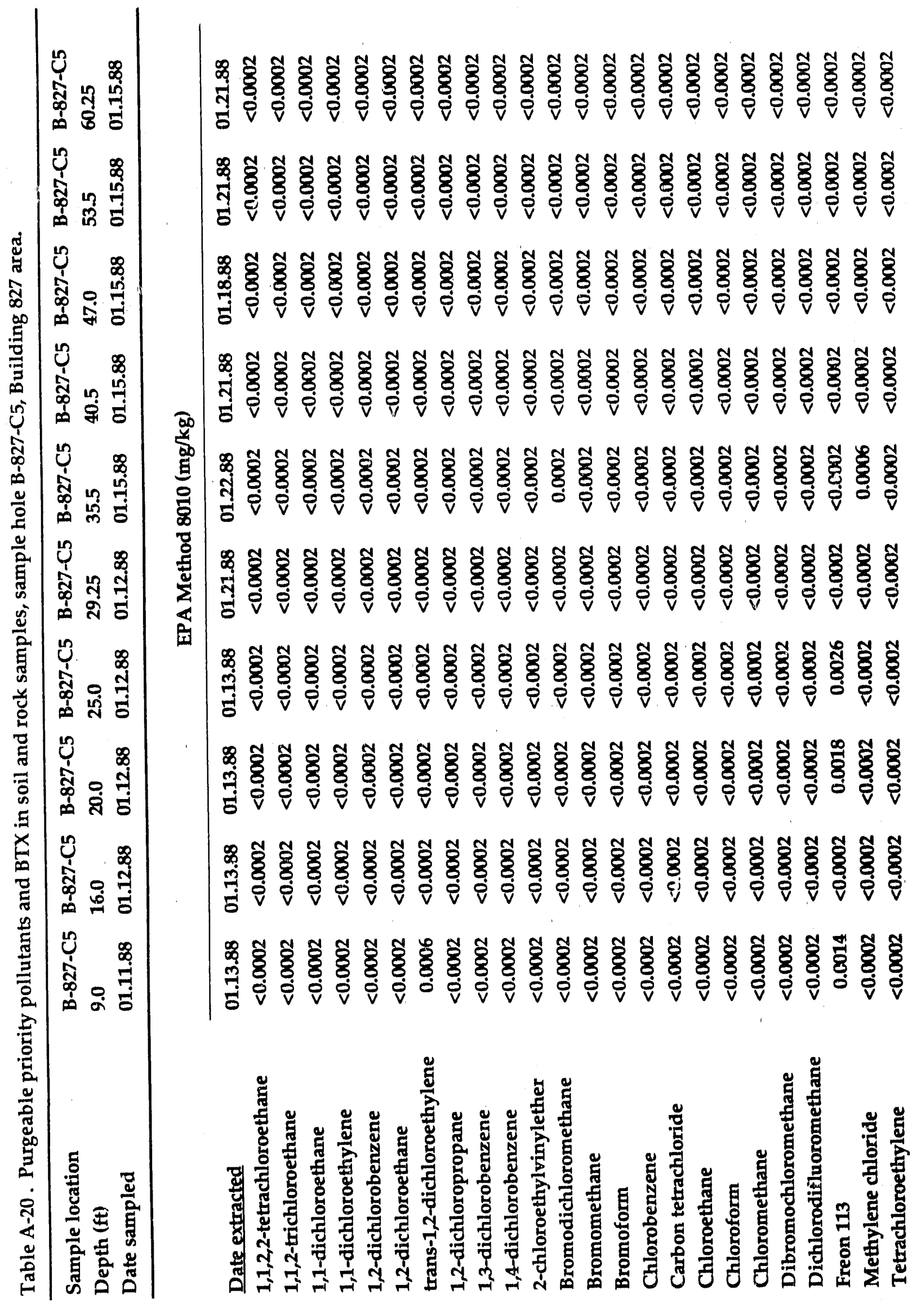




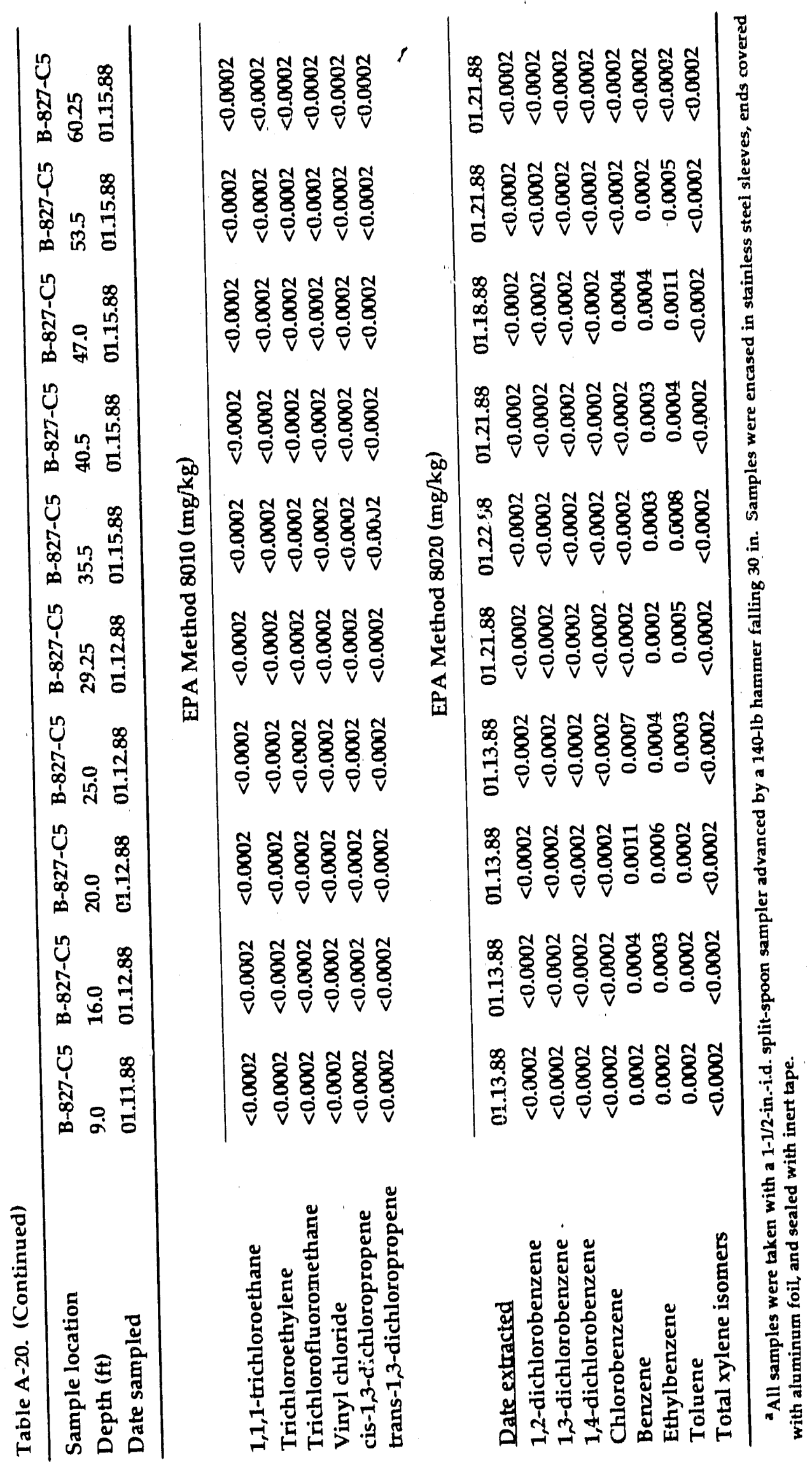


Table A-21. Purgeable priority pollutants in soll and rock samples, exploratory hole B-827-E2, 827E Lagoon area. Samples analyzed by EPA Method 8240.

\begin{tabular}{llll}
\hline Sample location $^{\mathrm{a}}$ & B-827-E2 & B-827-E2 & B-827-E2 \\
Sample depth (ft) & $1.0-1.5$ & $5.0-5.5$ & $6.5-7.0$ \\
Date sampled & 06.22 .87 & 06.22 .87 & 07.10 .87 \\
Extraction date & 07.02 .87 & 07.02 .87 & 07.15 .87 \\
\hline
\end{tabular}

Purgeable priority pollutants

1,1,1-Trichloroethane

1,1,2,2-Tetrachloroethane

EPA Method $8240(\mathrm{mg} / \mathrm{kg})$

1,1,2-Trichloroethane

1,1-Dichloroethane

1,1-Dichloroethylene

1,2-Dichloroethane

1,2-Dichloropropane

1,3-Dichloropropene

2-Chloroethylvinylether

Acrolein

Acrylonitrile

Bromodichloromethane

Bromomethane

Benzene

Chlorobenzene

Carbon Tetrachloride

Chloroethane

Bromoform

Chloroform

Chloromethane

Dibromochloromethane

Ethylbenzene

Methylene Chloride

Tetrachloroethylene

Trichloroethylene

Trichlorofluoromethane

Toluene

Vinyl Chloride

trans-1,2-dichloroethylene

trans-1,3-dichloropropene

\begin{tabular}{|c|c|c|}
\hline$<0.2$ & $<0.2$ & $<0.2$ \\
\hline$<0.2$ & $<0.2$ & $<0.2$ \\
\hline$<0.2$ & $<0.2$ & $<0.2$ \\
\hline$<0,2$ & $<0.2$ & $<0.2$ \\
\hline$<0.2$ & $<0.2$ & $<0.2$ \\
\hline$<0.2$ & $<0.2$ & $<0.2$ \\
\hline$<0.2$ & $<0.2$ & $<0.2$ \\
\hline$<0.2$ & $<0.2$ & $<0.2$ \\
\hline$<0.2$ & $<0.2$ & $<0.2$ \\
\hline$<2$ & $<2$ & $<2$ \\
\hline$<2$ & $<2$ & $<2$ \\
\hline$<0.2$ & $<0.2$ & $<0.2$ \\
\hline$<0.2$ & $<0.2$ & $<0.2$ \\
\hline$<0.2$ & $<0.2$ & $<0.2$ \\
\hline$<0.2$ & $<0.2$ & $<0.2$ \\
\hline$<0.2$ & $<0.2$ & $<0.2$ \\
\hline$<0.2$ & $<0.2$ & $<0.2$ \\
\hline$<0.2$ & $<0.2$ & $<0.2$ \\
\hline$<0.2$ & $<0.2$ & $<0.2$ \\
\hline$<0.2$ & $<0.2$ & $<0.2$ \\
\hline$<0.2$ & $<0.2$ & $<0.2$ \\
\hline$<0.2$ & $<0.2$ & $<0.2$ \\
\hline$<0.2$ & $<0.2$ & $<0.2$ \\
\hline$<0.2$ & $<0.2$ & $<0.2$ \\
\hline$<0.2$ & $<0.2$ & $<0.2$ \\
\hline$<0.2$ & $<0.2$ & $<0.2$ \\
\hline$<0.2$ & $<0.2$ & $<0.2$ \\
\hline$<0.2$ & $<0.2$ & $<0.2$ \\
\hline$<0.2$ & $<0.2$ & $<0.2$ \\
\hline$<0.2$ & $<0.2$ & $<0.2$ \\
\hline
\end{tabular}

a Samples were obtained in 1-1/2-in.-0.d. stainless-steel tubes filled by hand-driving a 1-1/2-in.-i.d. snlit-spoon sampler. Tube ends were covered with aluminum foil and sealed with inert tape. 
Tabl. A-22, Sol1 andyag in mg/kg (ppm) for volatile organde compounds reported by January 1,1990 .

\begin{tabular}{|c|c|c|c|c|c|c|c|c|}
\hline $\begin{array}{c}\text { Borehole } \\
\text { Date }\end{array}$ & $\begin{array}{r}D \in p t h \\
(f t)\end{array}$ & $\mathrm{T}^{\prime} \mathrm{CE}$ & $\mathrm{PCE}$ & $\begin{array}{c}\text { Tota } 1 \\
1,2 \\
\text { DCE }\end{array}$ & $\begin{array}{l}1,2 \\
D C A\end{array}$ & Bentene & Tolueno & $x y 1 \cdot n \in g$ \\
\hline $\begin{array}{r}D-807-01 \\
26-J U N-89 \\
26-J U N-89 \\
27-J U N-89 \\
27-J U N-89\end{array}$ & $\begin{array}{r}3.8 \\
10.5 \\
17.3 \\
21.0\end{array}$ & $\begin{array}{r}0.0002 \\
<0.0002 \\
<0.0002 \\
<0.0002\end{array}$ & $\begin{array}{r}0.0004 \\
0.000 \% \\
<0.0002 \\
<0.0002\end{array}$ & $\begin{array}{l}<0.0002 \\
<0.0002 \\
<0.0002 \\
<0.0002\end{array}$ & $\begin{array}{l}<0.0002 \\
<0.0002 \\
<0.0002 \\
<0.0002\end{array}$ & $\begin{array}{l}- \\
- \\
-\end{array}$ & $m$ & $\begin{array}{l}- \\
- \\
-\end{array}$ \\
\hline$w-809-01$ & & & $\cdot$ & & & & & \\
\hline $\begin{array}{l}03-M A R-88 \\
03-M A R-88 \\
03-M A R-88 \\
03-M A R-88 \\
03-M A R-88 \\
03-M A R-88 \\
03-M A R-88 \\
03-M A R-88 \\
03-M A R-88 \\
07-M A R-88\end{array}$ & $\begin{array}{r}5.0 \\
10.0 \\
15.0 \\
20.0 \\
25.0 \\
30.0 \\
35.0 \\
40.0 \\
45.0 \\
69.5\end{array}$ & $\begin{array}{l}<0.0002 \\
<0.0002 \\
<0.0002 \\
<0.0002 \\
<0.0002 \\
<0.0002 \\
<0.0002 \\
<0.0002 \\
<0.0002 \\
<0.0002\end{array}$ & $\begin{array}{l}<0.0002 \\
<0.0002 \\
<0.0002 \\
<0.0002 \\
<0.0002 \\
<0.0002 \\
<0.0002 \\
<0.0002 \\
<0.0002 \\
<0.0002\end{array}$ & $\begin{array}{l}<0.0002 \\
<0.0002 \\
<0.0002 \\
<0.0002 \\
<0.0002 \\
<0.0002 \\
<0.0002 \\
<0.0002 \\
<0.0002 \\
<0.0002\end{array}$ & $\begin{array}{l}<0.0002 \\
<0.0002 \\
<0.0002 \\
<0.0002 \\
<0.0002 \\
<0.0002 \\
<0.0002 \\
<0.0002 \\
<0.0002 \\
<0.0002\end{array}$ & $\begin{array}{l}<0.0002 \\
<0.0002 \\
<0.0002 \\
<0.0002 \\
0.0006 \\
0.0005 \\
0.0003 \\
<0.0002 \\
\angle 0.0002 \\
0.0002\end{array}$ & $\begin{array}{l}<0.0002 \\
<0.0002 \\
<0.0002 \\
<0.0002 \\
0.0004 \\
<0.0002 \\
<0.0002 \\
<0.0002 \\
<0.0002 \\
0.0005\end{array}$ & $\begin{array}{l}<0.0002 \\
<0.0002 \\
<0.0002 \\
<0.0002 \\
<0.0002 \\
<0.0002 \\
<0.0002 \\
<0.0002 \\
<0.0002 \\
<0.0002\end{array}$ \\
\hline
\end{tabular}

$W-809-02$

$14-M A R-88$

w-809-03

$07-J U L-89$

$07-J \cup L-89$

$07-J \cup L-89$

$07-J U L-89$

$10-J \cup L-89$

$10-J \cup L-89$

$10-J \cup L-89$

$11-J \cup L-89$

$11-J \cup L-89$

$11-J \cup L-89$

$12-J \cup L-89$

$12-J \cup L-89$

$12-J \cup L-89$

$12-J \cup L-89$

$D-810 A-01$

$28-J \cup N-89$

$28-J \cup N-89$

$28-J \cup N-89$

$28-J U N-89$

$28-J \cup N-89$

$D-810 C-01$

20-NOV-B9

16 -NOV-89

$20-\mathrm{NOV}-89$

20-NOV-89

$20-N O V-89$

$W-810-01$

$04-F E B-88$

$04-F E B-B 8$

$04-F E B-8 B$

$04-F E B-88$

$04-F E B-8 B$

$05-F E B-B \theta$

$05-F E B-8 B$

$05-\mathrm{FEB}-88$

$0 B-F E B-\theta 8$

$08-F E B-88$

$08-F E B-8 B$

$09-F E B-8 B$

$09-F E B-8 B$
$96.4<0.00,02$

$<0.0002$

$<0.0002$

$<0,0002$

$\begin{array}{rrr}0.5 & 0.0005 & <0.0002 \\ 5.8 & <0.0002 & <0.0002 \\ 11.3 & <0.0002 & <0.0002 \\ 16.0 & <0.0002 & <0.0002 \\ 21.0 & <0.0002 & <0.0002 \\ 28.6 & <0.0002 & <0.0002 \\ 41.3 & <0.0002 & <0.0002 \\ 50.0 & <0.0002 & <0.0002 \\ 61.0 & <0.0002 & <0.0002 \\ 70.2 & <0.0002 & <0.0002 \\ 80.1 & <0.0002 & <0.0002 \\ 89.1 & <0.0002 & <0.0002 \\ 98.5 & <0.0002 & <0.0002 \\ 08.5 & <0.0002 & <0.0002\end{array}$

$<0.0002$

$<0.0002$

$<0.0002$

$<0.0002$

$<0.0002$

$<0.0002$

$<0.0002$

$<0.0002$

$<0.0002$

$<0.0002$

$<0.0002$

$<0.0002$

$<0.0002$

10.0002

$<0.0002$

$<0.0002$

$<0.0002$

$<0.0002$

$<0.0002$

$<0.0002$

$<0.0002$

$<0.0002$

$<0.0002$

$<0.0002$

$<0.0002$

$<0.0002$

$<0.0002$

$<0.0002$

$<0.0002$

$<0.0002$

$<0.0002$

$<0.0002$

$10.5 \quad 0.0021$

$15.3 \quad 0.0021$

21.0

0.0069

$<0.0002$

$<0.0002$

$<0.0002$

$<0.0002$

$<0.0002$

$<0.0002$

$<0.0002$

$<0.0002$

$15.4<0.0002$

$17.8<0.0002$

$19.5<0.0002$

0.0002

$<.0002$

$<0.0002$

$4.6<0.0002$

$<0.0002$

$<0.0002$

<0.0002

$15.0 \quad 0.0056$

$20.0<0.0002$

$25.0<0.0002$

$33.4<0.0002$

$39.2<0.0002$

$43.1<0.0002$

$52.5<0.0002$

$61.2<0.000$

$72.0<0.0002$

$97.0<0.0002$

$108.0<0.0002$
0.0002

(0.0002

(0.0002

$<0.0002$

(0.0.002

$<0,0002$

$<0.0002$

$<0.0002$

(0.0002

$\therefore .0002$

$<0.0002$
$<0.0002$

$<0.0002$

10.0002

10.0002

$<0.0002$

$<0.0002$

$<.0002$

(0.0002

(0.0002

10.0002

6.0002
$<0.0002$

$<0.0002$

$<0.0002$

$<0.0002$

$<0.0002$

0.0002

0.0002

0.0002

.0002

0.0002

$<0.0002$

$<0.0002$

$<0,0002$

< 0.0002

10.0002

c 0.0002

$<0.0002$

$<0.0002$

< 0.0002

$<0.0002$

$<0.0002$

$<0.0002$

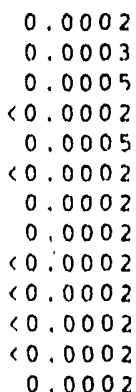

0.0003

0.0003

0.0006

0.0003

0.0003

0.0005

0.0003

0.0007

0.0003

0.0007

0.0004

0.0006

0.0003
0.0003
0.0003
0.0012
0.0003
0.0005
$<0.0002$
$<0.0002$
$<0.0002$
$<0.0002$
$<0.0002$
$<0.0002$
$<0.0002$
$<0.0002$ 
Table A-22. Soll analyses in mg/kg (ppm) for volatile orgando campounda raportad by Junury $1, .1990$.

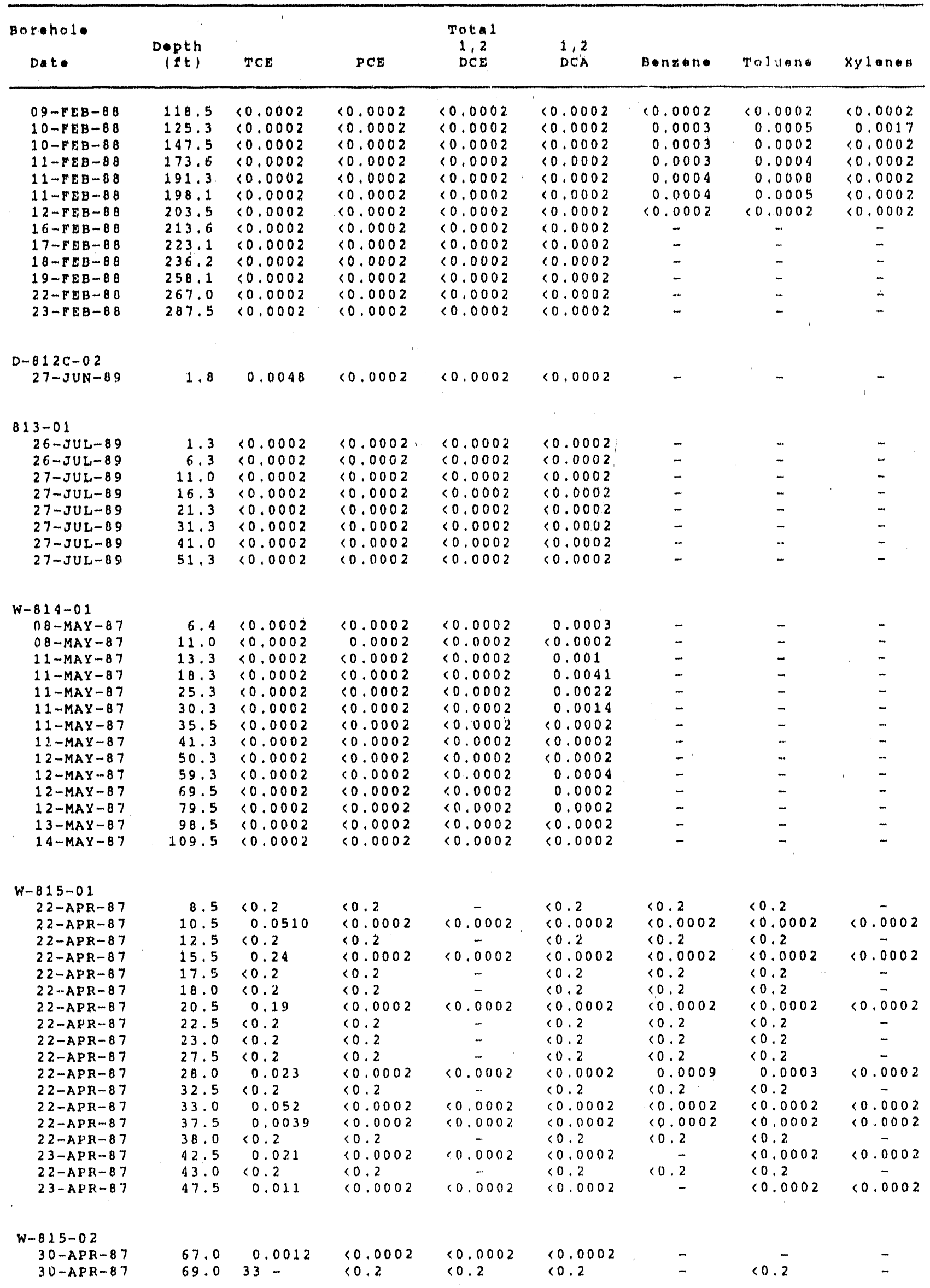




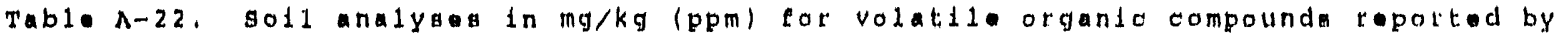
Ianury 1,1990 .

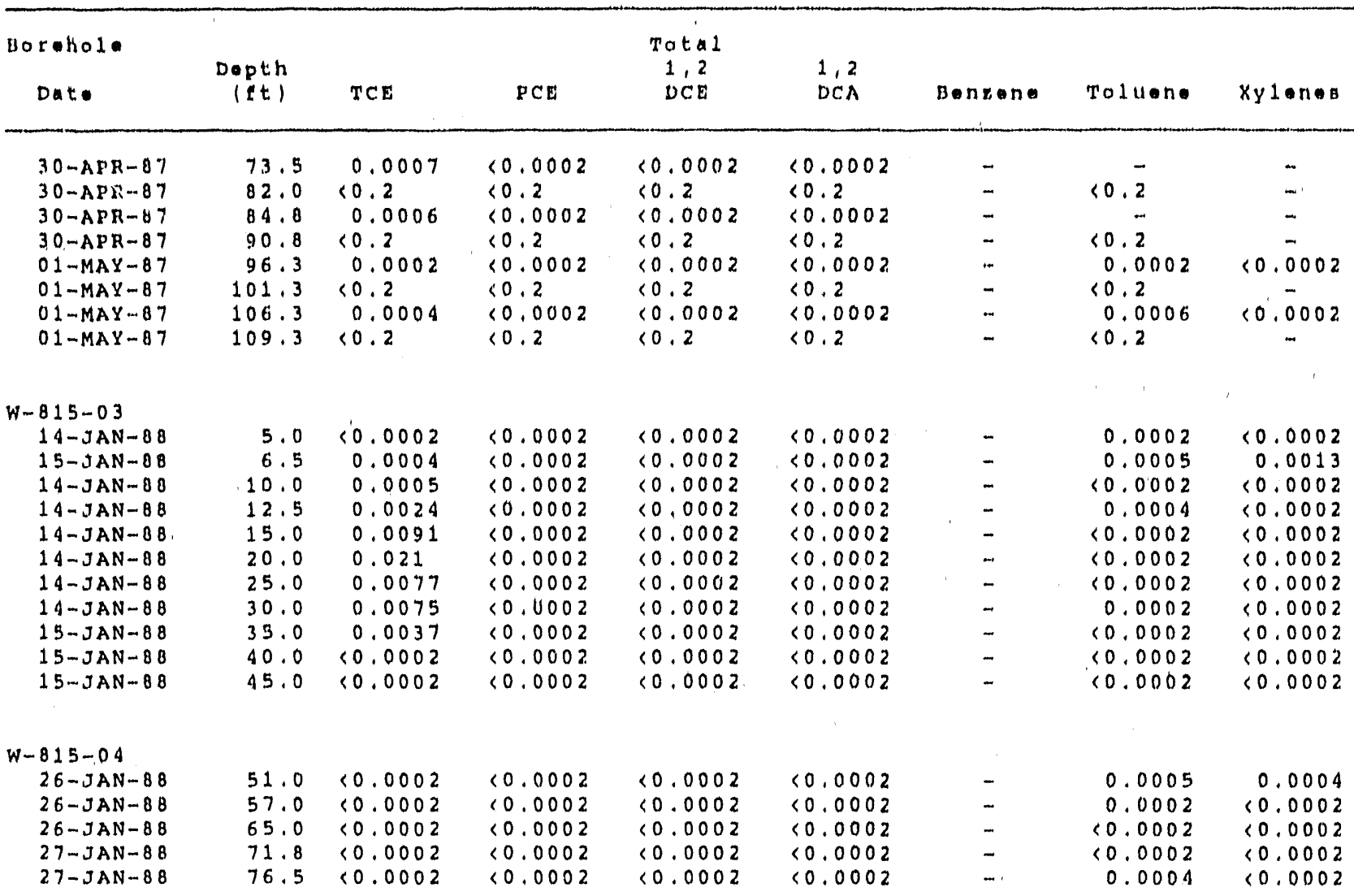

$W-815-05$

$21-J \cup L-89$

$21-J U L+89$

$21-J \cup L-89$

$21-J \cup L-89$

$21-J \cup L-89$

$21-J \cup L-89$

$24-J \cup L-89$

$24-J \cup L-B 9$

$W-817-05$

$09-M A Y-8 B$

$09-M A Y-8 B$

$09-M A Y-8 B$

$09-M A Y-B B$

$09-M A Y-8 B$

$09-M A Y-88$

$09-M A Y-38$

$10-M A Y-88$

10-MAY - $8 B$

$10-M A Y-8 B$

$10-M A Y-8 B$

10-MAY- 88

$12-M A Y-8 B$

$12-M A Y-88$

$12-M A Y-88$

$12-M A Y-88$

$12-M A Y-88$

$12-M A Y-B B$

$12-M A Y-B 8$

$12-M A Y-88$

$12 \sim M A Y-88$

$12-M A Y-8 B$

$12-M A Y-88$

$12-M A Y-88$

$12-M A Y-\theta 8$

$12-M A Y-88$

$12-M A Y-88$

$\begin{array}{rl}1.0 & <0.0002 \\ 5.8 & <0.0002 \\ 11.0 & <0.0002 \\ 16.1 & <0.0002 \\ 21.0 & <0.0002 \\ 31.3 & <0.0002 \\ 38.6 & <0.0002 \\ 47.6 & 10.0002\end{array}$

$5.5<0.0002$

$10.3<0.0002$

$15.5<0.0002$

$20.3<0.0002$

$25.8<0.0002$

$30.0<0.0002$

$35.0<0.0002$

$40.8<0.0002$

$45.5<0.0002$

$50.5<0.0002$

$56.0<0.0002$

$60.5<0.0002$

$65.5<0.0002$

$70.5<0.0002$

$75.5<0.0002$

$80.5<0.0002$

$85.5<0.0002$

$90.8<0.0002$

$95.5<0.0002$

$100.5<0.0002$

$105.5<0.0002$

$110.5<0.0002$

$115.5<0.0002$

$120.5<0.0002$

$125.8<0.0002$

$130.5<0.0002$

135.5
0.0034

$<0.0002$

$<0.0002$

$<0.0002$

$<0.0002$

$<0.0002$

$<0.0002$

$<0.0002$
$<0.0002$

$<0.0002$

$<0.0002$

$<0.0002$

$<0.0002$

$<0.0002$

$<0.0002$

$<0.0002$
$<0.0002$

$<0.0002$

$<0.0002$

$<0.0002$

$<0.0002$

$<0.0002$

$<0.0002$

$<0.0002$
$<0.0002$

$<0.0002$

$<0.0002$

$<0.0002$

$<0.0002$

$<0.0002$

$<0.0002$

$<0.0002$

$<0.0002$

$<0.0002$

0.0004

$<0.0002$

$<0.0002$

$<0.0002$

$<0.0002$

$<0.0002$

$<0,0002$

$<0.0002$

$<0.0002$

$<0.0002$

$<0.0002$

$<0.0002$

$<0.0002$

$<0.0002$

$<0.0002$

$<0.0002$

$<0.0002$
$<0.0002$

10.0002

$<0.0002$

$<0.0002$

$<0.0002$

$<0.0002$

$<0.0002$

$<0.0002$

$<0.0002$

$<0.0002$

< 0.0002

$<0.0002$

$<0.0002$

< 0.0002

(0.0002

$<0.0002$

$<0.0002$

$<0.0002$

(0.0002

$<0.0002$

$<0.0002$

$<0.0002$

$<0.0002$

$<0.0002$

$<0.0002$

$<0.0002$.

< 0.0002
$(0,0002$ $<0.0002$

$<0.0002$

$<0.0002$

$<0.0002$

$<0.0002$

$<0.0002$

$<0.0002$

$<0.0002$

$<0.0002$

$<0.0002$

$<0.0002$

$<0.0002$

$<0.0002$

(0.0002

( 0.0002

$<0.0002$

$<0.0002$

$<0.0002$

$<0.0002$

$<0.0002$

$<0.0002$

(0.0002

< 0.0002

$<0.0002$

$<0.0002$

( 0.0002
<0.0002

$<0.0002$

$<0.0002$

0.0003

$<0.0002$

$<0.0002$

$<0,0002$

$\therefore 0.0002$

$<0.0002$

$<0.0002$

$<0,0002$

$<0,0002$

0.0011

0.0002

$<0.0002$

0.0002

$<0.0002$

$<0,0002$

.0 .0002

10.0002

(0.0002

0.0003

$<0.0002$

$<0.0002$

0.0002

0.0003

0.0002
$<0.0002$

$<0.0002$

$<0.0002$

0.0004

$<0.0002$

$<0.0002$

$<0.0002$

$<0.0002$

$<0.0002$

$<0.0002$

0.0007

$<0.0002$

0.0003

$<0.0002$

$<0.0002$

$<0.0002$

$<0.0002$

0.0002

0.001

$<0.0002$

$<0.0002$

$<0.0002$

$<0.0002$

$<0.0002$

$<0.0002$

0.0002

$<0.0002$
$<0.0002$

$<0.0002$

$<0.0002$

0.001

0.0008

$<0.0002$

0.0002

0.0007

$<0.0002$

$<0.0002$

0.0019

0.0006

0.0012

0.0008

0.0003

0.0003

$<0.0002$

0.0011

0.0003

0.0002

0.0002

0.0007

$<0.0002$

0.0002

0.0003

0.0002

$<0.0002$ 
Table A-22, sold analyos in mg/kg (ppm) for volatile orgando oompounda roported by January 1,1990 .

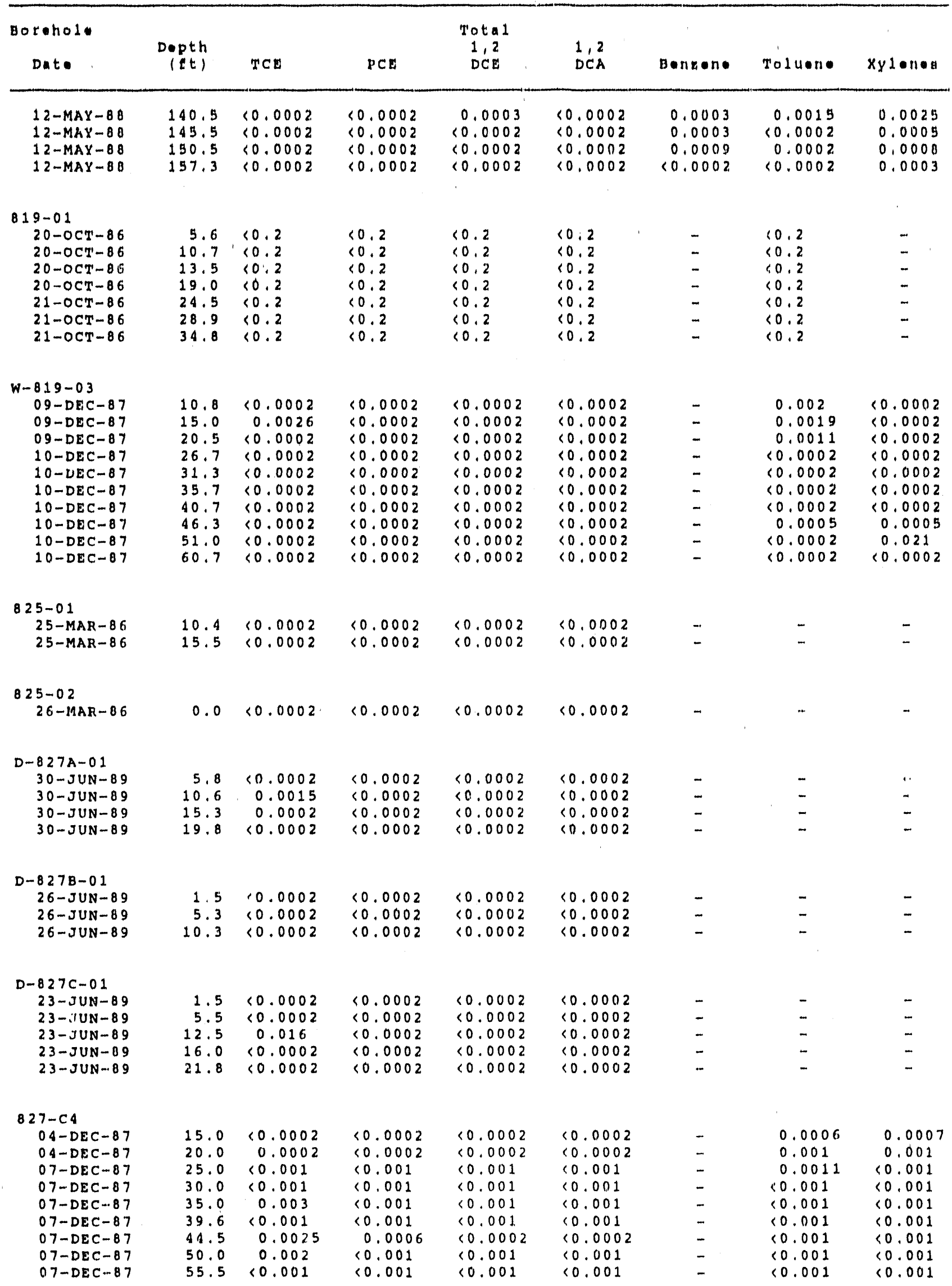




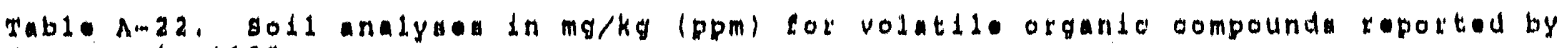
Januiry 1,1990 .

\begin{tabular}{|c|c|c|c|c|c|c|c|c|}
\hline $\begin{array}{c}\text { Horahole } \\
\text { Date }\end{array}$ & $\begin{array}{r}\text { Depth } \\
(t,)\end{array}$ & $\operatorname{tct}$ & $P C A$ & $\begin{array}{c}\text { Tota } 1 \\
1,2 \\
\text { DCD }\end{array}$ & $\begin{array}{l}1,2 \\
D C A\end{array}$ & Benzone & Toluene & $x y \perp \circ n \in n$ \\
\hline $\begin{array}{l}D-0270-01 \\
22-J \cup N-00 \\
22-J \cup N-09 \\
22-J \cup N-09 \\
23-J \cup N-B 9\end{array}$ & $\begin{array}{r}4.0 \\
10.0 \\
15.5 \\
21.2\end{array}$ & $\begin{array}{l}<0.0002 \\
<0.0002 \\
40.0002 \\
0.0013\end{array}$ & $\begin{array}{l}<0.0002 \\
<0.0002 \\
<0.0002 \\
10.0002\end{array}$ & $\begin{array}{l}<0.0002 \\
\angle 0.0002 \\
<0.0002 \\
0.0002\end{array}$ & $\begin{array}{l}10.0002 \\
10.0002 \\
10.0002 \\
10.0002\end{array}$ & $=$ & $\stackrel{-}{m}$ & $\bar{m}$ \\
\hline $\begin{array}{r}D-8278-01 \\
21-J U N-89 \\
21-J U N-89 \\
22-J U N-8.9 \\
22-J U N-89 \\
22-J U N-89\end{array}$ & $\begin{array}{r}3.0 \\
6.0 \\
10.6 \\
16.3 \\
20.5\end{array}$ & $\begin{array}{l}<0.0002 \\
\angle 0.0002 \\
\angle 0.0002 \\
\angle 0.0002 \\
<0.0002\end{array}$ & $\begin{array}{l}<0.0002 \\
<0.0002 \\
<0.0002 \\
<0.0002 \\
<0.0002\end{array}$ & $\begin{array}{l}<0.0002 \\
<0.0002 \\
10.0002 \\
10.0002 \\
10.0002\end{array}$ & $\begin{array}{l}<0.0002 \\
10.0002 \\
<0.0002 \\
10.0002 \\
10.0002\end{array}$ & $\begin{array}{l}= \\
= \\
=\end{array}$ & $\ddot{-}$ & $\begin{array}{l}m \\
m \\
m\end{array}$ \\
\hline $\begin{array}{l}829-01 \\
17-0 C T-86 \\
17-0 C T-86 \\
17-0 C T-86 \\
17-0 C T-86 \\
17-0 C T-86 \\
17-0 C T-86 \\
17-0 C T-86 \\
17-0 C T-86 \\
17-0 C T-86\end{array}$ & $\begin{array}{r}2.5 \\
4.7 \\
9.5 \\
14.5 \\
24.9 \\
39.0 \\
34.8 \\
39.5 \\
44.4\end{array}$ & $\begin{array}{l}<0,2 \\
<0,2 \\
\angle 0.2 \\
<0,2 \\
<0,2 \\
<0.2 \\
<0.2 \\
\angle 0.2 \\
<0.2\end{array}$ & 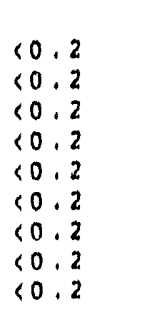 & $\begin{array}{l}<0,2 \\
<0.2 \\
<0.2 \\
<0.2 \\
<0.2 \\
<0.2 \\
<0.2 \\
<0.2 \\
<0.2\end{array}$ & $\begin{array}{l}<0.2 \\
<0.2 \\
<0.2 \\
<0.2 \\
<0.2 \\
<0.2 \\
<0.2 \\
<0.2 \\
<0.2\end{array}$ & $\begin{array}{l}\overline{-} \\
= \\
\overline{-} \\
\overline{-} \\
=\end{array}$ & $\begin{array}{l}<0,2 \\
<0,2 \\
<0,2 \\
<0,2 \\
<0,2 \\
<0,2 \\
<0,2 \\
<0,2 \\
10,2\end{array}$ & $\begin{array}{l}= \\
= \\
= \\
= \\
= \\
-\end{array}$ \\
\hline
\end{tabular}

Note :

- Indicates no analysio performed for this compound. 


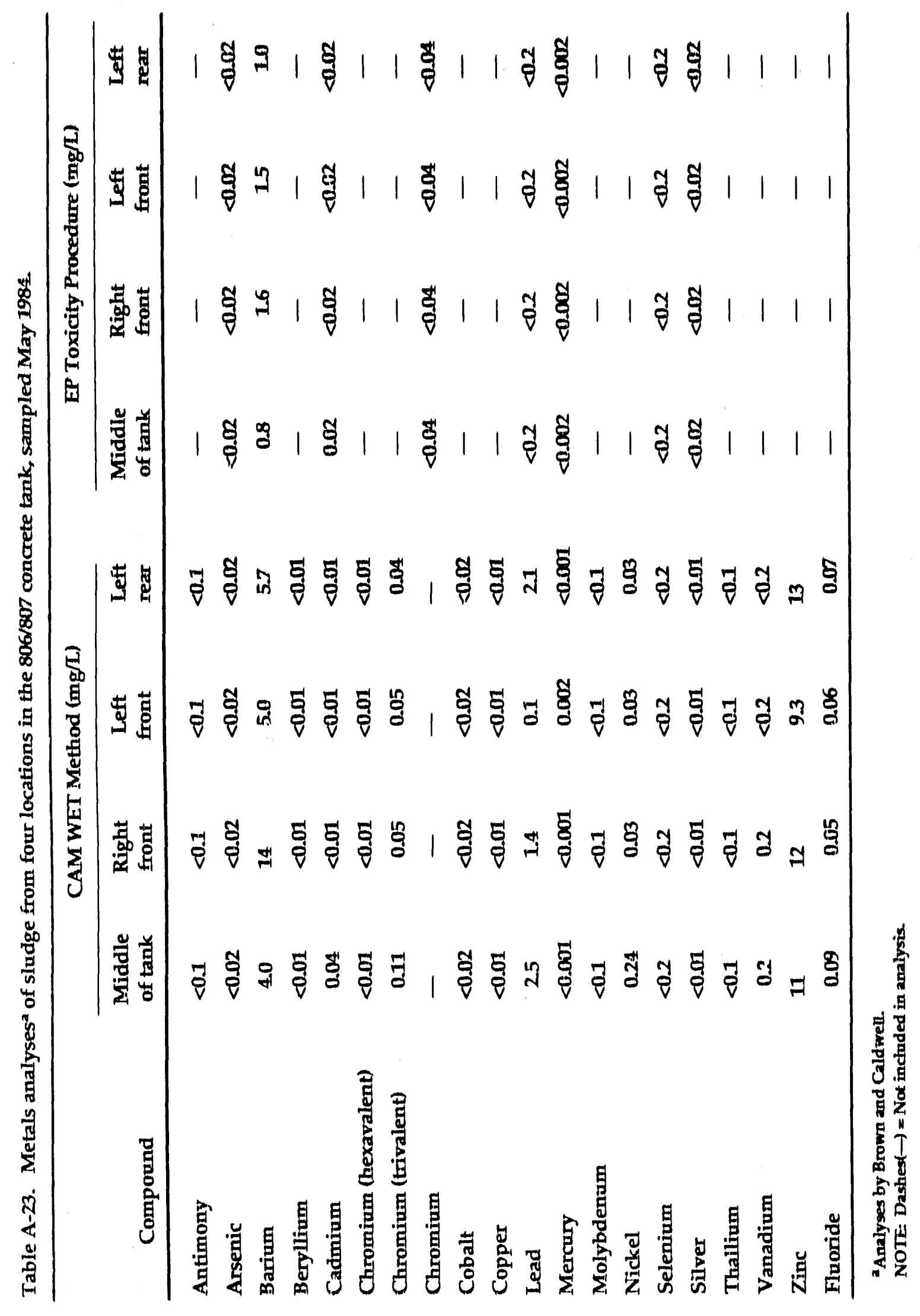




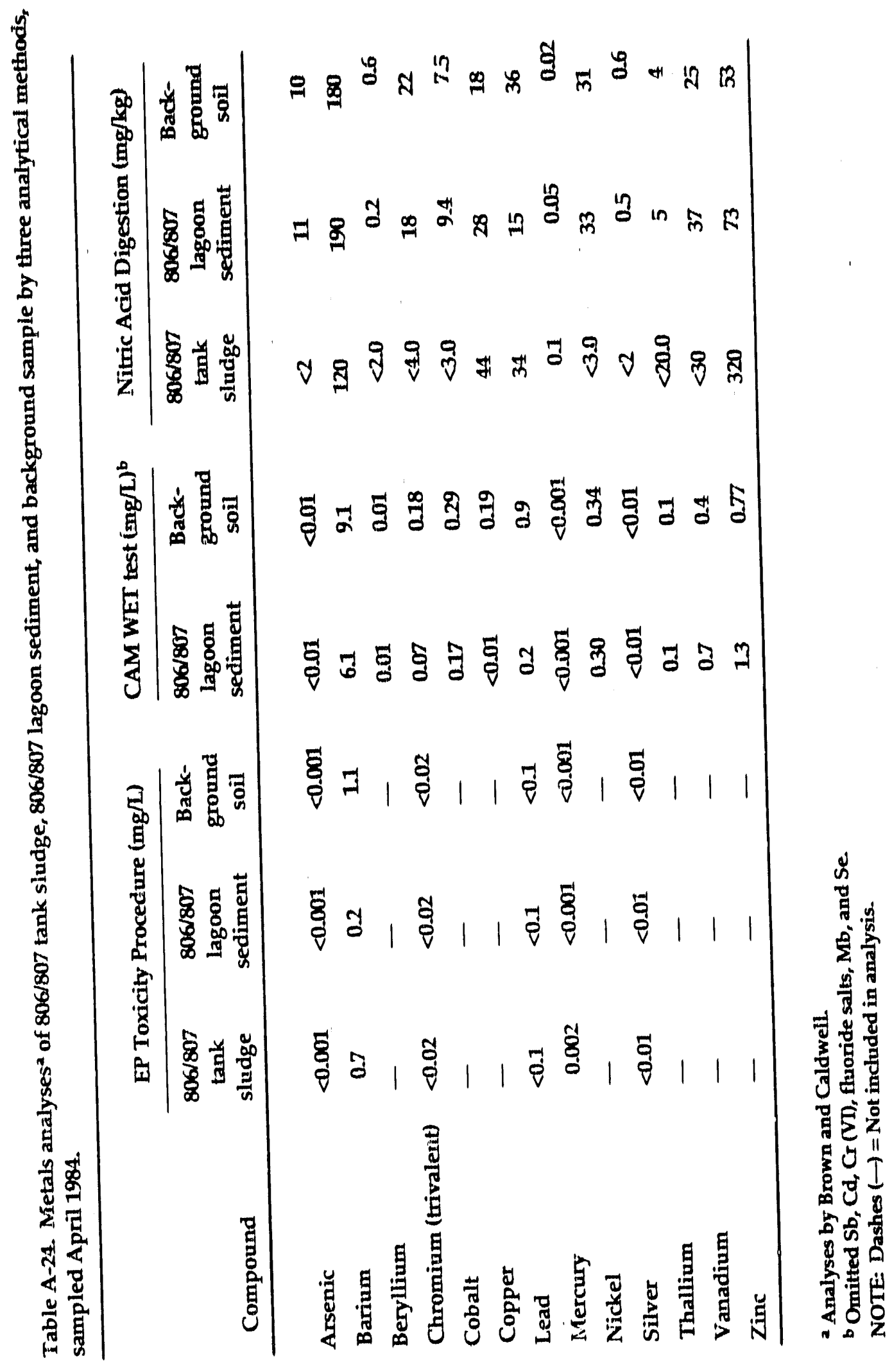


Table A-25. Metals analyses" of 806/807 Lagoon sediment from three locations, sampled May 1984.

\begin{tabular}{|c|c|c|c|c|c|c|}
\hline \multirow[b]{2}{*}{ Compound } & \multicolumn{3}{|c|}{ CAM WET Method (mg/L) } & \multicolumn{3}{|c|}{ EP' T'oxicity Procedure (mg/L) } \\
\hline & $\begin{array}{l}1 \mathrm{ft} \text { from } \\
\text { outfall }\end{array}$ & $\begin{array}{l}2 \mathrm{ft} \text { from } \\
\text { outrall }\end{array}$ & $\begin{array}{l}10 \mathrm{ft} \text { from } \\
\text { outfall }\end{array}$ & $\begin{array}{l}1 \mathrm{ft} \text { from } \\
\text { outfall }\end{array}$ & $\begin{array}{l}2 \mathrm{ft} \text { from } \\
\text { outfall }\end{array}$ & $\begin{array}{l}10 \mathrm{ft} \text { from } \\
\text { outfall }\end{array}$ \\
\hline Antimony & $<0.1$ & $<0.1$ & $<0.1$ & - & - & - \\
\hline Arsenic & 0.05 & $<0.02$ & 0,1 & $<0.01$ & $<0.01$ & $<0.01$ \\
\hline Barium & 35 & 20 & 22 & 1.1 & 3.5 & 0.6 \\
\hline Beryllium & 0.01 & $<0.01$ & 0.01 & - & - & - \\
\hline Cadmium & $<0.01$ & $<0.01$ & $<0.01$ & $<0.01$ & $<0.01$ & $<0.01$ \\
\hline Chromium (hexavalent) & $<0.01$ & $<0.01$ & $<0.01$ & - & - & - \\
\hline Chromium (trivalent) & 0.15 & 0.07 & 0.11 & - & - & - \\
\hline Chromium & - & - & - & $<0.02$ & 0.02 & $<0.02$ \\
\hline Cobalt & 0.09 & 0.03 & 0.16 & - & - & - \\
\hline Copper & $<0.01$ & 0.01 & $<0.01$ & - & - & - \\
\hline Lead & $<0.1$ & 0.7 & 0.2 & $<0.01$ & 0.2 & $<0.1$ \\
\hline Mercury & $<0.001$ & $<0.001$ & $<0.001$ & $<0.001$ & $<0.001$ & $<0.001$ \\
\hline Molybdenum & 0.1 & $<0.1$ & $<0.1$ & - & - & - \\
\hline Nickel & 0.21 & 0.33 & 0.15 & - & - & - \\
\hline Selenium & $<0.2$ & $<0.2$ & $<0.2$ & $<0.1$ & $<0.1$ & $<0.1$ \\
\hline Silver & $<0.01$ & 0.02 & $<0.01$ & $<0.01$ & 0.03 & $<0.01$ \\
\hline Thallium & $<0.1$ & 0.6 & $<0.1$ & - & - & - \\
\hline Vanadium & 1.0 & 0.2 & 1.5 & 一 & 一 & - \\
\hline Zinc & 0.96 & 1.0 & 1.1 & - & - & - \\
\hline Fluoride & 0.31 & 0.35 & 0.91 & - & - & - \\
\hline
\end{tabular}

- Analyses by Brown and Caldwell.

bThe "outfall" is the point of rinsowater discharge into the lagoon.

NOTE: Dashes (-) - Not included in analysis. 


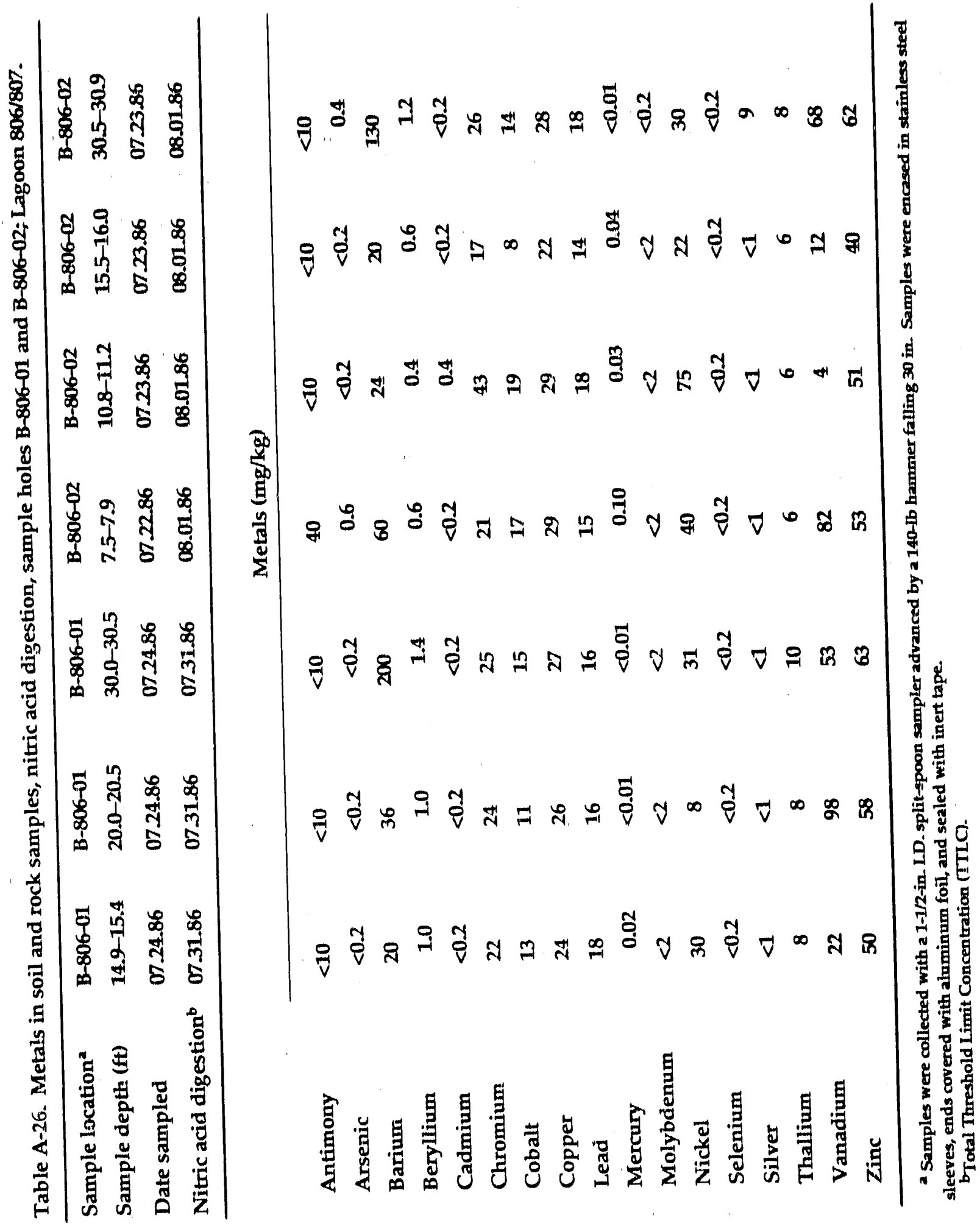




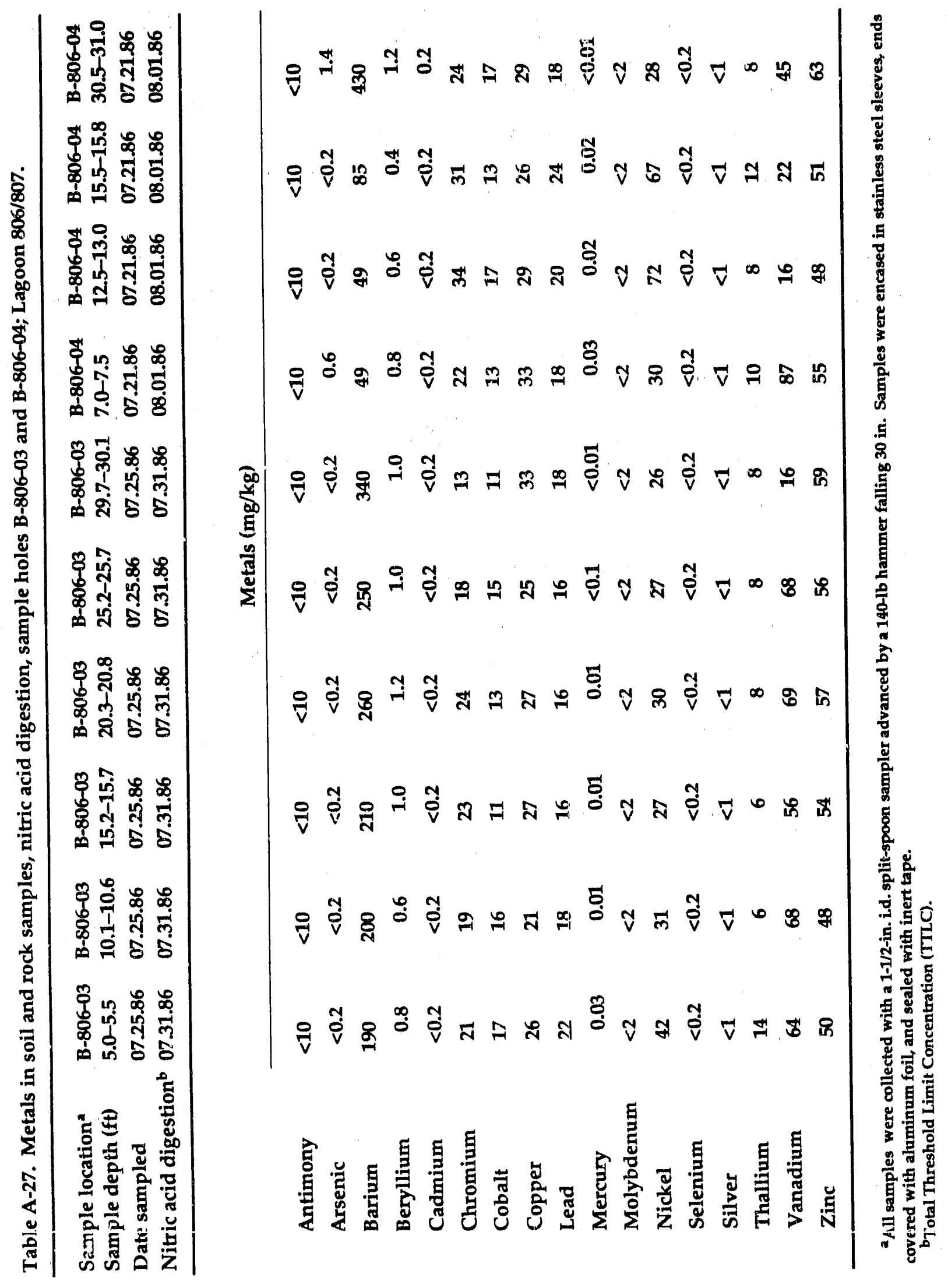


Table A-28. Metals in soil anc' rock samples, CAM WET extraction, sample holes B-806-01, B-806-02, B-806-03, and B-806-04; Lagoon 806/807.

\begin{tabular}{lccccc}
\hline Sample location & B-806-01 & B-806-02 & B-806-02 & B-806-03 & B-806-04 \\
Sample depth (ft) & $30.0-30.5$ & $7.5-7.9$ & $30.0-30.9$ & $29.7-30.1$ & $30.5-31.0$ \\
Date sampled & 07.24 .86 & 07.23 .86 & 07.23 .86 & 07.25 .86 & 07.23 .86 \\
CAM WET ext.b, & 09.10 .86 & 09.10 .86 & 09.10 .86 & 09.10 .86 & 09.10 .86 \\
\hline & & & Metals (mg/L) & & \\
CAM WET extraction & & & & & \\
Antimony & 0.2 & 0.1 & 0.2 & 0.2 & 0.3 \\
Arsenic & 0.03 & $<0.01$ & 0.04 & 0.02 & 0.07 \\
Barium & 9.6 & 0.2 & 6.9 & 4.1 & 7.5 \\
Beryllium & $<0.01$ & $<0.01$ & $<0.01$ & $<0.01$ & $<0.01$ \\
Cadmium & $<0.01$ & 0.07 & $<0.01$ & $<0.01$ & $<0.01$ \\
Chromium & 0.02 & $<0.02$ & $<0.02$ & $<0.02$ & 0.02 \\
Cobalt & $<0.05$ & 0.20 & 0.27 & 0.10 & 0.08 \\
Copper & 0.17 & 0.18 & 0.12 & 0.35 & 0.18 \\
Lead & $<0.1$ & $<0.1$ & $<0.1$ & $<0.1$ & $<0.1$ \\
Mercury & $<0.001$ & $<0.001$ & $<0.001$ & 0.001 & $<0.001$ \\
Molybdenum & $<0.1$ & $<0.1$ & $<0.1$ & $<0.1$ & $<0.1$ \\
Nickel & $<0.05$ & 1.6 & $<0.05$ & $<0.05$ & $<0.05$ \\
Selenium & 0.06 & $<0.01$ & 0.04 & 0.02 & 0.03 \\
Silver & $<0.01$ & $<0.01$ & $<0.01$ & $<0.01$ & $<0.01$ \\
Thallium & $<0.1$ & $<0.1$ & $<0.1$ & $<0.1$ & $<0.1$ \\
Vanadium & 0.5 & $<0.2$ & 0.5 & 0.4 & 0.5 \\
Zinc & 0.16 & $<0.01$ & $<0.01$ & 0.11 & $<0.01$ \\
\hline
\end{tabular}

all samples were collected with a 1-1/2-in. I.D. split-spoon sampler advanced by a 140-lb hammer falling 30 in. Samples were encased in stainless steel sleeves, ends covered with aluminum foil, and sealed with inert tape.

b Citric acid.

'Soluble Threshold Limit Concentration (STLC). 


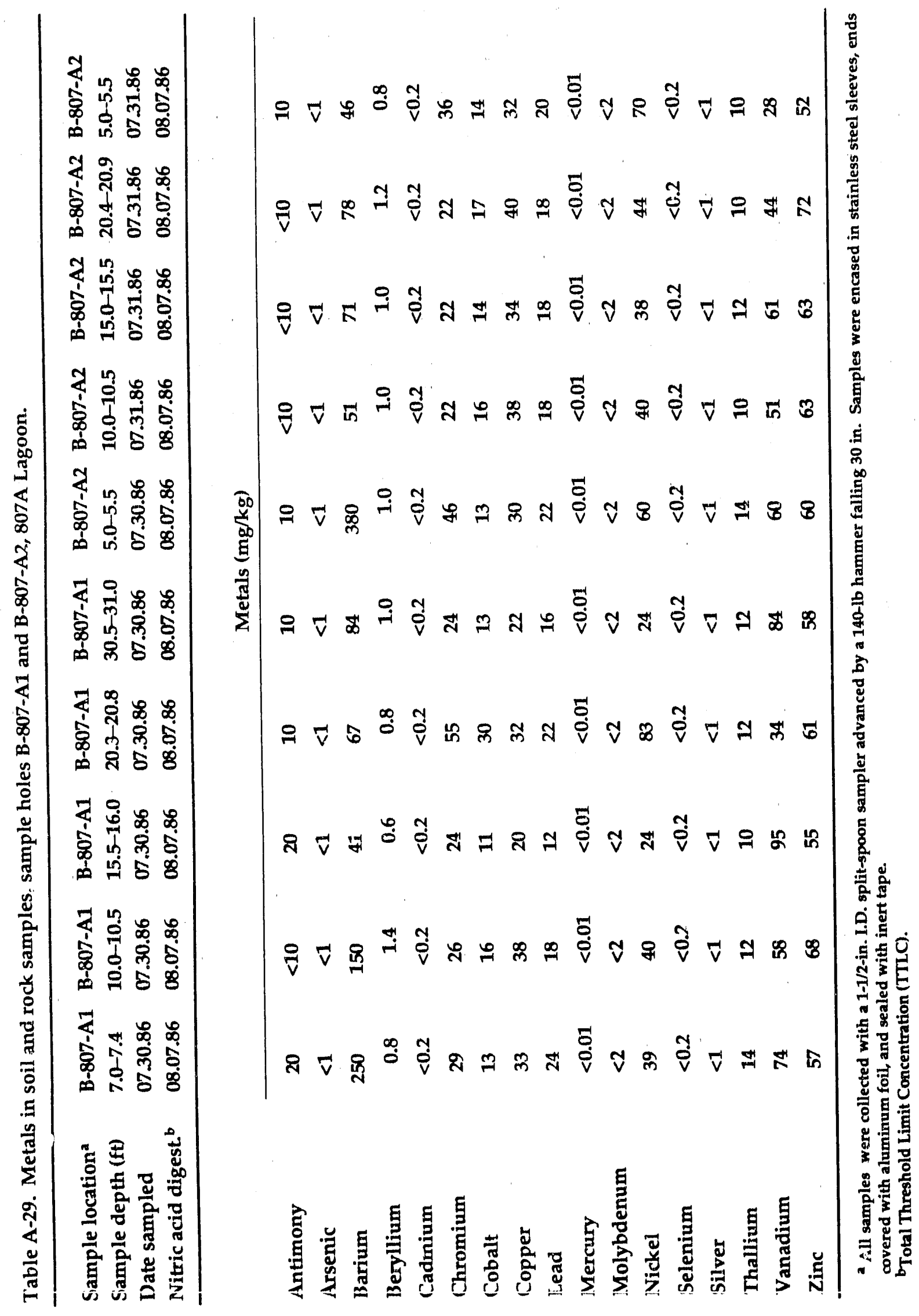


Table A-30. Metals in soil from sample hole B-807-A1, 807A Lagoon.

\begin{tabular}{lc}
\hline Sample locationa & B-807 A1 \\
Sample depth (ft) & $10-10.5$ \\
Date sampled & 07.30 .86 \\
CAM WET Extraction (STLC) & Metals (mg/L) \\
\hline & 0.2 \\
\cline { 2 - 2 } Antimony & 0.03 \\
Arsenic & 16 \\
Barium & $<0.01$ \\
Beryllium & $<0.01$ \\
Cadmium & $<0.02$ \\
Chromium & 0.27 \\
Cobalt & 0.16 \\
Copper & 0.2 \\
Lead & $<0.001$ \\
Mercury & 0.3 \\
Molybdenum & 0.35 \\
Nickel & 0.05 \\
Selenium & $<0.01$ \\
Silver & $<0.1$ \\
Thallium & 0.9 \\
Vanadium & 0.08 \\
Zinc & \\
\hline
\end{tabular}

a All samples were collected with a 1-1/2-in.-i.d. split-spoon sampler advanced by a $140-1 b$ hammer falling $30 \mathrm{in}$. Samples were encased in stainless stecl sleeves, ends covered with aluminum foil, and sealed with inert tape. 
Table A-31. Metals in soil and rock samples, sample hole B-807-B1, 807B Lagoon.

\begin{tabular}{|c|c|c|c|c|c|}
\hline Sample location & & & B-807-B1/4b & & B-807-B1/7b \\
\hline $\begin{array}{l}\text { Sample depth (ft) } \\
\text { Date sampled }\end{array}$ & $\begin{array}{l}5.0-5.5 \\
07.30 .86\end{array}$ & $\begin{array}{l}9.8-10.3 \\
07.30 .86\end{array}$ & $\begin{array}{l}14.8-15.3 \\
07.30 .86\end{array}$ & $\begin{array}{l}19.8-20.3 \\
07.30 .86\end{array}$ & $\begin{array}{l}30.0-30.5 \\
07.31 .86\end{array}$ \\
\hline \multirow[t]{2}{*}{ Nitric acid digestion ${ }^{b}$} & 08.07 .86 & 08.07 .86 & 08.07 .86 & 08.07 .86 & 08.07 .86 \\
\hline & \multicolumn{5}{|c|}{ Metals (mg/kg) } \\
\hline Antimony & $<10$ & $<10$ & $<10$ & $<10$ & $<10$ \\
\hline Arseric & $<1$ & $<1$ & $<1$ & $<1$ & $<1$ \\
\hline Barium & 54 & 52 & 52 & 80 & 46 \\
\hline Beryllium & 1.4 & 1.0 & 1.0 & 1.0 & 0.8 \\
\hline Cadmium & $<0.2$ & $<0.2$ & $<0.2$ & $<0.2$ & $<0.2$ \\
\hline Chromium & 26 & 24 & 26 & 34 & 24 \\
\hline Cobalt & 15 & 13 & 15 & 22 & 9 \\
\hline Copper & 40 & 32 & 32 & 32 & 22 \\
\hline Lead & 24 & 18 & 18 & 18 & 14 \\
\hline Mercury & $<0.01$ & $<0.01$ & $<0.01$ & $<0.01$ & 0.02 \\
\hline Molybdenum & $<2$ & $<2$ & $<2$ & $<2$ & $<2$ \\
\hline Nickel & 46 & 32 & 34 & 64 & 24 \\
\hline Selenium & $<0.2$ & $<0.2$ & $<0.2$ & $<0.2$ & $<0.2$ \\
\hline Silver & $<1$ & $<1$ & $<1$ & $<1$ & $<1$ \\
\hline Thallium & 12 & 12 & 10 & 12 & 10 \\
\hline Vanadium & 42 & 82 & 81 & 42 & 30 \\
\hline Zine & 68 & 64 & 63 & 64 & 52 \\
\hline
\end{tabular}

all samples were collected with a 1-1/2-in. -i.d. split-spoon sampler advanced by a 140-lb hammer falling 30 in. Samples were encased in stainless steel sleeves, ends covered with aluminum foil, and sealed with inert tape.

TTotal Threshold Limit Concentration (TTLC). 


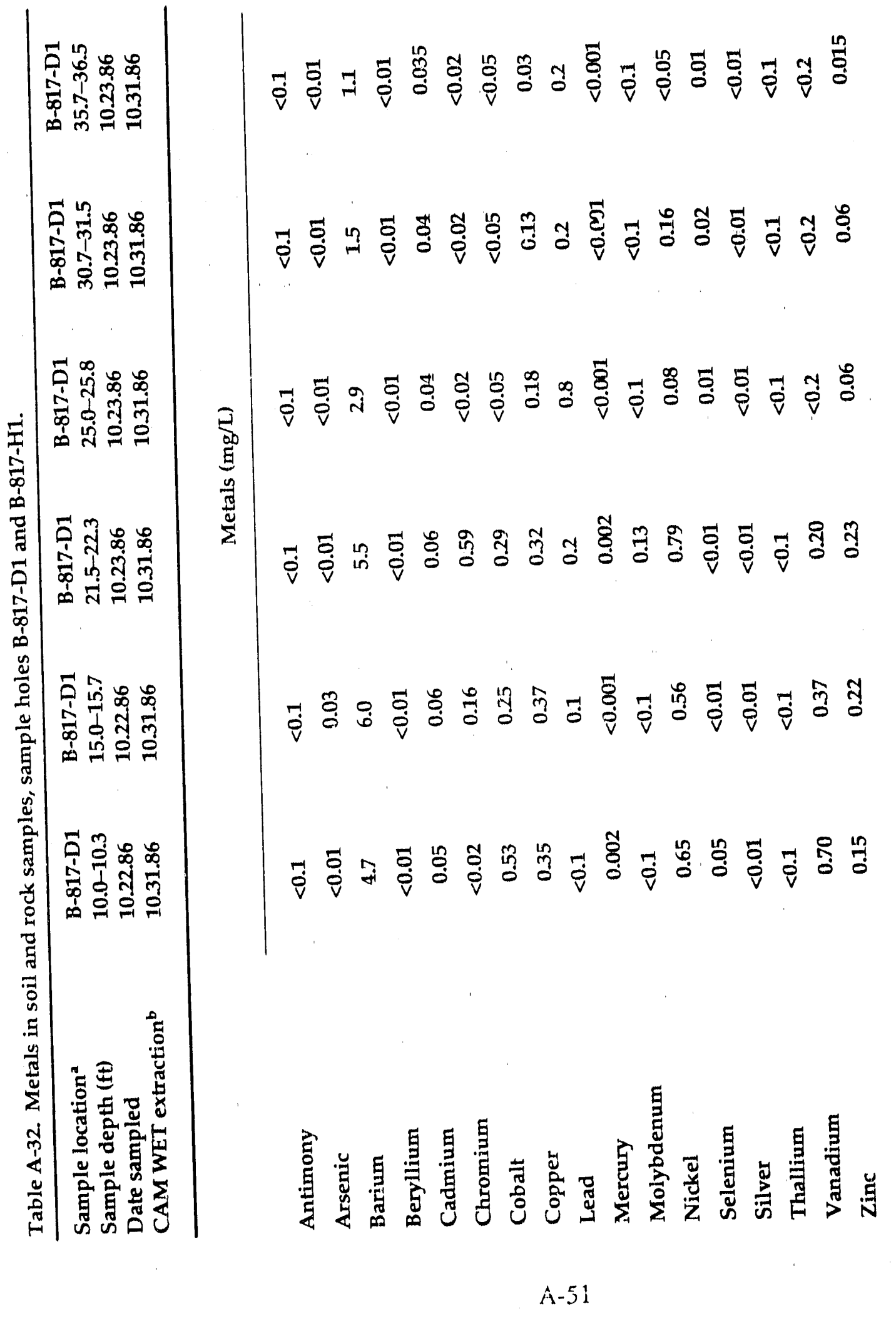




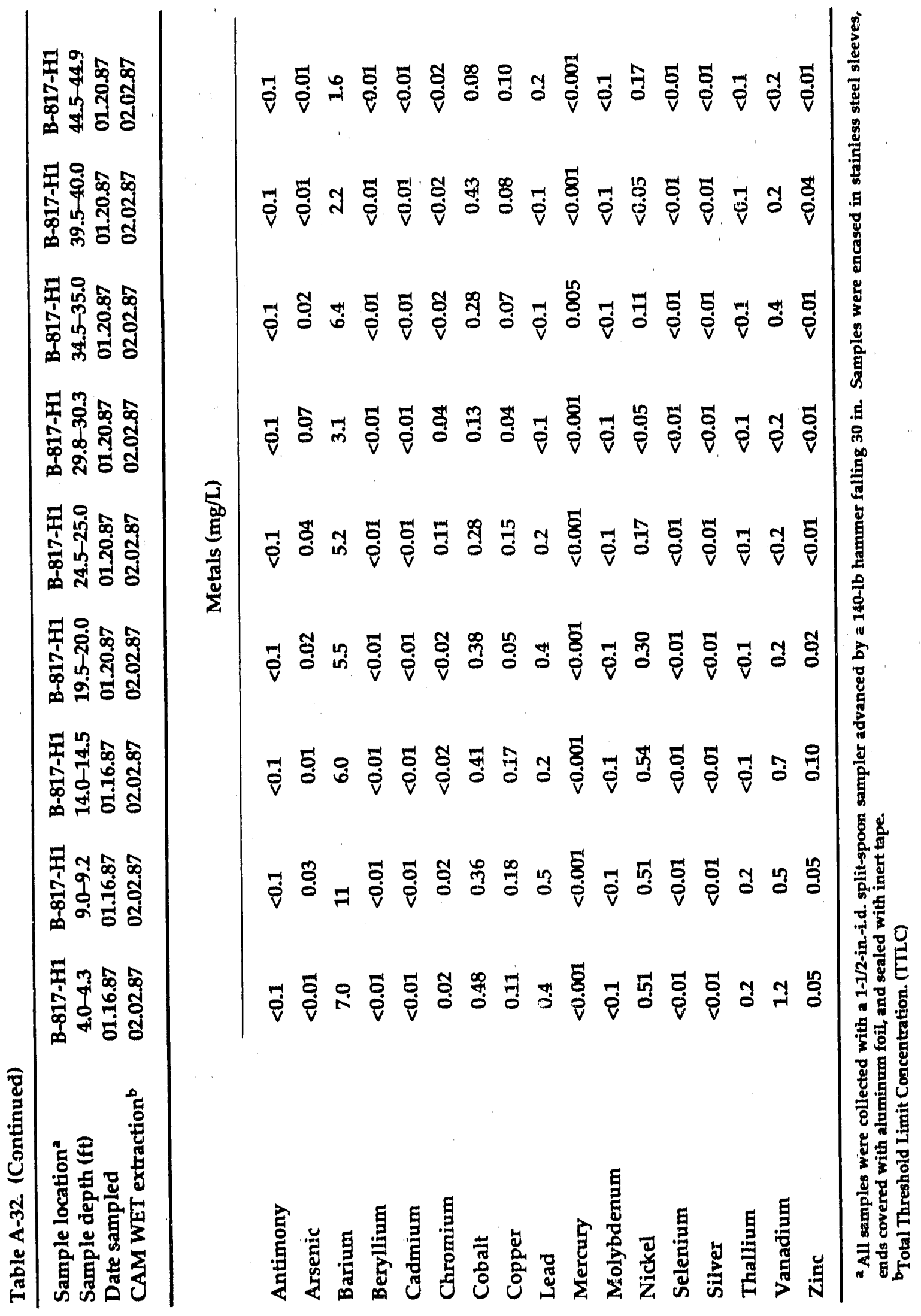


Table A-33. Metals' in surface samples collected within and adjacent to $\mathrm{HE}$ process area rinse-water Lagoon $81 \%$.

\begin{tabular}{lcc}
\hline Sample location & $817-\mathrm{L}^{\mathrm{b}}$ & $817-\mathrm{LBC}^{\mathrm{C}}$ \\
Date sampled & 08.12 .87 & 08.12 .87 \\
CAM WET extractiond & 08.21 .87 & 08.21 .87 \\
\hline & \multicolumn{2}{c}{ Metals (mg/L) } \\
\cline { 2 - 3 } & $<0.1$ & $<0.1$ \\
Antimony & 0.04 & 0.03 \\
Arsenic & 3.5 & 15 \\
Barium & $<0.01$ & 0.01 \\
Beryllium & 0.01 & 0.01 \\
Cadmium & 0.02 & 0.05 \\
Chromium & 0.13 & 0.41 \\
Cobalt & 0.37 & 0.22 \\
Copper & $<0.01$ & 0.1 \\
Lead & $<0.001$ & $<0.001$ \\
Mercury & $<0.1$ & $<0.1$ \\
Molybdenum & 0.16 & 0.44 \\
Nickel & $<0.01$ & $<0.01$ \\
Selenium & 0.01 & 0.02 \\
Silver & $<0.1$ & 0.2 \\
Thallium & 0.2 & 2.1 \\
Vanadium & 0.57 & 0.10 \\
Zinc & & \\
\hline
\end{tabular}

a Samples were obtained with a hand shovel, particles larger than 1/4-in, diam were excluded, and material was then sealed in glass jars using inert tape.

bample was obtained within lagoon.

CBackground sample.

d Soluble Threshold Limit Concentration. 
Table A-34. Metals in soil and rock samples, sample hole B-817-L1, Building 817 area.

\begin{tabular}{|c|c|c|c|c|c|c|}
\hline Sample location" & B-817-L1 & B-817-L1 & B-817-L1 & $B \sim 817-L 1$ & B-817-L1 & B-817-L1 \\
\hline Sample depth (ft) & $12.6-13.1$ & $17.2-17.5$ & $20.2-20.7$ & $25.5-26.0$ & $30.4-30.9$ & $36.1-36.6$ \\
\hline Date sampled & 08.04 .86 & 08.04 .86 & 08.04 .86 & 08.05 .86 & 08.05 .86 & 8.05 .86 \\
\hline \multirow[t]{2}{*}{ Nitric acid digestion ${ }^{b}$} & 08.12 .86 & 08.12 .86 & 08.12 .86 & 08.12 .86 & 08.12 .86 & 8.12 .86 \\
\hline & \multicolumn{6}{|c|}{ Metals (mg/kg) } \\
\hline Antimony & $<10$ & $<10$ & $<10$ & $<10$ & $<10$ & $<10$ \\
\hline Arsenic & $<0.2$ & $<0.2$ & 1.1 & $<0.2$ & $<0.2$ & $<0.2$ \\
\hline Barium & 72 & 34 & 21 & 28 & 40 & 42 \\
\hline Beryllium & 1.0 & 0.8 & 0.8 & 1.2 & 0.6 & 1.4 \\
\hline Cadmium & $<0.2$ & $<0.2$ & $<0.2$ & $<0.2$ & $<0.2$ & $<0.2$ \\
\hline Chromium & 18 & 38 & 39 & 34 & 30 & 17 \\
\hline Cobalt & 13 & 15 & 14 & 18 & 10 & 15 \\
\hline Copper & 36 & 28 & 31 & 28 & 26 & 34 \\
\hline Lead & 14 & 20 & 16 & 16 & 15 & 18 \\
\hline Mercury & 0.02 & 0.02 & $<0.01$ & $<0.01$ & 0.02 & $<0.01$ \\
\hline Molybdenum & $<2$ & $<2$ & $<2$ & $<2$ & $<2$ & $<2$ \\
\hline Nickel & 30 & 90 & 92 & 32 & 26 & 30 \\
\hline Selenium & $<0.2$ & $<0.2$ & $<0.2$ & 0.2 & $<0.2$ & $<0.2$ \\
\hline Silver & $<1$ & $<1$ & $<1$ & $<1$ & $<1$ & $<1$ \\
\hline Thallium & 4 & 8 & 4 & 6 & 4 & 8 \\
\hline Vanadium & 66 & 32 & 41 & 63 & 72 & 82 \\
\hline Zinc & 56 & 60 & 53 & 56 & 54 & 64 \\
\hline Total solids (TS) in \% & 78.1 & 78.7 & 76.7 & 82.8 & NR & 79.2 \\
\hline Volatile solids as \% of TS & 2.5 & 2.4 & 2.0 & 2.8 & $\mathbf{N R}$ & 3.0 \\
\hline
\end{tabular}

all samples were taken with a 1-1/2-in.-i.d. split-spoon sampler advanced by a 140-lb hammer falling 30 in. Samples were encased in stainless steel sleeves, ends covered with aluminum foil, and sealed with inert tape.

b Total Threshold Limit Concentration (TTLC).

NOTE: NR $=$ Not reported. 
Table A-35. Metals in soll and rock samples, sample hole B-817-L2, Bullding 817 Area.

\begin{tabular}{|c|c|c|c|c|c|}
\hline Sample locationa & $B \cdot 817 \cdot L 2$ & {$[3-817-L 2$} & B $-817 \cdot L 2$ & $13-817-[.22$ & $B-817-L_{2}$ \\
\hline Sample depth (ft) & $4.3-4.7$ & $9.3-9.6$ & $14.3-14.8$ & $19.3-19.8$ & $29.6-30.1$ \\
\hline Date sampled & 08.05 .87 & 08.05 .86 & 08.06 .86 & 08.06 .86 & 08.06 .86 \\
\hline Nitric acid digestion ${ }^{b}$ & 08.12 .87 & 08.12 .86 & 08.12 .86 & 08.12 .86 & 08.12 .86 \\
\hline & \multicolumn{5}{|c|}{ Metals (mg/kg) } \\
\hline Antimony & $<10$ & $<10$ & $<10$ & $<10$ & $<10$ \\
\hline Arsendc & 0.4 & 1.1 & 3.2 & 5.8 & $<0.2$ \\
\hline Barlum & 360 & 260 & 100 & 56 & 24 \\
\hline Beryllium & 1.0 & 1.0 & 0.7 & 0.2 & 1.0 \\
\hline Cadmium & $<0.2$ & $<0.2$ & $<0.2$ & $<0.2$ & $<0.2$ \\
\hline Chromium & 16 & 20 & 12 & 9.4 & 46 \\
\hline Cobalt & 11 & 12 & 9 & 7 & 15 \\
\hline Copper & 30 & 54 & 21 & 16 & 36 \\
\hline Lead & 20 & 22 & 11 & 12 & 18 \\
\hline Mercury & $<0.01$ & $<0.01$ & $<0.01$ & 0.03 & 0.05 \\
\hline Molybdenum & $<2$ & $<2$ & $<2$ & $<2$ & $<2$ \\
\hline Nickel & 34 & 38 & 26 & 32 & 82 \\
\hline Selenium & $<0.2$ & 0.8 & 0.2 & 0.3 & $<0.2$ \\
\hline Sllver & $<1$ & $<1$ & $<1$ & $<1$ & $<1$ \\
\hline Thallium & 8 & 8 & 4 & 6 & 6 \\
\hline Vanadlum & 64 & 76 & 91 & 44 & 32 \\
\hline Zine & 50 & 54 & 43 & 38 & 62 \\
\hline Total sollds (TS) in \% & 86 & 85 & 80 & 95 & 79 \\
\hline Volatile solids as \% of TS & 2.6 & 2.9 & 2.3 & 0.8 & 3.1 \\
\hline
\end{tabular}

a All samples were taken will a 1-1/2 In, - id. spllt-spoon sampler advanced by a 140-16 hammer falling 30 in. Samples were encased in stainless steel sleoves, ends covered with aluminum foll, and sealed wlth inert tape.

b'otal Threshold Limit Concentration. (TTLC) 
Table A-36. Metals in surface samples collected withln and adjacent to Lagoon 82.5.

\begin{tabular}{|c|c|c|c|c|}
\hline Sample location" & $B \sim 825 \cdot L 1^{b}$ & $B-825-L .2^{b}$ & $13 \sim 825 \sim L^{3} 3^{b}$ & B $3 \sim 825-L_{1} B^{\prime}$ \\
\hline Date sampled & 08.12 .87 & 09.16 .87 & 09.16 .87 & 08.12 .87 \\
\hline \multirow[t]{2}{*}{ CAM WET extraction (reported date)d } & 08.21 .87 & 10.16 .87 & 10.16 .87 & 08.21 .87 \\
\hline & \multicolumn{3}{|c|}{ Metals (mg/L) } & \\
\hline Antimony & $<0,1$ & $<0.1$ & $<0.1$ & $<(), 1$ \\
\hline Arsenic & 0.02 & $<0.020$ & $<0.020$ & $<0.01$ \\
\hline Barlum & 5.6 & 6.3 & 6.6 & 9.0 \\
\hline Beryllium & 0.01 & $<0.01$ & $<0.01$ & 0.03 \\
\hline Cadmium & 0.26 & 0.09 & 0.11 & 0.01 \\
\hline Chromium & 0.36 & 0.199 & 0.12 & 0.03 \\
\hline Cobalt & 0.37 & 0.39 & 0.42 & 0.48 \\
\hline Copper & 11 & 3.9 & 2.6 & 0.18 \\
\hline Lead & 6.9 & 1.6 & 1.1 & $<0.1$ \\
\hline Mercury & $<0.001$ & $<0.001$ & $<0.001$ & $<0,0001$ \\
\hline Molybdenum & $<0.1$ & $<0.1$ & $<0.1$ & $<0.1$ \\
\hline Nickel & 17 & 0.98 & 1.2 & 0.47 \\
\hline Selenium & $<0.01$ & $<0.010$ & $<0.010$ & $<0.01$ \\
\hline Silver & 0.01 & $<0.01$ & $<0.01$ & $<0.01$ \\
\hline Thallium & $<0.1$ & $<0.1$ & $<0,1$ & $<0.1$ \\
\hline Vanadium & 0.2 & $<0.2$ & $<0.2$ & 0.6 \\
\hline Zinc & 51 & 17 & 11 & 10 \\
\hline
\end{tabular}

- Samples were obtained with a hand shovel, particles larger than $1 / 4-1$, diam removed, and the remaining materlal sealed in glasu jars using Inert tape.

Sample obtained within lagoon.

c Background ample.

dSoluble Threshold Limit Concontration, (STLC) 
Table A.37. Metals in surface samples collected within and adjacent to the 826 Lagoon.

\begin{tabular}{|c|c|c|}
\hline $\begin{array}{l}\text { Sample location" } \\
\text { Date sampled } \\
\text { CAM WET extractlon" }\end{array}$ & $\begin{array}{l}826 \mathrm{~m} \mathrm{~L}^{6} \\
08.12 .87 \\
08.21 .87\end{array}$ & $\begin{array}{l}826 \cdot 1.13^{4} \\
08.12 .87 \\
08.21 .87\end{array}$ \\
\hline & \multicolumn{2}{|c|}{ Metals (mg/L) } \\
\hline Antimony & $<0.1$ & $<0.1$ \\
\hline Arsenic & 0.25 & 0.04 \\
\hline Barlum & 5.9 & 7.1 \\
\hline Berylllum & 0.01 & 0.01 \\
\hline Cadmilum & 0.07 & $<0,01$ \\
\hline Chromlum & 0.56 & 0.02 \\
\hline Cobalt & 0.41 & 0.44 \\
\hline Copper & 2.3 & 0.25 \\
\hline Lead & 0.4 & $<0.01$ \\
\hline Morcury & $<0.0001$ & $<0.001$ \\
\hline Molybdenum & 0.6 & $<0.1$ \\
\hline Nickel & 0.52 & 0.47 \\
\hline Selenium & $<0.01$ & $<0.01$ \\
\hline Sllver & 0.01 & 0.01 \\
\hline Thalllum & $<0.1$ & $<0.1$ \\
\hline Vanadluan & 0.9 & 0.9 \\
\hline Zinc & 26 & 0.27 \\
\hline
\end{tabular}

a Samples wero obtalned wlih a hand shovel, partlcles $>1 / 4$ In. -dlam excluded, and remaining materlal goaled lon glass jars using lnorl tape.

bample oblalned wlihin ligoon.

$c_{\text {Background sample. }}$

Wotal Threshold limit Concontration (TTTSC.C). 
Table A-38. Metals in soll and rock samples, sample holes B-826-1 and B-826-2.

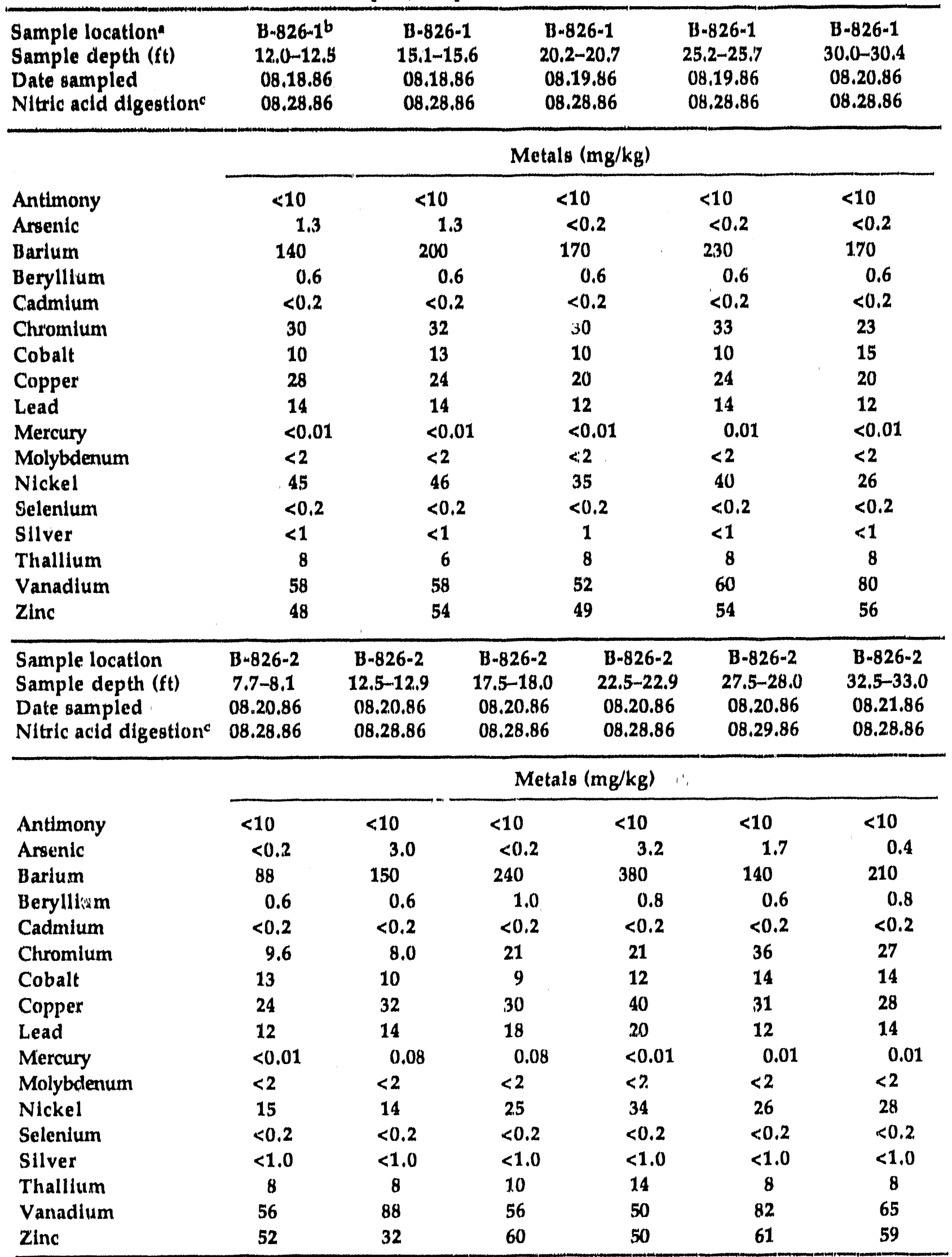

"All samples were collected with a 1-1/2-In. l,d, apllt-spoon sampler advancod by a 140-1b hamimer falling 30 In. Samples were encased in stainlesusteel sleoves, onds covered with aluminum foll, and sealed with inert tape.

b Samples recovered from B-826-1 at <12 ff depth were of insufficlent volume and/or quality to be aultable for analyals.

crotal Threshold Limil Concentration (TTLC). 
Table A-39. Metals in soll and rock samples, sample holes 13-827-C1, B-827-C2, and $13-827-\mathrm{C} 3$, Bulldlug 827 Area.

\begin{tabular}{|c|c|c|c|c|c|c|}
\hline $\begin{array}{l}\text { Sample location" } \\
\text { Sample depth (ft) } \\
\text { Date sampled } \\
\text { Nitric acid digestion b }\end{array}$ & $\begin{array}{l}13-827 . \mathrm{C} 1 \\
5.0-5.5 \\
08.27 .86 \\
09.08 .86\end{array}$ & $\begin{array}{l}\text { B-827-C1 } \\
9.8-10.3 \\
08.27 .86 \\
09.08 .86\end{array}$ & $\begin{array}{l}B \sim 82 \% \cdot C 1 \\
15.0-1.5 .5 \\
08.27 .86 \\
09.08 .86\end{array}$ & $\begin{array}{l}B-827-\mathrm{C} 1 \\
20.5-21.0 \\
08.27 .86 \\
09.08 .86\end{array}$ & $\begin{array}{l}13-827 \cdots C 1 \\
29.8-30.3 \\
08.27 .86 \\
09.08 .86\end{array}$ & $\begin{array}{l}13-827 \times \mathrm{C1} \\
35.01-35.5 \\
06.27 .86 \\
09.08 .86\end{array}$ \\
\hline & \multicolumn{6}{|c|}{ Metals (mg/kg) } \\
\hline Antimony & $<10$ & $<10$ & $<10$ & $<10$ & $<10$ & $<10$ \\
\hline Arsenic & $<0.2$ & $<0.2$ & $<0.2$ & $<0.2$ & $<0.2$ & $<0.2$ \\
\hline Barlum & 190 & 130 & 160 & 270 & 48 & 130 \\
\hline Beryllium & 1.0 & 1.2 & 0.8 & 1.0 & 1.0 & 0.6 \\
\hline Cadmlum & $<0.2$ & $<0.2$ & $<0.2$ & $<0.2$ & $<0.2$ & $<0.2$ \\
\hline Chromium & 19 & 24 & 23 & 19 & 20 & 10 \\
\hline Cobalt & 13 & 16 & 14 & 17 & 14 & 13 \\
\hline Copper & 30 & 32 & 37 & 34 & 24 & 17 \\
\hline Lead & 18 & 20 & 19 & 18 & 18 & 14 \\
\hline Mercury & $<0.01$ & $<0.01$ & $<0.01$ & $<0.01$ & $<0.01$ & $<0.01$ \\
\hline Molybdenum & 6 & 6 & 2 & 6 & 6 & 4 \\
\hline Nickel & 28 & 30 & 28 & 26 & 24 & 12 \\
\hline Selenium & $<0.2$ & $<0.2$ & $<0.2$ & $<0.2$ & $<0,2$ & $<0.2$ \\
\hline Silver & $<1.0$ & $<1.0$ & $<1.0$ & 1.0 & $<1.0$ & $<1.0$ \\
\hline Thallium & 8 & 8 & 8 & 8 & 10 & 8 \\
\hline Vanadlum & 60 & 90 & 65 & 77 & 66 & 84 \\
\hline Zinc & 64 & 68 & 66 & 66 & 76 & 54 \\
\hline Sample location" & $\mathrm{B} \cdot 827-\mathrm{C} 2$ & $B-827-C 2$ & $\mathrm{~B} \cdot 827 \cdot \mathrm{C} 2$ & $B-827-C 2$ & $B-827 \cdot C 2$ & B-827-C2 \\
\hline Sample depth $(\mathrm{ft})$ & $1.6-2.1$ & $5.5-6.0$ & $10.2-10.7$ & $15.6-16.1$ & $21.0-21.5$ & $30.3-30.8$ \\
\hline Date sampled & 08.26 .86 & 08.26 .86 & 08.26 .86 & 08.26 .86 & 08.26 .86 & 08.26 .86 \\
\hline \multirow[t]{2}{*}{ Nitric acid digestion ${ }^{b}$} & 09.08 .86 & 09.08 .86 & 09.08 .86 & 09.08 .86 & 09.08 .86 & 09.08 .86 \\
\hline & \multicolumn{6}{|c|}{ Metals (mg/kg) } \\
\hline Antimony & $<10$ & $<10$ & $<10$ & $<10$ & $<10$ & $<10$ \\
\hline Arsenic & 2.8 & 0.6 & $<0.2$ & 2.2 & $<0.2$ & $<0.2$ \\
\hline Barlum & 140 & 100 & 150 & 100 & 110 & 130 \\
\hline Beryllium & 0.8 & 0.8 & 1.2 & 1.0 & 1.0 & 0.6 \\
\hline Cadmlum & $<0.2$ & $<0.2$ & $<0.2$ & $<0.2$ & $<0.2$ & $<0.2$ \\
\hline Chromium & 24 & 24 & 24 & 28 & 22 & 19 \\
\hline Cobalt & 12 & 11 & 11 & 18 & 18 & 12 \\
\hline Copper & 26 & 2.2 & 30 & 40 & 40 & 30 \\
\hline Lead & 16 & 16 & 18 & 22 & 18 & 18 \\
\hline Mercury & $<0.01$ & $<0,01$ & $<0.01$ & $<0.01$ & $<0.01$ & $<0.01$ \\
\hline Molybdenum & $<2,0$ & $<2.0$ & 4 & 6 & 6 & 6 \\
\hline Nickel & 24 & 21 & 28 & 44 & 32 & 20 \\
\hline Selenium & $<0.2$ & $<0.2$ & $<0.2$ & $<0.2$ & $<0.2$ & $<0.2$ \\
\hline Silver & $<1.0$ & $<1.0$ & $<1.0$ & $<1.0$ & $<1.0$ & $<1.0$ \\
\hline Thallium & 8 & 8 & 8 & 10 & 8 & 8 \\
\hline Vanadlum & 78 & 78 & 52 & 58 & 78 & 56 \\
\hline Zinc & 64 & 60 & 64 & 80 & 68 & 70 \\
\hline
\end{tabular}


Table A-39. (Continued).

\begin{tabular}{|c|c|c|c|c|c|c|}
\hline $\begin{array}{l}\text { Sample location } \\
\text { Sample depth (ft) } \\
\text { Date sampled } \\
\text { Nitric acid digestion }\end{array}$ & $\begin{array}{l}\text { B-827-C3 } \\
1.5-1.8 \\
08.26 .86 \\
09.08 .86\end{array}$ & $\begin{array}{l}\text { B-827-C3 } \\
5.8-6.5 \\
08.26 .86 \\
09.08 .86\end{array}$ & $\begin{array}{l}\text { B-827-C3 } \\
10.0-10.8 \\
08.26 .86 \\
09.08 .86\end{array}$ & $\begin{array}{l}\text { B-827-C3 } \\
16.5-17.0 \\
08.27 .86 \\
09.08 .86\end{array}$ & $\begin{array}{l}\text { B-827-C3 } \\
20.0-20.5 \\
08.27 .86 \\
09.08 .86\end{array}$ & $\begin{array}{l}\text { B-827-C3 } \\
30.0-30.3 \\
08.27 .86 \\
09.08 .86\end{array}$ \\
\hline & \multicolumn{6}{|c|}{ Metals (mg/kg) } \\
\hline Antimony & $<10$ & $<10$ & $<10$ & $<10$ & $<10$ & $<10$ \\
\hline Arsenic & 1.4 & 0.4 & 2.0 & 1.0 & 0.6 & 0.4 \\
\hline Barium & 210 & 140 & 150 & 250 & 200 & 84 \\
\hline Beryllium & 0.6 & 0.6 & 0.4 & 1.0 & 0.6 & 1.2 \\
\hline Cadmium & $<0.2$ & $<0.2$ & $<0.2$ & $<0.2$ & $<0.2$ & $<0.2$ \\
\hline Chromium & 28 & 24 & 23 & 26 & 40 & 14 \\
\hline Cobalt & 11 & 11 & 9 & 11 & 16 & 13 \\
\hline Copper & 26 & 22 & 20 & 46 & 28 & 36 \\
\hline Lead & 20 & 16 & 14 & 22 & 16 & 16 \\
\hline Mercury & $<0.01$ & 0.01 & 0.01 & $<0.01$ & $<0.01$ & $<0.01$ \\
\hline Molybdenum & 6 & 6 & 6 & 6 & $<2.0$ & $<2.0$ \\
\hline Nickel & 34 & 28 & 36 & 38 & 30 & 16 \\
\hline Selenium & $<0.2$ & $<0.2$ & $<0.2$ & $<0.2$ & $<0.2$ & $<0.2$ \\
\hline Silver & $<1.0$ & $<1.0$ & $<1.0$ & $<1.0$ & $<1.0$ & $<1.0$ \\
\hline Thallium & 10 & 8 & 8 & 12 & 8 & 6 \\
\hline Vanadium & 56 & 46 & 32 & 85 & 110 & 110 \\
\hline Zinc & 52 & 50 & 44 & 68 & 72 & 62 \\
\hline
\end{tabular}

a All samples were taken with a 1-1/2-in.-i.d. split-spoon sampler advanced by a 140-lb hammer falling 30 in. Samples were encased in stainless steel sleeves, ends covered with aluminum foil, and sealed with inert tape.

b Total Threshold Limit Concentration (TTLC). 


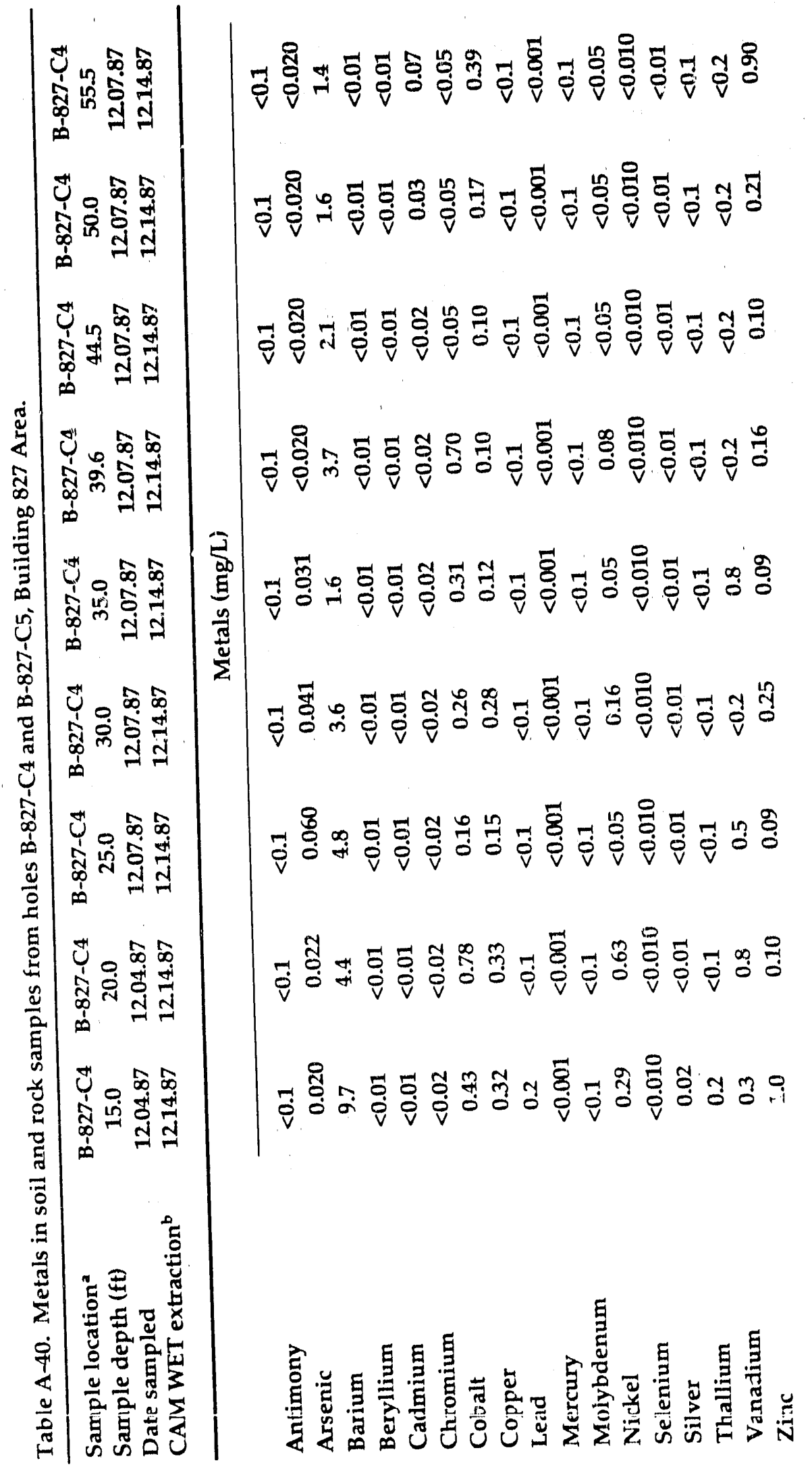




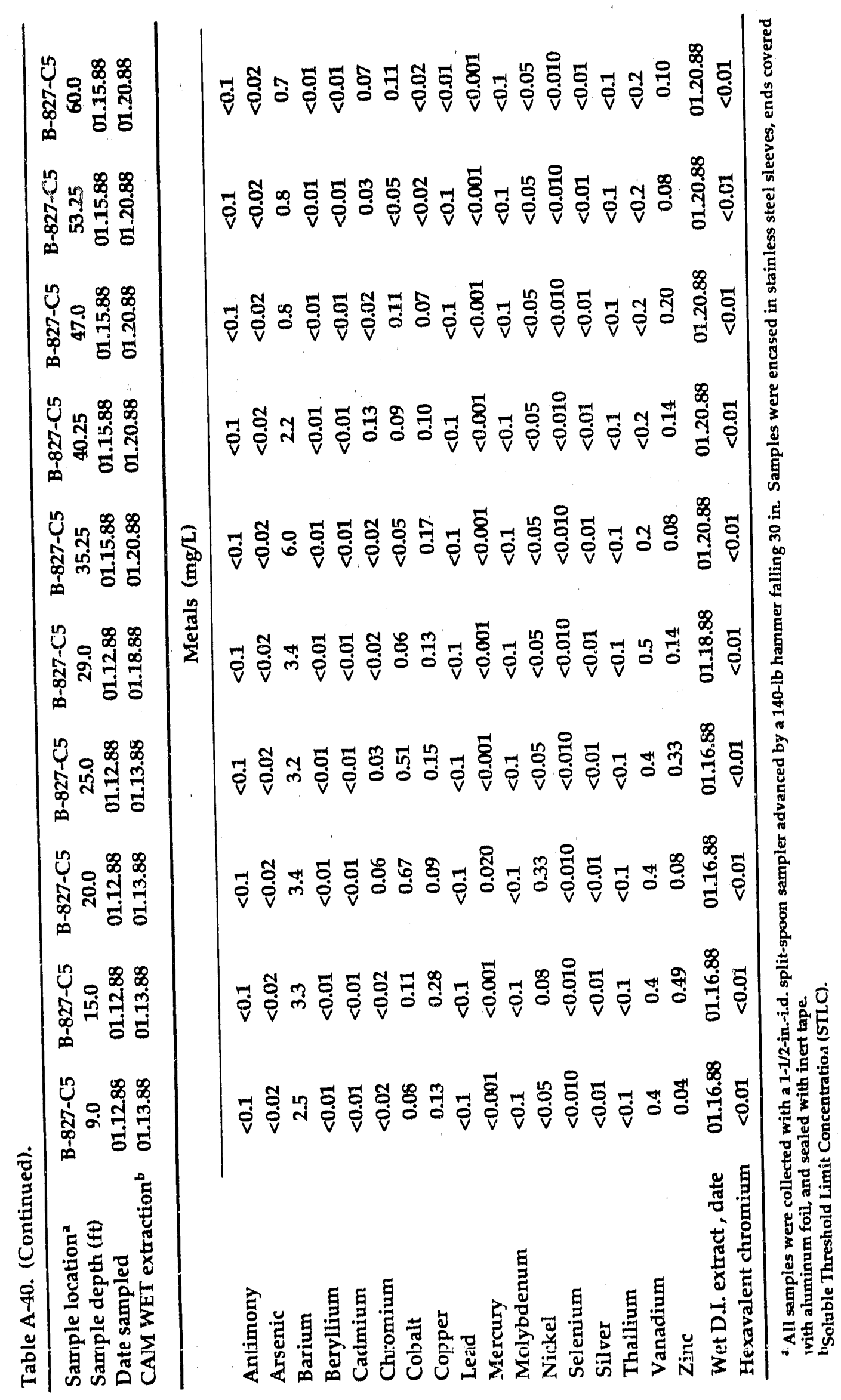


Table A-41. Metals in surface samples collected within and adjacent to HE Process Area rinsewater lagoons.

\begin{tabular}{lcc}
\hline \hline Parameter & \multicolumn{2}{c}{ Sample Designation $^{\mathrm{a}}$} \\
\cline { 2 - 3 } & $827-\mathrm{CL}^{\mathrm{b}}$ & $827-\mathrm{CLB}^{\mathrm{c}}$ \\
Date Sampled & 08.12 .87 & 08.12 .87 \\
CAM WET Extraction & 08.21 .87 & 08.21 .87 \\
\hline Antimony, $\mathrm{mg} / \mathrm{L}$ & $<0.1$ & $<0.1$ \\
Arsenic, $\mathrm{mg} / \mathrm{L}$ & 0.03 & 0.04 \\
Barium, $\mathrm{mg} / \mathrm{L}$ & 6.5 & 3.1 \\
Beryllium, $\mathrm{mg} / \mathrm{L}$ & 0.01 & $<0.01$ \\
Cadmium, $\mathrm{mg} / \mathrm{L}$ & 0.30 & $<0.01$ \\
Chromium, $\mathrm{mg} / \mathrm{L}$ & 0.74 & 0.22 \\
Cobalt, $\mathrm{mg} / \mathrm{L}$ & 0.23 & 0.34 \\
Copper, $\mathrm{mg} / \mathrm{L}$ & 3.9 & 0.34 \\
Lead, $\mathrm{mg} / \mathrm{L}$ & 3.0 & $<0.1$ \\
Mercury, $\mathrm{mg} / \mathrm{L}$ & $<0.001$ & $<0.001$ \\
Molybdenum, $\mathrm{mg} / \mathrm{L}$ & $<0.1$ & 0.1 \\
Nickel, $\mathrm{mg} / \mathrm{L}$ & 0.47 & 0.36 \\
Selenium, $\mathrm{mg} / \mathrm{L}$ & $<0.01$ & $<0.01$ \\
Silver, $\mathrm{mg} / \mathrm{L}$ & 0.01 & 0.01 \\
Thallium, $\mathrm{mg} / \mathrm{L}$ & $<0.1$ & 0.1 \\
Vanadium, $\mathrm{mg} / \mathrm{L}$ & 0.8 & 0.8 \\
Zinc, $\mathrm{mg} / \mathrm{L}$ & 12 & 0.15 \\
\hline \hline
\end{tabular}

asamples were obtained with a hand shovel, particles $>1 / 4$ " diam excluded, and remaining material sealed in glass jars using inert tape.

bSample obtained within lagoon.

'Background sample. 
T'able A-42. Metals in soil and rock samples from hand auger hole B-827-E2 and from surface samples, 827E Lagoon area.

\begin{tabular}{|c|c|c|c|c|c|}
\hline Sample location" & B-827-E2 & B-827-E2 & B-827-E2 & $827-E L^{b, c}$ & $827-$ LLEB $^{b, d}$ \\
\hline Sample depth (ft) & $1.0-1.5$ & $5.0-5.5$ & $6.5-7.0$ & $-^{c}$ & $-m^{d}$ \\
\hline Date sampled & 06.26 .87 & 06.26 .87 & 07.10 .87 & 08.12 .87 & 08.12 .87 \\
\hline \multirow[t]{2}{*}{ CAM WET extraction date ${ }^{\mathrm{e}}$} & 07.22 .87 & 07.22 .87 & 07.29 .87 & 08.21 .87 & 08.21 .87 \\
\hline & \multicolumn{5}{|c|}{ Metals (mg/L) } \\
\hline Antimony & 0.2 & $<0.1$ & $<0.1$ & $<0.1$ & $<0.1$ \\
\hline Arsenic & 0.01 & 0.02 & $<0.01$ & $<0.01$ & $<0.01$ \\
\hline Barium & 5.4 & 4.9 & 12 & 4.4 & 9.4 \\
\hline Beryllium & 0.01 & $<0.01$ & 0.02 & 0.03 & $<0.01$ \\
\hline Cadmium & $<0.01$ & $<0.01$ & $<0.01$ & 0.02 & 0.10 \\
\hline Chromium & 0.03 & 0.03 & $<0.02$ & 1.5 & 0.04 \\
\hline Cobalt & 0.33 & 0.33 & 0.16 & 0.18 & 0.13 \\
\hline Copper & 0.30 & 0.61 & 0.63 & 0.86 & 0.65 \\
\hline Lead & 0.21 & $<0.01$ & 0.2 & $<0.1$ & 0.2 \\
\hline Mercury & $<0.001$ & $<0.001$ & $<0.001$ & $<0,001$ & $<0.001$ \\
\hline Molybdenum & $<0.1$ & $<0.1$ & $<0.1$ & $<0.1$ & $<0.1$ \\
\hline Nickel & 0.28 & 0.30 & 0.59 & 0.42 & 0.12 \\
\hline Selenium & $<0.01$ & $<0.01$ & 0.01 & $<0.01$ & $<0.01$ \\
\hline Silver & $<0.01$ & $<0.01$ & $<0.01$ & $<0.01$ & $<0.01$ \\
\hline Thallium & $<0.1$ & $<0.1$ & $<0.1$ & $<0.1$ & $<0.1$ \\
\hline Vanadium & 0.3 & $<0.2$ & 0.8 & 0.2 & 0.2 \\
\hline Zinc & 0.73 & 0.45 & 0.10 & 2.8 & 19 \\
\hline
\end{tabular}

"Samples obtained in 1-1/2-in.-0.d. stainless steel tube filled by hand-driving a 1-1/2-in.-i.d. split-spoon sampler. Tube ends were covered with aluminum foil and sealed with inert tape.

b Samples obtained with a hand shovel, particles $>1 / 4$ in. diam excluded, and remaining material sealed in glass jars using inert tape.

'Sample obtained within lagoon.

'Background ample.

'Soluble Threahold Limit Concentration (STLC). 
Table A-43. Metals in soil and rork samples, sample hole B-828-1, Building 828 area.

\begin{tabular}{|c|c|c|c|c|}
\hline $\begin{array}{l}\text { Sample location" } \\
\text { Sample depth (ft) } \\
\text { Date sampled } \\
\text { Nitric acid digestion date }\end{array}$ & $\begin{array}{l}B-828-1^{b} \\
15.2-15.7 \\
08.13 .86 \\
08.21 .86\end{array}$ & $\begin{array}{l}\text { B } \sim 828-1 \\
20.0-20.4 \\
08.13 .86 \\
08.21 .86\end{array}$ & $\begin{array}{l}\text { B-828-1 } \\
30.6-31.1 \\
08.13 .86 \\
08.21 .86\end{array}$ & $\begin{array}{l}\text { B-828-1 } \\
35.6-36.0 \\
08.13 .86 \\
08.21 .86\end{array}$ \\
\hline & \multicolumn{4}{|c|}{ Metals (mg/kg) } \\
\hline Antimony & $<10$ & $<10$ & $<10$ & $<10$ \\
\hline Arsenic & $<0.2$ & $<0.2$ & $<0.2$ & $<0.2$ \\
\hline Barium & 560 & 120 & 220 & 520 \\
\hline Beryllium & 0.6 & 0.8 & 0.6 & 1.0 \\
\hline Cadmium & $<0.2$ & $<0.2$ & $<0.2$ & $<0.2$ \\
\hline Chromium & 20 & 18 & 20 & 20 \\
\hline Cobalt & 11 & 8 & 13 & 13 \\
\hline Copper & 30 & 36 & 28 & 50 \\
\hline Lead & 14 & 16 & 16 & 18 \\
\hline Mercury & 0.04 & 0.02 & 0.05 & 0.04 \\
\hline Molybdenum & $<2$ & $<2$ & $<2$ & $<2$ \\
\hline Nickel & 26 & 22 & 24 & 22 \\
\hline Selanium & $<0.2$ & $<0.2$ & $<0.2$ & $<0.2$ \\
\hline Silver & $<1$ & $<1$ & $<1$ & $<1$ \\
\hline Thallium & 4 & 8 & 4 & 6 \\
\hline Vanadium & 110 & 36 & 100 & 130 \\
\hline Zinc & 62 & 44 & 60 & 56 \\
\hline
\end{tabular}

aAll samples were taken with a 1-1/2-In.-i.d. split spoon sampler advanced by a' $140-1 \mathrm{~b}$, hammer falling 30 in. Samples were encased in stainless steel sleeves, ends covered with aluminum foll and sealed with inert tape.

bSamples recovered at $<15 \mathrm{ft}$ depth were of insufficient volume and/or quality to be sultable for analysis.

'Total Threshold Limit Concentration (TTLC.). 


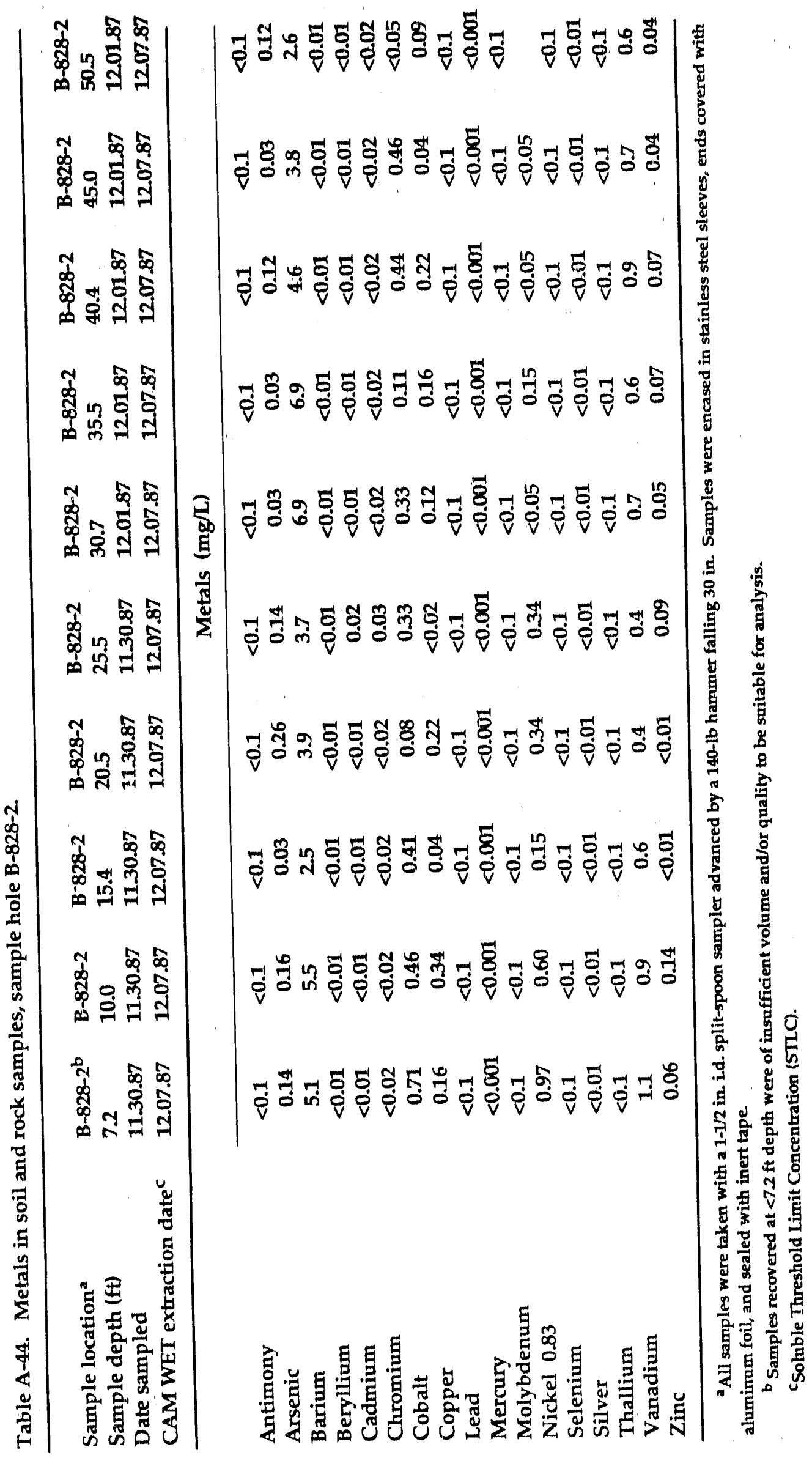


This page intentionally left blank

Following table has facing pages 


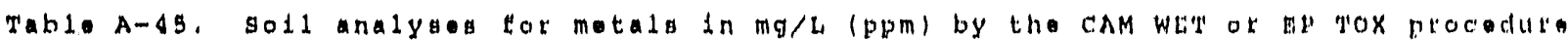

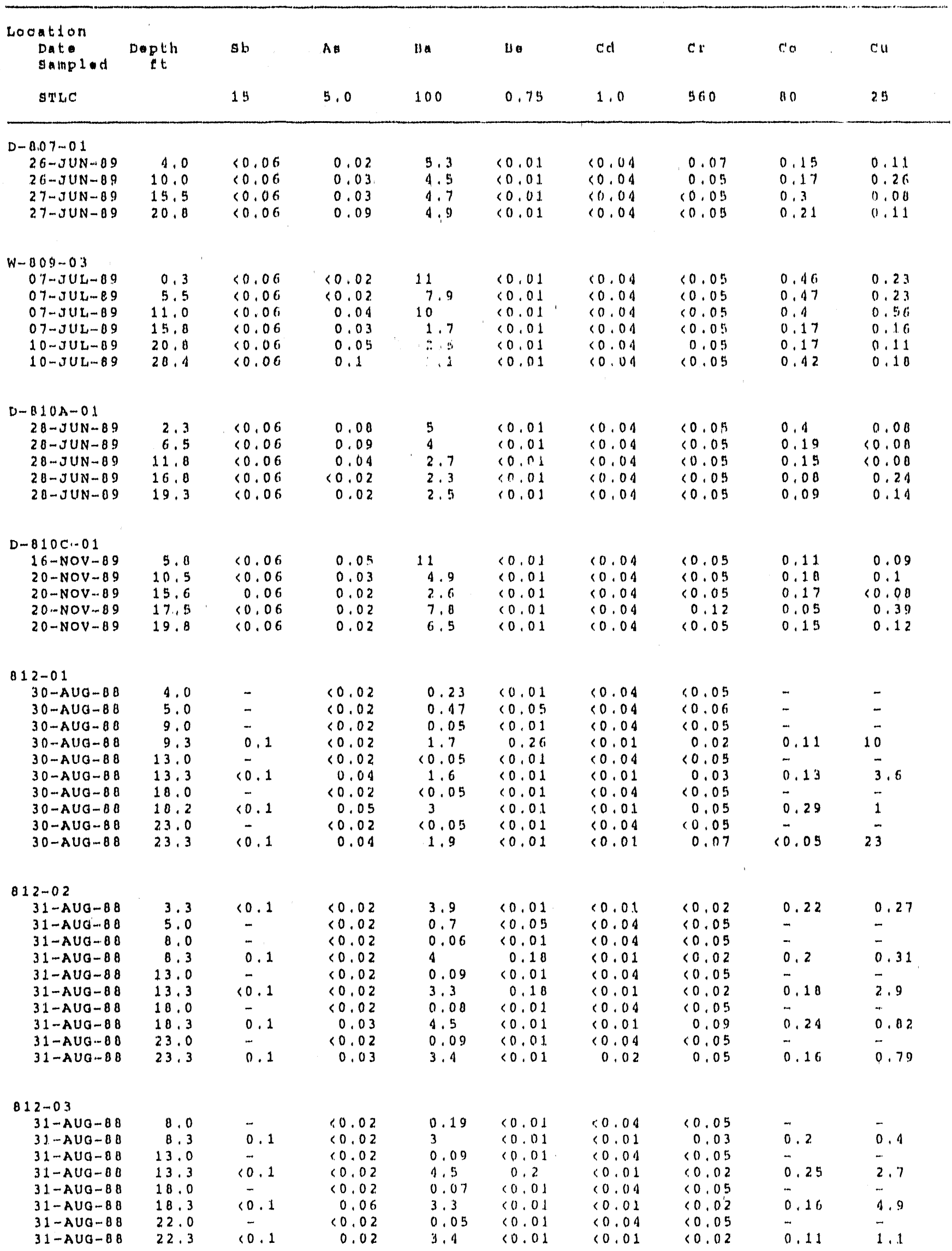


for OtLC.

\begin{tabular}{|c|c|c|c|c|c|c|c|c|}
\hline $\mathrm{pb}$ & Hdg & Mo & NI & 5 & $A g$ & $\eta^{\prime} 1$ & $v$ & ant Loontan \\
\hline 5.0 & 0.2 & 350 & 20 & 1.0 & 5 & 7.0 & 21 & 250 \\
\hline $\begin{array}{l}<0,3 \\
<0,3 \\
<0,3 \\
<0,3\end{array}$ & $\begin{array}{r}(0.001 \\
<0.001 \\
0.002 \\
0.001\end{array}$ & $\begin{array}{l}<0,08 \\
<0.08 \\
<0.00 \\
<0.08\end{array}$ & $\begin{array}{l}0.11 \\
0.21 \\
0.113 \\
0.17\end{array}$ & $\begin{array}{l}10.02 \\
10.02 \\
10.02 \\
10.02\end{array}$ & $\begin{array}{l}<0.02 \\
<0.02 \\
<0.02 \\
<0.02\end{array}$ & $\begin{array}{l}<0,2 \\
<0,2 \\
<0,2 \\
<0,2\end{array}$ & $\begin{array}{l}0.2 \\
0.23 \\
0.01 \\
1.1\end{array}$ & $\begin{array}{l}0,1^{0-007-01} \\
0.10 \\
0.03 \\
0.00\end{array}$ \\
\hline $\begin{array}{l}<0,3 \\
<0,3 \\
<0,3 \\
<0,3 \\
<0,3 \\
<0,3\end{array}$ & $\begin{array}{l}<0.001 \\
<0.001 \\
<0.001 \\
<0.001 \\
<0.001 \\
<0.001\end{array}$ & $\begin{array}{l}<0.00 \\
<0.00 \\
<0.00 \\
<0.08 \\
<0.08 \\
<0.08\end{array}$ & $\begin{array}{l}0.41 \\
0.35 \\
0.64 \\
0.11 \\
0.1 \\
0.12\end{array}$ & $\begin{array}{l}<0.02 \\
<0.02 \\
<0.02 \\
<0.02 \\
<0.02 \\
<0.02\end{array}$ & $\begin{array}{r}<0,02 \\
0.11 \\
<0,02 \\
<0,02 \\
<0,02 \\
<0,02\end{array}$ & $\begin{array}{l}<0,2 \\
10,2 \\
<0,2 \\
<0,2 \\
10,2 \\
<0,2\end{array}$ & $\begin{array}{l}0.93 \\
0.9 \\
0.96 \\
0.33 \\
0.92 \\
0.47\end{array}$ & $\begin{array}{l}\quad w-009.03 \\
0.22 \\
0.06 \\
0.1 \\
0.12 \\
0.06 \\
0.01\end{array}$ \\
\hline $\begin{array}{l}<0,3 \\
<0,3 \\
<0,3 \\
<0,3 \\
<0.3\end{array}$ & $\begin{array}{l}<0.001 \\
<0.001 \\
<0.001 \\
<0.001 \\
<0.001\end{array}$ & $\begin{array}{l}<0.08 \\
<0.08 \\
<0.08 \\
10.08 \\
<0.08\end{array}$ & $\begin{array}{l}0.16 \\
0.00 \\
0.08 \\
0.08 \\
0.08\end{array}$ & $\begin{array}{l}<0.02 \\
<0.02 \\
<0.02 \\
<0.02 \\
10.02\end{array}$ & $\begin{array}{l}<0,02 \\
<0.02 \\
<0.02 \\
<0.02 \\
<0.02\end{array}$ & $\begin{array}{l}<0,2 \\
<0,2 \\
<0,2 \\
<0,2 \\
<0,2\end{array}$ & $\begin{array}{l}1.5 \\
0.94 \\
0.65 \\
0.30 \\
0.52\end{array}$ & $\begin{array}{l}0.010 \mathrm{~A}-01 \\
0.04 \\
0.02 \\
0.01 \\
0.05 \\
0.04\end{array}$ \\
\hline $\begin{array}{l}<0,3 \\
<0,3 \\
<0,3 \\
<0,3 \\
<0,3\end{array}$ & $\begin{array}{l}<0.001 \\
<0.001 \\
<0.001 \\
0.26 \\
<0.001\end{array}$ & $\begin{array}{l}<0.00 \\
<0.00 \\
<0.00 \\
0.14 \\
<0.08\end{array}$ & $\begin{array}{r}0.07 \\
0.04 \\
<0.03 \\
0.03 \\
0.03\end{array}$ & $\begin{array}{r}0.02 \\
0.02 \\
<0.02 \\
0.02 \\
<0.02\end{array}$ & $\begin{array}{l}<0.02 \\
<0.02 \\
<0.02 \\
0.02 \\
<0.02\end{array}$ & $\begin{array}{l}<0,2 \\
<0,2 \\
<0,2 \\
<0.2 \\
<0.2\end{array}$ & $\begin{array}{l}0.76 \\
0.9 \\
0.6 \\
0.05 \\
0.46\end{array}$ & $\begin{array}{l}\quad D-810 C-01 \\
<0.01 \\
<0.01 \\
<0.01 \\
<0.01 \\
<0.01\end{array}$ \\
\hline $\begin{array}{l}10,3 \\
<0,3 \\
<0,3 \\
2,5 \\
<0,3 \\
<0,1 \\
<0,3 \\
<0,1 \\
<0,3 \\
10.8\end{array}$ & $\begin{array}{l}<0.0002 \\
<0.0002 \\
<0.0002 \\
<0.001 \\
<0.0002 \\
<0.001 \\
<0.0002 \\
<0.001 \\
<0.0002 \\
<0.001\end{array}$ & $\begin{array}{l}\overline{-} \\
\overline{0} \\
\overline{0} .1 \\
\overline{0} .1 \\
\overline{0} .1 \\
\overline{0} .1\end{array}$ & $\begin{array}{l}\overline{-} \\
\overline{0} \\
\overline{0} .05 \\
\overline{0}, 05 \\
\overline{0} .15 \\
\overline{0} .05\end{array}$ & $\begin{array}{l}<0.01 \\
<0.01 \\
<0.01 \\
<0.01 \\
<0.01 \\
<0.01 \\
<0.01 \\
<0.01 \\
<0.01 \\
<0.01\end{array}$ & $\begin{array}{l}<0.02 \\
<0.02 \\
<0.02 \\
<0.01 \\
0.02 \\
<0.01 \\
<0.02 \\
<0.01 \\
0.02 \\
10.02\end{array}$ & $\begin{array}{l}- \\
\overline{0} \\
\overline{0} .1 \\
\overline{0} .1 \\
\overline{0} .1 \\
\overline{0} .1\end{array}$ & $\begin{array}{l}- \\
- \\
\overline{0} .2 \\
\overline{0} .2 \\
\overline{0} .3 \\
\overline{0}, 2\end{array}$ & $\begin{array}{l}- \\
\overline{-} \\
\overline{1} .6 \\
\overline{0} .50 \\
\overline{0} .15 \\
\overline{10.97}\end{array}$ \\
\hline $\begin{array}{r}0.4 \\
60.3 \\
60.3 \\
0.4 \\
60.3 \\
0.4 \\
<0.3 \\
60.1 \\
<0.3 \\
<0.1\end{array}$ & $\begin{array}{l}<0.001 \\
<0.0002 \\
<0.0002 \\
<0.001 \\
<0.0002 \\
<0.001 \\
<0.0002 \\
<0.001 \\
<0.0002 \\
<0.001\end{array}$ & $\begin{array}{l}<0.1 \\
- \\
- \\
0.1 \\
\overline{0} .1 \\
\overline{0} \\
\overline{0} .1 \\
<0.1\end{array}$ & $\begin{array}{l}0.05 \\
- \\
- \\
0.15 \\
- \\
0.05 \\
- \\
0.33 \\
- \\
0.17\end{array}$ & $\begin{array}{l}<0.01 \\
<0.01 \\
<0.01 \\
60.01 \\
<0.01 \\
<0.01 \\
<0.01 \\
<0.01 \\
<0.01 \\
<0.01\end{array}$ & $\begin{array}{l}<0.01 \\
<0.02 \\
<0.02 \\
<0.01 \\
<0.02 \\
<0.01 \\
<0.02 \\
<0.01 \\
<0.02 \\
<0.01\end{array}$ & $\begin{array}{l}<0.1 \\
- \\
=0.1 \\
-\overline{0} .1 \\
- \\
<0.1 \\
-\overline{0} \\
<.1\end{array}$ & $\begin{array}{l}0.4 \\
- \\
- \\
0.1 \\
\overline{0} .2 \\
\overline{0} .2 \\
-\overline{0} .2\end{array}$ & $\begin{array}{l}0.06 \\
0.012-02 \\
- \\
0.05 \\
-0.73 \\
\cdots \\
0.14 \\
-0.14\end{array}$ \\
\hline & & & & & & & & $012-03$ \\
\hline$<0.3$ & $\angle 0,0002$ & - & - & $(0,01$ & $<0.02$ & - & - & - \\
\hline$<0.1$ & $<0,001$ & $<0,1$ & 0.21 & .0 .01 & $(0.01$ & $<0.1$ & $<0.2$ & 0.04 \\
\hline 10.3 & $<0.0002$ & - & - & $<0.01$ & 10.02 & - & - & - \\
\hline 14 & $<0.001$ & $<0.1$ & 0.09 & .0 .01 & 10.01 & $<0.1$ & 0.4 & 0,31 \\
\hline 40.3 & $<0.0002$ & - & - & 10.01 & 10.02 & - & - & - \\
\hline 0.1 & $<0.001$ & $(0.1$ & 10.05 & 10.01 & 10.01 & $(0.1$ & 0.6 & 0.44 \\
\hline 10.3 & $<0,0002$ & -- & - & $(0.01$ & $<0.02$ & - & - & - \\
\hline$<0.1$ & $<0,001$ & $<0,1$ & 10.05 & $(0.01$ & $<0.01$ & $<0.1$ & $<0.2$ & 0.15 \\
\hline
\end{tabular}




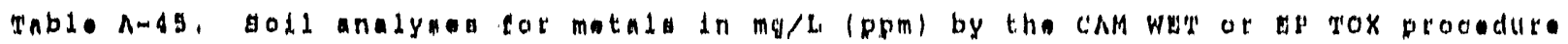

\begin{tabular}{|c|c|c|c|c|c|c|c|c|c|}
\hline \multirow{2}{*}{$\begin{array}{c}\text { Lootion } \\
\text { Dote } \\
\text { gumplod } \\
\text { oTLC }\end{array}$} & \multirow[t]{2}{*}{$D \bullet p t h$} & \multirow{2}{*}{ ob } & \multirow{2}{*}{$\begin{array}{l}A B \\
0.0\end{array}$} & \multirow{2}{*}{$\begin{array}{l}10 \\
100\end{array}$} & \multirow{2}{*}{$\begin{array}{l}110 \\
0.79\end{array}$} & \multirow{2}{*}{$\begin{array}{l}\text { cd } \\
1.0\end{array}$} & \multirow{2}{*}{$\begin{array}{l}c t \\
560\end{array}$} & \multirow{2}{*}{$\begin{array}{l}\mathrm{Co} \\
00\end{array}$} & \multirow{2}{*}{$\begin{array}{ll}\mathrm{Cu} \\
29\end{array}$} \\
\hline & & & & & & & & & \\
\hline $\begin{array}{l}D-012 C-02 \\
27-J U N-89\end{array}$ & 1.5 & 10.06 & $<0,02$ & 9 & $<0.0 .1$ & 10.04 & 0.13 & 0.66 & 0.1 \\
\hline $\begin{array}{l}013-01 \\
26-J \cup L-09 \\
26-J U L-09 \\
27-J U L-09 \\
27 \ldots J \cup L=09 \\
27-1 J U L-09 \\
27-J U L-09 \\
27 \ldots J U L-89 \\
27-J \cup L-89\end{array}$ & $\begin{array}{r}1.0 \\
0.0 \\
10.0 \\
16.0 \\
21.0 \\
31.0 \\
40.0 \\
11.0\end{array}$ & 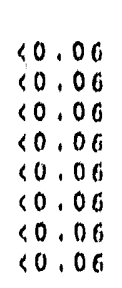 & $\begin{array}{l}60.02 \\
0.03 \\
0.07 \\
0.21 \\
0.04 \\
0.03 \\
0.03 \\
0.03\end{array}$ & $\begin{array}{l}10 \\
12 \\
7,6 \\
0 \\
4.2 \\
5.3 \\
4.9 \\
11\end{array}$ & $\begin{array}{l}<0,01 \\
20.01 \\
20.01 \\
20.01 \\
20.01 \\
20.01 \\
20.01 \\
40.01\end{array}$ & $\begin{array}{l}<0.04 \\
20.04 \\
<0.04 \\
20.04 \\
20.04 \\
<0.04 \\
<0.04 \\
<0.04\end{array}$ & $\begin{array}{l}<0.05 \\
<0,09 \\
<0.09 \\
<0,05 \\
<0,05 \\
<0.05 \\
<0.05 \\
<0.05\end{array}$ & $\begin{array}{l}0.20 \\
0.09 \\
0.42 \\
0.19 \\
0.26 \\
0.37 \\
0.01 \\
0.19\end{array}$ & $\begin{array}{r}0.12 \\
0.00 \\
0.31 \\
0.00 \\
0.19 \\
0.23 \\
0.19 \\
0.47\end{array}$ \\
\hline 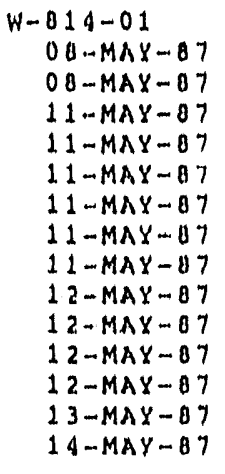 & $\begin{array}{r}5.5 \\
10.5 \\
13.5 \\
10.5 \\
25.5 \\
30.5 \\
35.8 \\
10.5 \\
50.5 \\
59.5 \\
69.8 \\
79.8 \\
99.0 \\
109.8\end{array}$ & $\begin{array}{l}= \\
= \\
= \\
= \\
= \\
= \\
= \\
= \\
-\end{array}$ & $\begin{array}{l}- \\
= \\
= \\
= \\
= \\
= \\
= \\
= \\
=\end{array}$ & 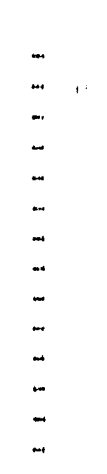 & $\begin{array}{l}- \\
- \\
-. \\
- \\
- \\
- \\
- \\
- \\
- \\
-\end{array}$ & $\begin{array}{l}<0.01 \\
<0.01 \\
40.01 \\
0.01 \\
60.01 \\
<0.01 \\
10.01 \\
<0.01 \\
0.02 \\
0.01 \\
<0.01 \\
<0.01 \\
<0.01 \\
<0.01\end{array}$ & $\begin{array}{l}<0.02 \\
40.02 \\
40.02 \\
40.02 \\
40.02 \\
0.02 \\
10.02 \\
40.02 \\
10.02 \\
10.02 \\
0.03 \\
10.02 \\
<0.02 \\
10.02\end{array}$ & $\begin{array}{r}0.07 \\
0.32 \\
<0.09 \\
0.07 \\
<0.05 \\
80.05 \\
<0.05 \\
<0.05 \\
0.28 \\
80.05 \\
40.05 \\
40.05 \\
0.29 \\
0.15\end{array}$ & $\begin{array}{ll}0.05 \\
0.05 \\
0.15 \\
0.1 & 3 \\
0.1 & 5 \\
0.1 & 0 \\
0.3 & 4 \\
0.1 & 2 \\
0.1 & 0 \\
0.1 & 1 \\
0.25 \\
0.25 \\
0.31 \\
0.26\end{array}$ \\
\hline $\begin{array}{l}W-815-05 \\
21-J U L-09 \\
21-J U L-09 \\
21-J U L-89 \\
21-J U L-09 \\
21-J U L-09 \\
21-J U L-09\end{array}$ & $\begin{array}{r}0.8 \\
5.3 \\
10.5 \\
15.5 \\
20.5 \\
30.8\end{array}$ & $\begin{array}{l}<0.06 \\
<0.06 \\
<0.06 \\
<0.06 \\
<0.06 \\
<0.06\end{array}$ & $\begin{array}{l}0.07 \\
0.05 \\
0.1 \\
0.11 \\
0.21 \\
0.1\end{array}$ & $\begin{array}{l}7.3 \\
7.5 \\
9.3 \\
4.1 \\
0.8 \\
5.7\end{array}$ & $\begin{array}{l}<0.01 \\
<0.01 \\
<0.01 \\
<0.01 \\
<0.01 \\
<0.01\end{array}$ & $\begin{array}{l}<0.04 \\
<0.04 \\
<0.04 \\
<0.04 \\
<0.04 \\
<0.04\end{array}$ & $\begin{array}{r}<0.05 \\
0.13 \\
<0.05 \\
0.05 \\
0.12 \\
<0.05\end{array}$ & $\begin{array}{l}0.34 \\
0.61 \\
0.40 \\
0.70 \\
0.49 \\
1.2\end{array}$ & $\begin{array}{c}0.89 \\
15 \\
0.53 \\
0.14 \\
0.7 \\
0.22\end{array}$ \\
\hline $\begin{array}{l}819-01 \\
20-0 C T-86 \\
20-O C T-86 \\
20-0 C T-86 \\
20-O C T-86 \\
21-O C T-86 \\
21-O C T-8 G \\
21-O C T-86\end{array}$ & $\begin{array}{l}5.6 \\
10.7 \\
13.5 \\
19.0 \\
24.5 \\
28.9 \\
34.8\end{array}$ & $\begin{array}{l}- \\
- \\
- \\
- \\
-\end{array}$ & $\begin{array}{l}- \\
- \\
- \\
- \\
- \\
-\end{array}$ & $\begin{array}{l}- \\
- \\
- \\
- \\
- \\
-\end{array}$ & $\begin{array}{l}- \\
- \\
- \\
- \\
-\end{array}$ & $\begin{array}{l}0.12 \\
0.03 \\
0.01 \\
0.09 \\
0.08 \\
0.05 \\
0.09\end{array}$ & $\begin{array}{l}0.35 \\
0.29 \\
0.06 \\
1.5 \\
0.33 \\
0.1 \\
0.1\end{array}$ & $\begin{array}{l}0.53 \\
0.29 \\
0.21 \\
0.49 \\
0.94 \\
0.17 \\
0.41\end{array}$ & $\begin{array}{l}0.1 \\
0.2 \\
0.15 \\
0.00 \\
0.15 \\
0.10 \\
0.00\end{array}$ \\
\hline $\begin{array}{l}W-819 \cdots 03 \\
09-D E C-87 \\
09-D E C-89 \\
09-D E C-07\end{array}$ & $\begin{array}{l}10.8 \\
15.0 \\
20.5\end{array}$ & $\begin{array}{l}- \\
-\end{array}$ & $\begin{array}{l}- \\
-\end{array}$ & $\begin{array}{l}- \\
-\end{array}$ & $\begin{array}{l}- \\
-\end{array}$ & $\begin{array}{l}0.01 \\
<0.01 \\
0.01\end{array}$ & $\begin{array}{l}0.02 \\
0.09 \\
0.08\end{array}$ & $\begin{array}{l}0.19 \\
0.22 \\
0.17\end{array}$ & $\begin{array}{l}0.09 \\
0.26 \\
0.30\end{array}$ \\
\hline $\begin{array}{l}D \cdots 827 A-01 \\
30-J U N-89 \\
30-J U N-89 \\
30-7 U N-89 \\
30-J U N-89 \\
30-J U N \cdots 89\end{array}$ & $\begin{array}{r}2.8 \\
7.0 \\
11.8 \\
15.8 \\
19.7\end{array}$ & $\begin{array}{l}80.06 \\
<0.06 \\
80.06 \\
20.06 \\
10.06\end{array}$ & $\begin{array}{l}0.02 \\
0.02 \\
0.02 \\
0.031 \\
0.03\end{array}$ & $\begin{array}{l}4.3 \\
5 \\
6 \\
2.9 \\
1.9\end{array}$ & $\begin{array}{l}40.01 \\
60.01 \\
0.01 \\
0.01 \\
0.01\end{array}$ & $\begin{array}{l}80.04 \\
20.04 \\
20.04 \\
80.04 \\
60.04\end{array}$ & $\begin{array}{l}<0.05 \\
10.05 \\
10.05 \\
10.05 \\
0.05\end{array}$ & $\begin{array}{l}0.21 \\
0.27 \\
0.29 \\
0.2 \\
0.21\end{array}$ & $\begin{array}{l}0.09 \\
0.19 \\
0.1 \\
0.11 \\
0.17\end{array}$ \\
\hline $\begin{array}{l}D-827 B-01 \\
26-J \cup N-89 \\
26-J U N-89 \\
26-J \cup N-89\end{array}$ & $\begin{array}{r}2.0 \\
7.0 \\
10.0\end{array}$ & $\begin{array}{l}<0.06 \\
<0.06 \\
<0.06\end{array}$ & $\begin{array}{l}0.02 \\
0.02 \\
0.02\end{array}$ & $\begin{array}{l}2.3 \\
1.0 \\
5.5\end{array}$ & $\begin{array}{l}0.01 \\
<0.01 \\
<0.01\end{array}$ & $\begin{array}{l}<0.04 \\
<0.04 \\
<0.04\end{array}$ & $\begin{array}{r}0.05 \\
<0.05 \\
0.18\end{array}$ & $\begin{array}{l}0.10 \\
0.10 \\
0.16\end{array}$ & $\begin{array}{l}0.24 \\
0.2 \\
1.2\end{array}$ \\
\hline
\end{tabular}




\begin{tabular}{|c|c|c|c|c|c|c|c|c|}
\hline W b & $11 \mathrm{~g}$ & Mo & $N !$ & no & $\Lambda \mathrm{d}$ & 'I'I & $v$ & \#n linent tant \\
\hline 4.0 & 0,2 & 350 & 20 & 1.0 & $!$ & 7,0 & 21 & 240 \\
\hline$(0,3)$ & 10.001 & $(0,00$ & 0.5 & $<0,0]$ & 10.02 & $<0.2$ & $0.1 ; 2$ & $0,110120.112$ \\
\hline $\begin{array}{l}<0,3 \\
<0,3 \\
<0,3 \\
<0,3 \\
<0,3 \\
<0,3 \\
<0,3 \\
<0,3\end{array}$ & 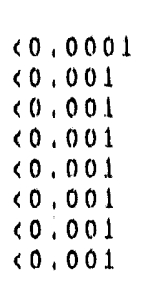 & $\begin{array}{l}<0,00 \\
\angle 0,00 \\
<0,00 \\
\angle 0,00 \\
<0,00 \\
\angle 0,00 \\
\angle 0,00 \\
<0,08\end{array}$ & $\begin{array}{c}0.21 \\
0.03 \\
0.23 \\
0.013 \\
0.09 \\
0.311 \\
0.03 \\
0.0\end{array}$ & $\begin{array}{l}<0,02 \\
\langle 0,0) \\
(0,02 \\
40.0) 2 \\
0.02 \\
0.02 \\
0.0) 2 \\
0.02\end{array}$ & $\begin{array}{l}(0,02 \\
40,02 \\
40,02 \\
40,02 \\
20,02 \\
40,02 \\
40.02 \\
0.02\end{array}$ & $\begin{array}{l}<0, ? \\
<0,2 \\
<0,2 \\
<0,2 \\
<0,2 \\
<0,2 \\
<0,2 \\
<0,2\end{array}$ & $\begin{array}{l}0.20 \\
0.37 \\
1.19 \\
1.17 \\
0.0 \\
0.18 \\
0.30 \\
0.96\end{array}$ & $\begin{array}{l}0.12 \\
0.01 \\
0.01 .01 \\
0.17 \\
0.72 \\
0.01 \\
0.01 \\
0.00\end{array}$ \\
\hline $\begin{array}{l}<0.1 \\
<0.1 \\
<0.1 \\
0.1 \\
0.1 \\
0.1 \\
0.1 \\
0.1 \\
<0.1 \\
0.1 \\
<0.1 \\
0.1 \\
0.1 \\
0.1 \\
0.3 \\
0.1\end{array}$ & 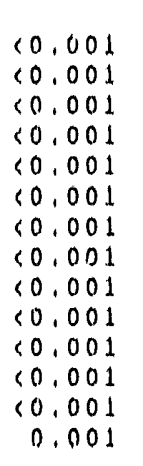 & $\begin{array}{l}<0,1 \\
<0,1 \\
<0,1 \\
00,1 \\
<0,1 \\
<0,1 \\
<0,1 \\
<0,1 \\
<0,1 \\
<0,1 \\
<0,1 \\
<0,1 \\
<0,1 \\
60,1 \\
<0,1\end{array}$ & $\begin{array}{l}0.29 \\
0.1 \\
0.01 \\
0.11 \\
0.11 \\
0.11 \\
0.11 \\
0.11 \\
0.90 \\
0.00 \\
0.11 \\
0.09 \\
0.40 \\
0.1\end{array}$ & 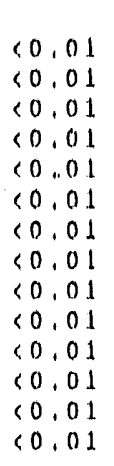 & $\begin{array}{l}(0.01 \\
40.01 \\
0.01 \\
0.01 \\
0.01 \\
0.01 \\
0.01 \\
0.01 \\
0.01 \\
0.01 \\
0.01 \\
0.01 \\
0.01 \\
0.01 \\
0.01 \\
0.01\end{array}$ & 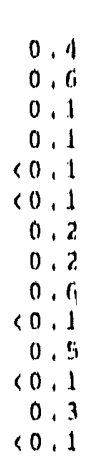 & $\begin{array}{r}60,2 \\
0,3 \\
0,3 \\
<0,2 \\
<0,2 \\
<0,2 \\
<0,2 \\
0,0 \\
0,3 \\
0,3 \\
<0,2 \\
0,4 \\
0,1 \\
0.2\end{array}$ & 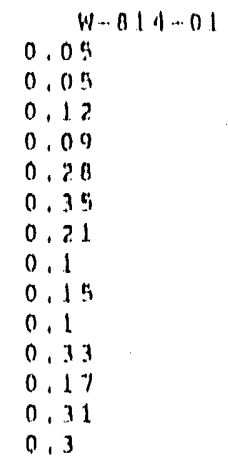 \\
\hline $\begin{array}{l}<0,3 \\
0,3 \\
\because, 3 \\
20,3 \\
0,3 \\
<0,3\end{array}$ & $\begin{array}{l}<0.001 \\
<0.001 \\
<0.001 \\
<0.001 \\
<0.001 \\
<0.001\end{array}$ & $\begin{array}{l}<0.08 \\
<0.08 \\
0.08 \\
<0.08 \\
<0.00 \\
<0.08\end{array}$ & $\begin{array}{l}0.3 \\
0.611 \\
0.47 \\
0.09 \\
0.52 \\
0.41\end{array}$ & $\begin{array}{l}<0,02 \\
40,02 \\
0,02 \\
0,02 \\
0,07 \\
0,02\end{array}$ & $\begin{array}{l}<0.02 \\
<0.02 \\
<0.02 \\
<0.02 \\
0.02 \\
40.02\end{array}$ & $\begin{array}{l}<0,2 \\
<0,2 \\
<0,2 \\
<0,2 \\
0,2 \\
<0,2\end{array}$ & $\begin{array}{l}0,77 \\
1,0 \\
1.3 \\
0,93 \\
1,5 \\
0,67\end{array}$ & 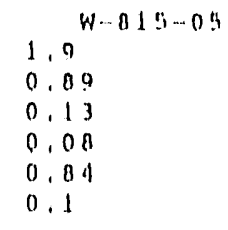 \\
\hline $\begin{array}{r}0.3 \\
<0.1 \\
0.1 \\
0.2 \\
0.1 \\
0.1 \\
0.1\end{array}$ & $\begin{array}{l}<0.001 \\
\angle 0.001 \\
<0.001 \\
\angle 0.001 \\
<0.001 \\
40.001 \\
0.001\end{array}$ & $\begin{array}{l}<0,1 \\
<0,1 \\
<0,1 \\
0,1 \\
<0,1 \\
<0,1 \\
<0,1\end{array}$ & $\begin{array}{l}0.74 \\
1.3 \\
1.2 \\
0.34 \\
0.7 \\
0.2 \\
0.05\end{array}$ & $\begin{array}{l}1 \\
<0.01 \\
0.01 \\
0.01 \\
00.01 \\
<0.01 \\
<0.01 \\
<0.01\end{array}$ & $\begin{array}{l}<0.01 \\
<0.01 \\
<0.01 \\
<0.01 \\
<0.01 \\
<0.01 \\
0.01\end{array}$ & $\begin{array}{r}0,1 \\
<0,1 \\
<0,1 \\
0,2 \\
<0,1 \\
<0,1 \\
<0,1\end{array}$ & $\begin{array}{l}<0.2 \\
<0.2 \\
<0.2 \\
0.2 \\
0.37 \\
0.37 \\
0.34\end{array}$ & $\begin{array}{l} \\
0.05 \\
0.15 \\
0.05 \\
0.05 \\
0.04 \\
0.06 \\
0.05 \\
0.07\end{array}$ \\
\hline $\begin{array}{l}<0,1 \\
<0,1 \\
<0.1\end{array}$ & $\begin{array}{r}0.001 \\
0.002 \\
0.009\end{array}$ & $\begin{array}{l}<0,1 \\
<0,1 \\
<0,1\end{array}$ & $\begin{array}{r}0.16 \\
0.63 \\
<0.05\end{array}$ & $\begin{array}{l}60,1 \\
0,1 \\
0,1\end{array}$ & $\begin{array}{l}(0,0) \\
0.01 \\
0.01 \\
0.01\end{array}$ & $\begin{array}{l}60,1 \\
0,1 \\
0,1\end{array}$ & $\begin{array}{r}0,2 \\
0,2 \\
0,3\end{array}$ & $\begin{array}{l}\quad w-819 \ldots .03 \\
0.07 \\
0.12 \\
0.32\end{array}$ \\
\hline $\begin{array}{l}<0.3 \\
<0.3 \\
60.3 \\
60.3 \\
60.3\end{array}$ & $\begin{array}{l}<0.001 \\
<0.001 \\
<0.001 \\
<0.001 \\
<0.001\end{array}$ & $\begin{array}{l}<0.08 \\
<0.08 \\
<0.08 \\
<0.08 \\
<0.08\end{array}$ & $\begin{array}{l}0.21 \\
0.28 \\
0.21 \\
0.14 \\
0.28\end{array}$ & $\begin{array}{l}60.02 \\
60.02 \\
60.02 \\
10.02 \\
0.02\end{array}$ & $\begin{array}{l}<0.02 \\
0.02 \\
0.02 \\
0.02 \\
0.02 \\
0.02\end{array}$ & $\begin{array}{l}60,2 \\
<0,2 \\
<0,2 \\
0,2 \\
0.2\end{array}$ & $\begin{array}{l}0.27 \\
0.5 \\
0.18 \\
0.5 .5 \\
0.94\end{array}$ & $\begin{array}{l}\quad D \cdots 027 \mathrm{~A}-01 \\
0.03 \\
0.25 \\
0.01 \\
0.01 \\
0.09\end{array}$ \\
\hline $\begin{array}{l}<0.3 \\
<0.3 \\
<0.3\end{array}$ & $\begin{array}{l}(0.001 \\
<0.001 \\
0.001\end{array}$ & $\begin{array}{r}0.08 \\
0.08 \\
0.15\end{array}$ & $\begin{array}{l}0.17 \\
0.11 \\
0.27\end{array}$ & $\begin{array}{l}<0.02 \\
<0.02 \\
<0.02\end{array}$ & $\begin{array}{l}0.02 \\
0.02 \\
0.02\end{array}$ & $\begin{array}{l}<0.2 \\
<0.2 \\
40.2\end{array}$ & $\begin{array}{l}0.51 \\
0.12 \\
0.10\end{array}$ & $\begin{array}{l}\quad 1) 0271101 \\
0.42 \\
0.19 \\
0.66\end{array}$ \\
\hline
\end{tabular}




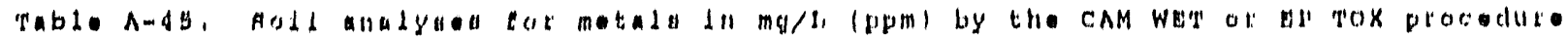

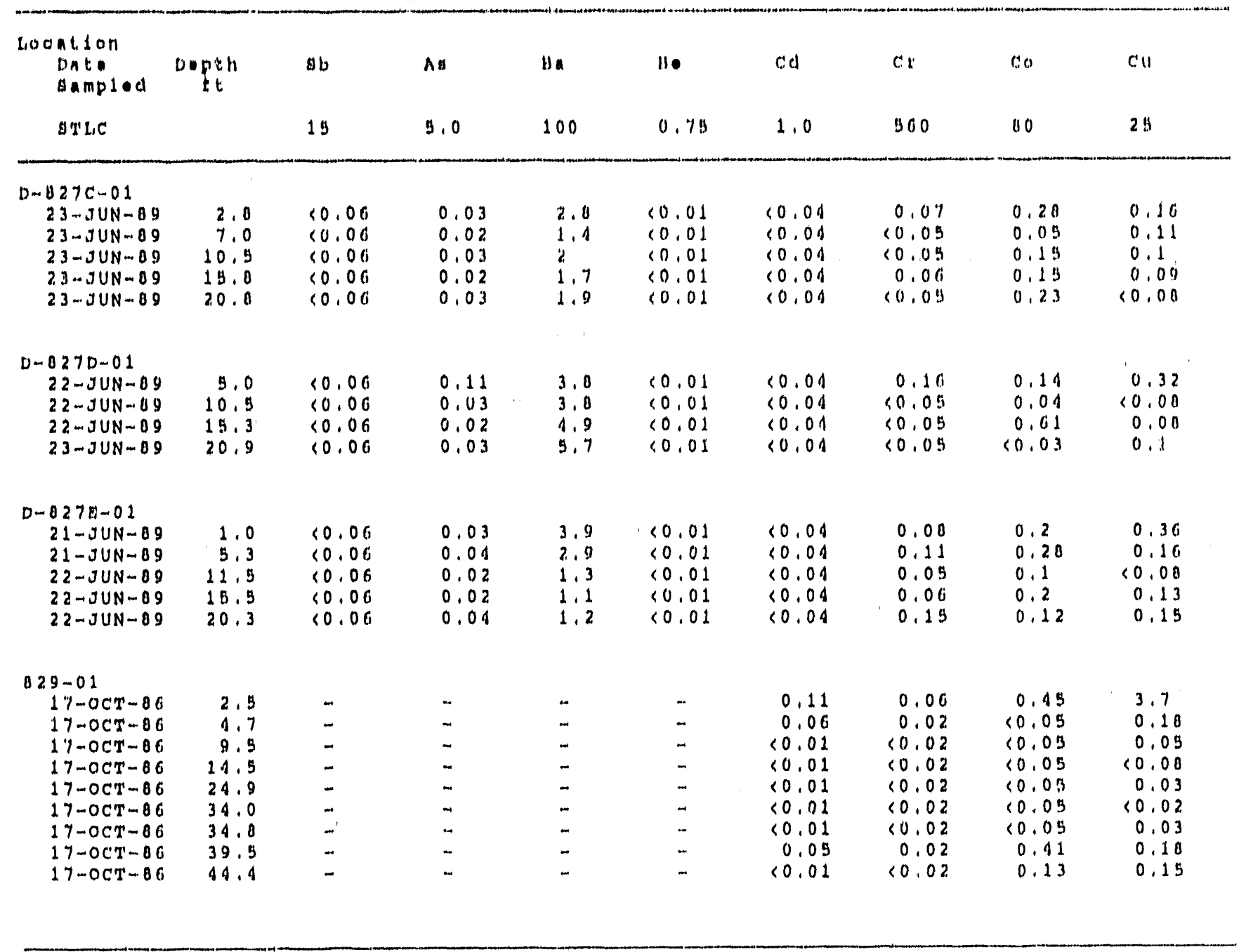


tor $\$$ Tt LC.

\begin{tabular}{|c|c|c|c|c|c|c|c|c|}
\hline Ib & $11 \S$ & Mo & $\mathrm{N} 1$ & $\mathrm{Be}$ & $\mathrm{Ag}$ & II 1 & $v$ & $z_{n}$ tocation \\
\hline 3.0 & 0.2 & 350 & 20 & 1.0 & B & 7.0 & 24 & 250 \\
\hline $\begin{array}{l}<0,3 \\
<0,3 \\
<0,3 \\
0,3 \\
0,3\end{array}$ & $\begin{array}{l}<0.001 \\
20.001 \\
20.001 \\
20.001 \\
0.001\end{array}$ & $\begin{array}{l}<0.00 \\
<0.00 \\
<0.08 \\
<0.08 \\
<0.08\end{array}$ & $\begin{array}{l}0.09 \\
0.03 \\
0.05 \\
0.05 \\
0.05\end{array}$ & $\begin{array}{l}40.02 \\
80.02 \\
40.02 \\
40.02 \\
40.02\end{array}$ & $\begin{array}{l}<0.02 \\
40.02 \\
<0.02 \\
<0.02 \\
0.02\end{array}$ & $\begin{array}{l}<0.2 \\
<0.2 \\
<0.2 \\
<0.2 \\
10.02\end{array}$ & $\begin{array}{l}0.29 \\
0.13 \\
0.7 \\
0.93 \\
0.5\end{array}$ & $\begin{array}{l}\quad 0-027 C \cdots 01 \\
0.08 \\
0.17 \\
0.1 \\
0.00 \\
0.13\end{array}$ \\
\hline $\begin{array}{l}<0,3 \\
<0,3 \\
<0,3 \\
<0,3\end{array}$ & $\begin{array}{l}<0.001 \\
<0.001 \\
<0.001 \\
<0.001\end{array}$ & $\begin{array}{l}<0.08 \\
<0.08 \\
<0.08 \\
<0.08\end{array}$ & $\begin{array}{r}0.11 \\
0.05 \\
0.15 \\
0.03\end{array}$ & $\begin{array}{l}<0.02 \\
<0.02 \\
<0.02 \\
<0.02\end{array}$ & $\begin{array}{l}<0.02 \\
<0.02 \\
<0.02 \\
<0.02\end{array}$ & $\begin{array}{l}<0,2 \\
<0,2 \\
<0,2 \\
0,2\end{array}$ & $\begin{array}{l}1.1 \\
0.40 \\
0.63 \\
0.42\end{array}$ & $\begin{array}{l}0-0270-01 \\
0.22 \\
0.11 \\
0.11 \\
0.11\end{array}$ \\
\hline $\begin{array}{l}<0,3 \\
<0,3 \\
0,0,3 \\
0,3 \\
0,3\end{array}$ & $\begin{array}{l}0.007 \\
0.002 \\
0.001 \\
10.001 \\
0.001\end{array}$ & $\begin{array}{l}<0.08 \\
<0.08 \\
<0.08 \\
<0.00 \\
10.08\end{array}$ & $\begin{array}{l}0.21 \\
0.2 \\
0.06 \\
0.08 \\
0.09\end{array}$ & $\begin{array}{r}60.02 \\
0.02 \\
<0.02 \\
<0.02 \\
<0.02\end{array}$ & $\begin{array}{l}<0.02 \\
10.02 \\
<0.02 \\
<0.02 \\
10.02\end{array}$ & $\begin{array}{l}<0,2 \\
<0.2 \\
<0.2 \\
<0.2 \\
0.2\end{array}$ & $\begin{array}{l}0.20 \\
0.31 \\
0.08 \\
0.1 \\
0.22\end{array}$ & $\begin{array}{l}\quad 0-0278-01 \\
1.3 \\
0.23 \\
0.11 \\
0.14 \\
0.31\end{array}$ \\
\hline 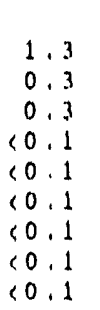 & $\begin{array}{l}<0.001 \\
<0.001 \\
\angle 0.001 \\
\angle 0.001 \\
\angle 0.001 \\
\angle 0.001 \\
\angle 0.001 \\
\angle 0.001 \\
\angle 0.001\end{array}$ & $\begin{array}{l}<0,1 \\
<0,1 \\
<0,1 \\
<0,1 \\
<0,1 \\
0,1 \\
0,1 \\
<0,1 \\
<0,1 \\
<0,1\end{array}$ & $\begin{array}{r}0.39 \\
<0.05 \\
0.05 \\
0.22 \\
0.3 \\
80.05 \\
0.05 \\
0.26 \\
0.17\end{array}$ & $\begin{array}{r}0.02 \\
10.01 \\
10.01 \\
20.01 \\
20.01 \\
10.01 \\
40.01 \\
0.01 \\
40.01\end{array}$ & $\begin{array}{l}<0.01 \\
<0.01 \\
<0.01 \\
<0.01 \\
<0.01 \\
<0.01 \\
<0.01 \\
0.01 \\
10.01\end{array}$ & $\begin{array}{l}<0,1 \\
<0,1 \\
<0,1 \\
<0,1 \\
<0,1 \\
<0,1 \\
<0,1 \\
<0,1 \\
<0.1\end{array}$ & $\begin{array}{l}0.54 \\
0.37 \\
40.2 \\
10.2 \\
10.2 \\
10.2 \\
10.2 \\
10.2 \\
10.2\end{array}$ & $\begin{array}{l}11 \\
0.19 \\
0.11 \\
0.07 \\
0.05 \\
0.02 \\
0.05 \\
0.12 \\
0.08\end{array}$ \\
\hline
\end{tabular}

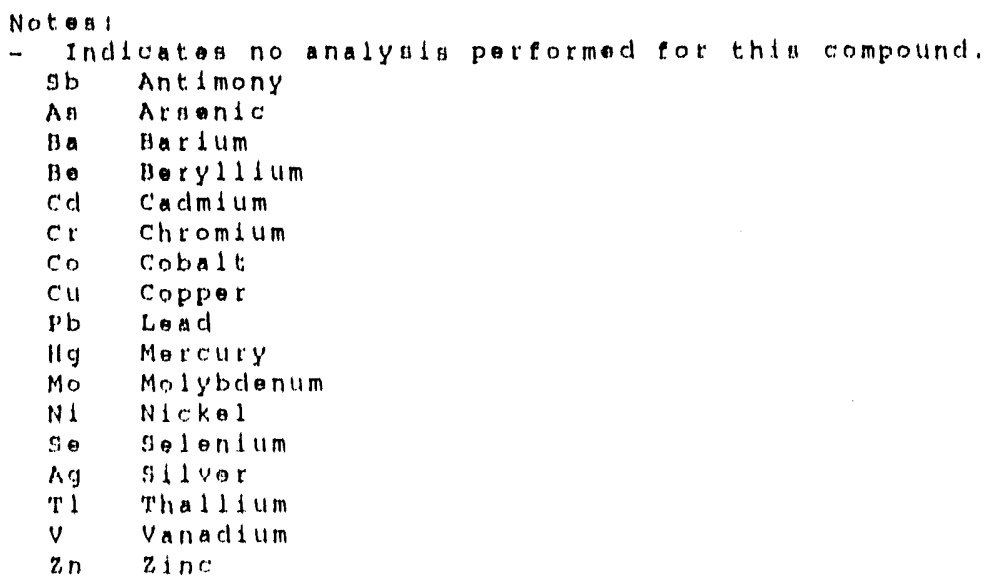


rable A-46. Soll and rock analyoes tn mg/kg (ppm) for motals using nitrte acid digestion

\begin{tabular}{|c|c|c|c|c|c|c|c|c|c|}
\hline $\begin{array}{c}\text { Location } \\
\text { Date } \\
\text { sampled }\end{array}$ & $\begin{array}{c}\text { Depth } \\
\text { t }\end{array}$ & $s b$ & $\mathrm{As}$ & $\mathbf{B a}$ & Be & $\mathrm{Cd}$ & $\mathrm{Cr}$ & Co & $\mathrm{Cu}$ \\
\hline TTLC & & 500 & 500 & 10,000 & 75 & 100 & 2,500 & 8,000 & 2,500 \\
\hline $\begin{array}{r}827-E 2 \\
25-J U N-87 \\
25-J U N-87\end{array}$ & $\begin{array}{l}1.5 \\
5.5\end{array}$ & $\begin{array}{r}17 \\
<10\end{array}$ & $\begin{array}{l}0.6 \\
0.8\end{array}$ & $\begin{array}{l}210 \\
130\end{array}$ & $\begin{array}{l}0.31 \\
<0.2\end{array}$ & $\begin{array}{l}<0.2 \\
<0.2\end{array}$ & $\begin{array}{l}16 \\
14\end{array}$ & $\begin{array}{r}11 \\
8.7\end{array}$ & $\begin{array}{l}25 \\
22\end{array}$ \\
\hline
\end{tabular}


for TTLC.

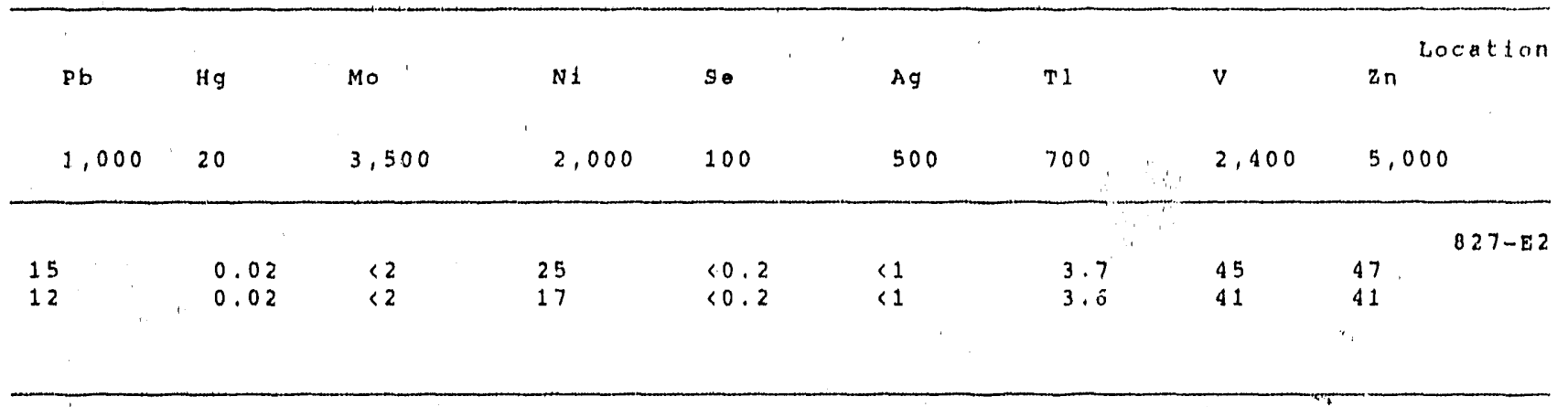

Notes:

- Indicates no analyalo performed for this compound.

$\mathrm{Sb}$ Antimony

As Arsenic

Ba Bardum

Be Beryl11um

Cd Cadmium

Cr Chromium

Co Cobalt

$\mathrm{Cu}$ Copper

$\mathrm{Pb}$ Lead

Hg Mercury

Mo Molybdenum

NI Nicke1

Se Selenium

Ag silver

TI Thalldum

$\checkmark$ vanadium

in zinc 
Table A-47. HE compounds in soll and rock samples from sample holes B-828-1 and B-828-2.

\begin{tabular}{|c|c|c|c|c|}
\hline \multirow[b]{2}{*}{ Sample ID ${ }^{\mathbf{a}}$} & \multirow{2}{*}{$\begin{array}{l}\text { Sample } \\
\text { depth } \\
\text { (ft) }\end{array}$} & \multicolumn{3}{|c|}{ HE compounds in $\mu \mathrm{g} / \mathrm{g}$ of soil ${ }^{b}$} \\
\hline & & HMX & RDX & TNT \\
\hline $828-1-1 A$ & $5.5-6.0$ & 0.067 & 0.40 & $<0.0008$ \\
\hline $828-1-2 A$ & $9.0-9.5$ & 0.14 & 0.75 & $<0.0008$ \\
\hline $828-1-3 A$ & $15.0-15.2$ & 0.22 & 1.2 & $<0.0008$ \\
\hline $828-1-4 B$ & 20.4-20.6 & 1.1 & 5.3 & $<0.0008$ \\
\hline $828-1-5 A$ & 25.1-25.6 & 0.074 & 0.62 & $<0.0008$ \\
\hline $828-1-6 A$ & $30.1-30.6$ & 0.022 & 0.36 & $<0.0008$ \\
\hline $828-1-7 A$ & $35.1-35.6$ & 0.24 & 0.93 & $<0.0008$ \\
\hline $828-2$ & 5.0 & 9.8 & 3.0 & $<0.0008$ \\
\hline $828-2$ & 7.7 & 7.6 & 3.0 & $<0.0008$ \\
\hline $828-2$ & 10.0 & 3.9 & 3.2 & $<0.0008$ \\
\hline $828-2$ & 15.0 & 1.3 & 1.8 & $<0.0008$ \\
\hline $828-2$ & 20.0 & 0.69 & 2.3 & $<0.0008$ \\
\hline $828-2$ & 25.0 & 1.4 & 3.0 & $<0.0008$ \\
\hline $823 \cdots$ & 30.2 & 0.61 & 1.1 & $<0.0008$ \\
\hline $828-2$ & 35.0 & 0.51 & 1.0 & $<0.0008$ \\
\hline $828-2$ & 40.0 & 0.36 & 0.44 & $<0.0008$ \\
\hline $828-2$ & 45.0 & 0.077 & 0.054 & $<0.0008$ \\
\hline $828 \cdot 2$ & 50.0 & 0.027 & 0.002 & $<0.0008$ \\
\hline $828-2$ & 54.0 & $<0.0008$ & $<0.0008$ & $<0.0008$ \\
\hline $828-2$ & 59.0 & $<0.0008$ & $<0.0008$ & $<0.0008$ \\
\hline
\end{tabular}

all samples were taken with a 1-1/2 -in. -i.d. split-spoon sampler advanced by a 140-lb hammer falling $30 \mathrm{in}$. Samples were encased in stainless steel sleeves, ends covered with aluminum foil, and sealed with inert tape.

Analyses by normal HPLC procedure. 
Table A-48. Extractable and purgeable priority pollutants in soil and rock samples, sample hole B-828-1.

\begin{tabular}{|c|c|c|c|c|}
\hline Sample location & $B-828-1^{b}$ & B-828-1 & B-828-1 & $B-828-1$ \\
\hline Sample depth $(\mathrm{ft})$ & $15.2-15.7$ & $20.0-20.4$ & $30.6-31.1$ & $35.6-36.6$ \\
\hline Date sampled & 08.13 .86 & 08.13 .86 & 08.13 .86 & 08.13 .86 \\
\hline & \multicolumn{4}{|c|}{ EPA Method $8270(\mathrm{mg} / \mathrm{kg})$} \\
\hline \multicolumn{5}{|l|}{ B/NaA ext priority pollutatants } \\
\hline Extraction date & 08.19 .86 & 08.19 .86 & 08.19 .86 & 08.19 .86 \\
\hline Date analyzed & 08.21 .86 & 08.22 .86 & 08.22 .86 & 08.22 .86 \\
\hline 2,4-dinitrophenol & $<3$ & $<3$ & $<3$ & $<3$ \\
\hline 2-methyl-4,6-dinitrophenol & $<5$ & $<5$ & $<5$ & $<5$ \\
\hline 3,3'-dichlorobenzidine & $<4$ & $<4$ & $<4$ & $<4$ \\
\hline 4-nitrophenol & $<3$ & $<3$ & $<3$ & $<3$ \\
\hline Bis(2-ethylhexyl)ph thalate & $<10$ & $<10$ & $<10$ & $<10$ \\
\hline Benzidine & $<4$ & $<4$ & $<4$ & $<4$ \\
\hline Dibutylphthalate & $<5$ & $<5$ & $<5$ & $<5$ \\
\hline Dimethylphthalate & $<3$ & $<3$ & $<3$ & $<3$ \\
\hline N-nitrosodi-n-propylamine & $<4$ & $<4$ & $<4$ & $<4$ \\
\hline N-nitrosodimethylamine & $<8$ & $<8$ & $<8$ & $<8$ \\
\hline Other $\mathrm{B} / \mathrm{N}, \mathrm{A}$ ext. priority pollutants & $<0.1$ & $<0.1$ & $<0.1$ & $<0.1$ \\
\hline \multicolumn{5}{|l|}{ Semi-quantified resultsc } \\
\hline \multirow[t]{2}{*}{$\mathrm{C}_{10} \mathrm{H}_{20}$ hydrocarbon matrix } & - & 50 & - & - \\
\hline & \multicolumn{4}{|c|}{ EPA Method $8240(\mathrm{mg} / \mathrm{kg})$} \\
\hline \multicolumn{5}{|l|}{ Purgeable priority pellutants } \\
\hline Extraction date & 08.18 .86 & 08.18 .86 & 08.18 .86 & 08.18 .86 \\
\hline Acrolein & $<2$ & $<2$ & $<2$ & $<2$ \\
\hline Acrylonitrile & $<2$ & $<2$ & $<2$ & $<2$ \\
\hline Trichloroethylene & 7 & $<0.2$ & $<0.2$ & $<0.2$ \\
\hline Other purgeable priority pollutants & $<0.2$ & $<0.2$ & $<0.2$ & $<0.2$ \\
\hline
\end{tabular}

all samples were taken with a 1-1/2-in.-i.d. split-spoon sampler advanced by a 140-lb hammer falling 30 in. Samples were encased in stainless steel sleeves, ends covered with aluminum foll, and sealed with inert tape.

bSamples recovered at $<15 \mathrm{ft}$ depth were of insufficient volume and/or quality to be suitable for analysis.

cQuantification based upon comparison of total ion count of the compound with that of the nearest internal standard. 


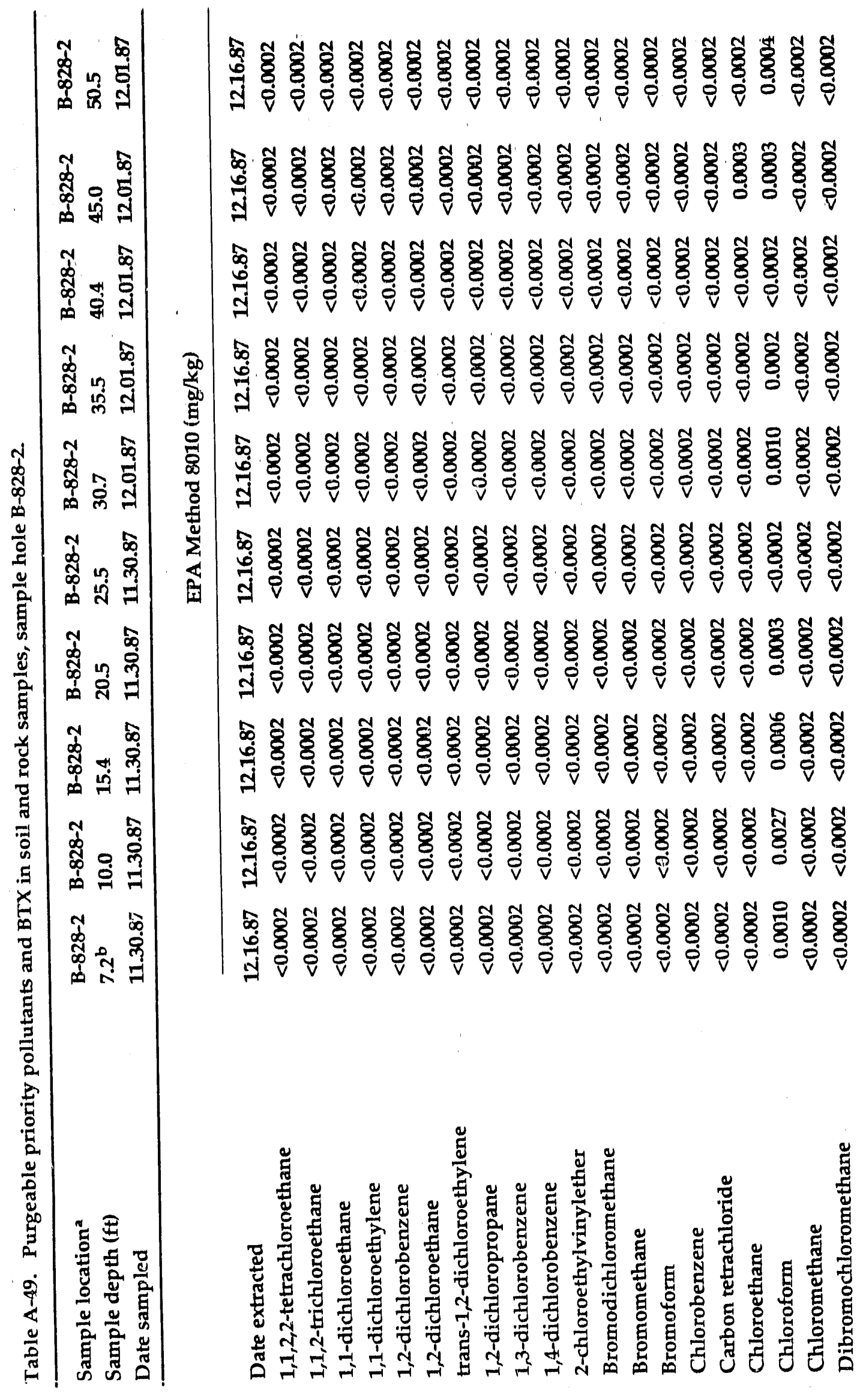




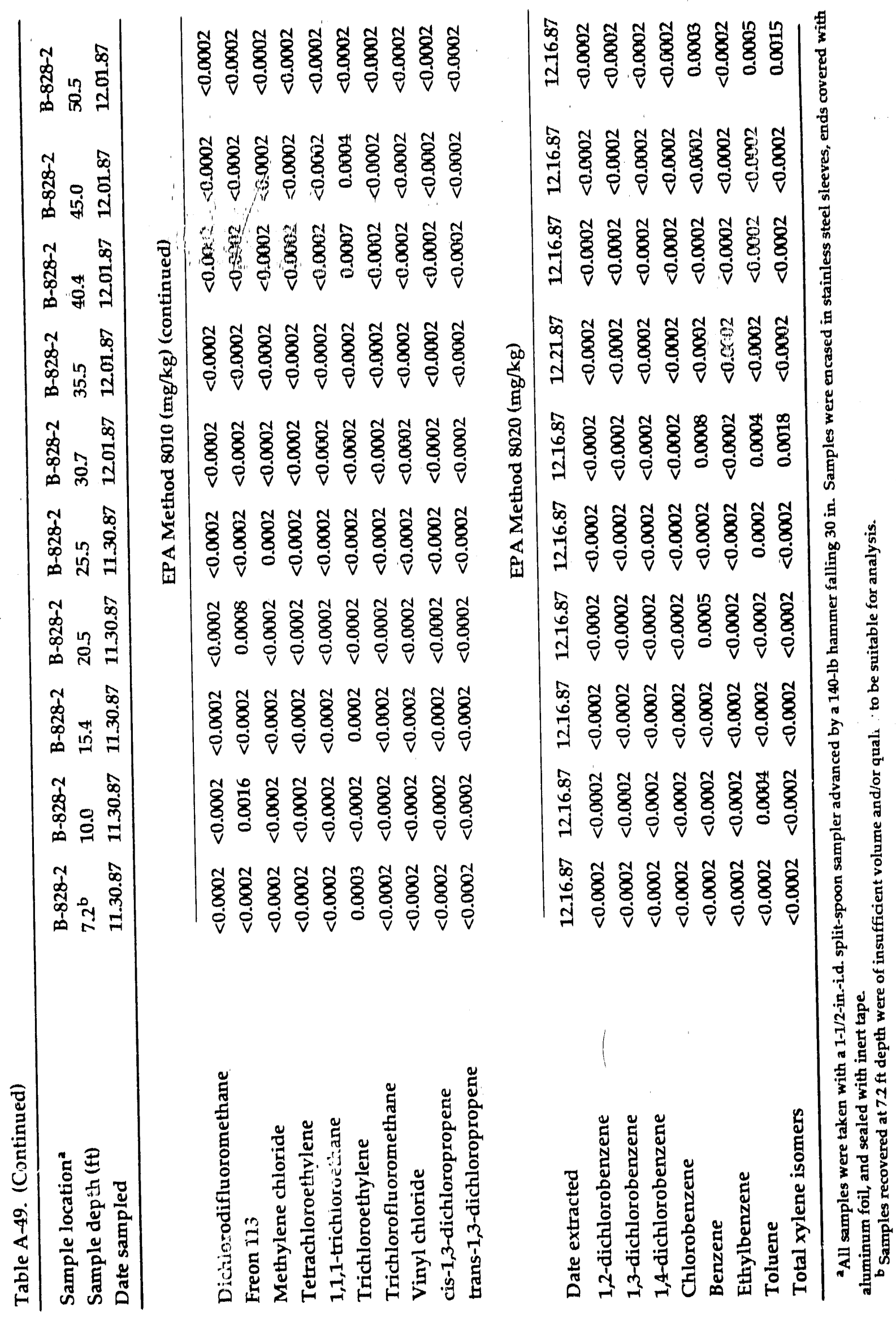




\section{Appendix B}

\section{Ground Water Data: HE Compounds, VOCs, Metals, Etc.}


Table B-1. Ground water analyses for HE compounds (HMX, RDX, and TNT) reported by March 1990.

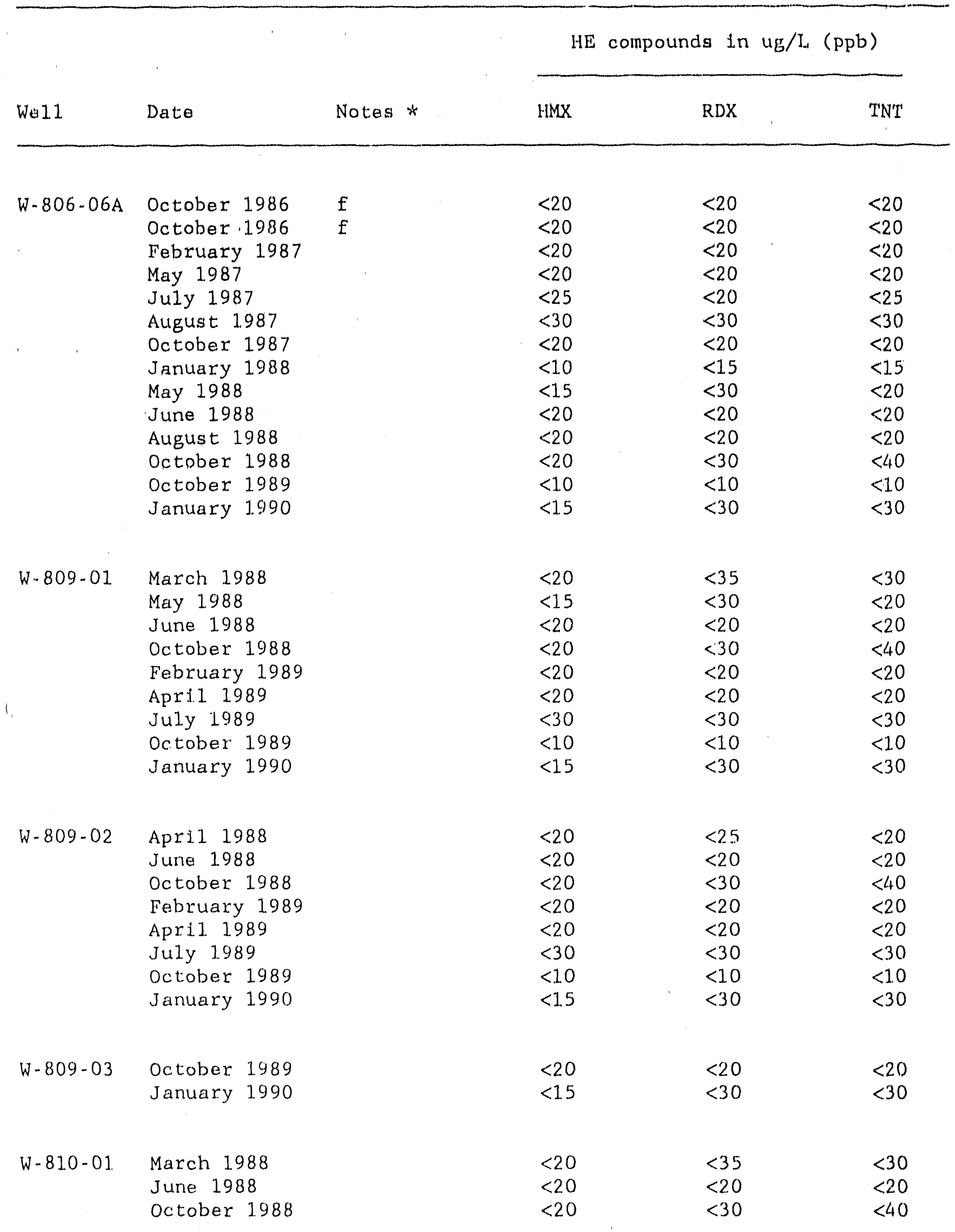


Table B-1, Ground water analyses for HE compounds (HMX, RDX, and I'N'I) reported by March 1990 .

\begin{tabular}{|c|c|c|c|c|c|}
\hline \multirow[b]{2}{*}{$W_{\Theta} 11$} & \multirow[b]{2}{*}{ Dater } & \multirow[b]{2}{*}{ Notess * } & \multicolumn{3}{|c|}{$H E$ compounds in $u g / L$ (ppb) } \\
\hline & & & HMX & RDX & T'NT \\
\hline \multicolumn{6}{|c|}{. } \\
\hline & \multicolumn{2}{|l|}{ Fabruary 1989} & $<20$ & ? & $<20$ \\
\hline & \multicolumn{2}{|l|}{ Apri1 1989} & $<20$ & $\cdot 1$ & $<20$ \\
\hline & \multicolumn{2}{|l|}{ Ju1y 1989} & $<30$ & .30 & $<30$ \\
\hline & \multicolumn{2}{|l|}{ October 1989} & $<10$ & $<10$ & $<10$ \\
\hline ' & \multicolumn{2}{|l|}{ January 1.990} & $<15$ & $<30$ & $\ll 30$ \\
\hline \multirow[t]{4}{*}{ W. 814-01 } & \multicolumn{2}{|l|}{ February 1988} & $<20$ & $<20$ & $<20$ \\
\hline & \multicolumn{2}{|l|}{ June 1988} & $<20$ & $<20$ & $<20$ \\
\hline & \multirow{2}{*}{\multicolumn{2}{|c|}{$\begin{array}{l}\text { October } 1989 \\
\text { January } 1990\end{array}$}} & $<10$ & $<10$ & $<10$ \\
\hline & & & $<15$ & $<30$ & $<30$ \\
\hline \multirow[t]{13}{*}{ W- $815-01$} & \multicolumn{2}{|l|}{ July 1987} & $<25$ & 190 & $<25$ \\
\hline & November 1987 & $f$ & $<20$ & 210 & $<20$ \\
\hline & November 1987 & $\mathrm{f}$ & $<20$ & 220 & $<20$ \\
\hline & January 1988 & ah & 10 & 200 & $<20$ \\
\hline & January 1988 & ah & 10 & 197 & $<20$ \\
\hline & March 1988 & & $<20$ & 350 & $<20$ \\
\hline & June 1988 & & $<20$ & 170 & $<20$ \\
\hline & October 1988 & & $<20$ & 1.95 & $<40$ \\
\hline & February 1989 & & $<20$ & 260 & $<20$ \\
\hline & Apr11 1989 & & $<20$ & 203 & $<20$ \\
\hline & July 1989 & & $<30$ & 165 & $<30$ \\
\hline & October 1989 & & $<10$ & 135 & $<10$ \\
\hline & January 1990 & & $<15$ & 220 & $<30$ \\
\hline \multirow[t]{14}{*}{$W-815-02$} & \multicolumn{2}{|l|}{ May 1987} & $<20$ & $<20$ & $<20$ \\
\hline & \multicolumn{2}{|l|}{ July 1987} & 30 & 30 & $<25$ \\
\hline & November 1987 & $\mathrm{f}$ & $<20$ & 35 & $<20$ \\
\hline & November 1987 & $\mathrm{f}$ & $<20$ & 30 & $<20$ \\
\hline & Januas y 1988 & $\mathrm{f}$ & $<8$ & 35 & $<20$ \\
\hline & January 1988 & $f$ & $<8$ & 25 & $<20$ \\
\hline & March 1988 & & $<15$ & 40 & $<15$ \\
\hline & June 1988 & & $<20$ & 30 & $<20$ \\
\hline & October 1988 & & $<20$ & 40 & $<40$ \\
\hline & February 1989 & & $<20$ & 31 & $<20$ \\
\hline & Apri1 1989 & & $<? 0$ & 49 & $<20$ \\
\hline & July 1989 & & $<30$ & 36 & $<30$ \\
\hline & October 1989 & & $\because 10$ & 34 & $<10$ \\
\hline & January 1990 & & $<1.5$ & 64 & $<30$ \\
\hline
\end{tabular}


Table b-1, Ground water analysas for HE compounds (HMX, RDX, and I'N'I') roportad by March 1.990.

HE compounds in ug/L $(p p)$

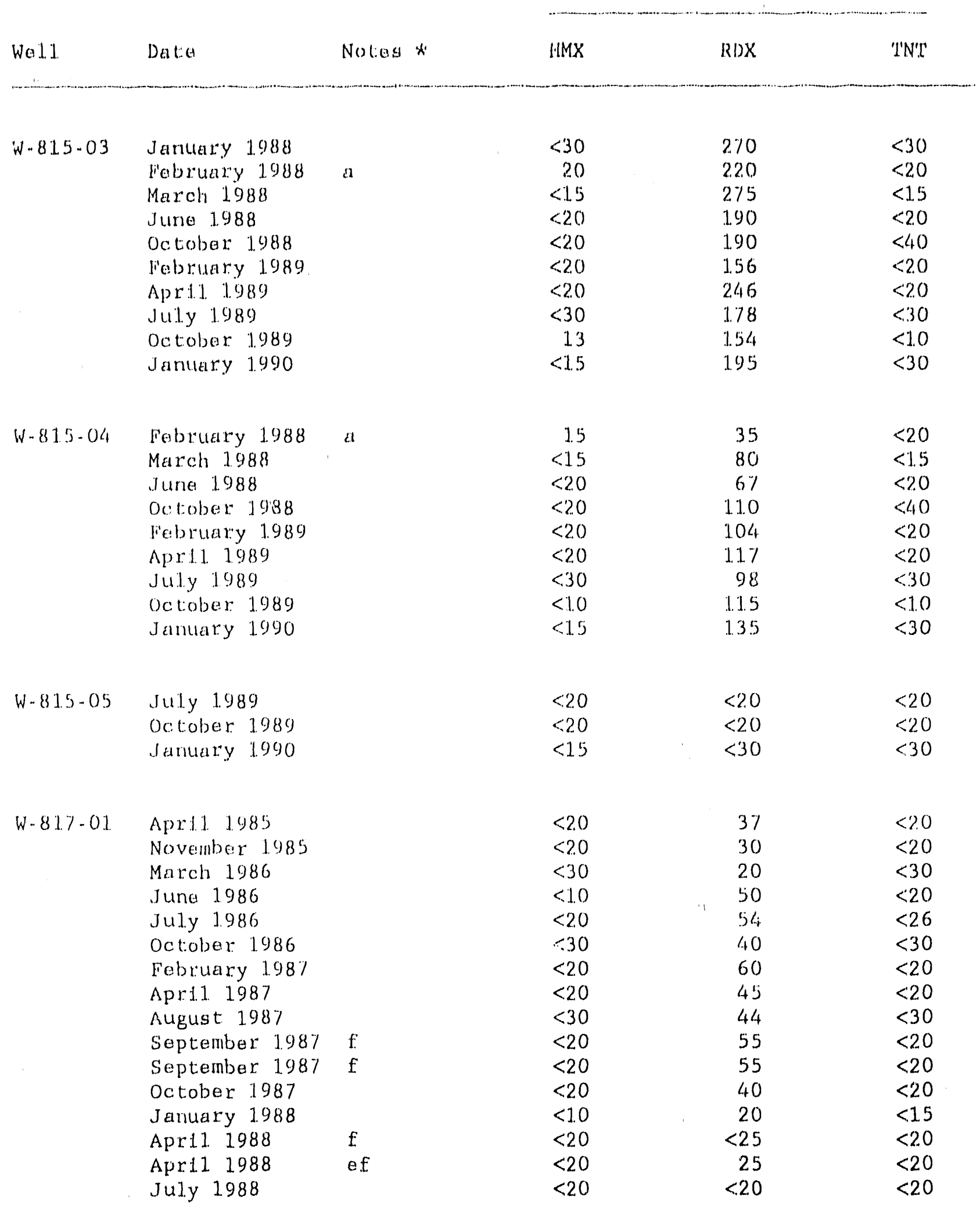


Tablo B.1. Ground water analyses for HE compounds (HMX, RDX, and 'IN'I') reportad by March 1990 .

$H E$ compounds in $u g / L(p p l)$

Well Date Notes * HMX 'RDX 'INI'

November 1988

January 1989

January 1989

January 1989

January 1989

Apr11 1989

Apr11 1989

July 1989

October 1.989

October 1989

November 1989

November 1989 h

January 1990

January 1990

January 1990

January 1990

W-817.1? Apri1 1985

November 1985

March 1986

June 1986

July 1986

October 1986

February 1987

Apr11 1987

August 1987

August 1987

October 1987

January 1988

Apr 1.1 1988

July 1988

November 1988

February 1989

February 1989

February 1989

February 1989

Apr11 1989

July 1.989

July 1989

October 1989

Octuber 1989

October 1989

g
gh
gh
gh
ef
fh
h
h
h
h
h

gh

gh

gh

of

fh

h

h

h

h

h

-

$<20$

$<20$

$<30$

$<10$

$<20$

$<30$

$<20$

$<20$

$<30$

$<30$

$<20$

$<10$

$<20$

$<20$

$<20$

$<20$

$<20$

$<20$

$<20$

$<20$

$<20$

$<20$

$<20$

$<20$

$<20$

ef

fh

$\begin{aligned} 53 & <40 \\ 62 & <20 \\ 62 & <20 \\ 62 & <20 \\ 62 & <20 \\ 45 & <20 \\ 45 & <20 \\ 20 & <20 \\ 64 & <30 \\ 80 & <30 \\ 103 & <30 \\ 105 & <30 \\ 83 & <30 \\ 83 & <30 \\ 86 & <30 \\ 104 & <30\end{aligned}$

$<20$

$<20$

$<20$

$<30$

$<20$

$<26$

$<30$

$<20$

$<20$

$<30$

$<30$

$<20$

$<15$

$<20$

$<20$

$<40$

$<20$

$<20$

$<20$

$<20$

$<20$
$<20$

$<20$

$<30$

$<30$

$<20$

$<20$

$<30$

$<30$

$<30$ 
Tabla B-1, Ground watar analyos for HE compounds (HMX, RDX, and TNT') reportad by March 1990.

\begin{tabular}{|c|c|c|c|c|c|}
\hline \multirow[b]{2}{*}{ Wo11 } & \multirow[b]{2}{*}{ Dateo } & \multirow[b]{2}{*}{ Noteg * } & \multicolumn{3}{|c|}{ HE compounds f.n ug/L (ppb) } \\
\hline & & & $\operatorname{HMx}$ & $\mathrm{RDX}$ & 'I'N'I' \\
\hline & October 1989 & ef: & $<20$ & $<30$ & $<30$ \\
\hline & November 1.989 & $f:$ & $<20$ & $<30$ & $<30$ \\
\hline & November 1989 & af & $<20$ & $<30$ & $<30$ \\
\hline & November: 1.989 & fh & $<20$ & $<30$ & $<30$ \\
\hline & November 1989 & ef: & $<20$ & $<30$ & $<30$ \\
\hline & Jaruary 1990 & & $<1.5$ & $<30$ & $<30$ \\
\hline & January 1990 & $\mathrm{~h}$ & $<1.5$ & $<30$ & $<30$ \\
\hline & January 1990 & h & $<15$ & $<30$ & $<30$ \\
\hline & January 1990 & $h$ & $<15$ & $<30$ & $<30$ \\
\hline \multirow{32}{*}{$W-81.7-0.3$} & Apr11 1985 & & $<20$ & $<20$ & $<20$ \\
\hline & Novemter 1985 & & $<20$ & $<20$ & $<20$ \\
\hline & March 1986 & & $<30$ & $<30$ & $<30$ \\
\hline & June 1986 & & $<10$ & $<20$ & $<20$ \\
\hline & July 1986 & & $<20$ & $<30$ & $<26$ \\
\hline & October 1986 & & $<30$ & $<30$ & $<30$ \\
\hline & l'ebruary 1987 & & $<20$ & $<20$ & $<20$ \\
\hline & Apr11 1987 & & $<20$ & $<20$ & $<20$ \\
\hline & August 1.987 & & $<30$ & $<30$ & $<30$ \\
\hline & October 1987 & $f$ & $<20$ & $<20$ & $<20$ \\
\hline & October: 1987 & ef & $<20$ & $<20$ & $<20$ \\
\hline & January 1.988 & & $<1.0$ & $<15$ & $<15$ \\
\hline & Apre11 1988 & & $<20$ & $<25$ & $<20$ \\
\hline & July 1.988 & & $<20$ & $<20$ & $\ll 20$ \\
\hline & November 1988 & $\mathrm{E}$ & $<20$ & $<30$ & $<40$ \\
\hline & November 1988 & ef & $<20$ & $<30$ & $<40$ \\
\hline & February 1989 & & $<20$ & $<20$ & $<20$ \\
\hline & February 1989 & h & $<20$ & $<20$ & $<20$ \\
\hline & February 1989 & $\mathrm{~h}$ & $<20$ & $<20$ & $<20$ \\
\hline & February 1.989 & h & $<20$ & $<20$ & $<20$ \\
\hline & Apri1 1989 & & $<20$ & $<20$ & $<20$ \\
\hline & July 1.989 & & $<20$ & $<20$ & $<20$ \\
\hline & October 1989 & & $<20$ & $<30$ & $<30$ \\
\hline & October 1989 & $\mathrm{~h}$ & $<20$ & $<30$ & $<30$ \\
\hline & November 1.989 & & $<20$ & $<30$ & $<30$ \\
\hline & November 1989 & $\mathrm{~h}$ & $<20$ & $<30$ & $<30$ \\
\hline & January 1990 & ef: & $<1.5$ & $<30$ & $<30$ \\
\hline & January 1990 & fh & $<1.5$ & $<30$ & $<30$ \\
\hline & January 1990 & $\in \mathrm{f}$ & $<15$ & $<30$ & $<30$ \\
\hline & January 1990 & Fit & $<1.5$ & $<30$ & $<30$ \\
\hline & January 1990 & $\theta f$ & $<15$ & $<30$ & $<30$ \\
\hline & January 1990 & fh & $<15$ & $<30$ & $<30$ \\
\hline
\end{tabular}


Table B-1. Ground water aralyses for HE compounds (HMX, RDX, and (NTS) reported by March 1990.

\begin{tabular}{|c|c|c|c|c|c|}
\hline \multirow[b]{2}{*}{ Wo11 } & \multirow[b]{2}{*}{ Date } & \multirow[b]{2}{*}{ Notes * } & \multicolumn{3}{|c|}{$H E$ compounds $\ln u g / L(p p b)$} \\
\hline & & & HMX & RDX & 'I'N'I' \\
\hline & $\begin{array}{ll}\text { January } & 1990 \\
\text { January } & 1990\end{array}$ & $\begin{array}{l}\text { of } \\
\text { fhi }\end{array}$ & $\begin{array}{l}<15 \\
<15\end{array}$ & $\begin{array}{l}<30 \\
<30\end{array}$ & $\begin{array}{l}<30 \\
<30\end{array}$ \\
\hline$W .81 \% .03 A$ & $\begin{array}{l}\text { Apr11 } 1985 \\
\text { November } 1985 \\
\text { March } 1986 \\
\text { June } 1986 \\
\text { October } 1986 \\
\text { February } 1987 \\
\text { Apr11 } 1987 \\
\text { August } 1987 \\
\text { October } 1987 \\
\text { January } 1988 \\
\text { Apr11 } 1988 \\
\text { July } 1988 \\
\text { November } 1988 \\
\text { February } 1989 \\
\text { February } 1989 \\
\text { February } 1989 \\
\text { February } 1989 \\
\text { Apri1 } 1989 \\
\text { July } 1989 \\
\text { October } 1989 \\
\text { January } 1990\end{array}$ & $\begin{array}{l}\mathrm{h} \\
\mathrm{h} \\
\mathrm{h}\end{array}$ & $\begin{array}{l}<20 \\
<20 \\
<30 \\
<10 \\
<30 \\
<20 \\
<20 \\
<30 \\
<20 \\
<10 \\
<20 \\
<20 \\
<20 \\
<20 \\
<20 \\
<20 \\
<20 \\
<20 \\
<20 \\
<20 \\
<15\end{array}$ & $\begin{array}{l}<20 \\
<20 \\
<30 \\
<20 \\
<30 \\
<20 \\
<20 \\
<30 \\
<20 \\
<15 \\
<25 \\
<20 \\
<30 \\
<20 \\
<20 \\
<20 \\
<20 \\
<20 \\
<20 \\
<30 \\
<30\end{array}$ & $\begin{array}{l}<20 \\
<20 \\
<30 \\
<20 \\
<30 \\
<20 \\
<20 \\
<30 \\
<20 \\
<15 \\
<20 \\
<20 \\
<40 \\
<20 \\
<20 \\
<20 \\
<20 \\
<20 \\
<20 \\
<30 \\
<30\end{array}$ \\
\hline$W-817.04$ & $\begin{array}{l}\text { Apri1 } 1985 \\
\text { November } 1985 \\
\text { March } 1986 \\
\text { June } 1986 \\
\text { July } 1986 \\
\text { October } 1986 \\
\text { February } 1987 \\
\text { Apr11 } 1987 \\
\text { Auguwt } 1987 \\
\text { October: } 1987 \\
\text { January } 1988 \\
\text { January } 1988 \\
\text { Apr } 111988 \\
\text { July } 1988 \\
\text { July } 1988 \\
\text { November } 1988\end{array}$ & $\begin{array}{l}f \\
\text { ef } \\
f \\
\text { ef }\end{array}$ & $\begin{array}{l}<20 \\
<20 \\
<30 \\
<10 \\
<20 \\
<30 \\
<20 \\
<20 \\
<30 \\
<20 \\
<10 \\
<10 \\
<20 \\
<20 \\
<20 \\
<20\end{array}$ & $\begin{array}{l}<20 \\
<20 \\
<30 \\
<20 \\
<30 \\
<30 \\
<20 \\
<20 \\
<30 \\
<20 \\
<15 \\
<15 \\
<25 \\
<20 \\
<20 \\
<30\end{array}$ & $\begin{array}{l}<20 \\
<20 \\
<30 \\
<20 \\
<26 \\
<30 \\
<20 \\
<20 \\
<30 \\
<20 \\
<15 \\
<15 \\
<20 \\
<20 \\
<20 \\
<40\end{array}$ \\
\hline
\end{tabular}




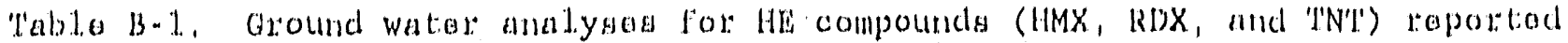
by March 1990.

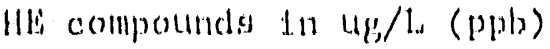

Wall Dota Notas $*$ HMX RIDX I'N'I

Fibruary 1.989

Fobruary 1989

liabruary 1989

February 1989

Fobruary 1989

Fobruary 1.989

February 1989

Pobruary 1.989

Aprel1 1989

July 1989

October 1989

October 1989

November: 1989

November: 1989

January 1990

Jarmary 1.990

January 1990

fobruary 1990

$W-817-0.5$

May 1988

July 1988

July 1988

July 1.988

October 1.988

February 1989

Apre1. 1989

Muly 1989

October 1989

January 1990

W-817.06A May 1988

June 1988

October 1988

Fabruary 1989

Apr11 1989

July 1989

October 1989

January 1990

\begin{abstract}
als
\end{abstract}
of

af:

of

fin

fin

fin

fh

$<20$

$<20$

$<20$

$<20$

$<20$

$<20$

$<15$

$<15$

$<15$

$<15$

$a$

ch

cilh

h

h

20

$<20$

$<0,2$

$<0,2$.

$<20$

$<20$

$<20$

$<30$

$<10$

$<15$

$<20$

$<20$

$<20$

$<20$

$<20$

$<30$

$<10$

$<15$

$<20$
$<20$

$<20$

$<20$

$<20$

$<20$

$<20$

$<20$

$<20$

$<20$

$<20$

$<30$

$<30$

$<30$

$<30$

$<30$

$<30$

$<30$

$<30$

$\begin{array}{rr}50 & <20 \\ <20 & <20 \\ <0.2 & <0.2 \\ <0.2 & <0.2 \\ <60 & <40 \\ <20 & <20 \\ <20 & <20 \\ <30 & <30 \\ <10 & <10 \\ <30 & <30\end{array}$

$<20$

$<20$

$<2.0$

$<40$

W.819-02 January $1987 \quad f$
$<20$

$<20$

$<30$

$<10$

$<30$

$<20$

$<20$

$<30$

$<10$

$<30$

$<20$ 
Table B-1. Ground water analyses for HE compounds (HMX, RDX, and TNT) reported by March 1990.

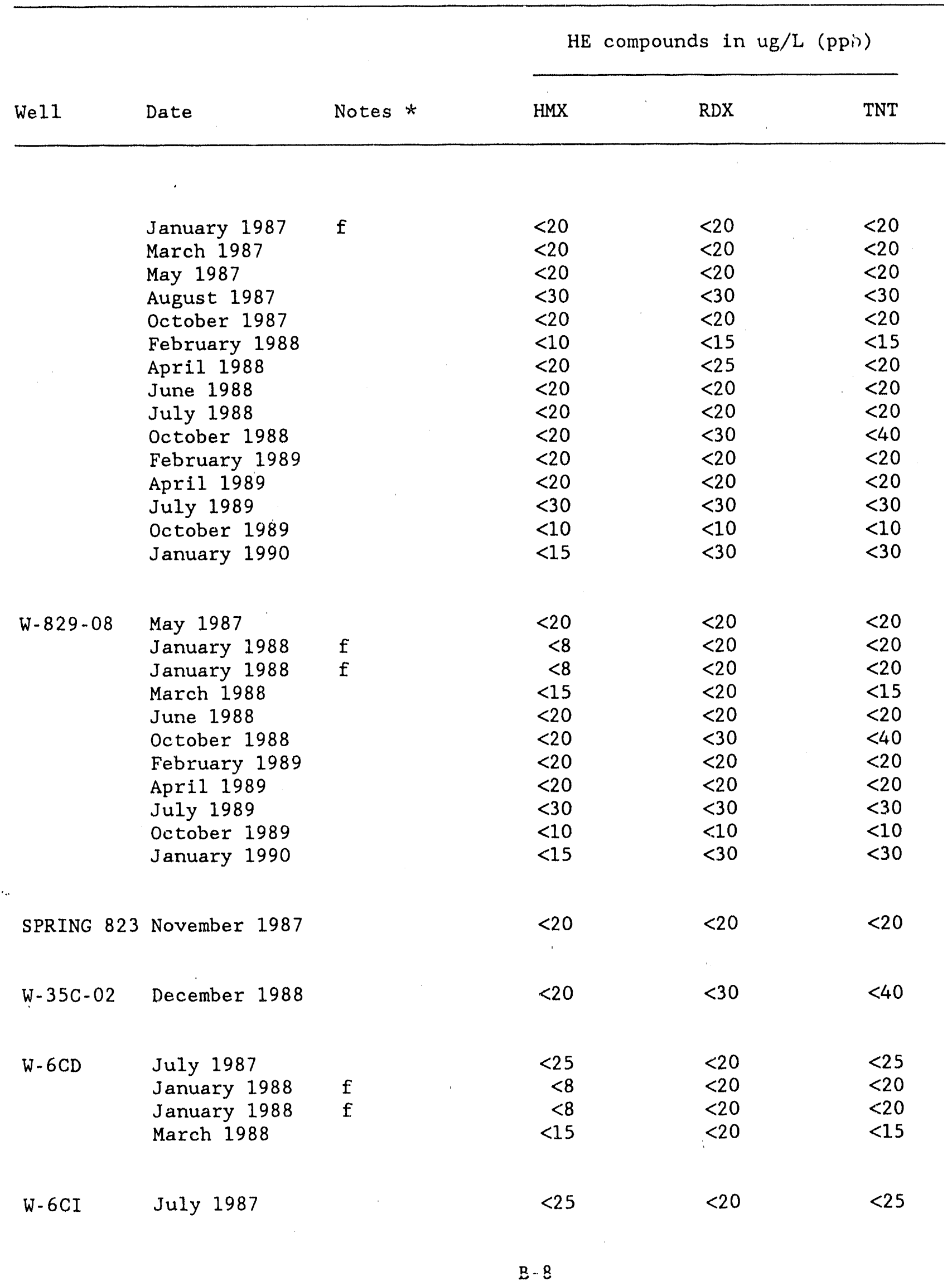


Table B-1. Ground water analyses for HE compounds (HMX, RDX, and TNT) reported by March 1990 .

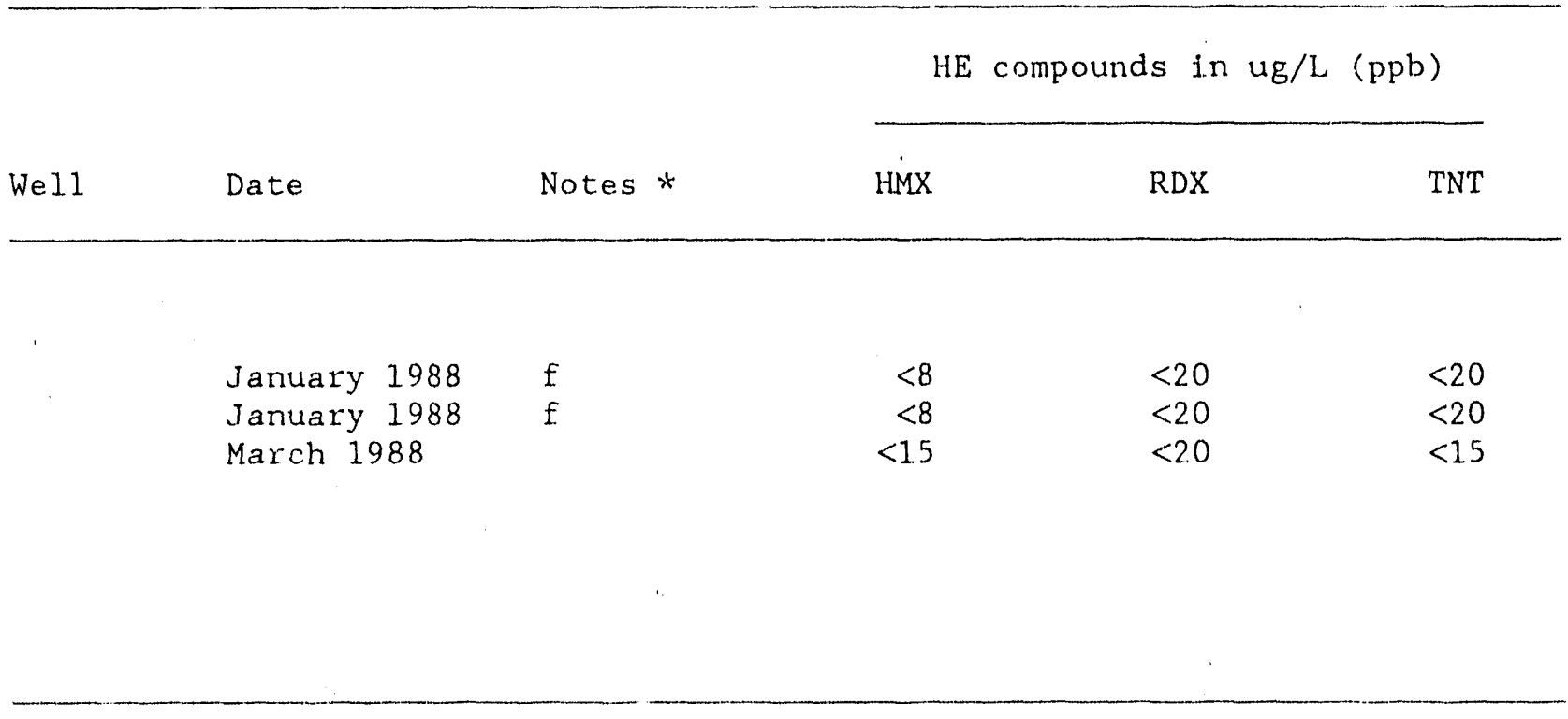

Notes:

A]1 analyses performed by HPLC Laboratory, LLNL.

a Reported results are unreliable for this sample.

b $40 \mathrm{ml}$ sample analyzed using standard procedures.

c $460 \mathrm{ml}$ sample evaporated to dryness then analyzed.

d $500 \mathrm{ml}$ sample freeze-dried then analyzed.

e Blind sample, sent to the lab without well identity.

f Intralaboratory duplicate sample.

g HMX identity suspect.

h Replicate sample taken during this quarter. 
Table B-2. Water analyses (ppm) for metals in ground water samples reported by March 31 , 1990.

\begin{tabular}{|c|c|c|c|c|c|c|c|}
\hline $\begin{array}{c}\text { Installation } \\
\text { Date } \\
\text { sampled }\end{array}$ & Aritimony & Arsenic & Barium & Beryllium & Cadmium & $\begin{array}{c}\text { chromiumi } \\
\text { total }\end{array}$ & $\begin{array}{l}\text { Chromium } \\
\text { hexavalent }\end{array}$ \\
\hline \multicolumn{8}{|l|}{$W-806-06 A$} \\
\hline $23-0 \mathrm{CT}-87$ & 0.007 & 0.19 & 0.004 & $(0.0001$ & $<0.0001$ & 0.0025 & - \\
\hline $03-0 E C-87$ & - & 0.21 & - & - & - & - & - \\
\hline $29-J A N-88$ & $<0.1$ & 0.22 & $<0.1$ & $<0.0001$ & $<0.01$ & $<0.02$ & - \\
\hline $06-M A Y-88$ & $<0.1$ & 0.16 & $<0.1$ & $<0.0001$ & 0.0001 & 0.011 & - \\
\hline $02-A \cup G-88$ & $<0.1$ & 0.19 & 0.1 & 0.0003 & $<0.0001$ & 0.0019 & - \\
\hline $24-0 C T-88$ & - & - & - & - & - & - & - \\
\hline \multicolumn{8}{|l|}{$w-809-01$} \\
\hline $20-0 \mathrm{CT}-88$ & - & - & - & - & - & - & - \\
\hline \multicolumn{8}{|l|}{$w-809-02$} \\
\hline $20-0 C T-88$ & - & - & - & - & - & - & - \\
\hline \multicolumn{8}{|l|}{$W-809-03$} \\
\hline $16-O C T-89$ & - & - & - & - & - & - & - \\
\hline \multicolumn{8}{|l|}{$W-810-01$} \\
\hline $21-O C T-88$ & - & - & - & - & - & - & - \\
\hline \multicolumn{8}{|l|}{$w-815-01$} \\
\hline $11-D E C-87$ & - & - & - & - & - & - & - \\
\hline $19-.0 C T-88$ & - & - & - & - & - & - & - \\
\hline \multicolumn{8}{|l|}{$w-815-02$} \\
\hline $11-D E C-87$ & - & - & - & - & - & - & - \\
\hline $20-n C T-88$ & - & - & - & - & - & - & - \\
\hline \multicolumn{8}{|l|}{$w-815-03$} \\
\hline $20-O C T-C 3$ & - & - & - & - & - & - & - \\
\hline \multicolumn{8}{|l|}{$W-815-04$} \\
\hline $20-0 C T-88$ & - & - & - & - & - & - & - \\
\hline \multicolumn{8}{|l|}{$w-815-05$} \\
\hline $18-0 C T-89$ & - & - & - & - & - & - & - \\
\hline \multicolumn{8}{|l|}{ W-817-01 } \\
\hline $24-A P R-85$ & $<0.1$ & 0.06 & $<0.1$ & $<0.01$ & 20.01 & $<0.02$ & $<0.01$ \\
\hline $09-J \cup L-85$ & $<0.1$ & 0.07 & $<0.1$ & $<0.01$ & $<0.01$ & $<0.02$ & - \\
\hline $22-$ NOV -85 & $<0.1$ & 0.053 & $<0.1$ & $<0.01$ & 0.01 & $<0.02$ & - \\
\hline $14-M A R-86$ & $<0.1$ & 0.06 & $<0.1$ & $<0.01$ & $<0.01$ & $<0.02$ & - \\
\hline $09-J \cup N-86$ & $<0.1$ & 0.062 & $<0.1$ & $<0.01$ & $<0.01$ & $<0.02$ & - \\
\hline $15-J \cup L-86$ & $<C .1$ & 0.062 & $<0.1$ & $<0.01$ & $<0.01$ & $<0.02$ & - \\
\hline $15-0 C T-86$ & $<0.1$ & 0.062 & $<0.1$ & $<0.01$ & $<0.01$ & $<0.02$ & - \\
\hline $02-F E B-87$ & - & - & - & - & - & - & - \\
\hline $09-F E B-87$ & $<0.1$ & 0.052 & 0.1 & $<0.01$ & $<0.01$ & 0.0019 & - \\
\hline $09-\mathrm{FEB}-87$ & $<0.1$ & 0.0510 & 0.1 & $<0.01$ & $<0.01$ & 0.0038 & - \\
\hline $27-A P R-87$ & $<0.2$ & 0.065 & $<0.1$ & $<0.01$ & $<0.01$ & $<0.02$ & - \\
\hline 12 -AUG-B7 & $<0.1$ & 0.048 & $<0.1$ & $<0.01$ & $<0.01$ & $<0.02$ & - \\
\hline $06-0 C T-87$ & $<0.001$ & 0.028 & 0.023 & $<0.0001$ & $<0.0001$ & 0.0003 & - \\
\hline $16-$ NOV -87 & - & - & - & - & - & - & - \\
\hline $13-3 A N-88$ & $<0.1$ & 0.031 & $<0.1$ & $<0.0001$ & $<u, C 1$ & 10.02 & - \\
\hline $13-A P R-8 B$ & $<0.1$ & 0.031 & $<0.1$ & $\angle 00001$ & 0.0005 & 0.0022 & - \\
\hline $13-A P R-88$ & 0.1 & 0.03 & $<0.1$ & $<0.0001$ & 0.0003 & 0.001 & - \\
\hline $12-J \cup 2,-88$ & $<0.1$ & 0.042 & $<0.1$ & 10.0001 & 0.0001 & 0.0014 & .. \\
\hline $01-\mu D V-88$ & $<0.06$ & 0.045 & $<0.1$ & $<0.0001$ & $<0.04$ & $<0.05$ & - \\
\hline $10-J A N-89$ & $<0.1$ & 0.047 & $<0.1$ & 0.0002 & 0.0005 & $<0.02$ & - \\
\hline $10-J A N-89$ & - & - & - & - & - & - & - \\
\hline $17-A P R-29$ & $<0.1$ & - & $<0.1$ & - & 0.0007 & - & - \\
\hline $17-A P R-B 9$ & $<0.1$ & - & $<0.1$ & - & 0.0006 & - & - \\
\hline $17-A P R-89$ & - & 0.043 & - & $<0.0001$ & - & $<0.02$ & - \\
\hline
\end{tabular}




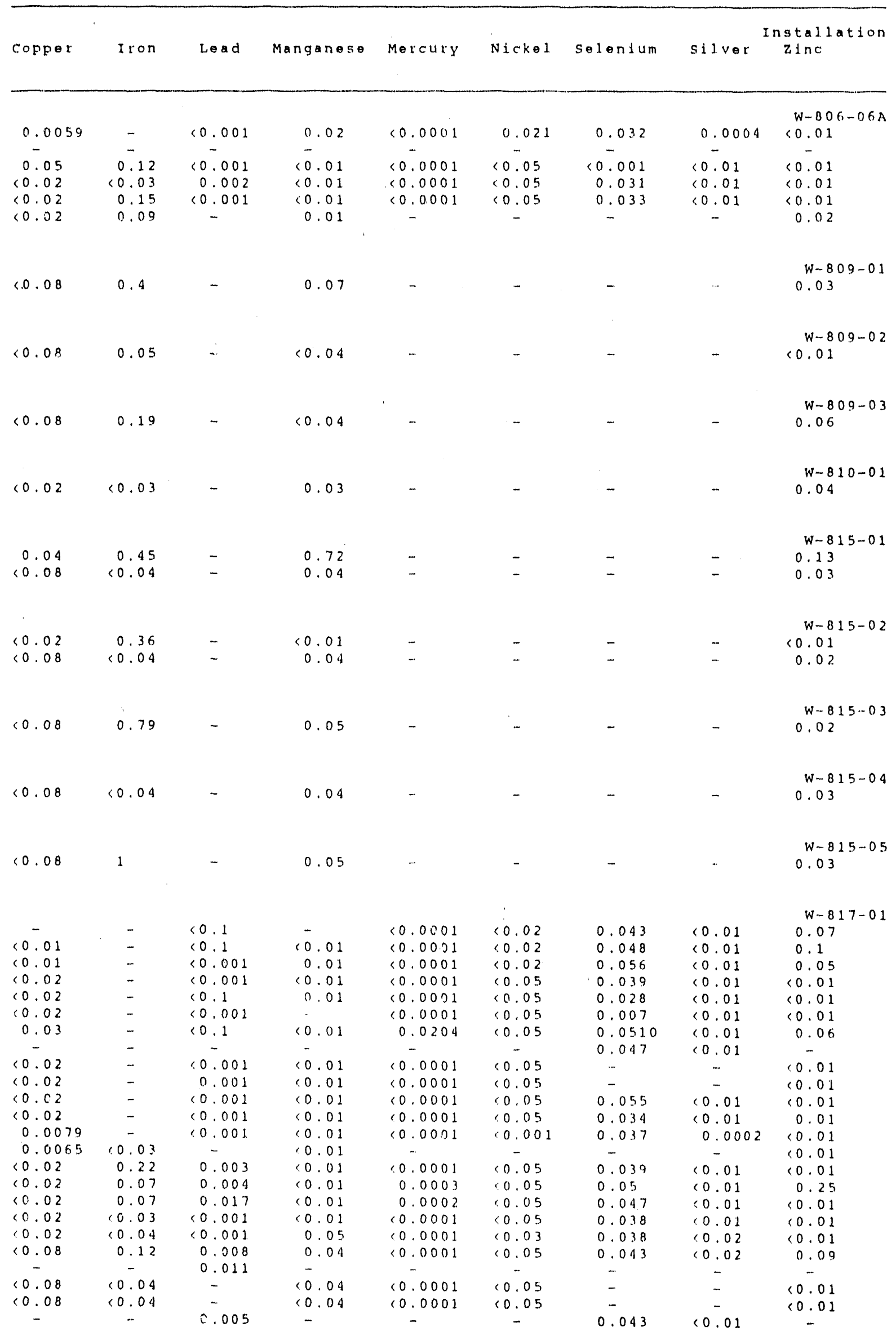


Table B-2. Water analyses (ppm) for metals in ground water samples reported by March 31 , 1990 .

\begin{tabular}{|c|c|c|c|c|c|c|c|}
\hline $\begin{array}{c}\text { Installation } \\
\text { Date } \\
\text { sampled }\end{array}$ & Antimony & Arsenic & Barium & Beryl11um & Cadmium & $\begin{array}{c}\text { chromium } \\
\text { total }\end{array}$ & $\begin{array}{l}\text { Chromium } \\
\text { hexavalent }\end{array}$ \\
\hline $17-A P R-89$ & . $\quad-$ & 0.043 & - & $<0.0001$ & - & $<0.02$ & - \\
\hline $26-J \cup L-89$ & - & 0.047 & - & $<0.0001$ & - & $<0.01$ & - \\
\hline $26-J \cup L-89$ & $<0.1$ & - & $<0.1$ & $-\quad i$ & $<0.01$ & - & - \\
\hline $23-0 C T-89$ & $<0.06$ & 0.063 & $<0.05$ & $<0.0005$ & $<0.04$ & $<0.005$ & - \\
\hline $30-0 C T-89$ & - & 0.072 & - & $<0.0005$ & - & $<0.005$ & - \\
\hline $06-$ NOV -89 & - & 0.068 & - & $<0.0005$ & - & $<0.005$ & - \\
\hline $13-$ NOV -89 & - & 0.064 & - & $<0.0005$ & - & $<0.005$ & - \\
\hline $12-J A N-90$ & $<0.06$ & 0.062 & $<0.05$ & $<0.0005$ & $<0.04$ & $<0.005$ & - \\
\hline $17-\mathrm{JAN}-90$ & - & 0.047 & - & $<0.0005$ & - & $<0.005$ & - \\
\hline $24-J A N-90$ & - & 0.048 & - & $<0.0005$ & - & $<0.005$ & - \\
\hline $31-J A N-90$ & - & 0.061 & - & $<0.0005$ & - & 0.007 & - \\
\hline
\end{tabular}

$W-817-02$

$24-A P R-85$

$09-\mathrm{JUL}-85$

22-NOV-85

18 -MAR- 86

$09-J U N-86$

I 5-JUL- 86

15-OCT-86

$02-F E B-87$

$02-F E B-87$

$27-A P R-87$

14-AUG-87

14-AUG-87

$07-0 C T-87$

$07-0 \mathrm{CT}-87$

$16-\mathrm{NOV}-87$

$12-J A N-88$

$13-A P R-8 B$

$12-J U L-88$

$02-N O V-88$

O3-NOV -88

$06-F E B-89$

06-FEB-89

$18-A P R-89$

$18-A P R-89$

27-JUL-89

27-JUL-89

27- TUL-89

27-JUL-89

23-OCT-89

$23-O C T-89$

$30-O C T-89$

$30-O C T-89$

06-NOV-89

06-NOV-89

13-NOV-89

$12-J A N-90$

$18-J A N-90$

25-JAN-90

$31-J A N-90$

W-817-03

24-APR- 85

09-JUL-85

22-NOV-85

14-MAR- 86

$09-J U N-86$

$15-J \cup L-86$

15-OCT-86

$02-F E B-87$

O2-FEB-87

27-APR-87

12-AUG -87

06-OCT- 87

06-OCT-87

16-NOV-87

$12-J A N-88$

13 - APR - 88

\begin{tabular}{|c|c|c|c|}
\hline$<0.1$ & 0.033 & $<0.1$ & $<0.01$ \\
\hline$<0.1$ & $0 . \cap 510$ & $<0.1$ & $<0.01$ \\
\hline$<0.1$ & 0.026 & $<0.1$ & $<0.01$ \\
\hline$<0.1$ & 0.041 & $<0.1$ & $<0.01$ \\
\hline$<0.1$ & 0.047 & $<0.1$ & $<0.01$ \\
\hline$<0.1$ & 0.044 & $<0.1$ & $<0.01$ \\
\hline$<0.1$ & 0.044 & $<0.1$ & $<0.01$ \\
\hline$<0.1$ & 0.044 & $<0.1$ & $<0.01$ \\
\hline- & - & - & - \\
\hline$<0.1$ & 0.044 & $<0,1$ & $<0.01$ \\
\hline$<0.1$ & 0.041 & $<0.1$ & $<0.01$ \\
\hline$<0.1$ & 0.041 & $<0.1$ & $<0.01$ \\
\hline 0.014 & 0.05 & 0.014 & $<0.0001$ \\
\hline- & - & - & - \\
\hline - & - & - & - \\
\hline$<0.1$ & 0.031 & $<0,1$ & $<0.0001$ \\
\hline$<0.1$ & 0.036 & $<0.1$ & $<0.0001$ \\
\hline$<0.1$ & 0.038 & $<0.1$ & $<0.0001$ \\
\hline - & - & - & - \\
\hline 0.5 & .035 & $<0.1$ & 0.0002 \\
\hline$<0.01$ & - & $<0.1$ & - \\
\hline- & 0.039 & - & $<0.0001$ \\
\hline$<0.1$ & - & $<0.1$ & - \\
\hline - & 0.044 & - & $<0.0001$ \\
\hline - & - & - & $<0.0001$ \\
\hline - & - & - & $<0.0001$ \\
\hline$<0.1$ & - & $<0.1$ & - \\
\hline$<0.1$ & - & $<0.1$ & - \\
\hline$<0.06$ & 0.059 & $<0.05$ & $<0.0005$ \\
\hline$<0.06$ & 0.059 & $<0.05$ & $<0.0005$ \\
\hline - & 0.068 & - & $<0.0005$ \\
\hline- & 0.069 & - & $<0.0005$ \\
\hline- & 0.044 & - & $<0.0005$ \\
\hline - & 0.056 & - & $<0.0005$ \\
\hline - & 0.061 & - & $<0.0005$ \\
\hline$<0.06$ & 0.064 & $<0.05$ & $<0.0005$ \\
\hline - & 0.047 & - & $<0.0005$ \\
\hline$\cdots$ & 0.048 & - & $<0.0005$ \\
\hline- & 0.056 & - & $<0.0005$ \\
\hline
\end{tabular}

$<0.01$
$<0.01$
$<0.01$
$<0.01$
$<0.01$
$<0.01$
$<0.01$
$<0.01$
$<0.01$
$<0.01$
$<0.01$
$<0.0001$
-
$<0.01$
0.0001
0.0001
-
0.0001
$<0.0001$
-
0.0008
$<-$
$<0.04$
$<0.01$
$<0.04$
-
$<0$
-
$<-$
-
-0
-

$<0.02$

$<0.02$

$<0.02$

$<0.02$

$<0.02$

$<0.02$

$<0.02$

$<0.02$

$<0.02$

$<0.02$

< 0.02

0.0004

0.0008

$<0.02$

0.0007

0.0015

0.02

$<0.02$

-

$<0.02$

$<0.01$

$<0.01$

$-$

$<0.005$

$<0.005$

$<0.005$

$<0.005$

$<0.005$

$<0.005$

$<0.005$

$<0.005$

$<0.005$

$<0.005$

0.006

$<0.01$
$<0.01$
$<0.01$
$<0.01$
$<0.01$
$<0.01$
$<0.01$
$<0.01$
$<-$
$<0.01$
$<0.01$
$<0.0001$
$<0.0001$
$<-$
$<0.01$
0.0001

$\begin{array}{cc}<0.02 & <0.01 \\ <0.02 & - \\ <0.02 & - \\ <0.02 & - \\ <0.02 & - \\ <0.02 & - \\ <0.02 & - \\ <0.02 & - \\ <0.02 & - \\ <0.02 & - \\ 0.0014 & - \\ 0.0013 & - \\ <0.02 & - \\ 0.0023 & -\end{array}$




\begin{tabular}{|c|c|c|c|c|c|c|c|c|}
\hline Copper & Iron & Lead & Manganese & Mercury & $N i c k \in 1$ & $S \cdot 1$ en $1 \mathrm{um}$ & silver & $\begin{array}{l}\text { nstallation } \\
\text { zinc }\end{array}$ \\
\hline- & - & 0.006 & - & - & - & 0.045 & $<0.01$ & - \\
\hline$<0.01$ & $<0.04$ & $<0.001$ & $<0.04$ & - & - & 0.034 & $<0.01$ & 0.03 \\
\hline- & - & - & - & $(0.0001$ & $<0.05$ & - & - & - \\
\hline$<0.08$ & $<0.04$ & $<0.002$ & $<0.04$ & $<0.0001$ & $\therefore 0.03$ & 0.026 & $<0.02$ & 0.21 \\
\hline- & - & $<0.002$ & - & - & - & 0.022 & $<0.01$ & - \\
\hline- & - & 10.002 & - & - & - & 0.032 & $<0.01$ & - \\
\hline- & - & $<0.002$ & - & - & - & 0.034 & $<0.01$ & - \\
\hline$<0.08$ & $<0.04$ & $<0.002$ & $<0.04$ & $<0.0001$ & $<0.03$ & 0.029 & $<0.02$ & 0.02 \\
\hline- & - & $<0.002$ & - & - & - & 0.031 & $<0.02$ & - \\
\hline- & - & $<0.002$ & - & - & - & 0.033 & $<0.02$ & - \\
\hline \multirow[t]{2}{*}{-} & - & 0.002 & - & - & - & 0.03 & $<0.02$ & - \\
\hline & & & & & & & & $w-817-02$ \\
\hline- & - & $<0,1$ & - & $<0.0001$ & $<0.02$ & 0.055 & $<0.01$ & 0.32 \\
\hline$<0,01$ & - & $<0.1$ & $<0.01$ & $<0.0001$ & $<0.02$ & 0.057 & $<0.01$ & 0.37 \\
\hline$<0.01$ & - & $<0.001$ & 0.01 & $<0.0001$ & $<0.02$ & 0.089 & $<0.01$ & 0.12 \\
\hline$<0.02$ & - & $<0.1$ & $<0.01$ & $<0.0001$ & $<0.05$ & 0.024 & $<0.01$ & 0.14 \\
\hline$<0.02$ & - & $<0.1$ & 0.01 & $<0.0001$ & $<0.05$ & 0.042 & $<0.01$ & 0.12 \\
\hline$<0,02$ & - & $<0.001$ & - & $<0.0001$ & $<0.05$ & 0.026 & $<0.01$ & 0.06 \\
\hline 0.02 & - & $<0.1$ & $<0.01$ & $<0.0001$ & $<0.05$ & 0.079 & 0.01 & 0.11 \\
\hline$<0.02$ & - & $<0.1$ & $<0.01$ & $<0.0001$ & $<0.05$ & 0.069 & - & 0.1 \\
\hline- & - & - & - & - & - & - & $(0.01$ & - \\
\hline$<0,02$ & - & $<0.001$ & $<0.01$ & $<0.0001$ & $<0.05$ & 0.074 & $<0.01$ & 0.06 \\
\hline$<0.02$ & - & 10.001 & $<0.01$ & $<0.0001$ & $<0.05$ & 0.068 & $<0.01$ & 0.05 \\
\hline$<0.02$ & - & $<0.001$ & $<0.01$ & $<0.0001$ & $<0.05$ & 0.07 & $<0.01$ & 0.03 \\
\hline 0.0078 & - & $<0.001$ & $<0.01$ & $<0.0001$ & $<0.001$ & 0.1 & 0.0005 & $<0.01$ \\
\hline- & - & - & - & - & - & - & - & - \\
\hline 0.0078 & $<0.03$ & - & $<0.01$ & - & - & - & - & $<0.01$ \\
\hline$<0.02$ & $<0.03$ & $<0.001$ & $<0,01$ & $<0.0001$ & $<0.05$ & 0.08 & $<0.01$ & $<0.01$ \\
\hline$<0.02$ & $<0.03$ & 0.005 & $<0.01$ & $<0.0001$ & $<0.05$ & 0.091 & $<0.01$ & $<0.01$ \\
\hline$<0.02$ & $<0.03$ & 0.002 & $<0.01$ & $<0.0001$ & $<0.05$ & 0.081 & $<0.01$ & $<0.01$ \\
\hline$<0.08$ & $<0.04$ & - & $<0,04$ & - & - & - & - & 0.05 \\
\hline- & - & 0.001 & - & $<0.0001$ & $<0.05$ & 0.077 & $<0.01$ & - \\
\hline$<0.08$ & $<0.04$ & 0.002 & 0.09 & 10.0001 & $<0.05$ & - & - & 1 \\
\hline- & - & $<0.001$ & - & - & - & 0.084 & $: 0.01$ & - \\
\hline$<0.08$ & 0.2 & - & $<0.04$ & $<0.0001$ & $<0.05$ & - & - & 0.03 \\
\hline- & - & 0.007 & - & - & - & 0.08 & $<0.01$ & - \\
\hline- & - & 10.001 & - & - & - & 0.074 & $<0.01$ & - \\
\hline- & - & $<0.001$ & - & - & - & 0.073 & $<0.01$ & - \\
\hline$<0.02$ & - & - & $<0.04$ & $<0.0001$ & $<0.05$ & - & - & 0.06 \\
\hline$<0.02$ & - & - & $<0.04$ & $<0.0001$ & $<0.05$ & - & - & 0.12 \\
\hline 0.12 & $<0.04$ & 0.008 & 10.04 & 10.0001 & $<0.03$ & 0.057 & $<0.02$ & 0.09 \\
\hline$(0.08$ & $<0.04$ & 0.005 & $<0.04$ & $<0.0001$ & $<0.03$ & 0.075 & $<0.02$ & 10.01 \\
\hline- & - & $<0.002$ & - & - & - & 0.047 & 0.02 & - \\
\hline- & - & $<0.002$ & - & - & - & 0.045 & $<0.01$ & - \\
\hline- & - & 0.002 & - & - & - & 0.05 & $<0.01$ & - \\
\hline- & - & 10.002 & - & - & - & 0.08 & $<0.01$ & - \\
\hline - & - & 10.002 & - & - & - & 0.087 & $<0.01$ & - \\
\hline$<0.08$ & $<0.04$ & $<0.002$ & $<0.04$ & $<0.0001$ & $<0.03$ & 0.085 & $<0.02$ & 10.01 \\
\hline- & - & $<0.002$ & - & - & - & 0.078 & 0.0001 & - \\
\hline- & - & $<0.002$ & - & - & - & 0.1 & $<0.02$ & - \\
\hline \multirow[t]{2}{*}{-} & - & $<0.002$ & - & - & - & 0.089 & $<0.02$ & - \\
\hline & & & & & & & & $w-817-03$ \\
\hline- & - & $<0.1$ & - & 10.0001 & 10.02 & 0.012 & $<0.01$ & 0.05 \\
\hline$<0.01$ & - & $c 0.1$ & $<0.01$ & $<0.0001$ & $<0.02$ & 0.009 & $<0.01$ & 0.11 \\
\hline$<0.01$ & - & $<0.001$ & 10.01 & 0.0001 & $<0.02$ & 0.018 & $<0.01$ & 0.03 \\
\hline 10.02 & - & $<0.001$ & 0.01 & $<0,0001$ & $\therefore 0.05$ & 0.013 & $<0.01$ & 0.02 \\
\hline$<0.02$ & - & $<0.1$ & 0.01 & $<0.0001$ & 10.05 & 10.001 & $<0.01$ & 0.02 \\
\hline 10.02 & - & $<0.001$ & - & $<0.0001$ & $<0.05$ & 0.003 & $<0.01$ & $<0.01$ \\
\hline 0.04 & - & 0.1 & $<0.01$ & $<0.0001$ & 10.05 & 0.02 & $<0,01$ & 0.02 \\
\hline$<0.02$ & - & $<0.1$ & $<0.01$ & $<0.0001$ & $<0.05$ & 0.013 & - & $<0.01$ \\
\hline- & - & - & -. & - & $\ldots$ & - & $<0.01$ & - \\
\hline$<0.02$ & - & 10.001 & 10.01 & $<0.0001$ & $<0.05$ & 0.016 & 10.01 & $<0.01$ \\
\hline 10.02 & - & $<0.001$ & $<0.01$ & .0 .0001 & 10.05 & 0.016 & $<0.01$ & $<0.01$ \\
\hline 0.01 & - & $<0.001$ & $(0.01$ & $<0.0001$ & 10.001 & 0.017 & 0.0003 & $<0.01$ \\
\hline 0.0041 & - & $<0.001$ & $(0.01$ & 10.0001 & 10.001 & 0.017 & 0.0003 & $<0.01$ \\
\hline 0.0071 & $<0.03$ & - & $<0.01$ & - & - & - & $\sim$ & $<0.01$ \\
\hline$<0.02$ & 0.25 & $<0.001$ & $<0.01$ & 10.0001 & 10.05 & 0.018 & $<0.01$ & $<0.01$ \\
\hline 10.02 & 0.19 & 0.002 & $(0.01$ & 0.0003 & 10,05 & 0.023 & $<0.01$ & $<0.01$ \\
\hline
\end{tabular}


Table B-2. Water analyses (ppm) for matals in ground water samples reported by Match 31 , 1990.

\begin{tabular}{|c|c|c|c|c|c|c|c|}
\hline $\begin{array}{c}\text { Installation } \\
\text { Dato } \\
\text { samplod }\end{array}$ & Ant imony & Arsendc & Barium & Beryl11um & Cadmium & $\begin{array}{c}\text { Chromium } \\
\text { total }\end{array}$ & $\begin{array}{c}\text { Chromium } \\
\text { hexavalent }\end{array}$ \\
\hline $12-J \cup L-88$ & $<0.1$ & 0.031 & $<0.1$ & $<0.0001$ & 0.0001 & 0.0027 & - \\
\hline $02-N O V-88$ & - & - & - & - & - & - & - \\
\hline $02-\mathrm{NOV}-88$ & - & - & - & - & - & - & - \\
\hline $03-\mathrm{NOV}-88$ & 0.5 & 0.034 & $<0.1$ & 0.0002 & $<0.0001$ & $<0.02$ & - \\
\hline $03-N O V-88$ & 0.5 & 0.033 & $<0.1$ & 0.0001 & 0.0002 & $<0.02$ & - \\
\hline $06-F E B-89$ & $<0.01$ & - & $<0.1$ & - & 0.0002 & $<0.02$ & - \\
\hline $06-F E B-89$ & - & 0.033 & - & $<0.0001$ & - & - & - \\
\hline $17-A P R-89$ & $<0.1$ & - & $<0.1$ & - & 0.0012 & - & - \\
\hline $17-A P R-89$ & - & 0.024 & - & $<0.0001$ & - & 10.02 & - \\
\hline $26-J \cup L-89$ & - & 0.043 & - & $<0.0001$ & - & $<0.01$ & - \\
\hline $26-J \cup L-89$ & $<0.1$ & - & $<0.1$ & - & $<0.01$ & - & - \\
\hline $24-0 C T-89$ & $<0.06$ & 0.044 & $<0.05$ & $<0.0005$ & $<0.04$ & 0.009 & - \\
\hline $30-0 C T-89$ & - & 0.043 & - & $<0.0005$ & - & $<0.005$ & - \\
\hline O6-NOV-89 & - & 0.048 & - & $<0.00 \cap 5$ & - & $<0.005$ & - \\
\hline $13-$ NOV -89 & - & 0.048 & - & $<0.0005$ & - & $<0.005$ & - \\
\hline $12-J A N-90$ & $<0.06$ & 0.046 & $<0.05$ & $<0.0005$ & $<0.04$ & $<0.005$ & - \\
\hline $12-J A N-90$ & $<0.06$ & 0.047 & $<0.05$ & $<0.0005$ & $<0.04$ & $<0.005$ & - \\
\hline $17-J A N-90$ & - & 0.044 & - & $<0.0005$ & - & $<0.005$ & - \\
\hline $17-J A N-90$ & - & 0.045 & - & $<0.0005$ & - & $<0.005$ & - \\
\hline $24-J A N-90$ & - & 0.04 & - & $<0.0005$ & - & 0.006 & - \\
\hline $24-J A N-90$ & - & 0.042 & - & $<0.0005$ & - & 0.006 & - \\
\hline $31-J A N-90$ & - & 0.052 & - & $<0.0005$ & - & $<0.005$ & - \\
\hline $31-J A N-90$ & - & 0.05 & - & $<0.0005$ & - & 0.006 & - \\
\hline \multicolumn{8}{|l|}{$W-817-03 A$} \\
\hline $16-$ NOV -87 & - & - & - & - & - & - & - \\
\hline \multicolumn{8}{|l|}{$w-817-04$} \\
\hline $24-A P R-85$ & $<0.1$ & 0.04 & $<0.1$ & $<0.01$ & $<0.01$ & $<0.02$ & $<0.01$ \\
\hline $09-J \cup L-85$ & $<0.1$ & 0.027 & $<0.1$ & $<0.01$ & $<0.01$ & $<0.02$ & - \\
\hline $22-N O V-85$ & $<0.1$ & 0.031 & $<0.1$ & $<0.01$ & $<0.01$ & $<0.02$ & - \\
\hline $14-M A R-86$ & 10.1 & 0.039 & $<0.1$ & $<0.01$ & 60.01 & $<0.02$ & - \\
\hline $09-J \cup N-86$ & $<0.1$ & 0.042 & $<0.1$ & $<0.01$ & $<0.01$ & $<0.02$ & - \\
\hline $15-J \cup L-86$ & $<0.1$ & 0.042 & $<0.1$ & $<0.01$ & $<0.01$ & $<0.02$ & - \\
\hline $15-0 C T-86$ & $<0.1$ & 0.039 & 0.1 & $<0.01$ & $(0.01$ & $<0.02$ & - \\
\hline $02-F E B-87$ & $<0.1$ & 0.04 & $<0.1$ & $<0.01$ & $<0.01$ & $<0.02$ & - \\
\hline $02-F E B-87$ & - & - & - & - & - & - & - \\
\hline $27-A P R-87$ & $<0.1$ & 0.045 & $<0.1$ & $<0.01$ & $<0.01$ & $<0.02$ & - \\
\hline $12-8 . U G-87$ & $<0.1$ & 0.046 & $<0.1$ & $<0.01$ & $<0.01$ & $<0.02$ & - \\
\hline $06-0 C T-87$ & $<0.001$ & 0.028 & 0.01 & $<0.0001$ & $<0.0001$ & 0.0018 & - \\
\hline $16-N O V-87$ & - & - & - & - & - & - & - \\
\hline $12-J A N-B 8$ & $<0.1$ & 0.031 & $<0.1$ & $<0.0001$ & $<0.01$ & $<0.02$ & - \\
\hline $12-J A N-88$ & $<0.1$ & 0.036 & $<0.1$ & $<0.0001$ & $<0.01$ & $<0.02$ & - \\
\hline $13-A P R-B B$ & $<0.1$ & 0.036 & 0.1 & 10.0001 & 0.0001 & 0.0049 & - \\
\hline $12-J \cup L-88$ & $<0.1$ & 0.042 & $<0.1$ & $<0.0001$ & $\checkmark, 0001$ & 0.0035 & - \\
\hline $12-J \cup L-88$ & 10.1 & 0.041 & $<0.1$ & 10.0001 & 0.0001 & 0.0034 & - \\
\hline $02-N O V-88$ & - & - & - & - & - & - & - \\
\hline $03-N O V-88$ & 0.5 & 0.038 & $<0.1$ & 0.0002 & $<0.0001$ & $<0.02$ & - \\
\hline $06-F E B-89$ & $<0.01$ & - & $<0.1$ & - & $<0.0001$ & $<0.02$ & - \\
\hline $06-\mathrm{TEB}-89$ & $<0.01$ & - & $<0.1$ & - & $<0.0001$ & $<0.02$ & - \\
\hline $06-F E B-89$ & - & 0.042 & - & $<0.0001$ & - & - & - \\
\hline $06-F E B-89$ & - & 0.04 & - & $<0.0001$ & - & - & - \\
\hline $18-A P R-89$ & $<0.1$ & - & $<0.1$ & - & 0.0005 & - & - \\
\hline $18-A P R-89$ & - & 0.039 & - & $<0.0001$ & - & $<0.02$ & - \\
\hline $27-J \cup L-89$ & - & 0.056 & - & $<0.0001$ & - & $<0.01$ & - \\
\hline $27-J \cup L-89$ & $<0.1$ & - & $<0.1$ & - & $<0.01$ & - & - \\
\hline $23-0 C T-89$ & $<0.06$ & 0.061 & $<0.05$ & 10.0005 & $<0.04$ & $<0.005$ & - \\
\hline $30-0 \subset T-89$ & - & 0.0510 & - & $<0.0005$ & - & $<0.005$ & - \\
\hline $06-N O V-89$ & - & 0.056 & - & $<0.0005$ & - & $<0.005$ & - \\
\hline $13-$ NOV -89 & - & 0.065 & - & $<0.0005$ & - & 10.005 & - \\
\hline $12-J A N-90$ & $<0.06$ & 0.066 & $<0.05$ & $<0.0005$ & $<0.04$ & 10.005 & - \\
\hline $1 B-J A N-90$ & - & 0.05 & - & $<0.0005$ & - & 0.005 & - \\
\hline $25-J A N-90$ & - & 0.062 & - & 10.0005 & - & $<0.005$ & - \\
\hline $01-F E B-90$ & - & 0.058 & - & $<0.0005$ & - & $<0.005$ & - \\
\hline \multicolumn{8}{|l|}{$w-817-05$} \\
\hline $25-0 C T-88$ & - & - & - & - & - & - & - \\
\hline
\end{tabular}




\begin{tabular}{|c|c|c|c|c|c|c|c|c|}
\hline Copper & J ron & Load & Manganese & Mercury & Nickel & selen 1 um & silvet & $\begin{array}{l}\text { Installation } \\
\quad \text { zinc }\end{array}$ \\
\hline$<0.02$ & $<0.03$ & 0.002 & $<0.01$ & $<0.0001$ & $<0.05$ & 0.018 & $<0.01$ & $<0,01$ \\
\hline$<0.08$ & $<0.04$ & - & $<0.04$ & - & $\sim$ & - & - & 0.03 \\
\hline$\angle 0.08$ & 10.04 & - & $<0.04$ & - & - & - & - & 0.03 \\
\hline- & - & 0.005 & - & $<0.0001$ & $<0.05$ & 0.016 & $<0.01$ & - \\
\hline- & - & 0.007 & - & $<0,0001$ & $<0.05$ & 0.018 & $(0.01$ & -.. \\
\hline$<0.08$ & $<0.04$ & 0.002 & 0.08 & $<0.0001$ & $<0.05$ & - & - & 1 \\
\hline- & - & 0.002 & - & - & - & 0.019 & $\angle 0.01$ & - \\
\hline$<0.08$ & $<0.04$ & - & 60.04 & $<0.0001$ & $<0.05$ & - & - & $<0.01$ \\
\hline- & - & 0.004 & - & - & - & 0.013 & $<0.01$ & - \\
\hline$<0.01$ & $<0.04$ & $<0.001$ & $<0.04$ & - & - & 0.021 & $<0.01$ & $<0.01$ \\
\hline- & - & - & $\ldots$ & $<0.0001$ & 10.05 & - & - & $\ldots$ \\
\hline$\angle 0.08$ & $<0.04$ & 0.008 & $<0.04$ & $<0.0001$ & $<0.03$ & 0.02 & 10.02 & $<0.01$ \\
\hline- & - & $<0.002$ & - & - & - & 0.016 & 10.01 & -- \\
\hline - & - & $<0.002$ & - & - & - & 0.02 & 10.01 & - \\
\hline- & - & $<0.002$ & - & - &.- & 0.024 & 10.01 & $\ldots$ \\
\hline 10.08 & $<0.04$ & $<0.002$ & $<0.04$ & $<0.0001$ & $<0.03$ & 0.022 & 10.02 & $(0.01$ \\
\hline$<0.08$ & $<0.04$ & $<0.002$ & $<0.04$ & 10.0001 & 10.03 & 0.022 & $<0.02$ & $<0.01$ \\
\hline- & - & $<0.002$ & - & - & - & 0.022 & $<0.02$ & - \\
\hline- & - & $<0.002$ & - & - & - & 0.022 & $<0.02$ & - \\
\hline- & - & $<0.002$ & - & - & - & 0.025 & 10.02 & - \\
\hline- & - & 0.017 & - & - & - & 0.024 & $<0.02$ & - \\
\hline- & - & $<0.002$ & - & - & - & 0.023 & $<0.02$ & - \\
\hline- & - & $<0.002$ & - & - & - & 0.022 & 10.02 & - \\
\hline \multirow[t]{2}{*}{0.012} & 10.03 & - & $<0.01$ & - & - & $\cdots$ & - & $\begin{array}{l}W-817-03 A \\
<0.01\end{array}$ \\
\hline & & & & & & & & $w-817-04$ \\
\hline ..- & - & $<0.1$ & - & $<0.0001$ & $<0.02$ & 0.013 & $(0.01$ & 0.01 \\
\hline$<0.01$ & - & $<0.1$ & $<0.01$ & $(0.0001$ & 10.02 & 0.012 & $<0.01$ & 0.06 \\
\hline$<0.01$ & - & 0.001 & $<0.01$ & $<0.0001$ & 10.02 & 0.016 & 10.01 & 0.03 \\
\hline$<0.02$ & .. & $<0.001$ & $<0.01$ & $(0.0001$ & $<0.05$ & 0.012 & $<0.01$ & $<0.01$ \\
\hline$<0.02$ & $\ldots$ & $<0.1$ & 0.01 & $<0.0001$ & $<0.05$ & $<0.001$ & $<0.01$ & $<0.01$ \\
\hline$<0.02$ & - & $<0,00.1$ & - & $<0.0001$ & 0.05 & 0.004 & $<0.01$ & $(0.01$ \\
\hline 0.05 & - & $<0.1$ & $<0.01$ & 0.0001 & 10.05 & 0.21 & 0.01 & 0.13 \\
\hline$<0.02$ & - & $(0,1$ & $<0.01$ & 10.0001 & $<0.05$ & 0.016 & - & 0.07 \\
\hline- & - & - & - & - & - & - & $<0.01$ & - \\
\hline 10.02 & - & 10.001 & $<0.01$ & $<0.0001$ & 10.05 & 0.021 & $<0.01$ & 0.03 \\
\hline$<0.02$ & - & $<0.001$ & 10.01 & $<0.0001$ & 0.05 & 0.018 & $<0.01$ & 0.03 \\
\hline 0.0058 & - & 0.001 & $<0.01$ & .0 .0001 & 0.0 .1 & 0.019 & 0.0004 & $<0.01$ \\
\hline 0.0061 & $<0.03$ & - & $<0.01$ & - & - & - & - & $<0.01$ \\
\hline$<0.02$ & 10.03 & $<0.001$ & $<0.01$ & $<0.0001$ & 0.05 & 0.019 & $<0.01$ & $<0,01$ \\
\hline$<0.02$ & - & $<0.001$ & $<0.01$ & 0.0001 & 10.05 & 0.017 & $<0.01$ & $<0.01$ \\
\hline$<0.02$ & .0 .03 & 0.012 & $<0.01$ & 0.0003 & $<0.05$ & 0.0206 & $<0.01$ & $<0.01$ \\
\hline$<0.02$ & 10.03 & 0.002 & $\therefore 0.01$ & $<0.0001$ & $<0.05$ & 0.019 & $<0.01$ & $<0.01$ \\
\hline$<0.02$ & $<0.03$ & 0.001 & $<0.01$ & $<0.0001$ & $<0.05$ & 0.019 & $<0.01$ & $<0.01$ \\
\hline$\angle 0.08$ & $<0.04$ & - & $<0.04$ & - & - & - & - & 0.03 \\
\hline- & - & 0.005 & - & $<0.0001$ & $<0.05$ & 0.016 & $<0.01$ & - \\
\hline$<0.08$ & 10.04 & 0.001 & 0.09 & $(0.0001$ & 10.05 & - & - & 0.75 \\
\hline$<0.08$ & $<0.04$ & 0.002 & 0.09 & $<0.0001$ & $<0.05$ & - & - & 0.16 \\
\hline- & - & $<0.001$ & - & - & - & 0.022 & $<0.01$ & - \\
\hline- & - & 10.001 & - & - & - & 0.019 & $<0.01$ & - \\
\hline 60.08 & $<0.04$ & - & $(0.04$ & $<0.0001$ & $<0.05$ & - & - & $<0.01$ \\
\hline- & - & 0.014 & - & - & - & 0.027 & $<0.01$ & - \\
\hline 10.02 & 10.04 & 0.001 & 10.04 & - &.. & 0.019 & $<0.01$ & $<0.01$ \\
\hline$<0.02$ & - & - & $: 0.04$ & $<0.0001$ & $<0.05$ & - & - & 10.01 \\
\hline$\angle 0.08$ & 10.04 & $<0.002$ & $<0.04$ & $<0.0001$ & $<0,03$ & 0.017 & $<0.02$ & $(0.01$ \\
\hline- & - & $<0.002$ & -. & - & - & 0.015 & $(0.01$ & - \\
\hline- & - & 0.002 & - & - & $\cdots$ & 0.02 & $<0.01$ & $\ldots$ \\
\hline - & - & $(0.002$ & - & - & - & 0.023 & $(0.01$ & - \\
\hline .0 .08 & $<0.04$ & $<0.002$ & 10.04 & $<0.0001$ & 10.03 & 0.019 & 0.02 & $(0.01$ \\
\hline- & - & $<0.002$ & - & - & - & 0.019 & $<0.0001$ & $\ldots$ \\
\hline- & - & 0.003 & - & -- & - & 0.02 & 10.02 & - \\
\hline$\ldots$ & - & 0.002 & - & & $\ldots$ & 0.02 & 10.02 & - \\
\hline 0.02 & 0.13 & - & $<0.01$ & - & $\cdots$ & - & - & $\begin{array}{l}W-817-05 \\
<0.01\end{array}$ \\
\hline
\end{tabular}


Table B-2. Wator analyos (ppm) for metaly in ground water amples reported by March 31 , 1990 .

\begin{tabular}{|c|c|c|c|c|c|c|c|}
\hline $\begin{array}{c}\text { Installation } \\
\text { Date } \\
\text { sampled }\end{array}$ & Antimony & Axsentc & Barium & Bery $111 \mathrm{um}$ & Cadmium & $\begin{array}{c}\text { Chromium } \\
\text { tota } 1\end{array}$ & $\begin{array}{c}\text { Chromfum } \\
\text { hexavalent }\end{array}$ \\
\hline \multicolumn{8}{|l|}{$W-817-06 A$} \\
\hline $20-0 \mathrm{CT}-88$ & - & - & - & - & + & - & - \\
\hline \multicolumn{8}{|l|}{$w-819-02$} \\
\hline $13-0 C T-87$ & $<0.001$ & 0.003 & 0.01 & $<0,0001$ & $<0.0001$ & 0.0001 & - \\
\hline $02-F E B-8 B$ & $<0.1$ & 0.002 & $<0.1$ & $<0.0001$ & $<0.01$ & $<0.02$ & - \\
\hline $13-A P R-88$ & $<0.1$ & 0.002 & $<0.1$ & $<0.0001$ & 0.0001 & 0.0004 & -. \\
\hline $29-J \cup L-88$ & $<0.1$ & $<0.002$ & $<0.1$ & $<0.001$ & $<0.0001$ & $<0.0001$ & - \\
\hline $21-0 C T-88$ & - & - & - & - & - & - & - \\
\hline \multicolumn{8}{|l|}{$w-829-08$} \\
\hline $08-D E C-87$ & - & - & - & - & - & - & - \\
\hline $25-0 C T-88$ & - & - & - & - & - & - & - \\
\hline \multicolumn{8}{|l|}{$w-35 c-02$} \\
\hline $12-J A N-89$ & - & - & - & - & - & - & - \\
\hline $09-F E B-89$ & - & $<0.002$ & $<0.5$ & - & $<0.0001$ & 0.003 & - \\
\hline $10-F E B-89$ & - & - & - & - & - & - & - \\
\hline \multicolumn{8}{|l|}{$W-6 C D$} \\
\hline $11-$ NOV -88 & - & - & - & - & - & - & - \\
\hline \multicolumn{8}{|l|}{$W-6 \mathrm{CI}$} \\
\hline $11-\operatorname{NOV}-88$ & - & - & - & - & - & $\cdots$ & - \\
\hline . & & & & & & & \\
\hline
\end{tabular}




\begin{tabular}{|c|c|c|c|c|c|c|c|c|}
\hline COpper & Iron & Lead & Manganese & Mercury & $N i c k \in 1$ & Selontum & st1ver & $\begin{array}{l}\text { Installation } \\
\text { zinc }\end{array}$ \\
\hline$<0.08$ & 0.15 & - & 0.05 & - & - & - & - & $\begin{array}{l}W-817-06 A \\
0.02\end{array}$ \\
\hline $\begin{array}{l}0.0069 \\
<0.02 \\
<0.02 \\
<0.02 \\
10.02\end{array}$ & $\begin{array}{r}0.17 \\
0.0 .03 \\
<0.03 \\
<0.03\end{array}$ & $\begin{array}{l}<0.001 \\
<0.001 \\
0.004 \\
0.003 \\
-\end{array}$ & $\begin{array}{l}0.01 \\
0.02 \\
<0.01 \\
<0.01 \\
<0.01\end{array}$ & $\begin{array}{r}0.0002 \\
<0.0001 \\
0.0002 \\
<0.0001 \\
-\end{array}$ & $\begin{array}{l}<0.001 \\
<0.05 \\
<0.05 \\
<0.05 \\
-\end{array}$ & $\begin{array}{l}<0.001 \\
<0.001 \\
<0.001 \\
<0.001 \\
-\end{array}$ & $\begin{array}{l}0.0006 \\
<0.01 \\
<0.01 \\
<0.01 \\
-\end{array}$ & $\begin{array}{l}w-819-02 \\
<0.01 \\
<0.01 \\
<0.01 \\
0.05 \\
<0.01\end{array}$ \\
\hline $\begin{array}{l}<0.02 \\
<0.02\end{array}$ & $\begin{array}{l}1.5 \\
0.15\end{array}$ & - & $\begin{array}{r}0.02 \\
\langle 3.01\end{array}$ & - & - & - & - & $\begin{array}{l}w-829-08 \\
<0.01 \\
0.06\end{array}$ \\
\hline $\begin{array}{c}<0.02 \\
- \\
<0.02\end{array}$ & $\begin{array}{c}0.05 \\
- \\
1.3\end{array}$ & 0.01 & $\begin{array}{l}0.18 \\
- \\
0.06\end{array}$ & $<0.0001$ & $\begin{array}{l}- \\
- \\
-\end{array}$ & $<0.004$ & 60.0005 & $\begin{array}{l}W-35 C-02 \\
0.01 \\
0.07\end{array}$ \\
\hline$<0.08$ & 0.48 & - & $<0.04$ & - & - & - & - & $0.05^{W-G C D}$ \\
\hline 60.08 & $<0.04$ & $\cdots$ & $\therefore .04$ & - & $\cdots$ & - & - & $0.07^{W-6 C I}$ \\
\hline
\end{tabular}

Notes:

- Indicates no analygis performed for this compound. 
Table B-3. Ground water analyses (ug/L) for volatile orgando compollnde tepoted by March 31,1990 .

\begin{tabular}{|c|c|c|c|c|c|c|c|c|c|c|}
\hline $\begin{array}{l}\text { We } 11 \\
\text { Date }\end{array}$ & Notes & $\begin{array}{l}1,1 \\
D C E\end{array}$ & $\begin{array}{c}T \circ t: 1 \\
1,2 \\
D C E\end{array}$ & TCE & PCE & $\begin{array}{l}1,1 \\
D C A\end{array}$ & $\begin{array}{l}1,2 \\
D C A\end{array}$ & $\begin{array}{c}1,1,1 \\
\text { TCA }\end{array}$ & $\begin{array}{l}\text { Chloro- } \\
\text { form }\end{array}$ & $\begin{array}{l}\text { Freon } \\
113\end{array}$ \\
\hline \multicolumn{11}{|l|}{$W-806-06 \mathrm{~A}$} \\
\hline $10-F E B-87$ & & $<1$ & $<1$ & $<1$ & ৫ & $<1$ & $<1$ & $<1$ & $<1$ & - \\
\hline $22-M A Y-87$ & & $<1$ & $<1$ & $<1$ & $<1$ & $<1$ & $<1$ & $<1$ & $<1$ & - \\
\hline $30-J U N-87$ & & $<1$ & $<1$ & $<1$ & $<1$ & $<1$ & $<1$ & $<1$ & 1 & - \\
\hline $1 B-A \cup G-A 7$ & & $<0.5$ & $<0.5$ & $<0.5$ & $<0.5$ & $<0.5$ & $<0.5$ & $<0.5$ & $<0.5$ & $<0.5$ \\
\hline $18-A \cup G-87$ & & $<1$ & $<1$ & $<1$ & $<1$ & $<1$ & $<1$ & 1 & $<1$ & - \\
\hline $23-0 \mathrm{CT}-87$ & & $<1$ & $<1$ & $<1$ & $<1$ & $<1$ & $<1$ & $<1$ & $<1$ & - \\
\hline $29-J A N-88$ & & $<1$ & $<1$ & $<1$ & $<1$ & $<1$ & $<1$ & $<1$ & $<1$ & - \\
\hline $06-M A Y-88$ & & $<1$ & $<1$ & $<1$ & $<1$ & $<1$ & $<1$ & $<1$ & $<1$ & - \\
\hline $23-J \cup N-88$ & & $<0.5$ & $<0.5$ & $<0.5$ & $<0.5$ & $<0.5$ & $<0.5$ & $<0,5$ & $<0.5$ & $<0.5$ \\
\hline $02-A \cup G-8 B$ & & $<1$ & $<1$ & $<1$ & $<1$ & $<1$ & $<1$ & $<1$ & $<1$ & - \\
\hline $24-0 C T-8 B$ & & $<0.5$ & $<0,5$ & $<0.5$ & $<0.5$ & $<0.5$ & $<0.5$ & $<0.5$ & $<0.5$ & $<0.5$ \\
\hline $19-0 \mathrm{CT}-89$ & & $<0.5$ & $<0.5$ & $<0.5$ & $<0.5$ & $<0.5$ & $<0.5$ & $<0.5$ & $<0.5$ & $<0.5$ \\
\hline $12-J A N-90$ & & $<0.5$ & $<0.5$ & $<0.5$ & $<0,5$ & $<0.5$ & $<0.5$ & $<0.5$ & $<0.5$ & $<0.5$ \\
\hline \multicolumn{11}{|l|}{$w-809-01$} \\
\hline $08-$ MAR -88 & & $<0.5$ & $<0.5$ & $<0.5$ & $<0.5$ & $<0,5$ & $<0.5$ & $<0.5$ & $<0,5$ & $<0.5$ \\
\hline $02-M A Y-88$ & & 0.6 & $<0.5$ & 1. $\epsilon$ & $<0.5$ & $<0.5$ & $<0.5$ & $<0.5$ & 2.7 & $<0.5$ \\
\hline $22-J \cup N-88$ & & 1.3 & $<0.5$ & 2.4 & $<0.5$ & $<0.5$ & $<0.5$ & $<0.5$ & 2.9 & $<0.5$ \\
\hline $20-0 C T-8 B$ & & 1.6 & $<0.5$ & 3.3 & $<0.5$ & $<0.5$ & $<0.5$ & 10.5 & 3.5 & $<0,5$ \\
\hline $07-F E B-89$ & & 1.3 & $<0.5$ & 3.6 & $<0.5$ & $<0.5$ & $<0.5$ & $<0.5$ & 3.6 & $<0,5$ \\
\hline $11-A P R-89$ & & 0.9 & $<0.5$ & 3.1 & $<0.5$ & $<0.5$ & $<0.5$ & $<0.5$ & 2.9 & $<0,5$ \\
\hline $12-J \cup L-89$ & & 1.4 & $<0.5$ & 4.4 & $<0.5$ & $<0.5$ & $<0.5$ & $<0.5$ & 4.3 & $<0.5$ \\
\hline $18-0 C T-89$ & & $<0.5$ & $<0.5$ & 4.3 & $<0.5$ & $<0.5$ & $<0.5$ & $<0.5$ & 3 & $<0.5$ \\
\hline $16-J A N-90$ & & $<0.5$ & $<0.5$ & 4.7 & $<0.5$ & $<0.5$ & $<0.5$ & 10.5 & 3.8 & $<0,5$ \\
\hline \multicolumn{11}{|l|}{$w-809-02$} \\
\hline $21-A P R-88$ & & $<0.5$ & $<0.5$ & $<0.5$ & $<0.5$ & $<0.5$ & $<0.5$ & $<0.5$ & $<0.5$ & $<0.5$ \\
\hline $22-J \cup N-88$ & $n$ & $<0.5$ & $<0.5$ & $<0.5$ & $<0.5$ & $<0.5$ & $<0.5$ & $<0.5$ & $<0.5$ & 0.5 \\
\hline $20-0 C T-88$ & & $<0,5$ & $<0.5$ & $<0.5$ & $<0.5$ & $<0.5$ & $<0.5$ & $<0.5$ & $<0.5$ & $<0.5$ \\
\hline $07-F E B-89$ & & $<0.5$ & $<0.5$ & $<0.5$ & $<0.5$ & $<0.5$ & $<0.5$ & $<0.5$ & $<0.5$ & $<0.5$ \\
\hline $10-A P R-89$ & & $<0.5$ & $<0.5$ & $<0.5$ & $<0.5$ & $<0.5$ & $<0.5$ & $<0.5$ & $<0.5$ & $<0.5$ \\
\hline $12-J \cup L-89$ & & $<0.5$ & $<0.5$ & $<0.5$ & $<0.5$ & $<0.5$ & $<0.5$ & $<0.5$ & $<0.5$ & $<0.5$ \\
\hline $18-0 C T-89$ & & $<0.5$ & $<0.5$ & $<0.5$ & $<0.5$ & $<0.5$ & $<0.5$ & $<0.5$ & $<0.5$ & $<0.5$ \\
\hline $16-J A N-90$ & & $<0.5$ & $<0.5$ & $<0.5$ & $<0.5$ & $<0.5$ & $<0.5$ & $<0.5$ & $<0.5$ & $<0.5$ \\
\hline \multicolumn{11}{|l|}{$w-809-03$} \\
\hline $16-O C T-89$ & & $<1$ & $<1$ & $<1$ & $<1$ & $<1$ & $<1$ & $<1$ & $<1$ & $<1$ \\
\hline $16-J A N-90$ & & $<0.5$ & $<0.5$ & $<0.5$ & $<0.5$ & $<0.5$ & $<0.5$ & $<0,5$ & $<0.5$ & $<0.5$ \\
\hline \multicolumn{11}{|l|}{$w-810-01$} \\
\hline $01-M A R-88$ & & $<0.5$ & $<0.5$ & $<0.5$ & $<0.5$ & $<0.5$ & $<0.5$ & $<0.5$ & $<0.5$ & $<0.5$ \\
\hline $23-J \cup N-88$ & & $<0.5$ & $<0.5$ & $<0.5$ & $<0.5$ & $<0.5$ & $<0.5$ & 1.3 & $<0,5$ & $<0.5$ \\
\hline $21-0 C T-88$ & & $<0.5$ & $<0.5$ & $<0.5$ & $<0.5$ & $<0.5$ & $<0.5$ & $<0.5$ & $<0.5$ & $<0.5$ \\
\hline $07-F E B-89$ & & $<0.5$ & $<0.5$ & $<0.5$ & $<0.5$ & $<0.5$ & $<0.5$ & $<0.5$ & $<0.5$ & $<0.5$ \\
\hline $11-A P R-89$ & & $<0.5$ & $<0.5$ & $<0.5$ & $<0.5$ & $<0.5$ & $<0.5$ & $<0.5$ & $<0.5$ & $<0.5$ \\
\hline $14-J \cup L-89$ & & $<0.5$ & $<0.5$ & $<0.5$ & $<0.5$ & $<0.5$ & $<0.5$ & $<0.5$ & $<0.5$ & $<0.5$ \\
\hline $19-0 \mathrm{CT}-89$ & & $<0.5$ & $<0.5$ & $<0.5$ & $<0.5$ & $<0.5$ & $<0.5$ & $<0.5$ & $<0.5$ & $<0.5$ \\
\hline $18-J A N-90$ & & $<0.5$ & $<0,5$ & $<0.5$ & $<0.5$ & $<0.5$ & $<0.5$ & $<0.5$ & $<0.5$ & $<0.5$ \\
\hline \multicolumn{11}{|l|}{$w-814-01$} \\
\hline $18-M A Y-87$ & & $<0.5$ & 1.3 & 1.2 & $<0.5$ & $<0.5$ & 0.7 & $<0.5$ & 0.6 & $<0.5$ \\
\hline $24-5 E P-87$ & & $<0.5$ & 0.6 & 2 & $<0.5$ & $<0.5$ & $<0.5$ & $<0.5$ & 1.2 & $<0.5$ \\
\hline $11-D E C-87$ & & $<0.5$ & 1.3 & 2.2 & $<0.5$ & $<0.5$ & 0.9 & $<0.5$ & 0.5 & 1.8 \\
\hline $10-M A R-8 B$ & & $<0.5$ & 1.7 & 1.3 & $<0.5$ & $<0.5$ & 0.6 & $<0.5$ & 1 & $<0.5$ \\
\hline $20-J U N-88$ & & $<0.5$ & 1.2 & 1.5 & $<0.5$ & $<0.5$ & 0.5 & $<0.5$ & 0.5 & $<0.5$ \\
\hline $13-A P R-89$ & & $<0.5$ & 1.5 & 2.3 & $<0.5$ & $<0.5$ & 0.8 & $<0.5$ & 1.3 & $<0.5$ \\
\hline $19-J \cup L-89$ & & $<0.5$ & 1.8 & 2.6 & $<0.5$ & $<0.5$ & 0.1 & $<0.5$ & 1.5 & $<0.5$ \\
\hline $10-0 \mathrm{CT}-89$ & & $<0.5$ & 0.5 & 1.5 & $<0.5$ & $<0.5$ & $<0.5$ & $<0.5$ & 0.5 & $<0.5$ \\
\hline $17-J A N-90$ & & $<0.5$ & $<0.5$ & $<0.5$ & $(0.5$ & $<0.5$ & $<0.5$ & 0.5 & $<0.5$ & $<0.5$ \\
\hline \multicolumn{11}{|l|}{$w-815-01$} \\
\hline $23-A P R-87$ & $\mathbf{f}$ & $<2.5$ & $<2,5$ & 280 & $<2.5$ & $(2.5$ & $<2.5$ & $<2.5$ & $<2.5$ & $<2.5$ \\
\hline $01-M A Y-87$ & $\mathbf{f}$ & $<5$ & $<5$ & 140 & $<5$ & $<5$ & $<5$ & $<5$ & $<5$ & $<5$ \\
\hline $13-M A Y-87$ & f & $? .7$ & $<1$ & 130 & $<1$ & $<1$ & $<1$ & $<1$ & 1 & $<1$ \\
\hline
\end{tabular}


Table B-3. Ground water analyan (ug/L) for volatile otgante compollnda repoted by March 31,1990 .

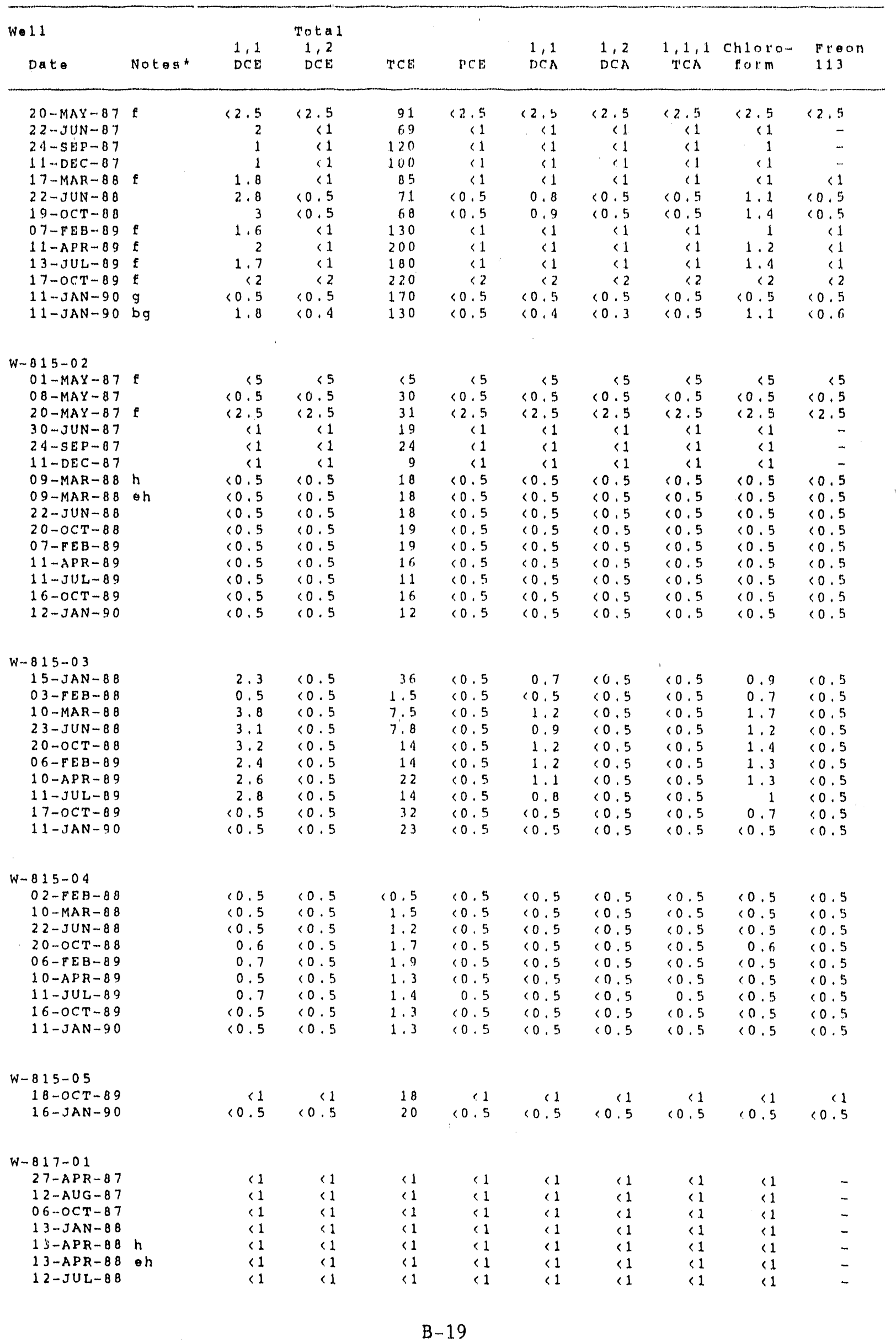


Table B-3. Ground water analyses (ug/L) for volatile organic compounds reported by March 31,1990 .

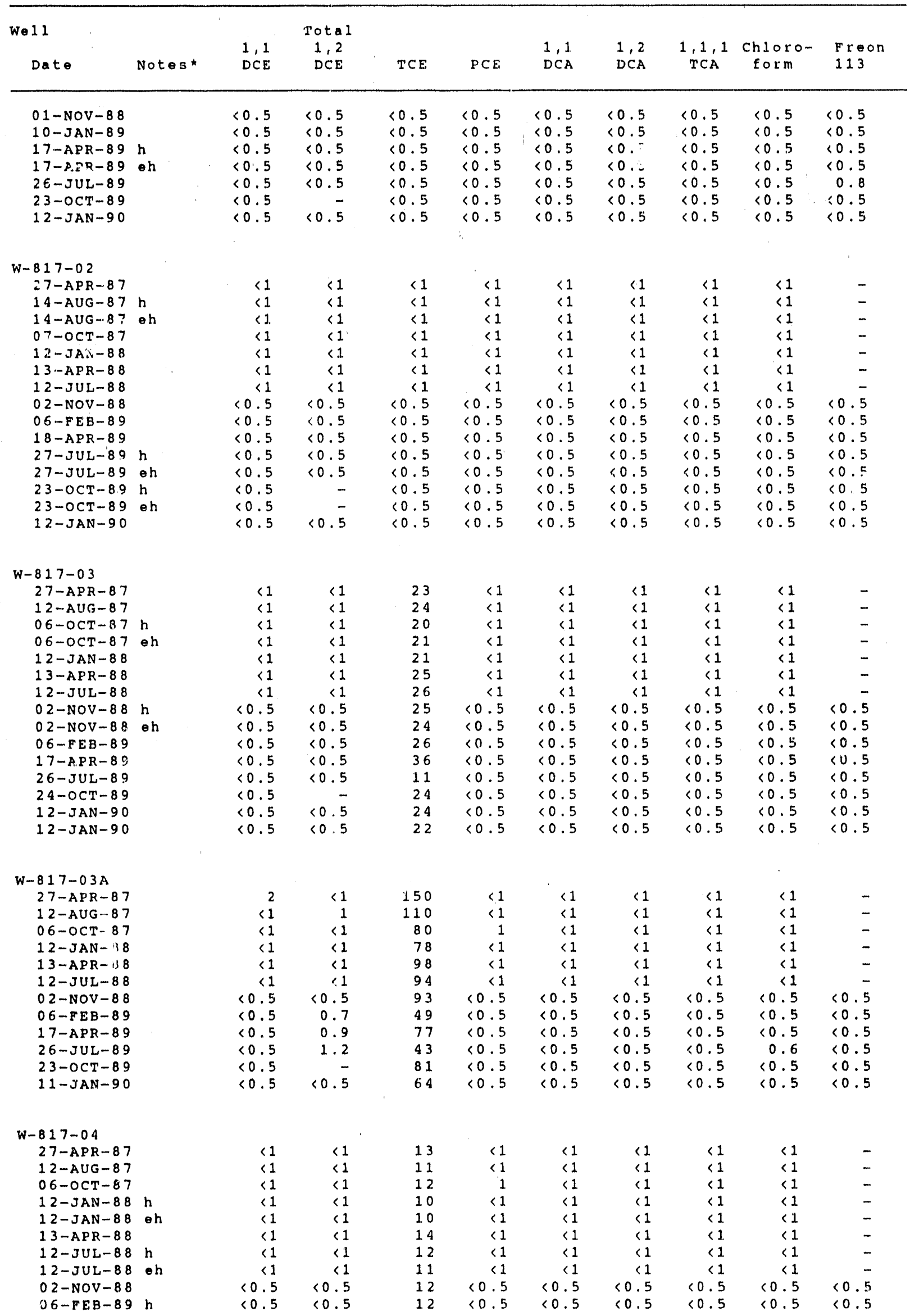


Table B-3. Ground water analyses (ug/L) for volatile organic compounds reported by March 31,1990 .

\begin{tabular}{|c|c|c|c|c|c|c|c|c|c|c|}
\hline we 11 & & & Total & & ' & & & & $\because$ & \\
\hline Date & Noteg* & $\begin{array}{l}1,1 \\
\mathrm{DCE}\end{array}$ & $\begin{array}{l}1,2 \\
D C E\end{array}$ & TCE & $P C E$ & $\begin{array}{l}1,1 \\
D C A\end{array}$ & $\begin{array}{l}1,2 \\
D C A\end{array}$ & $\begin{array}{l}1,1,1 \\
\text { TCA }\end{array}$ & $\begin{array}{l}\text { Chloro- } \\
\text { form }\end{array}$ & $\begin{array}{l}\text { Freon } \\
113\end{array}$ \\
\hline $\begin{array}{l}06-F E B-89 \\
18-A P R-89 \\
27-J U L-89 \\
23-O C T-89 \\
12-J A N-90\end{array}$ & oh & $\begin{array}{l}<0.5 \\
<0.5 \\
<0.5 \\
<0.5 \\
<0.5\end{array}$ & $\begin{array}{r}<0.5 \\
<0.5 \\
<0.5 \\
<0.5\end{array}$ & $\begin{array}{r}15 \\
12 \\
2.5 \\
11 \\
10\end{array}$ & $\begin{array}{l}<0.5 \\
<0.5 \\
<0.5 \\
<0.5 \\
<0.5\end{array}$ & $\begin{array}{l}<0.5 \\
<0.5 \\
<0.5 \\
<0.5 \\
<0.5\end{array}$ & $\begin{array}{l}<0.5 \\
<0.5 \\
<0.5 \\
<0.5 \\
<0.5\end{array}$ & $\begin{array}{l}<0.5 \\
<0.5 \\
<0.5 \\
<0.5 \\
<0.5\end{array}$ & $\begin{array}{r}0.8 \\
<0.5 \\
2.8 \\
<0.5 \\
<0.5\end{array}$ & $\begin{array}{l}<0.5 \\
<0.5 \\
<0.5 \\
<0.5 \\
<0.5\end{array}$ \\
\hline $\begin{array}{l}W-817-0 S \\
19-M A Y-88 \\
25-O C T-88 \\
09-F E B-89 \\
14-A P R-89 \\
14-J U L-89 \\
26-O C T-89 \\
12-J A N-90\end{array}$ & & $\begin{array}{l}<0.5 \\
<0.5 \\
<0.5 \\
<0.5 \\
<0.5 \\
<0.5 \\
<0.5\end{array}$ & $\begin{array}{l}<0.5 \\
<0.5 \\
<0.5 \\
<0.5 \\
<0.5 \\
<0.5 \\
<0.5\end{array}$ & $\begin{array}{l}<0.5 \\
<0.5 \\
<0.5 \\
<0.5 \\
<0.5 \\
<0.5 \\
<0.5\end{array}$ & $\begin{array}{l}<0.5 \\
<0.5 \\
<0.5 \\
<0.5 \\
<0.5 \\
<0.5 \\
<0.5\end{array}$ & $\begin{array}{l}<0.5 \\
<0.5 \\
<0.5 \\
<0.5 \\
<0.5 \\
<0.5 \\
<0.5\end{array}$ & $\begin{array}{l}<0.5 \\
<0.5 \\
<0.5 \\
<0.5 \\
<0.5 \\
<0.5 \\
<0.5\end{array}$ & $\begin{array}{r}<0.5 \\
<0.5 \\
<0.5 \\
<0.5 \\
1.3 \\
<0.5 \\
<0.5\end{array}$ & $\begin{array}{l}<0.5 \\
<0.5 \\
<0.5 \\
<0.5 \\
<0.5 \\
<0.5 \\
<0.5\end{array}$ & $\begin{array}{l}<0.5 \\
<0.5 \\
<0.5 \\
<0.5 \\
<0.5 \\
<0.5 \\
<0.5\end{array}$ \\
\hline $\begin{array}{l}W-817-06 A \\
08-J U N-88 \\
24-J U N-88 \\
20-O C T-88 \\
10-F E B-89 \\
14-A P R-89 \\
13-J U L-89 \\
27-O C T-89 \\
16-J A N-90\end{array}$ & & $\begin{array}{l}<0.5 \\
<0.5 \\
<0.5 \\
<0.5 \\
<0.5 \\
<0.5 \\
<0.5 \\
<0.5\end{array}$ & $\begin{array}{l}<0.5 \\
<0.5 \\
<0.5 \\
<0.5 \\
<0.5 \\
<0.5 \\
<0.5 \\
<0.5\end{array}$ & $\begin{array}{l}<0.5 \\
<0.5 \\
<0.5 \\
<0.5 \\
<0.5 \\
<0.5 \\
<0.5 \\
<0.5\end{array}$ & $\begin{array}{l}<0.5 \\
<0.5 \\
<0.5 \\
<0.5 \\
<0.5 \\
<0.5 \\
<0.5 \\
<0.5\end{array}$ & $\begin{array}{l}<0.5 \\
<0.5 \\
<0.5 \\
<0.5 \\
<0.5 \\
<0.5 \\
<0.5 \\
<0.5\end{array}$ & $\begin{array}{l}<0.5 \\
<0.5 \\
<0.5 \\
<0.5 \\
<0.5 \\
<0.5 \\
<0.5 \\
<0.5\end{array}$ & $\begin{array}{l}<0.5 \\
<0.5 \\
<0.5 \\
<0.5 \\
<0.5 \\
<0.5 \\
<0.5 \\
<0.5\end{array}$ & $\begin{array}{l}<0.5 \\
<0.5 \\
<0.5 \\
<0.5 \\
<0.5 \\
<0.5 \\
<0.5 \\
<0.5\end{array}$ & $\begin{array}{l}<0.5 \\
<0.5 \\
<0.5 \\
<0.5 \\
<0.5 \\
<0.5 \\
<0.5 \\
<0.5\end{array}$ \\
\hline $\begin{array}{l}\text { W- } 819-02 \\
19-D E C-86 \\
06-A P R-87 \\
30-J U N-87 \\
14-A U G-87 \\
14-A U G-87 \\
13-O C T-87 \\
02-F E B-88 \\
13-A P R-88 \\
24-J U N-88 \\
29-J U L-88 \\
21-O C T-88 \\
10-F E B-89 \\
12-A P R-89 \\
18-J U L-89 \\
10-O C T-89 \\
17-J A N-90 \\
14-F E B-90 \\
14-F E B-90\end{array}$ & 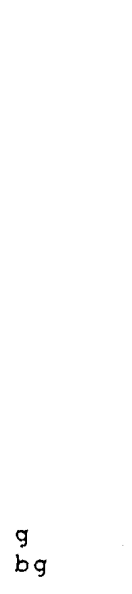 & $\begin{array}{r}<0.5 \\
<1 \\
<1 \\
<0.5 \\
<1 \\
<1 \\
<1 \\
<1 \\
<0.5 \\
<1 \\
<0.5 \\
<0.5 \\
<0.5 \\
<0.5 \\
<0.5 \\
<0.5 \\
<0.5 \\
<0.2\end{array}$ & $\begin{array}{r}<0.5 \\
<1 \\
<1 \\
<0.5 \\
<1 \\
<1 \\
<1 \\
<1 \\
<0.5 \\
<1 \\
<0.5 \\
<0.5 \\
<0.5 \\
<0.5 \\
<0.5 \\
<0.5 \\
<0.5 \\
<0.4\end{array}$ & $\begin{array}{r}<0.5 \\
<1 \\
<1 \\
<u .3 \\
<1 \\
<1 \\
<1 \\
<1 \\
<0.5 \\
<1 \\
<0.5 \\
<0.5 \\
<0.5 \\
<0.5 \\
<0.5 \\
0.9 \\
<0.5 \\
<0.3\end{array}$ & $\begin{array}{r}<0.5 \\
<1 \\
.1 \\
<0.5 \\
<1 \\
<1 \\
<1 \\
<1 \\
<0.5 \\
<1 \\
<0.5 \\
<0.5 \\
<0.5 \\
<0.5 \\
<0.5 \\
<0.5 \\
<0.5 \\
<0.5\end{array}$ & $\begin{array}{r}<0.5 \\
<1 \\
<1 \\
<0.5 \\
<1 \\
<1 \\
<1 \\
<1 \\
<0.5 \\
<1 \\
<0.5 \\
<0.5 \\
<0.5 \\
<0.5 \\
<0.5 \\
<0.5 \\
<0.5 \\
<0.4\end{array}$ & $\begin{array}{r}<0.5 \\
<1 \\
<1 \\
<0.5 \\
<1 \\
<1 \\
<1 \\
<1 \\
<0.5 \\
<1 \\
<0.5 \\
<0.5 \\
<0.5 \\
<0.5 \\
<0.5 \\
<0.5 \\
<0.5 \\
<0.3\end{array}$ & $\begin{array}{r}<0.5 \\
<1 \\
<1 \\
<0.5 \\
<1 \\
<1 \\
<1 \\
<1 \\
<0.5 \\
<1 \\
<0.5 \\
<0.5 \\
<0.5 \\
<0.5 \\
<0.5 \\
<0.5 \\
<0.5 \\
<0.5\end{array}$ & $\begin{array}{r}<0.5 \\
<1 \\
<1 \\
<0.5 \\
<1 \\
<1 \\
<1 \\
<1 \\
<0.5 \\
<1 \\
<0.5 \\
<0.5 \\
<0.5 \\
<0.5 \\
<0.5 \\
<0.5 \\
<0.5 \\
<0.5\end{array}$ & $\begin{array}{r}<0.5 \\
-5 \\
<0.5 \\
- \\
- \\
- \\
- \\
<0.5 \\
<0.5 \\
<0.5 \\
<0.5 \\
<0.5 \\
<0.5 \\
<0.5 \\
<0.5 \\
<0.6\end{array}$ \\
\hline $\begin{array}{r}\text { W- } 829-08 \\
22-A P R-87 \\
08-D E C-87 \\
14-M A R-88 \\
27-J U N-88 \\
25-O C T-88 \\
10-F E B-89 \\
12-A P R-89 \\
13-J U L-89 \\
12-O C T-89 \\
18-J A N-90\end{array}$ & & $\begin{array}{r}<0.5 \\
<1 \\
<0.5 \\
<0.5 \\
<0.5 \\
<0.5 \\
<0.5 \\
<0.5 \\
<0.5 \\
<0.5\end{array}$ & $\begin{array}{r}<0.5 \\
<1 \\
<0.5 \\
<0.5 \\
<0.5 \\
<0.5 \\
<0.5 \\
<0.5 \\
<0.5 \\
<0.5\end{array}$ & $\begin{array}{r}5.2 \\
<1 \\
5.4 \\
2.1 \\
4.5 \\
<0.5 \\
3.4 \\
5.8 \\
4.9 \\
4.2\end{array}$ & $\begin{array}{r}<0.5 \\
<1 \\
<0.5 \\
<0.5 \\
<0.5 \\
<0.5 \\
<0.5 \\
<0.5 \\
<0.5 \\
<0.5\end{array}$ & $\begin{array}{r}<0.5 \\
<1 \\
<0.5 \\
<0.5 \\
<0.5 \\
<0.5 \\
<0.5 \\
<0.5 \\
<0.5 \\
<0.5\end{array}$ & $\begin{array}{r}<0.5 \\
<1 \\
<0.5 \\
<0.5 \\
<0.5 \\
<0.5 \\
<0.5 \\
<0.5 \\
<0.5 \\
<0.5\end{array}$ & $\begin{array}{r}<0.5 \\
<1 \\
<0.5 \\
<0.5 \\
<0.5 \\
<0.5 \\
<0.5 \\
<0.5 \\
<0.5 \\
<0.5\end{array}$ & $\begin{array}{r}<0.5 \\
<1 \\
<0.5 \\
<0.5 \\
<0.5 \\
<0.5 \\
<0.5 \\
<0.5 \\
<0.5 \\
<0.5\end{array}$ & $\begin{array}{r}1.2 \\
0.5 \\
1.9 \\
<0.5 \\
<0.5 \\
<0.5 \\
<0.5 \\
<0.5 \\
<0.5\end{array}$ \\
\hline $\begin{array}{l}\text { SPRING } 823 \\
23-O C T-87 \\
16-N O V-87\end{array}$ & $\mathrm{f}$ & $\begin{array}{r}<10 \\
<0.5\end{array}$ & $\begin{array}{r}810 \\
<0.5\end{array}$ & $\begin{array}{r}<10 \\
<0.5\end{array}$ & $\begin{array}{r}10 \\
0.5\end{array}$ & $\begin{array}{r}10 \\
<0.5\end{array}$ & $\begin{array}{r}<10 \\
0.5\end{array}$ & $\begin{array}{r}<10 \\
<0.5\end{array}$ & $\begin{array}{r}<10 \\
<0.5\end{array}$ & $<0.5$ \\
\hline $\begin{array}{l}W-6 C D \\
15-M A Y-87 \\
20-M A Y-87 \\
23-J U N-87\end{array}$ & & $\begin{array}{r}<1 \\
0.5 \\
<1\end{array}$ & $\begin{array}{r}<1 \\
<0,5 \\
<1\end{array}$ & $\begin{array}{r}2.5 \\
0.5 \\
.1\end{array}$ & $\begin{array}{r}<1 \\
<0.5 \\
<1\end{array}$ & $\begin{array}{r}41 \\
<0.5 \\
<1\end{array}$ & $\begin{array}{r}<1 \\
<0.5 \\
<1\end{array}$ & $\begin{array}{r}<1 \\
<0<5 \\
<1\end{array}$ & $\begin{array}{r}<1 \\
<0.5 \\
<1\end{array}$ & $\begin{array}{r}<1 \\
<0.5 \\
-\end{array}$ \\
\hline
\end{tabular}


Table B-3. Ground water analyseg (ug/L) for volatile organir compounds reported by March 31,1990 .

\begin{tabular}{|c|c|c|c|c|c|c|c|c|c|c|}
\hline \multicolumn{2}{|l|}{ Wa 11} & \multicolumn{3}{|c|}{ Total } & & \multirow[b]{2}{*}{$\begin{array}{l}1,1 \\
D C A\end{array}$} & \multirow[b]{2}{*}{$\begin{array}{l}1,2 \\
D C A\end{array}$} & \multirow[b]{2}{*}{$\begin{array}{l}1,1,1 \\
\mathrm{TCA}\end{array}$} & \multirow[b]{2}{*}{$\begin{array}{l}\text { Chloro- } \\
\text { form }\end{array}$} & \multirow[b]{2}{*}{$\begin{array}{l}\text { Freon } \\
113\end{array}$} \\
\hline Date & Notes* & $\begin{array}{l}1,1 \\
D C E\end{array}$ & $\begin{array}{l}1,2 \\
D C E\end{array}$ & TCE & PCE & & & & & \\
\hline $24-$ SEP -87 & & $<1$. & $<1$ & $<1$ & $<1$ & $<1$ & $<1$ & $<1$ & $<1$ & - \\
\hline $11-D E C-87$ & & $<0.5$ & $<0.5$ & 0.5 & $<0.5$ & $<0.5$ & $<0.5$ & $<0.5$ & $<0.5$ & $<0.5$ \\
\hline $10-M A R-88$ & & $<0.5$ & $<0.5$ & $<0.5$ & $<0.5$ & $<0.5$ & $<0.5$ & $<0.5$ & $<0.5$ & $<0.5$ \\
\hline $28-J \cup N-88$ & & $<0.5$ & $<0.5$ & $<0.5$ & 0.5 & $<0.5$ & $<0.5$ & $<0.5$ & $<0.5$ & $<0.5$ \\
\hline $11-\mathrm{NOV}-88$ & & $<0.5$ & $<0.5$ & $<0.5$ & $<0.5$ & $<0.5$ & $<0.5$ & $<0.5$ & $<0.5$ & $<0.5$ \\
\hline $14-F E B-89$ & & $<0.5$ & $<0.5$ & $<0.5$ & $<0.5$ & $<0.5$ & $<0.5$ & $<0.5$ & $<0.5$ & $<0.5$ \\
\hline $02-M A Y-89$ & & $<0.5$ & $<0.5$ & $<0.5$ & $<0.5$ & $<0.5$ & $<0.5$ & $<0.5$ & $<0.5$ & 10.5 \\
\hline $07-J \cup L-89$ & & $<0.5$ & $<0.5$ & $<0.5$ & $<0.5$ & $<0.5$ & $<0.5$ & $<0.5$ & $<0.5$ & $<0.5$ \\
\hline $27-0 \mathrm{CT}-89$ & & $<0.5$ & $<0.5$ & $<0.5$ & $<0.5$ & $<0.5$ & $<0.5$ & $<0.5$ & $<0.5$ & $<0.5$ \\
\hline $21-F E B-90$ & & $<0.5$ & $<0.5$ & $<0.5$ & $<0.5$ & $<0.5$ & $<0.5$ & $<0.5$ & $<0.5$ & $<0.5$ \\
\hline \multicolumn{11}{|l|}{$W-6 C I$} \\
\hline $09-M A R-87$ & $\mathbf{f}$ & $<2.5$ & $<2.5$ & $<2.5$ & $<2.5$ & $<2.5$ & $<2.5$ & $<2.5$ & $<2.5$ & $<2.5$ \\
\hline $15-M A Y-87$ & & $<0.5$ & $<0.5$ & 0.8 & $<0.5$ & $<0.5$ & $<0.5$ & $<0.5$ & $<0.5$ & $<0.5$ \\
\hline $20-M A Y-87$ & & $<0.5$ & $<0.5$ & $<0.5$ & $<0.5$ & $<0.5$ & $<0.5$ & $<0.5$ & $<0.5$ & $<0.5$ \\
\hline $23-3 \cup N-87$ & & $<1$ & $<1$ & (1 & $<1$ & $<1$ & $<1$ & $<1$ & $<1$ & - \\
\hline $24-5$ E -87 & & $<1$ & $<1$ & $<1$ & $<1$ & $<1$ & $<1$ & $<1$ & $<1$ & - \\
\hline $11-\mathrm{DEC}-87$ & $f$ & $<1$ & $<1$ & $<1$ & $<1$ & $<1$ & $<1$ & (1) & $<1$ & $<1$ \\
\hline $10-M A R-88$ & & $<0.5$ & $<0.5$ & 0.6 & $<0.5$ & $<0.5$ & $<0.5$ & $<0.5$ & $<0.5$ & $<0.5$ \\
\hline $28-J \cup N-88$ & & $<0.5$ & $<0.5$ & 0.8 & $<0.5$ & $<0.5$ & $<0.5$ & $<0.5$ & $<0 . j$ & $<0.5$ \\
\hline $11-\mathrm{NOV}-8 \mathrm{~B}$ & & $<0.5$ & $<0.5$ & 1.1 & $<0.5$ & $<0.5$ & $<0.5$ & $<0.5$ & $<0.5$ & $<0.5$ \\
\hline $14-F E B-89$ & & 0.5 & $<0.5$ & 1 & $<0.5$ & $<0.5$ & $<0.5$ & $<0.5$ & $<0.5$ & $<0.5$ \\
\hline $02-M A Y-89$ & & $<0.5$ & $<0.5$ & $<0.5$ & $<0.5$ & $<0.5$ & $<0.5$ & $<0.5$ & $<0.5$ & $<0.5$ \\
\hline $07-J \cup L-89$ & & 0.5 & $<0.5$ & $<0.5$ & $<0.5$ & $<0.5$ & $<0.5$ & $<0.5$ & $<0.5$ & $(0.5$ \\
\hline $27-0 C T-89$ & & $<0.5$ & $<0.5$ & $<0.5$ & $<0.5$ & $<0.5$ & $<0.5$ & $(0.5$ & $<0.5$ & $<0.5$ \\
\hline $21-F E B-90$ & & 0.5 & $<0.5$ & $<0.5$ & $<0.5$ & $<0.5$ & $<0.5$ & $<0,5$ & 10.5 & $(0.5$ \\
\hline
\end{tabular}

Notes:

- Indicates no analysis performed for this compound.

* Unless otherwise indicated, all analyses performed by Brown and Caldwell, Emeryvilie, Calif.

a Analysis performed by Mckesson Environmental services, pleasanton, Calif.

b Analysis performed by clayton Environmental Consultants, pleasanton, Calif. (formerly Mckesson Environmental services).

c Analysis performed by Central coast Analytical services, san Luis oblspo, calif.

d Anolysis performed by Brown and Caldwell, pasadena, Calif.

- Blind sample, sent to lab without well identity.

sample dilution necessary for analysis, therefore detection limits inrioasd. Interlaboratory duplicate samplo.

Intralaboratory duplicate sample.

Sample of commorcially bottled drinking water.

Analysis performed by Hazards Control Lab, LLNL.

Analysis performed by Eureka Laboratories Inc., Sacramanto, Calif.

sample taken during hydraulic testing.

Analytical results from this sample are suspect.

sample held longer than 14 days before analysis. 


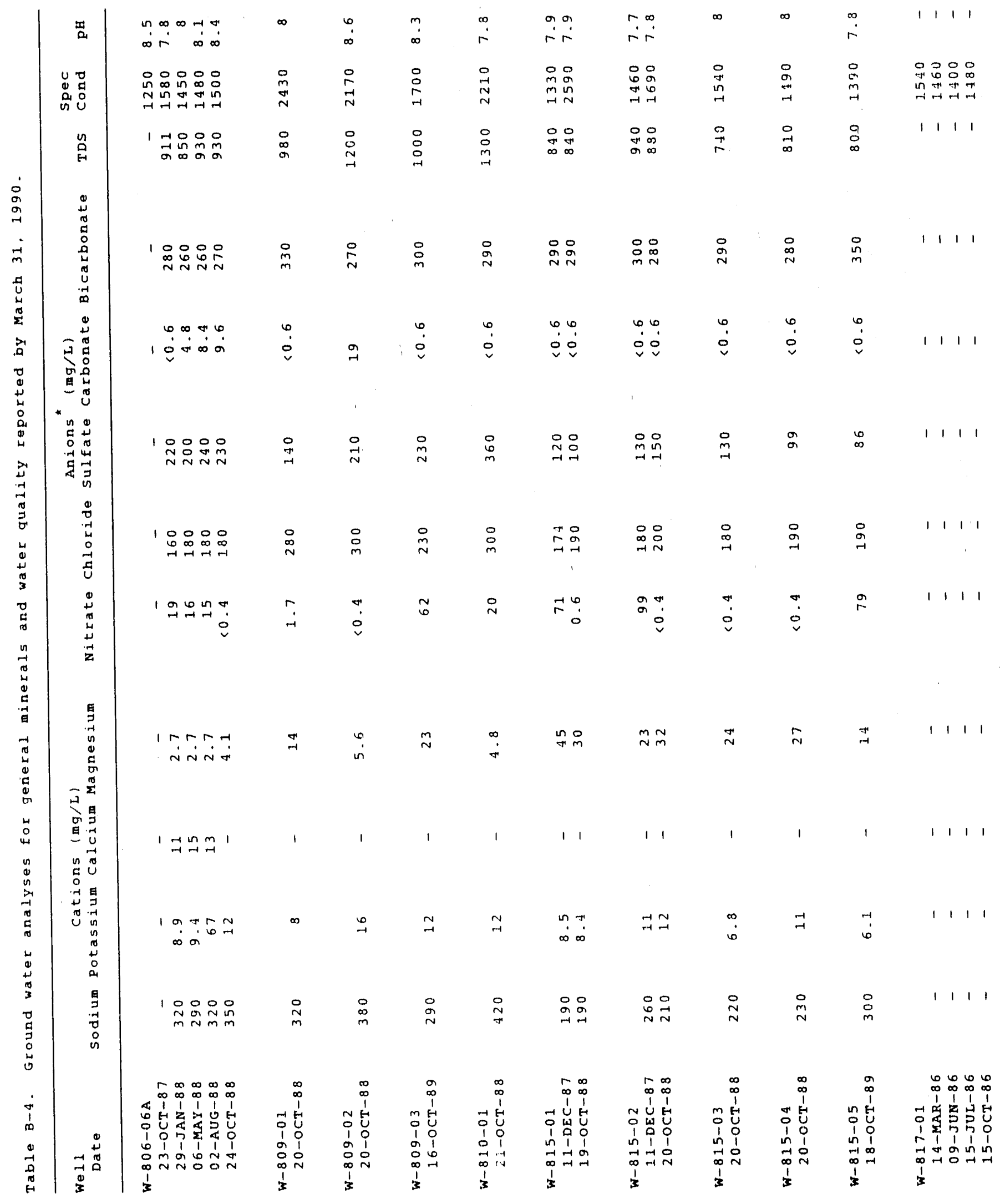




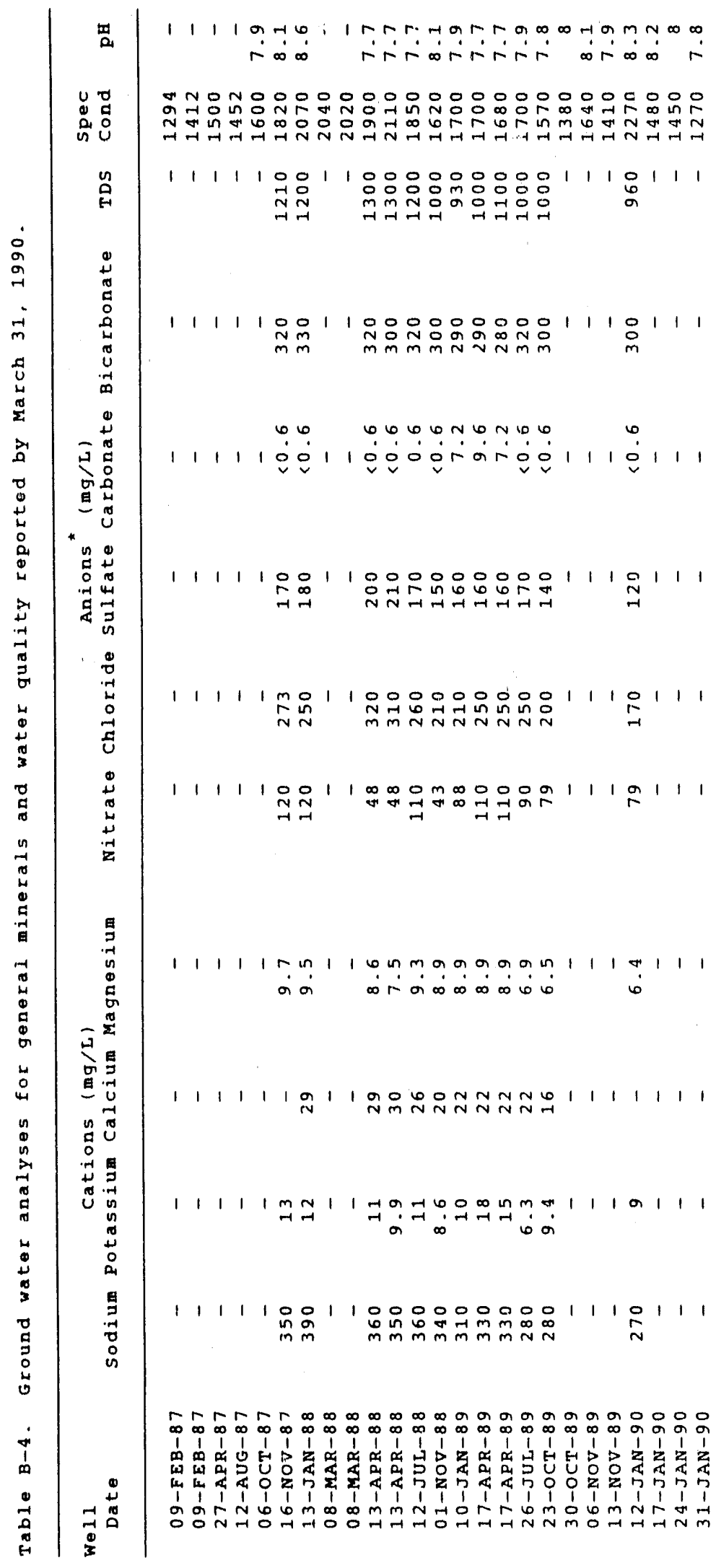

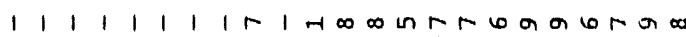

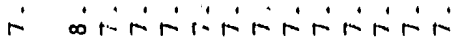

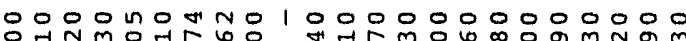
N

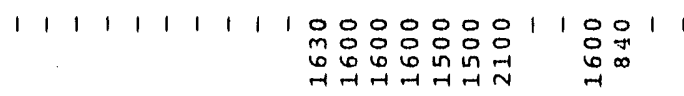

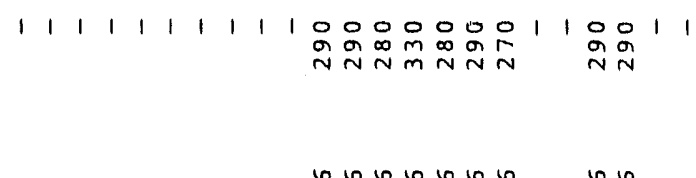

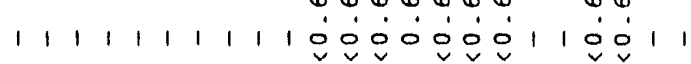

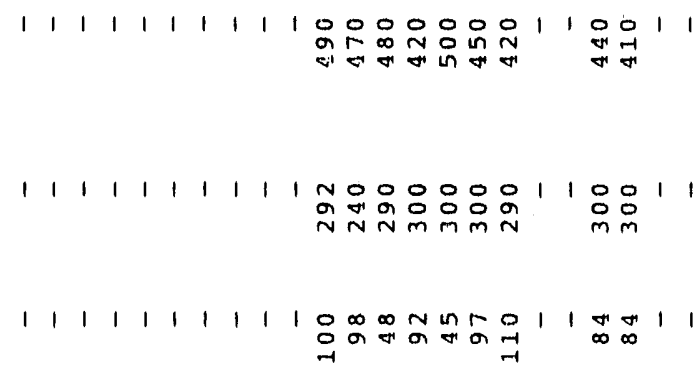

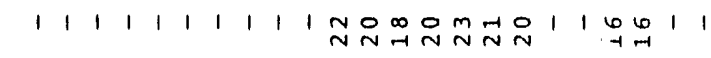

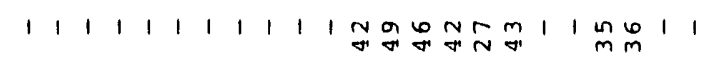

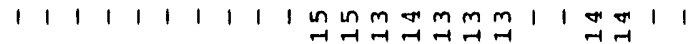

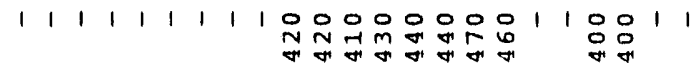

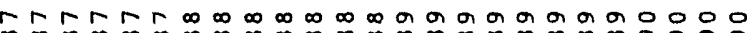

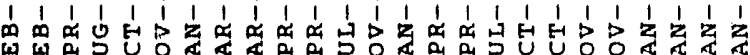

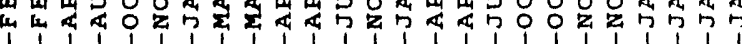

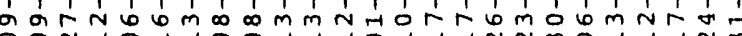

(1)




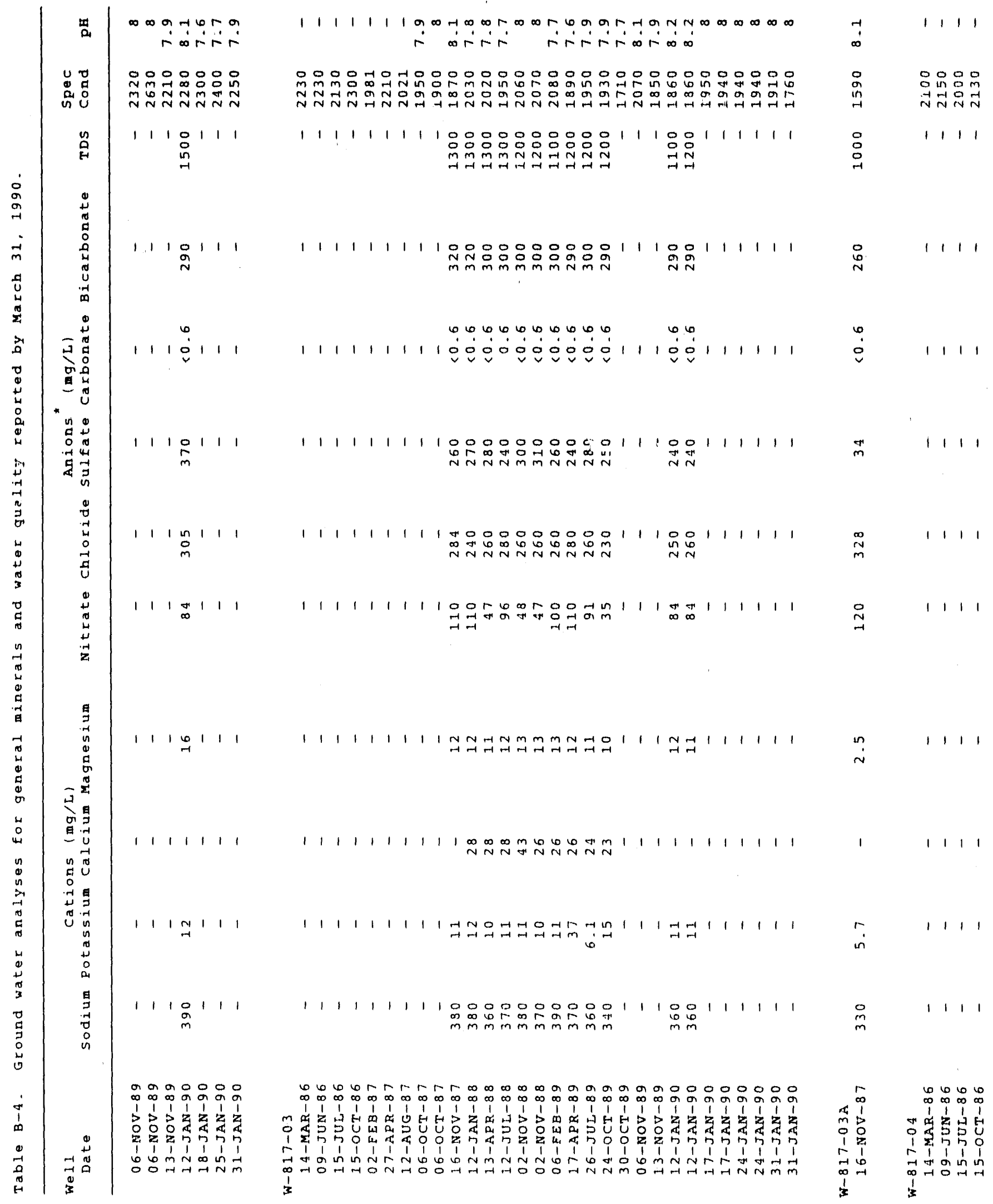




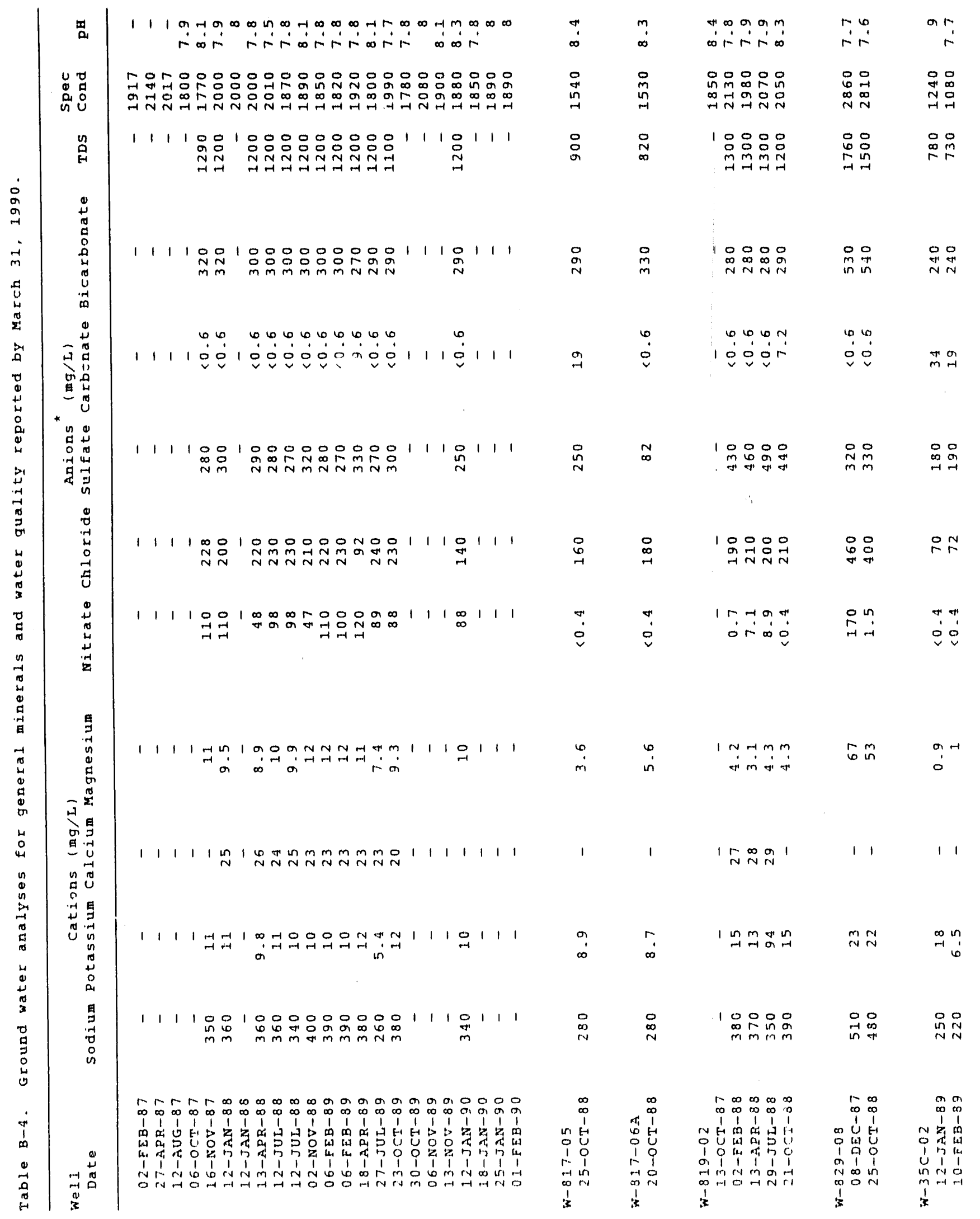




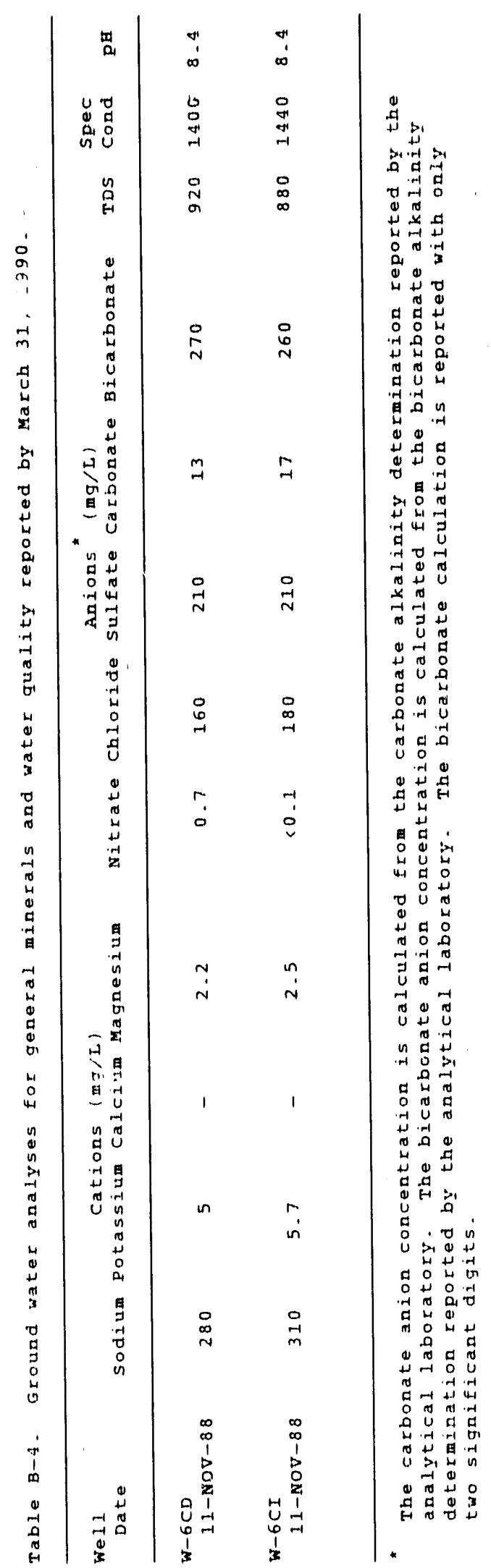


Appendix C

Well Logs 
Appendix C.

Logs of wells drilled subsequent to July 1988 are included in this section; logs of wells drilled prior to this date are located in the following reports:

Lamarre, A. L., T, L. Phillips, and N. B. Crow (1989b), Remedial Investigation of Dry Wells, Lawrence Livermore National Laboratory Site 300, Lawrence Livermore National Laboratory, Livermore, Calif. (UCID-21774).

Hoffman, F. (1990), Remedial Investigation of Dry Wells, Lawrence Livermore National Laboratory Site 300, personal communication to Michael J. Higgins, Regional Water Quality Control Board-Central Valley Region, January 29, 1990.

Money, K. C., and N. B. Crow (1989), Logs of Wells and Boreholes Drilled During Hydrogeologic Studies at Lawrence Livermore National Laboratory Site 300, June $D_{\text {, }}$ 1982--Jine 30, 1988, Lawrence Livermore National Laboratory, Livermore, Calif, (UCID215.36).

C- $1 / 2$ 


\section{JR WELL W-35C-02}

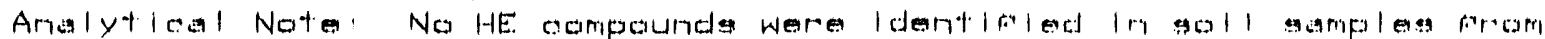

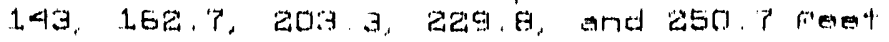

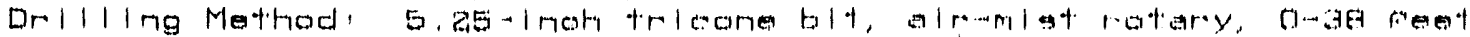

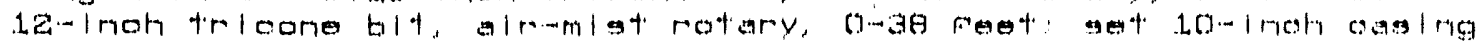

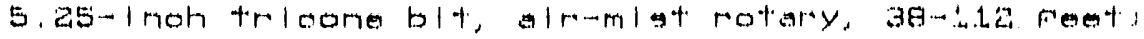
aet $4.5-1$ maty temporary os a rag

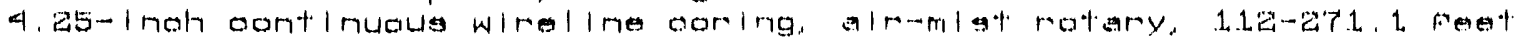

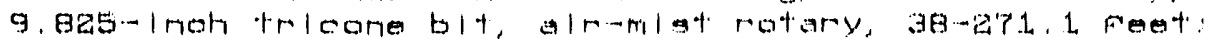

sent E-I noth ossing

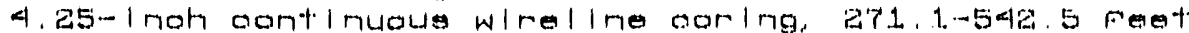

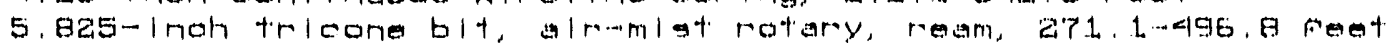

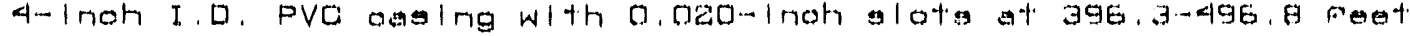

Estimetes of gravels, ands, and fines are field visul eatlmates,

Notat I an of bedding and Fraotures: roppth(s)/diplsio/oomimerits.

\begin{tabular}{|c|c|c|}
\hline JEX TO SYMBOLS & PSDR SLUGH MATERIAL & $\square$ INTERSECTING FrACTURES \\
\hline SAND & $\exists$ SLOTTED CAgING & CLOSED FRACTUIRES \\
\hline ND PACK & NEAT CEMENT GROUT & 1 OPEN FRACTURES \\
\hline NTONI TE & CEMENT-CAL SEAL GROUT & Iy FRACTURE ZONE \\
\hline
\end{tabular}

\section{Depth recovery Fraoturas Analytical soll samples} 11

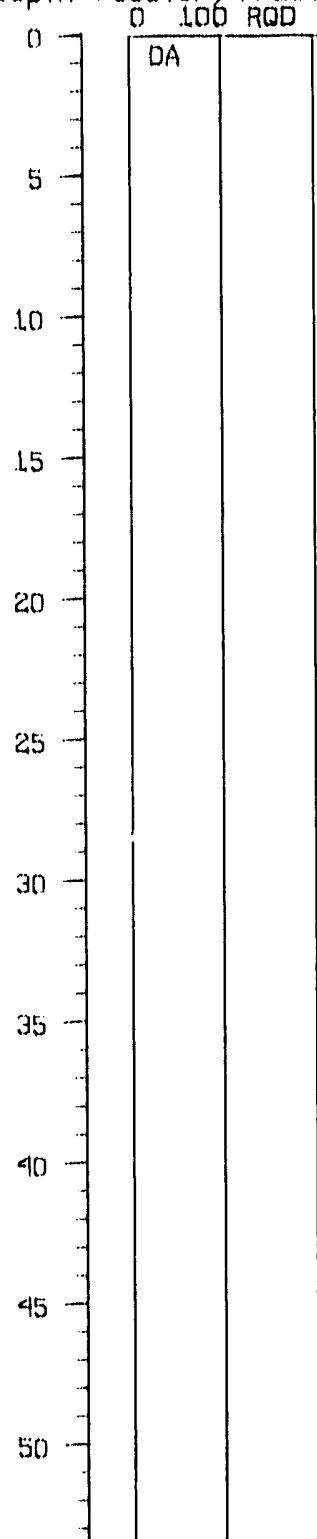




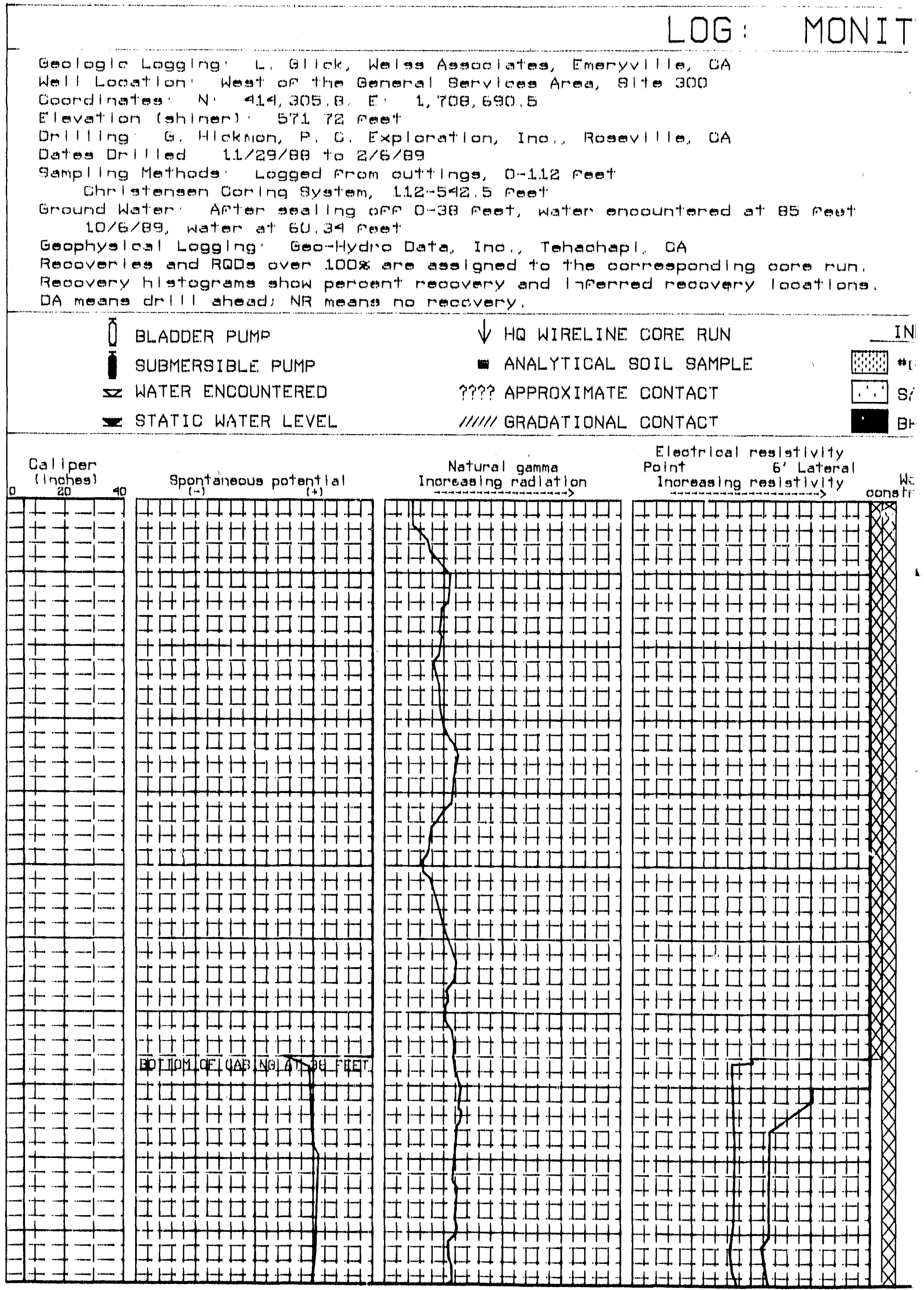




\section{$\sqrt{-35 C-02}$ (CONT INUED)}

: Core Amalytioal soll samplos

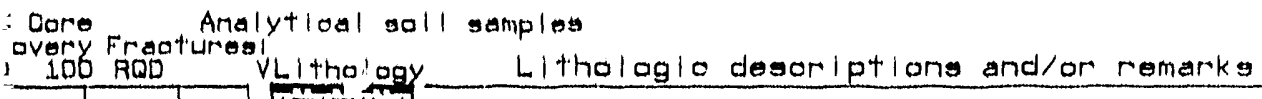

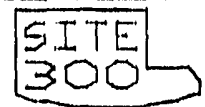

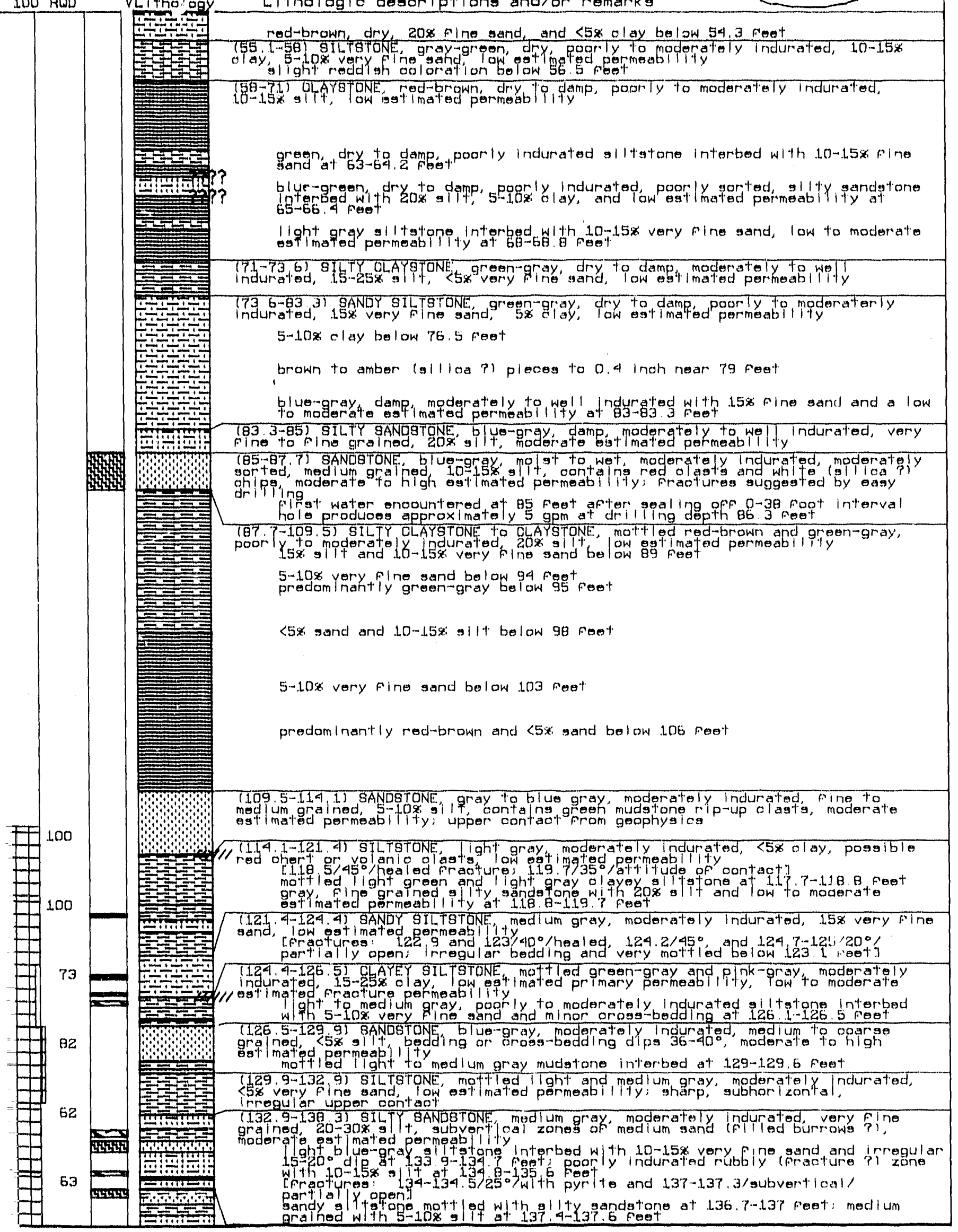




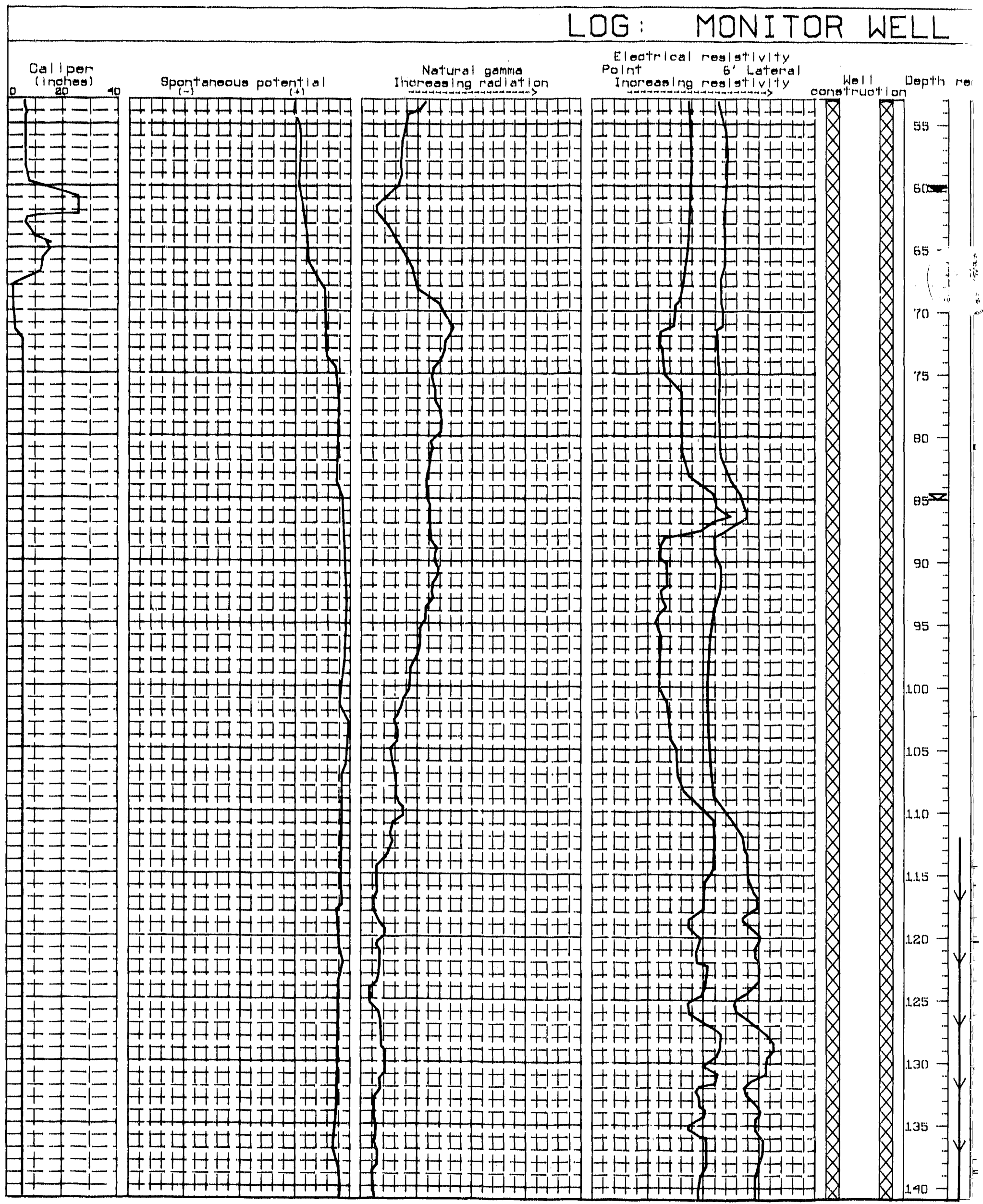

C- 4 


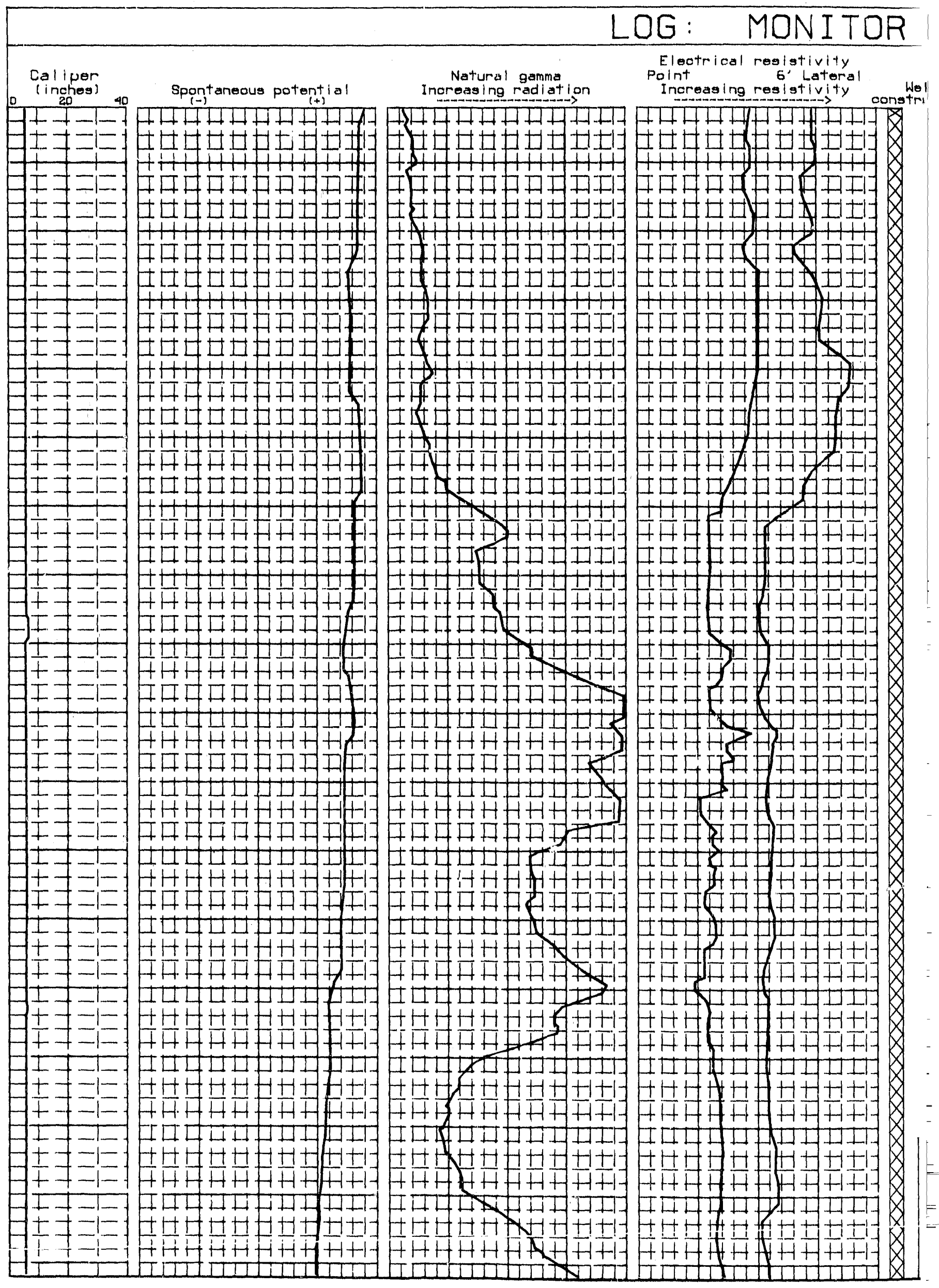




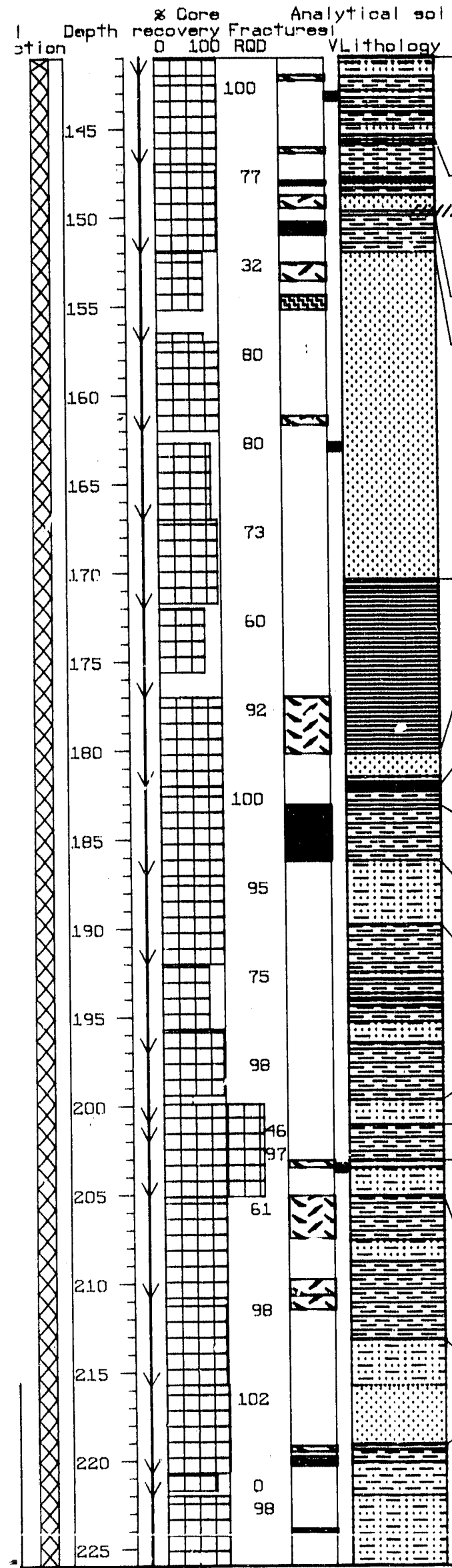

Lithologic desoriptions and/or remarks (138 $3-145.4)$ interbedded ight gray SILTSTONE and medium, gray SILTY bedded, cross-bedded, bedding d ps $10^{\circ}$ low to maderate est mated permeablitity

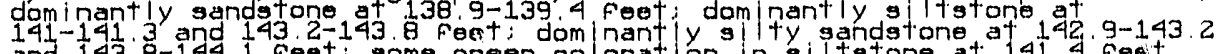

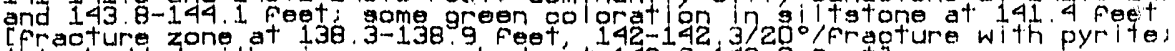
thin bedded with minor oross meds at 143 . 2 - 143 . B feet.

(145.4-149 7) SILTSTONE light gray moderately lndurated, $5-10 x$ very fine sand, mottled, some voids, jrregul ar y laminated, low estimated primary permeabli ity, low to mpderate est l mated fraoture permeablity subtiorizontal silty sandstone interbeds at 145.75

medium grained sandstone interbeds with a moderate estimated primary permeabl 148 . 1 \% losed fracture; $148.8-149.5$ /subhor i zontal/fractures] (149.7-152) CLAYEY SILTSTDNE, I ight gray with green and purple hyes, moderately indurated, $15 x$ clay, $25 x$ very fine sand, low estimated permeability 152-170.4) SANDSTDNE, dark gray, drieg blue-gray, poorly to moderafely permeability grained and moderate to high estimated permeability at 152.3-152.5 Feet $15-153,6 / 30^{\circ}, 45^{\circ}$ /Part i al ly closed fracture fracture zone at

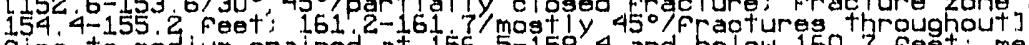
fine to medium grajped at $156.5-158.4$ and below 160.7 feet: medium to coarse grainad at 158 - 4-160.7 Feet; very thin interbed with clayey

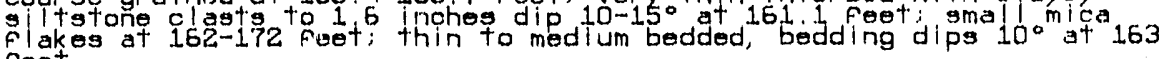
Feet

brown mudstone lamination at 168.5 feot

some thin green mudstone laminations below 170.1. foet

(170.4-180.2) CLAYSTONE, green and gray-red, poorly to moderately indurated, permeability moderately indurated and 5-15\% $\mathbf{s} 11+$ at $170.4-170.8$ feet

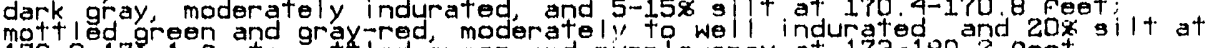

mott led green and gray-red, moderately to well indurated and zac

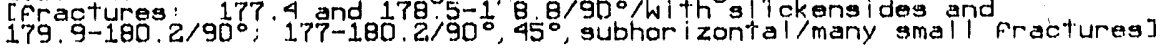

(180.2-182) SANDSTONE, medium to light gray, moderately indurated, medium

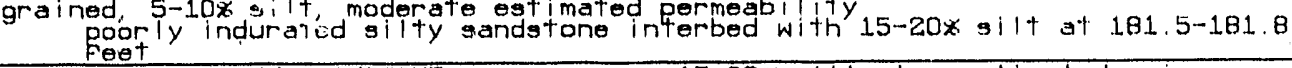

(182-183 1) SILTY CLAYSTONE, greer-gray, 15-20x silt, law estimated primary permeabil ty, low to moder ate est mated fracture perme

(183 1-186.2) CLAYEY SILTSTONE, mottled green and lighr gray, poor ly indurated, estimated Fracture permeabli ity, low estimated primary permeabil

2-189 8) SILTY SANDSTONE I I Tht blue-gray, moderately indurated $40-45 x$

(186.2-189.89) SILTY SANDST

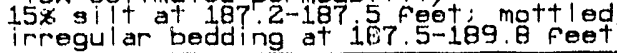

(1A9.8-199 7) CLAMEY SILTSTONE, I ight gray, moderately indurated, 20-25x clay,

slightly micaceous, low estimated permeabily with $20-30 x$ silt and low to

moderate estimated permeability at $1925-192.9$ foet

medium gray, fine to medium grained silty sandstone interbeds with 15-20\%

3 it and a moderate estimated permeability at 193 7-194, 194.1-194, 4, and

195. 3-196.5 foet

$5 \%$ very fine sand below 198.5 feet

(199.7-201.1) SILTY SANDSTONE, mottled light gray, moderately indurated, fine to medium grained, $15-20 x$ silt, low to moderate estimated permeability

201 1-203 1) CLAYEY SILTSTONE, green and purple-gray, moderately indurated, $30 x$ clay, low estimated permeability

.203 1-205 .11 SILTY SANDSTONE, green-gray, poor ly to moderately indurated, fine grained, $15-40 \%$ silt, moderate est imated permeab l ity morbed with 15-25x very dark green-gray, poor ly indurated sahdy siltatone interbed with $15-25 x$ Fine sand, moder

(205.1-213.2) CLAYEY SILTSTONE, green- and purple-gray, dry to damp, poorly to moderately indurated, $15-25 x$ elay, thin wavy bedding, low estimated primary permeability, low to moderate est imated fracture permeabl ty fine grained light to medium gray, moderately indurated, very fine to fine grained clasts and low to moderate porosity at $207.6-208$. drractures at $205.1-207.5$ feet i poss ible fractures at

(2.13 2-219 1) SILTY SANDSTONE to SANDSTONE, blue-gray, moderately indurated, poorly sorted, very fine to fine grained, $20-25 x$, 914 , no apparent bedding, 'low

estimated permeability
below 40 medium grained with $15-20 x$ silt below 214.9 feet: $10-15 *$ silt

(219.1-222) SILTSTONE to SANDY SILTSTONE, black and red-brown, poor ly to moderately indurated low estimated primary permeability, moder ate eationated I ght to medium gray, maderately indurated clayey giltstone interbed wh and $15-25 x$ very fine sand be low 220,1 feet: $30-40 x$ sand below 221 Feet ffractures Fractures with silickensides 


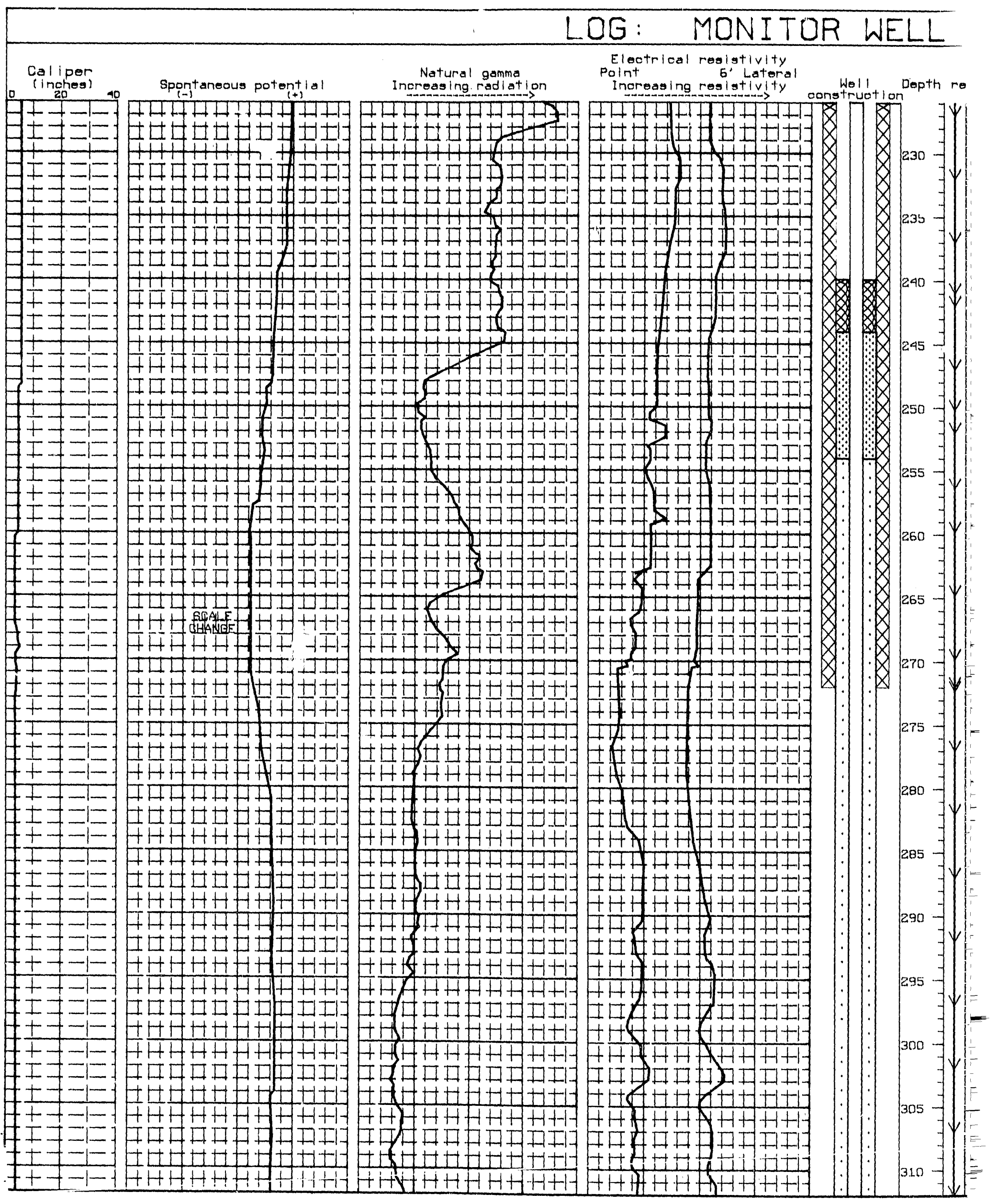

C-6 


\section{$\sqrt{-35 C-02}$ (CONT INUED)}

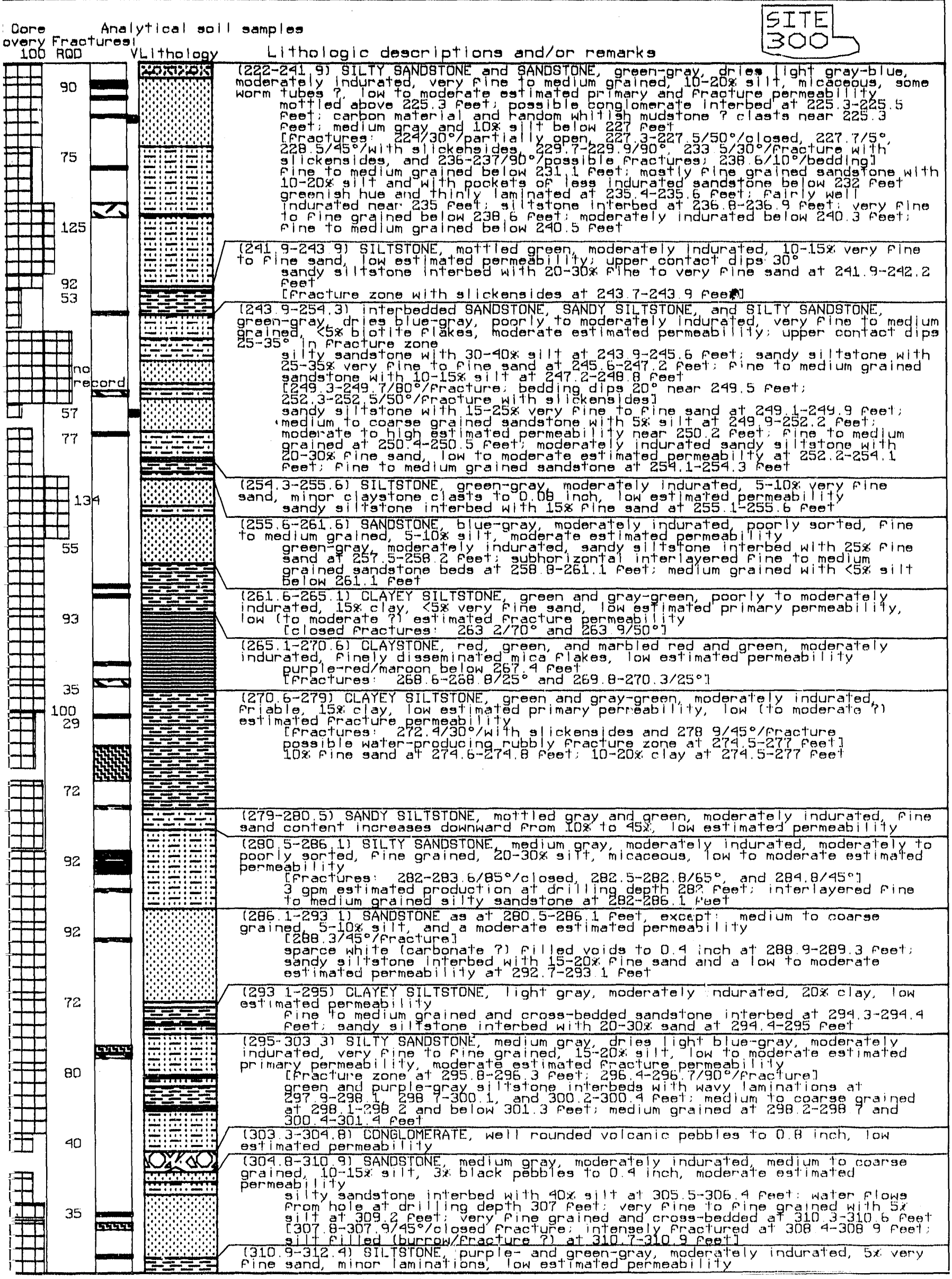




\section{WELL $W-35 C-02$ (CONT INUED)}

1 Depth recovery Fraotures Analytical soll samples

Depth recovery Fraotures I
ation

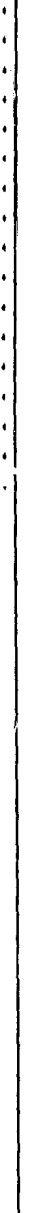

315

320

330

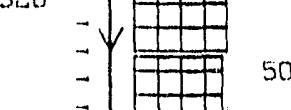

325

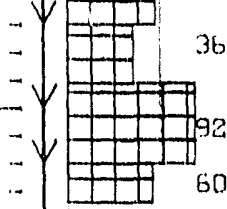

335

$\Psi$

340

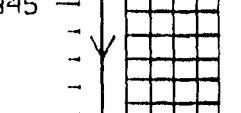

350

$=\square$

355

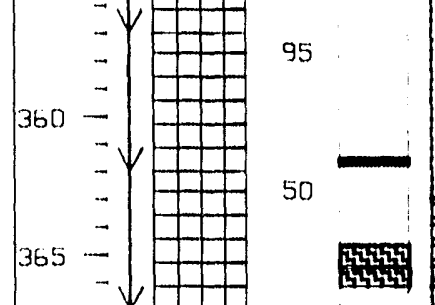

42

$370-$

375

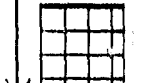

$\because \rightleftharpoons$

80

100

380

385

385

$-11$

$5 \%$

85

$=$

390

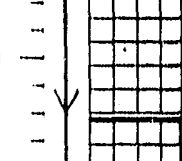

Lithologis desoriptions and/or remarks

$5 \mathrm{TTE}$

300

(312. 4-316 4) SANDSTONE, med lum aray poony to moderately lindurated very ostimated permeag il ped

mast 1 m med um grained below 31.34 feet: purple-grav giltstone interbed at

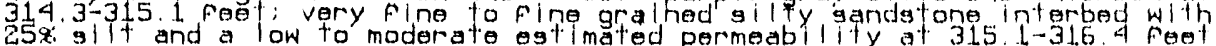

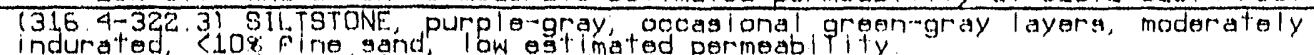

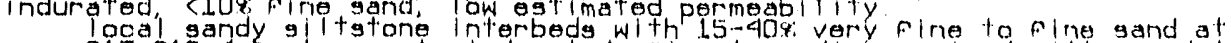

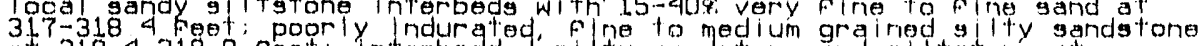

a. 318 4-3189 Feet: interbedded silty sandetone and 911 t stone at

3.19 .920 .1 Feet; med jum gra ined sandstone interbed at $3201-320$ and

(32a. 3-324 3) SANDSTONE, medlum gray, moderately indurated, fine to medium grained 5-15x silt, minor interbeds of grean-gray oross-bedded siltstone to

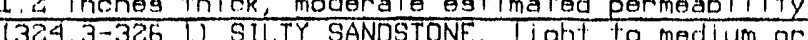

ane sANDSTONE, li ght to medium gray, modorately indurated, fine ta medium grained, zo-40e gilt, abundant carbon material, low egtimated permeability estimated permeability at 325-325.5 foet

1326.1-327) SILTY CLAYSTONE, purp is -gray, moderately indurated, $15-258$ sil some carbon material, low estimateo permeability

(327-3y9 7) SILTY SANDSTONE, light gray, moderately inrdurated, very fine

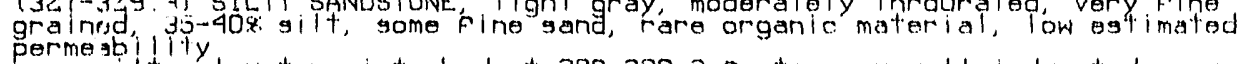

s. Ity claystone interbed at 329-329. 3 Feet; very well induratod gray-red alastone with silloa? pods a 329 . 3 -329.4 foe

(329:4 -330 9) CLAYEY SILTSTONE, light gray, moderately induratod, $20-25 \%$ elay, low est imated permeability

(330.9-334 3) SANDSTONE, medlum gray, moderately indurated, fine to medium grained, $5-10 x$ silt, low est imated permeablilty

siltatone interbed at 331 . $5-331$. 6 Feet: maderately wel 1 to very well

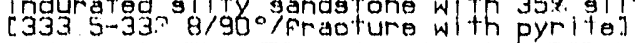

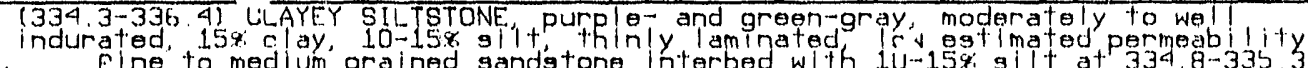

feet: minor pyrite and orosg-bedding at 336 9--338 9 feet

(336. 4-338 9) SANDSTONE, medlum gray, moderately indurated gralned, 10-15\% gilt moderate estimated permeability

1338 9-344.?) CLAYEY SILTSTONE, I ght gray, moderate y indurated, 30\% clay,

minor organic material, wavy laminations, low est imated permeablility

(344.7-353 6) MUDSTONE, Iight gray, maderately to well indurated, 40-45x $3 i$ t,

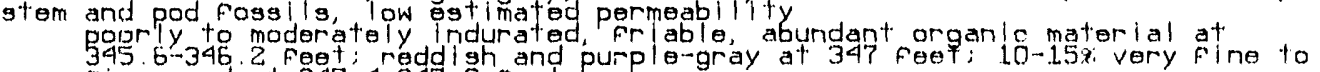

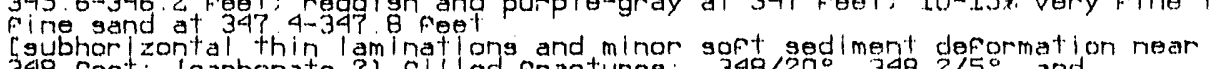

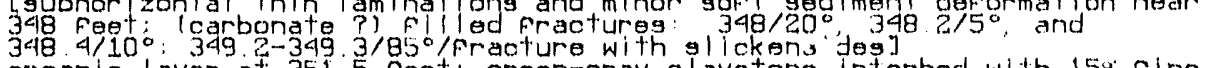

organic layer at 351 . 5 feet; green-gray claygtone interbed

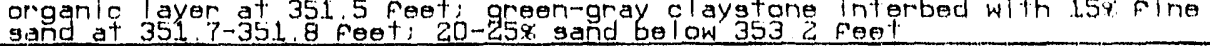

(353.6-363) SILTY SANDSTDNE blue-gray ta medium gray well to moderately

incheg common organic materlal, low est imated permeability

$[357.2 / 10 \%$ medium bedded: 361 . 7/subhorizontal/(desicoation ?) fracture fil od with loarbonate ? I $1363-366$
$15-20 \%$ SILTY CLAYSTONE, purple to brown gray moderately indurated,

greens i ty claystone below 363.7 feet

r racture zone at $364.7-3 b 5$. 5 feet; fructure zone with gilokensides and

$15 \%$ fine sand at $365.5-366$. 2 foet

1366 2-367 31 SILTY SANDSTONE, green-gray, poorly to moderately indurated,

pooriy sorted, $35-40 s$ silt, low est imated permeability

(367.3-373 8) SILTY CLAYSTONE, green, poorly indurated, moderate estimated

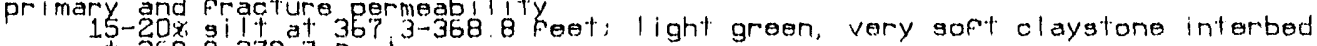
at 368 . $8-370.7$ Feet $2-372$ a Foet]

$(3738-3797$ ) SILTY SANDSTONE, green-gray, moderately indurated, fine grained,

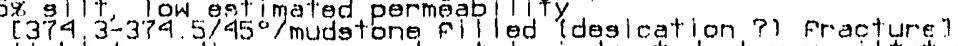

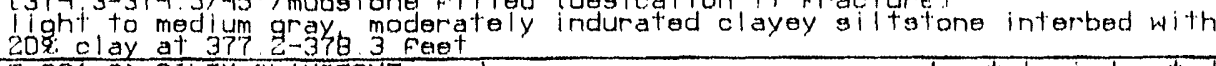

1379.7-381 9) SILTY CLAYSTONE, red-gray, some green-gray, moderateily indurated,

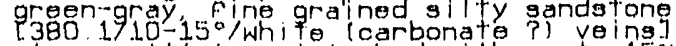

clayey giltstone interbed with up to $15 \%$ fine sand at $381.1-381.7$ foet

1381.9-384.91 interbedded CLAYSTONE, SILTSTONE, and SILTY SANDSTONE, IOW

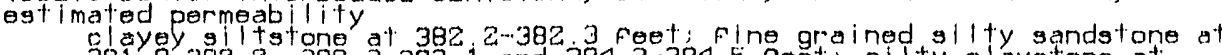

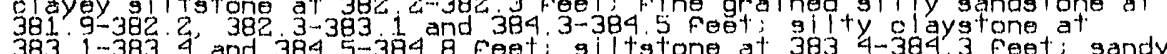

383 1-383 a and $384.5-384.8$ Feet

(384 9-386 1) SILTY SANDSTONE, medjum gray, moderately Indurated, $15-20 \%$ ilt,

low to moderate est imated permeabi 385 y

(386 1-387 8) S1LTY SANDSTONE Ight gray dry to damp moderately indurated

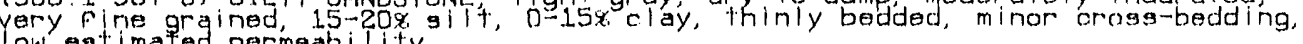

Yow estimated permeability
very fine to fine grained and no clay below $387.4 \mathrm{Feet}$ 


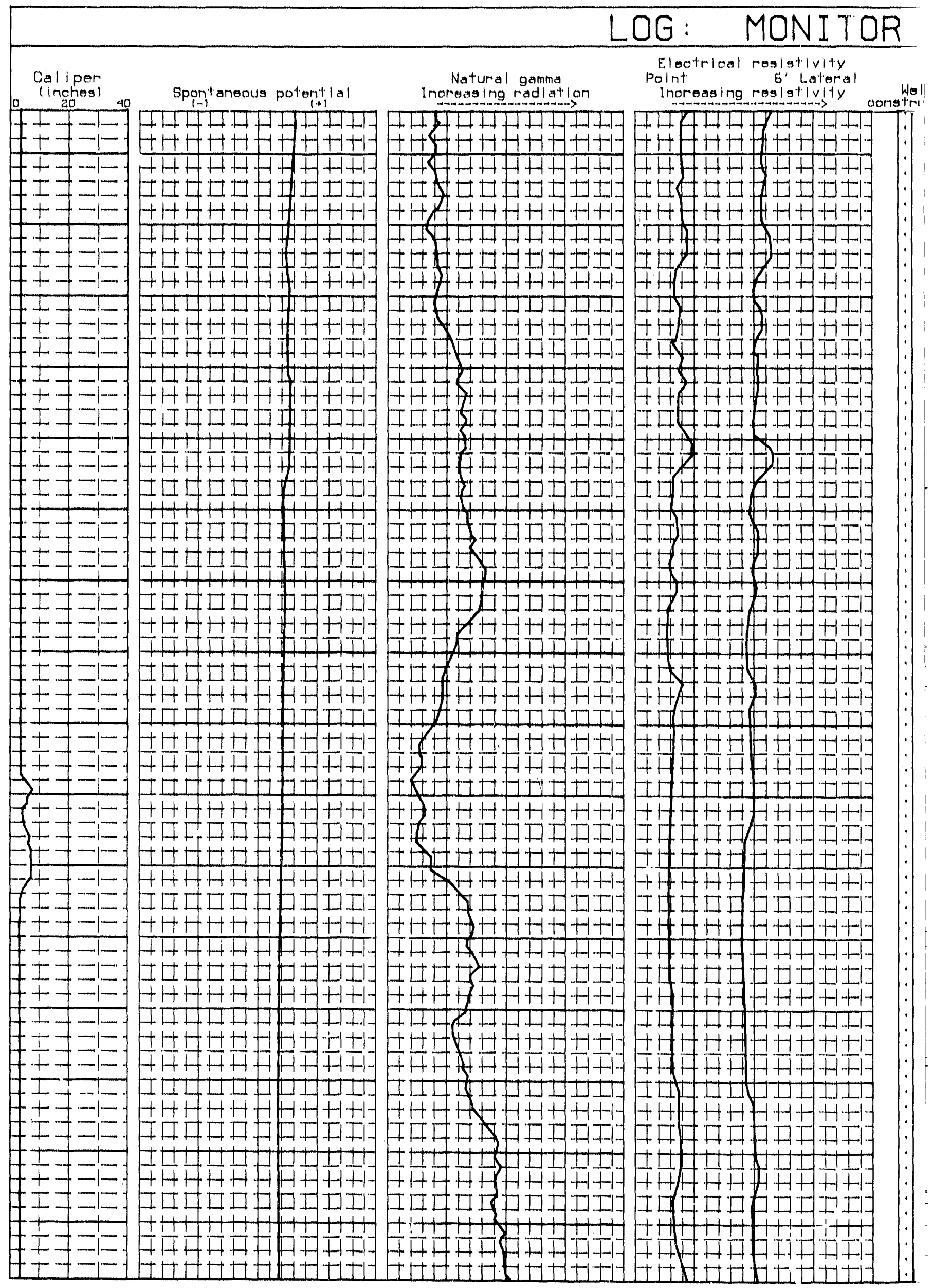




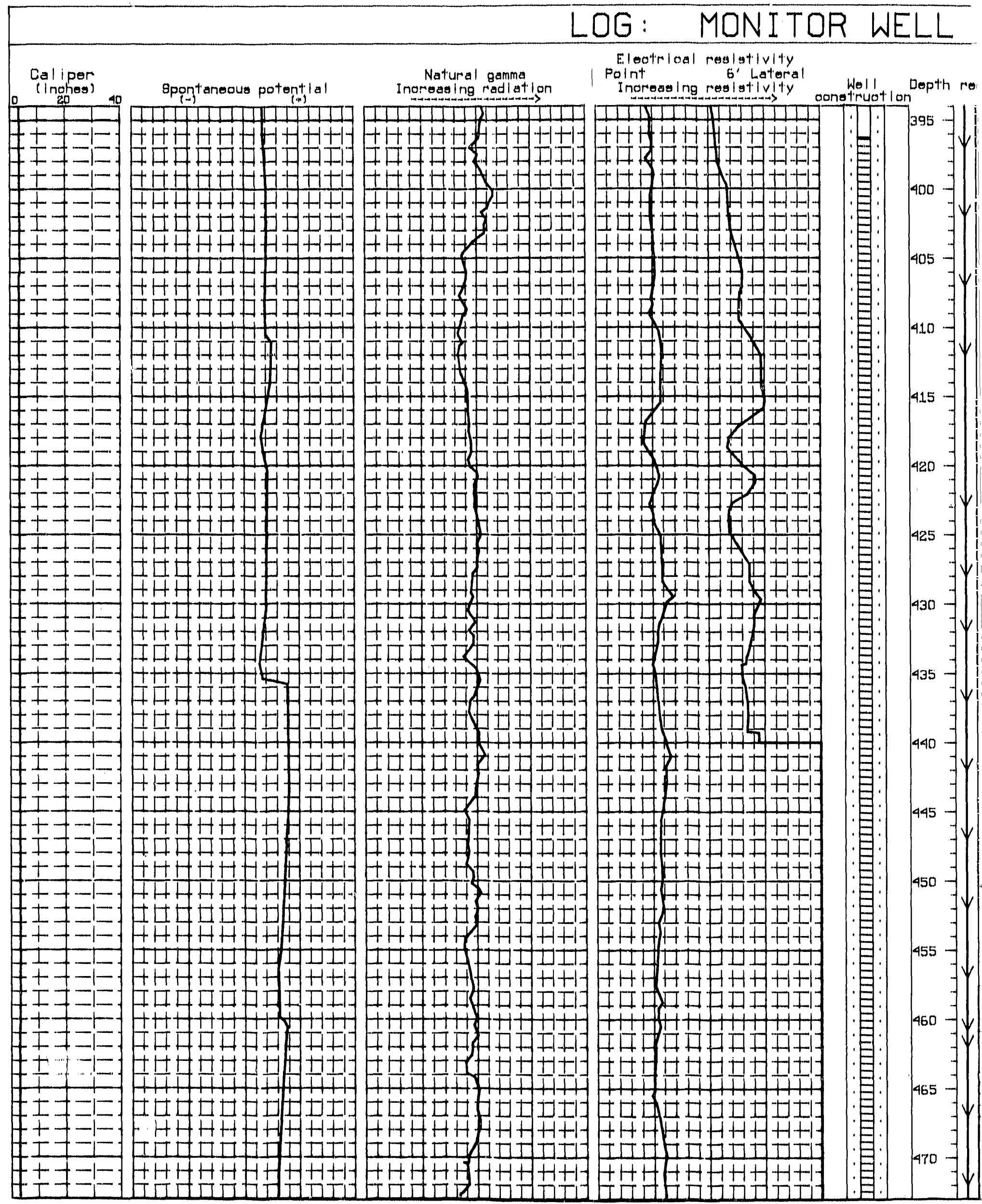




\section{$\bar{W}-35 C-02$ (CONT INUED)}

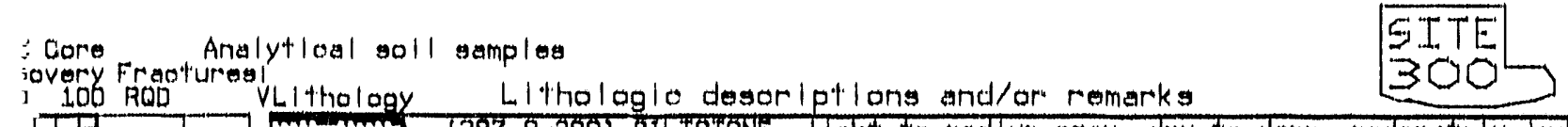

-1 3 .

low ga

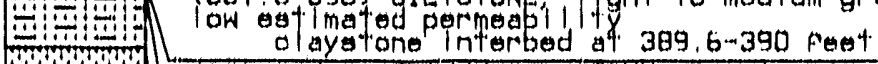

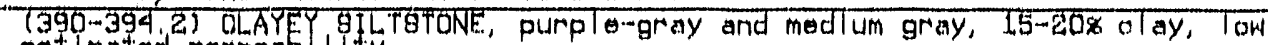

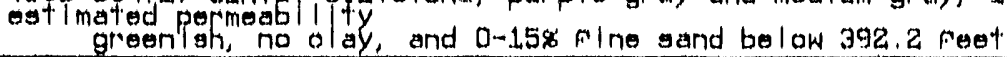

I

j

NR

60

i

78

10

E

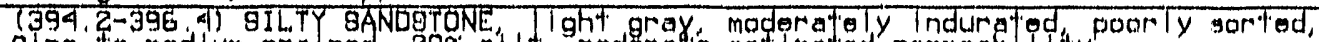

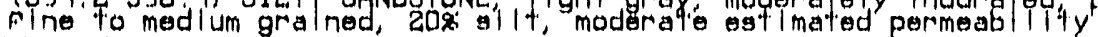

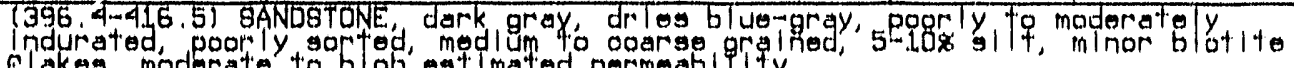

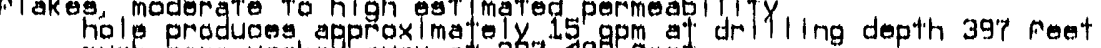

molo poroduos approx matoly $25 \mathrm{gpm}$ at drilling depth $40 \mathrm{a}$ foet

(416.5-419.5 SILTY 8ANDSTONE, brownaga poorly to moderatel $y$ I nduratod, very Fine gralned, $35-458$ s 11 t, volognio olasts 400.6 noh moderate estlinated permeabi ity; i rrogular cemmented upper oontact, oontaoty from geophyslos

med um gray, moderately ndurated al thatone interbed with $<15 x$ very mino

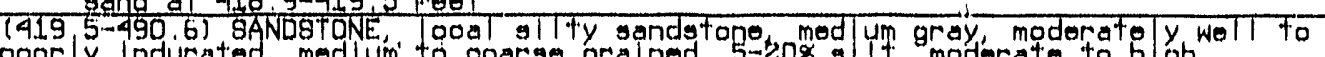
poorly indurated medlum to coarse gralned, 5-20s g/ it, modorato to high ostl matod permeabllity

por ly to moderately indurated silty sandstone with $15-20 x$ y l t at

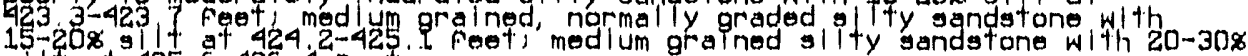
sil at 425 . $6-426.4$ root

oogrse grained, poorly ndurated, and $5-10 x \mathrm{~g} 11+$ below 426.4 foet' woll indurated and med um 9 ral ned below 428 . 6 foot muoh oore washed away at

poorly Indurated, medium to coarse grained, and 5-10z $311+$ bolow 432 foot

medium gralned s/14y sandstone with $15-208 \mathrm{~g} 11$ t at $436,1-436.2$ feet

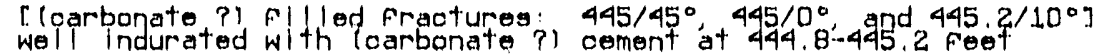




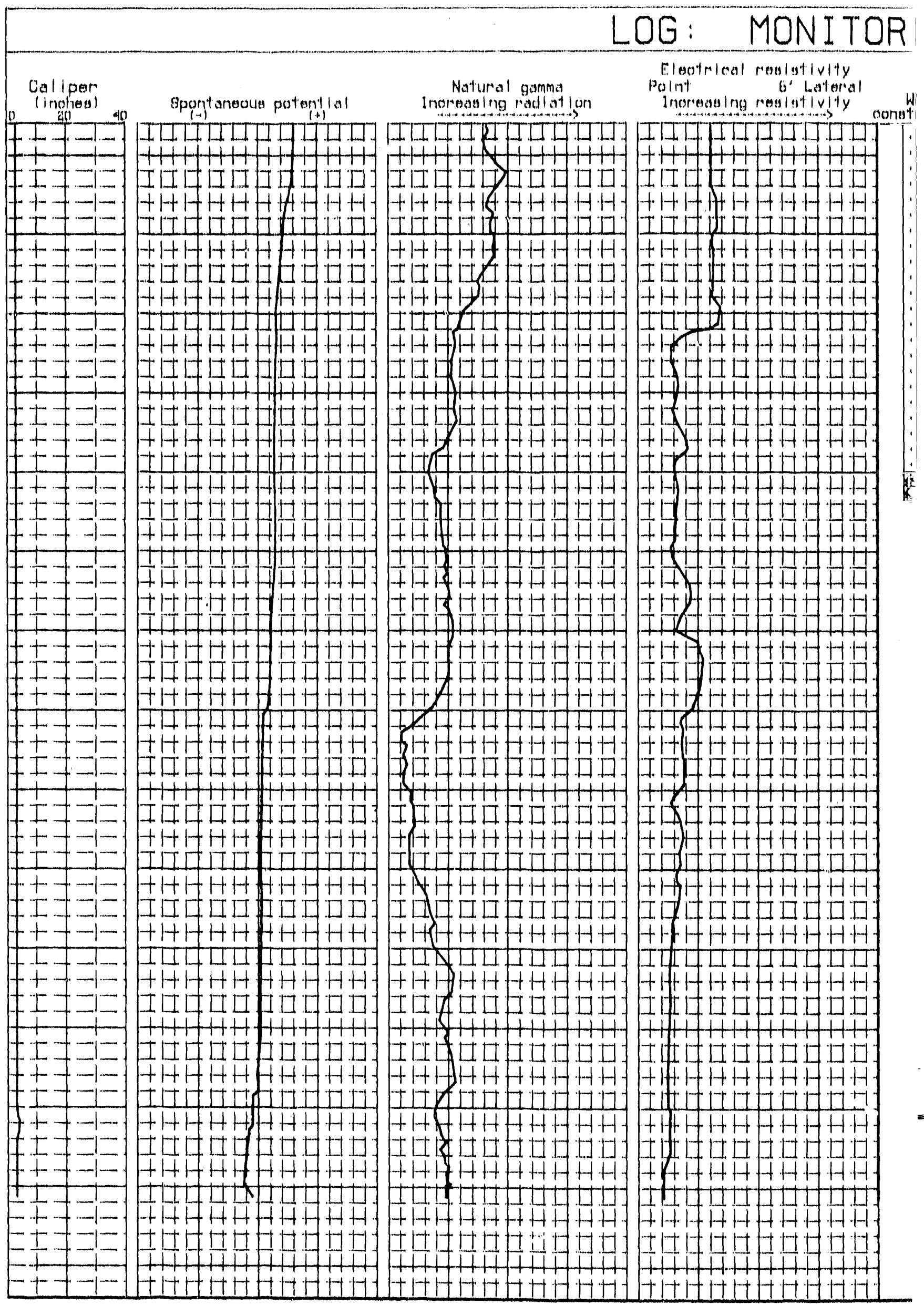




\section{WELL W-35C-02 (CONT INUED)}

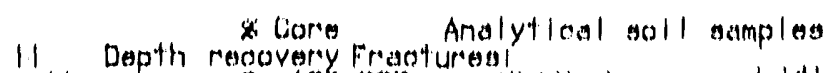

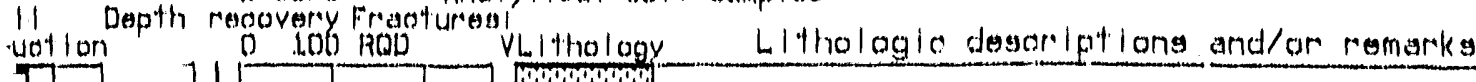

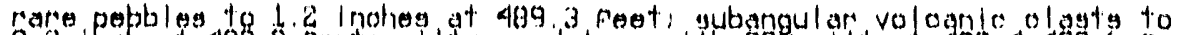

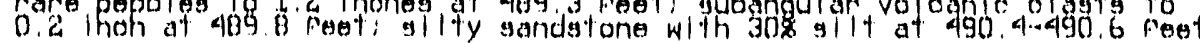

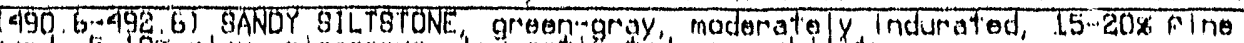
sarnd, 5-lox clay, micacoous, law ost imated permeablitity

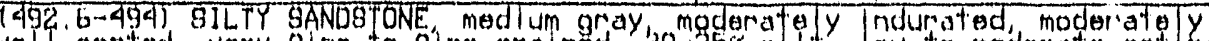

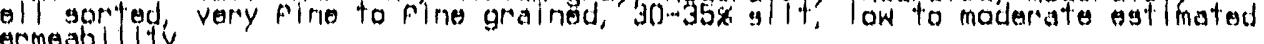

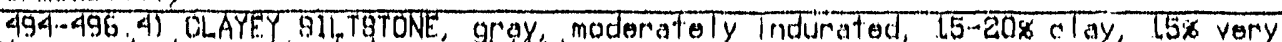
fine sand, low es imafod permesablity

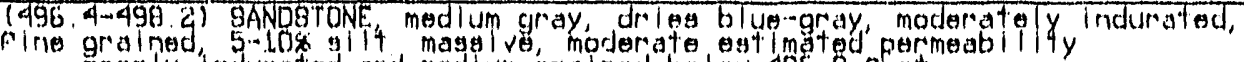

poor ly indurated and med lum aral ined bo low 496 . 3 foet

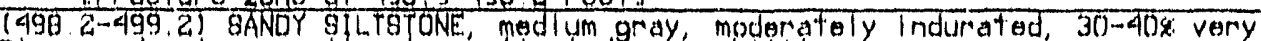

Fine sand, minor pyrile, low ent imated permeablility

(499.2-500.7) 9ILTY SANDSTONE, medlum gray, moderataly Induratod, very fine to

Fine gralned, $30=408$ gilt, low to moderate ostimated permestillily

-503 9l gILTSTONE. I ght gray moderately indurated, low est imated

permeability: upper contaot dips ab.

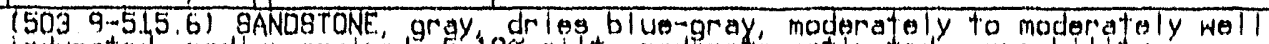

indurated, medium gralned, 5-.108 sitt, maderato est mated permeability modergtely indurated med um to ooarsegralned, and maderate to high

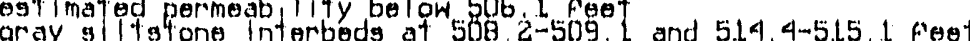

5.10

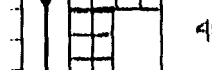

48

B2
Fine to medlum grained of 5.15. L-5.5.5.6 Foul

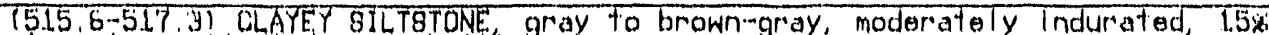
olay, low est imated permeability

(5.17 3-519 3 SILTY SANDETONE, medlum gray, moderately indurated, fine grained, $35-45 x$ silt, low to moderisto ost imatod permeablitity

15.19.3-52.L.5) CLAYEY SILTSTONE, gray, maderatoly ndurated, $15 \%$ a ay, minor

rip-up olasts, low ostimated pormeability, irrogular upper contaot dips $65^{\circ}$

1521.5-524.31 SILTY BANDSTONE, medIum gray, moderately indurated mederately to well sorted, fine grained, $35-458$ gilt, low to moderate estimated permeabli1 1 ty

sandy sil totorie interbed at 52z,5-523 foots poorly to moderately

$1524.3-526$. 2) GANDY SILTSTONE, medium gray, muder atoly indurated, 25 -35s fines sand, moderate egt mated permeabill ty

526.2-527 2l GILTY SANOBTONE, medium gray moderately indurated, fine grained, 15-20x silt, moderate est mated permeabilify

1527. 2-529.2) CLAYEY gII.TgTONE, That gray, moderately Indurated, 158 o ay, Tow est mated permeability

(529.2 530 4) CLAYSTONE, gray, poorty to moderately indurated, low ost mated permeability

530 4-534.?) SILTOTONE purp amay moderately to maderately well liduratod local interbedes with rip-up olasts and groen-gray mottling, ow est i mated permatility

1534.7-537.7) CLAYEY SANDSTONE, gray, moderately woll indurated, very fine to fine grained, $15 x$ ay, low estimated permeabillty

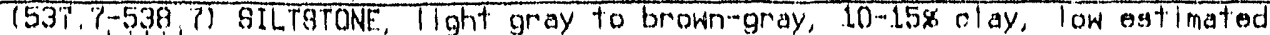
permeability

(538 7-539 9) 8ILTY CLAYGTONE gray $25 \%$ git, low egtimated permeability clayey silitstone lnterted at $539.7-5.39$. 9 poet

(539, 9-59.1.6) SANDY GILTSTONE, gray, moderatoly induraled, 4dx fhe sand, low ogt imated pormeablility

(541.6-542 5) 3ILTY SANDSTONE, gray, maderately hodurated, plne grained, $35 x$ gil, low to moderate egtimated permesability 


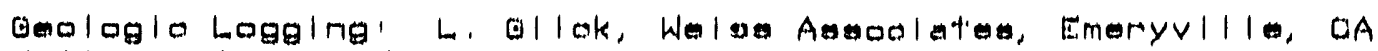

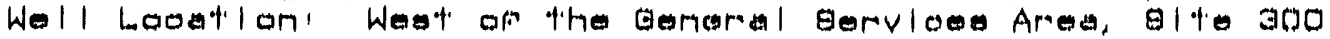

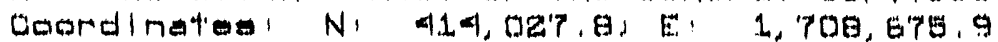

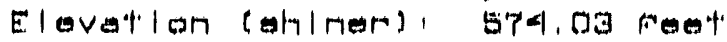

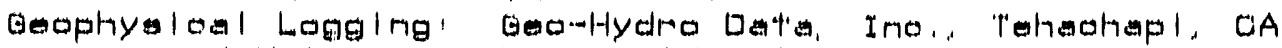
and Welonoa, Gakerale d, $\mathrm{CA}$

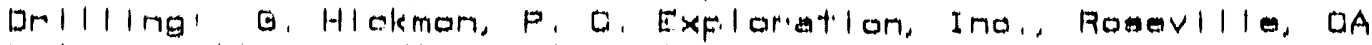

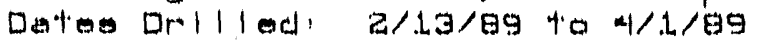

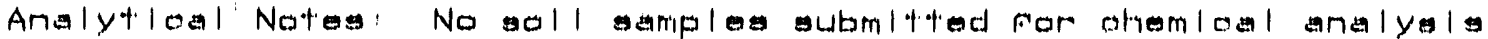

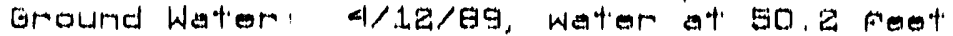

GLALUER PUMP
SUGMERSIBLE PUMP
$z$ WATER ENCQUNTERES
$=$ STATIC WATER LEVEL

INDEX TO SYMIE

MNALYTICAL GOIL GAMPLE

NEAT CEMIENT GROUT

CEMENTHCAL GEAL. GROUT

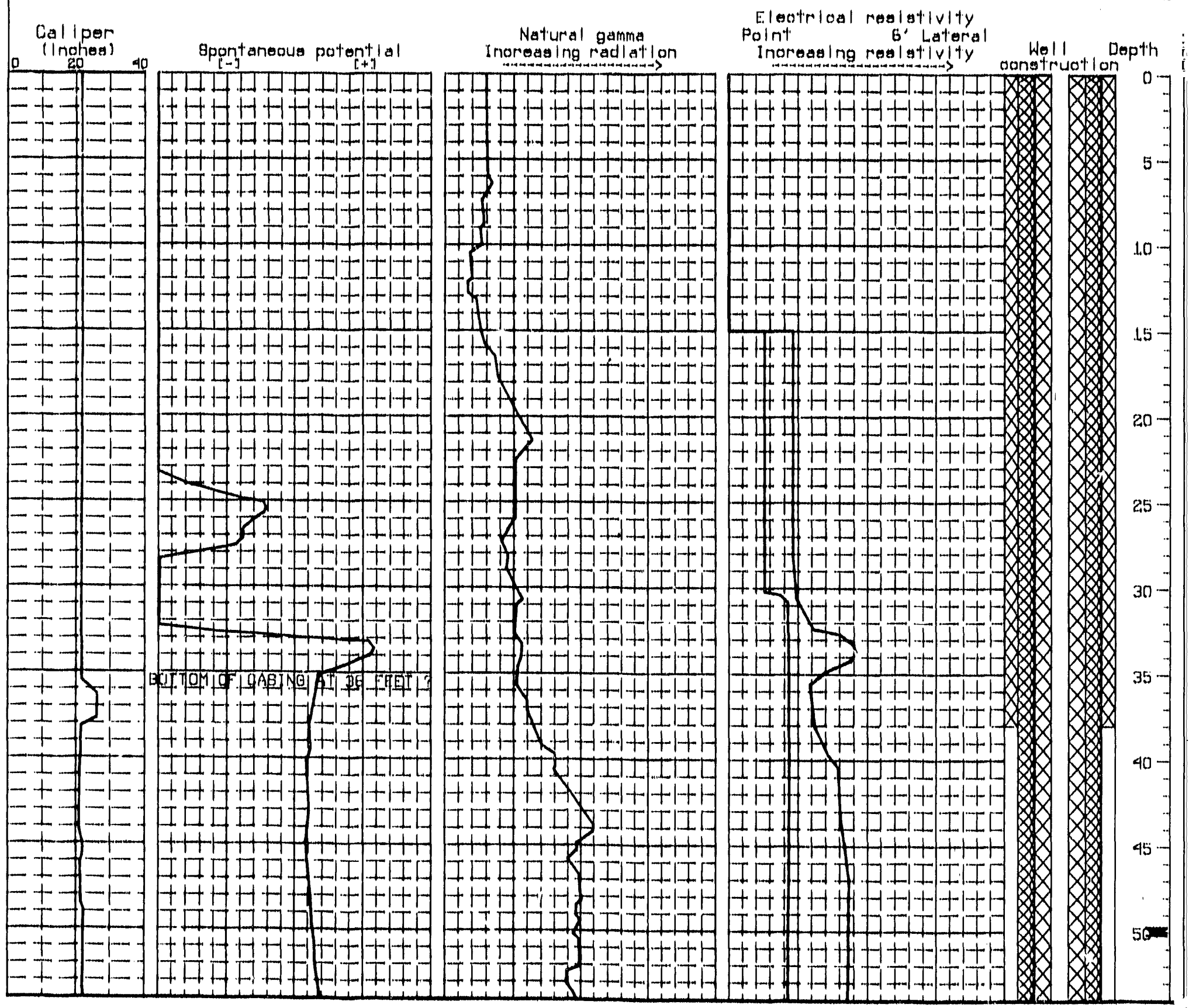


I Ing Method, zBu-l moth blade blt, mud metary, owag rent

24-1 moh teel odelng, 0-36 meet

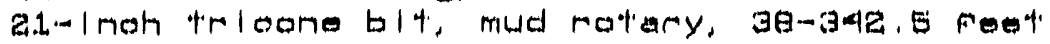

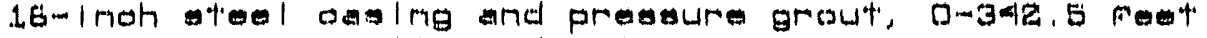

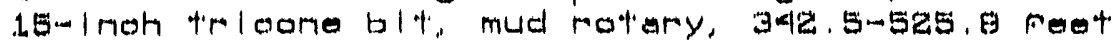

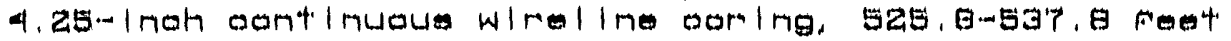

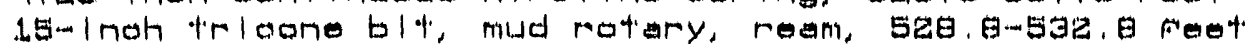

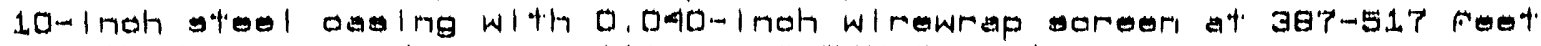

. I Ing Methode! Logged fram outtlinge, 0-Eizs, g Feet

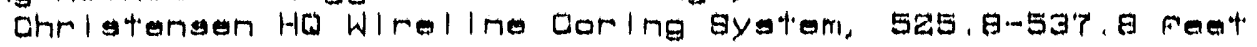

mates of gravele, sands, and filmes are fileld visual entlmates.

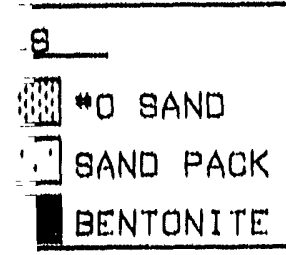

Đ SLOTTED CASING

SLOUGH MATERIAL

TTM? APPROXIMATE CONTACT

BENTONITE

IIIIII GRADATIONAL CONTACT

Core

oovery

100 ROD bithology

Llthologlo desoriptlons and/or romarks

SITE

300

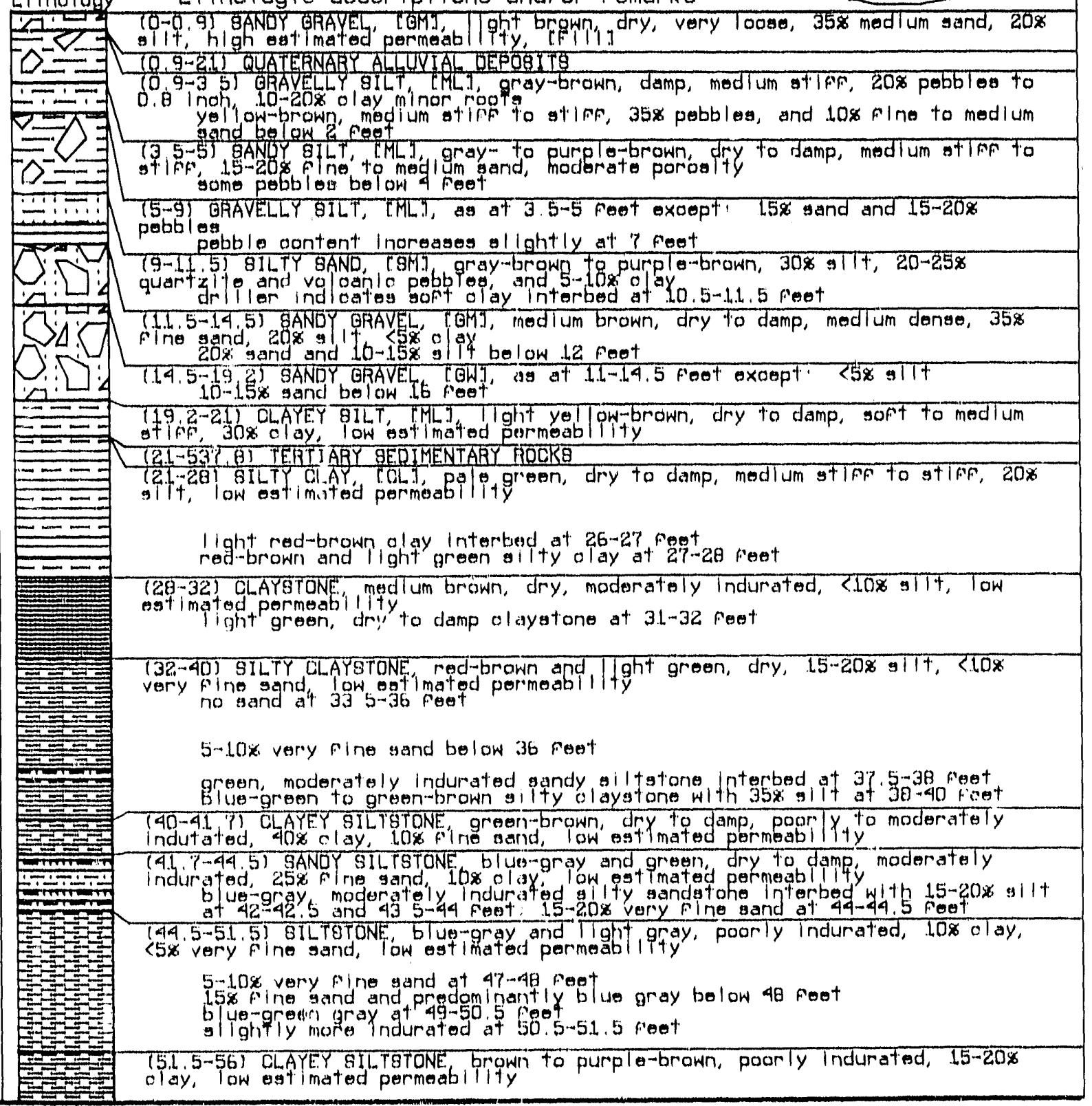




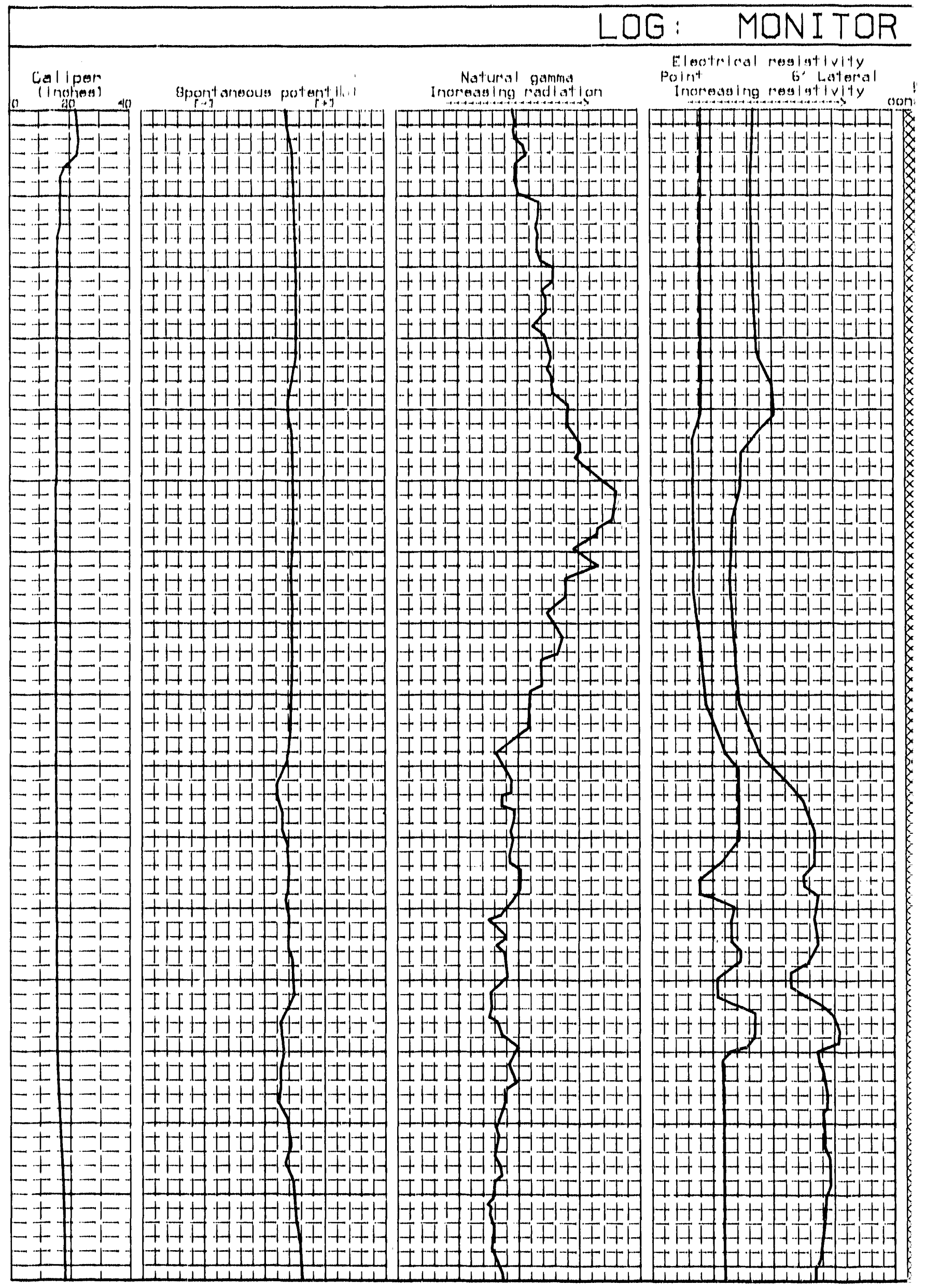




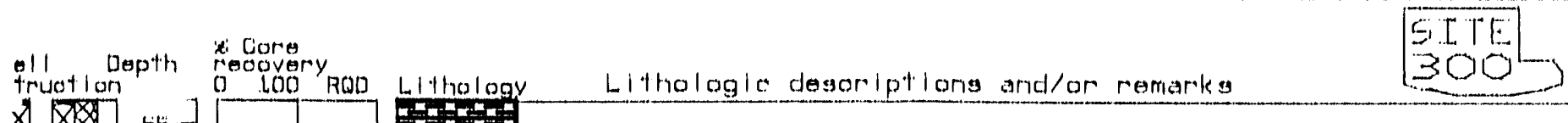

Depth reogvery
truatlan

permeablitity

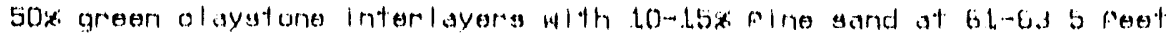

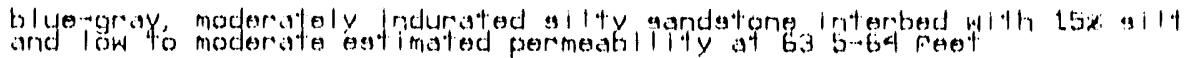

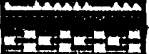

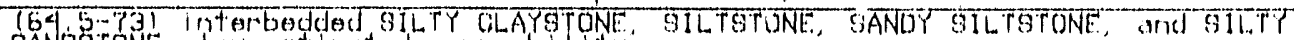

65

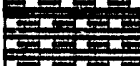

SANOERONE, low est Imatod pernesab il ty $5-65.6$

riye-gray to gray al tetone at $64.5-65$. b

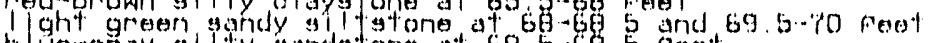

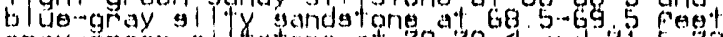

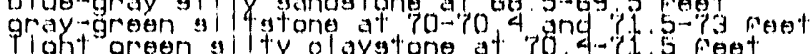

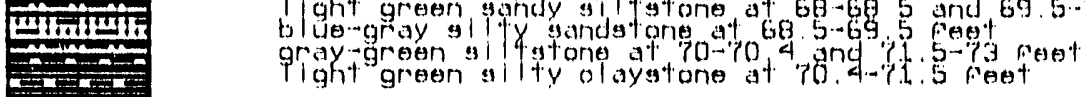

Ext?

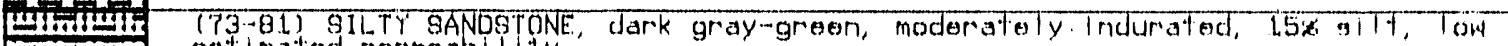

$\div \div \div \div \div=$

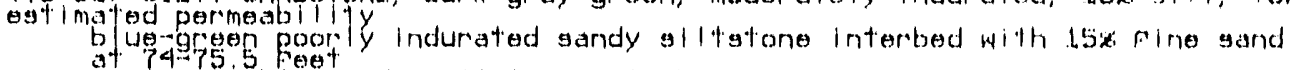

some possible sandy siltatone interbeds at $75.5-8 . \mathrm{L} \mathrm{Fesil}$

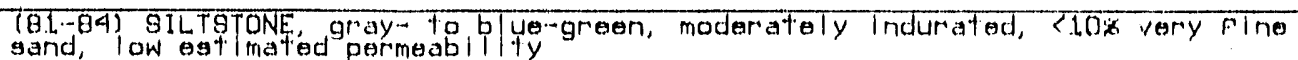

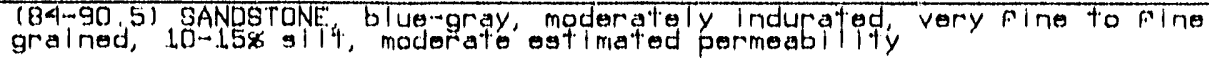

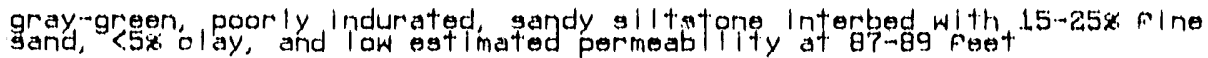

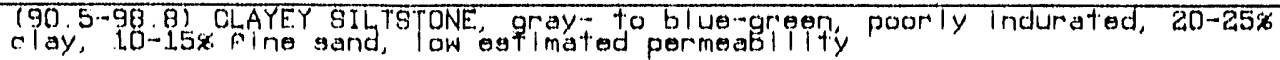

sandstones interbeds las at 84-90.5 feets at 92.5-94 and 96-9'? roet

198. 8-106.5] SILTY SANDSTONE, bTuegray moderately indurated very fine to driller, lower contant from goophyslos

Fine to medium grained sandstone interbed with <LOx gitt at $103-1055$ feet

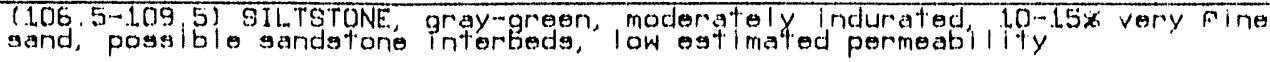

(.109.5-1.14.2) SANDSTONE, bTue-gray poorly to moderately indurated $10 \cdots 15 x \mathrm{~g} / \mathrm{t}$

moderato porosity, moderiste estimated permeablitity: contacts from geophysics

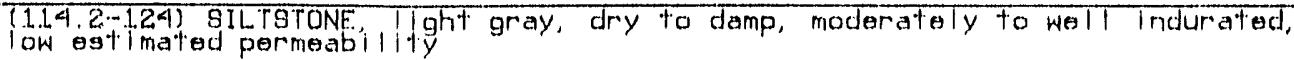

geophyslas Indicate possible sandstone Interbed at L.L6.5-1.19.9 foet

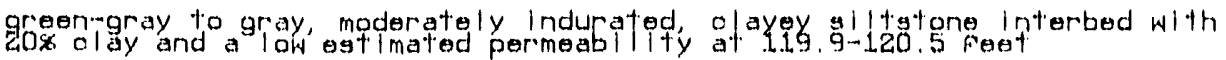

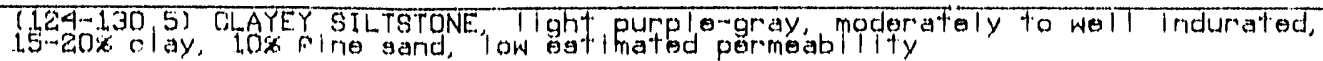

green and $10-15 x$ fine sand bolow lag foet

1130.5-150.51 8ILTSTONE, purploway to gray, moderately to woll indurated,

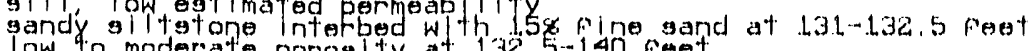




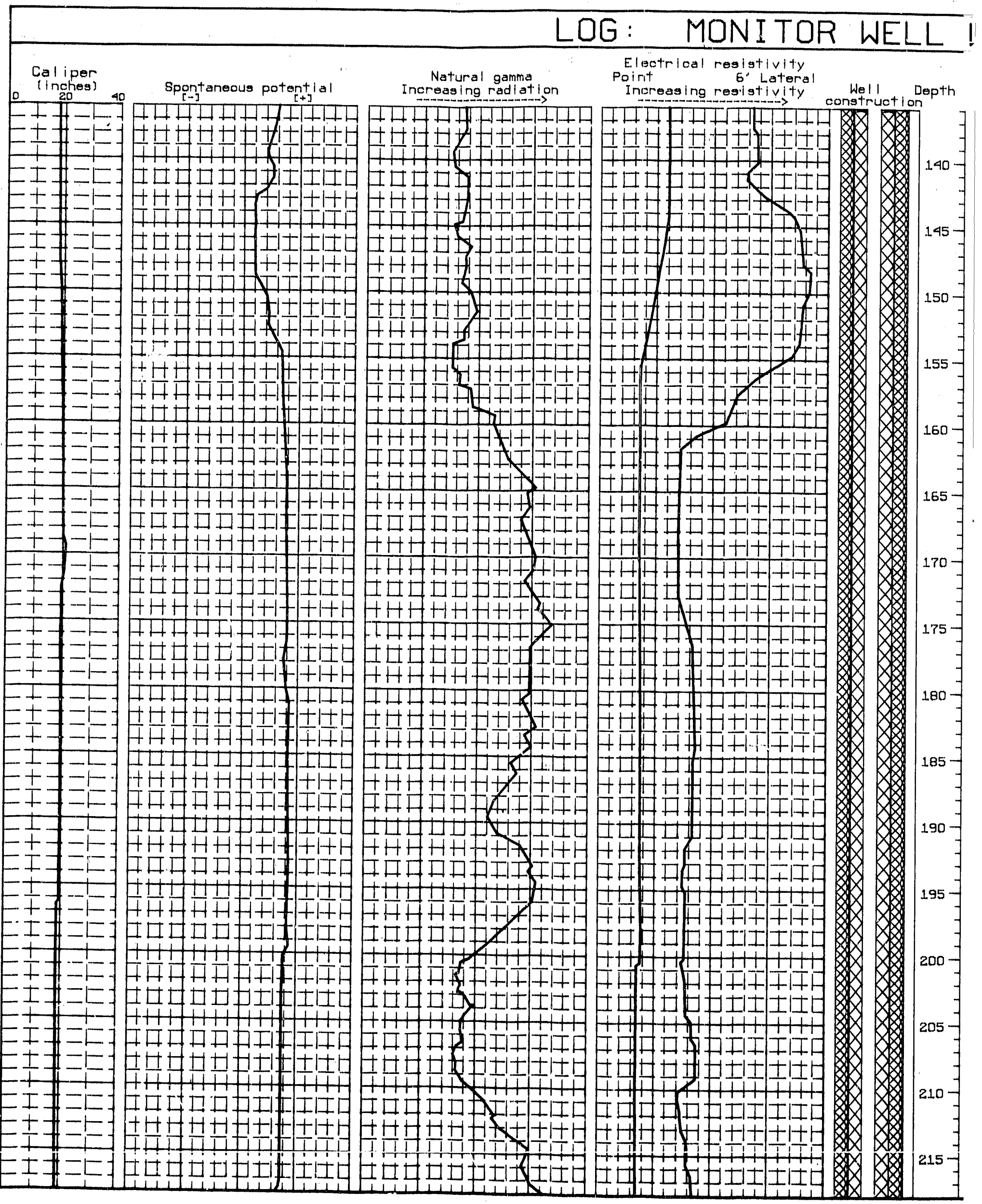




\section{$\sqrt{-35 C-03(C O N T \text { INUED) }}$}

Come ecovery 100 ROD
Lithology Lithologic descriptions and/or remarks

gray to dark gray fine grained sandstone interbeds with $<10-15 x$ s i t and Feot

gray to 1 ight gray, moderately indurated silty olaystone with $20-252$ silt damp to molst $\mathrm{p}$ at $146.5-148$ foet

10-158 very fine sand below 148 feet

(150.5-162) SANDSTONE, dark gray, moderately indurated, medium grained, <106 permeability

up to 158 red chert or volcanic graing below 157 feot

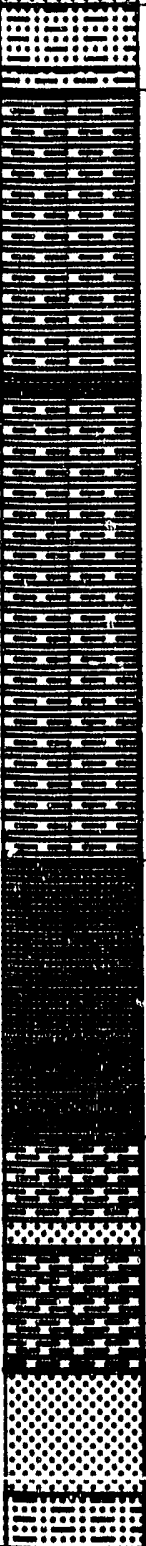

(162-165.1) SILTY SANDSTONE, as at 150.5-162 foot, excopt: 158 al|

possible green sandy siltstone interbed at 164.3-165.1 feet

(165 1-193) SILTY CLAYSTONE, brown-gray to groon, poorly indurated, 208 silt.

$30 x$ silt and $10 \%$ very fine sand below 169 foet

blue-green and $45 \%$ silt below 171 feet

purple-gray, moderately indurated claystone interbed at 175.4-176 feet green silty' claystone with $45-50 \%$ si it below 176 feet

light gray to gray, moderately indurated silty claystone with 258 silt

5-10x fine sand at 191-193 feet

(193-203) CLAYSTONE, as at 165.1-193 feet, except: <106 silt

10-158 silt at 202.5-203 foet

[203-211.5] CLAYEY SILTSTONE, purple- and green-gray, poorly indurated, $25 \%$

blye-gray moderately indurated sandstone interbed with $10-158$ silt and a
moderate ostimated permeability at $206-20$ foet fot

(211.5-250.5) SANDSTONE and SILTY SANDSTTNE, gray to blue 9ray moderately permeability

$20 x$ silt and $10 x$ clay bolow 216 foet 


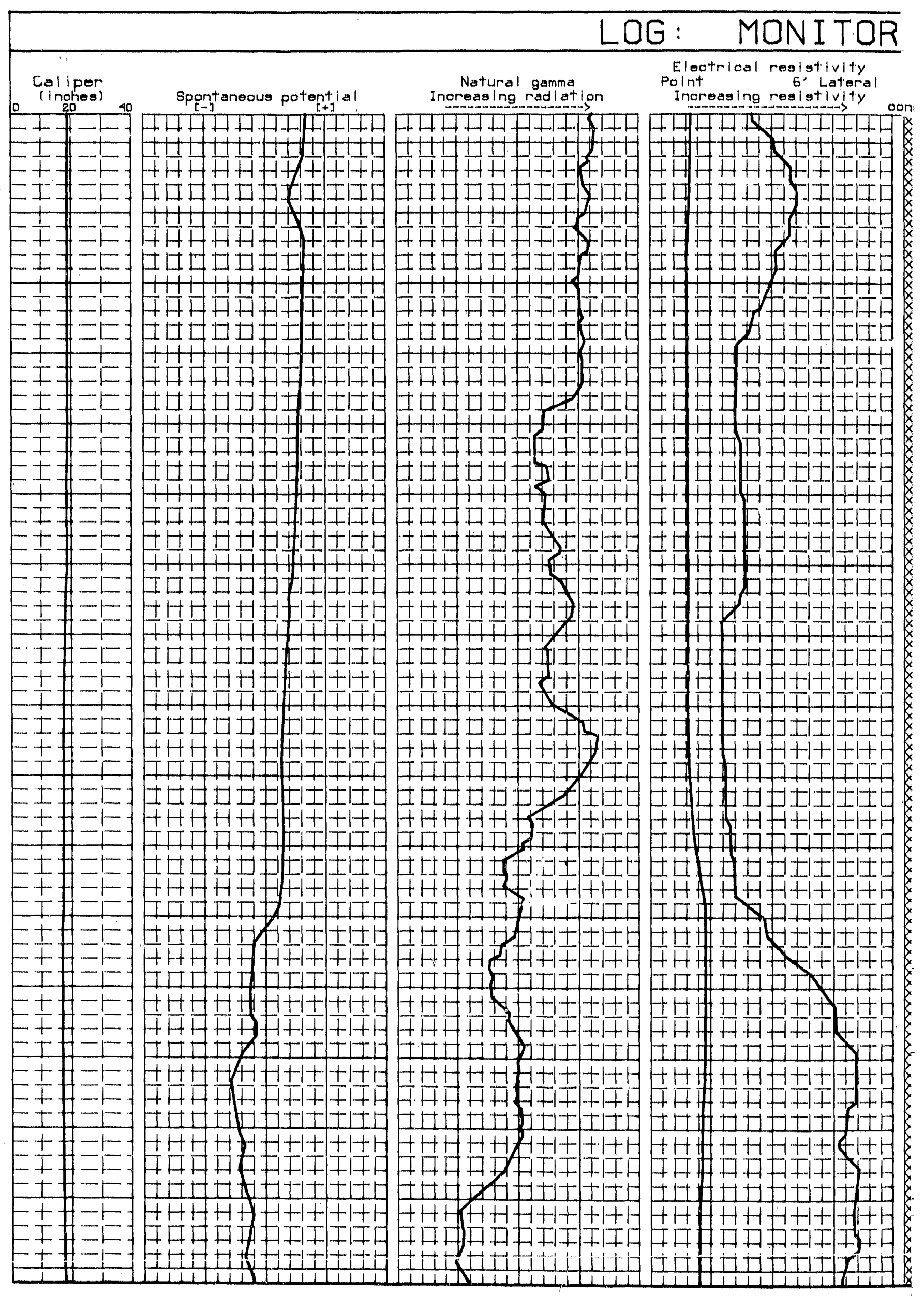




\section{WELL W-35C-03 (CONT INUED)}

oll Depth recore

truotion Depth reoovery Lithologlo descriptlons and/or remarks

green-g.ay moderately indurated siltatone interbed with a low estimated medium g-alned sandstone at $2435-250.5$ feet

medium gray, moderately indurated sandy ail tatune interbed with $15 x$ very Fine sand and a low est imated permeability at $248-249$ feet

Fine to medium gralned sandatorie at $250.5-254.5 \mathrm{Fe \theta t}$

blue green gray poor ly indurated, fine to medium grained silty gandatone interbed wi th $35 x$ sit and low est imated permeabil ity at $254.5-255.5$ feet

Fine to medium grained sardstone with <15\% silt at $257.5-258.5$ feet (258.5-262) CLAYEY SILTSTONE, green and gray-green, poorly indurated, $15-20 x$ (262-268) CLAYSTONE, greeri and red, moderately to poor y indurated, low
egtimated permeability: contacts from dril ar and cuttings (268-277) SILTSTONE to CLAYEY SILTSTONE, green-gray to purple-gray, moderately
indurated, ID-15x clay, low estimated permeability

blue-green, elayey giltatone with $25 x$ olay and $10-15 x$ very fine sand
below 272 feet

green, poorly indurated sandy siltstone interbed with 25-30x fine sand

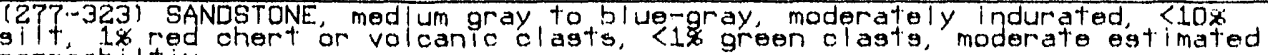
permeabil tiy

light gray, maderately indurated, laminated y ltatone interbed with $10 x$ dark gray to blue gray fine grained sandatone with $10-15 \%$ a 1 t and $5-10 x$ red grains below 293 Feot 


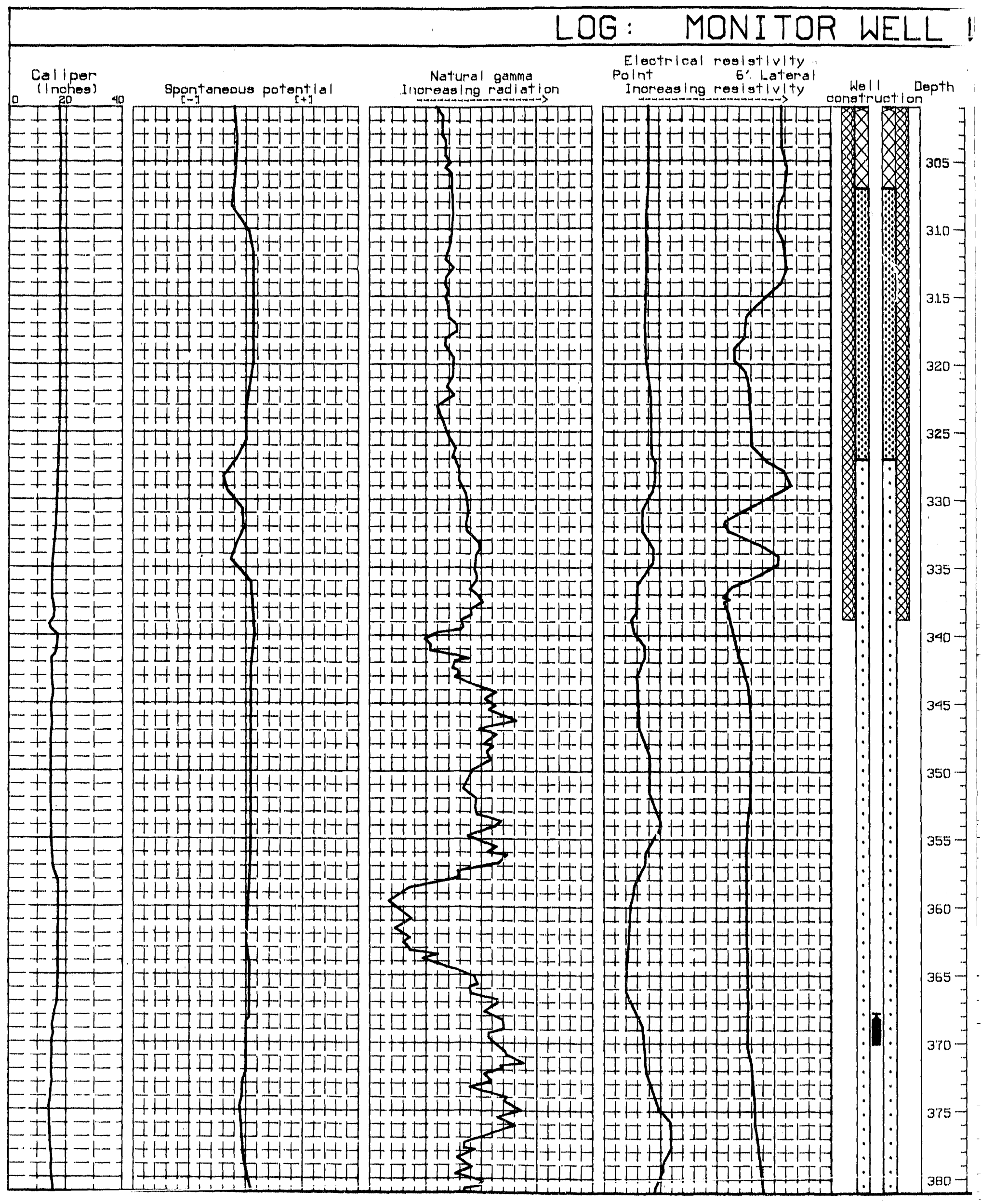

C- 14 


\section{$\sqrt{-35 C-03(C O N T \text { INUED) }}$}

\section{Core}

1 eovery 100 ROD

Lithology

Lithologie desoriptions and/or remarks

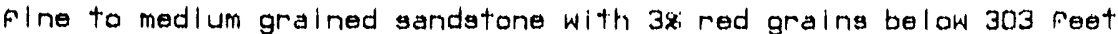

light gray to purple-gray, moderately indurated glltstone with a low salatone withe $10 x$ sil and a moderate to high estimated permeablity bandatang with 30 fort

very hard drilling suggests poss/ble oong fomerate interbed at 31.9 . 5-320 Feet green, poor ly inaurated silty c aystone interbed with $20 \%$ silt a 2. moderate est imated permeabli ity at $32 z-323$ foot

(323-329 5) SILTSTONE, black and purple-gray, moderately indurated, low

estimated permeability
fossils with pyrite overgrowths near 325 feet

(329.5-333) CLAYEY SILTSTONE, groen and green-gray, moderately indurated, $30 \%$

gree poorly ifrmedel claystone interbed at $331-331.5$ reot

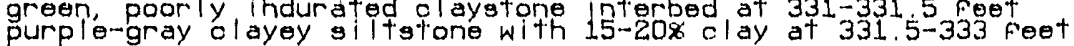

(333-344) SILTY CLAYSTONE, green and purple-gray, moderately indurated, $40 x$

silt, low porosity, low estimated permeability

stem fossills near 340 foet

(344-354.5) SANDSTONE, dark gray, moderately indurated, fine to medium grained, $10-158$ silt, 38 red grains, moderate porosity, moderate estimated

354.5-359) CLAYSTONE, light green-gray, poorly indurated, <106 gilt, low ostimated permeability

(359-362) SANDETONE, dark gray, poorly indurated, fine to med um grained, <fos a i t, $3 x$ red grains, moderate to high estimated permeability; from lack Fing grained sandstone at 361-361.5 feot; medium grained sandstone below

(362-368) CLAYSTONE, green, sticky; from driller

(368-371) SILTSTONE, gray, moderately indurated, $10-158$ clay, low estimated permeability (371-374) SANDSTONE dark gray to black, poorly indurated, 3-5x red grains,
moderate to high est imated permeability

(374-381.) CLAYSTONE, green, poorly indurated, 10-15\% silt, low est imated permeability 


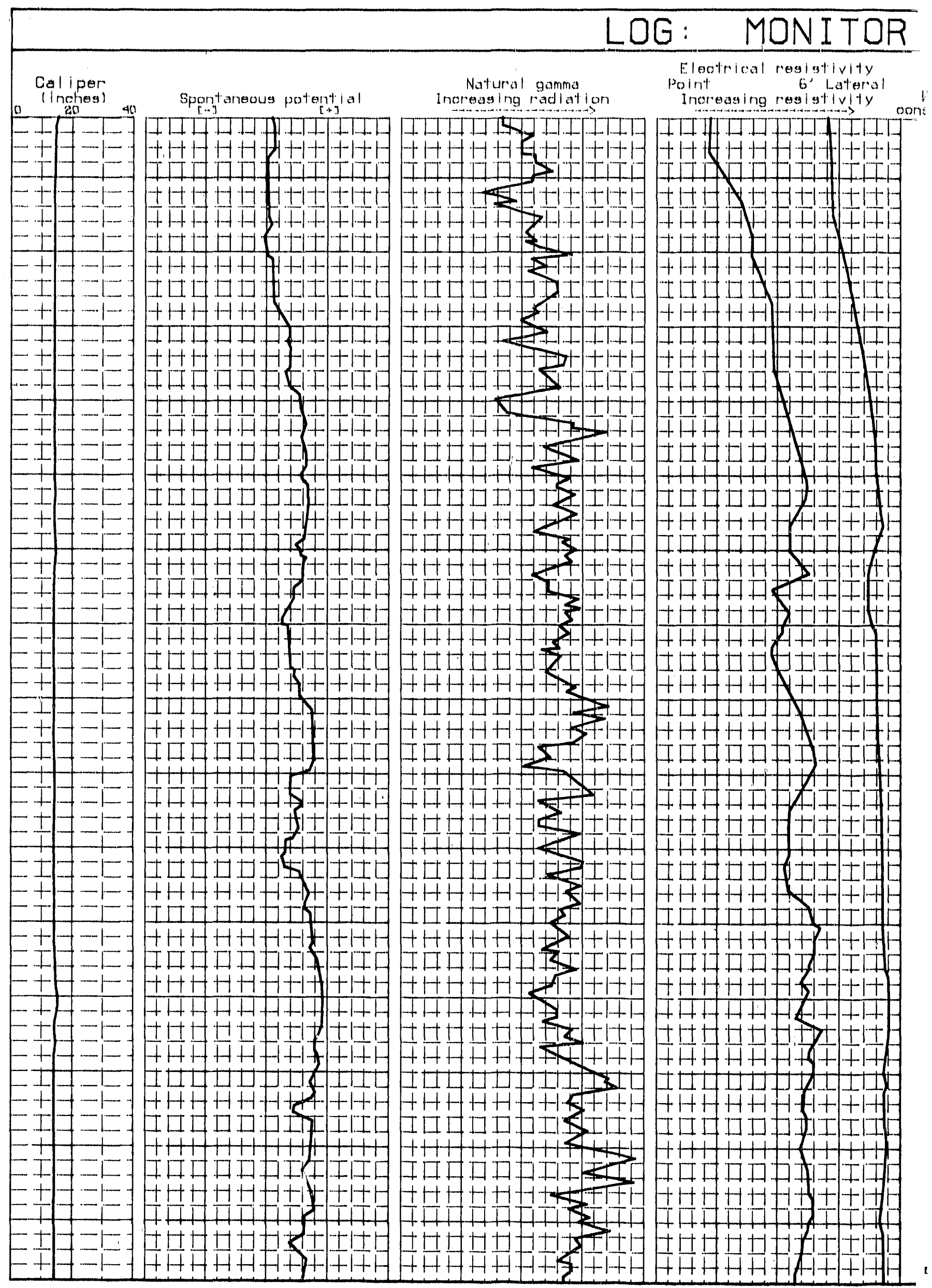




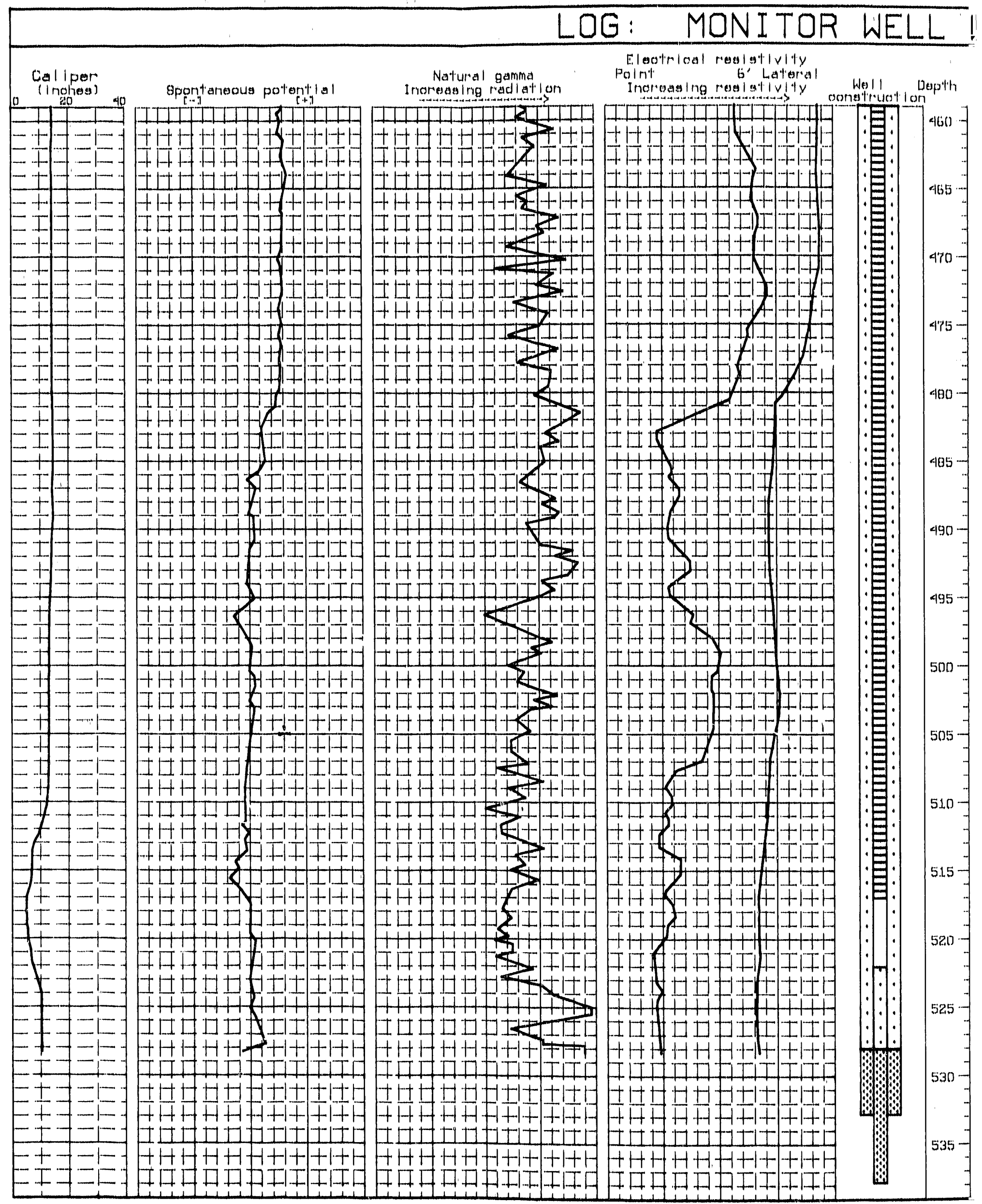


$\operatorname{cor} \theta$

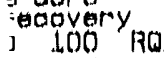

Li t tho l ogy

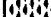

W thologlo desoriptlong and/or remarks

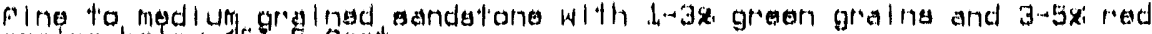
grathe be low a 6.5 . 5 foot

modium to ooarse grained andetone below al64 feet

9) Ightly ooarger gralned below ath.t feet

pyrite grains noar 475 froet

rough drilling suggests pobbly Interbed at 4177.5.4\%17.7 feest

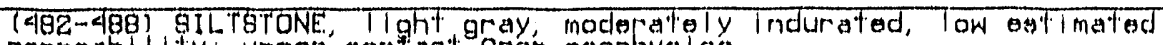
permeabllity: upper coritgot fróm geophyslos

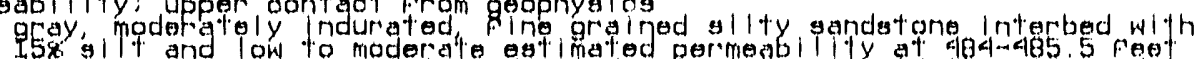

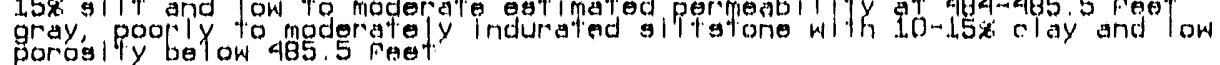
EEEE

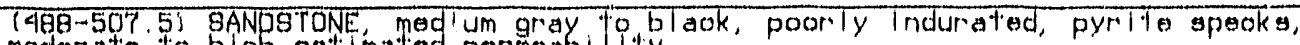

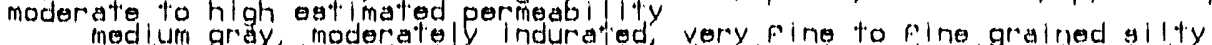

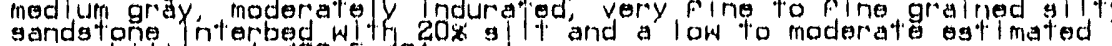
sandstone niterbeg Wl biack, medium to goarse grained sandstone with $5 x$ red gralng and high

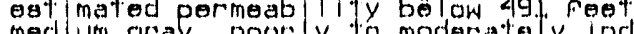

med um gray, poorly to modergtely induraled sil totone interbed with dontacts from goophys los

Fine graimed sandstone below sor feet

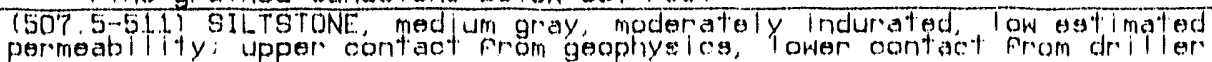

(5.L.-5.Le) SILTY SANDSTONE, medium gray, poorly to moderately indurated, very fine grained, zox silt moderate estimated permeability

Brown, poorly indurated silly olays one interbed with $35-40 * 311$ t and a low estimated permeability at 5.3 .5 .35 fest Fine grained silty sandstone with $15 x$ sit and a low to moderate poros ty and est imated permeability be low 5.35 feet

(5LE-5CLL) SILTY CLAYSTONE, I ght to medium gray, poorty indurated, $30-35 x$

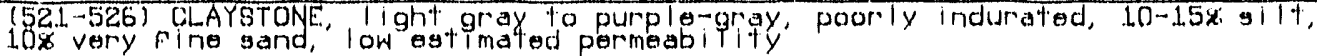

(52.5 537 . 8) 9ILTY SANDSTONE medium gray moderately indurated very fine grained, $20-40 x$ gitits $5 x$ red olasty medium gray to purplo-gray, micaceous gil storne ntorbed with $10 \cdots 15 x$

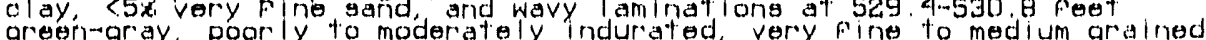
greerngray poor ly to moderately indurated, very fine to medium gralned bolow 530 .

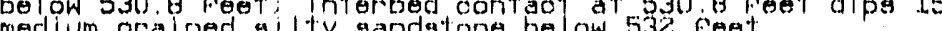

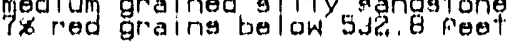

Fine to medium grained bolow 535,7 foot

med ium gray, maderate y to well indurated of ayoy siltstone interbed with 20* clay and a low est mated permeabli ty at $536.5-537$, z foet

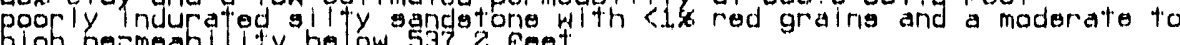
$T D=537 \%^{\circ}$ 


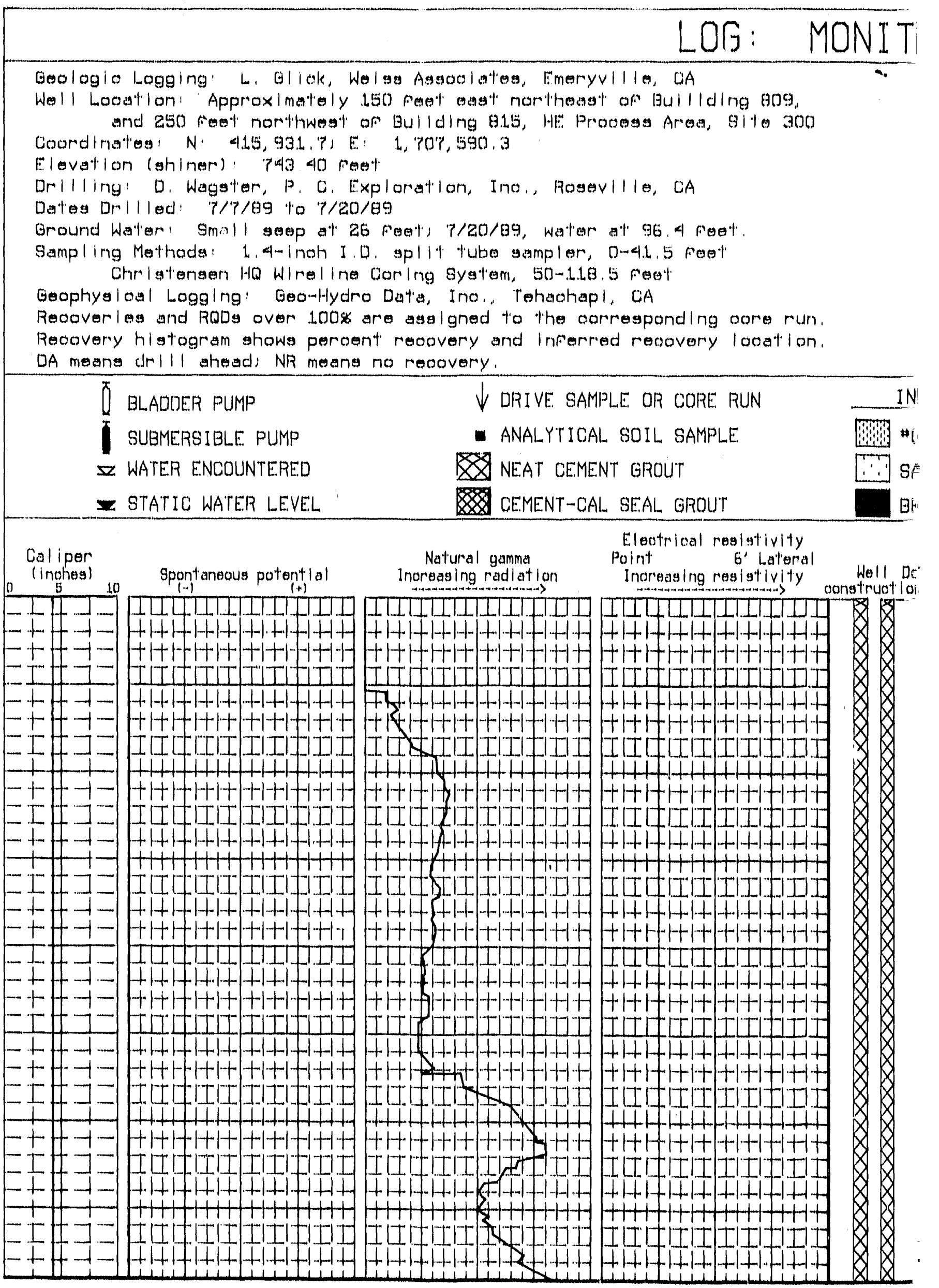




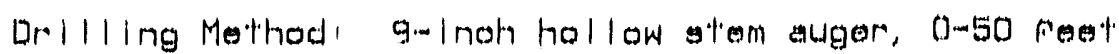

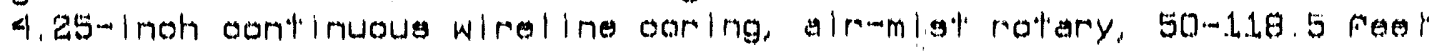

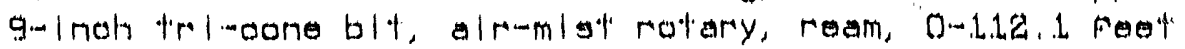

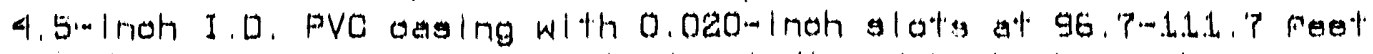

Analytiogl Notes: No VoC oonstituente lexoluding TOF. Whlah is shown on

log and ohloroform and froon 1.1, whloh may be laboratory artifaotss)

were identified in soll al or above the the deteotion $1 / \mathrm{mit}$ of

$0.0002 \mathrm{mg} / \mathrm{kg}$. No soluble melals were Identifed above the GTLC in

soll samples from 0.2, 5.5, 1.1, 15.7, 20.7 , and 28.3 Feot. The

desteotion $1 / \mathrm{mits}$ for HMX and RDX are <0,00.1 mg/kg exoept as noted.

ND Indloates none deteoted.

Estlmatos of gravels, sands, and fines are fild visual ostimates

Notation of bedding and Fraotures: l. Depth(s)/dip(s)\%/oumment (s) I]

\begin{tabular}{|c|c|c|}
\hline EX TO SYMBOLS & SISOS SLUGH MATERIAL & ¿] INTERSECTING FRACTURES \\
\hline SAND & \# SLOTTED CASING & CLOSED FRACTURES \\
\hline ND PACK & ???? APPROXIMATE CONTHW & $\triangle$ OPEN FRACTURES \\
\hline NTONITE & IIIIII GRADATIONAL CONTACT & [는뎐 FRACTURE ZONE \\
\hline
\end{tabular}

ith recovery Blows Fraotures

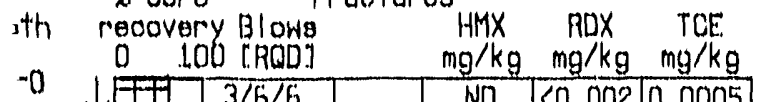

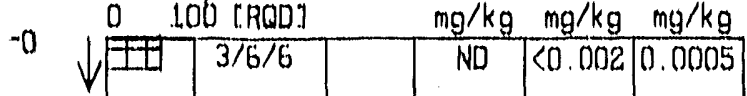

x

$-5 \quad \downarrow$

$3 / 42 / 49$

DA

$\cdot .15$

$\left.\vee \frac{\# A}{D A}\right|^{3 / 26 / 50+1}$

20

DA

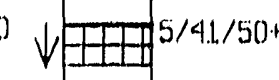

$D A$

25

30

0.005

ND

ND

ND

Analytioal soll samples

VLithology Lithologie deseriptions and/or romarks

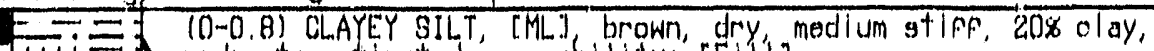
moderates est imated 'sermability: t.Fili

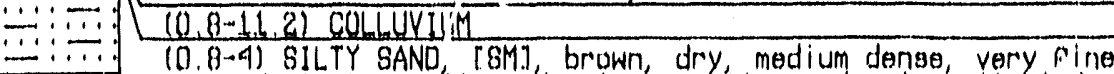
grained, $15-208$ silt, moderate porosity, moderate estilmated permeability

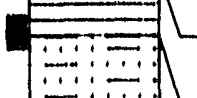

(4-5. 8) Cl.AY, TCLT brown, dry, medlum gt Iff, 10-158 allt, low ostimated permesability

(5.8-9) 8ILTY SAND, [8M1, yel low-brown, dry to damp, medium derrge, medium to voarse grained, 158 silt, moderate porren, moder'ate estimated permeability

$10-158$ pebbles to 0.1 inch at $5.8-6.5$ foet

(9-11.2) CLAYEY 81LT [MLI brown, dry to damp, very st IFF, 208 clay law estimated permeabllity

(1.1.2-1LB.5) TERIIARY SEDIMENTARY AOCKS

(1.1.2-22) interbedded SANDSTONE to SILTY SANDSTONE and

CONGLOMERATE, yol low-brown, dry to damp, moderately indurated, coarse gand well rounded pebbleg with minor angular (chert is

pebbles to 0.2 inch, 10-15x gilt, moderato porosity, low to moderate est i mated permeabilily

gilty gandstone with $20 x$ gilt below 1.3 foet

gandy giltatone interbed with fine sand at 15-15.3 feest:

coarge grained ail ty gandstone al $153-15$. 7 foet

conglomerate with pebbles to 0.3 inch at $15,7-16$ feet: very

coarse arained gilty gandstone with minor reddiah ffe-oxide

2) gtaing and rare carbonate or gypsum below lif feet

conglomerate with pebbles to 0.6 inoh at $18.5-19,19.7-19: 8$, and $20.9-22 \mathrm{Fe \theta t}$.

(22-27) CLAYSTONE, green-brown, molgt moderately indurated,

10-1.58 silt, low egtimated permieabilify

Los medium sand, minar Fe-oxide stains, and mira plakes below 23 s feet; very minor water production at drilling depth 26 feet

127-32,5) SANDY SILTSTONE, brown, damp to moist, $20-25 x$ fine to medium sand, low estimated permeabilitiy

(32.5-37.5) SILTY CLAYSTONE, green-brown, damp to moist, 15-208 silt, low estimated permeability

$=35$

(37. 5-39) GRAVELLY CLAYSTONE, groen-brown, damp to moi 9t, 158 woll rounded pebblos to 0.2 inch low gat'imated permeability 


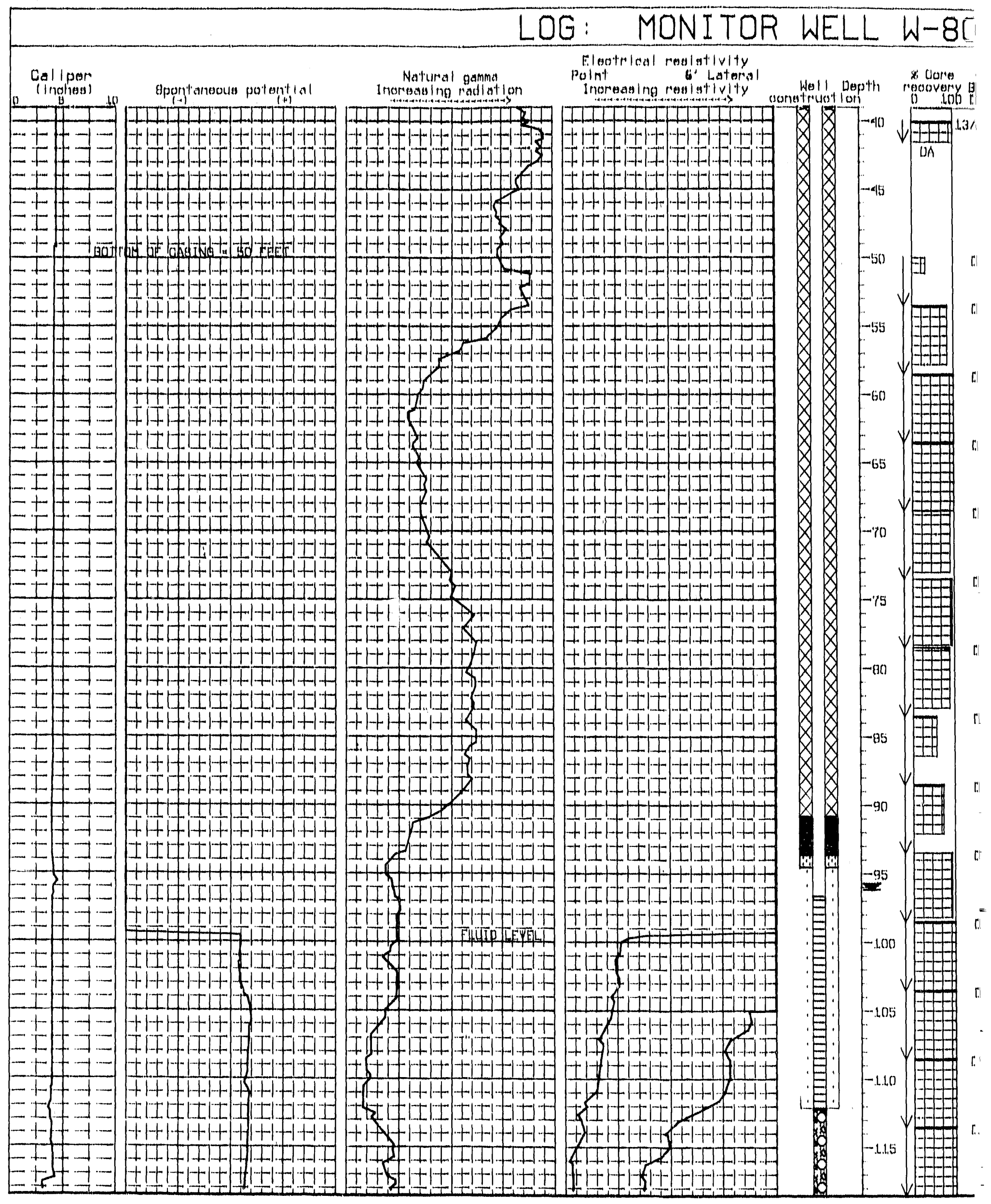




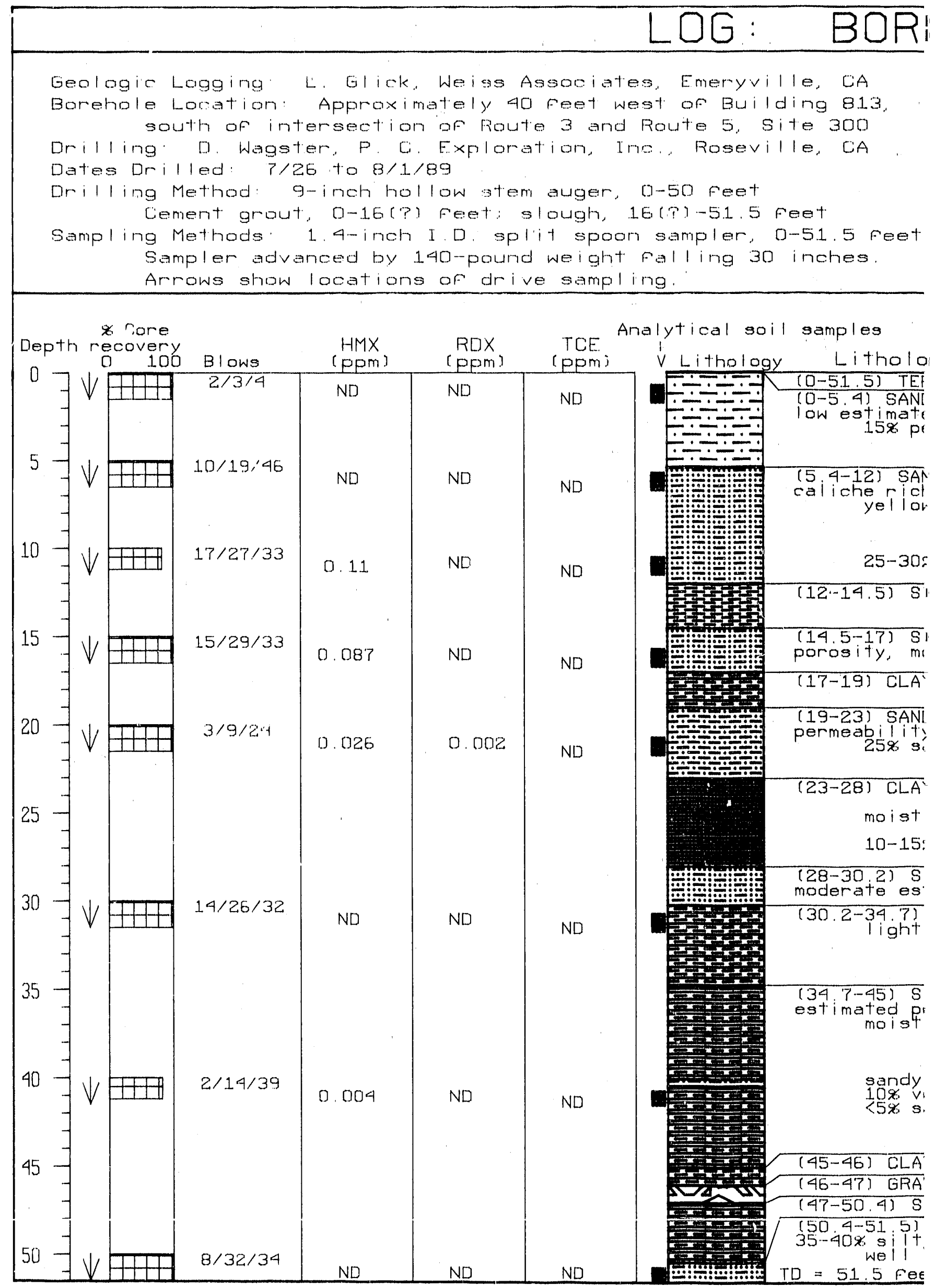




\section{HOLE 813-O1}

Ground Water. Not observed during dril I ing

Analytical Notes. No Vods lexcept for methylene chloride, a coman l aboratory artifact, which was identified at $0.0003 \mathrm{mg} / \mathrm{kg} \mathrm{im}$ a soil sample from 11 Feety were identified above 0.000R mg/kg No soluble metals were identified above their STLC in soil or rock samples from 1, F, 10.7, 16, 2.1. 31, 40.7, and 51 Feet. ND means none detected.

Recovery histograms show peroent recovery and recovery locations. Estimates of gravels, sands, and fines are field visual estimates.

3.ic desoriptions and/or remarks

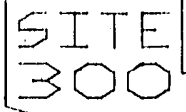

IARY SEDIMENTARY ROCKS y SILT, [ML] light brown, dry, medium stiff, $35 \%$ medium sand, $15 \%$ pebbles to 2 inches,

bbles to 0.2 inch at 0-0.5 feet; cel iche at 1.3 feet

DSTONE to SILTY SANDSTONE, white to light gray, dry, moderately indurated, 10-15\% silt, -brown with 15 -20

silt below 10.3 feet

LTSTONE, brown, dry to damp, 10-15\% clay, low to moderate estimated permeability LTY SANDSTONE, yel low-brown dry to damp, 15-20\% silt, some fe-axide stains, moderate

EY SILTSTONE, light brown, dry to damp, zos clay, low estimated permeability

Y SILTSTONE, light brown, dry to damp, 15\% fine to medium sand, low estimated nd below 20 feet

STONE, brown, dry to damp, 10-15\& silt, <5\& fine sand, low estimated permeability with 258 silt below 25 feet

isilt below 27 feet

LT SANDSTONE, yellow-brown, dry to damp, fine grained, $40 \%$ silt, moderate porosity. imated permeabi ity

CLAYEY SILTSTONE, brown dry to damp $20 \%$ clay, low estimated permeability green-gray to white with minor red [Feaxidel stains at 30.5 feet

LTY CLAYSTONE, gray-brown, dry to damp, 15-20\% silt, 5-10x pebbles to $1 / 8$ inch, low at $36-38$ and $38.5-40$ Feet

siltstone interbed with $15 x$ very fine sand at $40-40.4$ Feet

ry fine sand, no pebbles, and Fe-oxide 9 tains below 40 . 4 Feet

EY SILTSTONE, brown, damp to moist, 15-20\% clay, low estimated permeability

E.L, well rounded vocanic pebbles to 1.2 inches

LTY CLAYSTONE, brown, damp to moist, $20 x$ silt, Tow estimated permeability

SILTY SANDSTONE, Tight yellow-brown, to light gray, dry to damp fine to medium grained, Fe- and Mrooxide ota ned nodu! es, moderate ostimatod pormoability $-1$ 
Appendix D

Meteorological Data:

Site 300 
Table D-1. 1980 Site 300 rainfall (inches per day).

\section{Month}

Day-JAN- -FEB- -MAR- -APR- -MAY -JUN- JUL- -AUC- -SEP- OOCT- -NOV- -DEC-

\begin{tabular}{|c|c|c|c|c|c|c|c|c|c|c|c|c|}
\hline 1 & 0.02 & - & - & - & - & - & - & - & - & - & - & - \\
\hline 2 & - & - & 0.21 & - & - & - & 0.49 & - & - & - & - & - \\
\hline 3 & - & - & 0.01 & - & - & - & - & - & - & - & - & 0.34 \\
\hline 4 & - & - & - & 0.16 & - & - & - & - & - & - & - & 0.10 \\
\hline 5 & - & - & 0.20 & 0.24 & - & - & - & - & $\cdot$ & • & - & - \\
\hline 6 & . & - & 0.24 & - & - & - & - & - & - & - & - & - \\
\hline 7 & - & - & $\cdot$ & - & - & - & - & - & - & - & - & - \\
\hline 8 & 0.17 & - & - & - & $=$ & - & - & - & - & - & - & - \\
\hline 9 & 0.35 & - & - & - & 0.05 & - & - & - & - & - & - & - \\
\hline 10 & 0.30 & - & - & - & - & - & - & - & - & - & - & - \\
\hline 11 & 0.25 & - & - & - & - & - & - & - & - & - & - & - \\
\hline 12 & 0.11 & - & - & - & - & - & - & - & - & - & - & - \\
\hline 13 & 0.43 & - & - & - & - & - & - & - & - & - & - & - \\
\hline 14 & 0.03 & 0.22 & - & - & - & - & - & - & - & - & - & - \\
\hline 15 & 0.11 & 0.24 & - & - & - & - & - & - & - & - & - & - \\
\hline 16 & 0.01 & 0.38 & - & - & - & - & - & - & - & - & & - \\
\hline 17 & 0.28 & 0.07 & - & - & - & - & - & - & - & - & - & - \\
\hline 18 & - & 0.21 & - & - & - & - & - & - & - & - & : & - \\
\hline 19. & - & 0.44 & - & - & - & - & - & - & $"$ & - & - & 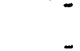 \\
\hline 20 & - & 0.37 & - & $0 .(22$ & - & - & - & - & - & - & - & 0.15 \\
\hline 21 & - & 0.07 & - & 0.08 & - & - & - & - & - & - & - & $\begin{array}{l}0.15 \\
001\end{array}$ \\
\hline 22 & - & 0.05 & - & 0.17 & - & - & - & - & - & - & 0.12 & 0.02 \\
\hline 23 & - & - & - & - & 0.06 & - & - & - & - & - & $\begin{array}{r}1.12 \\
.\end{array}$ & - \\
\hline 24 & - & - & - & - & - & - & - & - & - & - & - & 0.06 \\
\hline 25 & - & - & 0.20 & - & - & - & - & - & - & - & - & - \\
\hline 26 & - & - & - & - & - & - & - & " & - & - & - & - \\
\hline 27 & - & 0.21 & - & - & - & - & - & - & " & - & - & - \\
\hline 28 & - & - & - & 0.02 & - & - & - & - & - & - & - & 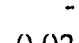 \\
\hline 29 & - & - & - & - & - & - & - & - & - & - & - & 0.03 \\
\hline 30 & - & - & - & - & - & - & 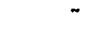 & - & - & - & - & $\begin{array}{r}0.46 \\
\end{array}$ \\
\hline 31 & - & - & 0.01 & - & - & - & - & - & - & - & - & 0.07 \\
\hline & 2.06 & 2.26 & 0.87 & 0.69 & 0.11 & 0.00 & 0.49 & 0.00 & $0.00)$ & $(0.0())$ & 0.12 & 0.61 \\
\hline
\end{tabular}

TOTAL: 1980 Rainfall 7.21 in.

Dash $(-)=$ No measurable rainfall 
Table D-2. 1981 Site 300 rainfall (inches per day).

\begin{tabular}{|c|c|c|c|c|c|c|c|c|c|c|c|c|}
\hline \multirow[b]{2}{*}{ Day. } & \multicolumn{12}{|c|}{ Month } \\
\hline & JAN- & -FEB- & -MAR- & -APR- & -MAY & $-. J U N-$ & -JUL- & -AUG- & -SEP- & $-O C T-$ & $-N O V$ & -DEC- \\
\hline 1 & - & - & 0.30 & - & - & - & - & - & - & - & - & - \\
\hline 2 & - & - & 0.09 & - & - & - & - & - & - & - & - & - \\
\hline 3 & - & - & - & - & - & - & - & - & - & - & - & - \\
\hline 4 & - & - & 0.22 & - & - & - & - & - & - & 0.13 & - & - \\
\hline 5 & - & - & - & - & - & - & - & - & - & - & 0.12 & - \\
\hline 6 & - & - & - & - & - & - & - & - & - & - & 0.02 & 0.01 \\
\hline 7 & 0.01 & - & - & - & - & - & - & - & - & 0.01 & - & 0.01 \\
\hline 8 & - & 0.28 & - & - & - & - & - & - & - & - & - & 0.04 \\
\hline 9 & - & 0.04 & - & - & - & - & - & - & - & - & - & 0.04 \\
\hline 10 & - & 0.03 & - & - & - & - & - & - & - & 0.01 & - & - \\
\hline 11 & - & 0.01 & - & - & - & - & - & - & - & - & 0.50 & 0.06 \\
\hline 12 & - & - & 0.12 & - & - & - & - & - & - & - & 1.30 & 0.03 \\
\hline 13 & - & 0.04 & 0.28 & - & - & - & - & - & - & - & - & - \\
\hline 14 & - & 0.06 & - & - & - & - & - & - & - & - & - & - \\
\hline 15 & 0.02 & - & 0.20 & - & - & - & . & - & - & - & - & - \\
\hline 16 & 0.01 & - & - & - & - & - & - & - & - & - & 0.09 & - \\
\hline 17 & 0.01 & - & - & - & - & - & - & - & - & - & 0.05 & - \\
\hline 18 & - & - & 0.14 & 0.37 & 0.15 & - & - & - & - & - & - & 0.17 \\
\hline 19 & - & 0.01 & 0.34 & 0.15 & - & - & - & - & - & - & - & 0.03 \\
\hline 20 & 0.02 & - & 0.02 & - & - & - & - & - & - & - & - & 0.11 \\
\hline 21 & - & - & 0.16 & - & - & - & - & - & - & - & 0.12 & - \\
\hline 22 & 0.22 & - & - & - & - & - & - & - & - & - & 0.02 & - \\
\hline 23 & 0.07 & - & - & - & - & - & - & - & - & - & 0.04 & - \\
\hline 24 & - & 0.09 & - & - & - & - & - & - & $\ldots$ & - & 0.03 & - \\
\hline 25 & - & 0.12 & 0.10 & - & - & - & - & - & - & - & - & - \\
\hline 26 & 0.53 & - & 0.05 & - & - & - & - & - & - & - & 0.08 & . \\
\hline 27 & 0.86 & - & - & - & - & - & - & - & - & 0.08 & 0.26 & - \\
\hline 28 & 0.62 & 0.01 & - & - & - & - & - & - & - & 0.54 & - & 0.75 \\
\hline 29 & 0.14 & - & - & - & - & - & - & - & - & 0.01 & - & 0.20 \\
\hline 30 & 2.51 & - & - & - & - & - & - & - & - & - & - & \\
\hline 31 & - & - & - & - & - & - & - & - & - & - & - & 0.01 \\
\hline & 5.02 & 0.69 & 2.02 & 0.52 & 0.15 & 0.00 & 0.00 & 0.00 & 0.00 & 0.78 & 2.63 & 1.46 \\
\hline
\end{tabular}

TOTAL: 1981 Rainfall 13.27 in.

Dash $(-)=$ No measurable rainfall 
Table D-3. 1982 Site 300 rainfall (inches per day).

\section{Month}

Day-JAN- -FEB- -MAR- -APR- -MAY -JUN- JUL- -AUG- $-\overline{S E P-}$-OCT- - NOV- - DEC-

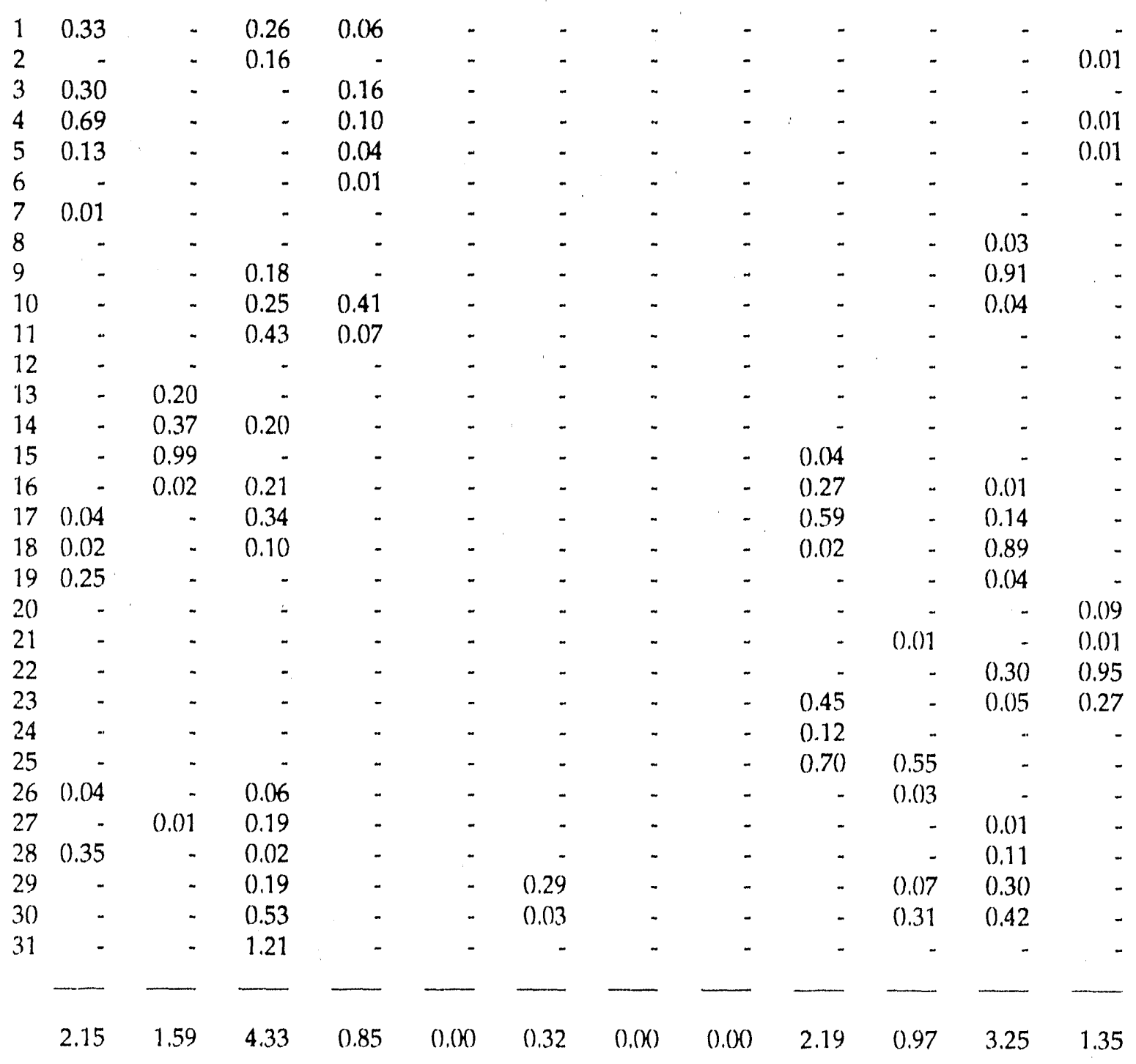

TOTAL: 1982 Rainfall $17.00 \mathrm{in}$.

Dash $(-)=$ No mcasurable rainfall 
Table D-4. 1983 Site 300 rainfall (inches per day).

\section{Month}

Day-JAN- -FEB- -MAR- -APR- -MAY -JUN- JUL- -AUG -SEP- OCT- -NOV- -DEC-

\begin{tabular}{|c|c|c|c|c|c|c|c|c|c|c|c|c|}
\hline 1 & - & - & 0.25 & - & - & . & - & - & - & 0.03 & - & - \\
\hline 2 & - & - & 0.21 & - & . & - & - & - & - & - & - & - \\
\hline 3 & - & - & 0.27 & - & - & - & - & - & - & - & - & 0.29 \\
\hline 4 & - & - & - & - & - & - & - & - & - & - & - & - \\
\hline 5 & 0.01 & 0.11 & 0.19 & - & 0.02 & - & - & - & - & - & - & - \\
\hline 6 & 0.01 & 0.64 & 0.17 & - & - & - & - & - & - & - & - & - \\
\hline 7 & - & 0.22 & - & - & - & - & - & - & - & - & - & - \\
\hline 8 & - & 0.07 & - & - & - & - & - & - & - & - & 0.08 & " \\
\hline 9 & - & - & - & - & - & - & - & - & - & - & 0.18 & 0.32 \\
\hline 10 & - & - & 0.76 & - & - & - & - & - & - & - & 0.99 & 0.08 \\
\hline 11 & - & 0.05 & - & - & - & - & - & - & - & - & - & 0.31 \\
\hline 12 & - & 0.11 & 0.42 & - & - & - & - & - & - & - & 0.02 & - \\
\hline 13 & - & 0.06 & 0.50 & - & $\cdot$ & - & - & - & - & - & 0.32 & - \\
\hline 14 & - & - & - & - & - & - & - & - & - & - & - & $(0.02$ \\
\hline 15 & 0.01 & . & - & - & - & - & - & - & - & - & - & - \\
\hline 16 & 0.25 & - & 0.10 & - & - & - & - & - & - & - & 0.20 & - \\
\hline 17 & - & - & 0.16 & - & - & - & - & - & - & - & 0.49 & - \\
\hline 18 & 0.37 & 0.37 & 0.02 & 0.10 & - & - & - & - & - & - & - & - \\
\hline 19 & 0.11 & - & - & 0.02 & - & $=$ & - & 0.63 & - & - & 0.15 & - \\
\hline 20 & & - & 0.07 & 0.23 & - & " & - & - & - & - & 0.55 & - \\
\hline 21 & 0.04 & - & - & - & - & - & - & - & - & - & - & \\
\hline 22 & 1.51 & - & 0.18 & - & - & - & - & - & - & - & 0.02 & 0.70 \\
\hline 23 & - & - & 0.12 & - & - & - & - & - & - & - & 0.90 & 0.10 \\
\hline 24 & 0.02 & 0.15 & 0.36 & 0.07 & - & - & - & - & - & - & - & 0.44 \\
\hline 25 & & & - & 0.21 & - & - & - & - & - & - & - & 0.10 \\
\hline 26 & 0.96 & 0.35 & 0.10 & - & - & - & - & - & - & - & - & 0.08 \\
\hline 27 & 0.11 & 0.49 & 0.22 & 0.65 & - & - & - & - & - & - & - & - \\
\hline 28 & 0.43 & 0.75 & - & 0.26 & - & - & - & - & - & - & - & - \\
\hline 29 & 0.03 & - & - & 0.16 & - & - & - & - & 0.02 & 0.19 & - & - \\
\hline 30 & - & - & - & 0.07 & - & - & - & - & 0.57 & 0.04 & - & 0.20 \\
\hline 31 & - & - & . & - & - & - & - & - & - & - & - & $0 .(02$ \\
\hline & 3.86 & 3.37 & 4.10 & 1.77 & 0.02 & $(0.06)$ & 0.0() & 0.63 & 0.59 & 0.26 & 3.90 & 2.66 \\
\hline
\end{tabular}

TOTAL: 1983 Rainfall $21.16 \mathrm{in}$.

Dash $(-)=$ No measurable rainfall 
Table D-5. 1984 Site 300 rainfall (inches per day).

\section{Month}

Day-JAN- -FEB- -MAR- -APR- -MAY -JUN- JUL- -AUG- -SEP- OCT- -NOV- -DEC-

\begin{tabular}{|c|c|c|c|c|c|c|c|c|c|c|c|c|}
\hline 1 & - & - & - & 0.10 & - & - & - & - &. & 0.03 & - & - \\
\hline 2 & - & - & - & - & - & - & - & - & - & - & - & 0.17 \\
\hline 3 & - & " & - & - & - & - & - & - & - & - & - & 0.01 \\
\hline 4 & - & - & - & - & - & - & - & - & - & - & 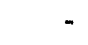 & - \\
\hline 5 & 0.01 & - & - & - & - & - & - & - & - & - & - & 0.02 \\
\hline 6 & 0.01 & - & - & - & - & - & - & . & - & - & 0.20 & - \\
\hline 7 & 0.01 & - & - & - & - & - & - & - & - & . & 0.30 & - \\
\hline 8 & 0.03 & - & - & 0.08 & - & - & - & - & - & - & 0.33 & - \\
\hline 9 & 0.05 & 0.21 & - & - & - & - & - & - & - & - & - & 0.20 \\
\hline 10 & 0.01 & - & : & 0.02 & - & - & - & - & - & - & 0.15 & 0.07 \\
\hline 11 & 0.01 & 0.02 & - & - & " & - & - & - & - & 0.34 & 0.01 & - \\
\hline 12 & - & 0.12 & - & - & - & - & - & - & - & - & 0.21 & - \\
\hline 13 & - & - & 0.11 & - & - & - & - & - & - & - & 0.29 & 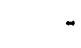 \\
\hline 14 & - & - & 0.03 & - & - & - & - & - & - & - & - & - \\
\hline 15 & 0.02 & - & 0.07 & - & - & - & - & - & - & - & 0.03 & 0.37 \\
\hline 16 & 0.16 & - & 0.15 & - & - & - & - & - & - & 0.49 & 0.19 & - \\
\hline 17 & - & - & - & - & - & - & - & - & - & - & 0.12 & ـ \\
\hline 18 & - & - & - & 0.16 & - & - & - & - & 0.02 & - & 0.04 & $0 .(03$ \\
\hline 19 & - & - & - & 0.06 & - & - & - & - & - & - & - & 0.01 \\
\hline 20) & - & - & - & - & - & - & - & - & - & - & ()() 1 & - \\
\hline 21 & - & - & - & - & - & - & - & - & - & - & - & - \\
\hline 22 & 0.10 & - & - & - & - & - & - & - & - & - & - & - \\
\hline 23 & - & - & - & - & - & - & - & - & - & - & . & - \\
\hline 24 & - & - & - & - & - & - & . & - & - & - & 0.24 & 0.01 \\
\hline 25 & - & - & - & - & " & - & - & - & - & - & - & - \\
\hline 26 & - & - & - & - & - & - & - & - & - & - & - & 0.25 \\
\hline 27 & - & - & - & - & - & - & - & - & - & - & 0.48 & - \\
\hline 28 & - & - & - & - & - & - & - & - & - & - & 0.09 & . \\
\hline 29 & - & - & - & - & - & - & - & - & - & $(0.12$ & - & $(0.01$ \\
\hline 30) & - & - & - & - & - & - & - & - & - & - & - & - \\
\hline 31 & - & - & - & - & - & - & - & - & - & - & - & - \\
\hline & 0.41 & 0.35 & 0.36 & 0.42 & $(0.0(1)$ & $0 .(K)$ & $0 .(0)$ & 0.00 & ().()2 & 0.95 & 2.69 & 1.15 \\
\hline
\end{tabular}

Dash $(-)=$ No measurable rainfall 
Table D-6. 1985 Site 300 rainfall (inches per day).

\section{Month}

Day-JAN- -FEB- -MAR- -APR- -MAY -JUN- JUL- -AUG- -SEP- OCCT- -NOV- -DEC-

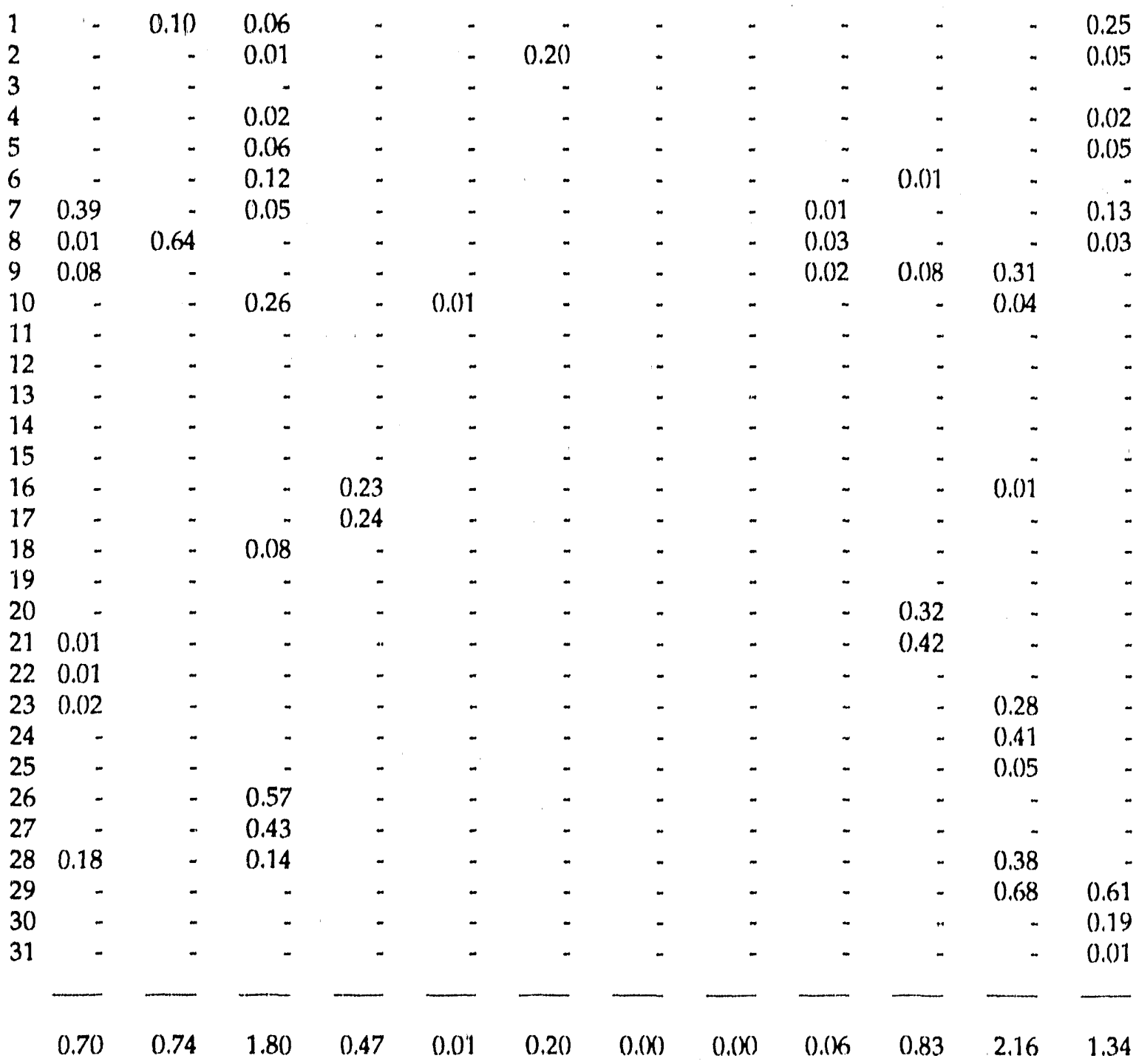

TOTAL: 1985 Rainfall 8.31 in.

Dash $(-)=$ No measurable rainfall 
Table D-7。 1986 Site 300 xainfall (Inches per day).

\begin{tabular}{|c|c|c|c|c|c|c|c|c|c|c|c|c|}
\hline \multirow[b]{2}{*}{ Day. } & \multicolumn{12}{|c|}{ Month } \\
\hline & JAN & -FEB. & -MAR & -Al'R. & -MAY & -JUN. & .JUL" & AUG. & -SEP. & OCT' & -NOV. & -DEC- \\
\hline 1 & - & 0.37 & - & - & - & - & - & - & - & 0.03 & . & 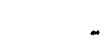 \\
\hline 2 & - & . & - & - & . &. & . & . & - & . & . & . \\
\hline 3 & 0.15 & 0.22 & - & & 0.03 & - &. & - & - & - & - & - \\
\hline 4 & 0.05 & & - & & 0.01 & - & - & - & - & . & - & - \\
\hline 5 & 0.07 & 0.03 & & 0.02 & - & . & - & - & - & . & - & 0.16 \\
\hline 6 & - & - & & 0.08 & . & - & . & - & - & . & . & - \\
\hline 7 & - & . & & 0.42 & - &. & - & - & - & - & - & - \\
\hline 8 & - & - & 0.10 & - & - & . & - & - & - & . & - & - \\
\hline 9 & - & - & 0.59 & - & - & " & - & - & ." & - & - & - \\
\hline 10 & - & - & 0.97 & - & - &. & . & - & - & 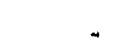 & - & - \\
\hline 11 & - & 0.04 & 0.21 & - & - & - & - & - & . & . & - & - \\
\hline 12 & - & 0.16 & 0.13 & - & - & - & - & - & - & - & - & - \\
\hline 13 & 0.01 & 0.06 & 0.31 & - & . & - & - & - & . & - & - & 0.01 \\
\hline 14 & 0.06 & 0.39 & . & - & . & - & - & - & - & . & - & 0.01 \\
\hline 15 & & 0.53 & 0.51 & 0.10 & . & . & - & . & - & . & - & 0.11 \\
\hline 16 & 0.08 & 0.16 & 0.12 & 0.01 & - & . & . & - & - & . & . & . \\
\hline 17 & 0.02 & 0.25 & - & - & - &. & - & - & 0.09 & . & - & . \\
\hline 18 & - & 1.00 & . & . & . &. & - & - & - & . & - & 0.05 \\
\hline 19 & 0.01 & 0.20 & - & . & - & . &. & - & - & - & - & 0.19 \\
\hline 20 & - & - & - & - & - & - & - & - & . & . & . & 0.11 \\
\hline 21 & - & 0.01 & - & " & - & - & - & - & - & . & - & - \\
\hline 22 & & - & - & - & - & - & - & - & - & . & - & . \\
\hline 23 & . &. & . & - & . & . & . & . & . & . & . & . \\
\hline 24 & - & - & - & - & . & - & . &. & 0.24 & . & - & \\
\hline 25 & - & - & - & - & " & - & - &. & . & . & - & - \\
\hline 26 & - & - & - & - & . & - & - & - & - & . & - & . \\
\hline 27 & - & - & - & - & - &. & - &. & 0.01 & 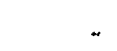 & - & 0.01 \\
\hline 2.8 & - & - & - & - & . & - & - & - & - & - & 0.02 & \\
\hline 29 & 0.12 & - & - & - & - & - & - & - & - & - & - & \\
\hline 30 & 0.23 & - & - & . & . & . & . & . & . & . & - & 0.01 \\
\hline 31 & 0.27 & - & . & - & - & - & " &. & . & . & - & 0.01 \\
\hline & 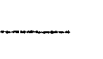 & $\ldots$ & - & - & - & - & - & - & $\ldots$ & - & - & $\ldots$ \\
\hline & 1.07 & 3.42 & 2.94 & 0.63 & 0.04 & $0.0(0)$ & 0.00 & 0.00 & 0.34 & 0.00 & 0.02 & 0.67 \\
\hline
\end{tabular}

TOTAL: 1986 Rainfall 9.13 in.

Dash $(-)=$ No measurable rainfall 
Table D-8. 1987 Site 30( rainfall (Inches per day).

Month

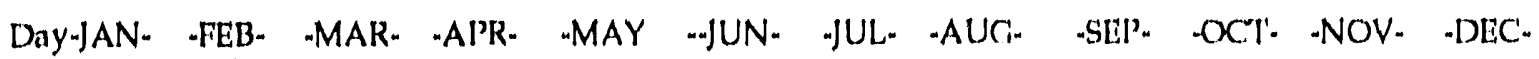

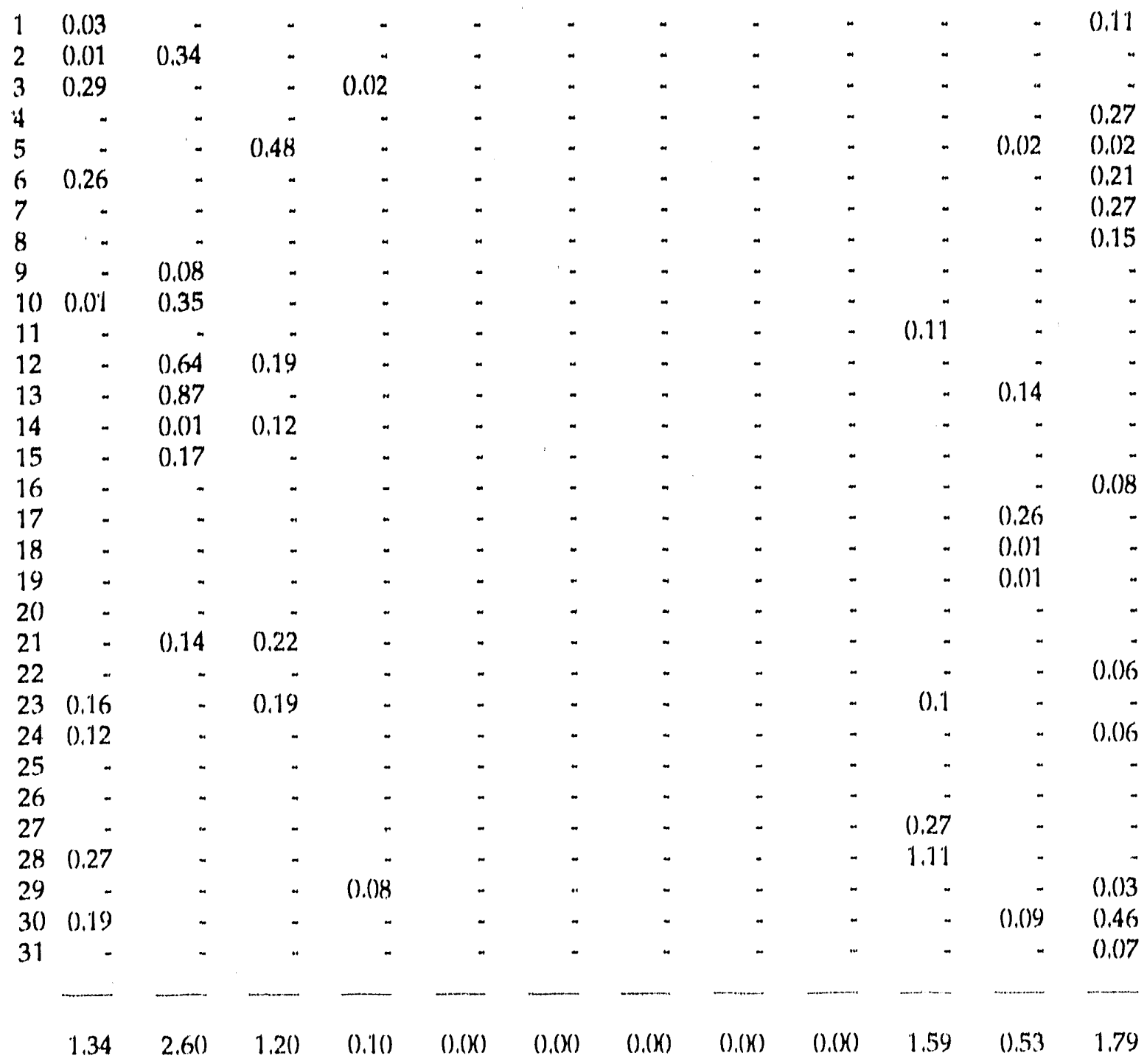

TOTAL: 1987 Rainfall $9.15 \mathrm{in.}$

Dash $(-)=$ No monsurable rainfall 
Table D-9. 1988 Slte 300 rainfall (luches per day).

Month

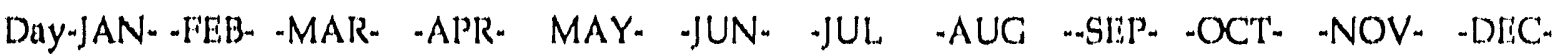

\begin{tabular}{|c|c|c|c|c|c|c|c|c|c|c|c|c|}
\hline 1 & 0.01 & . & 0.07 & . & . & - & - & . & . & . & - & 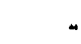 \\
\hline 2 & 0.18 & " & - & . & - & . & . & " & - & " & - & - \\
\hline 3 & 0.04 & . &. & . & - & . & . & $\because$ & . & - & - & . \\
\hline 4 & 0,14 & . & - & " & " & - & - & - & - & " & - & - \\
\hline 5 & 0.01 & - & . & - & 0.01 & - & " & - & " & - & - & . \\
\hline 6 & . & " & - & - & 0.1 & 0.13 & - & - & - & - & - & - \\
\hline 7 & 0.06 & - & . & - & 0,13 & 0.06 & - & . & - & " & " & . \\
\hline 8 & 0.01 & - & - & - & - & - & . &. & . & - & . & - \\
\hline 9 & “ & - & - & . & - & - & . & - & - & - & . & . \\
\hline 10 & 0.02 & - & - & - & . & - & . & - & - & - & - & . \\
\hline 11 & 0.03 & . & - & - & - & " & - & " & . & - & - & - \\
\hline 12 & . & - & . & - & . & - & . & . & - & . & 0,01 & . \\
\hline 13 & . & . & . & 0.07 & - & - & - & - & - & . & 0.12 & \\
\hline 14 & - & . & - & 0.34 & - & 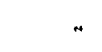 & . & - & . & 0,01 & 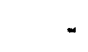 & - \\
\hline 15 & 0,19 & - & . & . & - & - & . &. & - & - & - & . \\
\hline 16 & 0.25 & - & . & - & 0.16 & 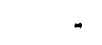 & . & - & . & - & 0.10 & . \\
\hline 17 & 0.69 & - & - & - & - & - & - & - & - & - & . & - \\
\hline 18 & - & - & - & - & " & - & - & - & . & - & - & . \\
\hline 19 & - & - & - & 0.01 & - & $\cdot$ & . & . & - & - & - & 0.12 \\
\hline 20 & - & . & - & 0.35 & . & - & - & - & - & - & - & 0,64 \\
\hline 21 & - & - & - & " & - &. & . & . & - & . & . & " \\
\hline 22 & . & - & - & 0.13 & - & - & - & - & . & . & - & 0.18 \\
\hline 23 & - & - & - & 0.03 & - & . & . & . & . & - & 0.59 & 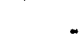 \\
\hline 24 & - & - & " & - & - & - & - & - & - & - & - & . \\
\hline 25 & - & - & - & - & - & - & . & . & . & " & - & - \\
\hline 26 & . & - & - & - & . &. & . & . & . & . & . & . \\
\hline 27 & . & - & . & - & . & . & - & - & - & - & - & $0,(1) 7$ \\
\hline 28 & " & - & - & - & 0.06 & - & - & - & . & - & " & 0.12 \\
\hline 29 & 0.05 & 0.21 & - & . & - & - & - & - & - & . & - & . \\
\hline 30) & - & . & - & $0,(03$ & - & . & . & - & . & - & - & 0.06 \\
\hline 31 & - & - & - & " & - & $\cdot$ & - & - & - & - & . & . \\
\hline & $\longrightarrow$ & & $-\cdots$ & $\longrightarrow$ & - & - & - & - & & 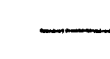 & 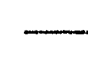 & $\longrightarrow$ \\
\hline & 1.68 & 0.21 & 0.07 & 0.96 & 0.46 & 0.19 & 0.00 & 0,00 & $0,00)$ & 0.01 & 0.93 & 1.54 \\
\hline
\end{tabular}

TOTAL : 1988 Rainfall 6.04 ln.

Dash $(-)=$ No moasurable rainfall 
Table D-10, 1989 Site 300 rainfall (inches per day).

\section{Month}

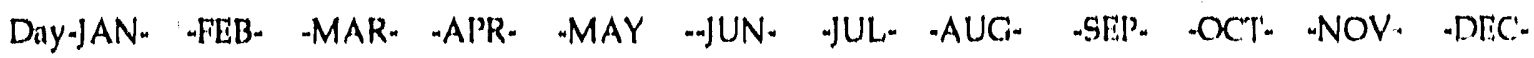

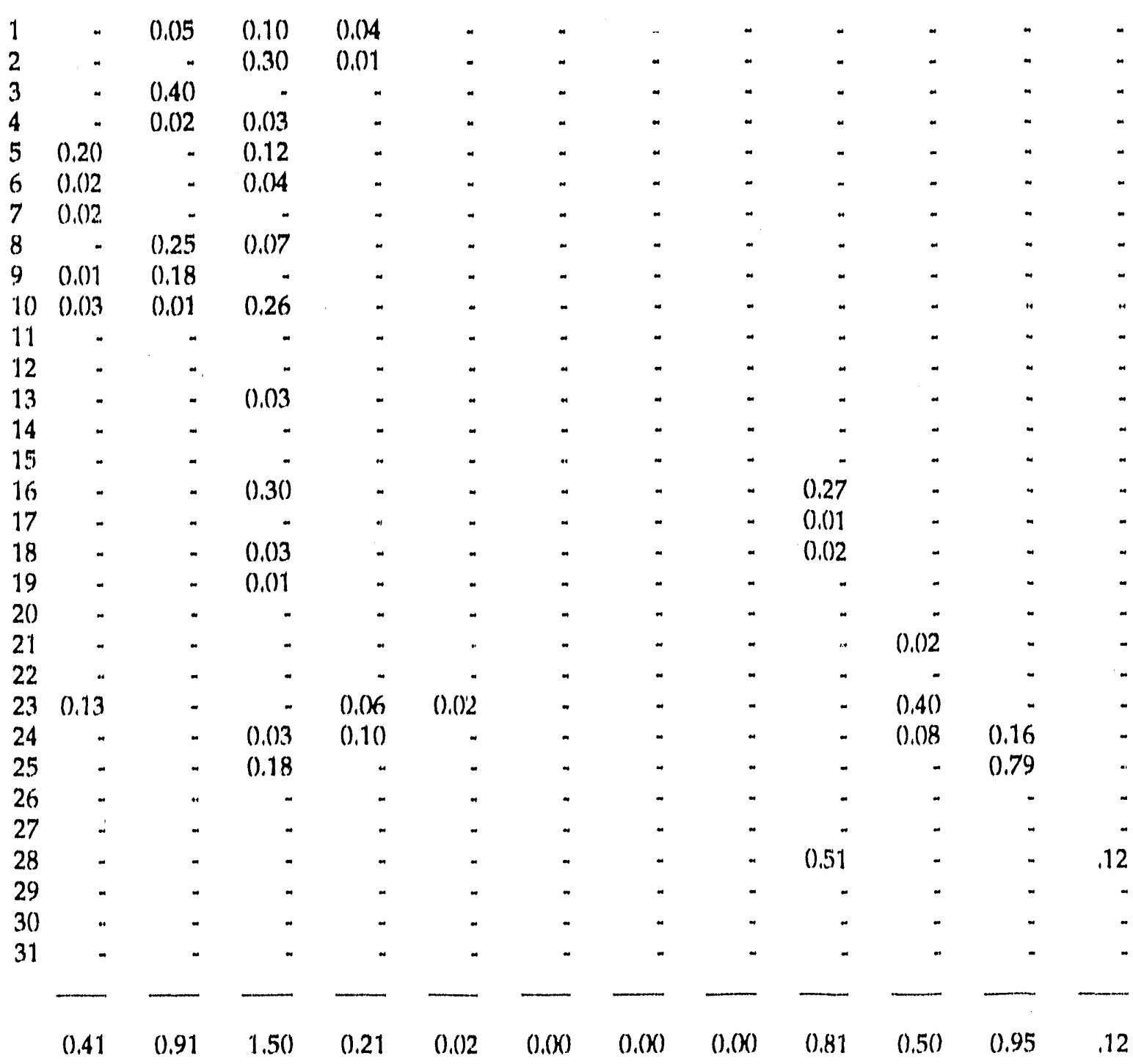

TOTAL: 1989 Rainfall 5.43 in.

Dash $(-)=$ No measurablo rainfall 


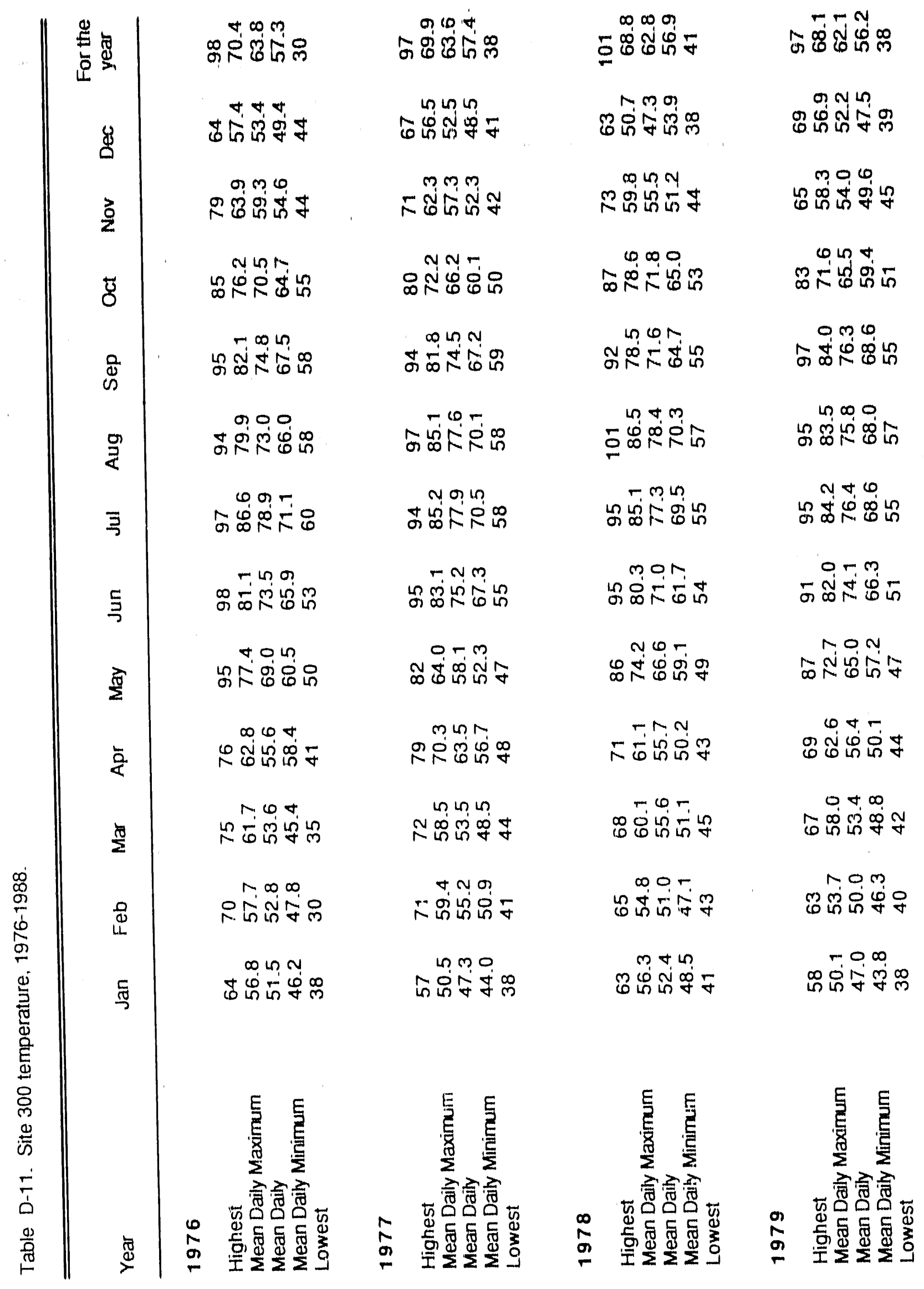




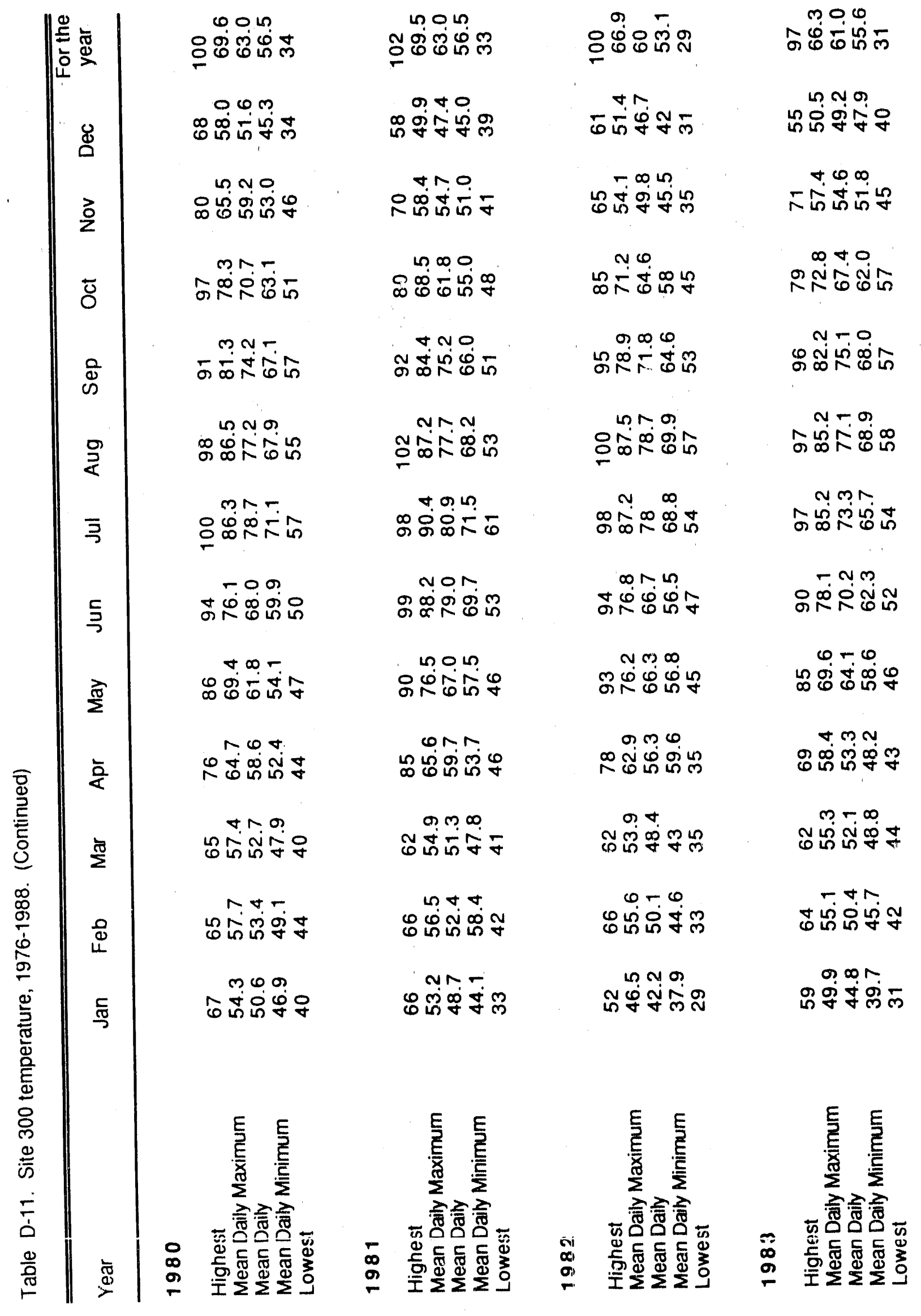




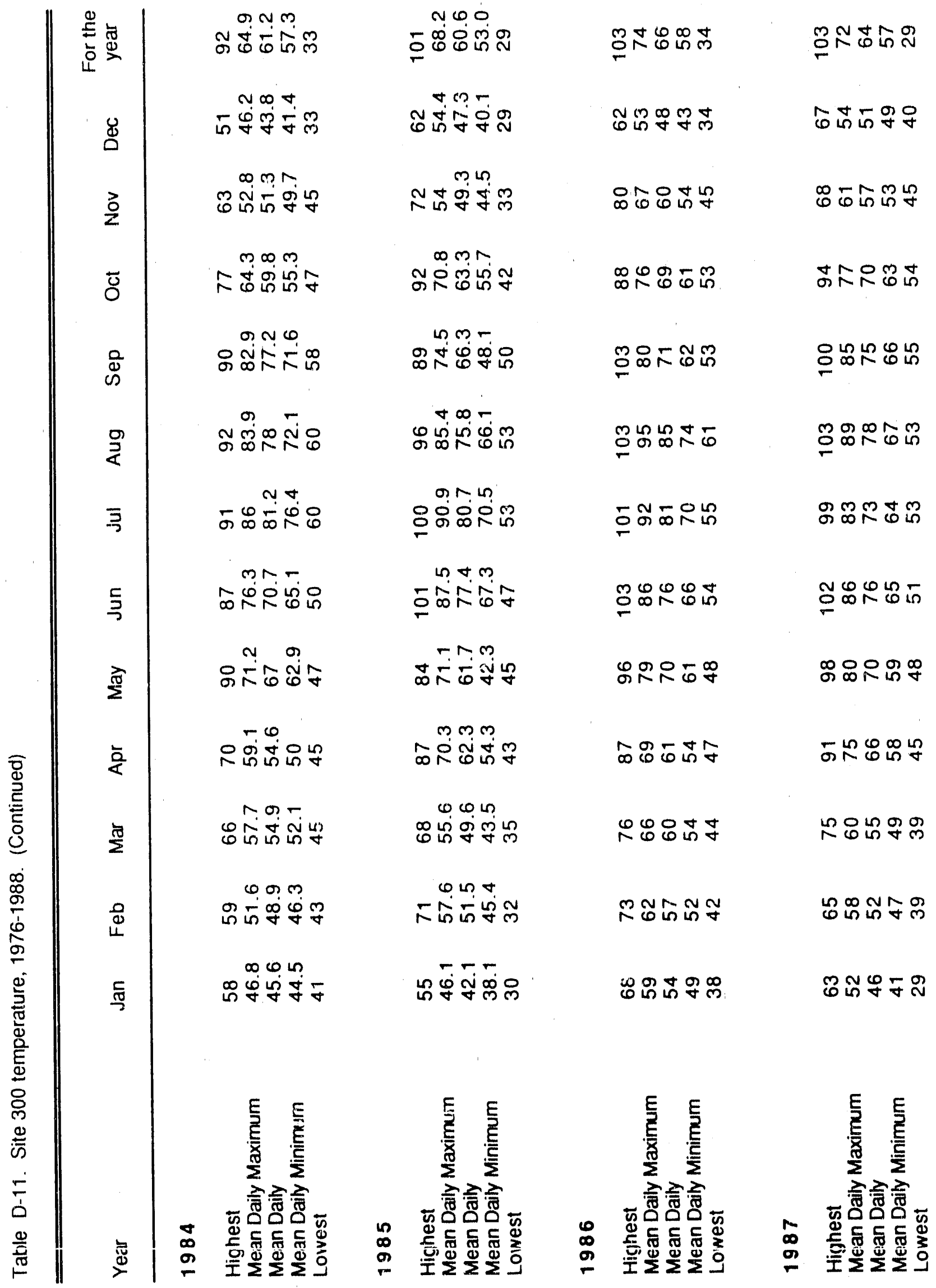




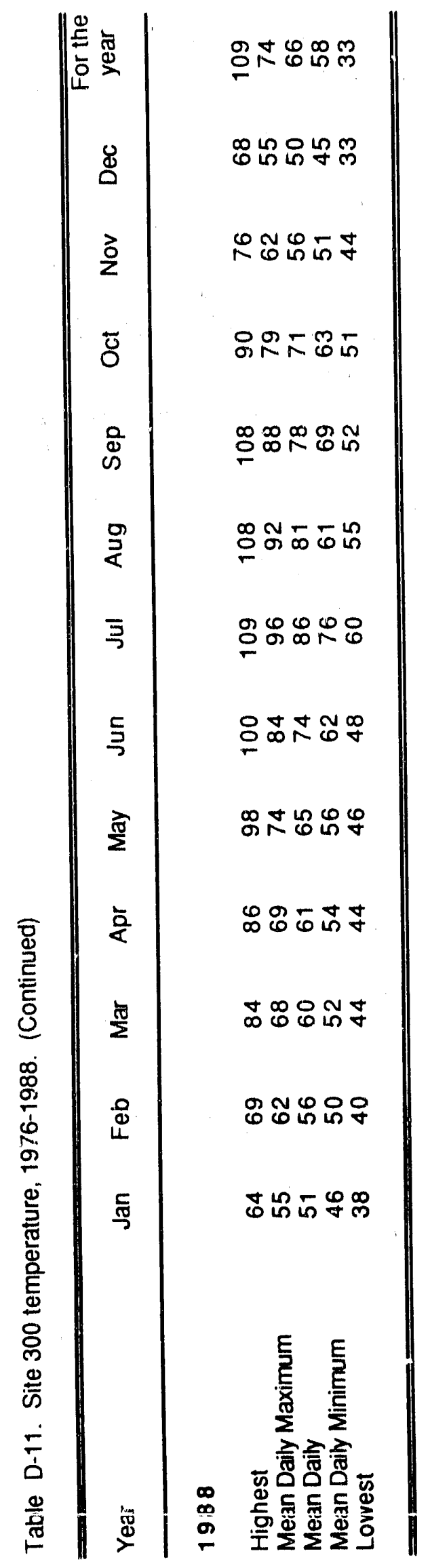


Appendix E

\section{Water Levels in Monitor Wells:} Site 300 
Table E-1. Water elevation for lnstallations in the HE process Area.

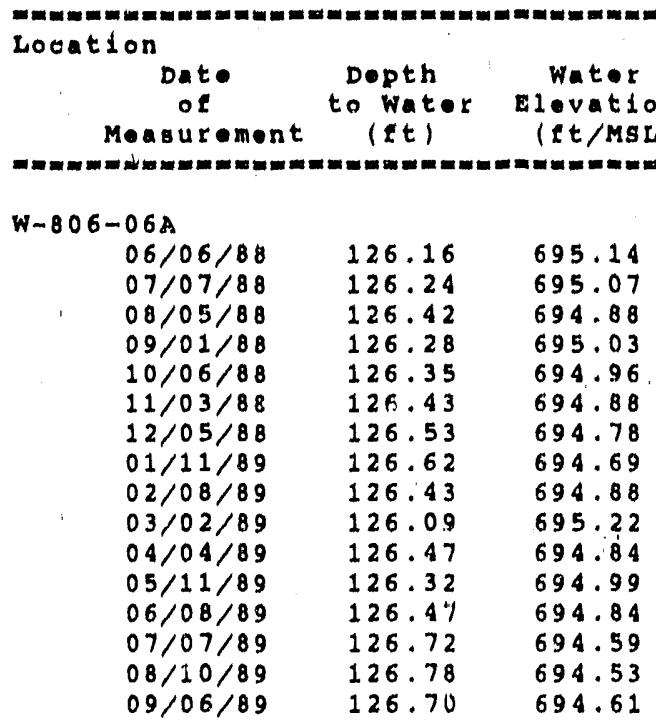

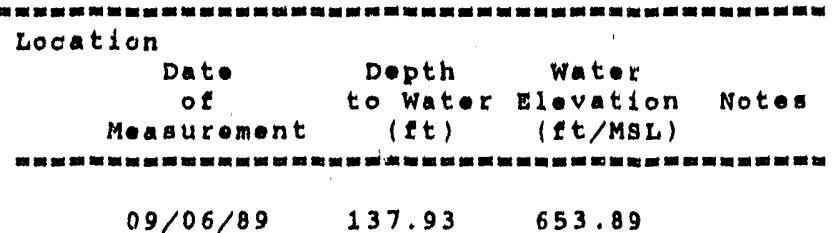

$09 / 06 / 89$

137.93

653.89

$W-809-03$

$09 / 06 / 89 \quad 99.48 \quad 646.59$

W-810-01

$\begin{array}{lll}04 / 05 / 88 & 236.94 & 604.09 \\ 05 / 03 / 88 & 237.03 & 604.00 \\ 06 / 06 / 88 & 238.94 & 602.09 \\ 07 / 07 / 88 & 236.85 & 604.18 \\ 08 / 05 / 88 & 237.67 & 603.36 \\ 09 / 01 / 88 & 237.70 & 603.33 \\ 10 / 06 / 88 & 238.35 & 602.68 \\ 11 / 04 / 88 & 238.26 & 602.77 \\ 11 / 29 / 88 & 238.10 & 602.93 \\ 01 / 11 / 89 & 238.00 & 603.03 \\ 02 / 10 / 89 & 237.86 & 603.17 \\ 03 / 02 / 89 & 237.43 & 603.60 \\ 04 / 10 / 89 & 237.47 & 603.56 \\ 05 / 09 / 89 & 237.76 & 603.27 \\ 06 / 08 / 89 & 238.00 & 603.03 \\ 07 / 07 / 89 & 238.43 & 602.60 \\ 08 / 10 / 89 & 238.73 & 602.30 \\ 09 / 06 / 89 & 238.96 & 602.07\end{array}$

$w-814-01$

$03 / 02 / 88 \quad 110.21 \quad 698.62$

$04 / 05 / 88 \quad 110.25 \quad 698.58$

$05 / 03 / 88 \quad 110.21 \quad 698.62$

$06 / 02 / 88 \quad 110.26 \quad 698.57$

$07 / 07 / 88 \quad 110.29 \quad 698.54$

$08 / 04 / 88 \quad 110.33 \quad 698.50$

$09 / 06 / 88 \quad 110.39 \quad 698.44$

$10 / 06 / 88 \quad 110.43 \quad 698.40$

$11 / 04 / 88 \quad 110.49 \quad 698.34$

$11 / 30 / 88 \quad 110.45 \quad 698.38$

$01 / 12 / 89 \quad 110.51 \quad 698.32$

$02 / 10 / 89 \quad 110.57 \quad 698.26$

$03 / 03 / 89 \quad 110.58 \quad 698.25$

$04 / 12 / 89 \quad 110.31 \quad 698.52$

$05 / 11 / 89 \quad 110.30 \quad 698.53$

$06 / 07 / 89 \quad 110.35 \quad 698.48$

$07 / 07 / 89 \quad 110.38 \quad 698.45$

$08 / 09 / 89 \quad 110.46 \quad 698.37$

$09 / 06 / 89 \quad 110.33 \quad 698.50$

$W-815-01$

$\begin{array}{lll}03 / 01 / 88 & 48.59 & 672.52 \\ 04 / 05 / 88 & 48.68 & 672.43 \\ 05 / 03 / 88 & 48.70 & 672.41 \\ 06 / 02 / 88 & 48.80 & 672.31 \\ 07 / 07 / 88 & 48.76 & 672.35 \\ 08 / 04 / 88 & 48.85 & 672.26 \\ 09 / 01 / 88 & 49.00 & 672.11 \\ 10 / 06 / 88 & 49.24 & 671.87 \\ 11 / 03 / 88 & 49.30 & 671.81 \\ 11 / 29 / 88 & 49.65 & 671.46 \\ 01 / 11 / 89 & 49.99 & 671.12 \\ 02 / 08 / 89 & 49.89 & 671.22 \\ 03 / 02 / 89 & 49.54 & 671.57 \\ 04 / 11 / 89 & 49.62 & 671.49 \\ 05 / 11 / 89 & 49.60 & 671.51 \\ 06 / 08 / 89 & 49.62 & 671.49 \\ 07 / 07 / 89 & 50.01 & 671.10 \\ 08 / 10 / 89 & 50.44 & 670.67 \\ 09 / 06 / 89 & 50.25 & 670.86\end{array}$

W-809-02

$\begin{array}{lll}04 / 06 / 88 & 136.98 & 654.84 \\ 05 / 03 / 88 & 137.13 & 654.69 \\ 06 / 02 / 88 & 137.15 & 654.67 \\ 07 / 07 / 88 & 137.08 & 654.74 \\ 08 / 04 / 88 & 137.24 & 654.58 \\ 09 / 01 / 88 & 137.17 & 654.65 \\ 10 / 06 / 88 & 137.32 & 654.50 \\ 11 / 03 / 88 & 137.60 & 654.22 \\ 11 / 29 / 88 & 137.75 & 654.07 \\ 01 / 11 / 89 & 137.95 & 653.87 \\ 02 / 08 / 89 & 137.72 & 654.10 \\ 03 / 02 / 89 & 137.12 & 654.70 \\ 04 / 10 / 89 & 137.54 & 654.28 \\ 05 / 11 / 89 & 137.70 & 654.12 \\ 06 / 08 / 89 & 137.72 & 654.10 \\ 07 / 07 / 89 & 138.04 & 653.78 \\ 06 / 10 / 83 & 137.37 & 653.85\end{array}$

22.45

722.51

722.44

722.58

654.84 $654.6 \%$

654.74

654.65

654.50

654.07

.87

54.70

54.12

653.25 
Table -1. Water elevation for lnstaliations in the Ha Process Area.

\begin{tabular}{|c|c|c|c|c|c|c|c|}
\hline Location & & & & tion & & & \\
\hline $\begin{array}{c}\text { Date } \\
\text { of } \\
\text { Mousurement }\end{array}$ & 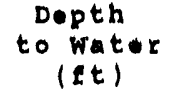 & $\begin{array}{l}\text { Water } \\
\text { Hevation } \\
\text { (Et/MgL) }\end{array}$ & Notes & $\begin{array}{c}\text { Date } \\
\text { of } \\
\text { Measurement }\end{array}$ & $\begin{array}{l}\text { Depth } \\
\text { to water } \\
(t \in)\end{array}$ & $\begin{array}{l}\text { Water } \\
\text { Elevation } \\
\text { (et/MgL) }\end{array}$ & Note \\
\hline
\end{tabular}

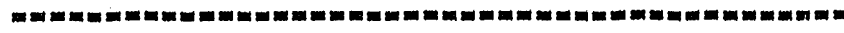

$W-815-02$

$\begin{array}{lll}03 / 01 / 88 & 81.49 & 640.86 \\ 04 / 05 / 88 & 81.80 & 640.55 \\ 05 / 03 / 88 & 81.79 & 640.56 \\ 06 / 02 / 88 & 82.02 & 640.33 \\ 07 / 07 / 88 & 82.08 & 640.27 \\ 08 / 04 / 88 & 82.23 & 640.12 \\ 09 / 01 / 88 & 82.36 & 639.99 \\ 10 / 06 / 88 & 82.54 & 639.81 \\ 11 / 03 / 88 & 82.77 & 639.58 \\ 11 / 29 / 88 & 83.09 & 639.26 \\ 01 / 11 / 89 & 83.27 & 639.08 \\ 02 / 08 / 89 & 83.26 & 639.09 \\ 03 / 02 / 89 & 82.95 & 639.40 \\ 04 / 11 / 89 & 83.29 & 639.06 \\ 05 / 11 / 89 & 83.45 & 638.90 \\ 06 / 08 / 89 & 83.52 & 638.83 \\ 07 / 07 / 89 & 83.80 & 638.55 \\ 08 / 10 / 89 & 84.04 & 638.31 \\ 09 / 06 / 89 & 83.82 & 638.53\end{array}$

$W-815-03$

$03 / 01 / 8$

$04 / 05 / 88$

$05 / 03 / 88$

$06 / 02 / 88$

$07 / 07 / 88$

$08 / 04 / 88$

$09 / 01 / 88$

$10 / 06 / 88$

$11 / 03 / 88$

$11 / 29 / 88$

$01 / 11 / 89$

$02 / 08 / 89$

$03 / 02 / 89$

$04 / 10 / 89$

$05 / 11 / 89$

$06 / 08 / 89$

$07 / 07 / 89$

$08 / 10 / 89$

$09 / 06 / 89$

$w-815-04$

$03 / 01 / 88$

$04 / 05 / 88$

$05 / 03 / 88$

$06 / 02 / 88$

$07 / 07 / 88$

$08 / 04 / 88$

$09 / 01 / 88$

$10 / 06 / 88$

$11 / 03 / 88$

$11 / 29 / 88$

$01 / 11 / 89$

$02 / 08 / 89$

$03 / 02 / 89$

$04 / 10 / 89$

$05 / 11 / 89$

$06 / 08 / 89$

$07 / 07 / 89$

$08 / 10 / 80$

$09 / 06 / 89$

$W-815-05$

$09 / 06 / 89 \quad 30.21 \quad 682.00$

$\begin{array}{ll}41.10 & 681.36 \\ 41.21 & 681.25 \\ 41.22 & 681.24 \\ 41.22 & 681.24 \\ 41.17 & 681.29 \\ 41.28 & 681.18 \\ 41.33 & 681.13 \\ 41.50 & 680.96 \\ 41.60 & 680.86 \\ 41.69 & 680.77 \\ 41.75 & 680.71 \\ 41.60 & 680.86 \\ 41.31 & 681.15 \\ 41.59 & 680.87 \\ 41.60 & 680.86 \\ 41.48 & 680.98 \\ 41.87 & 680.59 \\ 42.03 & 680.43 \\ 41.80 & 680.66\end{array}$

76.65

76.98

76.93

77.14

77.17

77.36

77.42

77.59

77.86

78.14

78.29

78.41

77.96

78.30

78.50

78.47

78.76

78.79

78.71

646.00

645.67

645.72

645.51

645.48

645.29

645.23

645.06

644.79

644.51

644.36

644.24

644.69

644.35

644.15

644.18

643.89

643.86

643.94 $w-817-01$

$03 / 02 / 88 \quad 133.24 \quad 640.87$

$04 / 05 / 8 \theta \quad 132.40 \quad 641.71$

$05,103 / 88 \quad 133.52 \quad 640.59$

$06 / 02 / 88 \quad 133.99 \quad 640.12$

$07 / 07 / 88 \quad 134.12 \quad 639.99$

$08 / 04 / 88 \quad 134.35 \quad 639.35$

$09 / 01 / 88 \quad 134.50 \quad 639.61$

$10 / 17 / 88 \quad 134.68 \quad 639.43$

$11 / 03 / 88 \quad 134.89 \quad 639.22$

$11 / 29 / 88 \quad 135.12 \quad 638.99$

$01 / 11 / 89 \quad 135.19 \quad 638.92$

$02 / 08 / 89 \quad 135.00 \quad 639.11$

$03 / 02 / 89 \quad 134.69 \quad 639.42$

$04 / 14 / 89 \quad 135.20 \quad 638.91$

$05 / 11 / 89 \quad 135.00 \quad 639.11$

$06 / 08 / 89 \quad 135.04 \quad 639.07$

$07 / 07 / 89 \quad 135.00 \quad 639.10$

$08 / 10 / 89 \quad 135.06 \quad 639.05$

$09 / 06 / 89 \quad 135.66 \quad 638.45$

$W-817-02$

$04 / 05 / 88 \quad 104.65 \quad 597.11$

$05 / 03 / 88 \quad 104.93 \quad 596.83$

$06 / 02 / 88 \quad 105.13 \quad 596.63$

$07 / 07 / 88 \quad 105.16 \quad 596.60$

$08 / 04 / 08 \quad 105.52 \quad 595.98$

$09 / 01 / 88 \quad 105.47 \quad 596.29$

$10 / 07 / 88 \quad 105.79 \quad 595.97$

$11 / 07 / 88 \quad 105.89 \quad 595.87$

$12 / 05 / 88 \quad 106.12 \quad 595.64$

$01 / 11 / 89 \quad 106.50 \quad 595.26$

$02 / 10 / 89 \quad 106.70 \quad 595.06$

$03 / 02 / 89 \quad 105.77 \quad 595.99$

$04 / 14 / 89 \quad 106.26 \quad 595.50$

$05 / 11 / 89 \quad 106.26 \quad 595.50$

$06 / 08 / 89 \quad 106.35 \quad 595.41$

$07 / 07 / 89 \quad 106.83 \quad 594.93$

$08 / 09 / 89 \quad 107.00 \quad 594.76$

$09 / 06 / 89 \quad 107.15 \quad 594.61$

$w-817-03$

$03 / 01 / 88 \quad 93.20 \quad 580.71$

$04 / 05 / 88 \quad 94.19 \quad 579.72$

$05 / 03 / 88 \quad 94.19 \quad 579.72$

$06 / 02 / 88 \quad 94.43 \quad 579.48$

$07 / 07 / 88 \quad 93.71 \quad 580.20$

$08 / 04 / 88 \quad 93.30 \quad 580.63$

$09 / 01 / 88 \quad 92.87 \quad 581.04$

$10 / 07 / 88 \quad 92.85 \quad 581.06$

$11 / 03 / 88 \quad 93.23 \quad 580.68$

$11 / 29 / 88 \quad 94.07 \quad 579.84$

$01 / 11 / 89 \quad 94.68 \quad 579.23$

$02 / 08 / 89 \quad 94.73 \quad 579.18$

$03 / 02 / 89 \quad 94.42 \quad 579.49$

$04 / 14 / 89 \quad 95.56 \quad 578.35$

$05 / 11 / 89 \quad 95.21 \quad 578.70$

$06 / 08 / 89 \quad 95.53 \quad 578.38$

$07 / 07 / 89 \quad 95.99 \quad 577.92$

$08 / 09 / 89 \quad 96.24 \quad 577.67$

$09 / 06 / 89 \quad 96.34 \quad 577.57$

$W-817-03 A$

$03 / 01 / 88$

$04 / 05 / 88$

$05 / 03 / 88$

$06 / 02 / 80$

$07 / 07 / 88$

$0 B / 0+8$ \&

$\begin{array}{ll}5.17 & 672.83 \\ 5.53 & 672.47 \\ 6.22 & 671.78 \\ 7.75 & 670.25 \\ 8.51 & 669.49 \\ 9.52 & 668.28\end{array}$


Table Q-1. Water elevation tor instadiations in the HE Process Area.

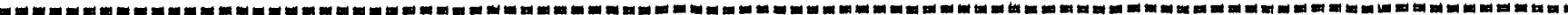

Looation

Date Depth Wattot

of to Water Elevation Notes

Moasuromont (tt) (tt/MSL)

프

$09 / 01 / 88 \quad 10.59 \quad 667.41$

$10 / 07 / 88 \quad 11.60 \quad 666.40$

$11 / 03 / 88 \quad 10,93 \quad 667.07$

$11 / 29 / 88 \quad 9.33 \quad 668.67$

$01 / 11 / 89 \quad 8,22 \quad 669.78$

$02 / 08 / 89 \quad 7.74 \quad 670.26$

$03 / 02 / 89-7.30 \quad 670.70$

$04 / 14 / 89 \quad 7.01 \quad 670.99$

$05 / 11 / 89 \quad 6.79 \quad 671.21$

$06 / 08 / 89 \quad 6.71 \quad 671.29$

$07 / 07 / 89 \quad 6.91 \quad 671.09$

$08 / 09 / 89 \quad 7.32 \quad 670.68$

$09 / 06 / 89 \quad 0.01 \quad 669.99$

$w-817-04$

$\begin{array}{lll}03 / 02 / 88 & 69.82 & 613.37 \\ 04 / 05 / 88 & 69.92 & 613.27 \\ 05 / 03 / 88 & 69.84 & 613.35 \\ 06 / 02 / 88 & 69.99 & 613.20 \\ 07 / 07 / 88 & 69.82 & 613.37 \\ 08 / 04 / 88 & 70.12 & 612.55 \\ 09 / 01 / 88 & 70.23 & 612.96 \\ 10 / 07 / 88 & 70.39 & 612.80 \\ 11 / 03 / 88 & 70.51 & 612.68 \\ 11 / 29 / 88 & 70.61 & 612.58 \\ 01 / 11 / 89 & 70.79 & 612.40 \\ 02 / 08 / 89 & 70.75 & 612.44 \\ 03 / 02 / 89 & 70.57 & 612.62 \\ 04 / 14 / 89 & 71.06 & 612.13 \\ 05 / 11 / 89 & 71.00 & 612.19 \\ 06 / 08 / 89 & 71.14 & 612.05 \\ 07 / 07 / 89 & 71.33 & 611.86 \\ 08 / 10 / 89 & 71.55 & 611.64 \\ 09 / 06 / 89 & 71.28 & 611.91\end{array}$

$w-817-05$

$\begin{array}{lll}06 / 02 / 88 & 127.12 & 637.21 \\ 07 / 07 / 88 & 127.80 & 636.53 \\ 08 / 04 / 88 & 127.85 & 636.48 \\ 09 / 01 / 88 & 127.76 & 636.57 \\ 10 / 17 / 88 & 128.04 & 636.29 \\ 11 / 03 / 88 & 128.30 & 636.03 \\ 11 / 29 / 88 & 128.65 & 635.68 \\ 01 / 11 / 89 & 128.71 & 635.62 \\ 02 / 08 / 89 & 128.45 & 635.88 \\ 03 / 02 / 89 & 128.05 & 636.28 \\ 04 / 14 / 89 & 128.30 & 636.03 \\ 05 / 11 / 89 & 128.30 & 636.03 \\ 06 / 08 / 89 & 128.27 & 636.06 \\ 07 / 07 / 89 & 128.35 & 635.98 \\ 08 / 10 / 89 & 128.38 & 635.95 \\ 09 / 06 / 89 & 128.05 & 636.28\end{array}$

W-817-06A

$07 / 07 / 88$

$08 / 04 / 88$

$09 / 01 / 88$

$10 / 17 / 88$

$11 / 03 / 88$

$11 / 29 / 88$

$01 / 11 / 89$

$02 / 08 / 89$

$03 / 02 / 89$

$04 / 13 / 89$

$05 / 11 / 89$

$06 / 08 / 89$

$07 / 07 / 89$

$08 / 10 / 89$

$09 / 06 / 89$

$\begin{array}{ll}111.02 & 657.44 \\ 109.48 & 658.98 \\ 109.36 & 659.10 \\ 109.56 & 658.90 \\ 109.87 & 658.59 \\ 109.76 & 658.70 \\ 109.83 & 658.63 \\ 109.74 & 658.72 \\ 109.59 & 658.87 \\ 109.48 & 658.98 \\ 109.59 & 658.67 \\ 109.59 & 658.87 \\ 109.85 & 658.61 \\ 109.84 & 658.62 \\ 109.74 & 658.72\end{array}$

Looution

of Measuremont

Depth Water

to Water blovation Notes (tet) (tt/MSL)

Мะ

$W-819-02$

$\begin{array}{lll}03 / 03 / 88 & 223.74 & 598.38 \\ 04 / 05 / 88 & 223.75 & 598.37 \\ 05 / 03 / 88 & 223.89 & 598.23 \\ 06 / 06 / 88 & 223.91 & 598.21 \\ 07 / 07 / 88 & 223.78 & 598.34 \\ 08 / 05 / 88 & 224.94 & 597.18 \\ 09 / 06 / 88 & 225.15 & 596.97 \\ 10 / 06 / 88 & 225.74 & 596.38 \\ 11 / 04 / 88 & 225.51 & 596.61 \\ 11 / 29 / 88 & 225.12 & 597.00 \\ 01 / 12 / 89 & 225.18 & 596.94 \\ 02 / 09 / 89 & 225.02 & 597.10 \\ 03 / 02 / 89 & 224.62 & 597.50 \\ 04 / 12 / 89 & 224.65 & 597.46 \\ 05 / 11 / 89 & 225.23 & 596.89 \\ 06 / 07 / 89 & 225.54 & 596.58 \\ 07 / 07 / 89 & 225.96 & 596.16 \\ 08 / 08 / 89 & 226.21 & 595.91 \\ 09 / 06 / 89 & 226.92 & 595.20\end{array}$

$W-829-06$

$03 / 03 / 88 \quad 95.92 \quad 976.37$

$04 / 06 / 88 \quad 95.85 \quad 976.44$

$05 / 04 / 88 \quad 95.73 \quad 976.56$

$06 / 02 / 88 \quad 95.83 \quad 976.46$

$07 / 07 / 88 \quad 95.91 \quad 976.38$

$08 / 05 / 88 \quad 95.92 \quad 976.37$

$09 / 06 / 88 \quad 95.78 \quad 976.51$

$10 / 10 / 88 \quad 96.05 \quad 976.24$

$11 / 04 / 88 \quad 96.31 \quad 975.98$

$11 / 29 / 88 \quad 96.44 \quad 975.85$

$01 / 12 / 89 \quad 96.46 \quad 975.83$

$02 / 08 / 89 \quad 96.26 \quad 976.03$

$03 / 02 / 89 \quad 95.78 \quad 976.51$

$04 / 14 / 89 \quad 96.25 \quad 976.04$

$05 / 12 / 89 \quad 96.07 \quad 976.22$

$06 / 08 / 89 \quad 96.01 \quad 976.28$

$07 / 07 / 89 \quad 96.28 \quad 976.01$

$08 / 08 / 89 \quad 96.45 \quad 975.84$

$09 / 06 / 89 \quad 95.94 \quad 976.35$

$w-829-08$

$03 / 03 / 88 \quad 98.08 \quad 976.6 \%$

$04 / 06 / 88 \quad 98.07 \quad 976.68$

$05 / 04 / 88 \quad 97.80 \quad 976.95$

$06 / 02 / 88 \quad 98.08 \quad 976.67$

$07 / 07 / 88 \quad 98.08 \quad 976.67$

$08 / 05 / 88 \quad 98.07 \quad 976.68$

$09 / 06 / 88 \quad 97.98 \quad 976.77$

$10 / 10 / 88 \quad 98.17 \quad 976.58$

$11 / 04 / 88 \quad 98.43 \quad 976.32$

$11 / 29 / 88 \quad 96.59 \quad 976.16$

$01 / 12 / 89 \quad 98.57 \quad 976.18$

$02 / 08 / 89 \quad 98.30 \quad 976.45$

$03 / 02 / 89 \quad 97.84 \quad 976.91$

$04 / 12 / 89 \quad 97.89 \quad 976.86$

$05 / 12 / 89 \quad 98.16 \quad 976.59$

$06 / 08 / 89 \quad 98.03 \quad 976.72$

$07 / 07 / 89 \quad 98.33 \quad 976.42$

$08 / 08 / 89 \quad 98.25 \quad 976.50$

$09 / 06 / 89 \quad 97.93 \quad 976.82$

$w-35 C-02$

$05 / 09 / 89$

$06 / 06 / 89$

$07 / 06 / 89$

$08 / 08 / 89$

$09 / 06 / 89$
33.87

71.36

75.36
NA

538.93

501.44

497.44 


\section{Appendix F}

\section{Well Construction Data: HE Process Area, Site 300}


This page intentionally left blank.

Table has facing pages. 
Table 1 1 - Well construction data for installations in and near the High Explosives (HE) Area.

\begin{tabular}{|c|c|c|c|c|c|c|c|}
\hline $\begin{array}{c}\text { Well } \\
\text { designation }\end{array}$ & Type & Northing & Easting & $\begin{array}{l}\text { Shiner } \\
\text { elevalion } \\
\text { (ft/MSL) }\end{array}$ & $\begin{array}{c}\text { POM } \\
\text { olevatton } \\
\text { (fLMSI) }\end{array}$ & $\begin{array}{l}\text { Depth of } \\
\text { scroened } \\
\text { Interval } \\
\text { (ft) }\end{array}$ & $\begin{array}{l}\text { Depth of } \\
\text { sand pack } \\
\text { Interval } \\
\text { (ft) }\end{array}$ \\
\hline$W=806-06 A$ & MW & 416393.4 & 1706329.4 & 818.64 & 821.31 & $141.00 \cdot 161.00$ & $133.00 \cdot 162.50$ \\
\hline W-806-07 & PIE & 416394.2 & 1706319.6 & 818.18 & $0 ? 1.18$ & $51.00 \cdot 57.00$ & $42.00 \cdot 60.00$ \\
\hline$W-809-01$ & $\mathrm{MW}$ & 416097.4 & 1707619.1 & 788.23 & 790.23 & $51.40 \cdot 70.80$ & $47.80 \cdot 72.00$ \\
\hline W-809-02 & $M W$ & 416106.7 & $170 \% 623.7$ & 789.15 & 791.82 & $135.00-150.00$ & $117,00-152,00$ \\
\hline W.809-03 & $M W$ & 415931.7 & 1707590.2 & 743,40 & 746.07 & $96,60 \cdot 111.60$ & $93.60 \cdot 112.10$ \\
\hline W-810-01 & $M W$ & 416034.3 & 1707195.4 & 838.37 & 841.03 & $269.30-289.50$ & $249.00 \cdot 291.00$ \\
\hline W-814-01 & MW & 416009.7 & 1708099.3 & 806.16 & 808.83 & $93.40 \cdot 108.00$ & $91.50-113.50$ \\
\hline W-815-01 & $M W$ & 415694.0 & 1707782.4 & 718.11 & 721.11 & $43,00 \cdot 48,00$ & $41.50 \cdot 48.80$ \\
\hline$W-815-02$ & MW & 415683.3 & 1707774.2 & 719,35 & 72.35 & $100.00-115.00$ & $91.00 \cdot 116.00$ \\
\hline$W-815-03$ & $\mathrm{MW}$ & 415807.1 & 1707727.3 & 719.45 & 722.46 & $34.20-39.00$ & $31.00-41.00$ \\
\hline W.815-04 & MW & 415798.8 & 1707716.8 & 719.65 & 722.65 & $84.50 * 99.00$ & $83.50 \cdot 100.00$ \\
\hline W-815-05 & MW & 415855.8 & 1707816.7 & 709.55 & 712.21 & $22.50-32.50$ & $19.00 \cdot 3,3,00$ \\
\hline W-817-01 & $M W$ & 415546.7 & 1707334.4 & 772.11 & 774.11 & $121.00 \times 144.00$ & $112.50 \cdot 145.00$ \\
\hline W-817-02 & $M W$ & 414972.6 & 1707721.8 & 699.76 & 701.76 & $98.50-132.50$ & $86.50-136.00$ \\
\hline W.817-03 & $\mathrm{MW}$ & 415017.2 & 1707967.8 & 671.90 & 673.91 & $85.00-119.50$ & $76.50=120.00$ \\
\hline$W-817-03 A$ & PIE & 415043.9 & 1707959.3 & 675.00 & 678.00 & $4.50 \times 9.50$ & $2.00 * 9.50$ \\
\hline$W-817-04$ & MW & 415189.7 & 1707899.8 & 680.52 & 683.19 & $60,00 \cdot 95,00$ & $52.50-99.00$ \\
\hline W.817-05 & $M W$ & 415749.5 & 1707056.9 & 761.66 & 764.33 & $143,00 \cdot 153,00$ & $139.50 \cdot 153,00$ \\
\hline W.817-06A & $\mathrm{MW}$ & 415698.0 & 1707134.6 & 765.80 & 768.46 & $102.00 \cdot 117.00$ & $98.00-120.00$ \\
\hline W-819-02 & MW & 416278.6 & 1707976.9 & 819.12 & 822.12 & $259.10-288.00$ & $255.30-289.00$ \\
\hline W-829-06 & PIE & 417202.1 & 1703238.5 & 1069.29 & 1072.29 & $76.00-98,00$ & $70.50 \times 99.00$ \\
\hline$W-829-08$ & $M W$ & 417238.7 & 1703252.2 & 1071.75 & 1074.75 & $89.50-109.50$ & $83.50-109.50$ \\
\hline$W-35 C-02$ & $M W$ & 414305.8 & 1708690.4 & 570.13 & 572.80 & 396,30 - 496,80 & $244.00-542.50$ \\
\hline$W-35 C-03$ & SUP' & 414350.3 & 1708675.9 & 574.01 & - & $387.00-517.00$ & $307.00-537.80$ \\
\hline$W-6 C D$ & $M W$ & 414506.0 & 1708729.9 & 577.04 & 580.04 & $78.25 \cdot 137.00$ & $76.50 \cdot 137.00$ \\
\hline$W-6 C l$ & $M W$ & 414.504 .5 & 1708720.5 & 577.49 & 580.51 & $56.00 \cdot 60.80$ & $53.00-63.00$ \\
\hline
\end{tabular}

Type: MW, Monitor Well; PIE, Plezometer; SUP, Supply Well. 
T'able P-1. (Continued.)

\begin{tabular}{|c|c|c|c|c|c|c|}
\hline $\begin{array}{c}\text { Well } \\
\text { dlameler } \\
\text { I.D. } \\
\text { (In,) }\end{array}$ & $\begin{array}{c}\text { Casing } \\
\text { dopth } \\
\text { (fi) }\end{array}$ & $\begin{array}{l}\text { P'ump' } \\
\text { Intake } \\
\text { deplli } \\
\text { (fi) }\end{array}$ & $\begin{array}{c}\text { Maximum } \\
\text { stustalinable } \\
\text { ylold } \\
\text { (gipm) }\end{array}$ & I'ump typo & $\begin{array}{l}\text { HII' } \\
\text { voltage }\end{array}$ & $\begin{array}{l}\text { Date } \\
\text { comploled } \\
\text { notes }\end{array}$ \\
\hline 4.50 & 161.00 & 157,013 & 1.6 & GKUNDIS SP1.4 & $1 / 2 H^{1} / 220 \mathrm{~V}$ & $02-0 \mathrm{ct}-86$ \\
\hline 4.50 & 57.00 & N/A & N/A & NOPUMP & N/A & $21 \cdot A u g+86$ \\
\hline 4.50 & 74.30 & 74.00 & 0.5 & WHLL-WIZZZ & $\mathrm{N} / \mathrm{A}$ & 10-Marn88 \\
\hline 4.50 & 155.00 & 154.53 & 0.3 & WHLL.WYZZZ & $\mathrm{N} / \mathrm{A}$ & 21.Mar-A8 \\
\hline 4.50 & 112.10 & 111.10 & & WELL-WIZZZ & N/A & $20 \cdots J u 1-80$ \\
\hline 4.50 & 294.50 & 291.54 & 2.5 & GRUNDYSSI'1-16 & $1 / 2 \mathrm{H} \mathrm{I}^{\prime} / 220 \mathrm{~V}$ & 01-Mar-88 \\
\hline 4.50 & 112.80 & 108.03 & 0.3 & WILLL.WIZZZ & $\mathrm{N} / \mathrm{A}$ & 14-May-87 \\
\hline 4.50 & 48.00 & 43.50 & & WELL-WIZZ & N/A & $27-A$ pr-87 \\
\hline 4.50 & $115 .(K)$ & $112,(x)$ & 2.4 & GRUNDPSSP1.9 & $1 / 2 \mathrm{HP} / 2.20 \mathrm{~V}$ & 05-May-87 \\
\hline 4.50 & 45,00 & 43.29 & 0.4 & WELLLWWIZZ & N/A & 19.Jan -88 \\
\hline 4.50 & 104.801 & 101,80 & 2.0 & GRUNDFS SP1.9 & $1 / 2 \mathrm{HP}^{1} / 220 \mathrm{~V}$ & $08-$ Feb-88 \\
\hline 4.50 & 32.50 & 32.35 & & WELLWWIZZ & $\mathrm{N} / \mathrm{A}$ & $26 \cdot] 41-89$ \\
\hline 4.50 & 144.00 & 140,00 & & GRUNDIS SP1.9 & $1 / 3 H p / 110 V$ & $30-0 \mathrm{cl}-84$ \\
\hline 4.50 & 132.50 & 140,00 & & GRUNDFS SI'1.9 & $1 / 3 \mathrm{HP}^{\prime} / 110 \mathrm{~V}$ & 06. Nov-84 \\
\hline 4.50 & 119.50 & 110,99 & & GRUNDPS SP'1.9 & $1 / 3 H^{\prime} / 110 \mathrm{~V}$ & $01-N o v+84$ \\
\hline 4.50 & 9.50 & $\mathrm{~N} / \mathrm{A}$ & $\mathrm{N} / \mathrm{A}$ & NO PUMP & N/A & 07. Nov-84 \\
\hline 4.50 & 95.00 & 86.0 .3 & & GRUNDFS SP1.9 & $1 / 3 H P / 110 V$ & $09-$ Nov-84 \\
\hline 4.50 & 158.00 & 156.0 .3 & 2.3 & GRUNDFS SP1.9 & $1 / 2 \mathrm{HP} / 220 \mathrm{~V}$ & 24-May-88 \\
\hline 4.50 & 122.00 & 120.04 & 0.3 & WELLWWIZZ & N/A & $16-\int u n-88$ \\
\hline 4.50 & 288.00 & 286.00 & 2.3 & GRUNDIS SP1-22 & $3 / 4 \mathrm{HP}^{2} / 22 \mathrm{OV}$ & 19.Dec-86 \\
\hline 4.50 & 98.00 & N/A & $\mathrm{N} / \mathrm{A}$ & NO PUMP' & N/A & 18-Dec-86 \\
\hline 4.50 & 109.50 & 105.00 & 0.4 & WELL-WIZZ & $\mathrm{N} / \mathrm{A}$ & 14-Jan-87 \\
\hline 4.00 & 496.80 & $\mathrm{~N} / \mathrm{A}$ & N/A & NOPUMP & N/A & $06-$ Feb-89 \\
\hline 10.00 & 52.2 .050 & 370,00 & $35(1)$ & PIERLISS & $75111 / 480 \mathrm{~V}$ & $01-A p r-89$ \\
\hline 4.50 & 137.00 & $134 .(0)$ & 3.0 & GRUNDFSSP1.9 & $1 / 2 \mathrm{HP}^{\prime} / 220 \mathrm{~V}$ & 16-Mar -87 \\
\hline 4.50 & 60.80 & 58,98 & 1.8 & GRUNDFS SI'1.9 & $1 / 2 \mathrm{H} \mathrm{P}^{2} / 220 \mathrm{~V}$ & 17.Mar -87 \\
\hline
\end{tabular}




\section{Appendix G}

\section{Analytical and Sample Handling Procedures-Laboratory QA/QC}




\section{Appendix G. Analytical and Sample Handling Procedures-Laboratory QA/QC}

'This appendix includes unalytical protocols for soll and rock samples and for ground water sumples collected in the HE Process Area of Ste $3(x)$. This information supplements the discussion in Chapter 4. It also summarlzes the LLNL SOPs.

\section{G.1. Chain-of-Custody Procedures}

A sample of LLLNL's Chain-of-Custody Form is Included at the end of this appendix, In summary, the procedure is as follows:

- Chadi-of-custody documents are prepared for all sumples.

- All trunsfers ure recorded and the completed forms stored in binders for retrieval.

- Samples are clearly labeled with the name of the well, the type of sumple, the depth at which it was collected, the date, the mame of the collector, and any individuals who transported the sumple between the place of collection and the place of unalysis.

\section{G.2. Analyses Used in the HE Process Area}

\section{G.2.1. Analysis of Soll and Rock Samples}

Soil sumples are analyzed by California-certified contract anulytical laborutories for VOCs and metals. There is no state certification program for analysis for HE compounds,

The sumples ure analyzed for VOCs according to EPA Method 8()10) (EPA 8()1()), In some cases, EPA Method 8240) (EPA 8240) has been used. 'This procedure includes analyses for more substances, but does not have as low a detection level as EPA 8(01().

Soil samples are analyzed for metals according to the WET specified In Section 667()() , Title 22, Callformia Administrative Code (1985), which uses a leach solution acidified to phl 5 with citric acid.

\section{G.2.2. Analysis of Ground Water Samples}

Ground water samples from the HE Process Area are analyzed by California-certified contract laboratories for two sets of analyses.

The monitoring network for the HE Surface Impoundments is sampled guarterly in compliance with Waste Discharge Order 85-188 (RWQCB, 1985). Ground water from the wells is sampled and analyzed for metals, nitrate, TOC, TOX, EPA 6()1, conductivity, pH, and general minerals. The water is also anulyzed for tritum and HE compounds (IN'T', RDX, and (IMX),

Ground water from the monitor wells drilled in the course of our remedial investigations is analyzed quarterly for VOCs and HE compounds. VOCs are analyzed according to EPA Method 6()1 (EPA 6()1). At times, we have analyzed samples using EPA Methods $6(2)$ and 624 (EPA 6(2), EPA 624). These methods provide additional information, but with a lower delection limit. 


\section{G.3. Analytical Methods for Soil and Rock Samples: VOCs and Metals}

\section{G.3.1. Soil Analysis: VOCs}

- Method: $\quad$ EPA 8010,8020, 8024 (Code of Federal Regulations [CFR], 1987),

- Container: Steel or brass core tube, sealed at ends.

- Preservation: Cooler or refrigerator at $4^{\circ} \mathrm{C}$.

- Fleld Handling: Kept in cooler with ice or under refrigeration until analyzed.

\section{G.3.2. Soil Analysis: Metals}

- Method: $\quad$ EP Toxicity (EPA, 1986); WET (California Administrative Code, Title 22, 1989).

- Contalner: Steel or brass core tube, sealed at ends.

- Field Handling: No refrigeration required; for convenience, kept in cooler until dellvered to laboratory.

\section{G.3.3. Soil Analysis: HE Compounds}

- Method: High pressure liquid chromatography (HPLC) technique developed at LLNL by J. E. Clarkson (personal communications, 1988, 1989). Soil sample is disaggregated and leached in tetrahydrofuran, an organic solvent for HE compounds. Leachate is evaporated to dryness, taken up in $5 \mathrm{~mL}$ of methanol, and introduced to the chromatograph. The chromatogram is interpreted to establish concentrations of TNT, RDX, and HMX.

- Contalner: Steel or brass core tube, sealed at ends. If sample recovered is too small (less than approximately $500 \mathrm{mg}$ ), two or more drive samples may be composited to attain a weight of $500 \mathrm{~g}$. The composited sample is stored in a clean, wide-mouthed jar; the cap is sealed with inert duct tupe.

- Field Handling: No refrigeration required; for convenience, kept in cooler until delivery to laboratory.

\section{G.4. Analytical Methods for Water Samples}

\section{G.4.1. Analyses for HE Surface Impoundment (Waste Discharge Order 85*188)}

\section{G.4.1.1. VOCs (CFR, 1987)}

- Method: EPA 601, EPA 602, EPA 624.

- Bottes: $\quad$ 40-mL borosilicate glass bottle with Teflon-ficed sillicone septum in a screw-top cap. 
- Preservation: Refrigeration at $4^{\circ} \mathrm{C}$. EPA Method 624 requires preservation with hydrochloric acid to $\mathrm{pH} 2$ for aromatic hydrocarbons.

- Field Handling: Bottles are immediately placed in a cooler with ice.

\section{G.4.1.2. Metals (CFR, 1987)}

- Method: $\quad$ Lead, EPA 293.2; beryllium, EPA 210.2 (CFR, 1987).

- Bottles: $\quad 500 \mathrm{~mL}$ polyethylene.

- Preservation: $5 \mathrm{~mL} 70 \%$ nitric acid, added immediately upon return to the laboratory.

- Field Handling: Bottles are triple-rinsed and retained in a cooler for convenience.

\section{G.4.1.3. Gross Radioactivity (Taffet et al., 1989)}

- Method: Gross alpha ASTM D 1943-81 (American Public Health Association [APHA], 198\%); Gross beta ASTM 1890-81 (APHA, 1987).

- Bottles: 1-L polypropylene.

- Preservation: $5 \mathrm{~mL} \mathrm{70 \%} \mathrm{nitric} \mathrm{acid,} \mathrm{added} \mathrm{immediately} \mathrm{upon} \mathrm{return} \mathrm{to} \mathrm{laboratory.}$

: Field Handling: Bottles are triple-rinsed and retained in a cooler for convenience.

\section{G.4.1.4. Tritium (Taffet et al., 1989)}

- Method: LLNL technique for analysis of tritium in ground water (Garrison et al., 1985).

- Bottles: $\quad 30-m L$ scintillation vials.

- Preservation: None.

- Field Handling: No special precautions'.

Routine analysis of ground water for tritium is done by liquid-scintillation counting. Lowlevel samples are electrolytically enriched before counting, and a single $5-\mathrm{mL}$ aliquot of the enriched water is analyzed. For more details, see Taffet et al., 1989, p. E-3.

\section{G.4.2. Analysis of Fround Water Samples for Remedial Investigations}

\section{G.4.2.1. VOCs (CFR, 1987)}

- Method:

EPA 601, EPA 602, EPA 624.

- Bottles:

40- $\mathrm{mL}$ borosilicate glass bottle with Teflon-faced silicone septum in a screw-top cap.

- Preservation: Refrigeration at $4^{\circ} \mathrm{C}$. EPA Method 624 requires preservation with hydrochloric acid to $\mathrm{pH} 2$ for aromatic hydrocarbons.

- Field Handling: ottles are immediately placed in a cooler with ice. 


\section{G.4.2.2. Metals}

- Method: WET (California Administrative Code; Title 22, 1985).

- Bottles: 1-L plastic bottle.

- Preservation: $5 \mathrm{~mL} 70 \%$ nitric acid, added immediately upon return to laboratory.

- Field Handling: No refrigeration required. If samples will not arrive immediately át laboratory, acidify in field.

\section{G.4.2.3. General Minerals Analysis}

- Method: Cations by inductively coupled plasma (ICP) spectrography; anions by various EPA-approved wet chemistry techniques; TDS by weight; $\mathrm{pH}$ and conductivity by standard instruments.

- Bottles: 21-L plastic bottles (see note under Field Handling).

- Preservation: Added immediately upon arrival at laboratory. Nutrients require acidification to $\mathrm{pH} 2$ with sulfuric acid; cations require acidification to $\mathrm{pH} 2$ with nitric acid.

- Field Handling: If sample will not arrive at laboratory immediately, an additional 500$\mathrm{mL}$ plastic bottle is collected for nutrients analysis. Both samples are acidified as required in the field.

\section{G.4.2.4. HE Compounds}

- Method: HPLC technique developed at LLNL by J. E. Clarkson (personal communications, 1988, 1989). Water sample is introduced directly to the chromatograph. The chromatogram is interpreted to establish concentrations of TNT, RDX, and HMX.

- Bottles: For convenience, a 40-mL borosilicate glass bottle with Teflon-faced silicone septum in a screw-top cap is used.

- Preservation: None required. For convenience, refrigerated until delivery to laboratory. 

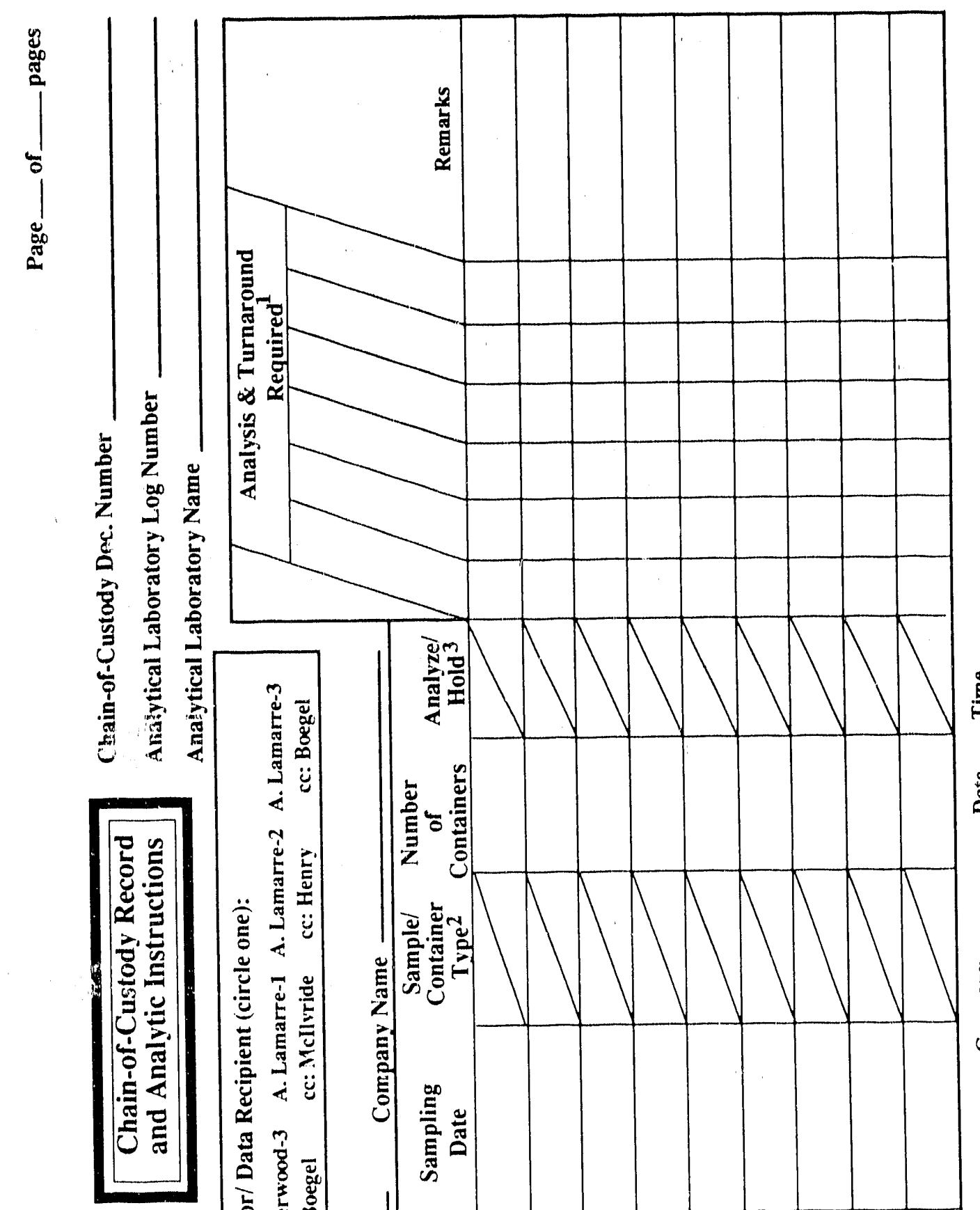

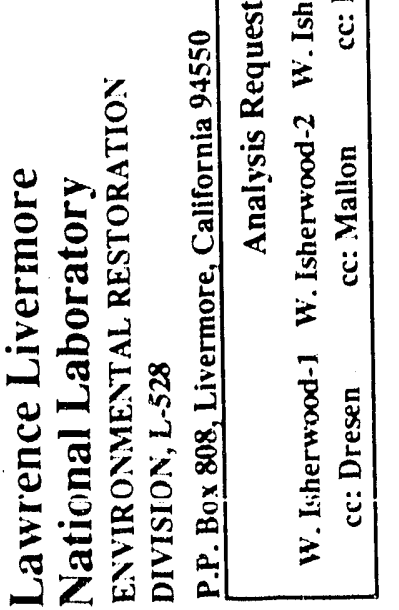

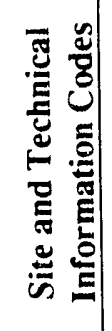

เั้

름

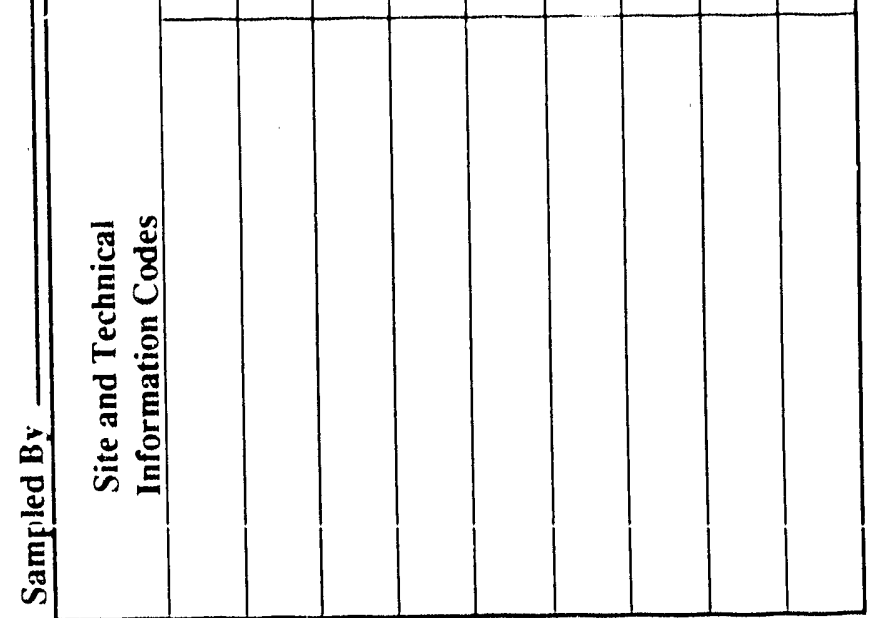

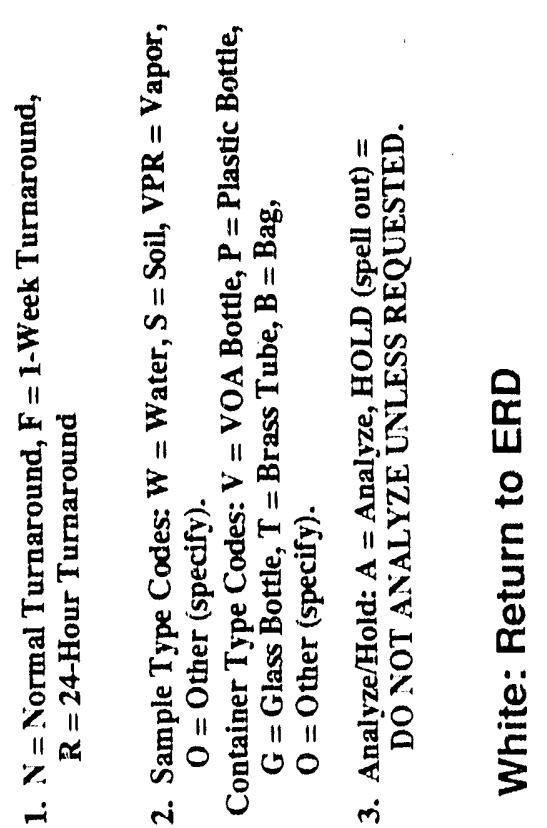
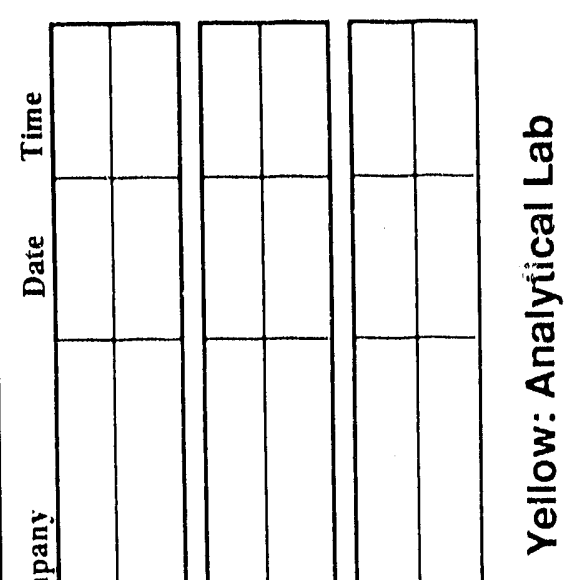
Appendix H

\section{RDX and HMX Toxicology and Regulatory Criteria}




\section{Appendix H. RDX and HMX Toxicology}

This appendix contains details of RDX and HMX toxicology and the calculations required to determine a proposed drinking water criterion and DL in soil for RDX.

The toxicity data available, about the lethal doses for $50 \%$ of a laboratory animal population $\left(\mathrm{LD}_{50}\right)$ for RDX and HMX, allow a qualitative comparison of the toxicities of RDX and HMX (Fig. 8.1). However, Wilson (1985), whose report is the major source of information about toxicity of HMX, did not report statistical analyses of data from studies of subchronic toxicity of HMX. For this reason, the data do not support determination of a NOEL dose. Because the drinking water criterion for HMX is calculated from the NOEL dose, we are not able to determine either a drinking water criterion or a DL for HMX.

Many of the toxicological studies discussed in this appendix make use of the concentration term $\mathrm{mg} / \mathrm{kg}$ in a different sense than that used in other parts of this report, primarily in studies of concentrations of solids in soil and rock. In the toxicology studies, mg/ $\mathrm{kg}$ means weight of the substance being tested (in mg units) divided by body weight (in $\mathrm{kg}$ units). It is used to normalize doses given to individual laboratory animals, with normal variations in weight between individuals in a test group, so that experimental results can be compared. In other parts of this report, the term $\mathrm{mg} / \mathrm{kg}$ is used to define the concentration of a solid substance relative to soil or rock.

In the toxicological reports reviewed here, the term $\mathrm{mg} / \mathrm{L}$ is used to define concentration of a solute in a solvent, for example, in defining the concentration of liquid doses when the weight of the test animal is not considered. This usage is essentially identical to the usage of the term in the other parts of this report.

\section{H.1. Toxicology and Pharmacology of RDX}

Etnier (1989) included a review of the toxicology of RDX in her article which discusses the establishment of a drinking-water criterion for RDX. We have summarized the review for this report; for additional detail, see Etnier (1989). Layton et al. (1987) also reviewed the literature for RDX; a part of our review is excerpted from that report.

\section{H.1.1. Toxicokinetics}

Following ingestion, RDX is slowly absorbed from the gastrointestinal tract and from across the surface of the lungs. Studies show no clinical evidence of dermal absorption (Etnier, 1989).

In laboratory animals, RDX is metabolized primarily in the liver; no intermediate metabolites have been identified. RDX does not accumulate appreciably in any tissue and is excreted in urine or exhaled as carbon dioxide (Etnier, 1989).

\section{H.1.2. Human Toxicity}

There are no controlled studies of RDX toxicity in humans, although accidental inhalation or ingestion of RDX has resulted in adverse health effects (Etnier, 1989). RDX exerts its primary toxic effect on the human central nervous system (CNS); these effects appear to be completely reversible (Etnier, 1989). Chronic RDX intoxication has been observed in munitions industry workers, where exposure resulted primarily from inhalation of RDX particles (Etnier, 1989). 
An unusually high incidence among workers at a munitions plant of systemic lupus erythematosus (SLE), an immune system disorder of unknown etiology, prompted a epidemiologic study to determine if there was a correlation between exposure to explosives and onset of this disease. The epidemiologic study by Hathaway and Buck (1977) covered three plants in which individuals were exposed to RDX or to mixtures of RDX and other explosives. There warta analyses of concentrations of explosives in air. Hathaway and Buck (1977) found no stativically significant differences in blood chemistry or in the presence of antinuclear antibodirs (which produce lupus symptoms) between exposed and unexposed workers.

\section{H.1.3. Animal Toxicity}

H.1.3.1. Acute Toxicity. As in humans, CNS excitation is the most prominent acute effect of RDX in most animals. Other toxic effects include gasping and labored breathing (Etnier, 1989).

Etnier (1989) summarized lethality data for RDX for various species and routes of exposure. In the rat, $\mathrm{LD}_{50}$ values for $\mathrm{RDX}$ range from 44 to $300 \mathrm{mg} / \mathrm{kg}$, indicating moderate to high toxicity (Etnier, 1989). Oral LD 50 values for the same species may differ among laboratories, depending on the physical form of the RDX and on the vehicle used to suspend or dissolve it (Schneider et al,, 1977). In addition, males and fernales of the same species may respond differently to RDX exposure (Etnier, 1989).

Sunderman (1944), in an attempt to learn whether RDX was affecting the CNS, found that Nembutal, an antispasmodic drug, prevented convulsions and death in rats.

When studies were evaluated of the neurobehavioral toxicity of acute RDX exposure, a dose-related response in schedule-controlied behavior, flavor-aversion conditioning, motor activity, and agility at $12.5 \mathrm{mg} / \mathrm{kg}$ (McPhail et al., 1984, 1985) was found.

H.1.3.2. Subchronic and Chronic Exposure Studies. Brown (1975) studied rats exposed for 12 weeks to $0.3,2.5,6.5$, or $12.5 \mathrm{mg} / \mathrm{kg}-\mathrm{d}$ RDX. Etnier (1989) does not report the dose route. Except at the lowest dose, the treatment was found to induce time- and doserelated biphasic changes in brain monoamine oxidase, cholinesterase, and oxygen uptake. None of these effects were found in rats dosed with $0.3 \mathrm{mg} / \mathrm{kg}-\mathrm{d}$. This level was reported as a subchronic NOEL (Brown, 1975).

Hart (1976) conducted a two-year study of the effects of dietary intake of RDX in rats at levels of $0,1.0,3.1$ and $10 \mathrm{mg} / \mathrm{kg}$-d. Tests of hematology, blood chemistry, urinalysis, gross necropsies, organ weight, and histopathological examination resulted in no significant evidence of RDX toxicity. Among RDX-treated animals, no significant increase in the incidence of neoplasms was observed when coinpared to controls.

Levine et al. (1983) conducted studies to evaluate the toxicity of chronic doses of RDX. In the two-year study, RDX mixed with 3 to $10 \% \mathrm{HMX}$ (corresponding to the composition of military-grade RDX) was administered in the diet of Fis (her 344 rats at doses of $0.3,1.5,8.0$, and $40.0 \mathrm{mg} / \mathrm{kg}-\mathrm{d}$. Rats given RDX at $1.5 \mathrm{mg} / \mathrm{kg}-\mathrm{d}$ and above exhibited anemia, heparotoxicity, possible CNS involvement, and urogenital lesions. However, the next lowest dose of RDX, 0.3 $\mathrm{mg} / \mathrm{kg}$-d, did not elicit any adverse effects. Thus under the conditions of this study, Levine $e t$ al. (1983) concluded that $0.3 \mathrm{mg} / \mathrm{kg}$-d represented the NOEL for RDX. No evidence of carcinogenicity was tound during this study.

Lish 4 : al. (1984) studied groups of male and female mice fed RDX at doses of 1.5, 7.0, 35.(), and $100.0 \mathrm{mg} / \mathrm{kg}$-d over a two-year period. Etnier (1989) reviewed a draft version of this report and cited it as Levine et al. (1984). Layton et al. (1990, in press) reviewed the final report and cited it as Lish et al. (1984). We cite it here as Lish et al. (1984). The RDX contained 1 to $11 \%$ HMX as an impurity, which corresponds tó the mixiuire iñ militâry-grade RDX. Initially, the 
high-dose group received RDX at $175 \mathrm{mg} / \mathrm{kg}$-d, but increased mortality necessitated a reduction in dose to $100 \mathrm{mg} / \mathrm{kg}-\mathrm{d}$. The major toxic effects included hepatotoxicity, possible CNS involvement, and testicular degeneration. A possible treatment-related increase in serum triglyceride levels was observed in female mice given RDX at $35 \mathrm{mg} / \mathrm{kg}-\mathrm{d}$. Elevated serum cholesterol levels were observed in female mice at $35 \mathrm{mg} / \mathrm{kg}-\mathrm{d}$, and possibly at $7 \mathrm{mg} / \mathrm{kg}-\mathrm{d}$. These effects were not seen in animals that received RDX at $1.5 \mathrm{mg} / \mathrm{kg}-\mathrm{d}$. Based on these observations, Lish et al. (1984) determined that under the conditions of this study, the NOEL was $1.5 \mathrm{mg} / \mathrm{kg}-\mathrm{d}$ of RDX. Lish et al. (1984) reported that there was a dose-related increase in hepatocellular carcinomas in female mice that was not statistically significant. However, the combined incidence of hepatocellular carcinomas and hepatocellular adenomas was statistically significant $(\mathrm{p}<0.05)$ for female mice in the 7.0 and $35.0 \mathrm{mg} / \mathrm{kg}-\mathrm{d}$ treatment groups.

\section{H.1.4. Genotoxicity and Developmental/Reproductive Toxicity}

Etnier (1989) stated that no evidence of genotoxicity or developmental/reproductive toxicity was found in various short- and long-term studies (e.g., Simmon et al., 1977; Stilwell et al., 1977; Cotruvo et al., 1978; Cholakis et al., 1980; and Isbister et al., 1984).

\section{H.1.5. Carcinogenicity}

The carcinogenicity of RDX has been studied during investigations of chronic RDX-toxicity by Hart (1976), Levine et al. (1983), and Lish et al. (1984). Refer to Section 1.1.3 for a review of the noncarcinogenic effects of chronic treatment.

Hart (1976) conducted a two-year study of the effects of dietary intake of RDX in rats at levels of $0,1.0,3.1$, and $10 \mathrm{mg} / \mathrm{kg}-\mathrm{d}$. Among RDX-treated animals, no significant increase in the incidence of neoplasms was observed when compared to controls.

Levine et al. (1983) conducted studies to evaluate the toxicity of chronic doses of RDX. In the two-year study, RDX, mixed with 3 to $10 \%$ HMX (corresponding to the composition of military-grade RIDX), was administered in the diet of Fischer 344 rats at doses of ().3,1.5, 8.(), or $40.0 \mathrm{mg} / \mathrm{kg}-\mathrm{d}$. No evidence of carcinogenicity was found in animals from any of the treatment groups (Levine et al, 1983).

Lish et al. (1984) studied groups of male and female B6C3F1 mice fed RDX at doses of 1.5, 7.0, 35.0, and $100.0 \mathrm{mg} / \mathrm{kg}$-d over a two-year period. The RDX contained 1 to $11 \% \mathrm{HMX}$ as an impurity, which corresponds to the mixture ia military-grade RDX. This study was performed in the same laboratory as the study reported by Levine et al. (1983). Lish et al. (1984) reported a dose-related increase in heptocellular carcinomas in female mice that was not statistically significant. However, the combined incidence of hepatocellular carcinomas and hepatocellular adenomas was statistically significant $(p<0.05)$ for the female mice in the 7.0 and $35.0 \mathrm{mg} / \mathrm{kg}-\mathrm{d}$ treatment groups.

Although these data indicate that high doses of RDX may be carcinogenic to mice, they have not been corroborated by other investigators. According to all other indications, RDX is not carcinogenic. Short-term tests of genotoxicity have given consistently negative results (e.g., Simmon et al., 1977). Hart (1976) and Levine et al. (1983) found no evidence of carcinogenicity. We quote the following indented passage from Etnier's (1989) conclusions:

... the absence of an adequate dose-response curve, the high mortality rate recorded at the highest concentration iested, and contamination with HMX, as well as the absence of any other supporting data in the study by Lish et al. (1984) preclude the development of a carcinogenicity-based risk assessment for humans based on these data. Furthermore, no evidence of carcinogenicity was apparent in a 24-month rat study performed in the same laboratory with the same mixture of RDX/HMX (Levine et al., 1983). 
Etnier (1989) concluded that data are insufficient to indicate that RDX is carcinogenic, and that drinking water criteria should be based on the long-term chronic toxicity studies of Levine $e t$ al. (1983).

\section{H.2. Calculation of Drinking Water Criterion}

Carcinogenicity data from human or animal tests are insufficient to derive a water quality criterion based on a nonthreshold, low-dose extrapolation procedure. There are also no human studies suitable for estimating a NOEL. Therefore, Etnier (1989) based calculations of a human health criterion on the long-term studies in rats that were administered RDX (mixed with 3 to 10 percent of $\mathrm{HMX}$ ) in the diet at concentrations of $0.3,1.5,8.0$, and $40.0 \mathrm{mg} / \mathrm{kg}-\mathrm{d}$ (Levine et al, 1983). These criterion are discussed in detail in the following paragraphs. Etnier also reviewed other studies in which a NOEL was reported.

\section{H.2.1. No-Observed-Effects-Level (NOEL) Dose}

Several reports (Brown, 1975; Levine et al., 1983; and Lish et al., 1984) have identified NOEL doses of RDX. These reports are discussed in Section F.1.1.3, and the discussion of toxicity is not repeated here. The information about NOEL doses is summarized.

Brown (1975) studied rats exposed to RDX in the diet for 2 to 12 weeks at $0.3,2.5,6.5$, and $12.5 \mathrm{mg} / \mathrm{kg}$-d RDX. Toxic effects did not occur in rats dosed with $0.3 \mathrm{mg} / \mathrm{kg}-\mathrm{d}$ RDX, but did occur in rats at higher doses. The lowest level, $0.3 \mathrm{mg} / \mathrm{kg}-\mathrm{d}$ RDX, was reported as a NOEL under the conditions of this study.

Levine et al. (1983) reported studies of chronic exposure of rats to RDX. Rats given RDX at $1.5 \mathrm{mg} / \mathrm{kg}-\mathrm{d}$ and above exhibited toxic effects. However, the next lowest dose of RDX, 0.3 $\mathrm{mg} / \mathrm{kg}-\mathrm{d}$, did not elicit any adverse effects, and Levine et al. (1983) concluded that, under the conditions of this study, $0.3 \mathrm{mg} / \mathrm{kg}-\mathrm{d}$ represented the NOEL for RDX.

Lish et al. (1984) studied groups of male and female mice fed RDX at doses of 1.5, 7.0, 35.0, and $100.0 \mathrm{mg} / \mathrm{kg}$-d over a two-year period. The RDX contained 1 to $11 \% \mathrm{HMX}$ as an impurity, which corresponds to the mixture in military-grade RDX. Toxic effects occurred at doses above $1.5 \mathrm{mg} / \mathrm{kg}-\mathrm{d}$. These effects were not seen in animals that received RDX at $1.5 \mathrm{mg} / \mathrm{kg}-\mathrm{d}$. Based on these observations, Lish et al. (1984) determined that under the conditions of this study, 1.5 $\mathrm{mg} / \mathrm{kg}-\mathrm{d}$ represented the NOEL for RDX.

On the basis of the toxicity studies that defined apparent NOELs for RDX, Etnier (1989) selected the lowest value of $0.3 \mathrm{mg} / \mathrm{kg}-\mathrm{d}$ RDX from a long-term study (Levine et al., 1983) as the most conservative NOEL.

\section{H.2.2. Derivation of the Water-Quality Criterion and Designated Level for RDX}

Etnier (1989) used the same methodology outlined to estimate water-quality criteria for protecting human health (U.S. Environmental Protection Agency [EPA], 1980) to estimate a water-quality criterion for RDX.

Using the NOEL value selected, $0.3 \mathrm{mg} / \mathrm{kg}-\mathrm{d}$ RDX, and an uncertainty factor of 100 , an acceptable daily intake (ADI) for a 70-kg human can be calculated as follows:

$$
\mathrm{ADI}=\frac{70 \mathrm{~kg} \times \mathrm{NOEL}(\mathrm{mg} / \mathrm{kg}-\mathrm{d})}{\text { uncertainty factor }}=0.21 \mathrm{mg} / \mathrm{d}
$$


where:

an uncertainty factor of 10 was is to account for interspecies variabillty, and an additional factor of 10 is used to adjust for intraspecies variability (EPA, 1987).

Given an ADI of $0.21 \mathrm{mg} / \mathrm{d}$, the human health criterion for RDX In drinking water can be: calculated from the expression:

$$
\mathrm{C}=\frac{\mathrm{ADI}-(\mathrm{DT}+\mathrm{IN})}{2 \mathrm{~L} / \mathrm{d}+(0 .(0) 65 \mathrm{~kg} / \mathrm{d} \times 1 \mathrm{~L} / \mathrm{kg} \times \mathrm{BCF})}
$$

where:

$$
\begin{aligned}
& \mathrm{C}=\text { Water quality criterion, } \mathrm{mg} / \mathrm{L} \text {; } \\
& \text { D'T = Dietary nonfish intake, assumed to be } 0 \mathrm{mg} / \mathrm{d} \text {; } \\
& \text { IN = Inhalation intake, assumed to be } 0 \mathrm{mg} / \mathrm{d} \text {; } \\
& 1 \mathrm{~L} / \mathrm{kg}=\text { Conversion factor (a close approximation); } \\
& 2 \mathrm{~L} / \mathrm{d}=\text { Daily water intake; } \\
& 0.0065 \mathrm{~kg} / \mathrm{d}=\text { Daily dietary fish intake; and } \\
& \mathrm{BCF}=\text { Bioconcentration factor, assumed to be } 4.7 \text { (dimensionless) } \\
& \text { by Bentley et al (1977). }
\end{aligned}
$$

Using EPA methodology (EPA, 1980), Etnier (1989) calculated a suggested ambient waterquality criterion for RDX of $103 \mu \mathrm{g} / \mathrm{L}$, which protects the health of the general population as well as sensitive individuals who ingest RDX-contaminated water and fish. This value was adjusted to $105 \mu \mathrm{g} / \mathrm{L}$ for ingestion of drinking water alone.

\section{H.2.3. Determination of Designated Level (DL) for RDX}

DLs are concentrations of waste constituents that provide a site-specific indication of the waste's potential to impair ground water quality. If measured concentrations of contaminants in soil and rock exceed the DLs, the soil or rock is assumed to pose a water quality threat at the site in question. Site 300 DLs for metals and TCE are shown earlier in Chapter 8, Tables 8.1,1-1 and 8.1.1-2.

The DL is determined by:

1. Specifying the bodies of water potentially affected by the waste.

2. Selecting the water quality goals that protect the potential beneficial uses of the water.

3. Determining the magnitude of environmental attenuation that would be expected to occur at the sita.

The nearest body of water to be protected in the HE Process Area is the first regional water-bearing zone. It lies at least $100 \mathrm{ft}$ beneath the land surface, except in the immediate vicinity of Building 815, where depth to the regional water table aquifer is slightly less. For RDX, the water quality goal selected is Etnier's (1989) suggested drinking water criterion of $105 \mathrm{ug} / \mathrm{L}$.

The DL was determined by using Marshack's (1989) technique. We selected the RDX drinking water criterion, $105 \mu / \mathrm{L}(\mathrm{ppb}) \mathrm{RDX}$, as cur water quality goal. The attenuation factor used was 100, the value Marshack (1987) propose for an "average" site. We calculated the DL. 
for RDX by multiplying the drinking water criterion for $\operatorname{RDX}(105 \mu \mathrm{g} / \mathrm{L})$ by the attenuation factor (100). Therefore the DL is $10.5 \mathrm{mg} / \mathrm{kg}$ (ppm) RDX.

The attenuation factor used is clearly very conservative for Site 300, where permeability and porosity are much lower than at the LAAP. The depth to ground water at Site $3(0)$ is generally substantially greater than at the LAAP. Higgins (1988) agrees that "the hydrogeology in the HE Process Area will attenuate pollutant migration much more than the 'average' attenuation."

\section{H.3. Toxicology and Pharmacology of HMX}

The literature contains very few studies of HMX toxicity. Much of our information is from Layton et al. (1987). We reviewed Wilson's (1985) report itself.

McNamara et al. (1974) studied the toxicity of HMX dissolved in the organic solvents dimethylsulfoxide (DMSO), cyclohexanone, and acetone. Details are speciffed in Section 2.1.1.1. The solvents were used because of the low solubllity of HMX in water. However, it is not likely that dry HMX, or HMX in an aqueous solution, would elicit the same adverse effects because of the limited absorption and low aqueous solubility of the explosive.

Most of Wilson's (1985) studies were made with HMX in aqueous solution, or with small amounts of organic solvents. Wilson (1983) reported many of his results without stating the results of statistical testing. We have complete confidence only in the results accompanied by statistical tests at a specified level of confidence. Some of Wilson's (1985) results are reported as quantitative values, but no confidence level is specified. Wilson reported a second set of his results in qualitative terms, such as "significantly" and "slight increase." We have less confidence in these two sets of data and treat them with caution.

Wilson (1985) reported other data in conditional language; these data appear to be estimates made only to bracket dose ranges for use in subsequent studies of HMX. We consider these values to be estimates only and do not compare them with other results.

\section{H.3.1. Pharmacology and Toxicology}

\section{H.3.1.1. Toxicokinetics}

H.3.1.1.1 Absorntion. Wilson (1985) measured HMX levels in the plasma of mice and rats that had received a single oral dose of radiolabeled HMX. A peak plasma concentration of 6 to $10 \mathrm{mg} / \mathrm{L}$ was observed after an oral dose of $500 \mathrm{mg} / \mathrm{kg}$. The time course was similar in both species, and peak concentrations in plasma were reached $6 \mathrm{~h}$ after ingestion. According to Wilson (1985), the plasma level was "extremely low in relation to dose" and the quantity of HMX in the plasma did not increase "significantly" with dose. However, Wilson (1985) did not report the level of statistical significance.

McNamara et al. (1974) found substantial differences in the toxicity of HMX to dogs, depending upon the route of exposure. In general, dermal applications of HMX $(17.5 \mathrm{mg} / \mathrm{kg}$ in acetone, $21.9 \mathrm{mg} / \mathrm{kg}$ in cyciohexanone, and $289.0 \mathrm{mg} / \mathrm{kg}$ in DMSO) did not produce consistent and predictable physiological alterations. Intravenous administration of HMX (1.55 or 1.1 $\mathrm{mg} / \mathrm{kg}$ in DMSO) caused changes in electroencephalograph (EEG) and electrocardiograph (EKG) readings, blood pressure, and haart rate. Absorption of HMX by rats and guinea pigs appears to be similar to that in dogs. si high concentrations in lipophilic solvents (i.e., $1.0 \mathrm{~mL}$ HMX [33 percent in DMSO]) HMX can penetrate the skin in amounts great enough to cause death in rabbits. Some deaths in guinea pigs also were recorded after single dermal applications of 465 to $546 \mathrm{mg} / \mathrm{L}$ HMX, presumably in DMSO (McNamara et al., 1974). 
H.3.1.1.2 Distribution. Reports of organ toxicity (McNamara et al., 1977; Wilson, 1985) following exposure to HMX indicate that this substance can reach the heart, CNS, immune system, liver, and kidneys. Wilson (1985) also noted that following oral $(50) \mathrm{mg} / \mathrm{kg}$ ) or Intravenous $(2.0 \mathrm{mg} / \mathrm{kg}$ ) administration of HMX to rats, the highest concentrations were found in the liver and kidneys, and the lowest concentrations, in the brain.

H.3.1.1.3 Metabolism and Ellimination. Wilson (1985) reported that fecal elimination (7.5 $1080 \%$ of the dose recovered in the feces) was the dominant route of excretion after oral administration of ${ }^{14} \mathrm{C}-\mathrm{HMX}$ at doses of $500 \mathrm{mg} / \mathrm{kg}$ to rats and mice over a four-day period. When ${ }^{14} \mathrm{C}$-HMX was given intravenously to rats at a dose of $2.0 \mathrm{mg} / \mathrm{kg}$ over a four-day period, urinary excretion $(61 \%)$ was predominant. Wilson (1985) stated that these data imply that HMX is poorly absorbed after oral dosing.

\section{H.3.2. Human Toxicity}

We found no studies of HMX toxicity in humans.

\section{H.3.3. Animal Toxicity}

H.3.3.1. Acute Toxicity. McNamara et al. (1974) reported that, at high concentrations in lipophilic solvents (i.e., 1.0 mL HMX |3.3 percent in DMSO|), a single application of HMX can penetrate the skin in amounts great enough to cause death in rabbits. Some deaths in guinea pigs also were recorded after single dermal applications of 465 to $546 \mathrm{mg} / \mathrm{L}$ HMX.

H.3.3.1.1 Acute toxicity (LD) 50 in rats and mice. Wilson (1985) presented results of several acute toxicity $\left(\mathrm{LD}_{50}\right)$ studies in rats and mice. We report four tests in rats and mice and two in rabbits.

1. In a study of acute HMX oral toxicity, Wilson (1985) administered HMX by gavage as a suspension in $0.5 \%$ aqueous carboxymethylcellulose to Fischer 344 rats. The median oral lethal dose $\left(L_{5())}\right.$ with $95 \%$ confidence limits for rats were calculated to be:

Mules: $\quad 6.49(5.98-6.99) \mathrm{g} / \mathrm{kg}$

Females: $\quad 7.59(6.88-8.31) \mathrm{g} / \mathrm{kg}$

Males and females: $\quad 7.36(6.89-7.83) \mathrm{g} / \mathrm{kg}$

Wilson (1985) stated that HMX may be considered practically nontoxic to rats.

2. Wilson (1985) administered HMX by gavage as a suspension in $0.5 \%$ aqueous carboxymethylcellulose to $\mathrm{B}_{6} \mathrm{C} 3 \mathrm{~F} 1$ mice. The $\mathrm{LD}_{50}$ with $95 \%$ confidence limits were calculated to be:

Males: $\quad 1.96(1.69-2.22) \mathrm{g} / \mathrm{kg}$

Females: $\quad 3.81(3.43-4.20) \mathrm{g} / \mathrm{kg}$

Males and females: $2.71(2.48-2.94) \mathrm{g} / \mathrm{kg}$

Wilson (1985) considers HMX to be slightly toxic to mice.

3. Wilson (1985) administered an intravenous dose of HMX (in DMSO) to Fischer 344 rats. Wilson calculated the $\mathrm{LD}_{50}$ to be:

Males

Females
$25.1(23,()-27.4) \mathrm{mg} / \mathrm{kg}$

$38.1(32.3-43.9) \mathrm{mg} / \mathrm{kg}$ 
Wilson did not state explicit confidence levels for these data.

4. Wilson (1985) applied HMX as a suspension in physiological saline solution under an occlusive dressing to the abraded skin of Fischer 344 rats. He reported that: "The ... $\mathrm{LD}_{50}$ dose is greater than $5.0 \mathrm{~g} / \mathrm{kg}$ body weight."

\section{H.3.3.1.2 Acute toxicity in rabbits.}

1. HMX was applied as a suspension in physiological saline solution or in carboxymethylcellulose under an occlusive dressing to the skin of rabbits. Wilson (1985) stated that:

The percutaneous median lethal doses (with $95 \%$ confidence limits) were calculated to be:
Males (nonabraded):
$634(532-736) \mathrm{mg} / \mathrm{kg}$
Males (abraded):
$674(562-785) \mathrm{mg} / \mathrm{kg}$
Females (nonabraded):
$719(596-842) \mathrm{mg} / \mathrm{kg}$
Females (abraded):
$1337(415-1759) \mathrm{mg} / \mathrm{kg}$
Males and females (nonabraded/abraded):
$982(861-1103) \mathrm{mg} / \mathrm{kg}$

2. V/ilson (1985) reported the results of acute HMX toxicity in rabbits. HMX was administered by gavage as a suspension in $0.5 \%$ aqueous carboxymethylcellulose. Wilson stated: "In males, the oral LD 50 might be between 100 and $250 \mathrm{mg} / \mathrm{kg}(\mathrm{ppm})$, while in females it might be less than $50 \mathrm{mg} / \mathrm{kg}$." Wilson reported no statistical analysis if these results.

On the basis of the test of dermal toxicity, we conclude that HMX has low toxicity in rabbits.

H.3.3.2. Subchronic Toxicity. Wilson (1985) conducted subchronic (13-week) toxicity studies of RDX in the diet of rats and mice. Male rats were given 50,150,450,1350, and $4000 \mathrm{mg} / \mathrm{kg}-\mathrm{d} \mathrm{HMX}$, and for female rats the doses were $50,115,270,620$, and $1500 \mathrm{mg} / \mathrm{kg}$ d HMX. "Significant" effects to livers (enlarged centrilobular cells) were observed in males at dose rates of $150 \mathrm{mg} / \mathrm{kg}-\mathrm{d}$ HMX and above. Kidney effects (focal atrophy and dilation) were observed in females at dose rates of $270 \mathrm{mg} / \mathrm{kg}-\mathrm{d}$ HMX or more. Wilson did not provide statistical levels of significance for these data.

In another 13-week study, male mice were given at $0,5,12,30,75$, and $200 \mathrm{mg} / \mathrm{kg}$-d HMX, and the females, 0, 10, 20,90,250, and 750 $\mathrm{kg} / \mathrm{mg}-\mathrm{d} \mathrm{HMX}$ (Wilson, 1985). Laboratory studies of the mice did not reveal any major differences between the treated animals and the control groups. At the highesi dose rate $(200 \mathrm{mg} / \mathrm{kg}$ for males, 250 or $700 \mathrm{mg} / \mathrm{kg}-\mathrm{d})$, mortality was high (13/20 males, 20/20 females).

Wilson (1985) did not identify a NOEL for either rats or mice, and no statistical tests were reported for comparisons between the control groups and the treatment groups.

H.3.3.2.1 Hepatic Effects. Wilson (1985) reported centrilobular degeneration of the liver of male rats fed a high dose (an average of $8504 \mathrm{mg} / \mathrm{kg}$-d) of HMX for 14 days. In the same study, female rats fed somewhat smaller doses (1280 to $3474 \mathrm{mg} / \mathrm{kg}-\mathrm{d}$ of HMX) exhibited hepatocyte hyperplasia.

Wilson (1985) also reported "significant increases" in levels of alkaline phosphatase in rats fed high dosages of HMX (400) $\mathrm{mg} / \mathrm{kg}$-d in males, 150$) \mathrm{mg} / \mathrm{kg}$-d in females) in the diet relative to controls; However, after 7 weeks, only the females continued to have abnormally high levels of the enzyme. In a 90-day experiment, Wilson found that a "significant" number of male rats 
fed high dosages of HMX (between 450 and $4(K)(\mathrm{mg} / \mathrm{kg} \cdot \mathrm{d}$ ) developed enlarged contrilobular llver cells. Wilson also found that alanine aminotransferase and alkallne phosphatase netlvily were "sllghtly depressed" In mule rats trented with moderate doses $(5$ to $2(x) \mathrm{m} / \mathrm{g} / \mathrm{kg}-\mathrm{d})$ of $11 \mathrm{MX}$. Mlee that dled before the completion of " 14 -day trentment perlod with HMX $(10)(0)$ to 5()()() $\mathrm{mg} / \mathrm{kg}-\mathrm{d}$ ) had a doserpelated increase in the incldence of hepatocollular hyperplasla (Wllson, 1985).

H.3.3.2.2 Renal Effects. Wilson (1985) found that blood urea levels were "significantly" elevated and that elevated levels of albumin occurred in both male and female rats glven HMX in their diet at 15()() $\mathrm{mg} / \mathrm{kg}$-d for 13 weeks. Male rats fed $4(0)(0 \mathrm{mg} / \mathrm{kg}$-d of $\mathrm{HMX}$ excrete( abnormal amounts of albumin in their urine after flve weeks of treatment. Localized atrophy of the kidney tubules was noted in female rats fed 270 to 1.5()() $\mathrm{mg} / \mathrm{kg}-\mathrm{d}$ of HMX for 1.3 weeks. Female rats also exhibited a dose-related increase in kidney welght.

H,3.3.2.3 Dermal Effects. Wilson (1985) Indicated that a suspenston of HMX In physiologic saline solution (to a concentration of 6()$\%$ ) was "mildly trritating" to the skin of rabbits.

H.3.3.2.4 Qcular Effects. Wilson (1985) reported that dry HMX, or HMX in distilled water (60) suspension), was "practically non-irritating" to the eyes of rabbits.

H.3.3.2.5 Cardievascular Effects. McNamara et al. (1974) reported vascular collapse and death in dogs after a single intravenous dose of $40 \mathrm{mg} / \mathrm{kg}$ of HMX in DMSO.

H.3.3.2.6 Central Nervous Sistem Effects. Wilson (1985) reported that mice of both sexes given 5 to $750 \mathrm{mg} / \mathrm{kg}$-d HMX in the det for 13 weeks had slighitly higher brain wcights than untreated controls.

H.3.3.2.7 Lematological Effects. During weeks 5 and 12 of a 13-week feeding study, Wilson (1985) observed a decrease in hemoglobin levels in high-dose male and female rats (40)() and $15(K) \mathrm{mg} / \mathrm{kg}-\mathrm{d})$. In the 12 th week, animals of both sexes developed a "slight increase" in the levels of methemoglobin and had a reduced red blood cell count.

H.3.3.2.8 Lmmune System Effects. Wilson (1985) found no evidence that HMX caused allergic sensitization in animals. Female rats fed HMX daily for 14 days (Wilson, 1985) displayed lymphocyte depletion in the thymus and spleen. The daily dose was not clearly specified; although the rats belonged to the group exposed to $9(X)() \mathrm{mg} / \mathrm{kg}$-d, the author reported that the actual average dose was $3055 \mathrm{mg} / \mathrm{kg}-\mathrm{d}$. Similar abnormalities were observed in female rats that died before the end of the 14-day treament period. These animals had received doses of either 1280 or $3474 \mathrm{mg} / \mathrm{kg}-\mathrm{d}$. A dose-related depletion of thymic and splenic cells was also found in mice given $1(x)$ to 5()$(0) \mathrm{mg} / \mathrm{kg}-\mathrm{d}$ of HMX over 14 days. These effects apparently were found only in animals that died before the end of treatment.

\section{H.3.4. Genotoxicity or Developmental/Reproductive Toxicity}

Simmon et al. (1977) evaluated the mutagenicity of compounds found in rinse water from munitions plants. HMX was tested in the rinse water both before any treatment and agnin after the rinse water was treated with chlorine for purification. HMX (0.25 mL) was tested in the Ames assay with Salmonella typhimurium, and in a separate series of tests, HMX (0.0(0)5 to (0.25 $\mathrm{mL}$ ) was allowed to react with 10 to $10(0)(\mathrm{mL}$ of chlorine before testing of $\mathrm{S}$. typhimurium. HMX did not significantly increase the frequency of reverse mutations in any of the tests.

\section{H.3.5. Teratogenicity and Carcinogenicity}

There are no data on the teratogenicity or carcinogenicity of HMX. 


\section{H.4. HIMX: Drinking Water and Designated Level Assessments}

\section{H.4.1. No-Observed-Effects-Level (NOEL) Dose}

Wilson (1985) did not Identify a NOEL for HMX in his 13-week studies of subchrontc toxicity in rats and mice, and he failed to provide any statistical analysis of the significance of his results. This lack of statistical testing of the data precludes selectlon of a NOEL from his data.

\section{H.4.2. Drinking Water Criterion}

Because the data do not support determination of a NOEL, calculation of a drinking-water criterion is not possible.

\section{H.4.3. Designated Level Assessment}

Because it is not possible to determine a drinking water criterion, we cannot determine a DL, 


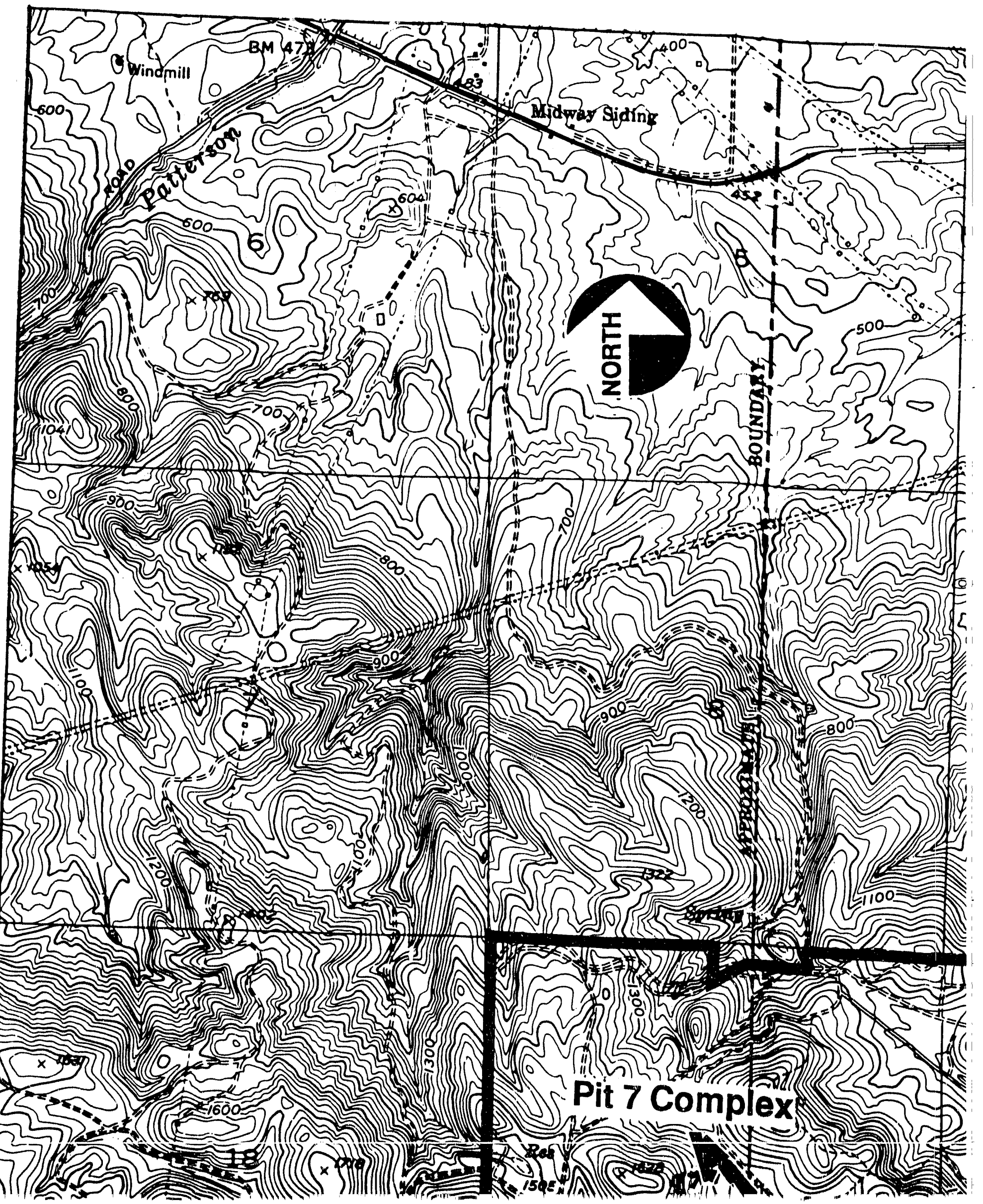




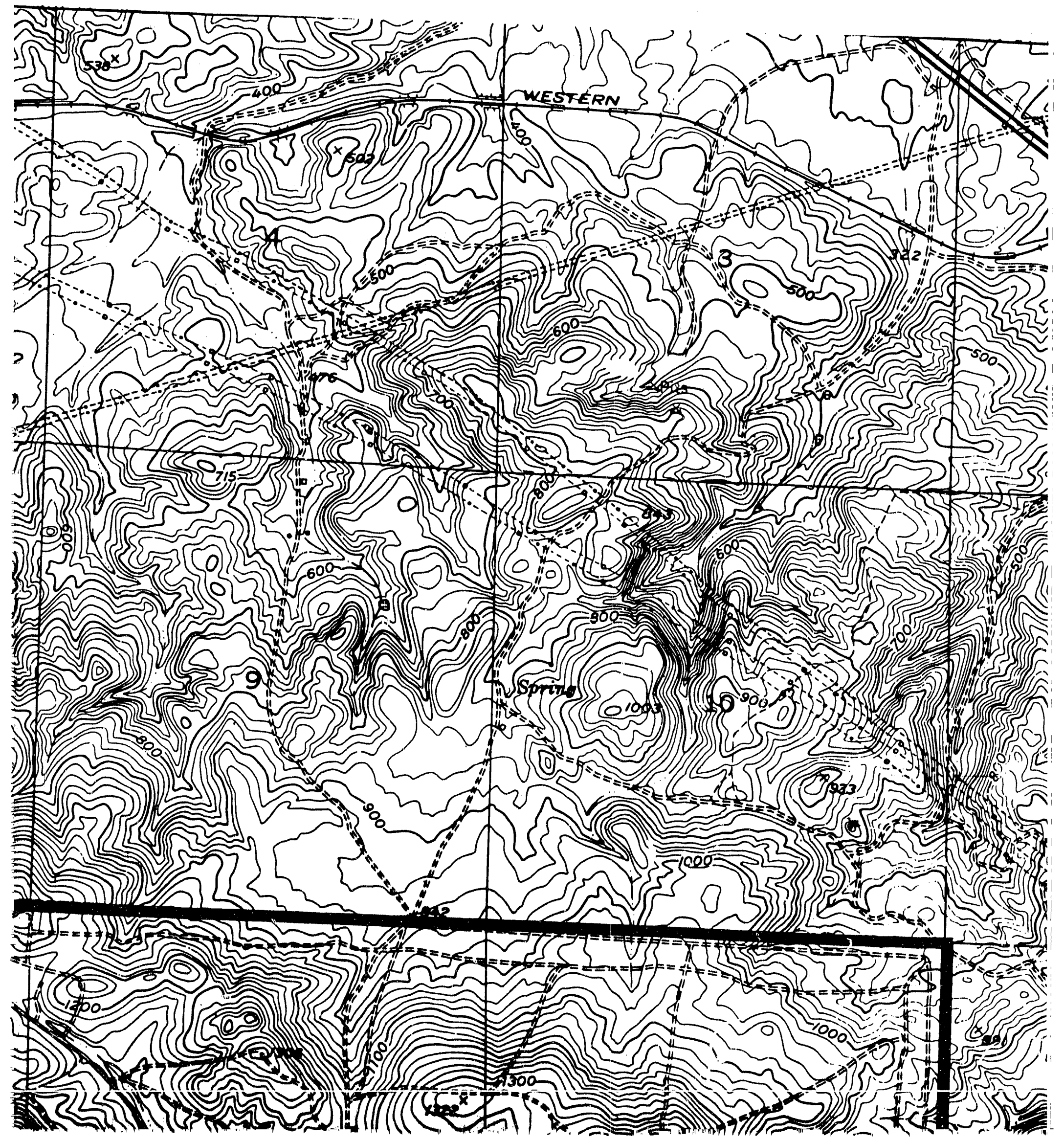




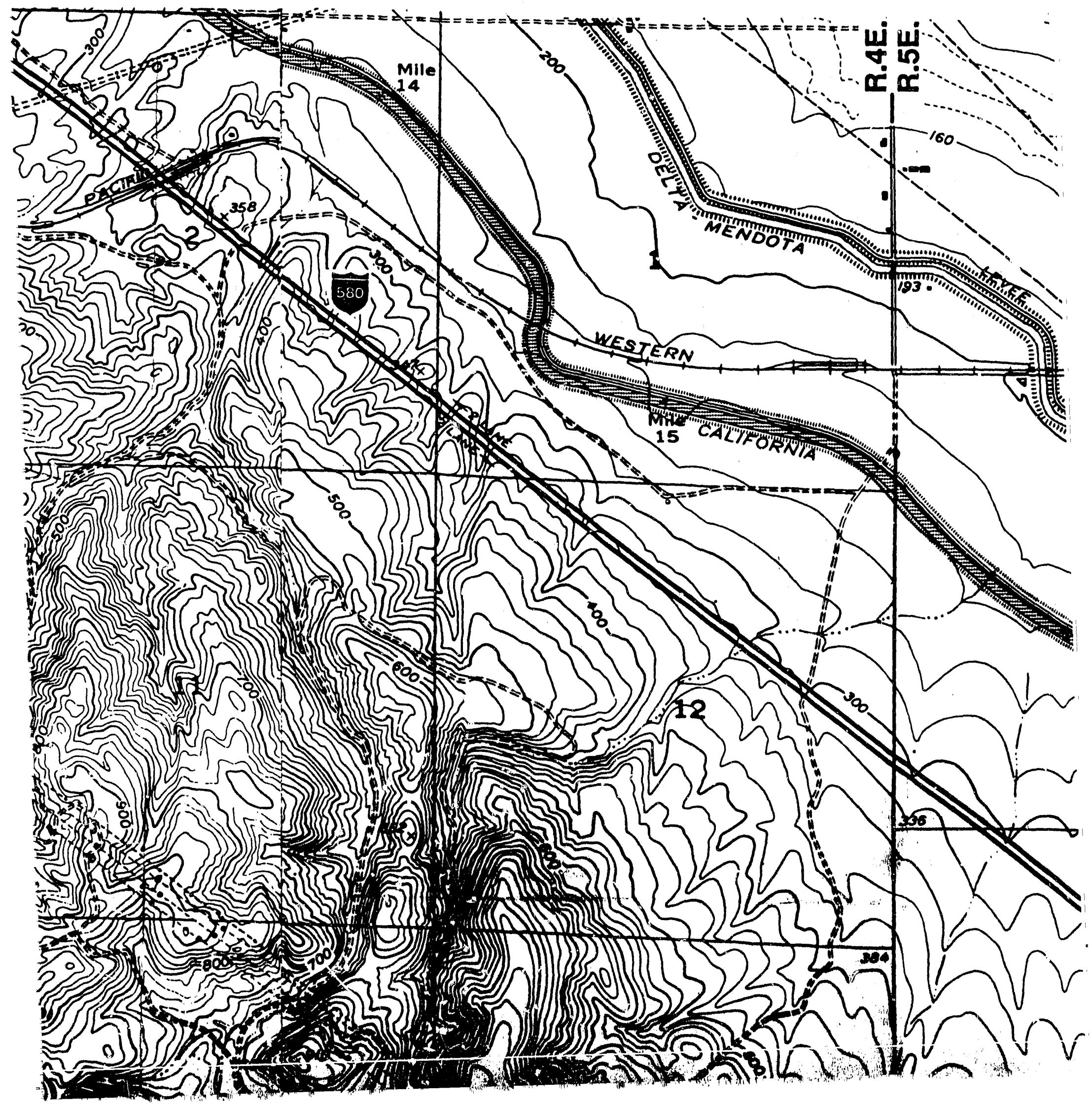




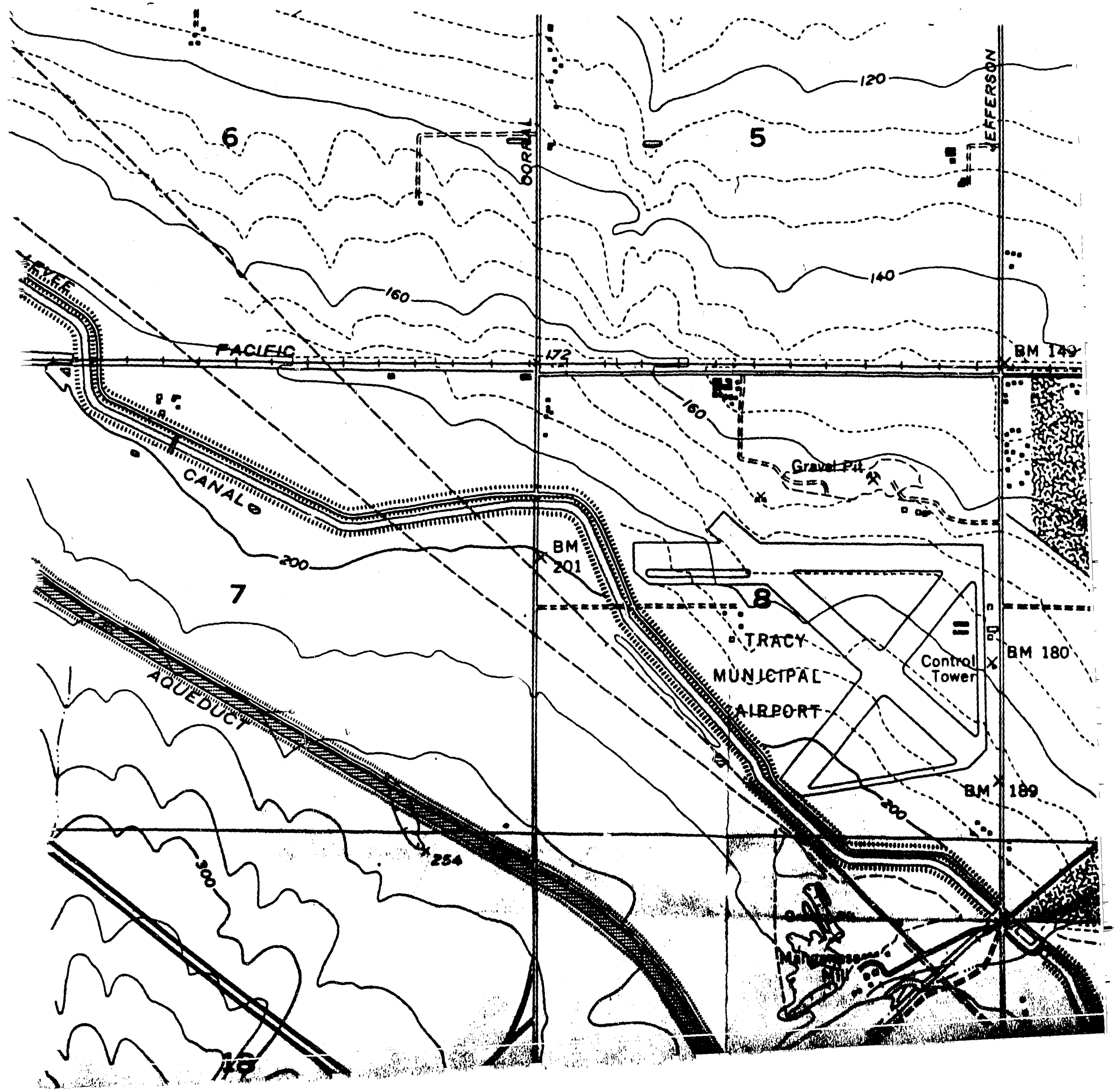




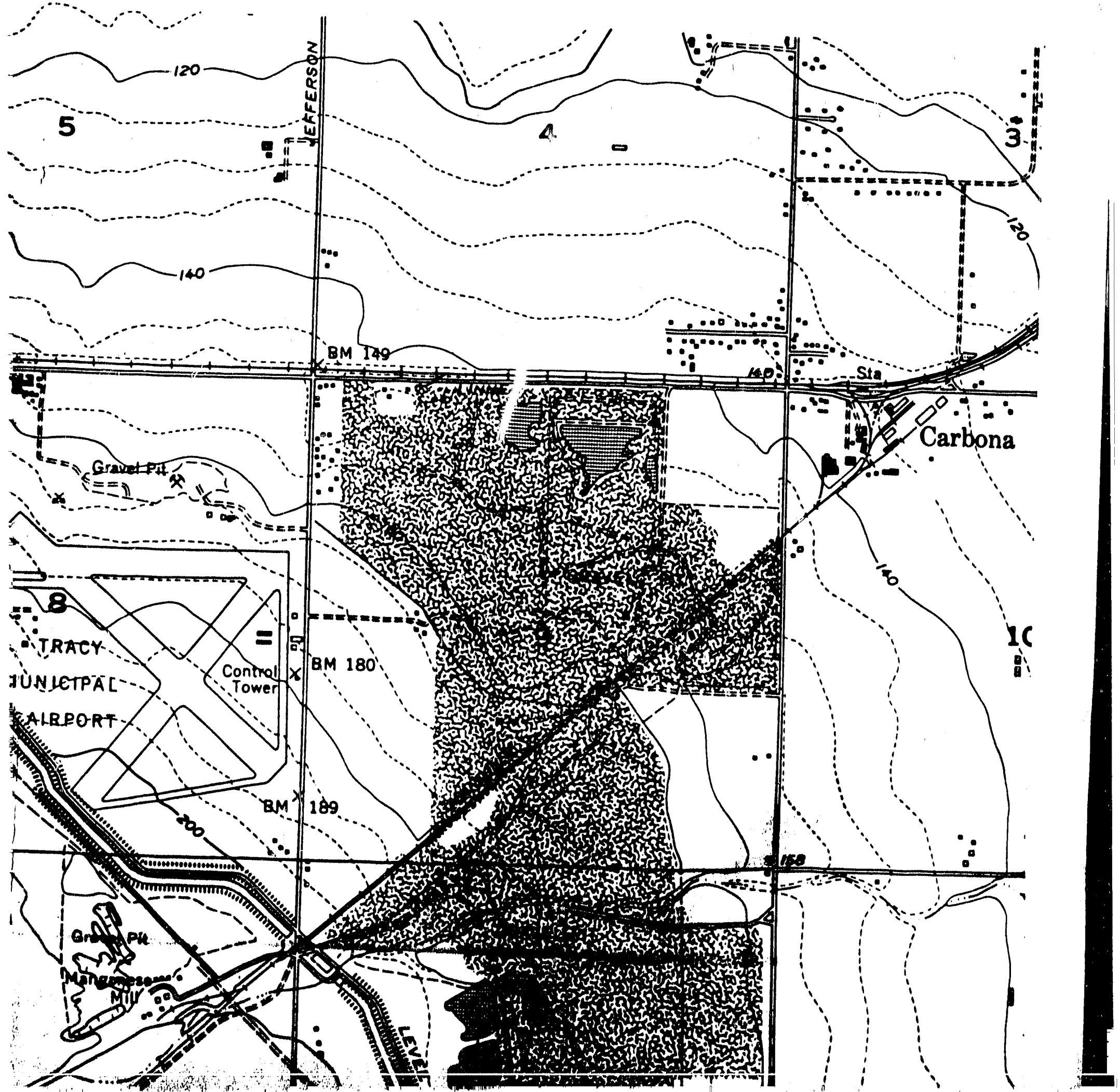




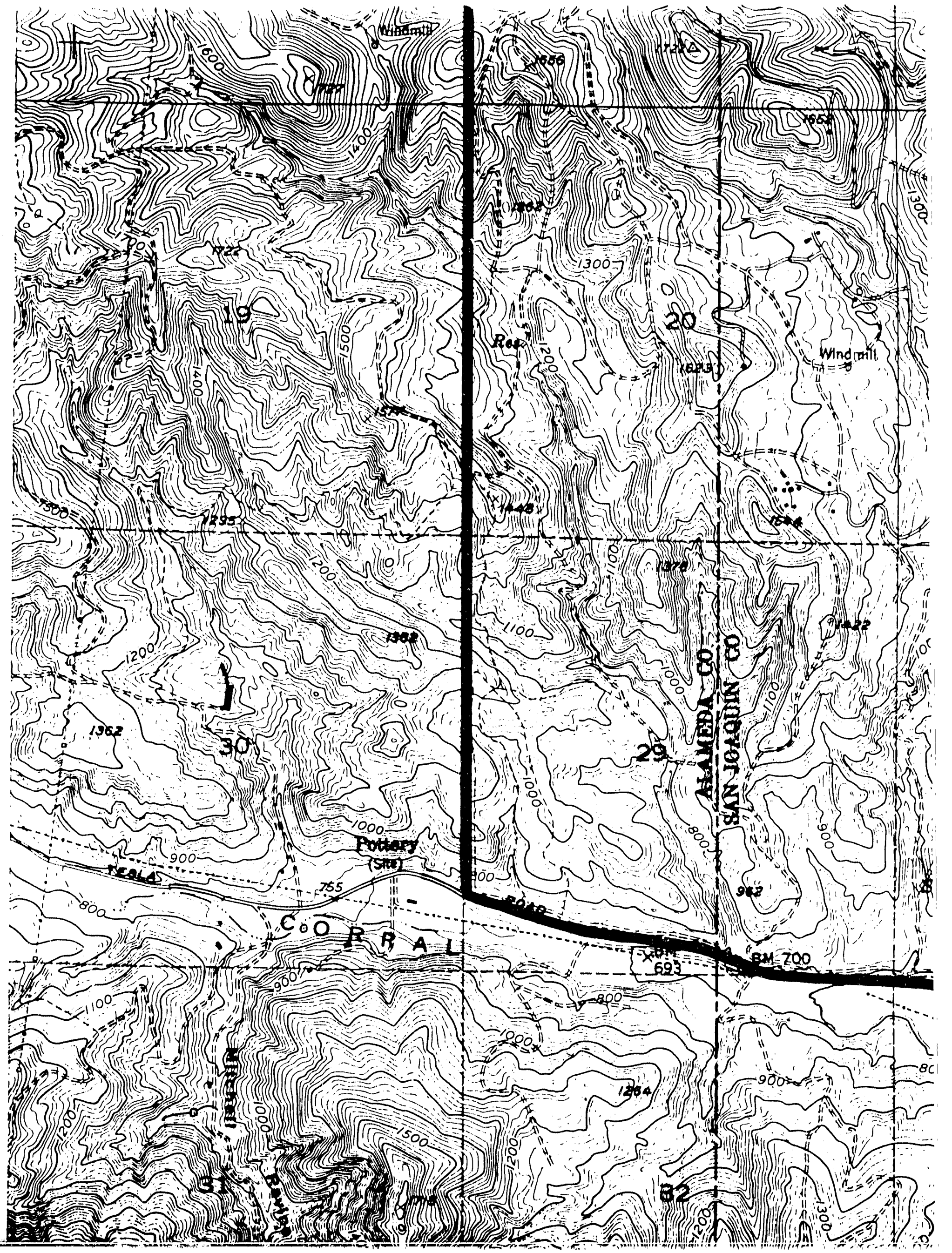


(j) H.

A.

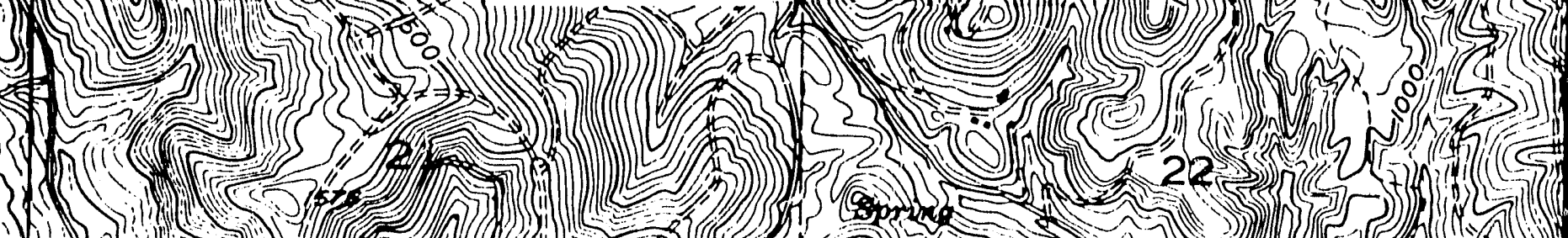

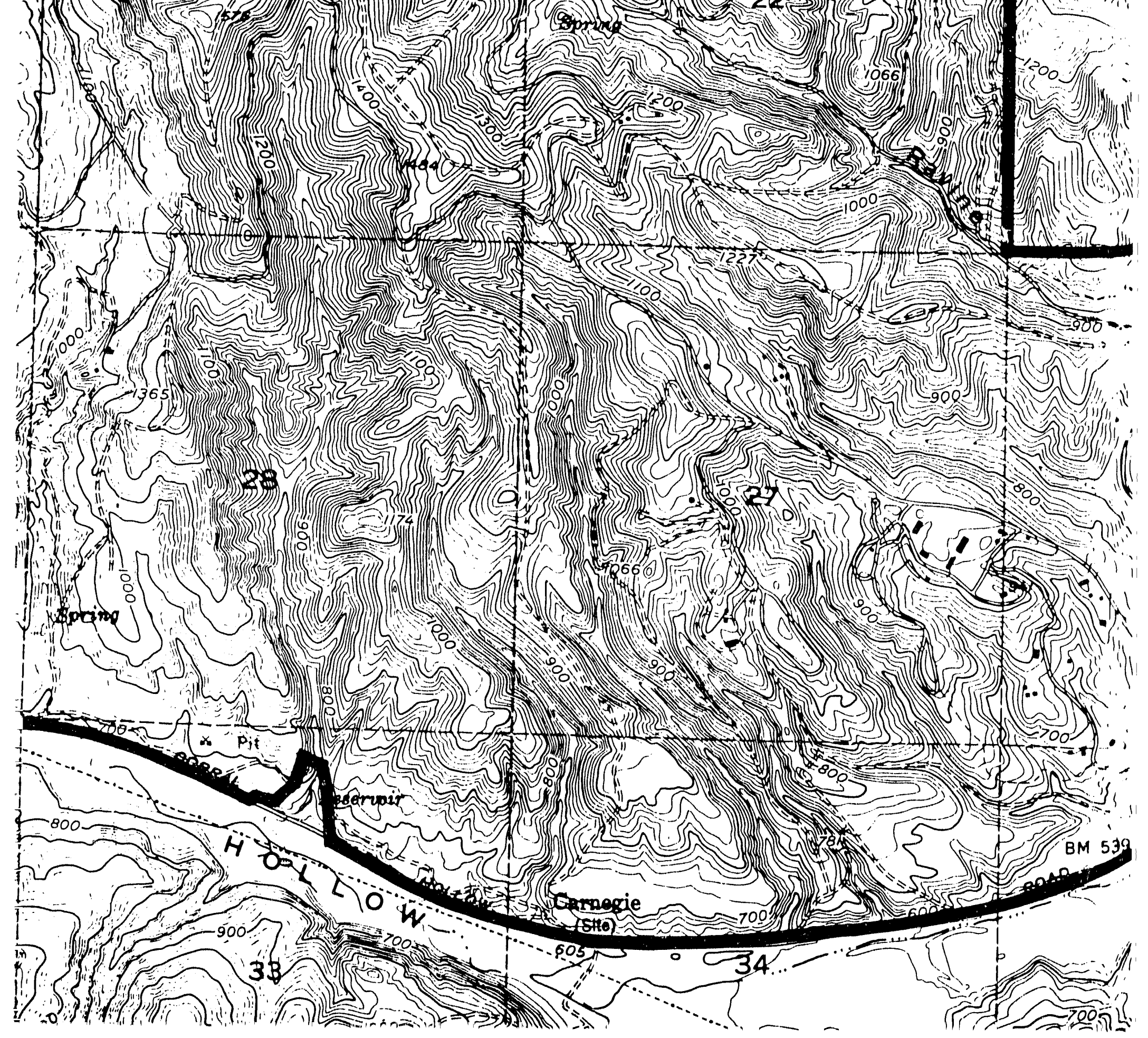




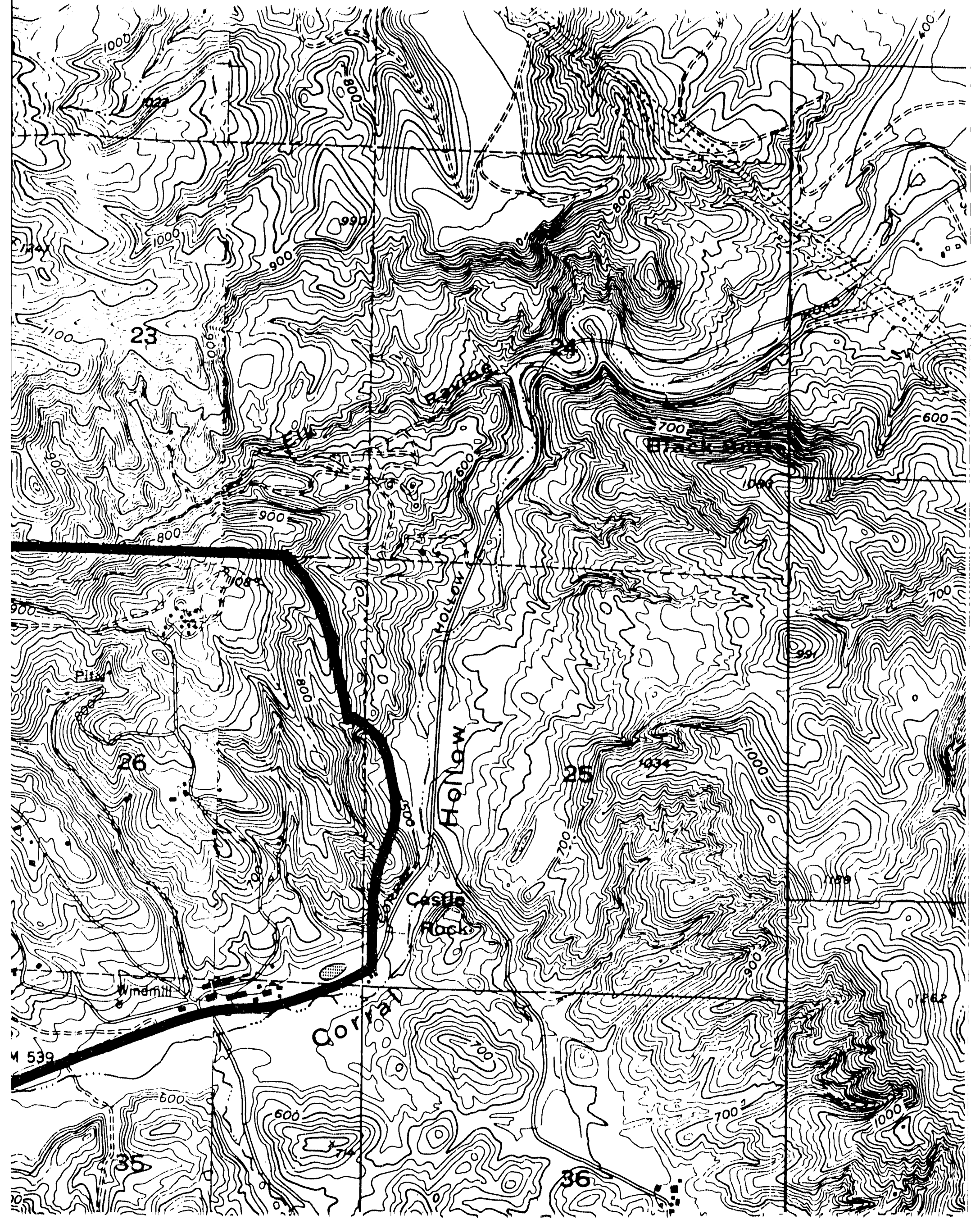




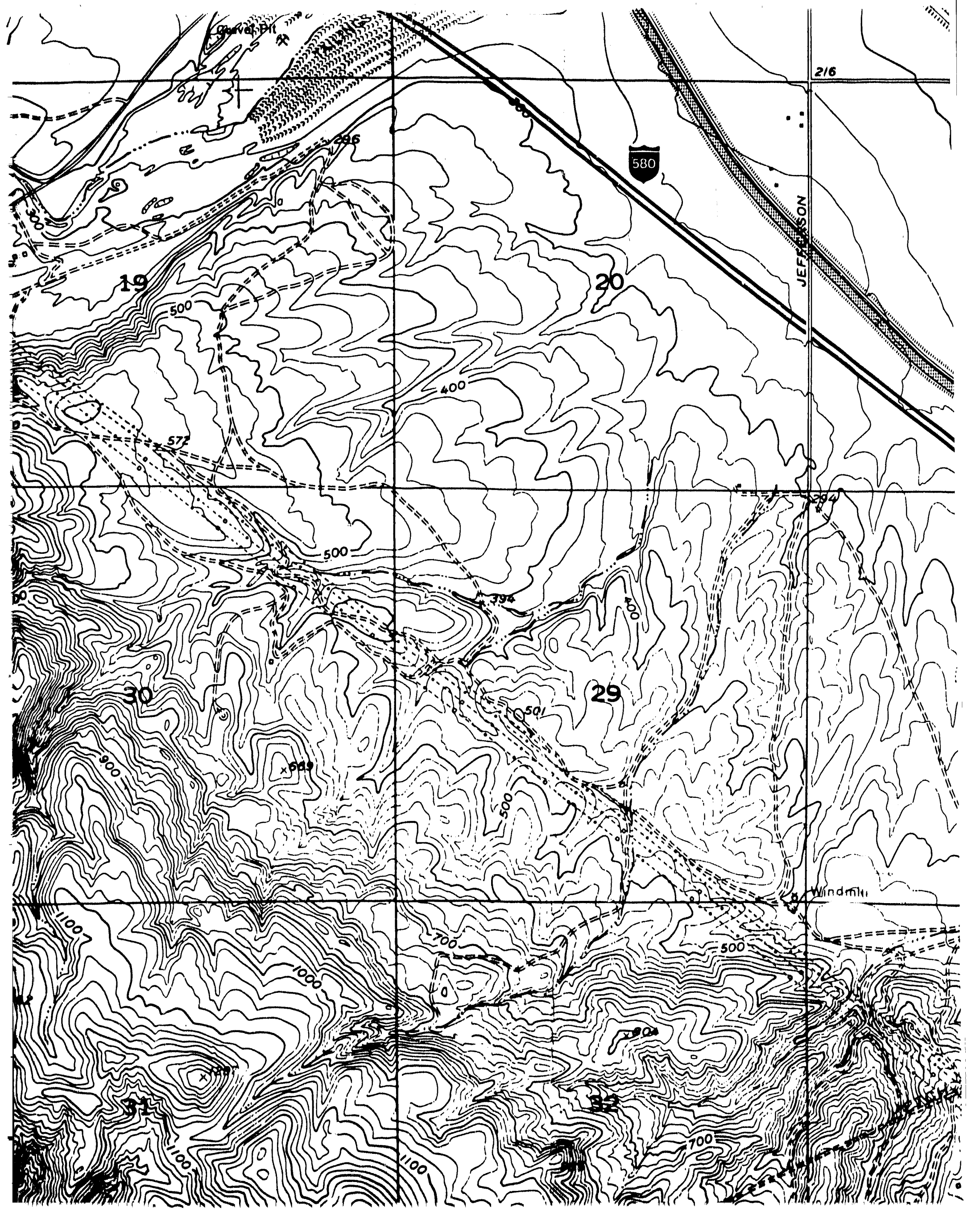




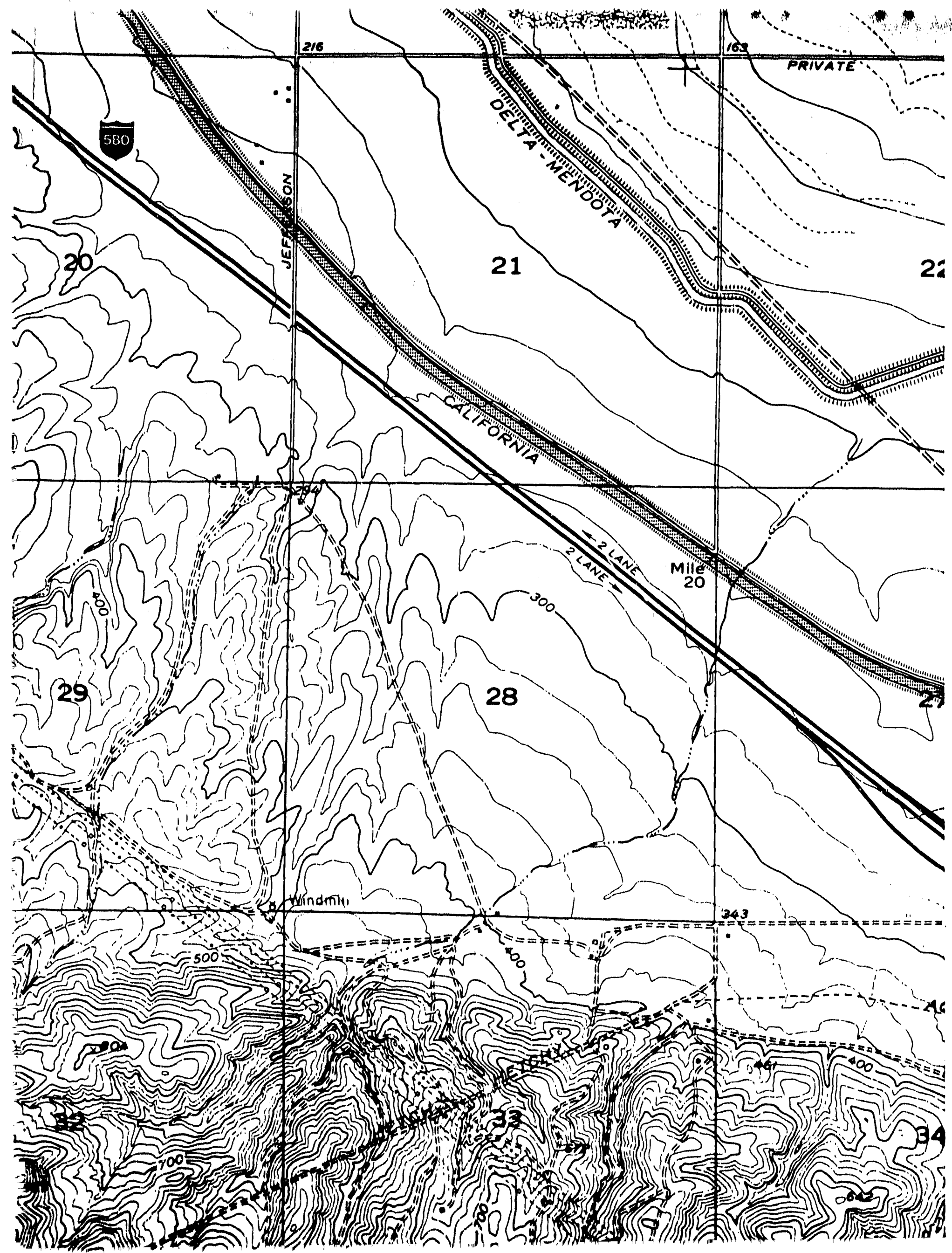




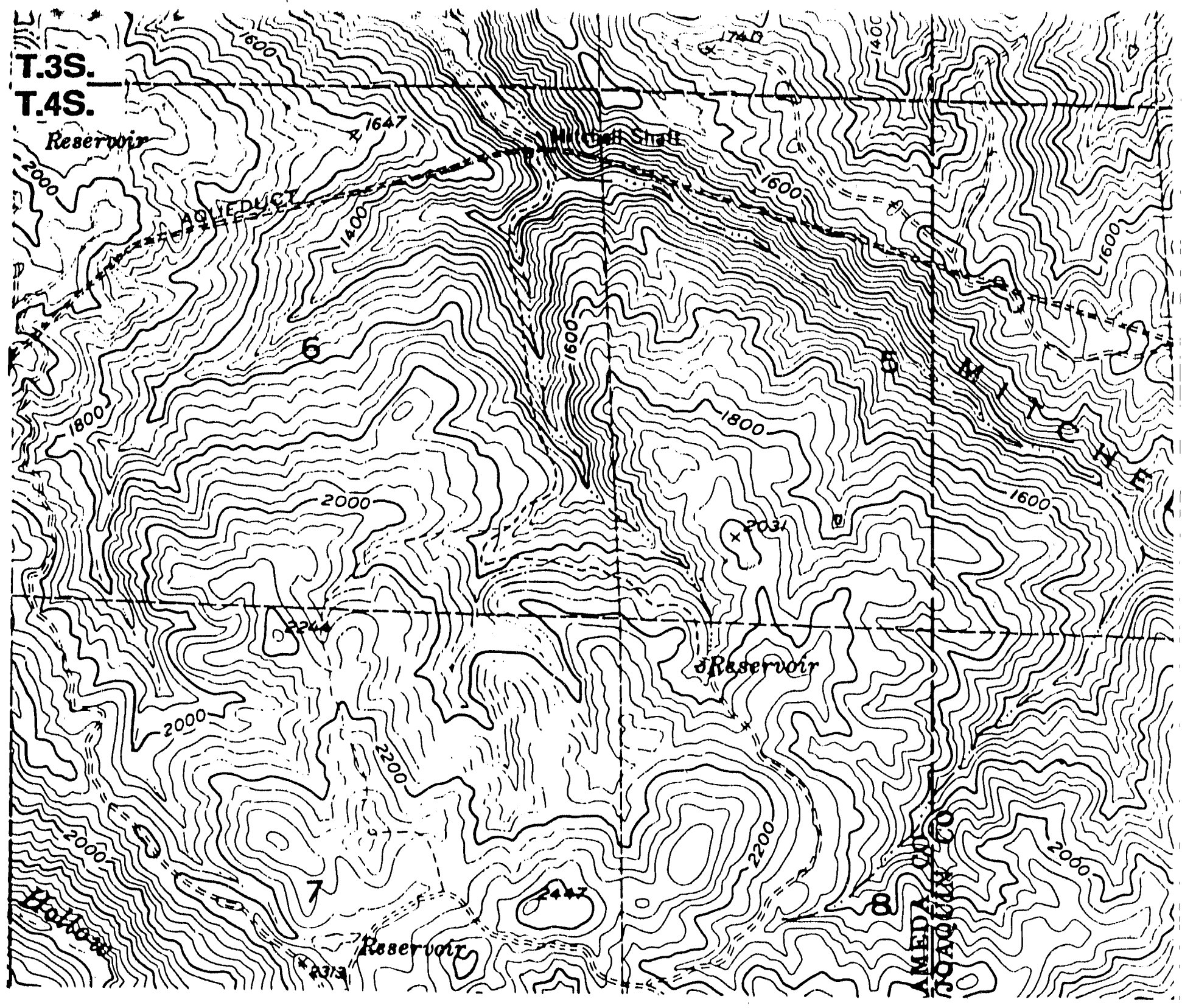




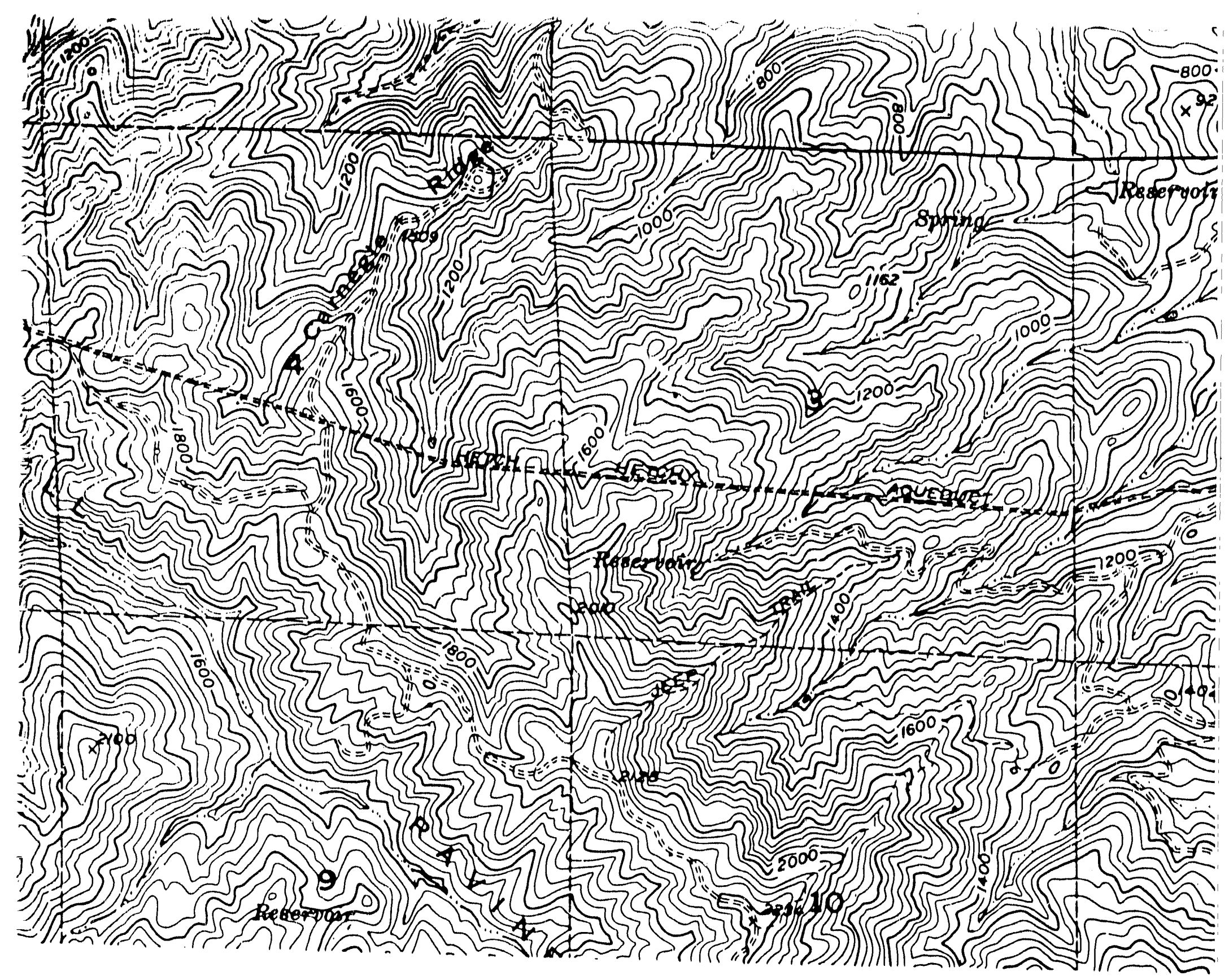



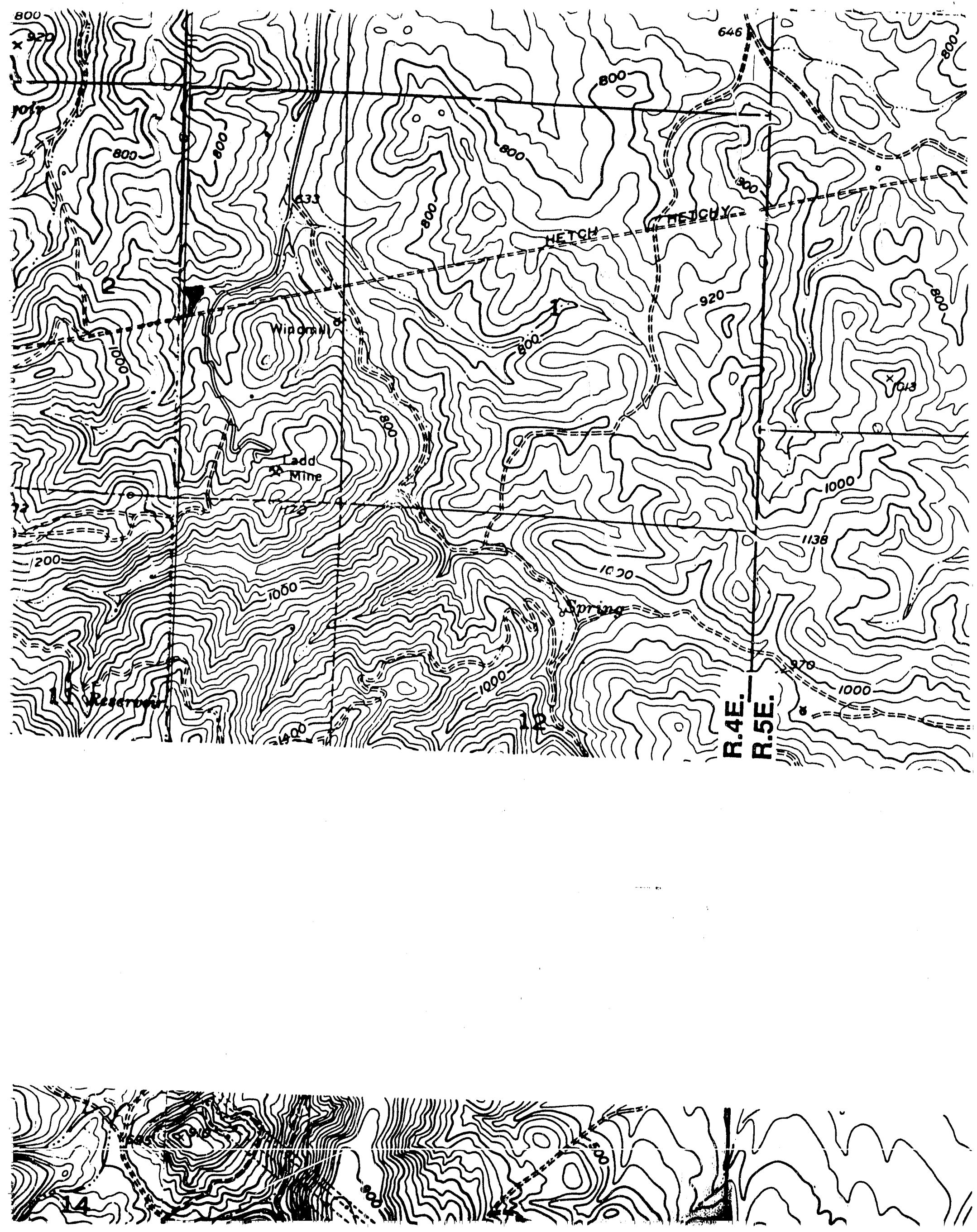


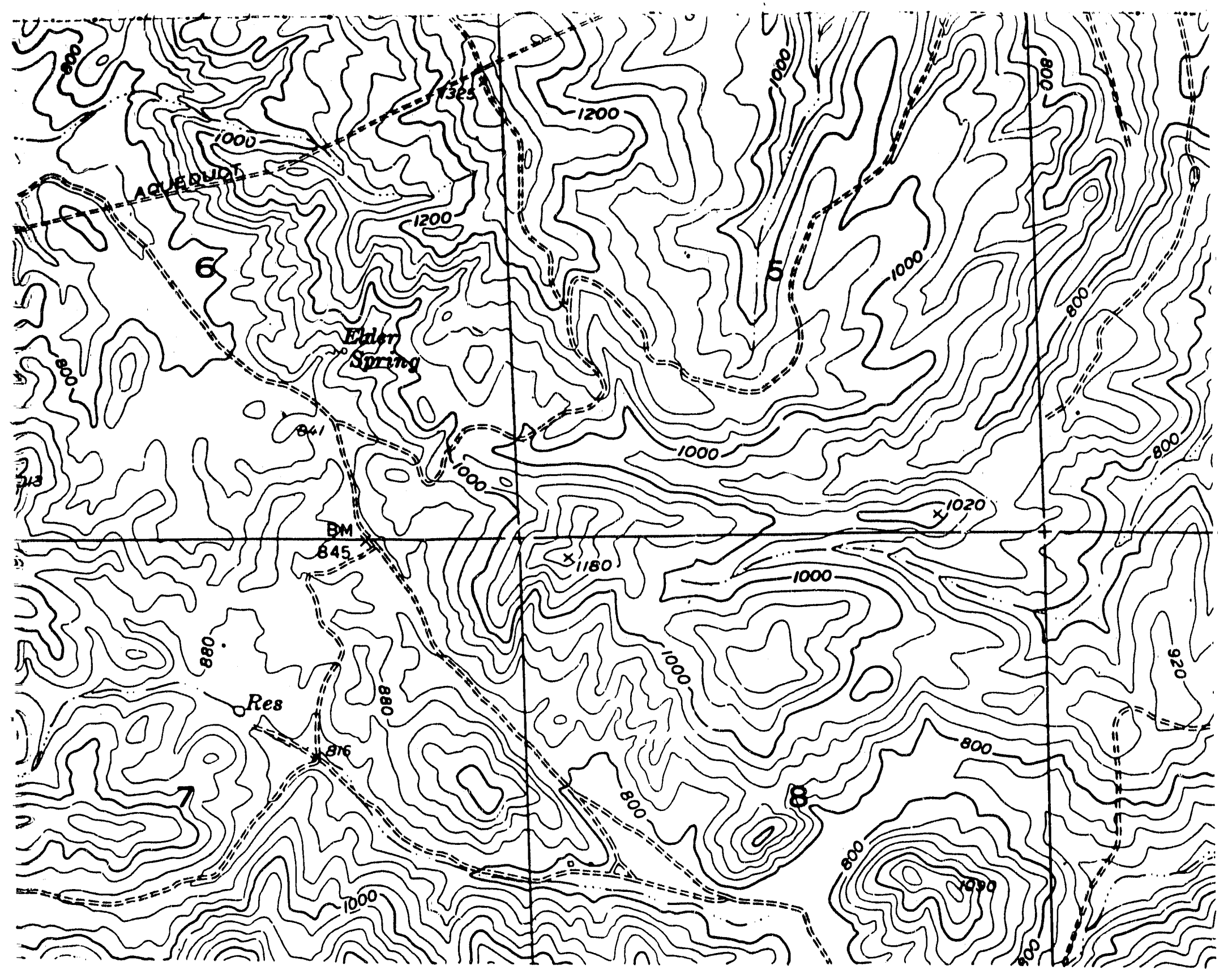

Plate 2. Topographlc m:
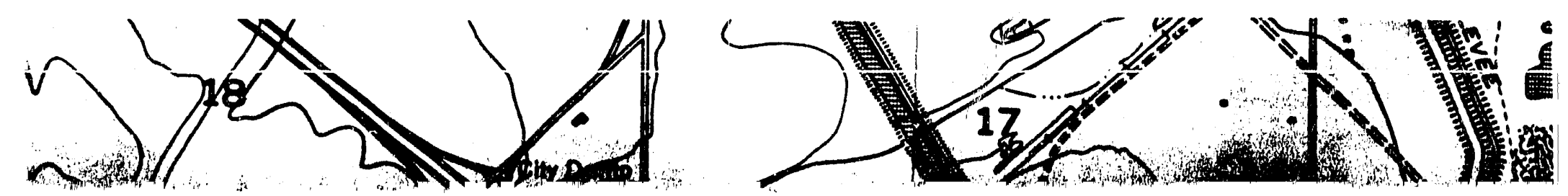


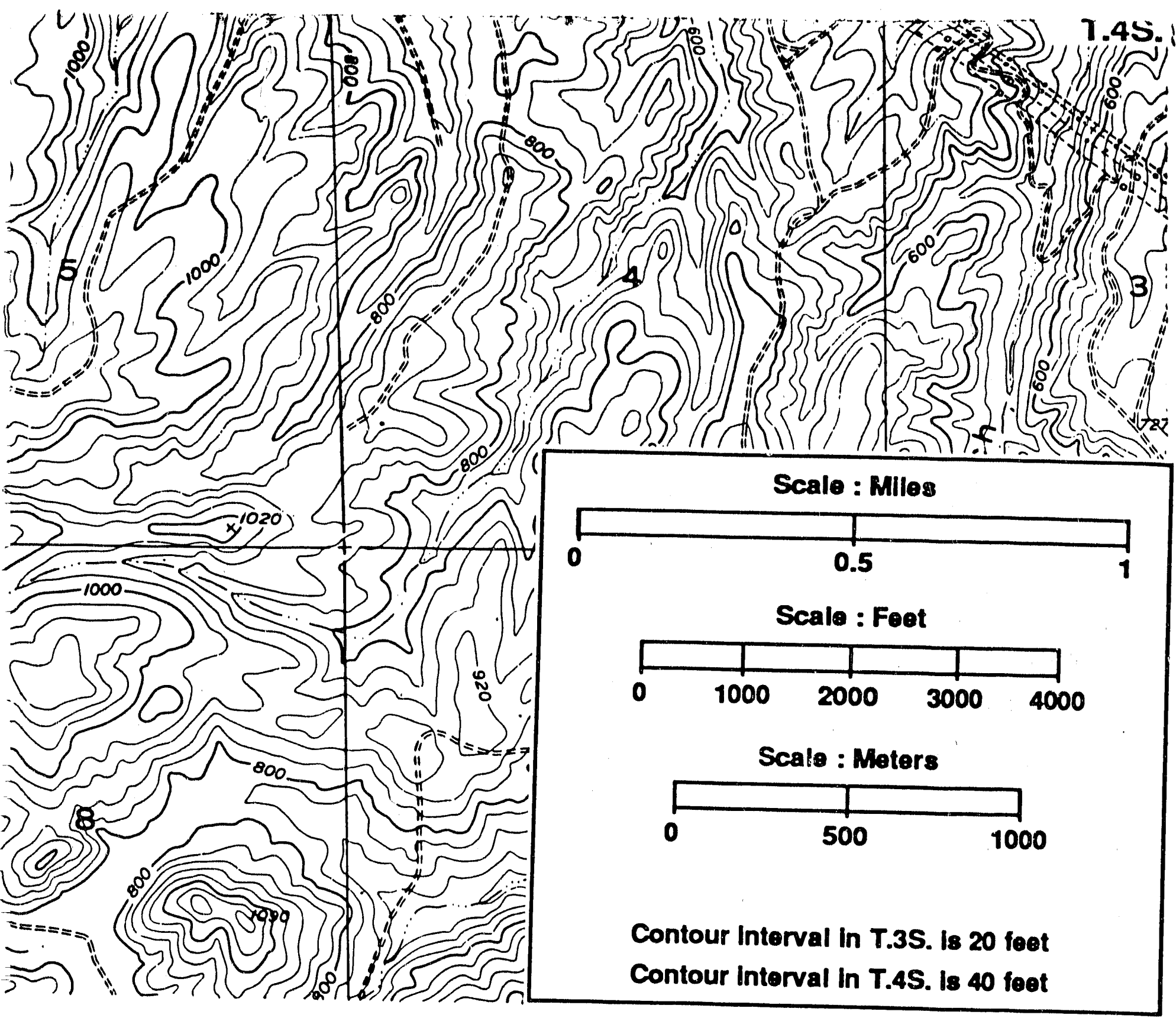

Plate 2. Topographic map of Site 300 and surroundings.

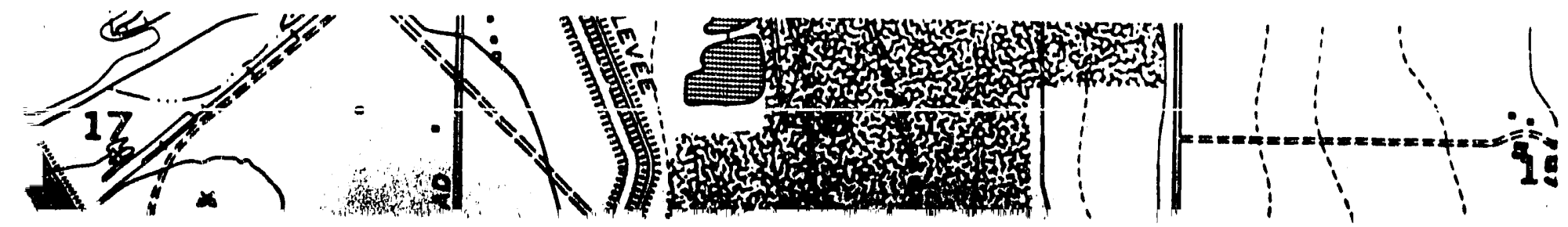




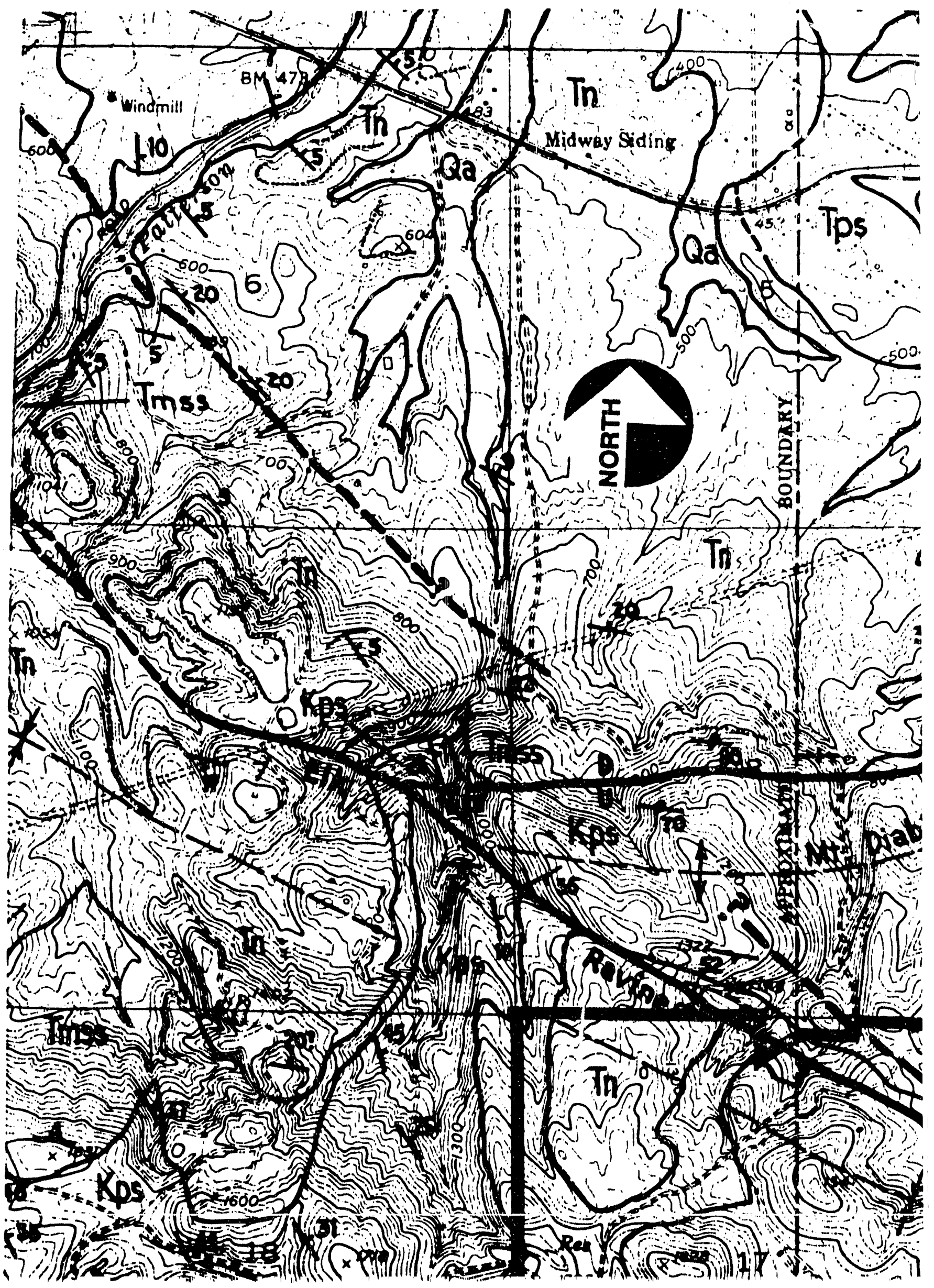




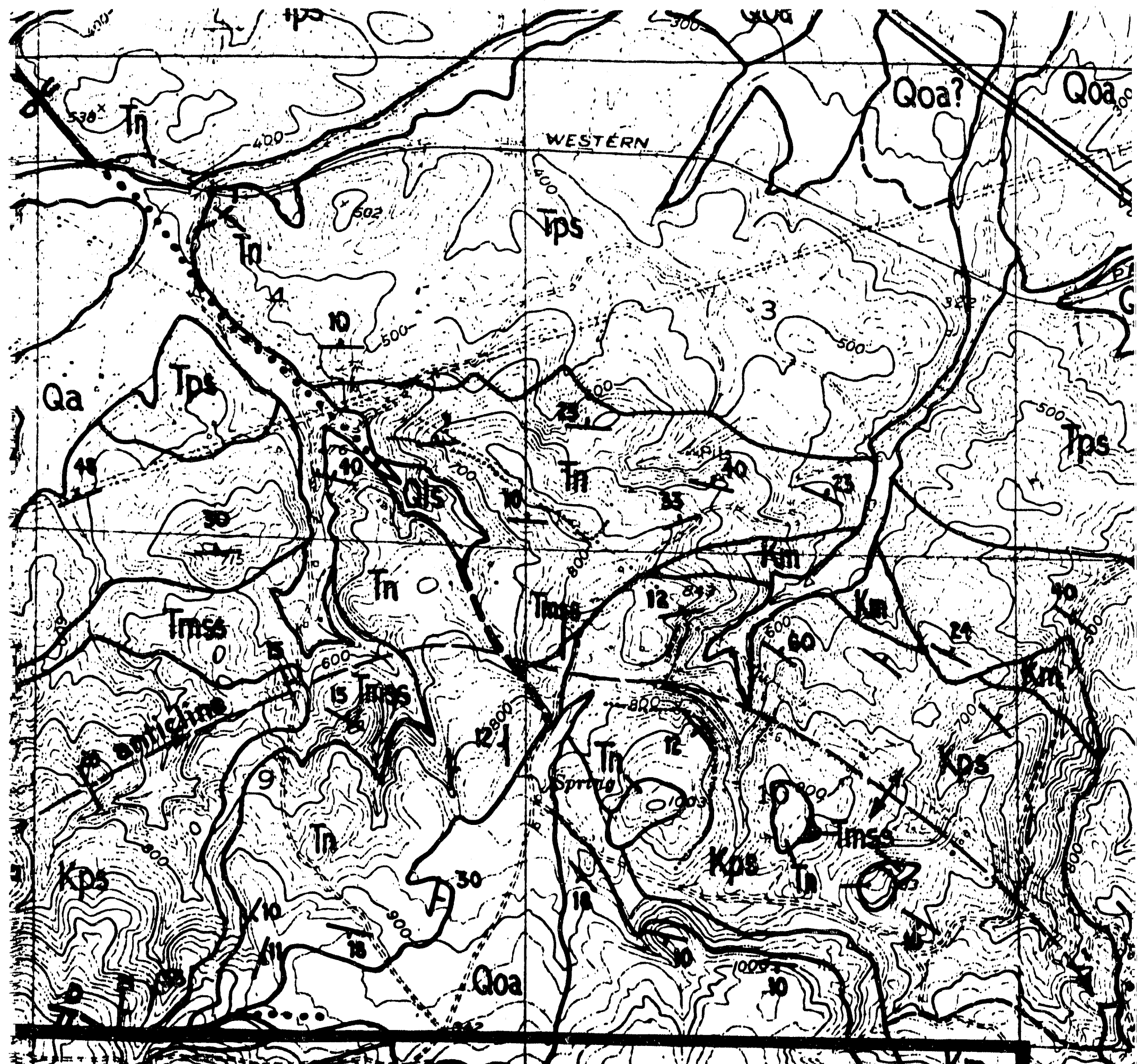

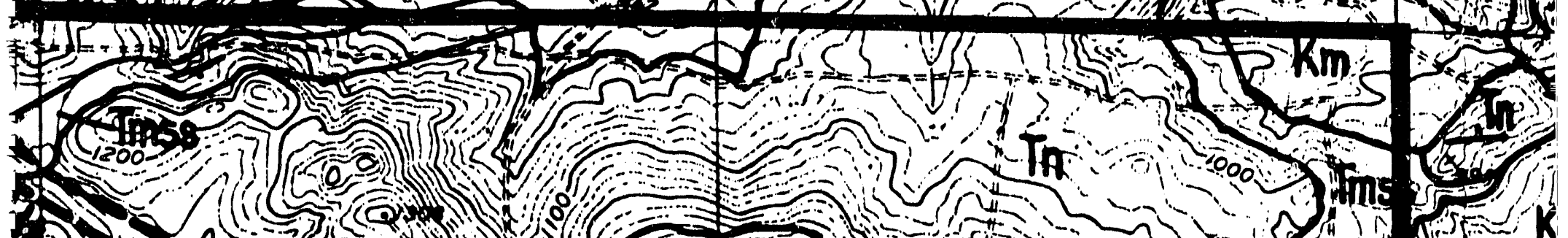
D) (2) 


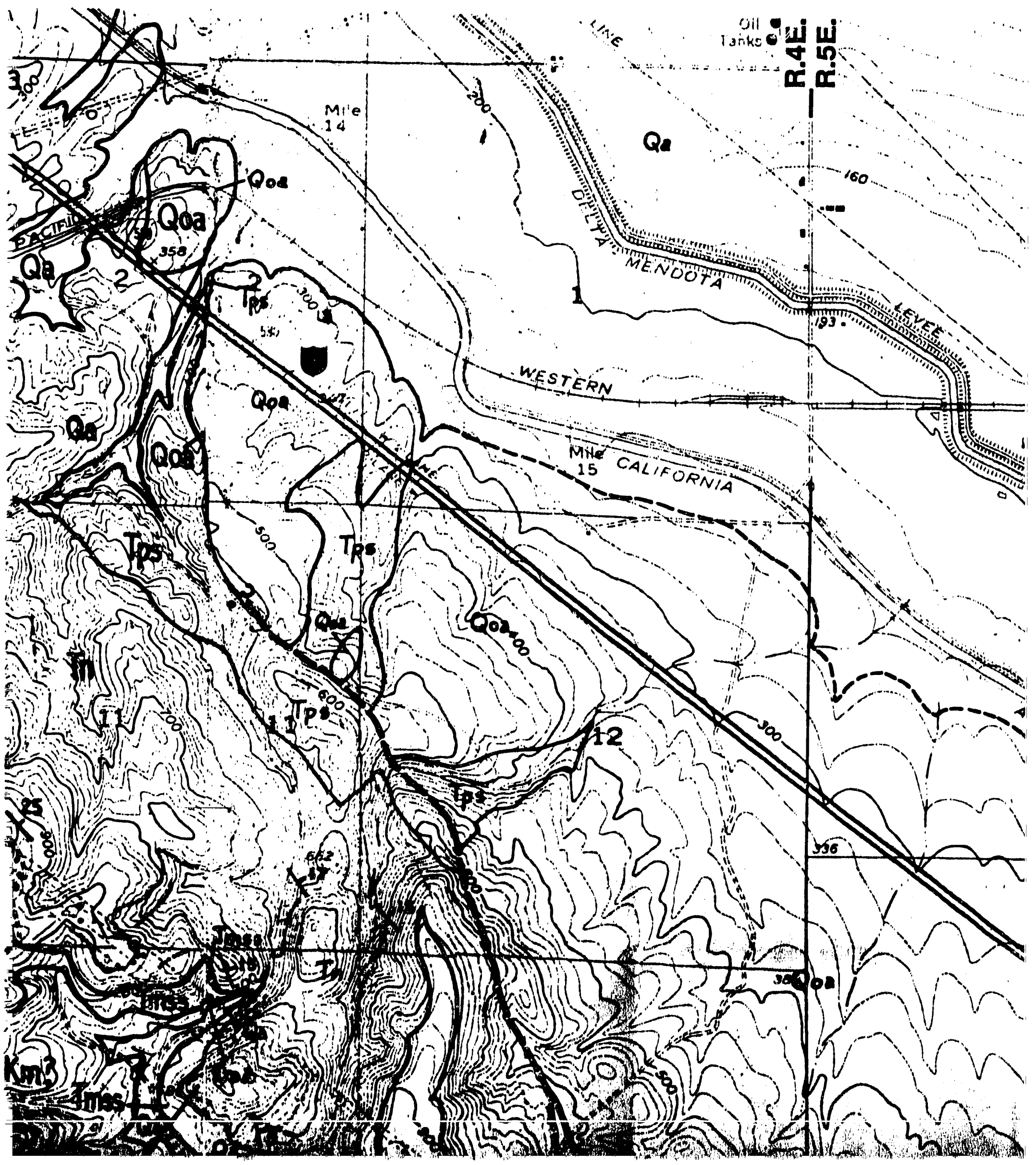




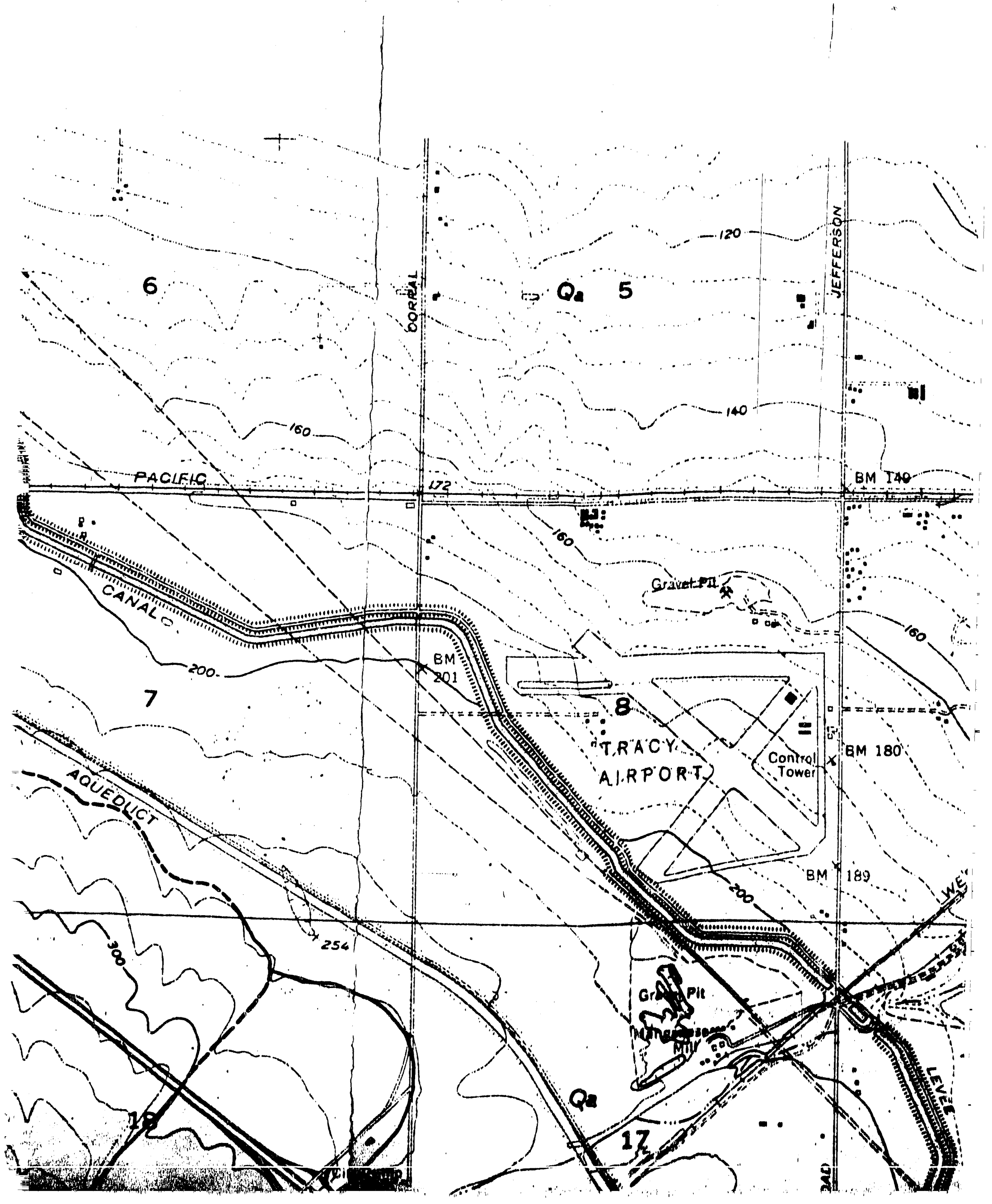




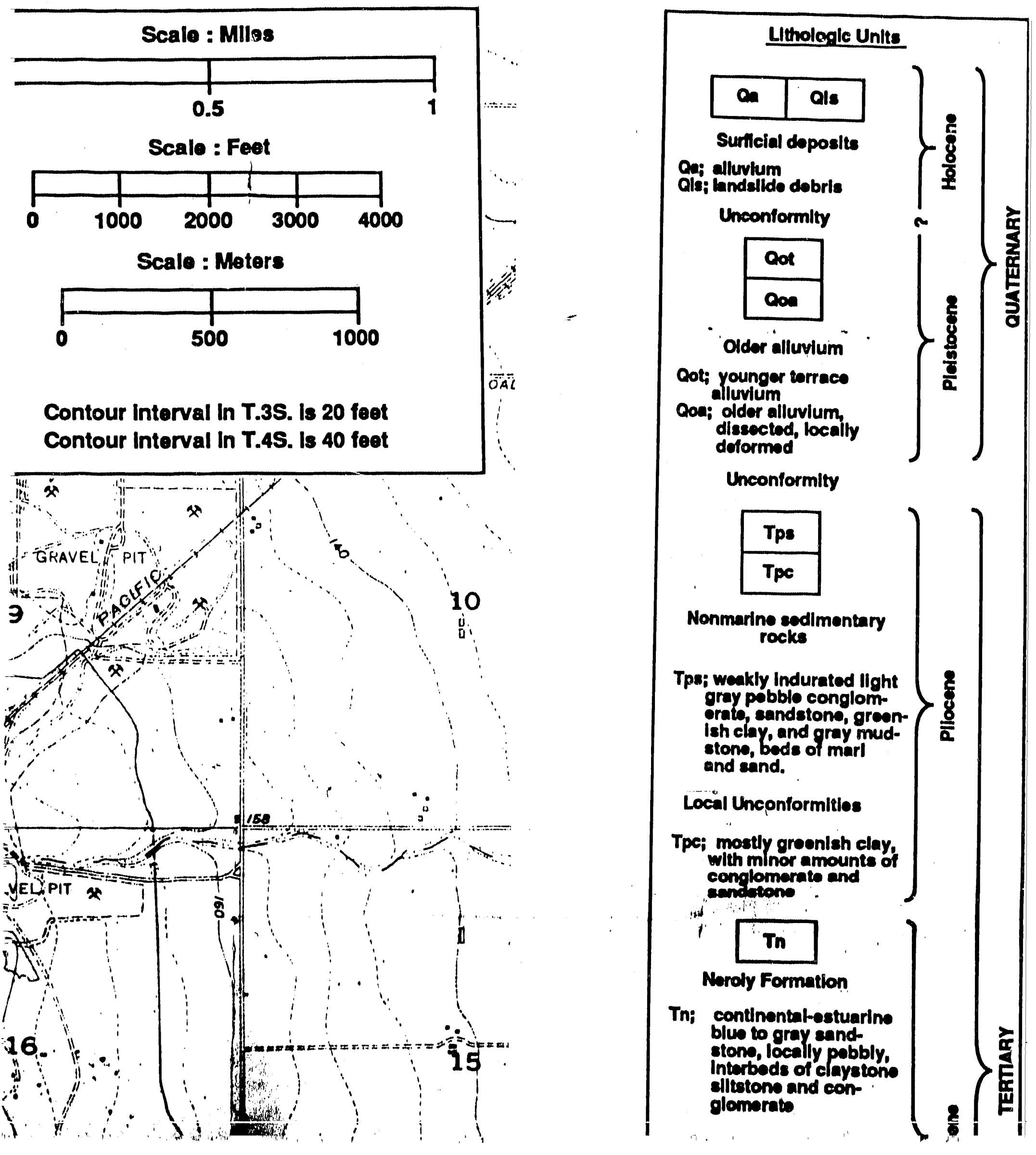




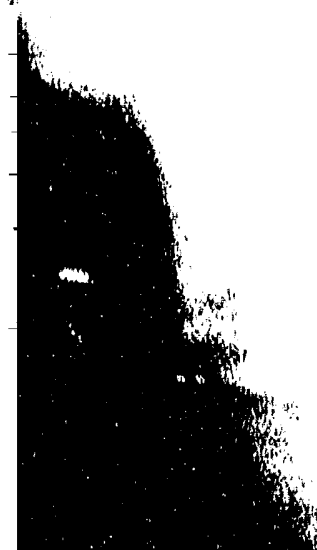

3) (1) (1) $b^{2}=1$ 3.

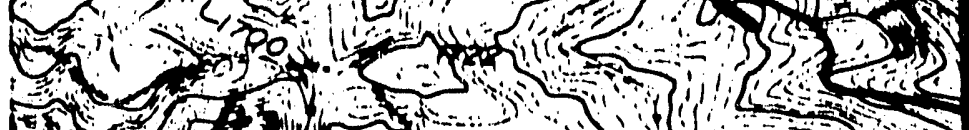

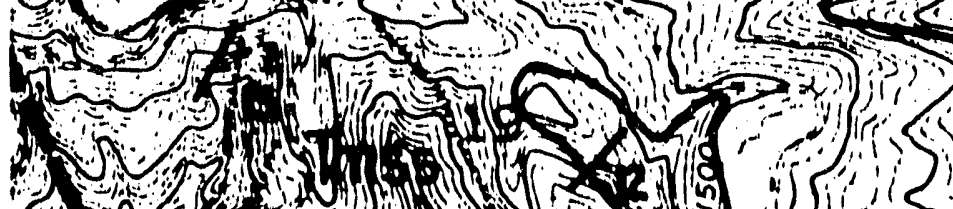
by thents $1(1)(5)$

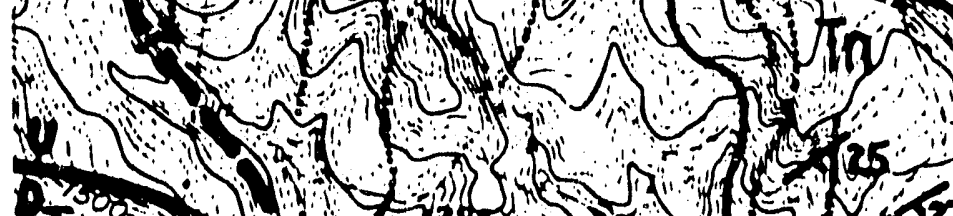

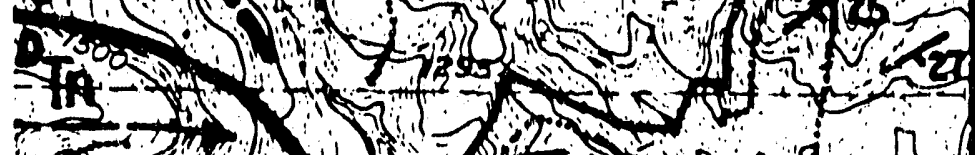
$\Rightarrow 2=1$ 1012 $1 .-1$ sypeline

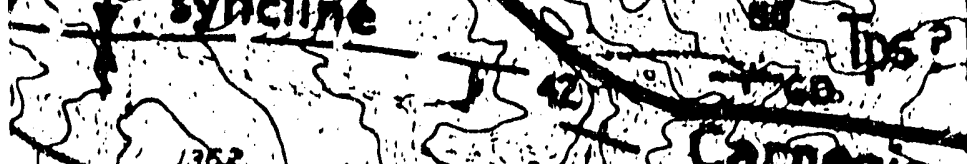

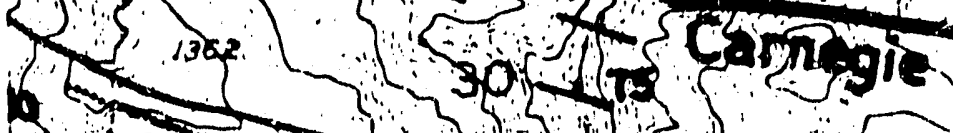
$+1,15$ It5 $>1 \%$

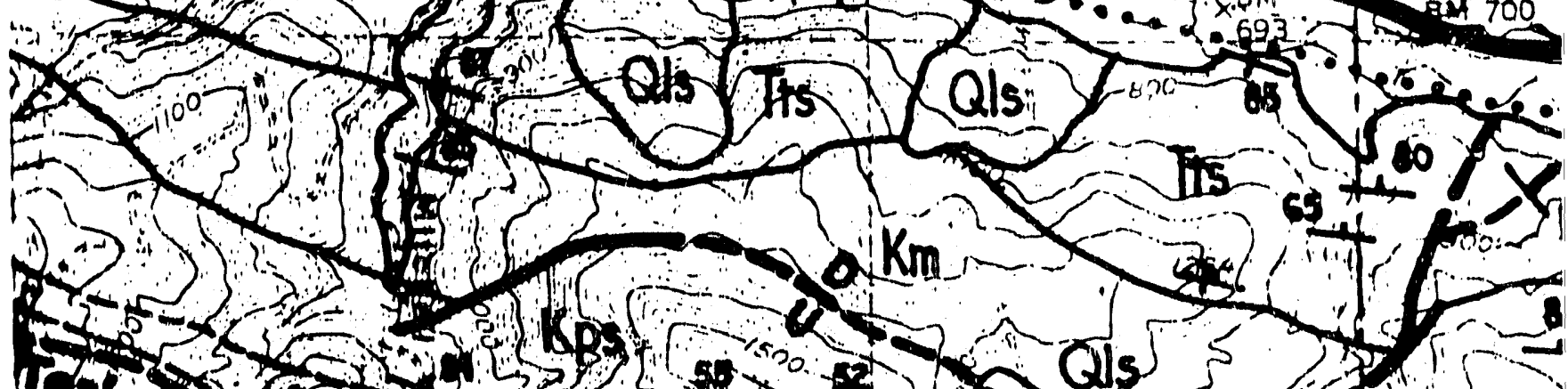

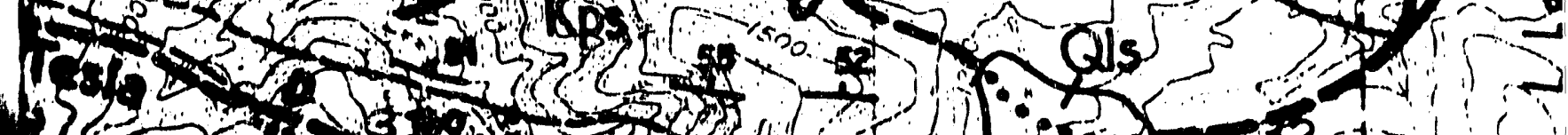

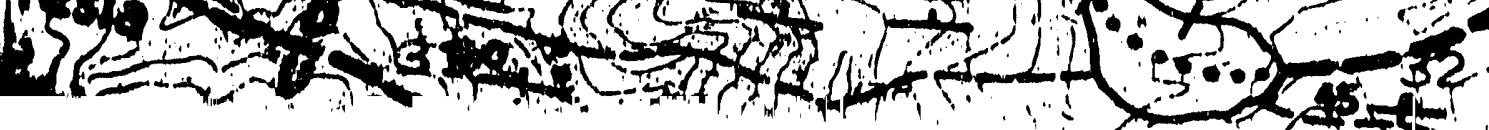




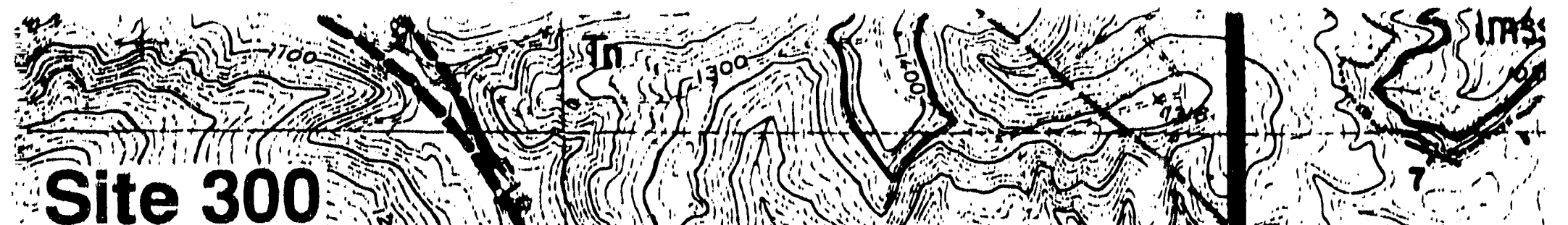

Site 300,4 (y) ond

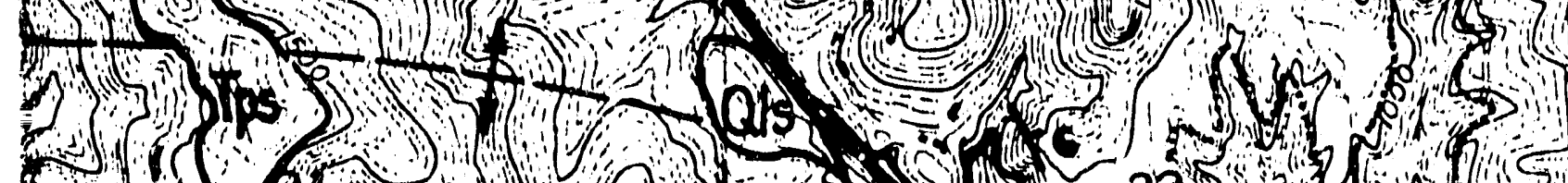

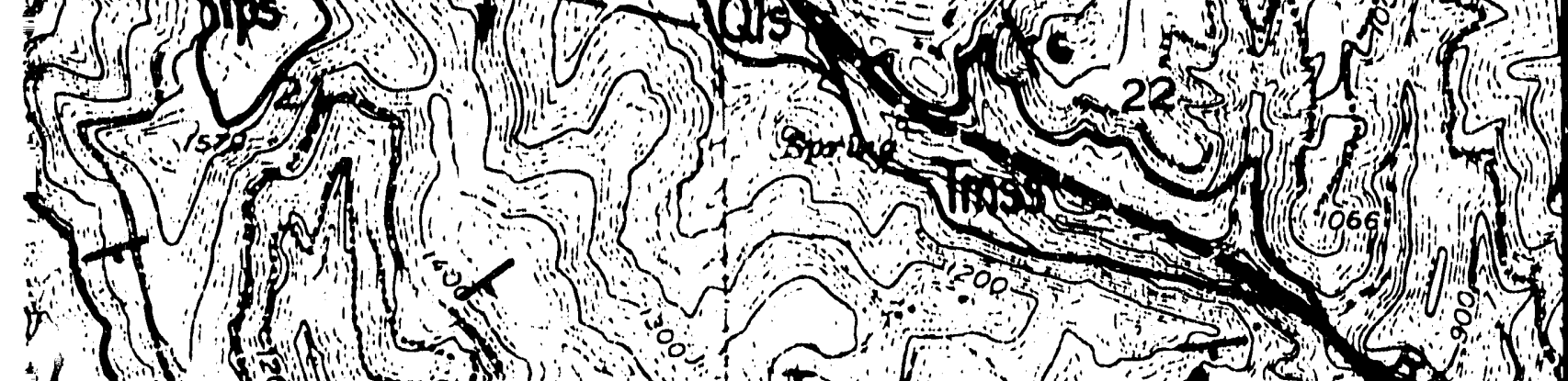

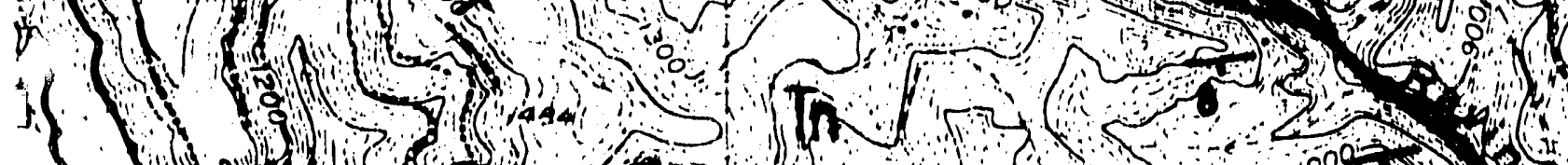
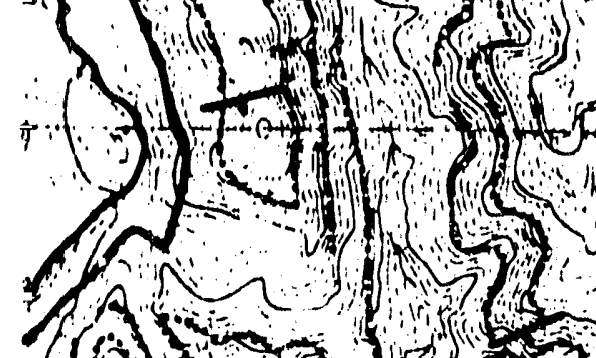

(1)

(1)

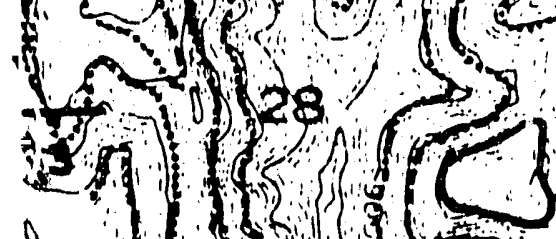

II)

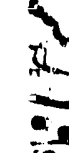

S-

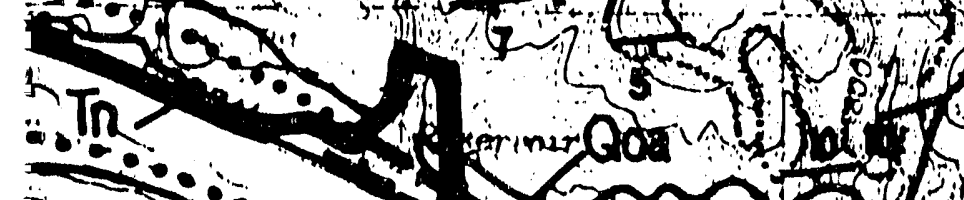

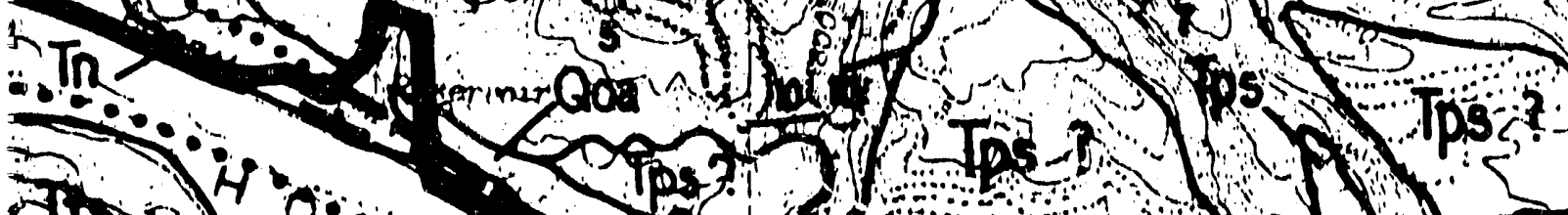

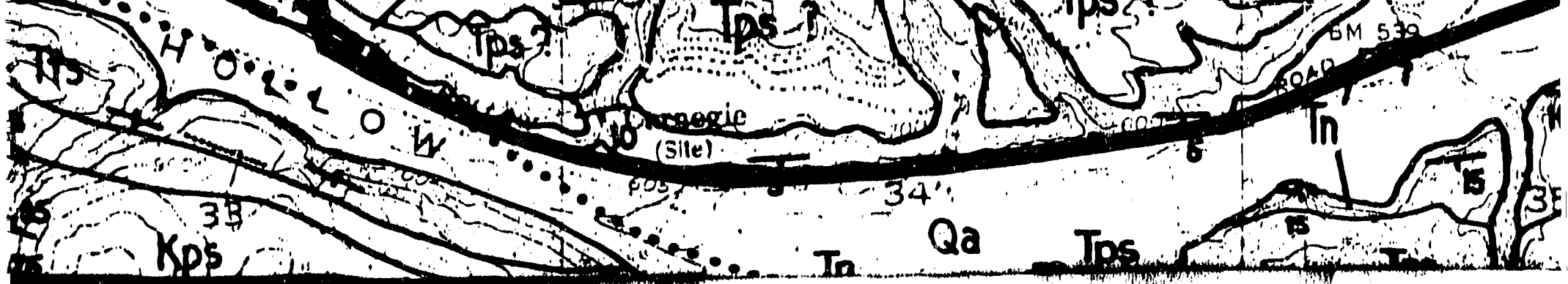




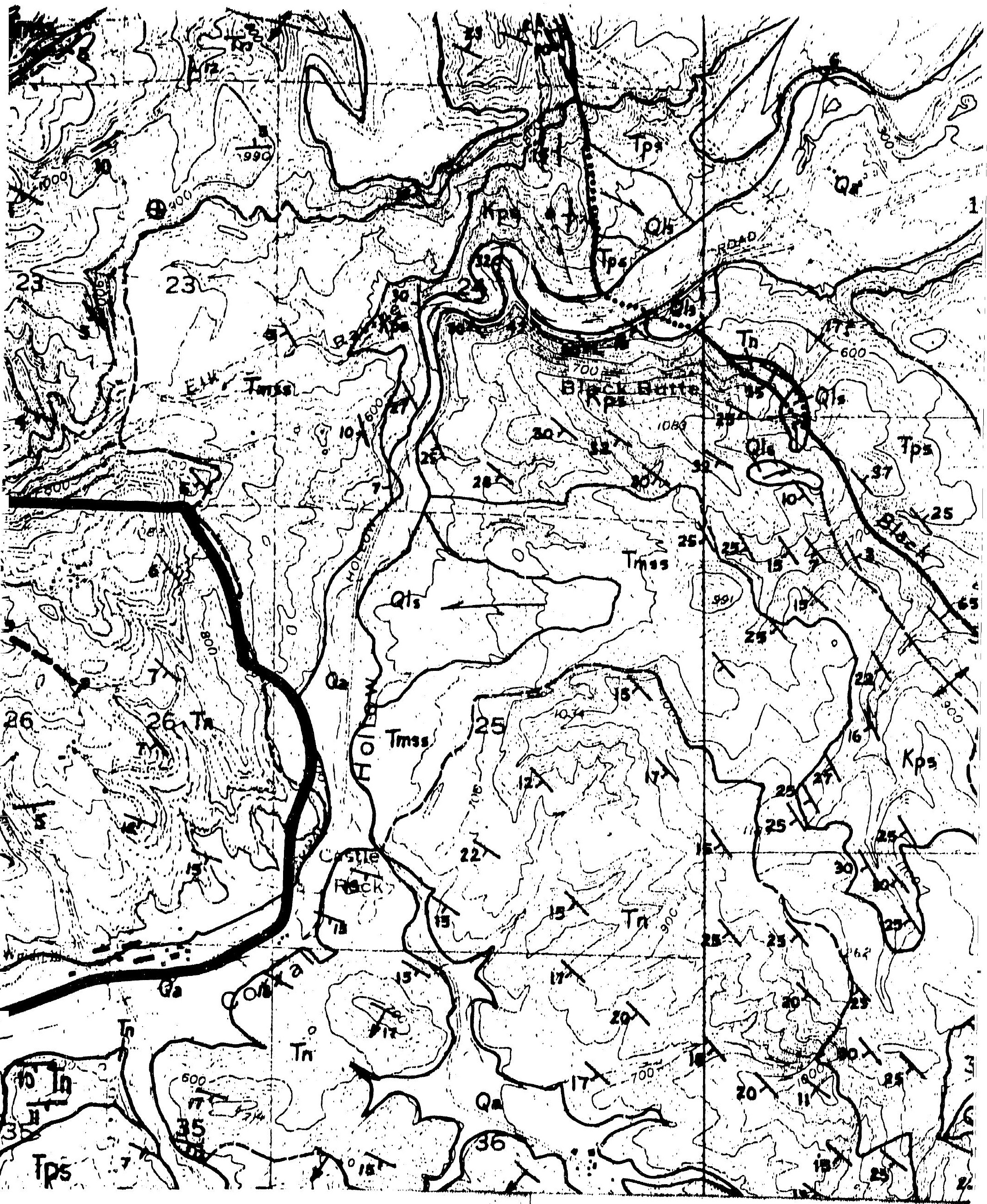




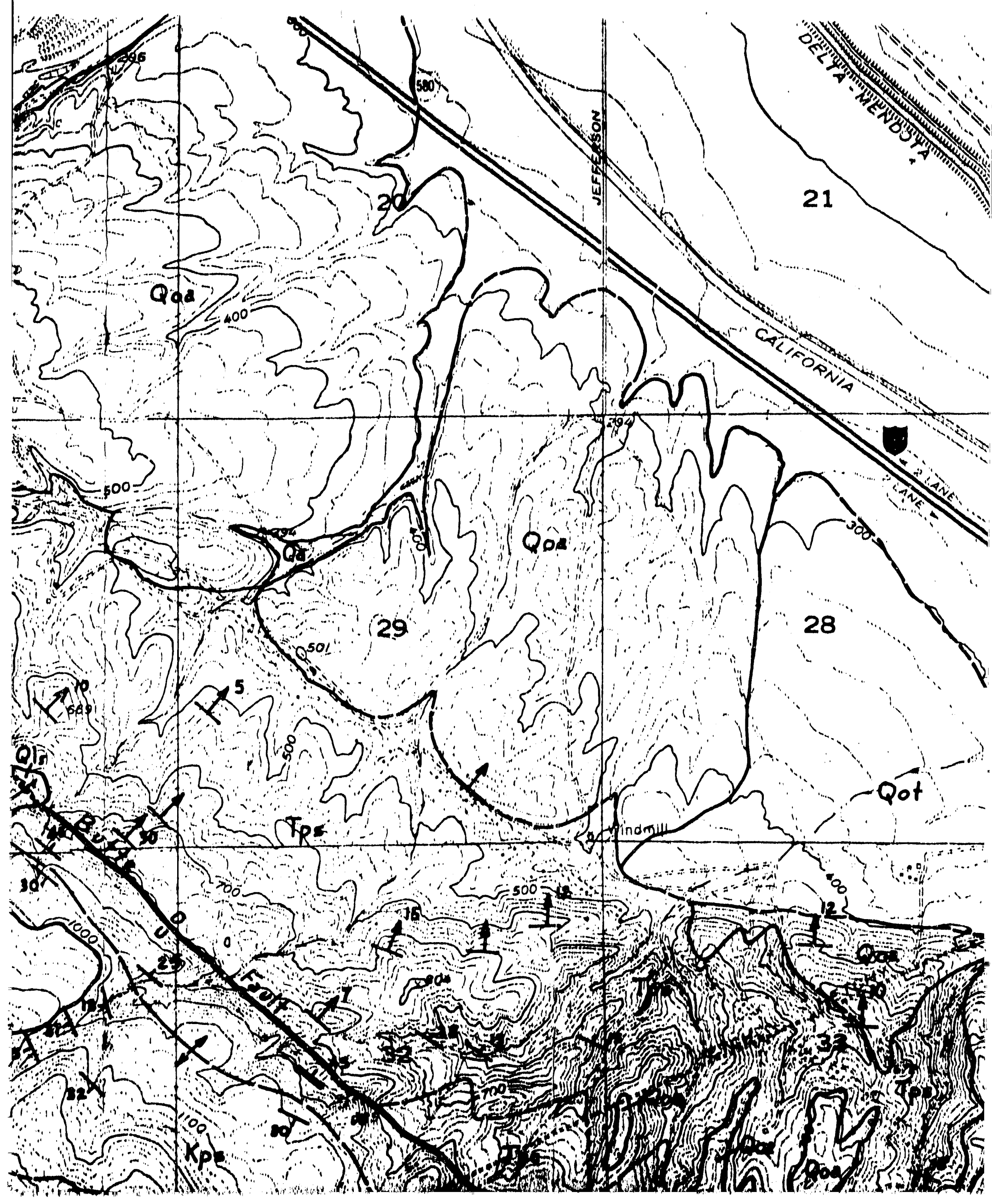




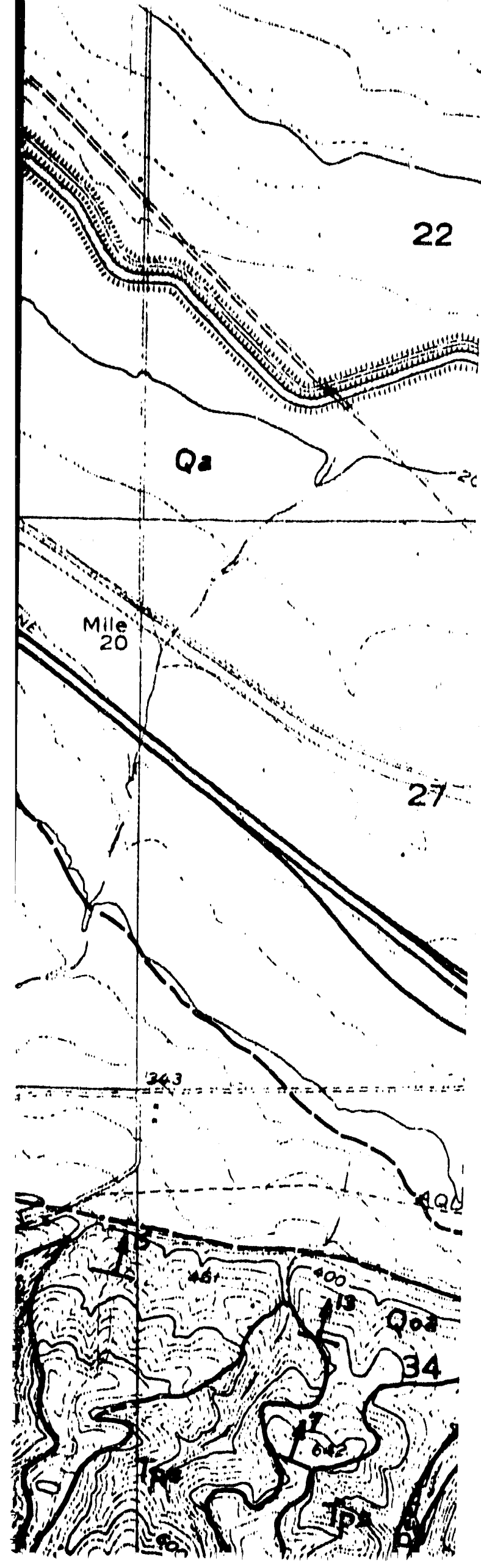

sume-wuarse jocally pobbly, fossiliferous

Unconformity

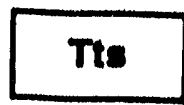

Tesla Formation

Tts; shallow marlne finegrained sandstone and siltstone, whilto to tan arkoslc sandstone and sandy slltstone; contalns pobbly bods and thin coal beds locally

i. Unconformity

Great Valley Soquence

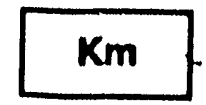

Moreno shalo

$\mathrm{Km}$; marlino ciay shalo

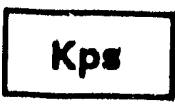

Groat Valley Soquenco

Panoche Formation

Kps; marine and light gray arkosle sandstone, with large coneretons and some Interbedded micaceous minor clay shale

8

Cosst Range Thrust

(Fault contact)

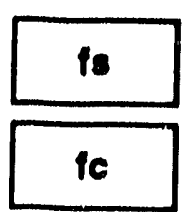

Franciscan Aseemblage

(Porvaslvely shoared, sllo'htly motamorphosed marine codimentary sequenco)

fo; eandaton (graymacko), and intorbudded micaceoue chale

fes verteolored chart

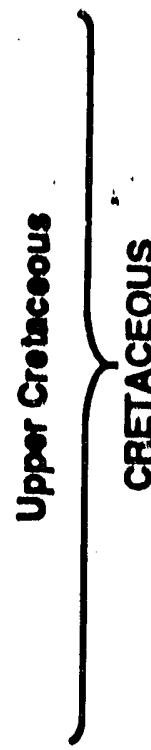

\section{Lerend}

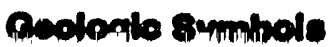




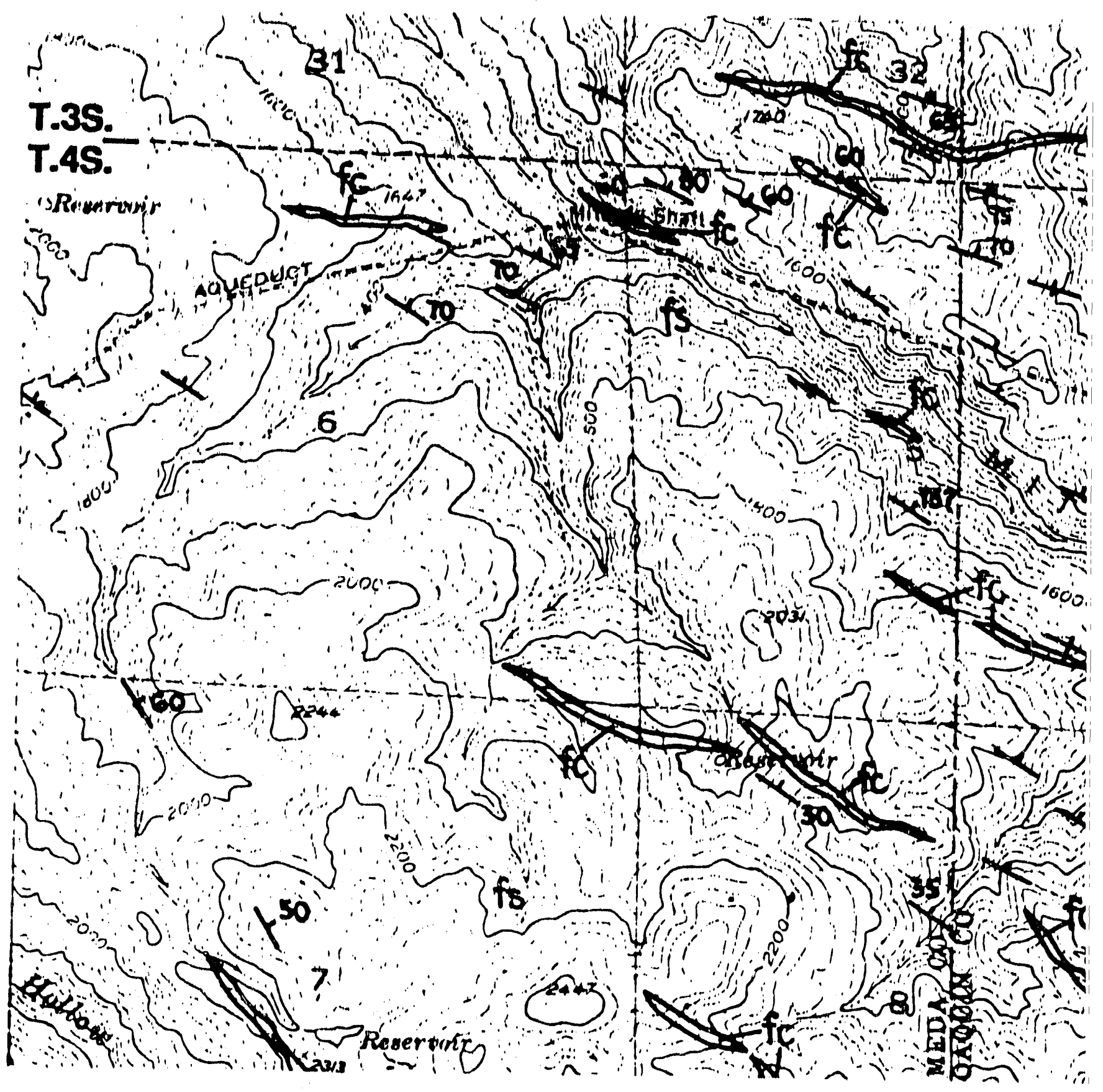


- 201

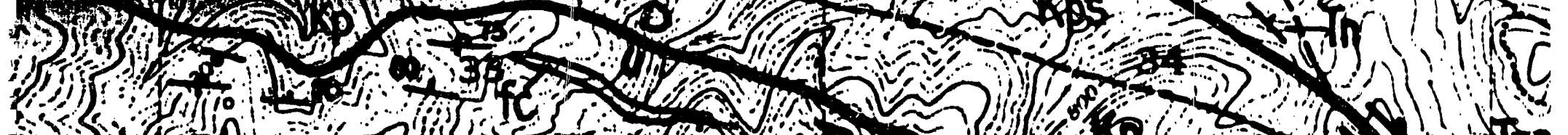

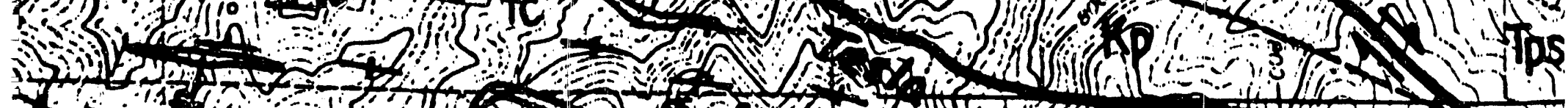

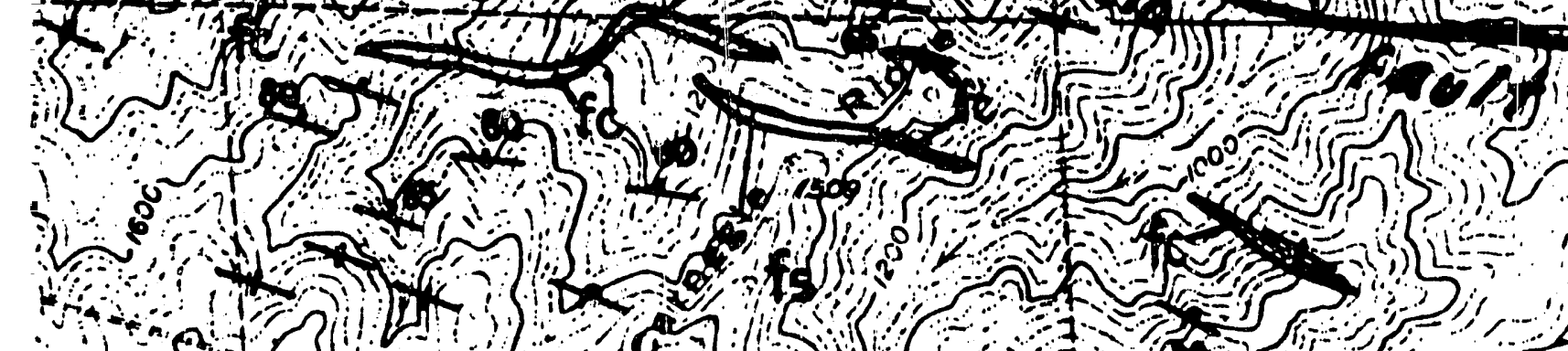

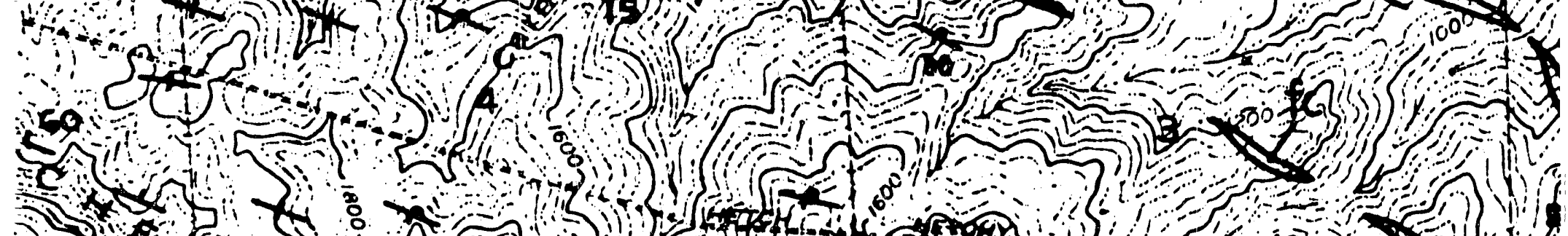

(1)

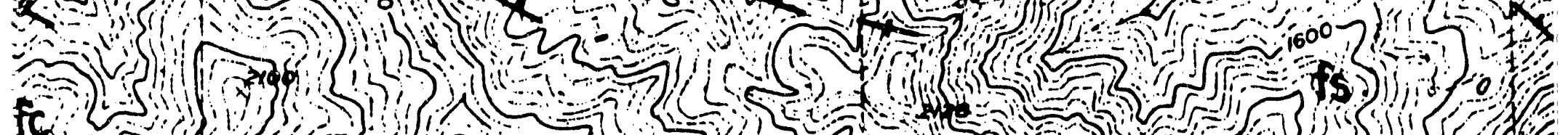

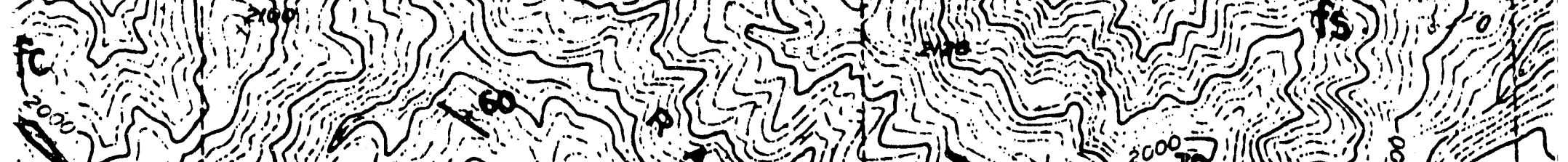

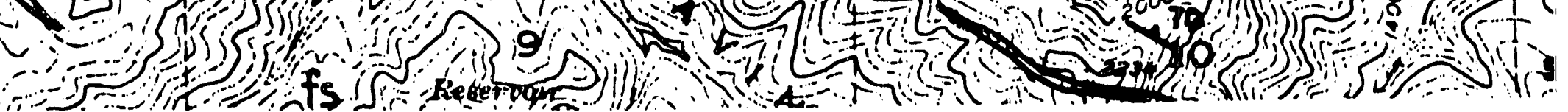




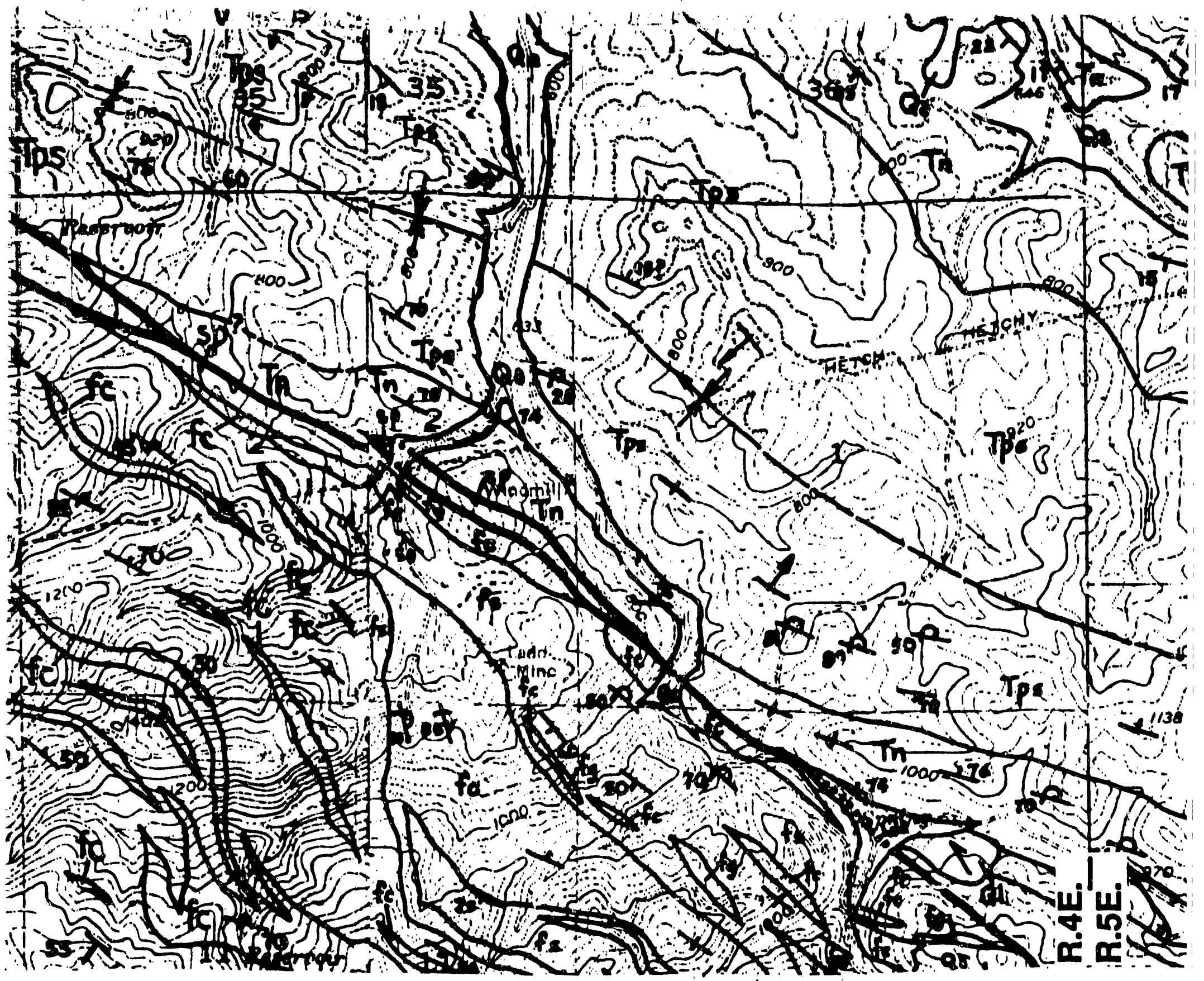




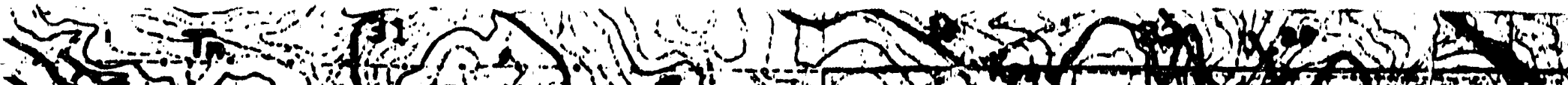

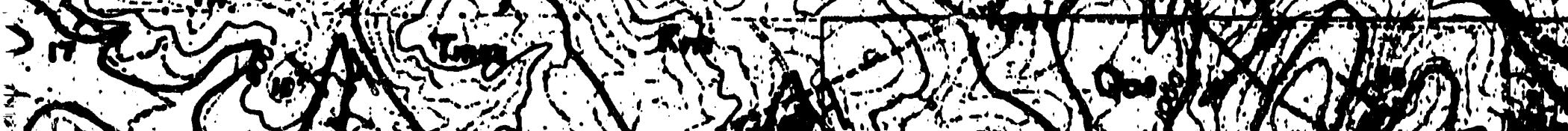

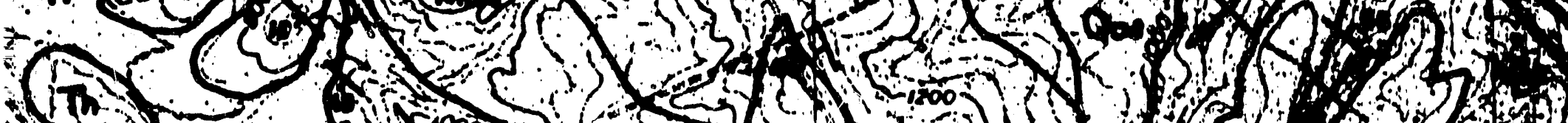

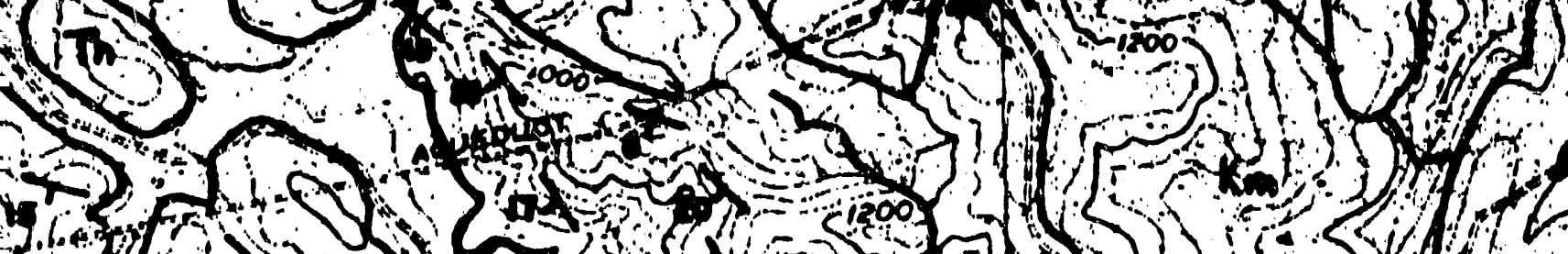

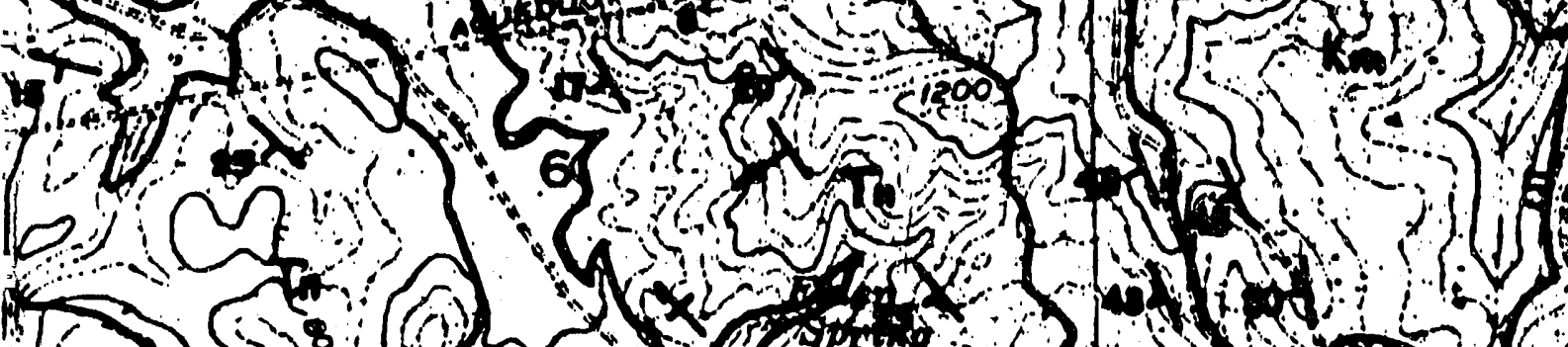

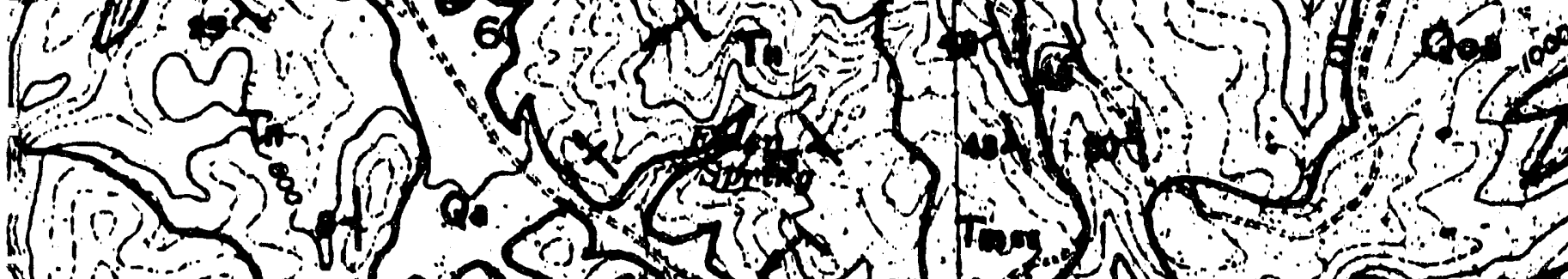

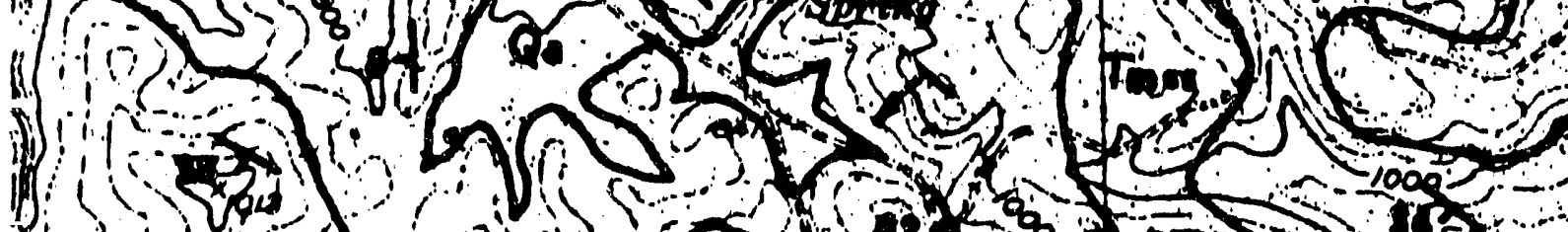

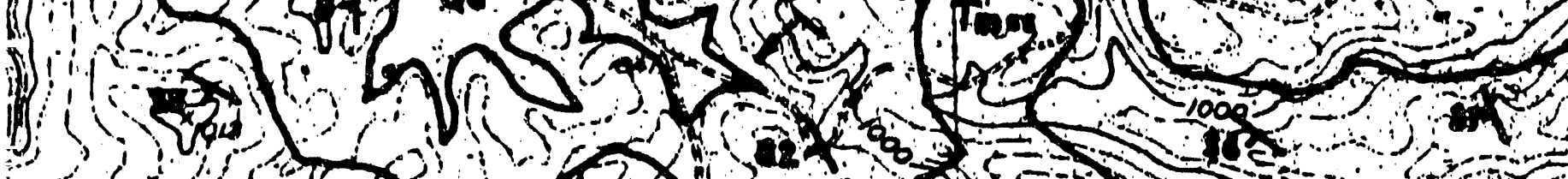

?

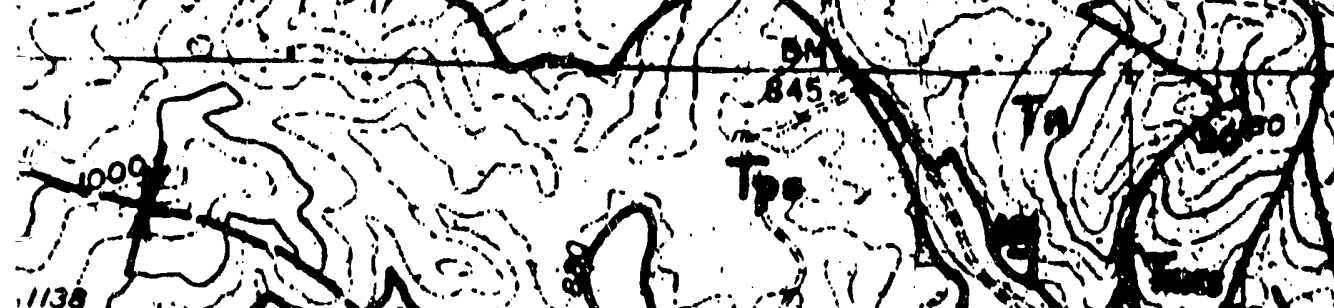

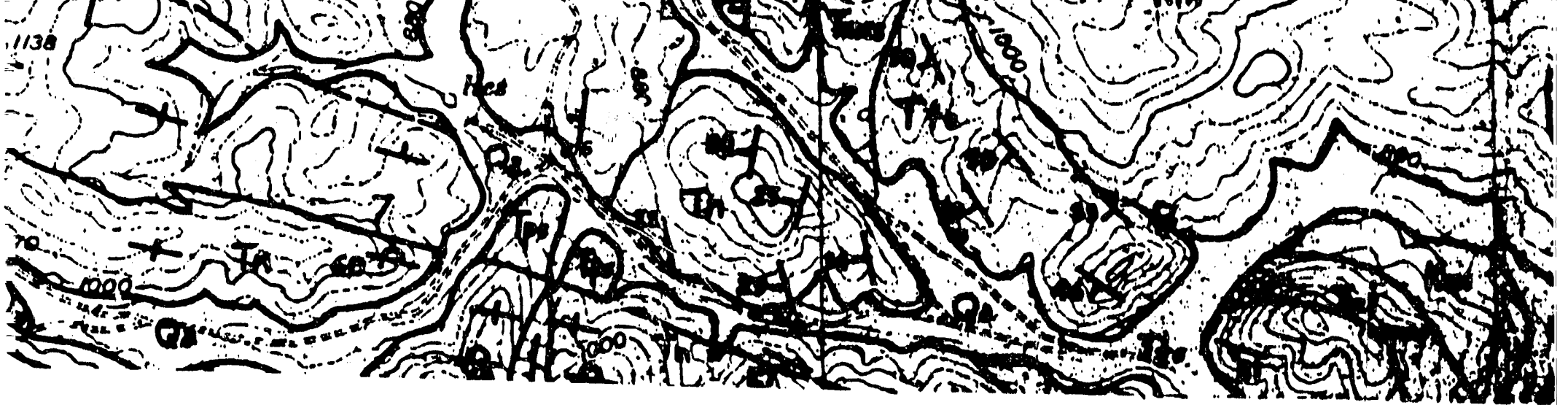




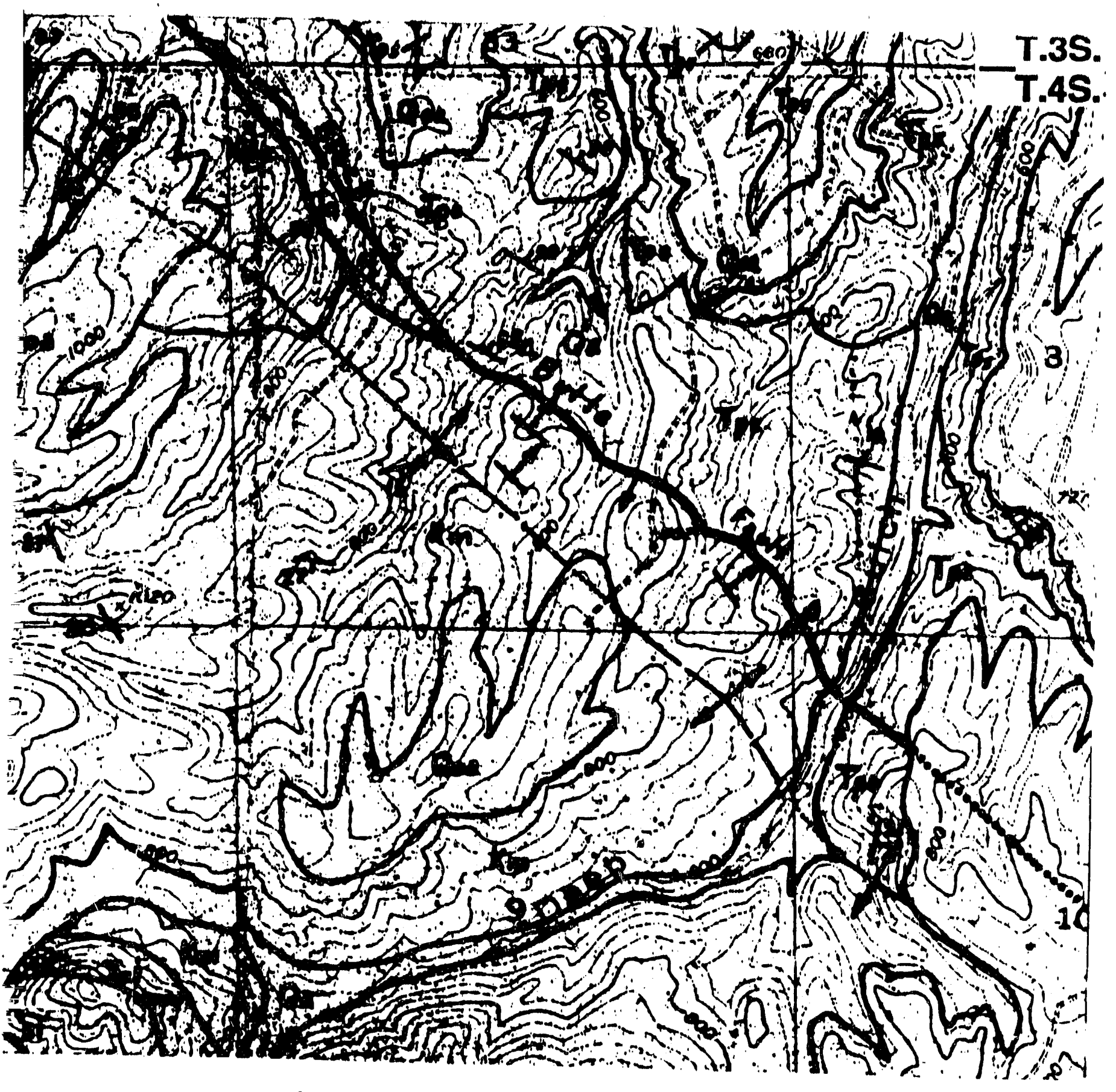

Plate 1. Geologic map of Site 300 and surroundings (modifl) 

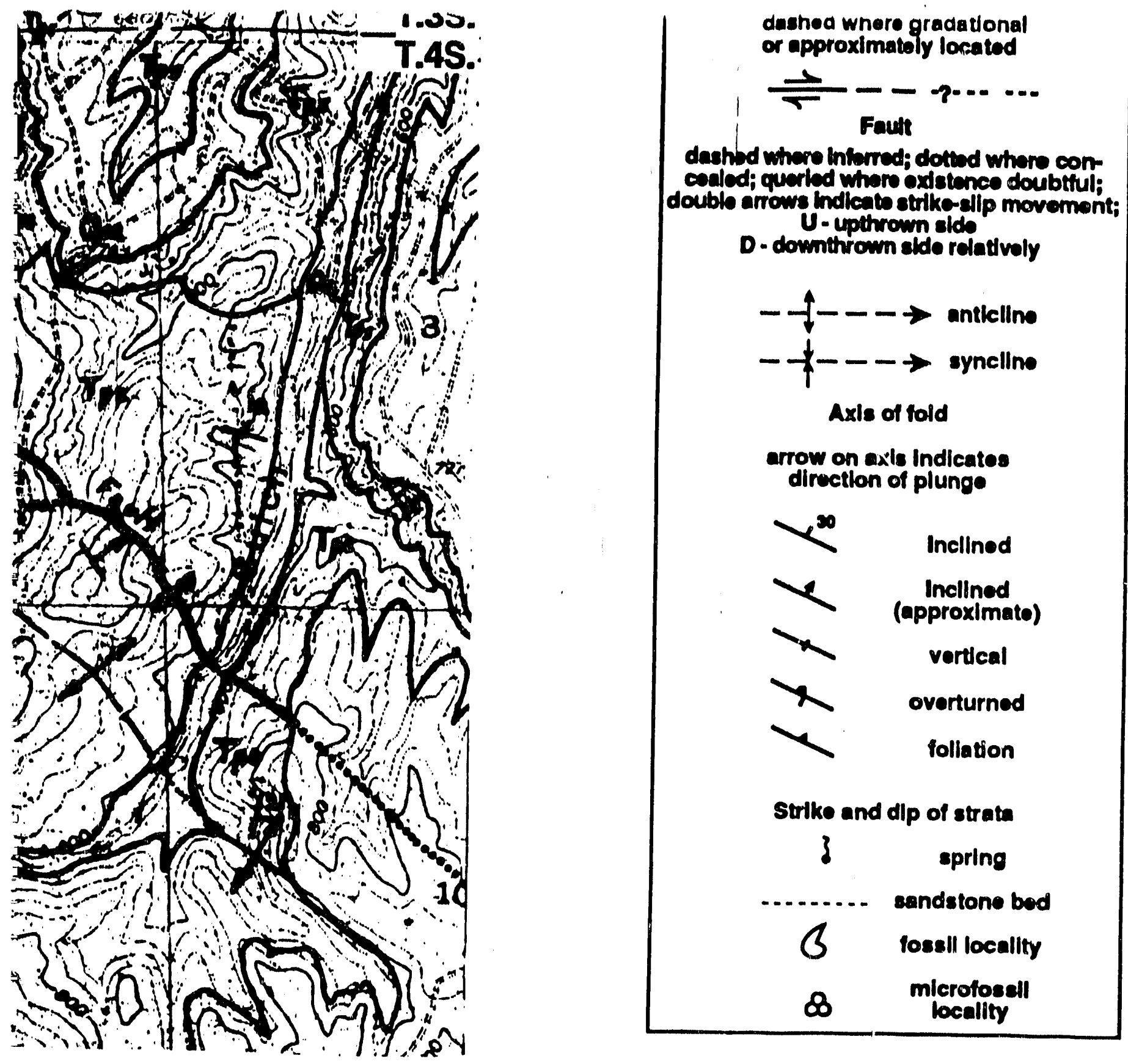

'glc map of Site 300 and surroundings (modlfied from Dibblee 1980a, b, c \& d). 

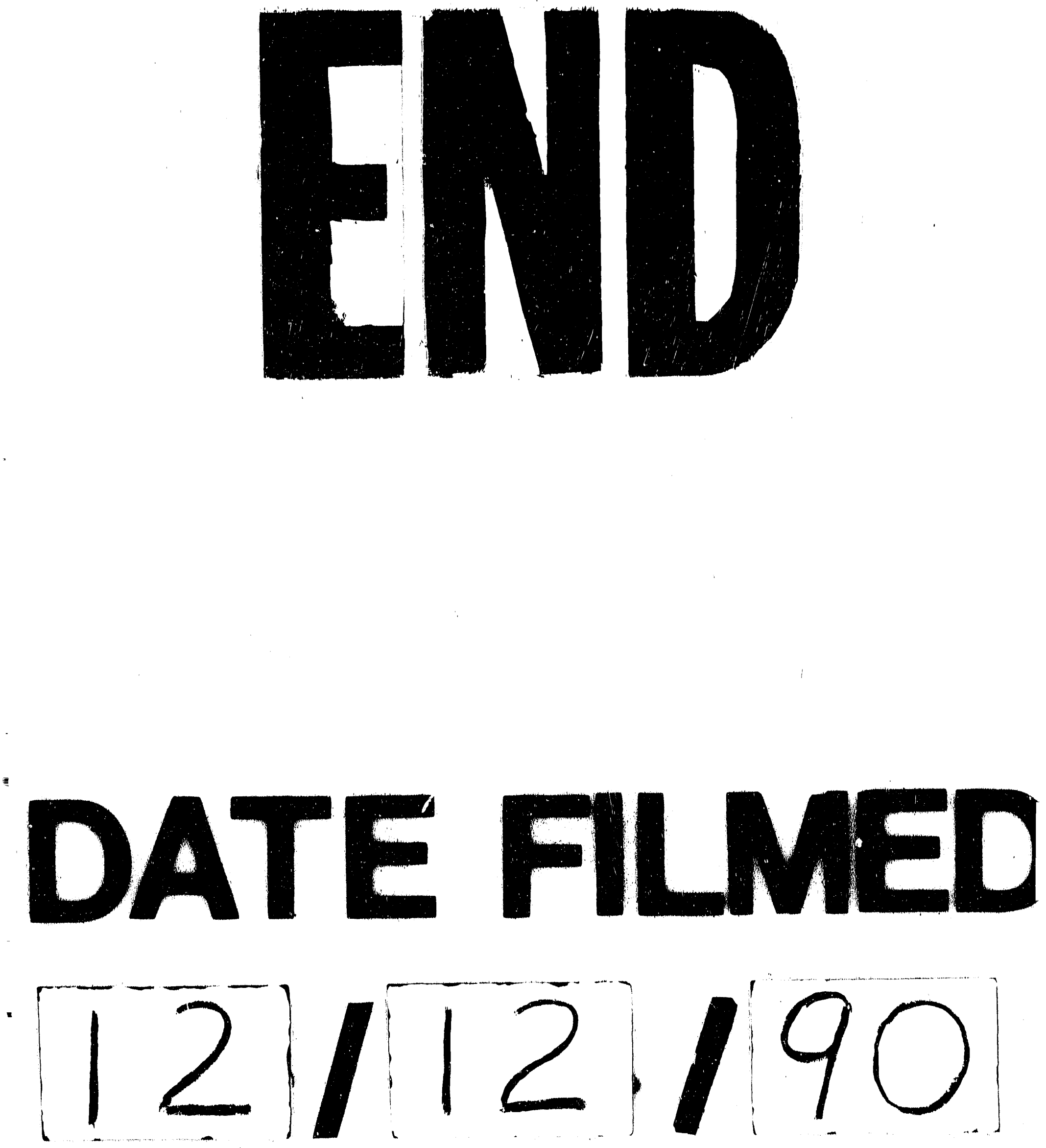
